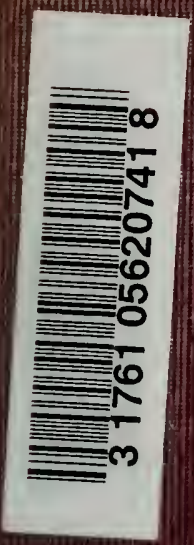


H lo-

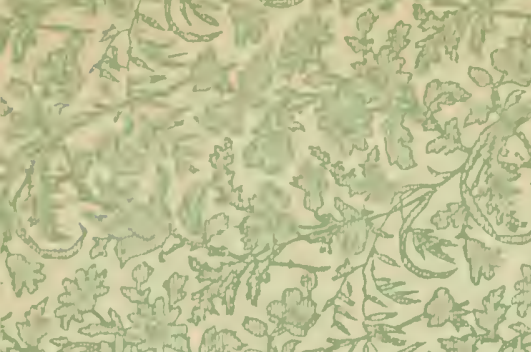
(.)

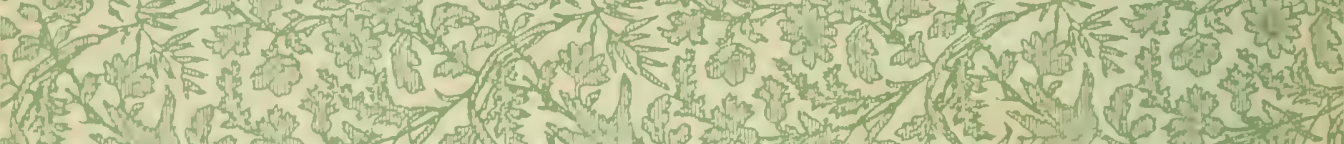
Non:

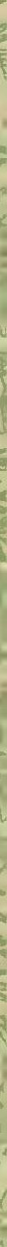

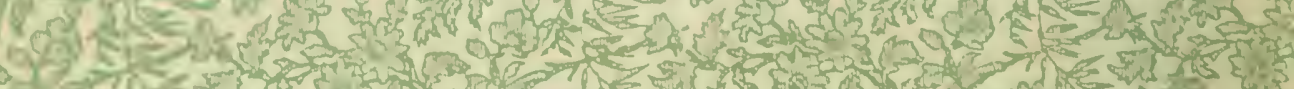

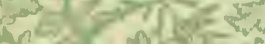

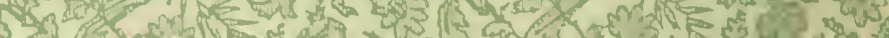






\section{THE RUSTS OF AUSTRALIA (UREDINEAE).}






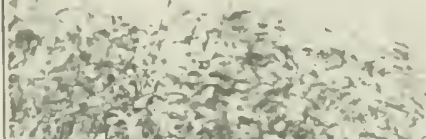

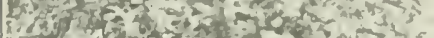

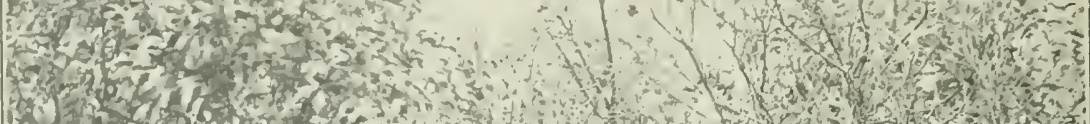

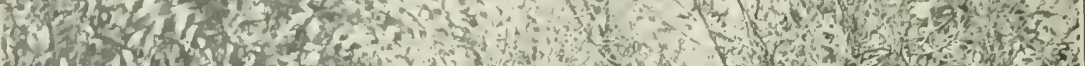

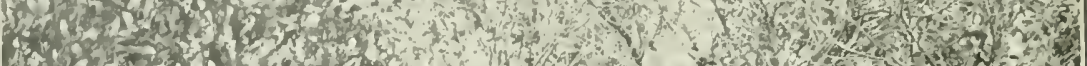

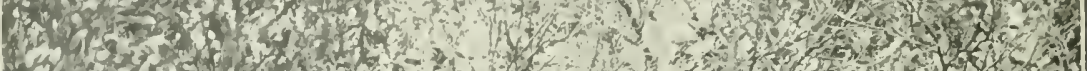
6 (n)

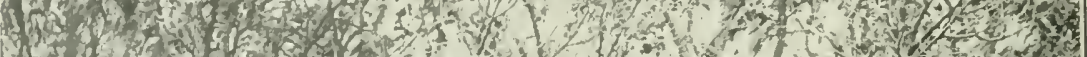

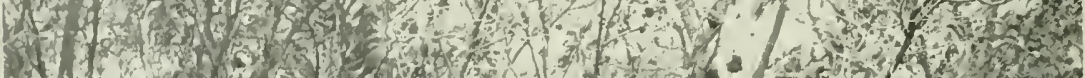

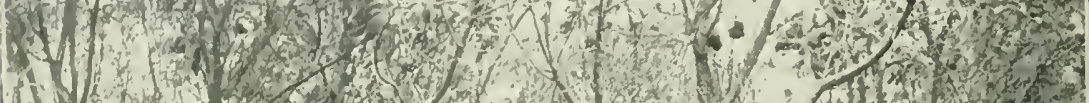

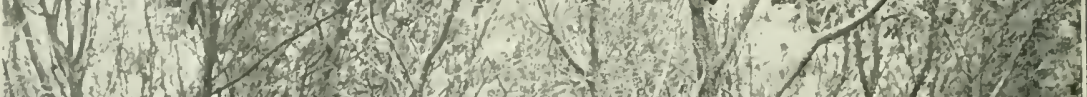

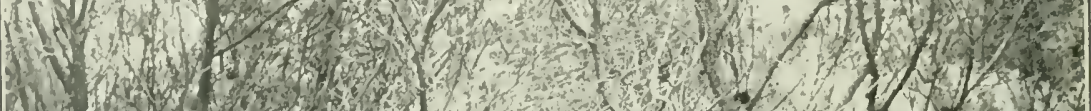
3 (1) (1) $1+1+1$

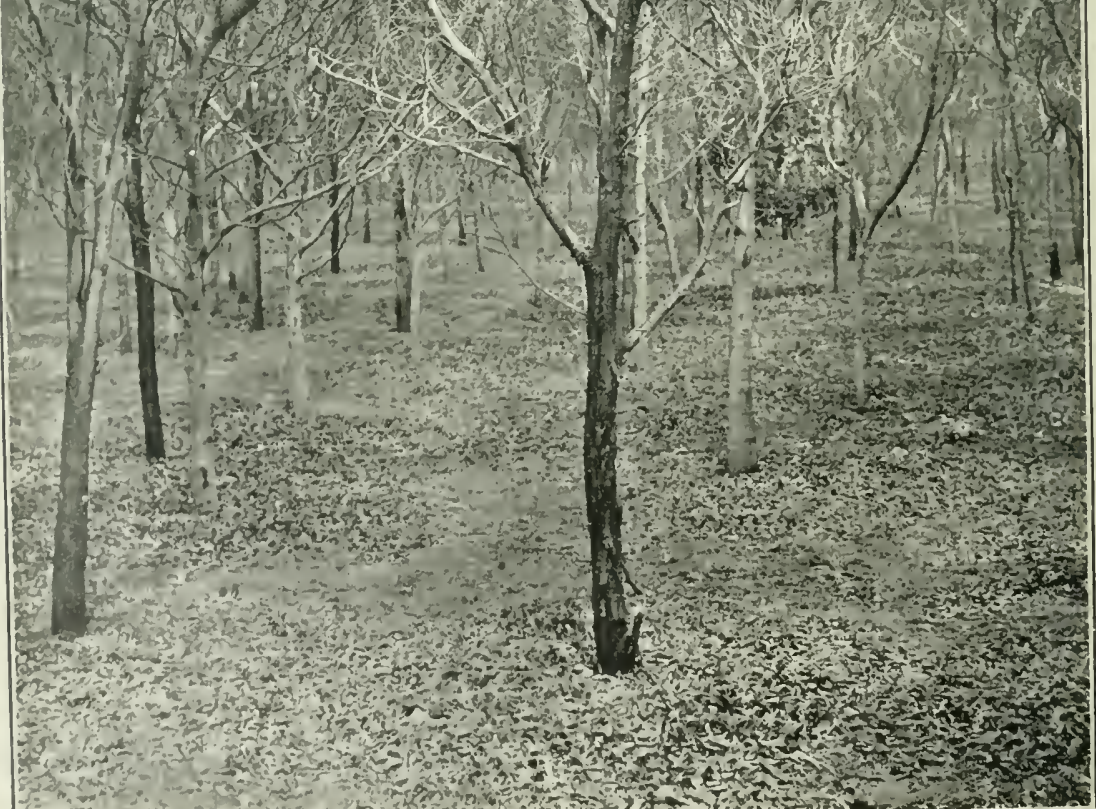


DEPARTVENT OF AGRICULTURE, VICTORIA.

\section{THE RUSTS OF AUSTRALIA}

THEIR STRUCTURE, NATURE, AND CLASSIFICATION.

D. MIAI, I I E,

Government Tregetable Pathologist.

WITH 55 PLATES (INCLUDING 366 FIGURES).

stirlbourne :

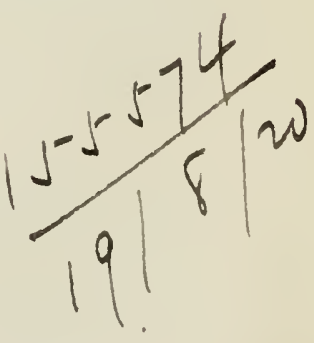

BY ACTHORITY : ROIT. S. BRAIN, LUVERIMENT PRINTER.

4:3s.

$\overrightarrow{1906}$. 
Digitized by the Internet Archive in 2010 with funding from University of Toronto 


\section{PREFACE.}

The Rusts are among the most widespread and destructive of our fungus parasites, and in order to mitigate the injury caused by them as much as possible, it is necessary to know their nature and mode of life.

The rust of wheat has naturally received a large share of attention on account of its influence upon one of our staple industries; but it is still only one of a number that require to be studied. Hence, at the several Rust in Wheat Conferences held in the different States, investigations were invariably recommended to be made "regarding all plants that are affected by rust in the different colonies," because it was felt that such a wide outlook was necessary even for understanding properly the history of a single species. The present work, then, which has been in hand for a number of years, aims at recording all rusts, as far as known in Australia at present, and this will prepare the way for a consideration of the best methods of preventing their appearance, or limiting their spread in the numerous commercial crops subject to their ravages.

The familiar saying that to know any subject well we must know the details of it, is very applicable in this case. The necessary details are given here to enable one to recognise the different forms the rusts assume, and the different stages through which they generally pass in order to complete their life-history. Besides, there is a special object in view in thus recording and describing the Rust-fungi of Australia, for this can afterwards be used as a basis in working out the life-history of those particular forms which attack our cultivated and economic plants, and often do considerable damage.

All the species known to occur in Australia are included, and when proved to be aliens, they are noted as introducet in the index. Every species of which specimens are arailable is also figured in its essential parts, so that there may be no doubt as to the form intended. In this I have been ably aided by my assistant, Mr. G. H. Robinson, who has supplied the numerous photomicrographs reproduced here, which give such a vivid representation of the peculiar and distinguishing characters of the spores. A number of drawings have likewise been executed by Mr. C. C. Brittlebank, who has had considerable experience in drawing from microscopic preparations.

The principal works consulted, or referred to, are given in the Bibliography at the end, and those wishing for fuller references, will find them in Klebahn's Die wirtswechselnden Rostpilze [The Heteroecious Rusts], 1904. This will give a good idea of what has already been done in the investigation of the rusts, but no one can fail to appreciate the work accomplished by that veteran mycologist, Dr. Cooke, in his 
IIandbook of Australian Fungi. When one considers that the material had to be sent such long distances, and often limited in quantity, as well as imperfectly preserved, it is surprising the number of rusts recorded, and the general accuracy of the descriptions. It is a matter within my personal experience, that in order to do justice to the rusts, it is necessary to have plenty of material and to have it fresh, and there is always a decicled advantage in collecting your own specimens. The Australian rusts recorded in the Handbook published in 1892 were 72 , and the number now has reached $\mathrm{I} 6 \mathrm{r}$.

To all those who have contributed specimens, my best thanks are due. The late Mr. Luehmann, F.L.S., Gorernment Botanist of Tictoria, allowed me free access to the specimens in the National Herbarium and Mr. Bailey, F.L.S., the Government Botanist of Queensland, who has done so much in every division of botany, always willingly aided me with specimens or information; the Gorernment Botanist of Ner South Wales, Mr. Maiden, F.L.S., as well as R. T. Baker, F.L.S., of the Technological Museum, and $A$. G. Hamilton also supplied me with any material required from the sister State, as Well as Dr. Morrison, of Western Australia, and Mr. Rodway, F.L.S., of Tasmania. Messrs. Molineux and Quinn, of South Australia, have also contributed, and Mr. J. G. O. Tepper, F.L.S., has generously supplied me with numerous, and often type specimens from his extensive collection.

My colleague, Mr. French. F.L.S., Gorernment Entomologist, and his assistant, Mr. C. French, junior, never lost an opportunity of securing specimens in their frequent collecting trips; and Messrs. Reader and Musson have added new species to the list. I have also to acknowledge the courtesy of the Director of the Royal Gardens, Kew, in supplying me with any specimens required for verification or illustration.

No one is more conscious than myself of how much yet remains t: be done before the Rusts of Australia are thoroughly understood, but the present work will at least lighten the labours of those who desire to increase that knowledge, and by the combined efforts of various workers in this promising field, their true nature and life-history may be so revealed that the ravages due to them, in a congenial climate such as ours, may be reduced to a minimum.

Mellourne, March, i 906. 


\section{CONTENTS.}

\section{PART FIRST.}

CHAPTER.

PAAE

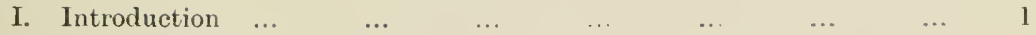

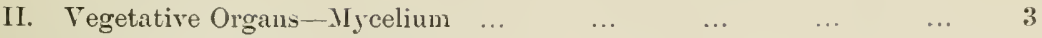

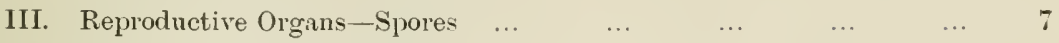

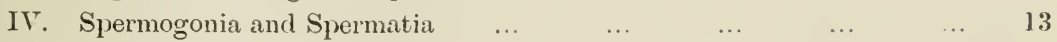

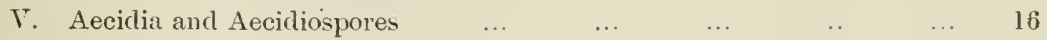

$\begin{array}{lllllllll}\text { VI. Uredospores } & \ldots & \ldots & \ldots & \ldots & \ldots & \ldots & \ldots & 19\end{array}$

$\begin{array}{llllllllll}\text { VII. Teleutospores } & \ldots & \ldots & \ldots & \ldots & \ldots & \ldots & \ldots & 23\end{array}$

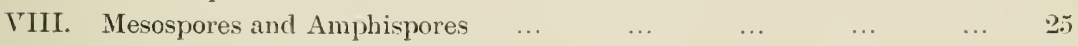

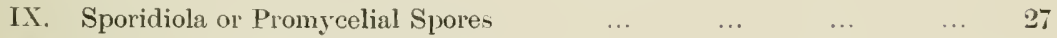

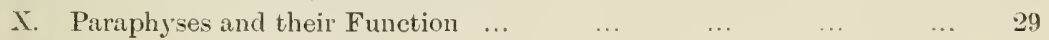

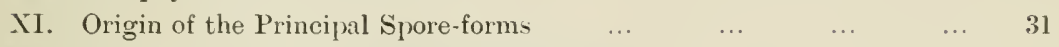

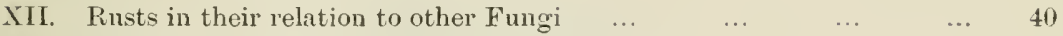

$\begin{array}{llllllll}\text { XIII. Incligenous and Introduced Species } & \ldots & \ldots & \ldots & \ldots & 42\end{array}$

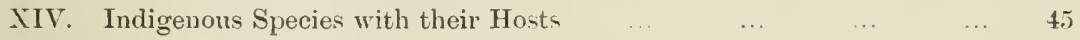

$\begin{array}{lllllllll}\text { XV. Anstralian Distribution ... } & \ldots & \ldots & \ldots & \ldots & \ldots & 50\end{array}$

$\begin{array}{llllllll}\text { XVI. Origin and Specialisation of Parasitism } & \ldots & \ldots & \ldots & \ldots & 52\end{array}$

$\begin{array}{lllllllll}\text { XVII. Heteroecism and its Origin } & \ldots & \ldots & \ldots & \ldots & \ldots & 55\end{array}$

$\begin{array}{lllllllllll}\text { XVIII. Predisposition } & \ldots & \ldots & \ldots & \ldots & \ldots & \ldots & \ldots & \ldots & 60\end{array}$

XIX. The present position of the Rust in Wheat question in Australia _.. 64

\section{PART SECOND.}

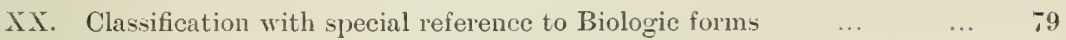

XXI. Systematic Arrangement and Technical Descriptions-

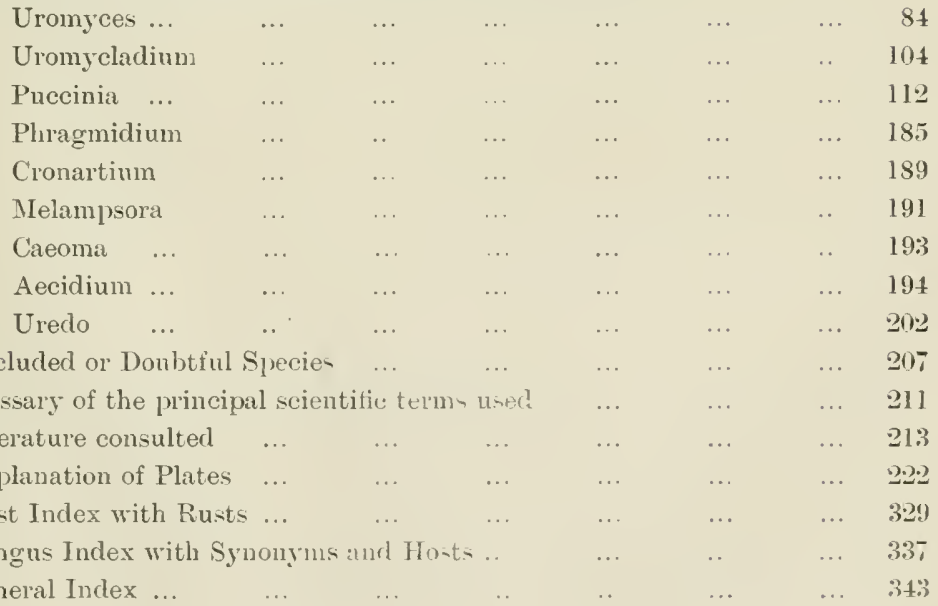





\section{PAR'T' FIRST.}

GENERAL CHARACTERS AND MODE OF LIFE. 



\section{CHAPTER 1 .}

\section{INTRODUCTION:}

The Uredineae, or rusts, constitute one of the most important groups of parasitic fungi, and their ravages are known wherever plants are cultivated. The cereals and grasses of our fields, the fruit trees of our orchards, even the ornamental plants of our gardens, and many of our forest trees are attacked by members of this family, and their study is not only interesting from the point of view of the scientist, but from that of every grower of plants for pleasure or for profit. Rusts are usually so conspicuous that they attract the attention of even the ardinary observer, and they have been known and recognised even from the earliest times. particularly from their blighting effects on the wheat and corn crops.

Although so long known as regards their naked-eye characters, and the effects they produce, their structure and life-history have only been understood within comparatively recent times, and even now there are many points concerning them which await investigation.

Their structure essentially consists of an inconspicuous mycelium bearing the usually conspicuous spores, and while this vegetative mycelium is generally similar throughout the group, the spores produced by it are very dissimilar. The general study of this group will therefore mainly resolve itself into a knowledge of the different spore forms, and their relation to each other, either on the same plant or on different plants. The finishing spore or telcutospore may be regarded as the ultimate stage of the Uredineae, and which, after usually resting for a period, long or short, germinates by putting forth a germ-tube, which bears. in turn, another kind of spore. The germ-tube is known as the pro-mycclinm, and the spore as the promycelial spore, or sporidiolum, so that if the latter is regarded as the starting point, the teleutospore will constitute the finish.

Between these two forms there may be various intermediate stages, and the series may consist of the following:-

I. The sporidiolum, when it produces its germ-tube, enters the tissues of the host-plant, and may either produce from its mycelium teleutospores similar to those from which it originated; or

2. It may give rise to uredospores at first. and subsequently teleutospore; or

3. It may produce aecidiospores, uredospores, and teleutospores in succession, the aecidiospores being generally preceded nr accompanied by a peculiar form of spore, known as a spermatium.

Hence the complete series of spore-forms will be spermatium, aecidiospore. uredospore, teleutospore, and sporidiolum, although between the initial sporidiolum and the final teleutospore, one or more of the abore mar be suppressed or omitted in the life-cycle. 
This succession of spore-forms may be represented graphically by the following diagrams:-

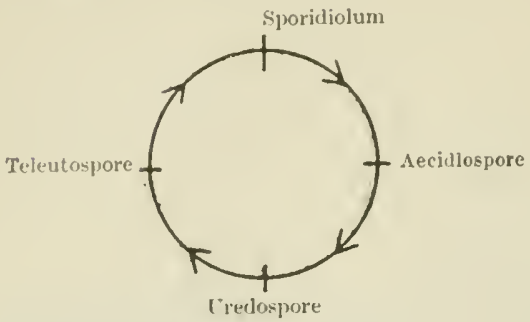

Fig. 1.

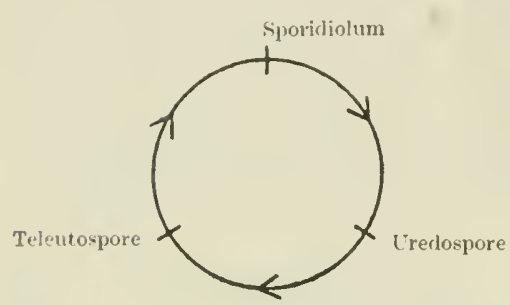

FIG. 3.

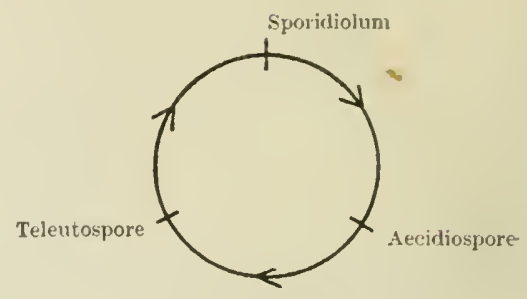

F'IG. …

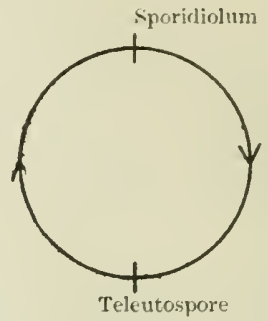

FIG. 4.

The first shows the complete cycle of derelopment in which all the spore-forms follow each other in invariable order, and this is the most common form. In the second the uredospore is suppressed, and the number of species undergoing this contracted cycle is much reduced. In the third the aecidiospore is wanting, and the number of forms is still further reduced. And in the fourth the cycle of development is reduced to its lowest limits, a direct succession of teleutospores occurs, and the number of species, instead of reacting a minimum, probably ranks next to those with a complete development.

The spermatia succeed the sporidiola, and are generally present in the life-cycle, but they do not enter into the general development.

Besides these regular forms, there are others which are generally regarded as representing either stages in the life-history of imperfectly knowm species or degraded forms of which only the uredospores or aecidiospores are known.

The subject, therefore, naturally divides itself into a consirleration of the regetative organs or mycelium and the various reproductive bodies or spores enumerated above, together with the structures accompanying them.

The life-history of each form, as far as known, will be briefly sketched; but this has still to be investifated in most of the recorded species. 


\section{CHAP'TER II. \\ Vegetative Organs-Mycelium.}

Ihe vegetative portion of many fungi is rery inconsplcuus as compared with the reproductive, but its importance is not to be measured by its size or extent, rather by the part it plays in the life of the organism; and since it is the foundation of the whole, it is worthy of the most careful study.

Of late years, however, this part has come into special prominence, particularly in the case of the cereal rusts, for it has been asserted that it is not always by external infection that the rust begins its career in the growing plant, but that in some cases it originates from within, and this theory will engage our attention later on. Meanwhile this is referred to to show that the key to the propagation of the rusts from year to year may be not only on the surface, among the special reproductive bodies which spread it throughout the growing season, but also in the interior among the cells where the first beginnings of its life may appear.

Among the recent investigations on the mycelium, there are two which stand out on account of their completeness. owing to the use of the most modern histological methods - the one by Professor Marshall Ward ${ }^{9}$ on the Histology of Uredo dispersa Eriks, and the Mycoplasm hypothesis, and the: other by Professor Eriksson ${ }^{14,15}$ on Das vegetative Leben der Getrciderostpilze [The Vegetative Life of the Cereal Rusts]. The study of an individual case will prepare us for the more general examination of the mycelium throughout the rusts, and we will begin with that of Puccinia dispersa Eriks., or, strictly speaking, P. bromina Eriks., which Ward has so thoroughly dealt with and illustrated with such admirable clearness.

Starting with the germination of the uredospore on the surface of the leaf, which usually occurs within twenty-four hours, we find that the young germ-tube grows rapidly, and that the nucleus of the spore passes into it; sometimes, however, two or more nuclei may appear in it. The tip of the tube begins to swell over a breathing pore or stoma into a thin resicle, and the contents derived from the spore accumulate here.

This external vesicle or appressorimm, as it is called, is the first stage in inoculation from the outside, for a thin process is passed through the opening of the stoma, and swells inside into another vesicle. The protoplasmic contents are transferred from the external to the internal resicle, and so the future growth takes place among the tissues of the leaf.

At one or more points this inner swelling forms a delicate tube, into which the protoplasm is ayain transferred, and its nucleus soon divides. This is the first-formerl hypha, and the foundation of the regetative sistem. It soon branches and derelops cross partitions or scpia, and extends rapidly. among the cells of the host-plant to form the mycelium. Even at an early stage, when the primary hypha is still unbranched and unseptate, suckers or haustoria may be formed to provide a large imbibing surface for the fungus. The haustorium begins as a small delicate process or projection from the hypha, and this pierces the cell-rall and swells up into a minute spherical head, which is provided with a nucleus. Shortly after entering the cell this head takes on an irregular growth, and may assume a rariety of shapes.

The mycelium now becomes denser towards the surface. and prepares for the production of the reproductive bodies or spores. This constitutes the history of the mycelium from the time it starts as a germ-tube until it rearhes its full develnprent. 
Eriksson has investigated on similar lines. and fully illustrated the inycelium of Puccinia glumarum, Eriks. and Henn., but with this important lifference that instead of starting with external infection from a spore, he begins with an assumed internal germ of disease, which he considers in certain cases to be a source of rust, in addition to the ordinary infection by spores. It is often stated that this rust passes the winter as mycelium in such leaves as are attacked in late autumn, and which persists till the following spring; but the examination of hundreds of sections of leaves taken from rusty plants, although not rusty at the place chosen for section. failed to reveal the presence of such a mycelium dormant in the tissues. It may be taken for granted, then, that there is no mycelium to start with, and it will be interesting to follow Eriksson's theory as to the manner in which the mycelium arises afresh in the tissues. In certain cells of the autumn and spring leaves a peculiar thick plasma is found, containing a distinct nucleus, and this Eriksson considers to be, not the ordinary protoplasm of the cell, but a mixture of it, with the earliest regetative form of the fungus. This intimate mixture or symbiosis, or living together of the ordinary protoplasm of the host and that of the fungus he distinguishes as mycoplasm. This mycoplasm is stated to occur only in certain cells. which farours the assumption that it is not a mecessary constituent of the cell.

The next step and the youngest stage of mycelial formation, according to Eriksson, is the presence of a plasma in the intercellular spaces, which is partly in the form of growing filaments, partly as irregular masses. 'There are no septa, and no distinctly recognizable nucleus, and even a distinct wall is not formed. The primary stage is quickly followed by a secondary stage, in which the only visible advance is a very distinct nucleus. These two stages are very sharply marked off from the normal mycelium. loth by their plasmodia-like nature and the absence of transverse septa. and for distinction the special name of protomycelium is given. Eriksson has no doubt that the intracellular mycoplasm and the intercellular protomycelium are genetically connected, but this, which is a necessary link in the chain of evidence, requires to be further investigated. (Note I, p. 74.) The formation of haustoria is the next prosess, and consists in a small straight prolongation of the protomycelium passing into the interior of the cell, and at the apex forming a globular swelling, probably containing a nucleus. Soon the whole forms a sac-like irregular organ. which may become detached from the protomycelium. These detached bodies in the cell were mistaken by Eriksson for a preliminary stage in the formation of hyphae, and called "special corpuscles," but Ward pointed out their true nature, and that they really had been formed by, instead of giving rise to the hyphae, a correction which Eriksson himself has acknowledged. The haustoria are often found closely adjoining the nucleus, which thereby degenerates, and simultaneously with the shrinking of the nucleus, and soon after the first entrance of the haustoria, transverse septa begin to be formed in the protomycelium. In most of the cells thus formed several nuclei are contained, and the stage is now reached where a true mycelium is present, composed of hyphae.

This multiplication of the cells of the funzus is a sign of adrancing malurity. By continued division a true pseudo-parenchyma is formed. ind at certain spots, where the cells appear to be particularly rich in foodmaterial, a kind of hymenium arises, from which ultimately the spores are detached. Where spores are being formed, there the complete destruction of the cells of the host-plant occurs, and now the regetative life of the fungus is cnded, and the reproductive phase is entered upon. 
Perennial Mycelium.- In contrast to the localized mycelium, there may be a mycelium with unlimited growth which does not confine itself to particular spots, but may permeate entire shoots, or even the whole plant. This is known as a perennial mycelium, and wherever it occurs the fungus may reappear on the same plant year after year without the necessity for reinfection by means of spores.

This vegetative reproduction through a perennial mycelium is not always easy to prove, but its importance cannot be overrated, for hidden in the tissues of the plant it cannot be reached by the ordinary means for controlling the growth and spread of fungi, but involves the destruction of the plant, or at least of those parts which harbour it. As Australian examples, we may note Uromyces trifolii, which attacks the white clover (Trifolium repens) and Phragmidium subcorticium or rose-rust, in which the mycelium of the aecidial stage penetrates all the tissues, and in each succeeding year forms a mew layer beneath the old.

Uromycladium notabile and $U$. tepperianum occurring on species of Acacia are further examples, for the mycelium gives rise to large galls, which persist from year to year and produce spores.

Eren although the host-plant is an annual, and dies down every year, it is still possible for the mycelium to be perennial, for it may be carried over winter in the seed, as in the case of Uromyces cuphorbiae, according to Carleton ${ }^{3}$.

IVitches'-brooms.- It is not unusual among the forest trees and shrubs of Europe to find shoots very much deformed and distorted, and looking at a distance like large birds' nests or brooms, and to these the popular name of witches'-brooms has been given. These peculiar and diseased conditions were difficult to account for, and so the idea may have originated with superstitious people that the trees were bewitched, in order that the witches might be provided with brooms for their midnight rides, hence the name.

But the true cause is seen when the matter is investigated in the light of our present knowledge, and parasitic fungi are often found to be responsible for the strange transformations of the normal shoots into the dense twiggy, irregular tufts met with. This may also be produced by other means, such as gall-mites, but a very striking case and the first recorded instance in Australia is that of the rust-fungus, Cronartium jacksoniae, which deforms the shoots of various leguminous plants as shown in Pls. XXXVII., XXXVIII. Uromycladium tesperianum also produces this peculiar appearance on Acacias as shown in Pl. XLII.

The perennial mycelium in the shoots stimulates a number of buds to abnormal growth, quite different from the ordinary, and the result is seen in the numerous densely crowded and considerably altered shoots as compared with the normal. They are also thickly studded with the ruddy hrown columns of teleutospores, in the case of Cronartium, which stand out like so many curved or straight, stiff bristles, towards the ends of the shoots, which are gradually being destroyed. Next year the mycelium will grow into the young shoots and produce the same result.

Formation of Galls.-It is well known that the mycelium of fungi exercises a stimulating effect upon growth. and not only causes the cells to grow larger and divide more frequently than usual, and the chlorophyll to disappear. but it may alter the character of the tissues. When an insect pierces the young and living tissue of a plant with its proboscis or ovipositor, it often causes the cells immediately surrounding it to grow and divide more rapidly than elsewhere, so that a swelling of the tissue occurs. which is known as a gall. So among the rusts there are instances where the stimulation of growth occurs in a marked degree, and if a regetable gall be 
considered als a morlid enlargement of the affected part of the plant, due to parasitic agency (Connold ${ }^{1}$ ), then there need be no hesitation in calling these structures galls.

l'erhaps the most striking illustration of a gall is seen in Uromycladium tepperianum. In the neighbourhood of Melboume hedges of Kan. garoo Acacias ( $A$. armata) are being gradually and completely destroyed by the ravages of this fungus, which resemble on a superficial view large galls caused by insects. Most of the branches, including the phyllodes, are infested with the chocolate-brown swellings, which may be in the form of a succession of small excrescences about the size of peas, or collected into large clumps about the size of walnuts, and measuring $4 \mathrm{~cm}$. across. In some cases they are solid round knobs, and the external appearance is due to the dense covering of the chocolate-brown teleutospores. One of the largest was met with at Myrniong on Acacia implexa of an irregular leg-ofmution shape anil weighing about $3 \mathrm{lb}$. (Pl. XI.I).

On A. pycnantha, or Golden Wattle, the galls are as large as potatoes, and in some of the wattle plantations, where the trees are cultivated for their bark, they hang in large numbers from the branches like so many fruits, and numbers of the trees are either dying or dead. The swellings are primarily caused by the fungus, and then various insect larvae may ultimately invade them, boring and tunnelling through them. In A. implexa the sivellings may run along the whole length of the elongated phyllodes, and in $A$. salicina there is an all-round swelling of the branches, and the periderm is ultimately ruptured. Magnus ${ }^{3}$ found the galls to be permeaterl ly an intercellular mycelium, which was multiseptate with numerous and somewhat branched haustoria.

Some very large galls were also found on the Black Wattle (A. decurrens) and Silver Wattle (A. dealbata) either surrounding or terminating the branches, and caused by $U$. notabile. Some measured 4-5 inches across, and $3-4$ inches was not uncommon, while one of the largest weighed $15 \mathrm{c}$.

The peculiar gall-like swellings caused by Gymnosporangium may be mentiunerl, the mycelium of which is perennial in the various species of Juniper, and from their appearance are popularly known as "cedar apples" in America. It may be an annual gall only bearing the teleutospores for one season, or a peremial gall, producing successive (rops ( f teleutospores year after year, and not requiring the transfer of the spores each seasron.

Localized 1/1celium.- The localized mycelium may likewise produce conspicuous swellings, particularly on the stem and midrib of the leaves. Thus, that of Aecidium urticae causes hard curved thick swellings of (.$) n$. siderable extent, and such a development of starch takes place in some Himalayan species of nettle attacked by this fungus that the natives eat the overgrown and hypertrophied stems for food.

In other cases the affected tissues may be so stimulated by the localized mycelium as to cause their rleath. Thus almond leaves have been found here badly ridcled with "shot-hole." due to the mycelium of Puccinia pruni Pers, just as $P$. malvaccarum may also destroy a circumscribed area which lecomes separated around it. circumference, and falls our. leaving a rircular hole.

The mycelium. whether localized or perennial, is always beneath the surfare of the plant, and formed within the living tissues. "It is delicate in texture. like all internal mycelia, and branches to form a regular network, ultimately forming rompact cushions or spore-beds. It can often be tracel from a single point of infection. whence it radiates all round and sprearls, gathering material for the fresh proluction of spores. 


\section{CHAPTER III.}

\section{Reproductive Organs-Spores.}

A detailed account of the different spore-forms will be given in the systematic part in connexion with the rarious species; but it will be convenient here to take a preliminary view of some of the more essential general features, such as distribution, germination, and infection, suppression or omission, and repetition of spore-forms.

\section{Distribution.}

The most important meanis of distribution of the rust-spores, as for fungus spores generally, is the wind. They are usually exposed on longer or shorter stalks, often powdery, and their immense numbers and lightness all render them easily detached, and spread by the slightest breath of wind.

That the wind is an important factor in the distribution of rust-spores is strikingly shown in an example given by Halsted ${ }^{1}$. The asparagus rust (Puccinia asparagi, DC.) was very bad, but in one field the plants had been cut over, and the rusty brush removed in order that the new growth might escape. On examining this field about five weeks afterwards, he found that the rust showed only on one side of the green plants, and that was the side exposed to an old and very badly rusted asparagus bed. That this was the source of infection was obvious from the fact that a house with a few trees around it intercepted a portion of this field. and there was less rust upon that portion of the new bed in line with the house.

The dust-storms which occur will also be a fruitful source of spreading them, and in our northern areas where the dust is sometimes carried in such quantities as to obliterate fences, it can easily be understood how even in virgin soil the spores of wheat rust may be found.

The rain will also help to scatter them, particularly over individual plants, and on the surface of the soil, for it is a common observation how rusty plants are cleared after a heary shower.

Insects as well as other animals serve the same purpose. I have often observed the larvae of a species of Cecidomvia feeding on uredo and aecidio-spores, and at the same time spreading them while crawling along. Lindroth ${ }^{1}$ has observed in Finland the occurrence of these larvae on no less than sixty-one species of rusts, and similar larvae have heen found feeding on the conidia of various species of Oidium (Salmon ${ }^{1}$ ). In some pot experiments with wheat, I found the larvae associated with the Oidium of F. graminis, and feeding on the conidia. At first sight it might seem as if this devouring of the spores would tend to reduce the fungus. but the wholesale way in which the spores are carried about more than counterbalances any decrease from this cause.

\section{Germindtion.}

As a rule, uredo and aecidio-spores germinate easily in a damp chamber, and I have found the method recommended by Plowright to be very convenient. A gardener's propagating glass is used. placed on a plate of water. and a simple stand is made with two flat oblong pieces of guttapercha. Holes are easily bored in them. and glass rods placed parallel iretween them, so that the microscopic slides may be laid across the rou!s. 
The influence of various chemical substances on germination has been investigated, and it has been found that some substances, such as solutions of sugar and nitrate solutions, hasten germination; but for general purposes water alone is all that is necessary. Sometimes, however, the spores will grerminate and infect the leaves of the host-plant, although they may not do so in water.

Freeman ${ }^{1}$ found this to be the case in dealing with the uredo-spores of Puccinia bromina, and concludes that the negative results in distilled water tests are not always an indication that the spores are incapable of germination. The temperature seems to exercise an important influence. Eriksson found that in many cases the spores germinated more freely if previously exposed to a temperature of $\circ \mathrm{deg}$. C. or under, and Marshall Ward that the uredospores of $P$. bromina were not injured by being exposed' to a temperature of $-5 \mathrm{deg}$. C. for ten minutes, while the same temperature continued for four to five hours killed them. Heat or cold, drought or damp, age and ripeness, are all factors of importance in germination.

\section{Duration of Germinating Power.}

How long do the spores retain their germinating power is an important question to settle; but not many definite determinations have been made.

De Bary states that the uredospores of $P$. graminis, kept dry, lose their germinating power in one to two months.

Marshall Ward found that the uredospores of $P$. bromina preserved dry for sixty-one days retained their germinating power; but it was feeble.

Barclay found certain uredospores still capable of germination after from two to eight months, the leaves on which they occurred being kept lry.

It is a question of great scientific interest in connexion with rust in wheat if the uredospores can retain their germinating power during the winter. The results vary, as might be expected, according to the conditions prevailing at the time. In contrast to De Bary's results. Eriksson found that the uredospores of $P$. graminis lost their germinating power Juring the winter if kept in the open, but retained it if kept inside. Iritchcock and Carleton ${ }^{1}$, however, collected fresh uredospores from growing plants of $P$. rubigo-vera at various times during the winter, and fnund them capable of germination. In our comparatively mild winters the uredospores retain their power of germination, and this seems to be the means whereby the fungus is continued from season to season. I have had freshly gatherer uredospores of $P$. graminis from growing wheat and oats, and $P$. triticina from wheat germinating freely in water in winter (June to August). The uredospores can germinate at once, and directly infect the host-plant, or they can act as resting spores for a time, and freely infect the next season's growth, under the climatic conditions which Inevail here.

The germination of teleutospores takes place at different periods, according to the nature of the species. They may either germinate immediately on reaching maturity, or, as is the case in the majority of heteroecious tusts, only after undergoing a period of rest-in the old world usually in the winter, but here, as no doubt sometimes elsewhere, the period of rest is often partly in the summer, when drought checks growth as effectively. as the cols of a European winter.

Eriksson ${ }^{10}$ has shown that the teleutospores of $P$. graminis, with few exceptions, only germinate in the spring following their formation. and only then if kept in the open during the winter. He kept spores in the herbarium for one or two winters, and then on exposing them for another winter, he found that they germinated, but this was exceptional. 
In other species there is considerable variation. According to Woronin ${ }^{1}$, the teleutospores of $P$. helianthi germinated equally well when kept dry in a room, or when taken from the leaves of a plant which had been under the snow all winter; and Carleton ${ }^{3}$ found them to germinate even without a resting period.

After wintering, Eriksson found that the teleutospores of $P$. graminis could retain their germinating power even to the beginning of autumnSeptember in Sweden.

In Victoria the germination of the teleutospores of $P$. graminis has been tested for several seasons, and it is found that after a period of rest extending over about eight months, and including the usually hot and dry summer, they begin to germinate in our spring (September), and if the weather conditions are favourable, may retain their germinating power until November. Rusted straw has been kept outside exposed to the weather, and in a room, but no germination took place outside of the above months. When spores have once begun to germinate it is a mistake to suppose that they will all germinate at the same time, for there is a certain irregularity about germination in the open which causes the period of germination to be considerably extended.

\section{INFECTION.}

The mode of infection usually varies in different classes of spores. The germ tube of the uredospore or aecidiospore generally enters by the stomata into the tissues of the host-plant, while that of the sporidiolum bores through the epidermis direct, and this difference in the mode of infection influences the stage at which it occurs in the development of the host-plant. The sporidiola are, as a rule, only able to infect young and tender portions of the plant; but the uredospores and aecidiospores can evidently attack old and fully developed organs.

Further, since the germ-tube of the sporidiolum in piercing the epidermal cells must dissolve the wall at the spot where it enters, there is evidently a reciprocal influence exerted between the parasite and its host; but eren in the case of the uredospores and aecidiospores, where an entrance is effected through the stomata, there also exists some mutual relation, for it is only in certain hosts that the parasite can grow and develop.

This relation will be more fully dealt with when the origin of parasitism is considered, but meanwhile the fact may be emphasized, that the mere entrance of the germ-tube through the stoma does not constitute infection. Miss Gibson ${ }^{1}$ carried out infection experiments with uredospores and aecidiospores of various rusts on a number of plants other than the original hosts, and she found that while the germ-tube may enter the stoma freely, yet, once inside, death ensues sooner or later, and in no single instance was a haustorium formed. The fungus was unable to penetrate the cells of the foreign host-plant, and so died of starvation.

The period which elapses between the entrance of the germ-tube into the host-plant and the appearance of the result is known as the incubation period. During this time the germ-tube grows and ramifies among the tissues, abstracting nourisliment from the cells by means of haustoria, and finally proceeds to the formation of fresh spores. The first visible trace of this does not generally appear before eight days, but, according to the nature of the fungus, it may take much longer. Schimper, in his masterly work on Plant Geography, begins with the statement- "No factor affecting plant life is so thoroughly clear as the influence of water," and even for parasitic fungi this factor is of prime importance. Smith ${ }^{1}$ has determined the water relation for Puccinia on asparagus, and probably the same prin. ciple applies in a genera! way to other rusts. From a study of the direct 
relation or the effect of atmospheric moisture upon the spores or mycelium, it has been shown that dew is absolutely necessary for infection, and of more importance than rain, and, in fact, that without dew there can be no infection. Further, that the effects of atmospheric dryness not only influence spore germination, but also spore production, and the aecidial and uredo stages are checked thereby, but if the mycelium is not completely destroyed, the teleuto stage may appear independently of conditions unfavorable to the others. The indirect relation of water or the effect of soil moisture. which acts upon the parasite through its host, has also been studied and shown to be of great importance. An abundance of soil moisture at the growing season. in the case of asparagus rust in California, is stated to increase the vigour and vitality of the host, and retard the development of the fungus. That the growth of the fungus is retarderl by increased vitality of the host scarcely agrees with Marshall Ward's conclusions in regard to brome rust (Chap. IVIII.). That the weather exercises a commanding influence in hastening the development of rust in wheat is abundantly shown by its rapid spread in hot "muggy" weather, especially when accompanied by heavy dews. Irrigation before ploughing gives the wheat a good start, but if applied in the spring it makes the wheat soft and rery liable to rust, a case in which great vigor of growth of the host is followed by a strong development of the rust.

While the ordinary mode of infection is as stated above, exceptions may occur. Thus, according to De Bary, the germ-tube of the sporidiolum of Puccinia dianthi ( $P$. arenariae) may enter by the stomata, and Bolley ${ }^{4}$ gives illustrations to show that the germ-tube of the uredospores of $P$. triticina may enter direct through the epidermal cells as well as by the stomata.

\section{Suppression OR OMISSION OF SPORE-FORMS.}

As already pointed out in the Introduction, the complete cycle of development follows an invariable order. The germinating teleutospore gives rise to sporidiola, from the mycelium of which arises the spermogonia and aecidia; later the uredospores appear, and finally the teleutospores complete the cycle.

The aecidio, uredo, and teleutospore forms are represented respectively for convenience by the Roman numerals I. II.. III.. and if the sporidiola arising from the teleutospore are designated by IV., and spermogonia by a cypher, then it will be comparatively easy to represent the different stages diagramatically. A complete cycle of development will be represented thus--O., 1., II., III., IV.

'The teleutospore with its sporidiola is believed to be a constant factor in the cycle, although there are various rusts in which it has not yet been found, so that I. or II., or both, may be omitted or suppressed, as well as $\mathrm{O}$, which. however, is rarely absent. The germinating sporidiolum produces a mycelium which may in turn give rise to spermogonia and aecidia. These may either occur on the same species of host-plant as that which vears the teleutospore, and the rust is thus said to be autoccious, or they may occur on a tutally rlifferent plant when the rust is said to be heteroccious. The aecidiospore on geminating may skip the uredo stage, and directly produce the teleutospore, and thus the crcle is shortened. There are numerous examples of this in Australian forms, among which mar he mentioned the rust on the marigolil ( $P$. calcndulae), and that on the daisy ( $P$ '. distincta).

This variation in the alternation of spore-forms has been used by Schroeter as a basis of grouping, and although these biological sections by no mcans indicate close aftinity, yet they conveniently group together forms whirh have similar associated stages. Taking the genus Puccinid as an 
example-and it applies to other genera as well-the complete crcle is clesignated Eu-puccinia, and represented diagramatically as O., I., II., III., IV.

Then the stage in which the uredo does not appear is known as. Pucciniopsis, and represented by O., I., III., IV. Again, the germinating sporidiolum may produce a mycelium which bears spermogonia and uredospores, thus skipping the aecidial stage. This stage is called Brachypuccinia, and represented by O., II., III., IV., or the spermogonia may likewise be suppressed when practically only half of the cycle is retained, and it is known as Hemi-puccinia, represented by II., III.. IV. This is a stage which is probably based upon imperfect observation, and the presumed absence of the spermogonia. Further, the germinating sporidiolum may skip the aecidial and uredo-stage and produce the teleutospore direct, with its accompanying spermogonium. This is known as Lepto-puccinia when the teleutospore germinates immediately, and Wicro-puccinia when it undergots a period of rest. It would be represented diagramatically as O. III., IV.

As might be anticipated. the greatest number of species have a complete life cycle, and next to that come probably: those species in which the life cycle is reduced to its lowest limits, thus showing that the aecidial and uredo generations may be dispensed with. In the former case there is, as it were, a succession of forms adapted to the varying seasons. Well fitted to meet any sudden changes, and living upon the same, or having a change of host-plant as may be found most convenient, while in the latter the change consists not in the variety of spore-forms, but in having a general purpose spore, which can either germinate upon the living plant as soon as it reaches maturity or undergo a period of rest in the decayed organic matter before producing sporidiola. Hollyrock rust, or Puccinia malvacearm, is a good illustration of a single-spored form adapting itself to the most varied conditions, and making its way in the world.

The complete scheme for grouping Puccinias, according to the alternation of their spore-forms, is as follows:-

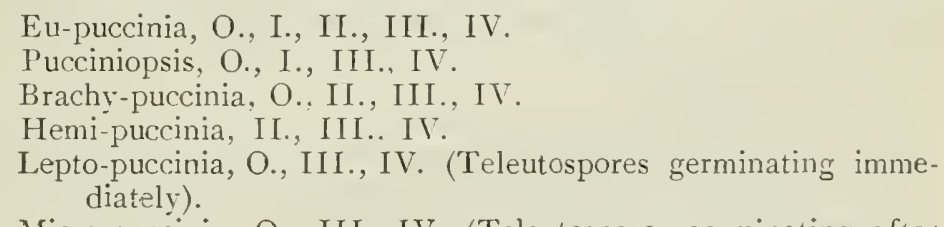

Micro-puccinia, O., III., IV. (Teleutospores germinating after a period of rest).

\section{REPETition OF SPORE-FORMS.}

In connexion with the suppression or omission of spore-forms, we may also consider the repetition of spore-forms, because it would appear that in many instances the suppression is brought about or initiated by one of the spore-forms being able to repeat itself in the course of the cycie. and thus making up for the loss of one member of it. It is the doctrine of substitution in another form. This will be more conveniently dealt with when treating specially of the aecidio and uredo spores. where it will be seen that when the uredo generation is suppressed or omited, the aecidiospores often repeat themselies, and when the aecidial generation is omitted thie uredospores repeat. themselves.

\section{Investigation of Spores.}

The microscopic investigation of rust spores is comparatively easy, although it requires careful observation with regard to their minute details. 
If the loose spores are examined as to their individual structure, whether aecidio uredo or teleutospores, it is simply necessary to mount then direct, and I find the most convenient mounting medium to be glycerine and water in equal proportions. For permanent preparations glycerine jelly may be preferable; but for the rapid examination of material the above serves very well, and where desirable the mount can be preserved. 'The surface markings of the spores are often obscured in mounting, and have sometines lseen overlooked by otherwise good observers. As a general rule, they are best seen in the dry condition and without any special preparation, but they are usually also seen in glycerine and water, especially: if examined when freshly mounted.

'The number and position of the germ-pores require to be carefully: studied, since they are often of specific value, and there are various reagents which show them up with great clearness. Among these, 1 have successfully used lactic acid and Bismarck brown.

A $5 \circ$ per cent. solution of lactic acid was used as a mounting medium, then the spores were added, and the slicle was heated over a spirit-lamp just until the liquid reached the boiling point. Sometimes it is necessary to boil for a little in order to get the best results, taking care not to burst the spores, but as a rule bringing it to the boil is sufficient. After the preparation has cooled, the cover-slip is placed over it. "Some use a mixture of equal parts of glycerine and alcohol for mounting the spores before adding the acid.

boiling in lactic acid not only drives out the air and makes the spores more transparent, but it swells them to their normal shape and size, and not only brings out the germ-pores, but the surface markings as well. For pale-coloured spores or spores which have partially lost their colour through age, I have found nothing to surpass Bismarck brown. The clear germ-pores show up well against the brown stain. The spores are simply laid in the smallest possible amount of water or water and glycerine on a slide, then thoroughly separated by stirring with a needle. Sufficient of the stain is next applied, covered, and after gentle boiling the spores are ready to be examined. It stains quickly, but does not overstain, and is fairly permanent.

Soaking hard tissues for twenty-four hours in a solution of caustic potash or caustic soda softens them wonderfully, and mounts made from minute pieces of the material thus treated are often extraordinarily beautiful, and the relation of the parts to one another is preserved in a surprising manner. Though soaking for several days nearly always destroys the colour of the spores, ret details may sometimes be distinguished with a certainty not obtainable by any other method.

For determining the average size and shape of the spores I know nothing better than photography. Numbers of spores are photographed together, and the general shape can be determined by comparison, while the size is deduced trom the exact measurement of individuals in large groups. In this way the arerage size has been obtained for the teleutospores chiefly, of all the species accessible for observation. At the same time a large number were measured direct by an eve-piece micrometer and the results compared. All the microscopic investigations were made with \%eiss' aporhromatic objectives, and the photomicrographs with lenses of Watson's holuscopic series. 


\section{CHAPTER IV.}

\section{Spermogonia and Spermatia.}

The spermogonium, sometimes called pycnidium, is a small punctiform body, hemispherical to flask-shaped, produced beneath the epidermis or cuticle, and ultimately the narrow neck bursts through in order to allow the contents to escape into the air. The narrow opening is generally surrounded by a brush of sterile projecting stiff hyphae, the so-called paraphyses, and in the interior of the spermogonium there are numerous conrerging hyphae surmounted by very minute oval or rounded bodies borne in short chains-the so-called spermatia. These bodies were considered to be of the nature of male sexual organs, hence the name; but whatever may have been their original function, now lost in the course of development, there is no reliable evidence to support the' view of their being sexual in function.

The spermatia are embedded in a sugary secretion, and though it is not known whether this serves to cause the spermatia to germinate, insects are probably attracted to the spermogonia sometimes by means of this sweet bait, and also by their powerful and penetrating odour, as in Puccinia suaveolens Pers., which is so named on account of its sweet scent. The honey colour of the spots may also serve as an attraction, and the projecting hairs or paraphyses are believed to retain the spermatia and prevent them being washed away.

Colour, scent, and honeydew will thus co-operate in alluring insects to the spot, and the evident resemblance of these relations to those which prevail in the fertilization of flowers by insects naturally led to the belief of the spermogonia and spermatia being concerned in some way with the fertilizing process. This view was further strengthened by the fact that in Lichens, which possess similar structures, there called pycnidia, a true process of fertilization occurs. But actual experiments fail to prove any such connexion, and the probabilities are that the original function has disappeared owing to modifications consequent upon' the fungus becoming parasitic. Spermatia do not germinate in water, but do so when placed in a suitable nutritive solution, such as white cane-sugar dissolved in water. Germination consists in a minute prolongation at one end, which ultimately becomes like the parent spore, and thus, as far as present know. ledge goes, the spermatia are isolated structures, and do not enter into the regular development of the fungus.

Spermatia, whatever may be their function, do not occur as solitary spore-forms, but always precede or accompany one of the others. They are usually associated with aecidia, but this is not invariably the case, for there may be aecidia without them, and in the absence of aecidia they may be associated with other spore-forms, such as uredospores in the case of Uromycladium robinsoni, Puccinia hieracii (Schum.) Mart. \&c., and teleutospores, as in $P$. liliacearmm Duby and Uromvcladium tepperianum (Sacc.) McAlp., and either uredo or teleuto spores, as in $U$. maritimum. The same mycelium which proceeds from the teleutospores, and produces the spermogonium, also produces aecidio uredo or teleutospores, as the case may be, although it may seem a needless waste of material and an unnecessary act, since the one is left behind in the race, while the others 
continue their further development. In a paper by Arthur ${ }^{3}$ on the Taxonomic Importance of the Spermogonium, he shows that, in the first plans, ihe presence of the spermogonium, along with its associated spore-forms, gives important information regarding the length of the life-cycle. Thus he concludes that if spermatia and uredospores arise from the same mycelium, aecidia do not occur, and if spermatia and teleutospores thus arise, neither uredo nor aecidio spores will occur. There are cases, however, in which the spermogonia are found in association with both uredo and teleuto spores, as in Uromycladium maritimum, $U$. notabile, and $U$. robinsoni. When the spermatia are associated with aecidia, it is only where teleutospores and aecidia arise from the same mycelium that it can be definitely stated that there are no uredospores.

In the second place, the characters of the spermogonium, such as position. size, form, and colour, and its relative position to the accompanying spore-forms, furnish characters for positive identification, although of minor value. There is an interesting relation of the spermogonium to other spore-forms to be noted in the cases afterwards referred to, where there is a repcated formation of aecidiospores, uredospores, or teleutospores, as the case may be, and these spore-forms do not directly proceed to their nornal development. In such cases, as far as our present knowledge goes, the spermogonium is the only one which does not repeat itself, is.s stated by Arthur ${ }^{3}$ :- "An observation more pertinent to our inquiry is that the spermogonium uccurs but once in the crcle, not being repeated with each generation of repeating aecidia or uredo. In case the teleutospore takes on the conidial function (repeating process), it is uncertain whether the spermogonium is repeated with each summer generation or not. In Puccinia malvacearum and similar Lepto-Uredineae, the spermogonium seems to be wholly suppressed even with the first generation in spring."

The question of sexuality has been raised in connexion with the presence of nuclei, but what constitutes an act of fertilization is interpreted differently by different authors.

Sappin-Trouff $y^{2}$, for instance, has observed in Uredineae having the various stages the following nuclear cycle:-

Uni-nucleate. -

Mature teleutospores.

Sporidiola.

Mrcelium. producing spermatia and aecidiospores.

Spermatia.

Bi-nucleate. -

Aecidiospores.

Mycelium, producing uredo and teleutospores.

Uredospores and

Young teleutospores.

In the mature teleutospore the two nuclei fuse, and this fusion was regarded by Sappin-Trouffy as an act of fertilization, but the fusion of the nuclei mav be interpreted otherwise. Blackman ${ }^{2}$ has confirmed the abore nuclear cycle, and concludes that the spermatia are male cells which have become functionless, the nuclear characters being those of male cells and not of spores.

The fertile cell of the aecidium or primary aecidiospore becomes binucleate lo the nucleus of a neighbouring regetitive cell migrating through the wall, and this association of the two nuclei Blackman considers to be fertilization rather than the act of fusion in the teleutospore. since the fertile rell is stimulatel to further development h the entrance of a nucleus from without.-(Note 2. page 75.) 
Massee also considers the aecidium to be a sexual product, and both authors a gree that the spermatia are not concerned in it. If the spermogonia and aecidia represented male and female reproductive organs, a distinct alternation of generations would be present, the spore-bearing stage or sporophyte commencing with the fertilized cell in the aecidium. and the eggbearing stage or gametophyte starting with the uni-nucleate teleutospore. But the most probable view is that the spermatium is a functionless organ, and its presence is an indication that the ancestors of the rusts may have possessed an alternation of generations similar to that referred to above. 


\section{CHAPTER V.}

\section{Aecidia and Aecidiospores.}

The aecidia, or cluster-cups, as they are often called, are usually brightly coloured, and attract attention not only from their colouration, but from their elegant forms as well. The mycelium derived from the germtube of a promycelial spiore may first produce its spermogonia, and then proceed to the development of aecidia, or aecidia may be succeeded by aecidia. The spore layers are contained in a receptacle or pseudo-peridium, which is formed from a simple layer of flattened sterile cells. It increases in size by the formation of new cells at its base, and is cup-shaped or cylindrical, rupturing at the apex to allow the escape of the spores.

The aecidiospores are always unicellular, and are arranged in linear series, arising from densely-crowded, erect hyphae or basidia in basipetal order. The young spores are at first separated from each other, according to) De Bary, by sterile, intermediate cells, which are soon, however, absorbed, and this makes it often difficult to prove their presence. From the mode of their formation, from above downwards, the ripe spores are at the top, and readily separate to be blown away, while the young spores become polygonal from mutual pressure, lateral and lengthwise.

The spores have usually a colourless membrane, with the exception of those of Gymmosporangizm, in which it is usually a deep brown, and in the great majority of species are provided with points, spines, or warts, to make them adhere in order to germinate. The granular contents are coloured, as a rule, with an orange-yellow or orange-red oil, although this also occurs in many uredo and teleutospores.

Germination takes place as in the uredospores by means of a simple cylindrical germ-tube which enters through the stoma into the interior of the host-plant. At certain weak spots in the membrane germ-pores are formed, which are usually only distinctly visible at germination, owing to the swelling of the membrane at these spots, and through these the endospore is protruded in the form of a tube. As the aecidiospore germinates very readily in water, the process of germination can be easily followed. A germ-tube rarely arises from more than one pore, and the contents of the spore gradually pass into it along with the orange-colouring matter, so that the sfore is ultimately emptied and the endochrome is towards the extremity of the tube.

I found aecidiospores of Puccinia tasmanica, from the common groundsel (Senecio vnlgaris), to germinate freely in the manner indicated. 'They: were very plentiful in November, and in a drop of water they began to germinate within a few hours, and soon produced germ-tubes of considerable length.

As to the length of time that aecidiospores retain their germinating power there is much difference of opinion. De Bary states that they may retain it for some weeks. while Plowright considers it a matter of hours. Eriksson, on the other hand, found that the spores of Aecidium berberidis, for instance, were very capricious and uncertain in their germination, but there is always the possibility that although the spores do not germinate in water, they may infect a host-plant when brought into direct contact with the living leaf.

According to Bolley, tle aecidiospores on barberry and other hosts are still capable of germination. even after lying in the herbarium for some time, or being sent through the post. 
The development of the aecidia has been traced by De Bary, Neumann ${ }^{1}$, and others. The hyphae derived from the promycelial spores form at certain points, deep down in the parenchyma of the leaf, little compact bodies which have been called primordia by De Bary, because they are the beginnings of the aecidia. These bodies gradually increase in size by the rapid multiplication of the mycelium until they assume a spherical form, only being slightly flattened at the part immediately beneath the epidermis, and considerably thickened at the base. If sections are made at this stage the differentiation of the cells is seen to have begun. From the dense basal layer of hyphae arise numerous, closely-crowded, short, erect hyphae, somewhat club-shaped, and generally known as basidia. From each of these erect hyphae an apical cell is separated off, and beneath that another, and so on until a linear series is formed. At the same time, as the basal cells give rise to the so-called basidia, the surrounding cells develop into the external envelope or peridium. At first they are absolutely indistinguishable from the others, but after the third or fourth division they are seen to be much broader. Then, simultaneously with the formation of the first spores, they acquire their characteristic markings and polygonal form. At first the peridial cells are filled with the coloured protoplasm or endochrome, but the colour gradually disappears.

With regard to the peridial cells, Fischer ${ }^{1}$ has shown that in Gymnosporanginm the sculpturing of the walls may be used for the distinction of species, and while in the genera Puscinia and Uromyces these cells are much more uniform in their markings, yet there is considerable variation. Mayus ${ }^{1}$ has examined peridial cells from several species of these two genera, and has found that within the limits of the same species the nature of the peridium undergoes variation under the influence of external conditions. These variations chiefly consist in the relations of the lumen and the thickness of the wall, the lumen being relatively larger in shady places and the converse in sunny places.

The typical accidium possesses an external envelope of cells or peridium, which surrounds the spores, and when this becomes ruptured at the top to allow the escape of the spores it assunies the form of a cup. But the envelope may assume different forms, or even be absent, and then lifferent names are given to it for convenience, although in its essential character of spore-formation it is still the same structure. When the peridium is elongated, and often horn-like, it is called a Roestelia, or it may be rather irregular in shape and confined to coniferous plants, when it is called a Peridermium (not represented in Australia), and when the peridium is absent it is known as a Caeoma, as in C. apocini.

Even in the genus Puccinia the pseudo-peridium is wanting in indiridual species. In a number of species, as in Puccinia prenanthis, the aecidium is sunken and formed by the more or less altered tissue of the host-plant, and a special pseudo-peridium is either completely wanting or very imperfect. Such aecidia are to be regarded as intermediate forms between the true distinctly walled aecidia and the caeoma form.

The origin of the aecidium has given rise to a good deal of discussion, and it is not universally accepted that it originates from non-sexual cells. Massee ${ }^{1}$, in his paper On the presence of Sexual Organs in Aecidium, considers it to be a sexual product, and has even drawn the swollen ends of two mycelial hyphae imbedded in the tissues of the host-plant, supposed to be in the act of conjugation. Arthur, in his Problems in the Study of Plant Rusts, ${ }^{2}$ and The Aecidium as a Derice to restore Vigour to the Fungus comes to the conclusion that "the aecidium, with its accompanying spermogonia, represents the original sexual stage of the fungus, and that it still retains much of its invigorating power." 
But it is fulte possible that the time of appearance of the aecidia has something to rlo with their invigorating power, if such exists. They usually appear in the spring, when the-first rush of vegetation commences, and naturally the parasite shares in the strong growth of the host-plant. The nature of the host will likewise affect the result. It may appear on the leares of an annual such as Helianthus annums, which also bears teleutospores, or on those of a deciduous shrub such as barberry, the urerlo and teleutospores of which occur on wheat and other grasses. But it is a striking fact that the aecidium is so rare upon a grass that, until the discovery of an aecidium on a species of Danthonia in Victoria, only one instance was known, viz., Puccinia graminella, in which the aecidia and teletutospores occur together, the latter being often very rare, or wanting aitogether.

Repcated Formation of Aecidia.-The normal development of heteroecious fungi, as well as of autoecious forms, follows a regular cycle, as already shown. In those forms possessing all stages in the life cycle, the sporidiola produce only the aecidia, and the aecidiospores in turn give rise only to uredo and teleutospores, as in Uromyces trifolii (Alb. \& Schw.) Wint. But among those autoecious species which produce aecidiospores and teleutospores without uredospores, this regular succession of forms may be departed from in some cases, and the aecidiospores, provided the mycelium is not perennial in the host, may repeatedly produce new aecidia before the teleutospores are reached, as in $P$. senecionis Lib.

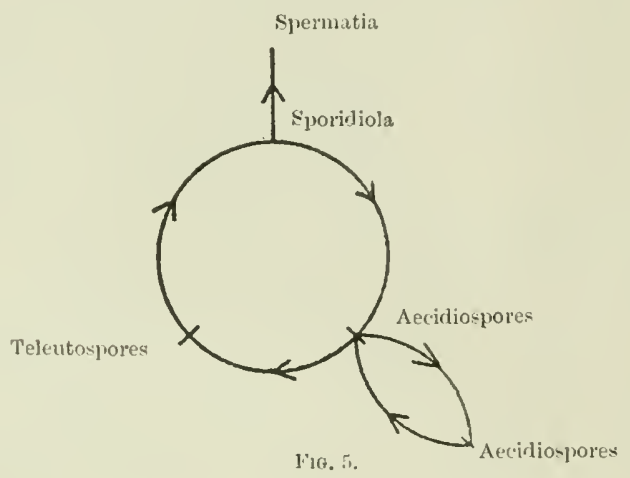

This repeated formation of aecidia was principally investigated by Dietel, who named the aecidia arising directly from the germination of teleutospores "primary aecidia," and those arising from the germination of aecidiospores "secondary aecidia;" and it was noticeable that spermogonia were usually absent from the latter. Thus the germinating sporidiolum may produce a mycelium which bears only aecidia; but the aecidiospores, instead of giving rise directly to teleutospores, may repeat themselves for several generations, and then give rise to teleutospores. However, in a complete cycle, the aecidia originate only from sporidiola. while in an incomplete cycle the aecidia at first originate from sporidiola, and then repeat themselves. 


\section{CHAPTER VI.}

\section{LREDOSPORES.}

Lredospores may originate from the hyphae developed from the germtube of an aecidiospore, a promycelial spore, or another uredospore. They are generally ovate or elliptic, and are developed singly on the ends of separate short upright hyphae, known as basidia. In some genera, however, such as Coleosporium and Chrysomyxa, they arise like the aecidiospores, in short chains, and thus resemble Caeoma-forms - in fact, they are sometimes regarded as such. The spore-bearing hyphae are crowded together just beneath the cuticle, or epidermis, of the plant, and such an aggregation is known as a spore-bed, or sorus.

The uredospores are always unicellular, and never smooth, the membrane being beset with projections in the form of short prickles (echinulate) or fine warts (verrucose). Two-celled uredospores have been described and drawn by Roze ${ }^{1}$ and Jacky? in I'uccinia chrysanthemi, but they are very probably monstrosities, as suggested by Sydow, two unicellular spores becoming united when young, and growing up together. In the same rust I found, in one instance, two uredospores produced on the same stalk. the one slightly beneath the other; but this was merely a freak. They differ generally from the aecidiospores on the one hand in the mode of formation, and from the unicellular teleutospores of the genus Lromices on the other, in having two or more germ-pores, and this character also distinguishes them from the mesospores. Only in exceptional rases is there only one, as in Puccinia monopora. They vary in colour, generally being some shade of orange or brown. and in the brown spores De Bary has shown that, as in teleutospores generally, the colouring matter is in the wall, and not in the contents.

Germination oncurs similarly to that of the aecidiospores. When ripe, and kept moist, a germ-tube is readily protruded through one nr more of the germ-pores, and this enters the host-plant by a stoma, and in the interior develops a mrcelium like that from which it originated.

It is interesting to notice that in some cases the uredospores may be produced, not only at the surface. but within the tissues. This happened with Puccinia primi, in a peach fruit, where spore-beds of rust freely producing uredospores were imbedded in the tissue, in more or less roundied cavities, up to $5 \mathrm{~mm}$. helow the surface. The decaving fruit would form a splendid matrix for preserving the spores till next season. Since they are chiefly produced in the summer, and adapted, as a rule, for rapid germination. they are often spoken of as summer spores, and as soon as they arrive at maturity become detached from their stalks.

Repeated Formation of $i$ redospares.-Just as aecidiospores may produce aecidiospores for several generations. so may uredospores produce uredospores. This is well seen, for instance, in $P$. graminis, where uredospores are produced direct from the uredospores without the intervention of aecidia and teleutospores, as is the case in Australia, and this repeated formation of uredospores may continue indefinitely. But there are sereral cases where the first-formed iredospores are different from those produced later, and, in order to distinguish such forms, the two kinds of generations are known respectively as primary and secondary 
The primary generation appears in the early spring, and originates either by infection from the promycelial spores, aecidiospores, or, it may.

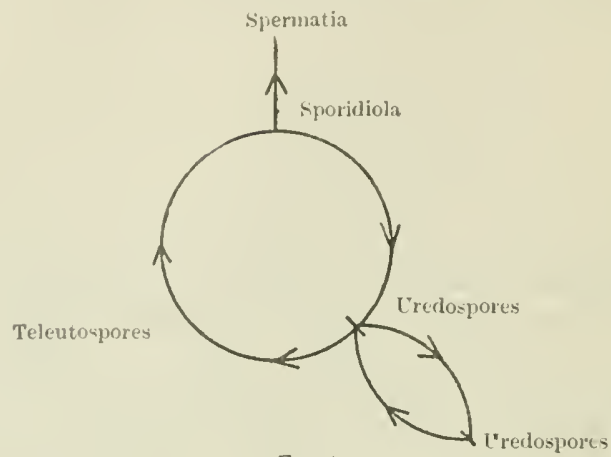

Fig. 6.

re, from a perennial mycelium. The spore-layer is usually distinguished by its larger size, and the corresponding injury it causes to the hostplant; while the secondary generation, produced by infection from the preceding uredospores, has a smaller spore-layer.

A well-investigated and very striking case is seen in Triphragmium nlmariae, in which the primary and secondary uredospores generally resemble each other; but the sori of the former are much larger and produced in great abundance, occurring on the stalks and midribs of the lcaves, while those of the latter are small and scattered on the under surface of the leaf. So striking is the difference that a special name has been roposed for the sorus, epiteosporiferous and epiteospore for the primary spore; but it is quite superfluous, since the larger and more prominent sori of the primary generation may be accounted for from the strong vigour of growth in the plant at the time when the first infection occurs.

The wintering of the rust-fungi, in the form of the uredo, depends on the nature of the rust itself, and also on that of the host-plant. If any portion of the host-plant remains green and succulent during the winter, then the fungus has an opportunity of surviving, and it is thus seen that climatic conditions have a deal to do with the persistence of the fungus. When the winter is mild and green vegetation flourishes, the mycelium of the rust fungus may continue to grow, and mav even produce spores; whereas, if the winter is severe, and the myceliun does not remain in the perennial parts of the plant, then the continuance of the fungus is likely to be by teleutospores, which can last through the winter on dead stems or other decaying vegetable matter. This so-called winterung of the uredo depends so much on the climate that in a mild climate the fungus may perpetuate itself exclusively by uredospores; whereas, under severe conditions, it has to resort to teleutospores.

A very striking case is recorded by Lagerheim ${ }^{1}$, in Uromyces fabae (Pers.), De Bary, which in Europe passes through the three stages of the aecidio-, uredo-, and teleuto-spore, while in Ecuador it only produces the ureclo-form. Heternecism. or alternation of generations, is an arrangement suited to conditions where the seasons are variable, but in an equable climate such as Ecuador there is no occasion to produce such a variety of snore-forms, and so the fungus adheres to the one which serves its purpose best. Australia is also a case in point as far as Puccinia graminis is concerned. and it is necessary to remember that our seasons are the reverse of those of the Old World. Our cereal crops are generally sown in the autumn months of April and May, or even earlier, and the harvest is 
reaped at the end of spring, or beginning of summer in November and December, so that it is the heat and drought of summer, not the cold and wet of winter, which the fungus has to provide against. In fact, the wintering of the uredo is a misnomer here, for it is the excessive dryness and heat which is most injurious.

Bearing this in mind, it is easy to understand that $P$. graminis, although it still continues to produce a certain amount of teleutospores, is perpetuated from season to season by means of uredospores. Self-sown wheat or oats, or even the aftermath of either of these crops cut for hay. is always more or less rusty during the late summer and autumn, the uredospores being freshly produced then through the depth of winter.

The teleutospores of $P$. graminis seem unable to infect the barberry in Australia, and this heteroecious rust would appear to be fast becoming like Uromyces fabae reduced to its lowest limits, and reproducing itself only by uredospores. Of course the absence of the barberry would tend to weaken if not destroy the capacity to produce the aecidial stage.

Although the germination of uredospores during winter has already been generally referred to. some definite instances may be given here, and I will select those of Puccinia graminis, $P$. triticina, and $P$. chrysanthemi from a number of tests made. The rust appeared on some self-sown wheat. which was growing vigorously during minter (June), and on placing the uredospores of $P$. graminis in a drop of water, they were found to germinate sparsely in seventeen hours, and in twenty-one hours they germinated freely and very generally. At the same time, and from the same wheat plants, uredospores of $P$. triticina were placed under similar conditions, and they also began to germinate within $2 \mathrm{I}$ hours, but after several hours longer, only a few were germinating, and not too luxuriously.

The uredospores of $P$. chrysanthemi were also taken from green leaves in $\mathrm{May}$, and they germinated freely, producing long curred germ-tubes.

Thus uredospores taken from growing plants during the winter are cap. able of germinating, and this proves conclusively that self-sown, or volunteer wheat, on the headlands or elsewhere in the neighbourhood of growing crops is one of the means whereby rust may be continued from season to season. In one case, which I have every reason to believe is quite exceptional, the season's wheat, sown at Wellington, New South Wales, in April, was badly rusted as early as May, but, as a general rule, it is exceedingly difficult, even for the trained observer, to find more than an odd speck of rust in a crop of wheat earlier than the end of September, though there may be plenty on self-sown plants.

There is a conflict of evidence, however, as to the conditions under which germination takes place when the spores are not taken direct from the fresh and growing plant.

Eriksson (Eriksson and Henning ${ }^{1}$ ) found that the uredospores of $P$. graminis lost their capacity for germination during the winter if exposed to the weather. but retained it if kept inside, and eren then it gradually disappeared, while Jack $y^{2}$ found that the uredospores of chrysanthemum rust still retained their germinating power, after exposure to the weather for 66 days, from ist December to 5th February. And Miss Gibson kept spores of the same rust in a dry test-tube in a cool room for 7 I dars, from March to May, and at the end of that time about one quarter germinated. while a week after none germinated.

The uredospore is primarily a spore for the rapid reproduction of the species. As a rule, it is produced in immense numbers, it is provided with a thin wall, having projections of some sort to act as a holdfast. and it generally infests the leaf or sheath, so that nutrition is not directly 
interfered with, as in the case of the teleutospores on the stem. But the uredo may become inured to unfarorable conditions, such as drought or cold, and carry on the life of the species, independent of the teleutospore. This is well seen in Puccinia poarm, for in both Europe and America it has been found on the leaves of Poa pratcnsis even after the melting of the snows, and in Australia it occurs on P'oa amma throughout the winter months, the rust disappearing with the withering of the host, which generally happens early in Octoler. An extreme case seems to have been reached in I'. a'cxans, Farl., where, in addition to the ordinary uredo, there is a specialised form to which the special name of amphispore has been given, which is thick-wallerl. strongly papillate. and only germinates after a period of rest.

It is ruite common for the uredo-layer to be attacked by the parasitic fungus, Darluca filum, Cast., so much so that it has been found upon 24 per cent. of the species of Puccinia. It is somewhat unfortunate that Dr. Colnb" has confounded this parasite with spermogonia, producing spermatia, for in referring to peach rust, he writes:- "I frequently find among the uredospores of a pustule of this rust, small black pycnidia, producing a multitude of two-celled spores, which. when placerl in a moist chamber, often bud and multiply after the manner of yeast plants, but which occasionally produce a mycelium. These two-celled bodies have, as I have on several occasions jublicly remarked, no slight resemblance to the socalled spermogonia of several species of Atcidium." Although spermatia are well-known to be unicellular, yet Carleton" quotes this authority for the statement that ordinary germ-tubes are produced in the germination of spermatia as well as in the other spore-forms. This rust parasite is very commonly distributed, attacking the mycelium and probably checking the development of spores. It occurs on aecidia, uredo, and teleuto-layers, and is recorded on Uromyces (9), Lromycladium (1), Puccinia (22), Phragmidium (1), and Aecidium (2).

Paraphrses most commonly occur in connexion with the uredosori, and are found in Australian species of Puccinia, Melampsora, and Pluragmidi:m as well as in Uredo.

Occasionally they arise in both uredo and teleuto-sori, as in Puccinia magnusiana and $P$. purpurea, and sometimes they are variable in their presence as in Puccinia poarmm, where Plowright found none in Britain, although they are common in Australian specimens. In Phragmidium subcorticium not only are the uredosori provided with paraphyses, but likewise the aecidial patches, since they are without a surrounding membrane.

The following are the known Australian species, with paraphyses in their uredosori:--Puccinia lolii, P. magnusiana, P. poarm, P. pruni, P. purpurea; Ilclampsora hypericormin. W. lini; Pleragmidium barnardi, $P$. subcorticinm; I'redo kuehnil, and $L$. spyridil. 


\section{CHAPTER VII.}

\section{TEleutospores.}

Teleutospores are very varied in theic shape and size, and are on that account often regarded as the characteristic form for distinguishing genera. They may be produced directly from the mycelium of the aecidiospore or uredospore, or indirectly from the teleutospore itself by means of the sporidiola. As the name denotes, it is the last formed, or finishing spore, in the life-history of rusts, although in many instances it is the only spore formed, and there are cases where it has not yet been found. Where it exists alone it may be that the other spore-forms originally existed, but have now come to be dispensed with, and where it does not exist it may he a degenerate type like the other, only it is the teleutospore form which has been dropped. It is a question, however, whether it is not a necessary stage in the life of every rust, and its apparent absence is simply owing to our not having discovered it.

As an example, Tredo sympleyti, DC. was considered by De Bary to be an independent species, and having lost its other spore-forms to be capable of existing without them, but Bubak ${ }^{2}$ afterwards fotind the teleutospore in Bohemia, and so it may turn out in other cases.

They arise like the uredospores in smaller or larger spore-beds, often closely crowded together, and usually directly beneath the epidermis which they often rupture. It is seldom that they originate directly beneath the cuticle. The colour of the spore layer is very variahle. hut generally it is darker than the uredo layer, being dark-brown to blackish, and only rarely reddish.

In the simplest cases teleutospores are unicellular, and originate in a similar manner to the uredospores. The spore-bed, consisting of interlacing and crowded hyphae, gives off erect branches, which become swollen at their free ends, and the finely granular protoplasmic contents are invested by an inner membrane, or endospore. in addition to the outer or epispore, which becomes relatively thick and dark in colour. The teleutospores are generally formed towards the end of the active vegetative period of the host-plant, and are often called winter spores in contrast to the uredo or summer spores. They are specially adapted and equipped for continuing the species over periods of drought, or damp, or cold, or seasons of scarcity. This is seen in the firm outer wall. which is often sculptured in various ways. as well as in the reserve material stored up in the contents. Sydow ${ }^{1}$ states that in all Leptopuccinieae, or those only possessing iteleutospores which germinate at once, the epispore is perfectly smooth; but there is one exception in Australia-P. plagianthi. In other groups the epispore may be smooth, warted, striated, \&c.

The portion of the hypha supporting the spore becomes the stalk, or pedicel, by means of which it remains attached to the spore-bed for a longer or shorter period.

In Endophyllum the teleutospores originate in chains, and are produced within a peridium similar to aecidia. They would be called aecidiospores. only they produce a four-celled promycelium, which bears promycelial spores. They serve the purpose of summer spores, since they germinate as soon as they are ripe, and the fungus winters by means of its mycelium in the host-plant. 
This genus is so anomalous, that it is now coming to be regarded, not as an independent form, but as a biologic genus in connexion with Puccinia or liromyces.

Teleutospores may be simple, as in Uromyces, or compound as in Pucrmia. In the newly-constituted Australian genus, Uromycladium, the: teleutospores are of the Uromyces type, but they have the peculiarity of being prorluced, not solitary at the end of a stalk, but in groups sometimes arcompanied by a colourless vesicle. In Uromyces and Uromycladium there is only one germ-Fore, situated at the apex, and the membrane is generally smonth, although it may be warted nr striated in Uromycladium.

As jet there are known only two Australian genera with compound spores-I'nccinia and l'hragmidium, in the one case consisting of two sportcells, and in the other of three or more in a vertical row.

In Puccinia the germ-pore of the upper cell is at the apex, and that of the lower at the side just beneath the transverse partition.

In Phragmidimm, the number of germ-pores varies in Australian species from one to three in each cell. Dietel ${ }^{1}$ has stated that there is only one grerm-pore in each cell of $P$. barmardi, but three were invariably found by me: in examining a large amount of material.

I'craphyses are not frequently found in teleutosori, probably because teleutospores are generally so well constructed for withstanding. variable conditions that they do not require such protection. The best-known example is that of the old species, Puccinia rubigo-vera, now split up into several, such as P'uccinia bromina and $P$. triticina, in which the teleutosori are divided into compartments by the clavate brown paraphyses.- Note 3, 1.75.$)$ It is worthy of note that the teleutospores are capable of ger munation in the autumn of the year in which they are produced. There are no other Australian species in which paraphyses are confined to the teleutosori, hut they may occur in connexion with the latter as well as with uredosori in Puccimia magnusiana, $P$. purpurea, and L'romyces phyllodionm.

The germination of the teleutospores of Puccinia graminis in Australia was tested under different conditions, and the most important condition seems to be the season of the year, for they were only known to germinate during the siring months. Badly rusted straw was placed in the cool stores for three months, one portion being kept at a temperature of 4 leg. C.. and another at -18 deg. C. A third portion of the same straw was simply kept in the opem, and when tested for germination in the spring only the spores exposed to the weather germinated.

Another feature of germination worthy of mention is the way in which it is spread over a period of time, and the spores in the different sori are not all ready at once. There seems to be a succession of ripening, for among a patch of sori only one out of every fifteen or twenty will be found to contain spores capable of germination. This shows the necessity for germinating spores in bulk when tests are being made, for you misht happen to select spores, which would not germinate, being taken from an unripe sorus. Not only are the spores ready for their work of germination at diffirent times, but the sporidiola are produced in succession, for you nerer find the promycelium learing its four spores all at once, at least in $P$. gra minis. 'This is well shown in Plate $\mathrm{XV}$., with the germinating teleutospores
of $/$ '. maliaccarmm. 


\section{CHAPTER VIII.}

\section{Mesospores and Amphispores.}

In the great majority of Australian Puccinias, 80 per cent. at least, there occur associated with the teleutospores, and quite distinct from the uredospores, unicellular spores which somewhat resemble the two-celled spore in coloration, though generally much paler. It is generally noticeable that wherever the teleutospores are thickened, or apiculate, or prolonged into processes at the apex, or warty on the surface, these spores possess the same characteristics. The conclusion one would naturally draw is that they are teleutospores in the process of making, with the lower cell wanting, just a survival of what is normal in the Uromices. From their partaking of the nature of a middle spore-form between $\dot{U}$ romyces and Puccinia, they are gentrally called mesospores, and simply represent an imperfectly developed or abortive teleutospore, which may, however, in certain cases perform the functions of a fully-dereloped teleutospore, although only one-celled.

In the newly-constituted genus Uromycladium there are found in considerable numbers among the uredosori, smooth-walled spores smaller than the uredospores, produced singly on basidia and entirely different from the teleutospores, to which the term mesospores has also been applied.

Just as there are two kinds of teleutospores, so there may be two kinds of uredospores, which are represented at present in a few species belonging to Uromyces and Puccinia, but have not hitherto been found in Australia. This modified uredospore, while agreeing with the normal uredospore in the mode of germination, possesses a thickened epispore, and a more or less persistent pedicel. From its partaking of the characters of both spores, those of the uredospore in its possession of two or more germ-pores, and those of the teleutospore in its germinating only after a period of rest, it has been called an Amphispore, by Carleton.

\section{AMPHISPORE.}

This peculiar kind of spore was first investigated in connexion with Puccinia vexans Farl. This species has a true uredo and teleuto-stage, in addition to a third form of unicellular spore, and the latter was the first to be recognised and recorded. In 1879 it was described as Uromyces brandegei by Peck, the unicellular spores being rough with minute warts, and therefore suggestive of Uromyces. Then, in 1883 , Dr. Farlow found true bilocular teleutospores associated with the supposed Uromyces, and named the fungus Puccinia vexans, the specific name referring to the perplexing nature of the unicellular spores. As Dr. Farlow writes:- "The perplexing question arises, are the one-celled spores a unilocular form of teleutospores similar to what is known as P. cesatii, Schr., or are they the uredospores of this species?" Their true nature was finally settled in 1897. when Carleton succeeded in germinating them, and ultimately they were found to give rise to two germ-tubes, as in the true uredospore which had been discovered the previous year. Now that the three spore-forms are known in this species, it becomes possible to answer the question, in what respect does the amphispore differ from the teleutospore, on the one hand, and the uredospore on the other. It agrees with the uredospore in being unicellular, and having more than one germ-pore, but differs in 
being strongly papillate instead of echinulate, thick instead of thin-walled, with persistent perlicel and only germinating after a period of rest. Its essential difference from the teleutospore is its unicellular character and the possession of more than one grerm-pore.

Besides the amphispores, mesospores are very numerous in this species, so that there is a f'uccinia provided with two kinds of uredospores, and two sorts of teleutospores.

Up till recently this was the only instance known of the occurrence of amphispores, but Arthur ${ }^{5}$ has given descriptions and illustrations of nine different speries, one of which belongs to the $U$ romyces, in which this form of spore is met with. According to this author, amphispores are mainly developed in arid or semi-arid regions, and represent a resting or winter form of uredospores, being provided with thickened walls to enable them to withstand unfarorable conditions, just like a teleutospore.

\section{Mesospores.}

In examining the relatively large number of Australian species of Puccinia possessing mesospores, one finds that as a rule they are comparatively. scarce in point of numbers, and that while a few may resemble the ordinary teleutospore in colouration the majority are paler and altogether with an imnature appearance. But there are a few cases, such as Puccinia heterospcra and $P$. simplex, in which the one-celled spores far outnumber the regular teleutospores, so much so that the latter have been frequently overlooked. and there is every probability that they undergo germination, and are therefore unicellular teleutospores in the fullest sense of the term. In $P$. heterospora there are no uredospores, and the unicellular spores are smooth, and otherwise resemble the teleutospores, while in $P$. simplex the uredospores are spinulose and yellow, and quite distinct from the smooth unicellular spores associated with the teleutospores. Owing to the teleutospores not having been obtained at first, the former has been variously named Uromyces pulcherrimus, B. and C., U. thweraitesii, B. and Br., and $\tau$. malvacearmm, Speg., and the latter as Uromyces hordei, Rost. In fact, these spores have been regarded as a transition stage from the unicellular Uromyces to the bicellular Puccinia spore. In such cases the one-celled spore functions as a teleutospore, and there would be a certain convenience in ristinguishing between the undereloped and immature spores and those which are fully formed, and in all probability capable of germination, reserving the tirm mesospore for the one, and unicellular teleutospore for the other. But it is so difficult to draw the line sometimes, and since it is not desirable to multiply names unnecessarily, I will use the term mesosprore to clesignate a unicellular teleutospore form in Puccinia and Uromycladium, which may either he imperfertly developed and incapable of germination, or fully formed and germinable.

The presence of mesospores in a species would seem to indicate its still close relationship to Tromjees, and that its separation from the parent form had not yet proceeded sufficiently far to obliterate every trace of its former commexion. 


\section{CHAPTER IX.}

\section{Sporidiola or Promycelial Spores.}

When the teleutospore germinates, whether at once or afiter a period of rest, the endospore is protruded through the germ-pore as a germ-tube, and the contained protoplasm passes into it. This germ-tube does not behave like that of the aecidiospore or uredospore, and elongate and branch indefinitely, but it soon ceases to grow in length, and terminates blindly. Hence it has received the special name of promycelium, because it directly produces its spores. The promycelium is soon divided by septa, generally stated as formed from above downwards, but my own observations in regard to Puccinia malvacearum show that the median septum is first formed, dividing the promycelium into two, and then each of these subdivides again into two, making in all four cells, from each of which there is a short lateral protuberance which dilates at the end, and becomes a promvcelial spore or sporidiolum. The two upper cells, as a rule, produce their sporidiola first, then the next, and lastly the lowest; but occasionally the two median cells start first. The name sporidium is often applied to this spore, but since it is already used as equivalent to ascospore, the present name has been proposed by Saccardo.

The sporidiola are easily detached, and, provided with moisture, they can germinate at once, and on the surface of a living leaf the germ-tube can pierce the epidermis, and, growing and branching in the interior, produces a mycelium similar to that derived from the aecidiospore or uredospore. But in the case of grasses the walls of the epidermis often contain much silica, and this may be one of the reasons why aecidia are so scarce in that family. Blackman ${ }^{1}$ has shown that there is considerable variation in the length of the promycelium, according to the conditions of growth. Teleutospores, germinating in moist air, produce very short promycelia, and form sporidiola almost imınediately, while those germinating in drop cultures, with their germ-tube submerged, grew to a length only limited by the reserve material, but no sporidiola were formed. On reaching the air, however, their formation took place. The free air necessary to their formation is correlated with their distribution by the wind.

If the teleutospore be regarded as the final stage of the cycle, then the sporidiolum will be the starting point, and from that there may proceed in regular succession the various spore-forms already enumerated, viz., spermatia, aecidio, uredo, and teleutospores, back to sporidiola again. All these may occur in the same species, and the general course of development is briefly as follows:-From the teleutospore in the spring, sporidiola are formed which develop on a suitable host-plant a mycelium, from which usually on the upper side of the leaf spermogonia are developed, and either on the same side, but generally on the opposite side, aecidia are soon afterwards produced. Infection by the aecidiospores produces the uredo-stage, and these spore-forms often reproduce themseives. The uredo is specially adapted for the rapid spread of the fungus, since from the time of infection up to the formation of new uredospores, only eight to ten days may elapse. Finally, along with the uredo. or in special layers, teleutospores arise which, on germination, produce again the promycelia and sporidiola, and thus complete the course of development. This is the typical mode in which the alternation of spore-forms occurs in many species belonging to different genera, but there is often variation in the order, or even omission of some of the stages. So constantly are aecidial or uredo stages associated 
with at least another stage, that when found alone or isolated they are regarded as incomplete, and it is taken for granted that the associated form has yet to be found. In the case of teleutospores, however, there are numerous species which produce them alone, and in such cases. all the other spore-forms are considered to have been suppressed or never formed. And of these surviving teleutospores, in some species they are able to germinate at once, and thus produce successive generations in the course of a year, while in others they can only do so after a winter's rest, and are thus produced only once a year.

In the heteroecious rusts there is no evidence to show that the sporidiola can infect the plant bearing the teleutospores, hence it would appear that $P$. graminis in Australia can only be propagated, as far as spores are concerned, by means of the uredospores. It has not been definitely proved how the sporidiola are distributed, but no doubt the wind is an important factor, and probably also animals assist in the distribution. In connexion with the teleutospores of Gymnosporangium, Plowright ${ }^{2}$ says :- "It is probable that the promycelial spores are implanted upon the ovary by insects which had previously visited the Podisoma under the delusion that it was a flower, and carried the minute spores with them to the hawthorn." The wind, however, is likely to be the common agency. Since the leaves and stalks bearing the germinating teleutospores often lie upon the ground, it might seem at first sight as if they were not farorably situated for the wind to act upon them. but as they are usually produced in large numbers, sufficient of the sporidiola are likely to be suspended in the air to infect fresh plants when the conditions are suitable.

How long the sporidiola retain their germinating power, and how far they can stand drying up, are questions not yet satisfactorily determined. 


\section{CHAPTER X.}

\section{Paraphyses AND their FunCtion.}

Paraphyses are variously shaped-often hair-like, or capitate unicellular bodies, sometimes accompanying the spores, and are just branches of the hyphae not concerned in, but accessory to, reproduction. These sterile filaments may occur in the spermogonia, where they assume the form of stiff hairs projecting from the mouth, and possibly serve to retain the spermatia until they are carried away and distributed by insects.

But it is in the uredo-layer that they are most commonly met with, and there they are of various shapes. They are recorded in Australian species of Puccinia, Phragmidium, Melampsora. and in Uromyces phyllodiorum, and along with other characters may be useful in the discrimination of species, as in Puccinia magnusiana, Koern., where they at once distinguish it from the other species occurring on Phragmites communis. They usually surround and arch over the spore-bed, and the apex is often swollen in a globose or clavate manner.

Their principal function is probably the same as that of the hairs in some grasses and other plants - to protect the spores when exposed by the rupture of the cuticle against excessive evaporation and consequent drying up during the day, and to moderate the temperature in the cold nights.

In the genus Melampsora and some species of Puccinia and Uredo, e.g., the uredo of $P$. poarum, $P$. magnusiana, and $U$. spyridii growing on hosts in damp situations or along rivers and in moist valleys, the paraphyses have always swollen capitate heads, and their function is suggested by their structure and position. The wall is much thickened, so as to leave a rery small cavity in the head, and in the stalk it may become so thick as completely to obliterate the cavity and thus render it solid. The thickened head has a great capacity for retaining moisture, and since they are crowded together and over-lap the spores, they will prevent them from getting soaked and at the same time protect them against excessive evaporation, which would have a drying effect according to Dietel ${ }^{9}$.

Their great function is as protective organs when the spores are exposed by the rupture of the cuticle, and Plowright compares them with the pseudoperidial cells of the aecidiospores. He has made observations on the paraphyses of certain species, and found that their presence greatly depends upon some special condition of the fungus. "I find them constantly present with the uredospores of Puccinia perplexans, Plow., when these have arisen, not directly, but rather at a considerable distance from the aecidiospores. On the other hand, when the uredo arises directly from the aecidiospore, they are hardly present at all; this looks very much as if they were an indication of exhaustion of vital energy on the part of the fungus, which was combated by protective efforts on the part of the parasite in conserving those spores which it does produce, but when full of vigour and fresh from the aecidiospore it is less careful of its spores. When it begins to feel the effect of exhaustion, and is unable to develop such energetic spores, it takes more care of those which are produced."

Or it may be that when the fungus begins to feel exhausted, it is unable to derelop so many spores, and barren protective filaments take the place of those which would normally produce spores. If the paraphyses serve to prevent excessive evaporation, then it would follow that in the early spring, when there is little need for protection on this account, there would be little use for them; but towards the summer, when the air is 
(1)y, they would be required in much larger numbers. The presence or absence of paraphyses at different periods of the year seems to have been only definitely observed in this one species, but there are other instances which may possibly belong to the same category. Thus Winter describes I'romyces dactylidis Oth. with capitate thickened paraphyses, and Plowright distinctly states that they are absent, and this discrepancy may arise from the observations having been made at different seasons of the year. Again, Puccinia poarum Niels. is without paraphyses, according to Plowright; but Schroeter found them in Germany, and I have found numerous long ones in Australia. In $P$. magnusiana Koern. the clavate paraphyses are of a dark smoky brown colour in the head and hyaline in the stalk. They only occur at the margin of the uredo-laver, and there is a slight indentation on the inner side, so that the head bends over. In Phragmidium subcorticium the tubular, thin walled paraphyses are always marginal both in the uredo- and aecidio-spore generation, and are curved inwards.

Another function has been suggested by Magnus ${ }^{6}$ in addition to that of protection. In several species of Coleosporium he found that the paraphyses served both for protection and for raising and bursting the epidernis so as to make room for the growing spores.

To a certain extent paraphyses may assist in raising the cuticle and hastening its rupture; but there are plenty of species which rupture the cuticle in the absence of paraphyses, and in the case of paraphyses associated with teleutospores, they rather appear to prevent the cuticle breaking away until it decays. 


\section{CHAPTER XI.}

\section{Origin of the Principal Spore-forms.}

The most characteristic feature of the Uredineae and that which renders them specially interesting is the variety of spore-forms which they produce. But while on the one hand there is a regular succession of sporeforms, on the other the number may be reduced even to a single kind, and the question arises in such cases whether the missing spore-forms have dropped out of the course of development, or whether they have never been iormed. Since, as we shall see, there is every reason to believe that the various spores originated from a primitive form, the natural conclusion would be that where they do not occur they have not yet been developed, yet there are cases where intermediate forms may have been suppressed, judging by what obtains in closely allied species.

In all rusts whose complete development is known there is one kind of spore which is invariably present, and which serves to distinguish the various genera, and that is the teleutospore. But the teleutospore on germination gives rise to another kind of spore, the sporidiolum, which may be regarded as the starting-point of the life-cycle, just as the teleutosrore is the last-formed or finishing spore.

The simplest form of spore, using this term in its widest sense, was at fisst developed from any joint of the exposed hyphal filament, but ultimately as the differentiation between the regetative and reproductive portions of the fungus became more marked, the point of origin was restricted to a definite spot of an upright hypha-towards the apex. By a process of abstriction, the end of the hypha was rounded off and detached by simple contraction without the formation of any septum. These might either be produced solitary or several formed in succession, constituting a chain. (Fig. 7 a, b.)

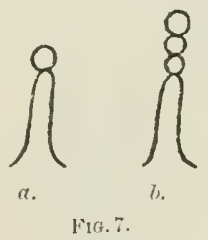

The spore might also originate by budding, as in the case of the Yeasts, where a small protuberance quickly grows to its full size, becomes rounded off, and detaches itself. In this process of budding the protuberance often narrows itself at the point of attachment into a slender stalk, whereby the connexion with the parent cell is maintained until the spore is fully formed. (Fig. 8.)

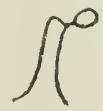

FIG. S.

This short delicate stalk proceeding from the parent cell is known as a sterigma, and either by abstriction or budding the origin of the various spore-forms may be explained. 


\section{SPORIDIOLUM.}

The sporidiolum was probably the earliest form of rust spore, and represents the transition from the saprophytic to the parasitic mode of life. If we start from undoubted saprophytes, the passage from the one to the wher will be made clear. It was not only necessary for the spread of these fungi that the spores should germinate rapidly, but that they should be produced in sufficient numbers, and so the basidium, or parent cell, had either to produce more than one spore or divide up into several cells. In accordance with this, in one type, the one-celled basidium produces mostly four spores (Fig. 9); in another ty'pe the basidium divides usually into

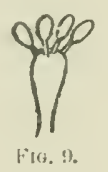

four cells, each cell producing a spore. The latter type is well seen in the Auriculariaceae where in such a genus as Saccoblastia the basidia are transversely septate, and each cell bears a sterigma with its spore (Fig. Io).

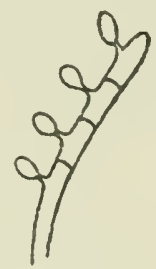

FIt. 10.

Tuming now to a parasitic genus such as Coleosporium, there is a close resemblance in the mode of formation of spores. The body called the teleutospore is found to consist of four cells placed one above the other, and each cell gives rise to a sterigma, with a sporidiolum at the end of it (Fig. I I). 'l'his is something very different from the typical teleutospore,

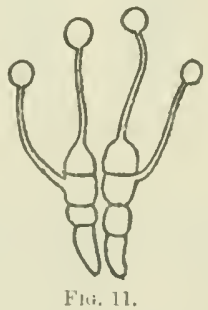

it which each cell produces, not an ordinary undivided germ-tube, but a promycelium divided into four cells, each of which bears a sterigma with it sporidiolum. The so-called teleutospore of Coleosporium is evidently the representative of the septate basidium in the Auriculariaceae, although it is generally considered to be an exceptional form of teleutospore, which occurs in other grenera of Rusts as well, such as Ochropsora, Trichopsora, and Chrysopsora. If the basiclia in one of the saprophvtic Auriculariaceae, such as Saccolnlastia ovispora Moell., are compared with those of the parisitic Coleosporium senecionis, there is seen to be complete agreement in the structure. 
The sporidiolum was thus at first the product of a basidium arising from a mycelium, but there was nothing specially characteristic in this, nor any advance upon the mode of reproduction in a saprophytic fungus. That which constituted the Rusts a distinct class, and separated them from their nearest allies, was the development of a new kind of spore, the teleutospore, which produced directly on germination, without the intervention of any mycelium, a basidium bearing sporidiola. In the one case the sporidiola were derived from a basidium borne by a mycelium nourished on dead or decaying matter; in the other the basidium, or so-called promycelium, was the direct product of a living spore. This spore is the special feature of this group of parasitic fungi, and will now be considered.

\section{Teleutospore.}

In the sporidiolum the fungus is provided with a spore capable of germinating at once and reproducing the original form, but a parasitic fungus requires further to accommodate itself to the varying seasons of grcwth of the host-plant, and so a spore that could persist during the winter while vegetative activity was practically suspended, became a necessity. Hence the teleutospore, or typical resting-spore, was introduced into the cycle to provide a thick-walled form, which could withstand the vicissitudes of climate and be ready to germinate when spring, with its revival of growth, returned. While some teleutospores are capable of immediate germination, the great majority undergo a period of rest, and a thickening of the wall is associated with this condition.

While the sporidiolum was thus probably the earliest-formed rust spore, it did not meet all the requirements of the new mode of life, and thus the teleutospore became a necessity for parasitic life, a condition dependent on the changes of a living organism. The great feature of a teleutospore is the mode of germination and its product, and perhaps the simplest form is represented by that of Barclayella Diet., in which there are several cells in a row, and each cell produces a promycelium or septate germ-tube. The peculiarity and primitiveness of this promycelium lies in the fact that, instead of dividing transversely and each cell giving rise to a sporidiolum, the promycelium itself breaks up into four divisions, each of which becomes a sporidiolum (Fig. I2).

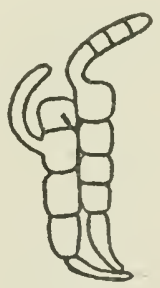

Fig. 12.

The only species belonging to this genus occurs on a Conifer (Picea morinda Link) in the Himalayas, and neither uredospores nor aecidiospores are known. It produces the most primitive form of teleutospore, and the germ-tube produced from each cell breaks up directly into sporidiola, which arain reproduce the fungus. This is an evident contrivance for multiplying the spore-form (teleutospore) and providing a fresh start with a sporidiolum, minute, light, and easily transported by the wind.

The next advance in the development of the teleutospore may be seen in an intenesting genus, just described by Arthur ${ }^{6}$, to which he has given the name of Baeodromus. It orcurs on Senecio, and resembles Coleosporium 
renecionis so much in general appearance, that it was at first regarded as that species, but the teleutospore produces a regular promycelium, with stcrigmata and sporidiola, so that it well illustrates the transition from the basiclia bearing sterigmata in Coleosporium to the typical teleutospore with a promvcelium. The teleutospores are united into a solid mass, and are arranged in chains consisting of $5-8$ cells in a series, and while Arthur considers each cell as a teleutospore, the chain of cells might be regarded as a multicellular teleutospore. The spores germinate immediately, and the promycelia, together with the four globose sporidiola, have bright orange contents (Fig. I3). Closely related to this form is Chrysomyxa, in

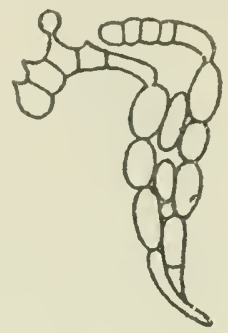

Fig. I3.

which the teleutospore consists of a series of cells, and on germination produces promycelia of several cells, each of which bears a sterigma with sporidiolun. In Mclampsora the unicellular teleutospores form a compact mass, producing promycelia of the typical form, and thus a teleutospore nay either consist of a simple cell or a series of superposed cells.

A teleutospore is thus a unicellular or multicellular spore, producing on germination a promycelium, which either directly breaks up into usually four sporidiola or divides into four cells, each of which produces a sporidiolum at the apex of a sterigma. There is one exception to this in the genus Endophyllum, in which the promycelium is the product of an aecidiospore, but this may be regarded as a case where the function of a teleutospore has been transferred to a derivative form, the aecidiospore.

\section{UREDOSPORE.}

The view that the uredospore is probably derived from the teleutospore is favoured by the variability of the latter in many species, and the gradations which are found to occur. At first sight the differences between the ureclo and teleutospore seem so great as to be insurmountable, but there are distinct transitional forms from the one to the other. The membrane of the typical uredospore is covered with spines, and this is an evident adaptation for the spore which germinates immediately and is short-lived. and the characteristic spines serve to attach it to the surface of the host-plant in order that germination may be successfully accomplished. Magnus 2, who inclines to the view that the uredospores have developed out of teleutospores, shows that in Uromyces scutellatus (Schrank). Lev., a gradation cin be traced between the reticulate or tuberculate membrane of the trleutospore and the finely tuherculate or echinulate membrane of the uredospore.

As to the thinning of the wall. there is also every gradation to be met with from the thick brown membrane to the thin, almost colourless one. 'The passage from the one th the other possibly took place through such a form as the amphispore, a modifierl uredospore still capable of undergoing a perind of rest, and in which the wall still retains its thickness, but there are several germ-pores. They may resemble the uredospores in shape, 
echinulation, and germ-pores, but still they are resting-spores with thickened walls. Fischer ${ }^{1}$ has also illustrated the transition in a series of twocelled teleutospores of Gymnosporangium confusum, which have all germirinated, and which show a dense thick membrane at one end of the series and an excessively fine one at the other. And Dietel ${ }^{3}$ has pointed out that the occurrence of thick and thin-walled spores in species of Gymmosporangium is quite common, and that it is a character of the genus that the teleutospores formed in the interior of the gelatinous mass are thinwalled, while the external ones are thick-walled. The gelatinous substance is formed from the gelatinous walls of the stalks of the teleutospore, and readily absorbs the rain-water and thus facilitates the germination of the spore. Another important difference between the uredospore and teleutospore of Uromyces is that while the latter only possesses one germ-pore, the former has two or more often arranged as an equatorial band. But here again Magnus shows in species such as $U$. proëminens (DC.) Pass. and $U$. tuberculatus, Fckl., every transition from the normal teleutospore with apical germ-pore, through one with the germ-pore becoming somewhat lateral, then with apical and lateral germ-pores, until the typical uredospore is reached with a band of germ-pores confined to the equator, or several scáttered.

In Puccinia podolepidis there is often a germ-pore on either side of the upper cell of the teleutospore, as shown in Pl. XXIX., Fig. 25\%. A third and very important difference between the uredospore and teleutospore lies in the mode of germination. Not only does the uredospore germinate immediately on maturity, but it puts forth a germ-tube which penetrates directly into the host-plant, while the teleutospore often undergoes a period of rest and does not directly reproduce the fungus, but gives rise to a fromycelium bearing promycelial spores, which germinate and enter a host-plant. It would appear at first sight as if this mode of germination created a distinct barrier between the two kinds of spore, but when closely looked into there is considerable variation in the germination of the teleutospore, and under certain conditions it may forego the production of intermediate spores.

Kienitz-Gerloff ${ }^{1}$ has shown that in Gymnosporangium clavariaeforme, Jacq., the thin-walled teleutospores do not produce a promvcelium and T,romycelial spores, but simply a germ-tube like that of a uredospore. And Dietel $^{3}$ has further shown that both thick and thin-walled spores may sometimes germinate in this way, and thus serve the purpose of the uredospore occurring in other genera. Fischer ${ }^{1}$ has also pointed out the influence of external conditions on the mode of germination, the sporidiola only being formed in air, while in water or in the interior of the gelatinous mass surrounding the spores, an elongated germ-tube is formed. This has been corroborated by Blackman ${ }^{1}$, who found that the germ-tube is incapable of sporidiola formation when submerged, and that under these conditions it continues to grow in length until its reserve material is exhausted. $\mathrm{He}$ also found that when germ-tubes of Phragmidium rubi.were produced in water, they might become divided into four cells, as if about to bear sporidiola, but these cells, instead of following the ordinary course, rounded themselves off and separated. Fischer observed in Gymnosporangium confusum that the cells of the promycelium separated before forming sterigmata and promycelial spores, but Blackman, in a MIS. note to his paper ${ }^{1}$, kindly sent to me. says: "These are the cells of the promycelium which are rounding themselies off and becoming directly sporidia." "So that there appears to be every gradation in the germination of the teleutospore. from the production of a simple germ-tube to the division of the germ-tube into cells which germinate, and. finally the promycelium bearing promycelial 
stures. It is worthy of mention that Magnus ${ }^{2}$ has repeatedly obsenved that whrn the teleutospores of I'uccinia graminis were germinated in water they proluced an undivided germ-tube just like that of a uredospore, but he could not satisfactorily settle the question, if this germ-tube could directly' penetrate the host-plant.

The passage from a thick to a thin wall, from one to a number of germ-pores, and from a typical promycelium to an ordinary germ-tube, has been shown, and it all tends to support the view that the uredospore may have been clerived from a teleutospore.

This peculiar germination of the teleutospore, in which cach promycelium lreaks up into three or four detached cells, apparently representing sporidiola, had been observed by Barclay ${ }^{3}$ as early as I89r, in Puccinia prainiana, Barcl., and Uromyces solidaginis, Niessl. He considered this annormal mole of germination to be due to the restricted supply of air obtainerl $\mathrm{l}, \mathrm{y}$ the spores in a hanging drop of water, for, when allowed to germinate in a watch-glass of water, with freer access of air, the germination was normal.

But this rounding off of the promycelial cells may be due to the influence of micro-organisms in the water. So far as our own observations go, ccrtain organisms are always present in great abundance when this rounding off of the cells occurs. A similar phenomenon is observed in connexion with the hyphae of numerous fungi growing in water or fluids invarlerl by hacteria.

In another respect the uredospores show a distinct transition. In is well-developed spore-layer they always precede the associated teleutospores, but in Uromyces scutellatus, as Magnus ${ }^{2}$ has repeatedly observed, in different years they may appear simultaneously.

The uredospores may thus be regarded as having been derived from the teleutospores, or from a mycelium common to both, and the question naturally arises as to the origin of the aecidiospores.

\section{Aecidiospores.}

Aecidiospores and uredospores are often so much alike that they are mistaken for each other, and sometimes there is a difference of opinion as to whether a spore-form should be regarcled as one or the other, as in Triphragminm "mlmariae; but, generally speaking, aecidiospores are produced in chains, and uredospores singly on evident pedicels. In Coleosporium and Chry'somyxa, however, the uredospores are developed in chains as well as the accidiospores, and this renders necessary the further distinction that the aecidiospore always precedes the uredospone in point of time.

In I'hragmidium subcorticium, for instance, the aecidiospores were not recognised at first as distinct from the uredospores, but although the individual spores resemble each other closely, the fact that one is produced in chains and the other not, distinguishes them. When aecidiospores are proclucel without any special envelope or pseudo-peridium, as it is called, it is distinguished from the Accidinm proper as a Caeoma, and there is every gradation from naked to covered aecidia. In Chrysomyxa the uredo is regarted as a raeoma-form by Raciborski but in Ploragmidinm the aecidiospores are protecterl by a dense layer of paraphyses, which surround them, and thus take the place of a peridium. Triphiragmium ulmariae (Schum.) Link, has what are called primary and secondary uredospores, although the former are described by De Toni as aecidiospores, but they are not procucial in chains. IVinter regards them as biological representatives of the accidium, and Drs. Milesi and 'Traverso' ${ }^{1}$ speak of them as epiteospores, to distinguish them from cacomospores, which are arranged in chains. There 
is no essential point of distinction between aecidiospores and uredospores, for though the former are always formed in chains, yet undoubted uredospores may also be thus produced. Hence there is no valid distinction between the two, even to the matter of nuclei, for both are binucleate.

The aecidiospore is just like the uredospore, thin-walled, and adapted for immediate germination; but since it is essentially a spring form, and required to keep pace with the rapid growth which then takes place, it is not formed solitary upon a stalk, but tier upon tier, to make abundant provision for the coming season. It is usually uredospores and aecidiospores which are confounded together, but there is one case at least in which the aecidiospore partakes of the character of a teleutospore. In Endophyllum the spores are produced in chains, and within a pseudoperidium just like normal aecidia, but instead of germinating in the usual way, each one produces a four-celled promycelium, giving rise to promycelial spores just like a teleutospore. They may either be described as aecidiospores which produce promycelia or as teleutospores resembling aecidiospores. This genus is not now generally regarded as independent, but as related biologically to Uronyces or Puccinia, and it will probably turn out to be a case where an aecidiospore still retains marks of its early origin from a teleutospore in its mode of germination. (Note 4, p. 75.)

\section{SPERMOGONIA AND SPERMATIA.}

If the aecidiospores were the result of a sexual process, as is sometimes maintained, then of course they could not be derived from teleutospores, and the mere fact that I have attempted to account for their origin from this source shows that some other explanation must be forthcoming for the so-called male sexual organs-spermogonia and spermatia. In lichen-fungi such as a Collema a true process of conjugation occurs, and the male organ or spermogonium, with its contained spermatia, resembles very closely in structure the similarly named bodies in the rusts. It was Tulasne who originally discovered these bodies in $185 \mathrm{I}$, and who suggested their sexual nature, which he based partly on the fact that the spermatia were not known then to germinate, and partly that they usually preseded or accompanied the bodies they were supposed to fertilize, viz., the aecidia.

Great attertion has, therefore, been paid to the spermatia, in order to discover if they were capable of germination, and it has been found that in a nutritive solution they grow and bud after the manner of yeast, but no definite mycelium has been produced.

It is generally stated that the spermogonia either precede or accompany the aecidia, but they may occur with all the spore forms, according to the one which is first produced. Aecidia usually follow the germination of the sporidiola, and therefore spermogonia accompany them most frenuently : but if the first formed spore is the uredo, as in Triplirasmium ulmariac, Uromycladium maritimum, and Puccinia obtegens (Lk.) Tul., then they accompany it, and if a teleutospore as in P. liliacearum, Duby, or Uromicladium tepperianm, the spermogonia are associated with it. But Arthur ${ }^{3}$ states the case more generally when he remarks that "every one who has made cultures of the rusts knows that in about a week after sowing the germinating teleutospores there will appear spermogonia, without any regard to the kind of spore that is to follow." There are even instances where the spermogonium has entirely disappeared, as in Puccinia nalvacearum!, Mont. It is acknowledged by those who have given special attention to the subject that the spermogonium is an isolated organ, of uncertain origin and function, and that the balance of evidence is against its being a sexual organ. The spermogonium is seldom absent from the life-cycle, and yet it takes no direct 
part in the reproduction of the fungus. Its meaning seems to have been lost, but its urigin from the sporidiolum seems to indicate that it may be the survival of the conidial reproduction of the sporidiolum.

Unless in cases where the mycelium is perennial, the sporidiolum germinates and produces a mycelium, which gives rise to the spermogonium. The same mycelium may either produce aecidia, as is usually the case, or in the absence of aecidia, urerlospores; or, if both are absent, the teleutospores, as in Uromycladium tepperianum. The spermogonia are never jroduced alone, but always precede or accompany some other spore form, for the very good reason that they are incapable of reproducing the fungus. When the spermogonium is about to be formed, the hyphae become interworen, and form a tangled mass in the sub-epidermal tissues. From this numerous delicate branches are given off, which are directed towards the epidermis. These branches converge towards a central point and form a somewhat round or piriform body, which is only covered by the cuticle at the top. The periphery of this body consists of a dense felted mass of sterile hyphae, quite unlike the peridium of the aecidia, which are likewise always deeper-seated than the spermogonia. The so-called spermatia arise inside the spermogonia in short chains by a process of abstriction at the end of fertile converging hyphae, and are held together by a gelatinous sub. stance which contains a certain amount of saccharine matter. (Pl. XXIII., Fig. 203.)

The probable origin of this puzzling body may thus be accounted for: We may suppose that the sporidiola were spread principally by wind and rain, and at first only produced teleutospores. But in order to secure the intervention of insects which were now becoming adapted to the floral world, a new kind of reproductive body was developed, and the spermatia abstricted in chains were produced in spermogonia with a sweet bait to attract insects. But when the teleutospores gradually developed uredospores and the same micelium could produce the three spore-formsspermatia, teleuto, and uredo spores - then the former became less and less necessary. When finally the aecidiospores were developed, produced in gleat abundance, and also in chains, then the competition was 100 keen, and the necessity for spermatia practically ceased to exist, since the germinating sporidiola could produce the aecidia, and the germinating aecidia both the uredospores and the teleutospores. Besides, the bright colour of the uredo and aecirlio spores may serve to attract insects for purposes of cistribution, and so they were able completely to replace the spermatia. Finally, the spermatia Inst their capacity for germination, and now the spermogonium is an orman which has survived its function, and only remains as a landmark to show what once had been the prevailing type of reproductive body adlapted for clistribution by insect life.

We can thus picture to ourselves the progenitors of the rusts leading a saprophytic existence and gradually adapting themselves to the new mode of life when the parasitic habit was developed and a modification in the spore-forms occurred. The evidence of this great change is shown in the development of a spore primarily adapted for undergoing a period of rast, ancl from the stored-up material directly producing a basidium with spmricliola, instearl of heing preceded by a more or less scattered mycelium.

The perisliarity of the teleutospore lies in the fact that it is an indeprencent lorly capable of griving rise directly and without any further forrl supply lii fresh spores by the production of a septate germ-tube, which levilops secondary spores unlike the original, being smaller, thinwallerl, and ready to germinate at once on the damp surface of a living leaf.

In conss of time the teleutospores became differentiated into forms arlapted for cotremes of tenprerature and resting, as well as other forms 
adapted for favorable conditions and rapid dissemination of the speciesuredospores. The third form of spore would probably be developed later in point of time. The aecidiospores were at first just like the uredospores, only produced tier upon tier as required, and the great purpose served by all these different kinds of spores would be to provide a continuous succession of spore-forms-aecidiospores in the early spring, when the first rush of growth commences; then uredospores during spring and summer, when steady growth is maintained; and finally teleutospores towards the autumn, capable of remaining dormant during the winter and starting the whole series again in the spring by means of promycelial spores.

The so-called spermogonium does not enter functionally into the present cycle, being a relic of the past and a survival of the time when insects were being catered for by the rust-fungi in order to aid in the distribution of their spores; but the development of such numerous and varied brightcoloured spore-forms has rendered unnecessary this special form of fructi fication.

\section{Variability of Teleutospores.}

When the teleutospores in the different genera of rusts are carefully examined, it is often found that there is not only considerable variation in the size and shape, but the seemingly constant character of the number of cells is departed from. It is not always convenient to record this in a systematic description, and I have selected a few species to give an indication of what is not at all uncommon throughout the Uredineae (Pl. XL.). This variability not only shows how the uredospore in each genus might have been derived from the teleutospore, but also how the multicellular form of spore might have originated from the unicellular. Starting with the genus Uromyces, there is no difficulty in showing how the bicellular spore of Puccinia may have originated as in Uromyces orchidearum, $U$. tricorynes, and $U$. vesiculosus (Pls. XVI., XVIII., XL.) Then in the genus Puccinia there is not only the unicellular teleutospore or mesospore to indicate its probable origin from the Uromyces, but in addition to the two-celled spore there are three and four celled spores, in which the cells are arranged in a manner suggestive of various genera. The different forms seen in a single preparation of $P$. dichondrae Mont. are shown in Plate XL., and there are at least seven forms met with-(I) the unicellular spore, or mesospore, generally with thickened apex, and resembling the uppermost cell of the next form; (2) the typical bicellular teleutospore; (3) the three or fourcelled spore, with the cells arranged in linear series, superposed more or less regularly, and after the Phragmidinm type; (4) a three-celled spore, consisting of one basal cell supporting two longitudinally divided on top, and resembling the Triptragmium tvpe; (5) a three-celled spore, consisting of two basal cells longitudinally divided and a single cell on top, as in Hapalophragmium; (6) a four-celled spore with the two lower superimposed, and the two upper longitudinally divided; (7) a four-celled ellipsoid spore longitudinally and transversely divided, as in Sphaerophragmium. It is worthy of note that there are no uredospores in $P$. dichondrae, but, even in $P$. ludwigii, where uredospores are present, there is also a considerable amount of variation. A two-celled spore is met with here, having the septum longitudinal instead of transverse, and the pedicel in a line with it, as in Diorchidium. $P$. graminis and $P$. triticina also show a considerable amount of variation, if large quantities of material are examined. Other genera exhibit variation of a similar kind, and there is a basis here provided for natural selection to work upon, and evolve the various forms which are used to characterize the different genera of the Uredines. 


\section{CHAPTER XII.}

\section{Rusts in their Relation to Other Fungi.}

The Fungi, as a class, are generally regarded as having descended from the Algae, but since the latter possess the green colouring matter or chlorophyll which enables them in the presence of sunlight to abstract carbon from the carbon dioxide of the air, they do not seem to be the most primitive forms. But the fission-fungi, such as the nitrifying bacteria occurring in the soil, are able, in the absence of light and chlorophyll, to split up carbon dioxide and obtain the necessary rarbon likewise from inorganic material, so that the first forms of life to appear upon the earth could thus obtain their nourishment witlout organic compounds at all. The derelopment of the chlorophill would thus occur at a later period, and the fungi proper, as well as the algae, may have had a common crigin from these primitive bacteria, instead of the one being a degenerate form of the other.

I lollowing the fate of the fungi, with which we are more immediately concerned, their course of development ran parallel with that of the algae, so much so that they have been regarded as degenerate algae or algae without chlorophyll. This primitive stock resembling the algae so closely is known as Phycomycetes, and from this divergence has taken place in two directions, the offshoots representing two main divisions of fungi. In the one case the Ascomycetes or fungi producing spores in delicate sacs or asci, and in the other. the Basidiomycetes or fungi producing naked spores on large terminal cells known as basidia. To this latter division belong the Uredines or rusts, since they produce basidia which are transversely divided, and bear naked spores; but they occupy a low position as compared with the higher Basidiomycetes, including the mushrooms and toadstools. In the Ustilagines or smuts closely related to the rusts, the basidia are not as yet definitely fixed, since the spores are produced at any part and new ones are developed when the old ones fall away, which is not the case in the rusts.

The following arrangement will show the position of the rusts in this scheme of classification :-

$$
\begin{aligned}
& \text { Fungi. }
\end{aligned}
$$

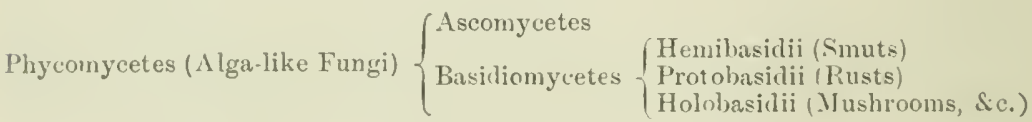

Starting from the Phycomycetes or alga-like fungi, there is one division of them which bears both sporangia and naked spores, and another in which the sporangia may be wanting. The former would give rise to the Ascomvcetes, and the latter to the Basidiomrcetes, whicli exclusively reproluce themselves by naked spores.

The smuts are generally regarded as stepping-stones from the Phrcomycetes towards the rusts. which have become more closely identified with the true Basidiomycetes, where the basidia are entire and not divided.

The alore gives a very general idea of the position of the rusts among the fungi, and indicates briefly, without entering into detail, how they: may have originated.

The parasitic habit of the rusts will account for several features in their life-history as well as in their structure. Being dependent on other 
plants for their sustenance, they must accommodate themselves to their surroundings, and so they may pass through different stages, sometimes on the same plant, or on different plants. These various stages represented by different reproductive bodies, enable the rust to produce spores which can germinate at once if food supplies are available, or others which can rest if need be. The change of host is an evident advantage, not only from the point of view of a change of diet, but it may thus pass from one plant that dies down to another that is perennial. It may even become perennial itself in the underground parts of some plants, and then it vegetates, only producing rarely the reproductive bodies which would be formed under normal conditions. 


\section{CHAPTER XIII.}

\section{INDIGENOUS AND INTRODUCED SPECIES.}

In a large continent like Australia, where so many plants have been introduced, both for economic and ornamental purposes, it is not always easy to determine what rust-fungi are native to the country, and those that have been introduced on imported plants. A plant may be indigenous, and yet the rust upon it may have been derived from an allied species, as in the case of $P$. thuemeni on native celery (Apium prostratum) which was possibly introduced with cultivated celery (Apium graveolens), $P$. menthae on native mint introduced upon cultivated mint, and Melampsora lini, on native and cultivated flax. On the other hand, species of rust occur on well-known imported plants, such as the daisy, groundsel, and marigold, which are not recorded elsewhere, and the natural conclusion is that they are indigenous, or have been overlooked elsewhere. It is only in rare cases that the first introduction of any species of fungus is observed and accurately determined, so that we must fall back upon some well recognised principle to settle whether a rust is indigenous or not. Where a new species is found on a native plant, it may be taken for granted that it is indigenous, and even where the species is already known, but the plant has a wide distribution, such as Pliragmites communis, then there is no reason to doubt that a rust upon it, such as Puccinia magnusiana is also indigenous. The great majority of the rusts here recorded are. of course, native, and it will only be necessary to single out those which have, in all probability, been imported firom other countries.

The following species may be regarded as having been introduced on the grounds indicated* :-

Puccinia anthoxanthi Fckl. on Anthoxanthum odoratum (1896).

P. arenariae (Schum.), Schroet. on Stellaria media (1896).

$P$. beckmanniae n. sp. on Beckmannia erucaeformis (1904).

P. chrysanthemi Roze, on Chrysanthemum indicum (1904).

P. cichorii (DC.) Bell., on Cichorium intybus (r885).

P. crani (Schleich.) Pass. on Centaurea cyanus (1904).

P. festucae Plowr. on Festuca pratensis (1903).

P. graminis Pers. on Wheat, \&c. (1825).

P. helianthi Schwein. on Helianthus annuus ( 1887 ).

P. hypochoeridis Oud. on Hypochoeris radicata ( 1889 ).

P. impatientis (Schw.) Arthur, on Elymus condensatus (I 903).

P. lolii Niels. on Lolium perenne (i 896 ).

P. malvacearum Mont. on Malva, \&c. (1857).

P. maydis Bereng. on Maize (1880).

P. menthae Pers. on Mentha laxiflora (1884).

P. poarum Niels. on Poa annua ( 1890 ).

P. prenanthis (Pers.), Lindr. on Lactuca sp. ( 1892 ).

P. pruni Pers. on Prunus sp. (i 883 ).

P. purpurea Cooke, on Sorghum halepense and S. vulgare (18gz).

P. simplex (Koern.), Friks. and Henn. on Barley (1902).

P. thuemeni (Thuem.) McAlp. on Apium graveolens and A. prostratum (1 892 ).

P. triticina Friks. on Wheat (probably 182.5 ).

Uromyces appendiculatus (Pers.). T.ink. on Tigna catjang (1905).

U. hetae (Pers.), Kuehn, on Beta vulgaris (1878). 
U. caryophyllinus (Schrank), Schroet. on Carnations ( 1896 ).

U. fabae (Pers.), De By. on Beans (1898).

U. polygoni (Pers.), Fckl. on Polygonum aviculare (1896).

U. trifolii Alb. and Schw. on Trifolium repens (1892).

Phragmidium subcorticium (Schrank), Wint. on Rosa sp. (1892).

Nelampsora lini (Pers.), Tul. on Linum usitatissimum and L. marginale ( ( 889 ).

Uredo kuehnii Krueg. on Sugar-cane (1893).

It would be interesting to trace from what quarter these species found their way into Australia, but from the very nature of the case, it is impossible to tell exactly, except in a few instances, and one can only make shrewd guesses as to the rest. The inquiry would mainly resolve itself into the importation of the host-plants, either by cuttings or seed, and the seed of such weeds as chick-weed (Stellaria media) and knot-weed (Polygonum aviculare) might easily be carried in straw packing or in hay.

Mr. Ellery, F.R.S., late Government Astronomer, has pointed out that the scarlet pimpernel (Anagallis arvensis) was first observed as an intro. duced weed in the Obsarvatory grounds, and he informs me that as many English and African plants appeared there at different times after unpacking cases from the different countries, he came to the conclusion that seeds from the packing were the source. Both uredo and teleutospores of Puccinia graminis have been found on wheat straw envelopes on bottles of wine imported from France.-(Note .5, p. 75.)

In the case of the cereals and grasses, the rust spores would probably be brought with the seed, and this is certainly true as regards Puccinia beckmanniae. The seed of Beckmannia erucaeformis Host. was forwarded to me in I 903 by the United States Department of Agriculture, and on growing it at Leongatha, the rust was very copiously developed in February and March, 1904. E. D. Holway informs me that it is known in Minnesota, U.S.A.. although it has not hitherto been published.

The seed of Elymus condensatus was alsa sent from America in 1903, and the rust (Puccinia impatientis) appeared upon the plants in December of the same year.

The latest addition to our imported rust-fungi is that of Puccinia chrysanthemi, and it was observed for the first time in New South Wales in I904. Cuttings had been imported from England, and thus the rust was carried; but it has not as yet spread very much. Only the uredospores occur tere as in England, and I was able to germinate them freely in tap-water towards the end of May. It is by means of this trade in cuttings that the rust is likely to be spread, unless proper precautions are taken. The history of its distribution is rather interesting. It is probably indigenous to Japan, and in 1895 it first appeared in England, then in France in 1897 , and about the same time in Denmark and Germany. In 1900 it reached America and Switzerland, and now. in I904, or earlier, it has come to Australia. probably by way of England. It was also recorded for New Zealand in 1904 .

The mallow rust (Puccinia malvacearum) has been known in Australia since 1857 , when it was found in the neighbourhood of Melbourne, and now it is one of the commonest rusts we have. It is remarkable for the rapidity of its spread, nearly over the whole world, since it was first described in 1852 from Chili, where it is indigenous. After its appearance in Australia, the next record of it is in Spain (1869). then France (1872). England and Germany (I873), Italy (1874), Switzerland and Cape of Good Hope (1875), Austria and Hungary (I876), Greece (1877), Nortb America (I886). Sweden (I887), and even reaching Finland (I890). 
The hollyhocks on which this rust occurs are ornamental plants, and the disease may have been spread in the ordinary course of trade or exchange. The first record of a rust is by no means a guide to its first appearance, for it is generally only when it has become established and has proved injurious that it attracts attention. The prune rust, Puccinia pruni, which now occurs in all the States, was first observed in Queensland in 1886 , and was recorded for Victoria in 1883 . Although confined at first to certain districts, it has since then spread considerably, and as settlement increases it becomes more widespread.

The flax rust, Melampsora limi, was first determined on some cultivated flax from South Australia in 1889 by Galloway of the Bureau of Plant Industry, U.S.A. Bolley, in a letter dated 29th December, I904, informs me that it is a very abundant rust upon all the wild varieties, and is always more or less destructive in the flax crop. It is common enough here on the native flax, and was probably introduced with flax seed.

There are four species of Phragmidium in Australia a genus confined to the Rose family, and only one of them is supposed to have been introduced. Phr. subcorticium only occurs on the imported genus Rosa, and was probably introduced in rose cuttings, since the mycelium of the aecidium is known to winter in the stem.

Phr. potentillae on species of Acaena was determined by Winter, and although referred by him to this widely distributed species, it is probably new. Phr. longissimum was first discovered at the Cape of Good Hope, and is now known to occur in other parts of Africa. Its appearance on a native Rubus in Queensland would seem to support the generally accepted opinion of a former land-connexion between Africa and Australia. But Wallace in his Island Life offers an alternative view. "We should prefer to consider the few genera [of plants] common to Australia and South Africa as remnants of an ancient vegetation, once spread over the Northern Hemisphere, driven southward by the pressure of more specialised types and now finding refuge in these two widely separated southern lands." From the shape and arrangement of the teleutospores and their germination immediately on ripening, this species stands apart from the others belonging to this genus, and Dietel ${ }^{13}$ draws the conclusion that it separated at a very early period from the common stem of the genus Phragmidium. a conclusion which harmonizes with the views of Wallace.

But the most interesting case of distribution is that of Phr. barnardi, which is not confined to Australia as was formerly beliered. Quite the same type has now been found in Japan on the same host-plant (Rubus parvifolizs), and, according to Dietel ${ }^{13}$, it is simply a variety of the Australian species, having fewer cells in the teleutospore, and therefore distinguished as variety pauciloculare.

A number of plants are common to Eastern Asia and Australia, and R. parvifolius is included by the late Baron von Mueller in a list of plants which extend from Eastern Australia to Japan. There are various wavs in which the species may have attained to its present wide distribution, which is given as Malaya, China, Japan, and Australia. Birds may have carried the seeds, and with it some attached spores of the fungus to the Asiatic continent. or inversely from Japan to Australia. There is also the possibility of a former land-connexion between Australia and Asia, which is assumed by the zoologists, and at that time the two forms of Phr. barnardi may have existed. The flora of Japan, like that of Australia, is regarded as heing of the same character as that of the Tertiary period. so that the wild raspberry and allied plants had plenty of time to spread from a point to the north of both Australia and Japan. carrying with them to their new homes, the rusts already dereloped upon them. 


\section{Indigenous Species with their Hosts.}

The great majority of Australian rusts complete their life-history on one and the same plant, and are thus autoecious; but, although heteroecism, or the division of the life cycle into two generations, each on different hostplants, has not yet been proved for any of them, still it has been so well established for several in other countries, that we may accept it for the present as likely to hold good here. As to the recognised indigenous species which are also heteroecious, there are only four-Puccinia agropyri, $P$. agrostidis, $P$. magnusiana, and $P$. caricis - the three former on Gramineae having their aecidial stage on Ranunculaceae, and the latter on Cyperaceae with its aecidial stage on Urticaceae.

If we arrange the indigenous species of rusts known in Australia under the different families of their host-plants, which are further classified according to their predominance, as determined by the late Baron von Mueller (Table) some interesting deductions may be made; but it must always be remembered that the number of known species is probably far short of those actually existing. Under these circumstances our conclusions can only be partial, still, even with these limitations, it will be instructive to compare the predominance of the native host-plants with that of the native rusts. It is found that the greatest number of rust-species occurs on the families of native plants which are large in point of numbers. Thus the Leguminosae with the greatest number of species have eighteen different rusts, while the Compositae, which only stand fourth in the list, have seventeen. At the same time it ought to be noted that future disooveries may alter this relation. for no less than seven species of the new genus, Uromycladium, have been added to the Leguminosae within the last few years.

The 'Cyperaceae, which succeed the Compositae, have only four species, while the Gramineat; which come next, have thirteen species. Then the Liliaceae have seven species and the Rubiaceae five; but on the remaining families they vary from one to five. The Leguminosae and Compositae have eighteen and seventeen species respectively, the Gramineae coming third with thirteen species. The grasses and composites are generally herbaceous, quick-growing plants, with succulent leaves, and the rust-fungi can most readily penetrate their tissues and secure during the growing season sufficiency of food. They would also be guided in their choice by the chemotactic nature of the substances contained in the hostplants ; but there are so many factors which enter into the choice of a hostplant by a rust that we can only mainly at present note their preferences. Confining our attention now to the species of Puccinia alone and comparing them with the numbers and distribution as given in Sydow's Monograph, it is found that while one-fourth of all the species inhabit Compositae and one-eighth occur in Gramineae, so with the native Puccinias in Australia more than one-seventh belong to the Compositae and oneninth to the Gramineae. In the Leguminosae only one species has been met with, and only fifteen. species are recorded altogether. 


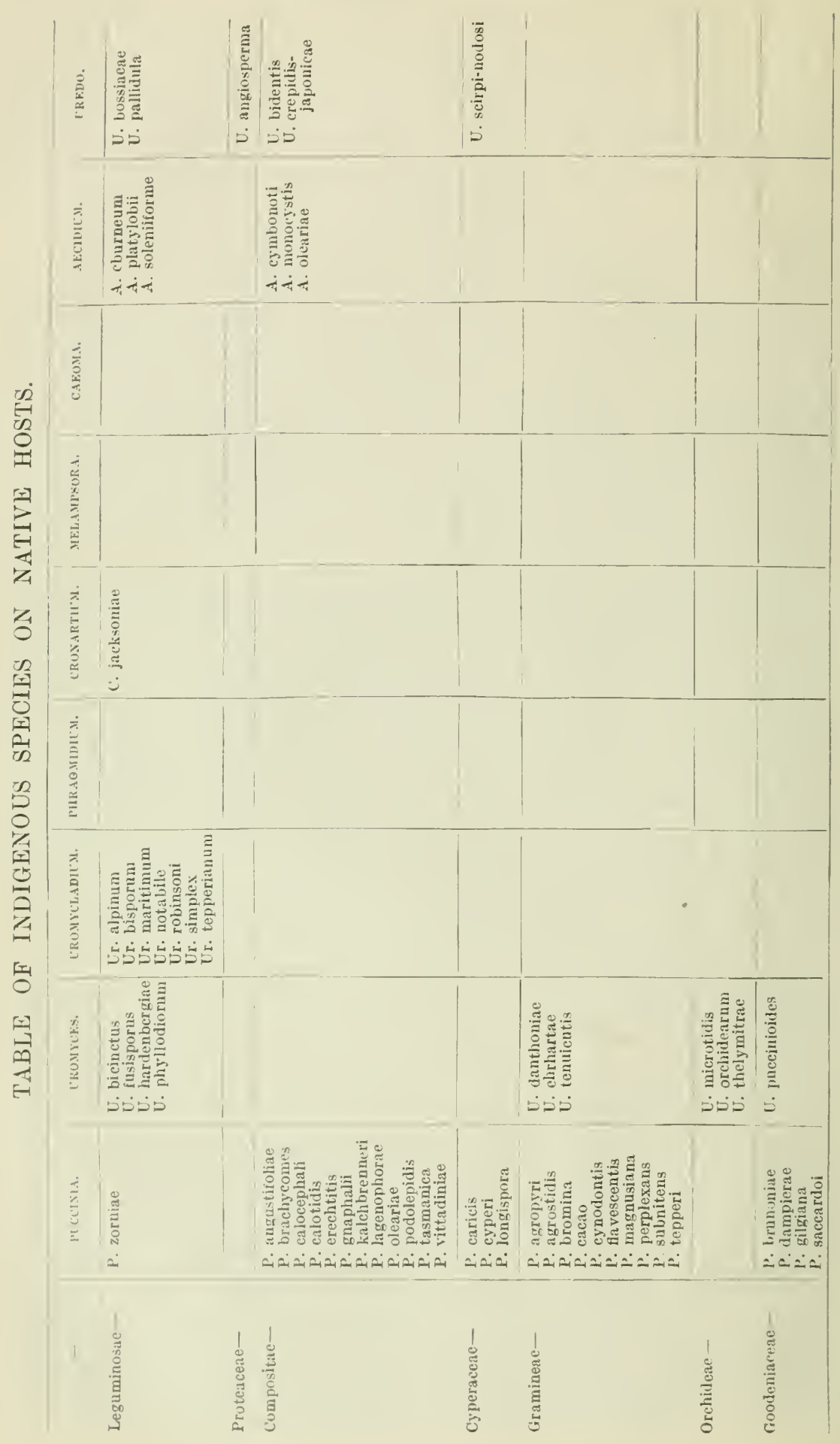


Indigenous Specics with their Hosts.

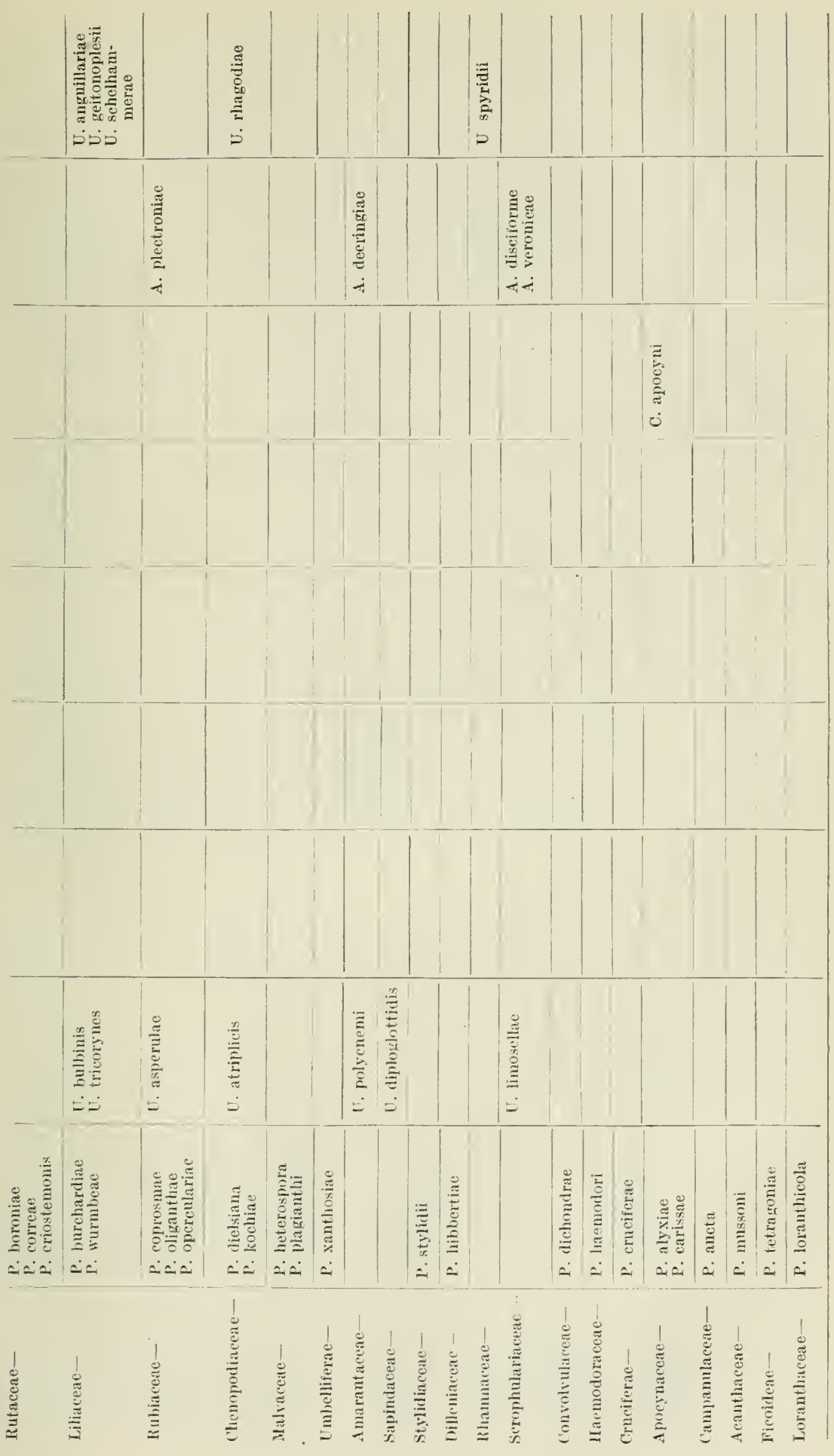


Indigenous Species with their Hosts.

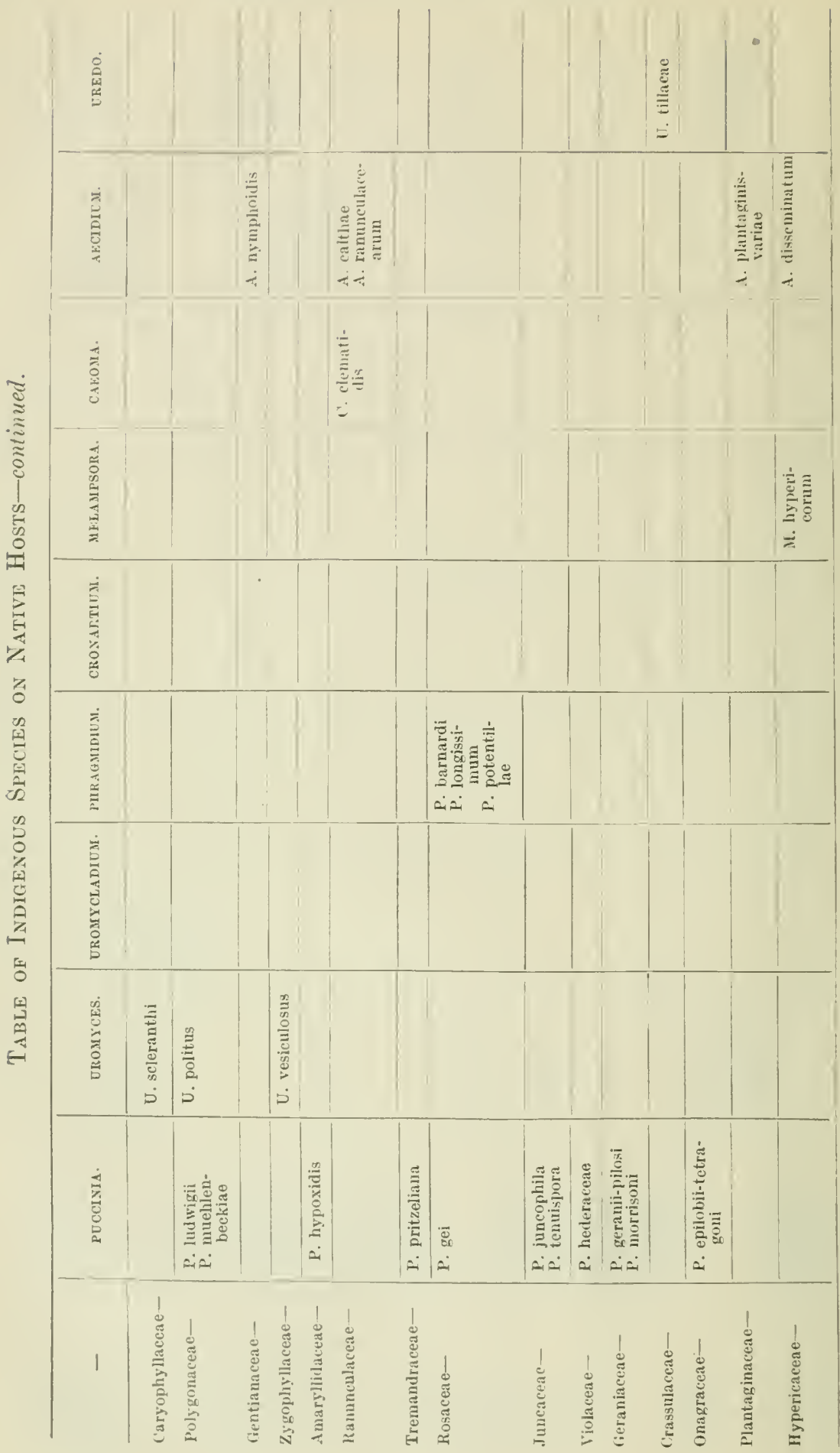


It is worthy of remark that on some of our most predominant families, such as Myrtaceae and Proteaceae, which are only exceeded by the Leguminosae, the rusts are practically absent. It is passing strange that upon our numerous Eucalypts and kindred species not a single rust-fungus should have developed, while in the Proteaceae, with their wonderful variety of foliage, only a single species, and that a Uredo, is recorded. Melampsora eucalypti Rabh. found in Calcutta on the leaves of Eucalyptus globulus is merely a name, and the specimens show no indications of a rust. I have carefully examined the original specimen in Rabenhorst's Fungi europaei 2592, and while the leaves have numerous blister-like swellings orer them, they are found to consist of discoloured cells, the epidermal cells particularly being brown and discoloured, and might superficially be mistaken for spores.

In the preceding table only indigenous rusts are given which occur on native host-plants, but such rusts may either be confined exclusively to native plants or they may occur on other allied introduced plants growing here as well. Thus Puccinia tasmanica is found on the introduced weed the common groundsel (Senecio vulgaris), but one stage of it is also found on native species of the same genus, and, therefore, it is regarded as indigenous. The rust may also be found on native plants, though in other parts of the world on allied species, and yet be regarded as native, as in the case of $P$. perplexans and $P$. agropyri. There are even cases where native rusts, or at least rusts not known elsewhere, are confined exclusively to imported plants, as $P$. calendulae, $P$. cinerariae, and $P$. distincta. As regards introduced rusts, they may be found on both native and imported plants, the presumption being that the rust spread from one to the other, though some may incline to the view that these are as much natives of Australia as of any other country. Disregarding Puccinia graminis, there are four such species, $P$. menthae, $P$. malvacearum, $P$. thuemeni, and Melampsora lini. There is still another group consisting of introduced rusts found here on imported plants alone, such as Puccinia chrysanthemi and Phragmidium subcorticium. 


\section{CHAPTER XV.}

\section{Australian Distribution.}

It would be premature to attempt to arrange the Australian rusts in geographical districts, since they are as yet too imperfectly known, and large areas have not been explored sufficiently to give any exact idea as to the number of species or the distribution of those already known. So for the present I will content myself with indicating their distribution in the different States, and this may lead to a filling up of many of the gaps, when it is seen what species may exist in one State, and are probably to be tound in some of the others.

There is one evident way in which our knowledge of this group might be extended and the area of distribution made better known. They depend for their existence on the occurrence of suitable host-plants, and since these are given for each species, as far as known, wherever the host-plants are to be found, there the parasites might be looked for.

The total number of species at present recorded is $\mathrm{r} 6 \mathrm{r}$, and they are distributed among the different genera as follows:-

\begin{tabular}{|c|c|c|c|c|}
\hline & & 1905 & & 1892 \\
\hline Uromyces & $\ldots$ & 27 & $\cdots$ & I 3 \\
\hline Uromycladium & ... & 7 & ... & - \\
\hline Puccinia & ... & 90 & ... & 24 \\
\hline Phragmidium & $\ldots$ & 4 & $\ldots$ & -4 \\
\hline Cronartium & ... & $\mathrm{r}$ & $\ldots$ & I \\
\hline Melampsora & $\ldots$ & 2 & $\cdots$ & 1 \\
\hline Roestelia & $\begin{array}{l}\cdots \\
\cdots\end{array}$ & - & 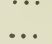 & I \\
\hline Caeoma & $\ldots$ & 2 & $\ldots$ & 2 \\
\hline Aecidium & $\ldots$ & I 5 & $\ldots$ & $x 6$ \\
\hline Uredo & .. & I 3 & $\ldots$ & 10 \\
\hline & & 161 & & 72 \\
\hline
\end{tabular}

It will be seen that the Puccinias constitute more than one-half of the whole, and the Uromyces come mext.

In Cooke's Handbook of Australian Fungi, published in $\mathrm{r} 892$, there are only 72 recorded, or less than half the number, and even somie of these do not stand the test of further investigation. In Melampsora, for instance, there are three species given, and two of these must be withdrawn, one belonging to another species also recorded, and another not being a rust at all. And in Sydow's Monograph, just completed for the Puccinias, only 43 are given for Australia.

The following list shows the distribution of species in the different States, and it is naturally very unequal. In Victoria, which heads the list, there has been a zealous band of collectors stimulated into activity by the late Baron von Mueller and encouraged by a progressive and active Field Naturalists' Club. In Queensland the Government Botanist has always been most enthusiastic in working up the Fungi generally, and in New South Wales and Tasmania good progress is being niade. Although Soutl Australia does not possess an official Government Botanist, that State is fortunate in having such a zealous Botanist as J. G. O. Tepper, F.L.S., 
who has given special attention to this group, and has not only described some species himself, but has had several mamed in his honour, such as Puccinia tepperi and Uromycladium tepperianum.

\begin{tabular}{|c|c|c|c|c|c|c|c|}
\hline - & $\begin{array}{l}\text { No. of } \\
\text { spectes. }\end{array}$ & Victoria. & $\begin{array}{l}\text { New South } \\
\text { Wales. }\end{array}$ & Zueensland. & $\begin{array}{c}\text { South } \\
\text { Australia. }\end{array}$ & $\begin{array}{c}\text { West } \\
\text { Allstralia. }\end{array}$ & Ta-mania. \\
\hline Uromyces $\quad .$. & 27 & 21 & 12 & 7 & 6 & $\ldots$ & 6 \\
\hline Uromycladium & 7 & 7 & 3 & I & 2 & $\mathrm{r}$ & 6 \\
\hline Puccinia $\quad .$. & 90 & 69 & 26 & 14 & 15 & 10 & $2 S$ \\
\hline Phragmidium .. & 4 & 3 & $\ldots$ & $\mathrm{I}$ & 3 & $\ldots$ & 2 \\
\hline Cronartium ... & i & I & $\ldots$ & I & $\ldots$ & $\ldots$ & I \\
\hline Melampsora ... & 2 & 2 & 1 & $\ldots$ & I & $\ldots$ & I \\
\hline Caeoma $\quad \ldots$ & 2 & 1 & $\ldots$ & 2 & $\ldots$ & $\ldots$ & $\ldots$ \\
\hline Aecidium & 15 & 9 & 5 & 3 & .. & $I$ & 7 \\
\hline Urerlo ... & 13 & j & 3 & 4 & ... & 1 & 2 \\
\hline Totals & $6 \mathrm{I}$ & II 8 & 50 & 33 & 27 & 13 & 53 \\
\hline
\end{tabular}




\section{CHAPTER XVI.}

\section{Tile Origin and Specialisation of Parasitism.}

In a group of parasitic fungi like the rusts the question naturally arises, How did this parasitic habit originate? Parasitism in fungi is an adaptation whereby the fungus can directly draw its nourishment from the living material, and in order to do this it must have become accustomed to a new mode of life, for it is assumed that originally the fungi obtained the requisite substances for food from dead or decaying organic material.

The saprophytic mode of life seems to have led up to the parasitic, for there is every sort of gradation between the two. Some parasites are able to complete their development entirely on artificial nutritive media. Others require to infect the living plant first, and then undergo their final development on dead tissue, while others begin their life on dead material, as a preparatory stage to passing over to the living substance.

The origin of parasitism and that of specialisation are so intimately bound up that they may be conveniently considered together, for at the critical moment, when the spore first put forth its germ-tube into the living tissue of a particular host-plant and was able to grow there, then parasitism was established. and if the fungus confined itself to that host then specialisation had begun.

What induced the fungus to enter the living plant by means of its germ-tube, and afterwards confine itself to one or a few closely-allied species is the question to be answered. It does not seem difficult to account for the entrance of the germ-tube into the stoma, for it follows the lines of junction of the cells, and ultimately comes to a stoma, into which it dips just as it would into any other opening. But to be able to penetrate the cells and abstract nourishment from them is the point which requires explanation.

It is assumed that the saprophytic habit was the normal one among fungi, and that parasitism is an acquired habit. Massee ${ }^{9}$ claims to have proved this assumption to be a fact, for he says - "A saprophytic fungus van be gradually educated to become an active parasite to a given hostplant, by means of introducing a substance positively chemotactic to the fungus into the tissues of the host. By similar means a parasitic fungus can be induced to become parasitic on a new host." Parasitism, then, is rlue to chemotaxis, which is a form of sensitiveness in the plant whereby it has an affinity for certain substances, and is opposed to others. Thus there are various substances which are capable of attracting or repelling the germtubes of fungi, and the name of positive or negative chemotaxis has been given to this property.

In an extensive series of experiments conducted with both parasitic and saprophytic fungi, Massee ${ }^{9}$ has shown that certain substances in the plant are positively chemotactic in their nature, and others negatively so. Thus it was found that sugar is the most general of positive chemotactic substances, although its action on the germ-tubes of obligate parasites is very slight. Experiments showed that "it was not sufficiently powerful in any irstance to attract the germ-tubes through perforations in mica or through stomata."

\section{Specialisation of Parasitism.}

Recent investigations in connexion with heteroecious rust-fungi, or those which change their hosts and produce a different kind of fungus on each 
host, together with the results of infection experiments, have considerably modified our views as to the limits of species in such fungi.

Eriksson ${ }^{1}$, in dealing with cereal rusts particularly, found that they were not liable to 'infect indiscriminately the different cereals, but were confined to one, or, at most, a few closely-allied host-plants, and to this phenomenon, so widespread among parasitic fungi, he applied the appropriate name of specialisation.

As examples of specialisation among heteroecious rust-fungi may be given those of Puccinia coronata, Corda, and P. graminis, Pers. Klebahn ${ }^{1}$ proved by infection experiments that the crown rust on Dactylis glomerata and other grasses only produced its aecidium on Frangula almus, while that on Lolium perenne required for its aecidial host Rhamms cathartica. Hence the old species was split up into two, which can also be separated by morphological characters. Eriksson ${ }^{1}$ also proved in 1894 that the wellknown and much-investigated species of Puccinia graminis could be split up into a series of forms, all of which agreed in producing aecidia on the barberry, but differed in the uredo and teleutospore generations, only being able to infect special host-plants. Puccinia dispersa, Eriks., was proved to be an independent species, with uredo and teleutospores on rye, and its aecidia on species of Anchusa. Included in this were a number of forms which had no krown aecidial stage, and they were afterwards separated and raised to specific rank as $P$. triticina, $P$. bromina, $P$. agropyrina, \&c.

If a general view be taken of this nhenomenon it is found that when two closely-related species, say, $A$ and $B$, are attacked bv a rust-fungus, the one on $A$ will not infect $B$, and that on $B$ will not infect $A$, eren although the two fungi are the same species, regarded from a morphological point of view. There must, however, be some adaptation between the host and the fungus, so that the latter is attracted towards the one host and repelled by the other. But it kas been shown by Ward ${ }^{1}$ that occasionally a spore from A may gain a footing on $B$, and once having done this it can continue to infect $B$, since it has now become adanted to it.

According to the same observer. parasites may be educated to attack fresh plants by means of what he calls bridging-species. Thus, while the parasite on $\mathrm{A}$ may be unable to infect $\mathrm{B}$, it mav be able easily to infect a related species $\mathrm{C}$, and after establishing itself on $\mathrm{C}$ it may then have the power to infect $\mathrm{B}$, so that $\mathrm{C}$ becomes the bridging species from $\mathrm{A}$ to $\mathrm{B}$.

Iassee ${ }^{9}$ has also shown that a parasitic fungus can be led to attack a new host-plant by injecting a substance positively chemotactic to the fungus into the tissues of the living leaf.

Parasitism is thus an acquired habit, and, generally speaking, it becomes specialised, because only in certain plants are the substances present which attract the fungi, while in others there are also certain substances which repel, and thus prevent their germ-tubes gaining a footing in the tissues.

But in contrast to this specialisation. there occurs in a few species what may be called general parasitism, where the parasitic fungus is able to infect host-plants widely separated in their affinities. Fischer ${ }^{3}$ and Klebahn 1 have shown that Cronartium asclepiadeum can attack plants belonging to such distantly related families as Ranunculaceae and Scrophulariaceae, as well as Asclepiadeae, so that it has become necessary to unite under this name, species which were formerly separated on account of the difference of host-plant.

Chemotaxis can hardly be held accountable for such a widely-divergent clistribution of host-plants. and although it does not clear the matter up, it may be referred to the "internal developmental tendencies" of Klebahn ${ }^{1}$ until a better explanation is forthcoming. 
The specialisation of parasitism resulting in the evolution of biologic forms is not confined to the Uredineae, but probably extends to parasitic fungi generally, whicli frequent more than one host, and this has been experimentally proved, particularly in the mildews or Erysiphaceae. Several biologic forms may occur within a morphological species, so that it will be necessary in the future, for the proper understanding of any such species, not only to determine its limits by means of structural characters, but also the special forms included in it with restricted powers of infection. Hitherto it has been generally assumed that the same parasitic fungus occurring on two closely related host-plants would be mutually infective, hut this does not necessarily follow, even with different species of the same genus.

Neger ${ }^{1}$, in 1902 , proved by numerous experiments that there were biologic forms of Oidium for several species of Erysiphe, and Marchal ${ }^{1}$ in the same year divided the one species of $E$. graminis into seven distinct forms, using only the conidia for purposes of infection. He showed that the biological form on barley was unable to infect wheat, oats, and rye, and Salmon ${ }^{2}$ carried the experiments a stage further by using the ascospores, which had the same restricted powers of infection.

This difference in infective power is not due to any apparent structural change in the fungus, for the form of $E$. graminis on the wheat is indistinguishable, even under the microscope, from that on the barley, and yet the form on barley cannot infect the wheat, nor can that on wheat infect the barley.

The difference, therefore, lies in the physiological peculiarities of the host-plant, and it has been suggested that the cells of the leaf contain an enzyme which is fatal to the growth of the haustorium of any other form. But probably the action is reciprocal, and the germ-tube of the fungus finds something in the particular host-plant which attracts it, and is conducive to its growth. 


\section{CHAPTER XVII.}

\section{HETEROECISM AND ITS ORIGIN.}

In a great many species the various stages of the self-same fungus, as already indicated, occur on the same host-plant, but the variety in the mode of reproduction has also brought about a variation in the mode of nutrition, for there are a number of species in which one part of their life is passed upon one species of plant, and the remainder on a totally: different species. The host-plants are not even related to each other, but stand far apart in their natural affinities. Those which passed their entire existence on one plant have been called autoecious species, while those which spread it over different plants are called heteroccious species.

As a general rule it is assumed that the different forms of rust occurring on the same host-plant are genetically connected, although it is always desirable, where possible, to have experimental proof of it. In Uromyces polygoni, for instance, the three stages of aecidio, uredo. and teleutospores may all occur together on the same leaf, or the aecidia may occur on one portion of the plant, and the uredo and teleuto sori on another; and in both cases the species is regarded as having three stages, which are different forms of the same fungus. It is but a step further to have, sar, the aecidia on one host-plant and the uredo and teleuto stages on another. and this affords a greater variety of food supply. Just as in the separation of the sexes in flowering plants, we are justified in assuming that all the different stages occurred at first on the same host-plant, but gradually, in the struggle for existence, one reproductive body matured on one plant and the others on a different plant, so that a change of food was secured and a succession of crops insured.

This heteroecism of the rusts was first discovered by De Bary in 1864 , when he proved that the rust in wheat, Puccinia sranimis, produced its uredo and teleutospores on the Gramineae, while its aecidial stage developed on the barberry.

It has thus been assumed that heteroecious species originated from autoecious species in the simple and seemingly natural way that the two generations separated, just to occupy fresh ground, at first passing over to nearly allied plants, and gradually to plants further and further removed in the natural system, until the present position of affairs was brought about that the two generations of the same fungus attack plants widely removed from each other, as far as their natural affinities are concerned.

But there is no evidence to prove that such a gradual separation took place, for even although the species of Puccinia on Phalaris may have their related aecidia on other Monocotyledons, and the Uromyces on the pea, with its aecidia on a Euphorbia, yet they are always considenably remote from each other. In fact, the view that heteroecism originated suddenly and without the different generations slowly and gradually passing from plant to plant, seems to have most in its favour. It is admittedly a difficult problem, since from the very nature of the case no one has been able to observe an autoecious fungus becoming heteroecious.

Heteroecism is only possible when more than one spore-form occurs in the life-cycle, and how the variety of spore-forms originated is capable of different interpretation. It may either have been a progressive derelopment from the simplest forms, or it may have been a retrogression from the most highly developed forms. We may conceive heteroecism to have 
jroreerled from the formation of teleutospores being succeeded by aecidiospores, presumably at first both arising from the same mycelium. Next a livision of labour took place, and the mycelium of the aecidia was proluced by the sporidiola, while the mycelium of the teleutospore proceeded from the aecidiospore. The advance to heteroecism took place when the aecidiospores profluces their nucelium in one host-plant and the teleutospores, through the sporidiola, in another, and the kernel of the matter lies in the answer to the juestion, How did this come about? It may either have taken place by a long series of slow and gradual changes, whereby the different spore-fonms gradually accustomed themselves to the new mode of life, or it may have developed suddenly by one of the spore-forms germinating and growing on a different host-plant. and continuing to do so. But this latter view is hardly borne out by some experiments conducted by Miss Gibson ${ }^{1}$, in which the aecidia from different host-plants were used 10 infect Ranunculus ficaria, and while the germ-tube as a rule entered the stoma freely, it was generally dead and shrivelled by the third day. This result was not supposed to be due to starvation, for she says:-"Thether the incapacity to penetrate the cells is due to lack of attractive substance or to the presence of anything actively repellent is not clear, though, as hefore stated, certain facts seem to suggest the presence of sommthing harmful to the hyphae."

A few concrete examples may be given to show how far these views are horne out by facts.

De Bary consirlered the probable origin of three species of Chrysomvia occurring in the Alps, and the relation existing between them :- $C$. rhocodendri (DC.) De Bary, forms its uredo and teleutospores on species of Rhododendron, while its aecidiospores occur on Picea cxcelsa, the name given to this form before its connexion was discovered being Accidium abictimm, Alb. and Schw. C. ledi (Alb. and Schw.) De Bary, forms uredo and teleutospores on Ledum palustre, and its aecidia also on Picea cxcclsa, there being little or no distinction between them and those of C. rhododendri. The third, C. abictis (Wallr.) Lng., forms the same kind of teleutospore on Picca cxcclsa, but the sporidiola from the germ-tube produce mycelia which only form teleutospores and no aecidia or uredospores have been observed. In seeking to account for this, he alssumes a common origin of the three forms, and considers that either the original form from which ther were all derived had no aecidial fructification to start with, or there was an aecidial fructification, and $C$. abietis has in course of time dropled it. The latter view is the one he favours. We can imagine these three forms competing for Picea as an aecidial host. and while wo succerled in establishing themselves, the third, $C$. abietis. was compelled to drop it altogether.

Barclay², in tracing the developmental history of Uredineae, attempted to show that in the struggle for existence. heteroecism vas beneficial. and that if two species compete against one another for a host. that which makes for heteroecism will more probably succeed than that which makes for autoecism.

There is anotier interesting series of forms worthy of consideration known as " coronate" rusts, hecause the apex of the teleutospore is prolonged into amd rownerl by a number of finger-like processes. There are Inth heteromious ant autoerious species as follows:-

1. P. coroniata, Cordil, 1. Frangula alnus, II.. III.. Grasses.

2. I'. Holii. Nicls., T. Rhamnus cathartica, Se.. II.. III., Grasses.

3. T'. himalavensis (Barcl.). Diet. I. R. dahuricia, II.. III., Grasses. 
4. P. festucae, Plow., I. Lonicera periclymenium, \&c., II., III., Grasses.

5. P. mesneriana, Thuem. III., Rhamnus alaternus.

6. P. digitata, Ell. and Hark. III., R. croceus.

7. P. schweinfurthii (P. Henn.) Magn. III., R. sıadrlo.

8. P. longirostris, Komarov III., Lonicera hispida.

9. Uromyces phyllodiorum (B. and Br.) McAlp. O., II., III., Acacia notabilis, \&c.

Fischer considered that the original forms of the heteroecious species lived both on the grasses and Rhammus as autoecious fungi, and that they could undergo their complete development on either of them. These original forms were thus supposed to be able to live on a variety of hosts, and it is assumed that only in recent times had they become specialised. In support of this view there is a rust-Puccinia graminella which produces both aecidia and teleutospores on a grass, and I have also found an aecidium on Danthonia, and although teleutospores were not observed on the same plant, I still regard the two as belonging to the same species, viz., Lromyces danthoniae.

Fischer presupposes that the original form was both autoecious and plurivorous, and it is reasonable to suppose that a fungus which could live upon two such distinct hosts as Rhammins and grasses would, at the same time, select numerous other plants as hosts, so that this view hardly explains the fact. It is much simpler to suppose that since these primary forms had begun to form aecidia and eventually uredospores, they no longer carried out their complete development on their original hosts, since a change of host was in a sense equivalent to a cross in flowering plants. They accorringly changed their teleutospores (and uredospores) to new hosts, so that the autoecious stage was dispensed with because it was not so advantageous as the other.

This change of host is not a haphazard affair, but takes place according to a definite plan. It may be confined to a single or a few distinct species. and attempts to bring it about on plants which do not belong to the regular cycle, as a rule, end in failure.

But, of course, the regular host plants may fail, owing to drought or some other climatic conditions, and then the fungus often obeys the law of self-preservation, by repeating the same generation again and again. This may even become a fixed habit until the single generation is more or less independent, and then it is all that remains of what was once a complete cycle.

Among the heteroecious fungi there is a regular course of development which is usually followed. The one host-plant bears the aecidium generation, and the other host-plant the uredo and teleuto spore generations, but there are slight differences in detail which may be noted here.

The complete crcle of development, as already stated in the introduction, is the most common, in which the teleutospores germinate in the spring after a winter's rest, and produce sporidiola. 'The sporidiola infect the young leaves of the proper host, and produce aecidia. usually accompanied or preceded by spermogonia. Then the aecidiospores infect the host which bears the uredo and teleuto spores, but as a rule the regular course of development is interrupted by the repeated production of uredospores before the final stage is reached. The fungus is thus wirlely spread from plant to plant by means of the uredospores and then the teleutospores are formed in the autumn, either from the same mycelium or from a teleuto. spore-bearing mycelium proceeding from the uredospores. 
This course of development may be represented graphically as follows, taking $P$. graminis as the type:-

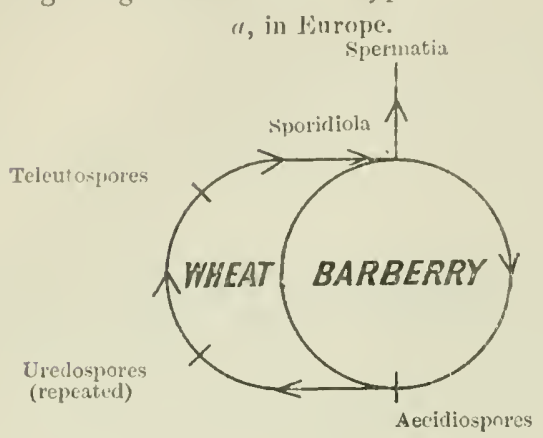

FIG. 14.

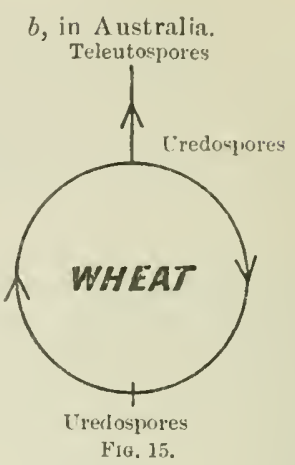

FIG. 15.

The aecidial stage of the spring rusts of wheat $(P$. triticina) or barley ( $P$. simplex) is not known, but Klebahn hazards the suggestion that the hosts to which they respectively belong may only exist in their original home, and thus not hitherto observed. With such widely and extensively cultivated plants. the uredospores could easily be carried on the grain or by the wind, and the fungus could thus be perpetuated without the intervention of an intermediate host.

The tiding over of the winter is most important for those fungi which depend upon two host plants for their continued existence, but while this is usually accomplished by means of the teleutospores, other and additional measures may be taken to secure the same result. Sometimes the uredomycelium persists during the winter, and in the case of Puccinia arrhenatheri the aecidium-mycelium becomes perennial, and reproduces the aecidia rear after year, while the teleutospore is also produced. When the aecidiai stage is dropped, as in the case of Puccinia graminis in Australia. then there is a profuse developnient of uredospores in comparison with teleutospores, and there is abundance for present needs, as well as for future germination in the spring. In other cases where the aecidial host is absent, the same thing has been observed, as in Coleosporium senecionis, when occurring in a ilistrict destitute of fir trees, or Chrysomyxa rhododendri when the silver fir is absent.

Heteroecism is said to increase the vigour of the fungus, and a striking illustration is given by Puccinia graminis on wheat. It is sometimes said that the aecidiospores from barberry are much more virulent than the uredospores derived from the wheat itself, since the teleutospores produced are earlier, more copious, and more injurious to the wheat. With reference to this, Plowright says:- "There is a wonderful difference in the amount uf injury done by mildew, when derived directly from the barberry, and when derived from uredo that has reproduced itself through several generations. . . The fungus grows with such energ! that it so injures the wheat plant as to prevent it producing more than a few starved kernels." As against this view, it may be well to bear in mind that in no country in the world prohably does $P$. graminis cause as great injury to wheat as it does in Australia, a country with barberries practically non-existent, and in which the aeciclial stage has never been fomd.

Of course further observations on a number of species are necessary to establish the fart. bui Klebahn considers that the utilization of the regetative periods and other peculiarities of the host-plants. rendered possible by the change of hosts, gives the fungus a decided advantage. 
Whatever view we take as to the cause of heteroecism, it is a wellestablished fact that the promycelial spores, no matter how freely applied, produce no effect on the grasses which bear them, and the most probable theory as to its origin assumes that the uredo and teleuto spore reneration were at first associated with the aecidia, but ultimately passed over to other hosts. 


\section{CHAPTER IVIII.}

\section{PREDISPOSITION.}

Wherever epidemic diseases caused by parasitic fungi occur, the question is raised as to the relative susceptibility of different varieties or indiriduals. The fungus has the power of causing disease in the host plant attacked, but the latter in its turn may either be favorably or unfarorably disposed towards its development. This predisposition of the host for the attacks of the parasite is very variable, and is influenced by varrous factors. It is generally considered that a sickly plant is more liable to rust than a sound one : but, on the contrary, strong and sound individuals are more easily and more virulently attacked, so that for artificial infection strong-growing plants are selected. Ward ${ }^{7}$ has shown that when the hostplant is starved by withholding certain mineral salts, and thus stunted in growth and generally enfeebled, it is not affected in its susceptibility or otherwise. A starved plant certainly develops smaller pustules and fewer spores on account of the diminished supplies of food available for the mycelium, but the power of infection is just as great as in normal plants. As far as brome rust is concerned-and we have no reason to doubt that it holds good for others as well-predisposition and immunity on the part of the host, and impotence and virulence on the part of the parasite are alike independent of mere nutrition. But, as we shall see afterwards, certain substances not of the nature of food-material, introduced into the plant may affect its liability to disease. There are various factors, however, which mav either dispose the plant towards disease or tend to render it immune, and some of these may be given here.

The age of the part attacked has an important influence on infection. particularly where the sporidiola are concerned. Young leaves and shoots are most easily infected, and when they get older little or no effect is produced. This is owing to the germ-tube of the sporidiolum penetrating the epidermis direct, and it is well known that this laver becomes firmer anrl tougher and less easily penetrable as it gets older. The uredospores and aecidiospores, on the other hand, infect the older leaves as well as the younger, and this is easily explained from the fact that their germ-tubes enter through the stomata.

Different parts of the same plant are also variously affecterl. Sometimes it is the leaves, sometimes leaf and stem, and it may he on one or both sides of the leaf. The different species of rust on the same hostplant are apt to choose different portions. Thus Puccinia triticina, from its earlier attark, is found most commonly on the lower leaves, and extends on to the sheath, mostly near its junction with the leaf, while $P$. graminis is worse on the upper leaves, and often parficularly bad on sheath and stem.

Different varieties or sorts of the same species vary considerably in their susceptibility. and, as will be shown later. it is by the selection and breerling of such rust-resistant sorts that solution of the rust-in-wheat question in Australia is being attempted. The same is the case with other rusts, and I have seen one kind of flax (Limum usitatissimum) badly attarked by Mclampsora lini. and another kind growing alongside quite free. Hennings ${ }^{5}$ has recently made observations which tend to show that plants previously susceptible to the attarks of a parasitic fungus mar gradually herome inmune when they are changed to rich ground where they are better nourished and more vigorous. 
In $189+$ several rhizomes of Peltandra virginica were sent to him from North America. and planted in pots. An aecidium developed on the sterns and midribs of the leaves, which was found to be new and named Aecidium importatum. One plant was left in the pot, which was placed in water, and the others were planted out in a soil composed of damp humus. The pot plant has annually produced the aecidia up till the time of writing (I902), while the other plants only showed the fungus very slightly in I895 and 1896 , after which they grew exceedingly strong, and since then have remained perfectly sound. It must be remembered that this is a hardy marsh-loving plant, and there is probably more than mere nutrition :oncerned in its freedom from disease, since it would be more reasonable to recard the result mentioned as due to the change of situation than to change of soil. Salmon ${ }^{3}$ considers that the evidence which is gradually accumulating on the subject of the relations between host-plants and parasitic fungi leads us to the conclusion that irnmunity and susceptibility are due to constitutional (physiological) peculiarities, and not to any structural ones. He has also shown experimentally that while the uninjured leaf may be immune, the same leaf when cut or injured may become liable to infection, and the conidia produced on such leaves are then able to infect uninjured leaves. In this way the range of infection of a biologic form mav be increased. Different species of the same genus, when they are generally attacked by a rust-fungus, may vary considerably in their susceptibility to infection.

If we attempt to explain the varying susceptibility of different plants or different kinds of plants, then the difficulty is apparent, and the symbiotic relation between the parasite on the one hand, and the host-plant on the other, complicates the matter. Why is the fungus able to infect certain host-plants, and not others? Why is the host-plant capable of resisting certain fungi. and not others? How is the fungus able to accommodate itself to certain plants, and not to others? These and other questions may be asked, but cannot be fully answered at present. De Bary" says :- "The phrsiological reason for these predispositions cannot, in most cases, be exactly stated; but it may be said in general terms to lie in the material composition of the host, and therefore to be indirectly dependent on the nature of its food."

The question has been asked, if there is any relation between liability to infection or power of resistance and the visible structural features of the leaf, and it has been answered differently by various investigators.

Hennings ${ }^{2}$ lays stress upon the phrsical characteristics of the parts of the plant on which the parasitic fungi occur. He considers that the parasite develops differently on a thin-skinned, delicate leaf, and a thickskinned, firm, leathery leaf. Also that the venation and hairiness of the leaf may affect the result.

Marshall Ward ${ }^{1}$ fully investigated the structural peculiarities of the leaves of the various species of Bromus used in his infection experiments with brown rust-such as thickness of cell-wall and cuticle, "bloom." size, number, and distribution of hairs, distribution of chlorophyll-tissue and vascular bundles - and he arrived at the conclusion that " the resistance to infection of the immune or partially immune species and varieties is not to be referred to observable anatomical or structural peculiarities, but to internal, that is, intra-protoplasmic properties berond the reach of the microscope."

Salmon ${ }^{3}$ comes to the same conclusion from his infection experiments with the oidium of Erysiphe, but the physical characters of the wheat-plant seem to hare some some effect on its liability to rust, for there are certain 
typical characters associated with the quality of rust-resistance, and they would appear therefore to have a share in bringing about this result. In a rust-resistant wheat, the leaves have a tough cuticle, and the straw is well-glazed often with a glaucous bloom. The flag is narrow not broad, erect not drooping, stiff and firm, not soft and flabby. Still all these characters may be present, and yet the climatic conditions may orerrule them and weaken the power of rust-resistance. It will thus be seen that a variety of causes may contribute to rendering a plant immune, and that not only the chemical and other properties of protoplasm come into play, but there is also the mutual reaction of the living protoplasm of host and parasite to be considered.

As far as the rust fungus is concerned, there is no such thing as a perfectly immune wheat-plant, for, given the necessary conditions of situation, heat, moisture, and spores at the right season, and at some time or another rust will appear. We express this by saying that there are "rust-resistant" wheats, but not "rust-proof."

Animals are sometimes rendered immune, or, at least less susceptible to disease, by repeated infections, so that they become gradually accustomed to the effecis of the parasite, and the impartant question arises, Can plants also be submitted to "protective inoculation"? Inoculation with attenuated bacteria is the simplest method with animals, and this treatment retards their vegetative development. and so lessens their injurious effects. This artificially-induced immunity only lasts a certain time, varying in different cases. Ehrlich and Huebener ${ }^{1}$ have shown, from numerous experiments upon animals, that an immunized mother can impart immunity to her offspring, but it is not lasting.

In the case of plants, as in animals, there seem to be two opposing forces at work. On the one hand, the protoplasm of the fungus is endearouring to overcome the resistance to its entrance offered by the hostplant, while on the other hand the host is more or less successfully resisting the inroads of the fungus. There are no known cases of a plant becoming "immune" or "partially immune" by inoculation with the parasitic fungus to protect it against further attack, but advantage has been taken of the great sensitiveness of certain spores to copper salts to protect the organism against them.-(Note 6, p. 75.)

Chemotaxis is the name given by Pfeffer $^{1}$ to a form of sensitiveness which certain organisms possess towards certain chemical substances. This power, which certain nutritive and other substances have of attracting bacteria and other organisms towards them, is known as positive chemotaxis, and of organic substances with a high nutritive value which are positively chemotactic, may be mentioned asparagin and peptone, while sugar, which is one of the best food stuffs and richest sources of energy, has but little attractive power. The power of other substances, on the contrary, to repel bacteria, is know as negative chemotaxis, and free acids and alkalies, as well as alcohol, have this effect. Glycerine, as far as known, is an inactive substance. Massee ${ }^{9}$ has stated that immunity is owing to the absence or small proportion of the substance chemotactic to the parasite in the plant not attacked, and if a plant can be impregnated with some substance which is negatively chemotactic, and at the same time does not affect the utility of the plant, then immunity against parasitic fungi may be obtained in this way.

Laurent ${ }^{1}$, acting on this principle, conducted a series of experiments to test the possibility of producing potatoes which would be proof against Jhytophthora infestans. He grew very susceptible varieties in pots, to the soil of which sulphate of copper was added, and when the tubers were harvested, some wire cut in two and their cut surface placed in contact with 
the mildew of potato leaves. After four days, the tubers grown in the soil containing copper did not show any infection, while those grown in untreated soil were infected in a very decided manner from being brought into contact with a mildewed leaf.

Marchal ${ }^{2}$, following on the same lines, tried to secure immunity to lettuce against Bremia lactucae, and he found that the plants treated showed considerable resistance, and the immunity seemed to be in proportion to the strength of the solution. He also experimented with cereals for protection against rusts, but without success, and the probability is that he did not use the proper substance which repelled the germ-tubes of the rustspores when they attempted to enter the plant.

Massee ${ }^{7}$ experimented with cucumber and tomato plants, watering the soil on which they were grown with a solution of sulphate of copper. The result was that "not a single one of the treated tomato plants showed a trace of disease" after being sprayed with water containing the spores of the fungus, while the untreated check plants were badly diseased.

It is important to note that tomatoes produced from plants treated with solutions of copper sulphate were found on analysis to show amounts of copper not sensibly greater than that found in the fruits obtained from untreated plants.

These experiments at least show that certain substances entering into the constitution of the host-plant render it for the time being immune to the attacks of certain fungi, even although it was naturally predisposed to that particular form of disease. 


\section{CHAPTER IIX.}

\section{The I'Resent Position of the Rust in Wheat Ruestion in Australia.}

It will tend to clearness if we confine our attention to the rust in wheat, for the general considerations which hold in this case will apply to the rusts on the other cereals chiefly cultivated, viz., oats and barley. And the rust which is most important from the farmer's point of ritw, because it does the most damage, will be chosen viz., Puccinia graminis, which is so distinct in its characters that there is no difficulty in recognisin it. There are only two kinds of rust in wheat in Australia, the positively injurious Puccinia graminis and the comparatively harmless $P$. triticina, because it does not pinch and shrivel the grain like the other. In the early days wheat and other cereals had to be imported into Sydney, but now it is grown to such an extent in the Australian Commonwealth that in the season I903-4 there were $5,566,340$ acres under wheat, yielding a total of $i 4,149,634$ bushels. Wheat will always form one of our staple products, and from the great extent of the industry, whatever increases the yield or tends to diminish the losses from disease, will have a corresponding far-reaching effect. Ever since attention has been given to the subject, it has been found that not a year passes without its being present on wheat to a greater or less extent, and in some years, which are commonly spoken of as rusty years, it seriously injures the grain and considerably diminishes the yield. To give some concrete idea of the extent of the loss, it may be stated that in a particularly bad season like that of $\mathbf{1} 889$, the loss was estimated to be for the whole of Australia between $£ 2,000,000$ and $£, 3,000,000$. In such farorable years for the rust, there is always an evident connexion between the weather and its epidemic nature. In 1889 it was a wet spring, and about the blooming season the weather was what was known as "muggy," consisting of showers with heat between, and heavy dews, so that the wheat-plant, at the time of coming into flower, was particularly susceptible, and the rust spores found a ready entrance into the tissues of the plant, with their accumulated stores of food, and thus it spread rapidly.

Atmospheric conditions are often regarded as the prime factors in the production of rust, but they are only concerned in the matter in so far as they favour or hinder the development of the parasite which causes it, and this is strikingly shown in the existence of rust-resisting wheats. Owing to the impartance of the subject, and the widespread losses, delegates from the various States were appointed to meet and confer periodically, and these various conferences extended from the first in 1890 to the last in 1896. The results of their labours may be seen in their voluminous reports, which practically cover the different phases of the question. But there were some important points with which they were not then in a position to deal, such as the effects of rust on the straw and grain, and experiments in the inoculation of the barberry. These will be consiclered preliminary to the main question.

\section{Fiffects of Rust on the StraW and Grain.}

The risible fffects of the rust on the wheat plant is well shown in Pl. XI,IV., where the straw of the rust-resistant Rerraf is bright, glossy, deep vellow, and well ripened, while that of th: badly rusted Queen's Jubilee has i dirty, streaky, patcliy appearance. The ears of the one are full-sized and well formed, with plump, well-filled grain, and the other has poor ears with light and shrivelled grain. 
But the effect upon the composition of the plant, and particularly its feeding value, is not known to the farmer, who cuts his crop for hay when rust threatens to ruin it.

This has recently been determined by F. T. Shutt ${ }^{1}$, chemist, Dominion Experimental Farms, Canada, who analyzed two samples of wheat grown at Manitoba in the same field and of the same age, only the one was rusted and the other rust free, so that the results are strictly comparable. The analysis is as follows:-

A.MALSIS OF Rested Axd Rust-Free WheAT-STRAW Axn Grais.

Straw from rust-free wheat Straw from rusted wheat Grain from rust-free wheat Grain from rusted wheat

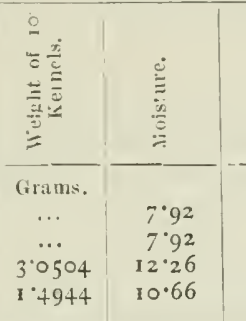

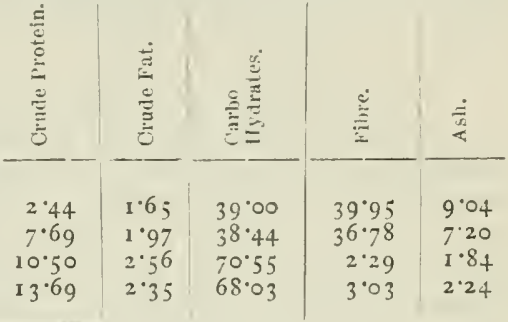

The Straw.- It is pointed out that in crude protein the rusted straw is much richer, and since this includes all the nitrogenous compounds of a food that go to repair waste, form blood and build up muscle, it may safely be concluded that the rusted straw is much superior in feeding value. There is also in the rusted straw slightly more fat and somewhat less fibre, so that all this affords additional evidence of its more highly nutritious nature.

The handling and feeding of rusty straw in Australia from the farmer's point of view has received attention. The experience of one who has done a deal of threshing is to the effect that when very bad it caused an itchy sensation, and made the men about the thresher rub their skin until it was broken. As regards feeding rusty hay, another with large experience informs me that horses and cattle relish it far before ordinary hay. Of course, it was fed as chaff.

The Grain.-This from the rusted wheat is only about one-half the weight of that from the rust-free wheat, but as the protein content shows. it has, weight for weight, a considerably higher nutritive value. $\mathrm{He}$ accounts for the higher protein content in the smaller grain in its larger proportion of bran, but chiefly in the partial and incomplete transference and accumulation of starch.

These results likewise afford interesting evidence as to the physiological effect of the rust on the wheat plant, and agree with what has been deduced from other data.

In the actively growing and feeding pariod of the plant's life, it is apparently able to provide for the wants of the fungus as well as its own. and therefore its vitality is not seriously affected. But when the second period of forming and ripening the seed arrives, when feeding is gradually ceasing, and the accumulated materials are being transferred to the seed. then the fungus draws upon the plant's capital, crippling its energies, and checking the movement of the food materials to the seed. As Shutt summarizes the whole process:- "The growth of the rust arrests development, and indicates premature ripeness, which, as we have seen, means a straw in which still remains the elaborated food, and a grain small, immature, rich in protein and deficient in starch."

This emphasizes what we have frequently insisted on, that the critical period, literally the turning point in the plant's life, is reached when it 
begins to form the grain, and if that season is favorable for the derelopment of rust, then the fungus has to draw upon the stored-up material, and consequently the grain is not fully formed, if at all. Incidentally this investigation also throws light upon the reason why the earlier rust $(P$. triticina) is comparatively harmless, since its period of greatest activity is when root and leaf are busy manufacturing material sufficient to provide for the necessities of both.

On account of the comparatively late appearance of $P$. graminis, it is by some considered to do the least damage to the grain, but, as a matter of observation, and on physiological grounds, it is known, at least in Australia, to be the most injurious.

\section{Puccinja Graminis and the Barberry in Australia.}

In Europe and America the identity of $P$. graminis is determined, not merely from its morphological characters, but from its ability to infect the barberry and produce aecidia. But in Australia infection of the barberry has not been successful, although several attempts have been made, and some have doubted whether we have got the true $P$. graminis, and not a distinct biological form of it. From a comparison with European specimens and a critical examination of the sori, the uredo and teleuto spores, there is no doubt that the rusts are very much alike, only if the infection of the barberry is accepted as a diagnostic character, then the identity is not proved. The relation of this rust, therefore, to the barberry in Australia became a pressing subject for experiment.

The germination of the teleutospores may be easily accomplished at the proper season, either by placing them in a drop of water on a slide under a bell-jar, or, better still, if copious germination is required, by taking some of the rusty straw and placing it on a drop or two of water in a petri dish, the cover of which is lined with damp blotting-paper. It is only after a considerable rest that they will germinate, and they start on warm days about the end of September, which is the beginning of our spring. This may continue through the warmer days of October, almost or entirely ceasing in a cold spell, and even until November germination continues if the conditions are favorable; but although numerous trials have been made. no germination has occurred outside these months. Generally speaking, the middle of October is the height of the season for germination, and then, too, the uredospores may be multiplying rapidly on the growing wheatplant; so that there is no "off " season in Australia, as far as wheat is concerned, when the teleutospores are active and the uredospores dormant. In any case, as our wheat crops are usually harvested in Norember and December, eren if the barberry were common, and developed rust freely, it could hardly be of much importance as a factor in spreading the wheat rust, since the recidia would not be developed profusely before the wheat crop had passed the danger point.

The barberry is not a native of Australia, and very few hedges exist. so that the question of its infection is not of great immediate practical importance, but it is of high scientific value to establish the fact that the rust may pass one portion of its life on one plant, say, wheat, and continue it on a very different plant as an intermediate host, say, barberry, and thus settle that the rust with which we have to deal is the $P$. graminis of Europe.

As early as October, 1892 , I succeeded in germinating the spores freely and copiously in a watch-glass with water, and infected four different species of barberry obtained from the Botanic Gardens, wo of which were 
known elsewhere to carry the aecidial stage of $P$. graminis. In one case the infected branch was placed under a bell-jar to preserve moist conditions, but there was no result with any of the species, since the weather was too hot and dry.

In 1902 , in order to give the experiment another trial under the most favorable conditions, Dr. Plowright kindly forwarded several young harberry bushes from England, which arrived here in December in good condition. Rusted straw was specially kept exposed to the weather in order to inoculate the barberries. About r6th September the barberries were putting forth their young leaves, and looked very healthy. One was kept as a check, and the others were infected, either by scattering rusted straw around the plants and tying it on to them, or, in two cases, by applying germinating spores direct to the leaves. Some plants were kept under bell-jars, others exposed, and all were attended to and watered freely. The result was that not the slightest trace of any fungus appeared on any of the barberry leaves. It may be stated that the conditions for fungus growth were most favorable, as at times that muggy heat prevailed, which so quickly spreads the rust in a growing crop.

In 1904 the experiments were continued in the pots, partly on the same lines with rusted straw, and partly by planting a rusty wheat beside the barberry, so that it might be naturally infected next season.

Cuttings from the English barberries have also been planted at Port Fairy in a rusty spot where they have thriven, and Queen's Jubilee wheat planted around them produced abundance of $P$. graminis. The rusted straw was allowed to die down on the spot, and every facility given for the inoculation of the barberry, but without result so far. Some $P$. graminis on wheat was sent by Dr. Plowright in March, I903, which was gathered in September, I902, and kept in his garden till March. On arrival here some of it was kept inside, and a portion placed outside exposed to the weather, just as was done with Australian rusted straw. It was thus exposed during our winter months of June, July, and August, and in September it was tested, being then exactly twelve months old. While the teleutospores about six months old from the Australian wheat germinated freely, there was no change in the spores from the English wheat, and although attempts were made at different times, there was never any sign of germination. Probably they were kept too long, as they might hare germinated on or about the English spring. Prior to this, I had sent rusty Australian straw for trial to Dr. Plowright, but none of the teleutospores showed the slightest trace of germination. "Writing in the Gardeners' Clironicle for I5th January, I 898 , he says ${ }^{6}$ - "I have tried on two occasions to get the teleutospore of Puccinia graminis from Australia to germinate in England, but I have not succeeded. The first attempt was made nine years ago, when Mr. D. McAlpine was good enough to send me material; but I was quite unsuccessful. Last year he was kind enough to send me a further supply; but, although I kept the straw out of doors during the latter part of last winter and the spring of 1897 . I was equally unsuccessful. Is it probably like the seeds of some of the higher vegetables, the teleutospores require not only a period of rest, but also an exposure to a certain degree of cold?" Seeing that the spores germinated freely here, the "exposure to cold" theory does not hold; and the most probable explanation is that they had been kept too long, and attempts to germinate them should have been made in the English autumn. As far as Australia is concerned, the rust which does the principal damage has apparently no intermediate stage. 
The Australian rust has been determined as l'uccinia graminis by Eriksson and other authorities; but if the ability to produce the aecidium on the barberry is laken as the final criterion, then judgment must br suspended in numerous other cases. Thus Massee ${ }^{4}$ has found $P$. sraminis on Alopecurus pratensis, and Avena clatior in the Royal Gardens. Kew; but he significantly adds- "Notwithstanding the great quantity of Iicrbiris and Mahonia present in the grounds, the most careful and continuer search has failed to reveal the presence of the aecidiospore stage." (Note 7, ]). 75.)

\section{The Proelen Stated.}

In dealing with the rust question from a practical point of view, there were two main issues to be determined:-

I. How is the rust spread and continued from season to season?

2. How may its injurious effects be mitigated or counteracted or prevented?

The first question is a most important one, for if we could find out where, and under what conditions, the rust is lying dormant during the time from reaping the crop to sowing it again, then we might be able to destroy it at this stage, and prevent its reappearance. Although the question may thus be simply stated, it is by no means easy to answer.

The second subject of prevention or mitigation will evidently depend on our linowledge of the life-history of the rust fungus, as well as of the wheat plant itself, and how far the conditions can be controlled which render it susceptible to the fungus.

How the Rust is Spread and Continued from Year to Year.-We know exactly now, thanks to the labours of Erilisson, Marshall Ward, and others, I.ow the rust-spores enter the plant by means of their germ-tubes, how they grow and ramify among the tissues, and drain them of their contents, until they again form a spore-layer, and reproduce the spores on the surface in great abundance. We thus know how fresh spores orginate once they have got a start; but it is the starting-point which is the difficulty.

Although the rust was known, and the effects produced by it were familiar from remote antiquity, yet its true nature was not discovered until the latter half of the eighteenth century. As late as I733, Jethro Tull, writing about it in his Horse-hoeing Husbandry, attributes it to the attacks of small insects "brought, some think, by the East wind, which feed upon the wheat, leaving their excreta as black spots upon the straw. as is shown by the microscope." In 1767 , its true nature as a fungus, and therefore is a plant, was determined by Felice Fontana, and in 1797 , Persoon gave it the name by which it is still known, Puccinia graminis. The rust then is a fungus growing inside the wheat-plant, and living at its expense, and reproducing itself by means of minute seed-like bodies or spores, which are so conspicuous on the leaves and stem of the wheat at certain seasons.

For a long time there was a suspicion in the minds of many practical farmers that the barberry busli had something to do with its spread, and so firmly was this believed in. that the State of Massachusetts passed an Act compelling the inhabitants to extirpate barberry bushes. And when $\mathrm{De}_{\mathrm{c}}$ Bary, in $\mathrm{s} 864$, justified the farmer, and proved scientifically that there was a connexion letween the fungus which appears on the barberry bush, and that which appears on the wheat, then it was thought by many that we harl reached the root of the matter, and that we had simply to destroy the harlerry lush in order to get rid of the rust. But it is well 
known that here in Australia, where barberry bushes are not native, and where they are comparatively scarce, the rust is particularly bad in certain seasons, so that there must be other causes to account for the prevalence of rust.

The connexion between wheat-rust and barberry has already been discussed, so need not be further referred to here. There are several possible ways in which the presence of the rust year after year may be accounted for, and it may be worth while to consider some of these.

I. The uredospores produced in such immense numbers may serve to carry it on. 'They are rery minute and light, easily distributed by the wind, and it has been shown that they exist in the air and on the ground. They might thus be readily transported and even carried to localities far remored from wheat-growing areas, in some cases by the duststorms which are very prevalent in the northern parts of Victoria. But the mere presence of spores is not sufficient to account for the rust being spread. since they must be capable of germination. 1 have often tried to germinate uredospores taken from straw that had been left on the ground, but without success. My latest attempt was with ureciospores still retaining their colour trom a sorus on a dead leaf of Queen's Jubilee wheat on March $25^{\text {th. }}$. The spores were kept moist under a bell-jar, but not a single one germinated. But the result is difterent when spores are taken from self-sown wheat growing in the interval between the two crops.-(Note 8, p. 75.)

2. These spores are not only in the arr and on the ground, but they are commonly to be found entangled in the bearded tip or "brush" of the grain. In one variety, Queen's Jubilee, this was so common that not a single grain could be found without the uredospores. Dr. Cobb ${ }^{11}$ has likewise examined the brush of a number of varieties in New South Wales. and found in about 57 per cent. of the grains examined that the spores were in the brush. This is an evident starting-point for the rust, but not the only one, since seed wheat treated with bluestone. formalin, corrosive sublimate, and other fungicides, produced rusty plants, and in fact there was little difference as regards rust between the plants from treated and untreated seed.

3. It was commonly supposed until recently that the rust could readily pass from one cereal crop to another, and thus it was passed on to the wheat at the proper season. This view was put forward as late as September, 1904, in the Journal of Agriculture of South Australia, by A. Molineux ${ }^{1}$, who states:-_ "I have observed for many rears that when ever we have a mild autumn and summer, accompanied with occasional showers, we have complaints of red rust in the succeeding crop; and I have been led to the belief that until the new wheat crops have started, the rust is nursed by the wild oats and other cereals that may always be found growing on the headlands and by the roadsides." Of course, this is a very convenient way of accounting for the presence of rust throughout the year, but Eriksson has shown that the spores from oats will neither infect wheat nor barley, nor will the spores from the barley infect wheat or oats. It follows from this that adjacent fields of these crops will not affect or be affected by each other, so far as this rust is concerned. Probably, howerer, Molineux's view is correct, except that it is the self-sown or volunteer wheat growing in our paddocks or on the headlands that carry it over. The system of harresting practised in Australia with the combined harvester, which takes off the heads only and delivers the winnowed grain into bags, necessarily implies the scattering of a certain amount of seed on the ground, and this zerminates with the first rain, and is almost always partly rusted, and often badly so. Our hay being largely made 
from wheat, when rains fall shortly after it has been cut, the second growth or aftermath is almost always rusted, and so a second crop of uredospores is produced.

4. Since "intermediate hosts." such as the barberry, are not concerned in carrying over the rust from season to season, it has been suggested that infection mar be communicated to the wheat from other grasses which, as we have elsewhere shown, may also be attacked by Puccinia graminis. Klebahn ${ }^{1}$ (p. 230) has shown that uredospores from various grasses will infect wheat, and it remains to be determined how far the grasses occurring in our wheat-fields, and attacked by this rust, are capable of infecting it.

5. Towards the end of the growing season, a second kind of spore is produced, known as the teleutospore. It will not germinate immediately, but only after a period of rest, and it may also aid in carrying over the rust from season to season. But although it can germinate in the spring, and produce other minute spores known as sporidiola, still they have not been proved to infect the wheat-plant, and so we do not know what purpose ther serve, if any. In other countries they are said to germinate upon Larberry leaves, and produce the aecidial form of the rust-and it may be that here they are simply dying out-are becoming functionless, because the barberry bush which they normally infect is not now available for them.

6. There is still another way in which some rusts are propagated, and that is by means of the threads of the fungus or mycelium remaining inside the seed and starting into life with the germination of the grain. But although hundreds of seeds have been carefully examined by the microscope, no trace of this has been found, and therefore for the present we must decline to regard it as a probable cause.

7. There still remains another possible means of continuation from season to season, which has been prominently brought forward by one who has devoted considerable attention to the study of the rusts in Sweden, Professor Eriksson. Although he has not ret succeeded in giving scientific proof of his theory, he considers that while infection by spores does occur, yet the primary infection is from within, from an internal germ of disease inherited from the parent plant and latent in the seed. He grew wheat in closed chambers, where it was believed to be secure against infection from without, and still the rust appeared all the same, and he can only account for this by supposing that in the cells of the seed the protoplasm is associated with the plasma of the fungus-what he calls mycoplasm-and from this there arises, if the conditions are favourable, the mycelium of the rust fungus, quite independent of external infection. He does not seem to have considered the possibility of the spores of the fungus being attached to the seed, and until the soil and the seed are thoroughly sterilized and every precaution taken to exclude infection from without, and the disease still produced, until then we must suspend our judgment and accept the Scotch verdict of Not Proven. A very striking case, however, that the seed may be the means of continuing rusts from season to season is given by Carleton ${ }^{3}$ in connexion with Euphorbia rust (Uromyces euphorbiae, Cooke and Peck). The pods of Euphorbia dentata, and even the naked seeds, were found to be affected with aecidia, and on growing the rusted seeds under a bell-jar, those that were disinfected produced plants without rust, while those not disinfected gave rise to rusted plants. Here the seeds actually bore the aecidia, and propagated the rust through the germinating seed. A similar instance is met with in Accidium platylobii McAlp.. where the aecidial cups are borne on the pods, and on opening the diseased ones, the seeds are frequently found corered with the mycelium, which, on microscopic examination, is found to penetirate them. 


\section{Prevention or Mitigation of the Rust.}

The all-important question now remains to be answered, how to prevent or mitigate the effects of the rust. In the various reports of the Rust-in-Wheat Intercolonial Conferences, special attention was paid to the solution of this question, and the effect on the crop of different cultural methods received a large share of attention.

Drainage.-It is commonly affirmed that rust is worst in hollows, where water lodges, and on general grounds it is considered that drainage by removing the surplus moisture would tend to afford the wheat the most favorable conditions for its healthy development, and thereby render the rust less injurious. But, as a matter of fact, when it was experimentallv tested in Victoria, an increased yield was the result; but as regards rust, it did not seem to affect it, for out of six areas artificially drained, five of them were rusty. In a number of our wheat-growing areas, it is not excess of moisture in the soil, but deficiency of it, which is complained of, and in such areas the rust is very severe in seasons marked by copious late spring rains.

Irrigation. - At the present time irrigation is the great problem which overshadows all others in connexion with the utilization of the land in Aus. tralia, and its relation to the development of rust has not been overlooked. In irrigated areas where wheat was grown, the effect was observed, and it was seen that the judicious application of water was beneficial if done at the right time, and with due regard to atmospheric conditions. There is only one rational method of irrigation for wheat in Victoria, and probably for all Australia, and that is a thorough soaking of the ground prior to ploughing. Mr. Geo. Pagan, of Ardmona, who has successfully irrigated in the Goulburn Valley, states in the Journal of the Department of Agriculture for March, I905, that his routine practice is to flood the land in March, unless there has been heavy rain, and then plough as soon as the horses can work without sinking.

This one watering, followed by proper working of the land, will usually mature the grain. Even in I902, when the year's rainfall was only six inches, this was the case. The application of water later in the growing season is always risky, and often does more harm than good. It spoils the grain, making it soft, may bring on rust, and results in very uneven ripening.

Seed-bed.-A relatively dry and firm seed-bed is generally considered best for wheat, and especially if there is a prospect of rain after sowing to ensure a good germination. Its effect on rust has not been definitely determined, but farmers are generally of opinion that sowing on a dry seed-bed gives the plant a better chance to escape the rust. If the seedbed is moist, the condition will be favorable for the rust-spores on the soil, or on the grain, to infect the germinating whieat-plant, but probably it is not so much the nature of the seed-bed as the aftergrowth which will affect the result. This also applies to the mode of sowing, for it did not appear to make any difference, as regards rust, whether the wheat was sown broad-cast or drilled.

Ploughing and Harrowing.-The question of deep as opposed to shallow ploughing does not seem to have much to do with the rust. In experimental tests, deep ploughing yielded the heavier crop, and thus indirectly favoured the development of rust; but both were about equally affected. Harrowing when the crop was about two feet high was equally inconclusive.

Rotation.-Rotation is undoubtedly good for the crop, and is a factor in clean cultivation; but it is another question. whether it is good or bad for 
the rust. At Port Fairy, in Victoria, where rotation is regularly practised, and where I have had crops grown the same stason, sometimes ifter mangels, or potatoes, or onions, there was no perceptible difference in rustiness from those crops of wheat grown in succession. From the stand-point of good farming, it is to be recommended; but cropping year after year does not seem to affect the liability to rust further than this, that self-sown wheat is likely to appear in the interval between the two crops. Such "volunteer" wheat, if not killed in cultivating, is much more forward than sown grain, and on account of its earliness may escape the rust, but on the other hand, there is a risk attending it, for it is sometimes more rusty than the ordinary wheat, and appears earlier, so that it is one of the means of carrying over the rust from one season to another. All such wheat should therefore be kept down by means of sheep.

F allowing.-This practice is similar in its effects to rotation as regards rust. Professor Lowrie, speaking from a large experience in South Australia, considers that the apparent exemption which fallow-land sometimes enjoys from rust is due to the fact that it is customary to sow bare fallow: land first, and the crop ripens sufficiently early to escape the rust in some seasons.

Burning Stubble.- It is sometimes recommended to burn the stubble in order to destroy any spores of rust that may be about; but as a matter of experience, this has not been found to produce any appreciable difference. Theoretically, the burning of the surface of the soil should destroy it number of spores, and to that extent is beneficial; but, practically, the difference in result is not marked. As far as most wheat-soils are concerned here, the loss of vegetable matter is much more serious than any possible increase of rust.

Soils.-Soils are sometimes said to be rust-liable and rust-free, like the wheat itself; but on closer investigation, it will be found that the soil is only one of several factors that require to be taken into consideration. Rich soils are said to suffer most, and in rusty years the best crops have sometimes been raised from the poorest soils. On the rich soils the crop is naturally heavier and more luxuriant than on poor soils, and the softer and more susceptible tissues are easily invaded by the parasite. Hence it is that the rust may sometimes be worst in the best crops. The mallee, in Victoria, is said to be particularly rust-free; but in some seasons the crop has to be cut for hay, in order to save it from being completely destroyed by rust. The reason for general freedom from rust lies not so much in the soil as in the light rainfall and the early ripening of the crop. But if "muggy" weather should prevail when the wheat is flowering, then the crop is just as liable to rust here as elsewhere. At Port Fairy the low-lying black soils more readily produce a rusty crop than the sandy soils, and this may be partly due to the fact that the dark-coloured soils absorb more heat, and are more likely to preserve the spores in a fit state for germination, or because they grow a heavier crop, which often lodges and thus encourages the rust.

Manures.-Perhaps no means for the prevention of rust have been more thoroughly and continuously tested than the application of different manures. In all the States, as well as in New Zealand, experiments have been conducted to this end. and the general opinion has been expressed by a late Director of Lincoln College, New Zealand:- "No manure has vet been discovered that is a preventative of rust in cereal crops." The tests were carried out under varying conditions, and. as might be expected. the results of one year were often contradicted by those of the next; still, it was generally found that nitrogenous manures favoured the rust. while phosphatic ones had a tendency to diminish it. Nitrogenous manures 
tend to increase the amount of flag, and retard ripening, by affording an excess of nitrogenous food, whereas phosphate of lime tends to induce early maturity, and thus enables the crop to escape the rust to a certain extent.

Treatment of Seed.- This was thoroughly gone into, since it is so often stated that the disease is in the seed. No doubt appropriate treatment destroys the spores entangled in the "brush." but inside the seed no mycelium has been traced. A great variety of "steeps" have been used, and I have myself experimented with over twenty, including the hot-water treatment; but ther were all of no practical benefit. Last season (1904) two plots of Queen's Jubilee wheat were sown the same dav and grown alongside of each other, in one of which the seed was treated with formalin, while the other was untreated. The rust was bad on both plots, and althour special attention was given to the matter in the field, I could not say that treatment of the seed with formalin gave any advantage as regards rust.

Both sulphate of copper and formalin destroy the rust spores on the seed-grains, and Dr. Hollrung, as the result of a series of experiments, has recommended the latter as the best for this purpose. But since infection chiefly takes place when the whear plant is above ground, it is evident that the formalin treatment does nut prevent it, and the experience of numerous farmers who have used formalin successfully for the treatment of stinking smut (Tilletia tritici). bears this out.

The hot-water treatment of the seed is constantly being brought forward as a remedy for rust, but in 1892 the seed for II 8 plots, consisting of different varieties of wheat, was treated with hot water at $55 \mathrm{deg}$. C., and in some cases the rust was just as bad as if no treatment had been given.

It was adopted as a conclusion at the last Rust-in-Wheat Conference that the treatment of the seed is valueless for rusit, and Dr. Cobb ${ }^{10}$ one of the representatives of New South Wales, went so far as to say:"As for curing rust by treating the seed, the idea is ridiculous. It would be just as reasonable to expect to prevent measles among mankind by soaking babies in some sort of nickle."

It has not been thought necessary to refer specially to spraying as a means of combating the rust; for although this method is practicable in an orchard, and has been found successful in treating peach and plum rust. still the mechanical difficulties to be overcome in spraying a wheat-fierd are so great, that it is no longer reyarded as of practical importance.

So far it would seem as if the rust in wheat defied treatment, and the only practical measures to be recommended for mitigating its effects were to sow early and to select early maturing varieties. In this way it is often possible to escape the rust, or the crop is too far advanced to suffer seriously. But in this, one is at the mercy of the weather, and the only hopeful remedy is to grow wheats which will be able successfully to resist the rust, even when the weather favours its development.

'The question has been raised as to whether a wheat which resists one kind of rust can succumb to another in a different country, and this has really been found to be the case. Professor Eriksson sent me ten varieties of Siredish wheats which had been grown in the experimental plots, and found to resist the rust which is prevalent in that part of the world, viz., Golden Rust (Puccinia glumarum). When grown here these rust-resisting Swedish wheats became rotten with rust, although of a clifferent kind : and this, along with other experiments, points to the possibility that a wheat may resist a rust such as $P$. graminis in one country and succumb to it in another.

Selection and Cross-breeding. - As the result of numerous experiments, and the trial of hundreds of varieties of wheat from all parts 
of the world (Europe, Asia, Africa, and America), it has been proved that no wheat is absolutely rust-proof, that is to say, there is no wheat known which will be proof against the rust when grown under conditions favorable to its development. But the same experiments have shown that among a number of varieties grown in a particular district, some will resist the rust more than others, are able by their constitution-it may be by their vigour of growth or toughness of their cuticle or glaucousness, or all combined-to resist the inroads of the rust sufficiently to prevent its seriously injuring the grain. and such wheats are known as rust-resisting wheats. At present we have at least one such wheat which has been grown in various districts of different States alongside of other wheats badly rusted, and it has been able to withstand the rust. Rerraf is the wheat referred to, and porhaps it, too, in course of time, will succumb to the rust.

For this great and burning rust-question the only measures I can suggest are :-

I. To produce wheats suited to our Australian conditions by crossing, as Mr. Farrer, Wheat Experimentalist of New South Wales, is now so successfully doing.

2. To select and carefully cultivate the most rust-resisting plants from these and other wheats having the necessary hardy, prolific, grain-holding, and milling qualities, keeping up the strain and constantly renewing their constitutional vigour.

3. To cultivate early maturing varieties and sow them early, combined with the best agricultural methods, such as clean cultivation, judicious rotation, suitable (phosphatic) manuring and fallowing, to insure a good crop.

In judicious crossing and careful selecting lies the solution of the great rust problem, as far as our present knowledge goes, snd to increase and extend this knowledge it would be desirable to follow the advice of Professor Eriksson, who has done more than any other single individual to enlighten us on the subject:- "The question of the rust of cereals being of the greatest practical importance for every country, means should be furnished to those in whose hands the direction of these investigations are placed, to meet from time to time, that is ti say, at least every five years, in order to discuss, according as experience is gained, the value of any new observations, and to gain for their work the advantage of being based on a plan common in its essentials to all."

Rust in wheat has been known in Australia for at least so vears. H. C. L. Anderson, Principal Librarian of the Public Library of New South Wales, informs me that the earliest record of it is given by Atkinson, ${ }^{1}$ who, referring to 1825 , or even earlier, says that " rust sometimes appears, but it is not very common." J. Montague Smith, in I 828, notes that the plains and forest lands of the Hunter district of New South Wales suffered from rust in wheat. As the wheat-growing area extended, the rust also spread with amazing rapidity, until now it is undoubtedly the most widely distributed and the most destructive of all the diseases to which cereals are subject.

\section{Note I.}

P. 4.-Eriksson ${ }^{28}$, in his latest work on the regetative life of Puciniu graminis, has described and figured a transition from the invcoplasm to the protomycelial stage, but it still remains to be seen how far his interpretation of the farts is borne out by other observers. 


\section{Note 2.}

P. I4. - Christman', however, has clearly shown that two fertile cells or swollen hyphal branches come into contact, and at the point of contact an opening is formed by solution of the cell wall, and thus their contents mix although the nuclei do not fuse. There is thus true sexual cell fusion without the intervention of spermatia.

\section{Note 3 .}

P. 24.-Arthur ${ }^{8}$ considers the sorus in such species as Puccinia bromina and $P$. triticina to be compound and the modified hyphae which separate the individual sori to form a stroma, hence they are not paraphyses, strictly speaking.

\section{Note 4.}

P. 37.-The origin of the aecidiospores as shown by Christman, ${ }^{1}$ from the fusion of sexual cells and the peridium from morphologically equivalent cells disposes of the view that the aecidiospores may have been derived from teleutospores. If, as Blackman suggests, the rusts originated from the red algae, then the sexual product or aecidium would represent an early stage in the history of the Rusts.

\section{Note 5 .}

P. 43.-Hooker, in his classical essay On the Flora of Australia (1859), has a chapter on some of the naturalized plants, showing that even nearly half a century ago, the chick-weed, knot-weed, scarlet pimpernel, daisy, mallow, sweetbrier, and various other common plants had been introduced. The groundsel, however, is not mentioned, and no doubt as trade increased with other countries and exchange of products took place, the importation of the seeds of weeds became common.

\section{Note 6.}

P. 62.-Beauverie ${ }^{1}$ has experimented with Botrytis cinerea, or grey rot, and obtained, in sterilised soil, an attenuated form of fungus. $\mathrm{He}$ infected soil liberally with this form, and grew plants therein from seeds and cuttings perfectly free from the fungus, while plants not rendered immune in this way perished.

Note 7 .

P. 68. -Kirk informs me by letter what he has already stated in his Annual Reports that "Barberries are being largely used in New Zealand for hedges, and, up to the present, I have never seen any sign of aecidia of Puccinia graminis on them, although I have examined hundreds. It would appear as if Puccinia graminis in Australin has lost the power of forming aecidia on barberries."

\section{Note 8.}

P. 69.-Bolley, ${ }^{5}$ however, has announced that he found the uredospores of Puccinia graminis successfully surviving upon dead leaves and straw, even retaining their vitality when exposed to the drying winds of autumn, and the intense cold of winter. 



\section{PART SECOND.}

\section{CLASSIFICATION AND TECHNICAL DESCRIPTIONS.}





\section{CHAPTER IX.}

\section{Classification, with Special Reference to Biologic Forms.}

Our views as to the limits of species have undergone a change owing to the results of infection experiments in the rusts as well as in other groups of fungi. Species have hitherto been distinguished on morphological grounds, those possessing the same structural characters being considered identical, and separated from those which differ from them in essential points. But in recent times, when infection experiments have been carried out on an extensive scale, it has been found that parasitic fungi, completely agreeing in structural characters, or at least differing so slightly as to be incapable of separation, have very different infective powers. It has therefore become necessary to recognise such forms, and since the differences are based upon physiological or biological characters, they will be distinguished as "biologic forms." Various names have been proposed for these different varieties, such as "special forms," by Eriksson; "biological species," by Rostrup; "sister species," by Schroeter; and "adapted races," by Magnus.

The truly morphological species, such as Puccinia graminis, Pers. or Errysiphe graminis, DC., have still to be recognised; but each one may be split up into a number of different forms, with distinct powers of infection.

\section{Gradations of Specific Variation.}

There is every possible gradation, however, between species which are morphologically distinct and those which can only be separated on biologic grounds. Puccinia graminis Pers., for instance, is recognised as an independent species, because all the forms of this rust produce aecidia on the barberry (except where it has lost this power), and the structural characters are always practically the same. It is regarded by Eriksson as a collective species, in which the different members are so closely related, both morphologically and biologically, that they are only separable into biologic forms, and not to be distinguished as species. The forms on the different hosts are not identical, but they constitute a series, each member of which runs its course on definite host-plants, and is more or less strictly confined to them. Arranged according to the principal host-plants they are as follows:-I, secalis; 2 , avenae; 3 , airae; 4 , agrostidis ; 5 , poae ; 6 , tritici.

The collective species known as Puccinia rubigo-vera (DC.) Wint. was first divided in 1894 by Eriksson and Henning ${ }^{1}$ into the two distinct species of $P$. glumarum (Schum.) Eriks., the Yellow Rust, and $P$. dispersa, Eriks. and Henn. the Brown rust. $P$. glumarum has not heen found in Australia, and it is not necessary here to refer to the various biologic forms into which it has been divided. No aecidial stage has been found in connexion with it.

$P$. dispersa, when first separated from $P$. glumarum, was split up into four biologic forms by Eriksson, since he did not at that time consider them sufficiently distinct to be designated species. These forms were:I, secalis; 2, tritici; 3, bromi; 4, agropyri. Further investigation, however, led him in 1899 to raise the various biologic forms to the rank of independent species, and it will be interesting from our present standpoint to consider the reasons given by Eriksson for differentiating between 
the bioloric forms of $P$. dispersa and those of $P$. graminis. The name of $P$. dispersa Firiks. was reserved for the form on rye, and it is separated from that on wheat, for example, on the following grounds:-

1. The uredo is only alite to infect the host-plant, Sccale.

2. This form regularly appears sereral weeks earlier than that on wheat, eren when the host-plants are growing alongside of each other.

3. The atcidiospores on Auchusa spp. only infect Secale, and the teleutospores of this form can in turn only produce the aecidia on Anchusa.

. T. The teleutospores are only capable of germination immediately after they are formerl, while those of the others only germinate in the following spring.

It will be observed that these are only liological or phrsiolorical differences, but in the two species recognised by Eriksson which occur in Australia, viz., $P$. triticina and $P$. bromina, there are also structural differences sufficient to separate them apant from other considerations. In $P$. bromina the uredo-sori are much larger, and the bright orange uredospores are also slightly larger. It is in the teleutospores, however, that the difference is most striking, and those of $P$. triticina are much narower, only being about three-fourths that of the other.

P. hieracii (Schum.) Mart., as at first constituted, was a collective species, but. like so many others, when the test of infective power is applied to them, it had to be broken up into several. It has been proved by Jack.1 that the common Puccimia occurring on species of Hieracium can only infect this, and not other genera of Composites, so that the original name is restricted to the species found on this genus. Other species of Puccimia occur on Hieracium, but they are readily distinguished by their different morphological characters. Similar results have been obtained with Puccinias occurring on other genera, so that they also must le revarded as distinct species.

It will be olserved that only biological characters are here taken into account, depending on the nature of the host-plant, but it is beliered that the closer and more careful inrestigation now rendered necessary will result in structural differences being found. possibly of a more minite and less striking character than formerly, where they were hitherto unsuspected and overlooked.

The thice types selected for illustration will show the spirit of our classification.

$P$. graminis is the type of a single species which is split up into a number of biologic forms, agreeing in the fact of producing aecidia on the Larberrs. and the aecidiospores in turn infect the grasses.

$P$. dispersa, as originally constituted, is the type of a collectire species at first divided into biologic forms, which were afterwards found to he distinct species, both on morphologic and biologic grounds. And the original $P$. hicracil is the type of a collective species, the members of which are strictly limited in their infective power to single genera, and their main title to distinction as species is this biological peculiarity.

The phenomenon of specialisation, first discorered by Eriksson, has thus caused us to revise our conceptions of species, and it will be necessary in the future not only to include under that mame such forms as possess rlistinct morphological characters. but also those which. although norphoIngically similar, are yet confined to definite host-plants. It will thus be necessary to split up the old species of $P$. hieracii into several of equal rank. and the one growing on I/ieracium spp. will form a type round which the others may be grouped. Just as in the old species there were differences of opinion as to the amount of structural differentiation necessary to separate 
two allied forms, so in the new there is the same difficulty with the biological characters, but it may be laid down, as a general rule, that the sharper the distinction between two biologically different forms, the greater the reason for calling them species, while the less distinctly marked would be called biologic forms. It is all a matter of degree, and it must be left to the good tact of the investigator, as Klebahn says, where to draw the line between species and biologic forms.

Among the heteroecious rusts, there may be structural resemblances between one generation and differences in the other. In that case, as a matter of convenience, if the differences in the one generation are sufficiently distinct, such should be designated species.

Biologic forms, in fact, may be regarded as incipient morphological species, the physiological differences at present existing becoming ultimately associated with morphological distinctions, which will mark them off as true species. It is not easy to explain how this has come about, but we may be sure that the explanation is to be sought, not along one line, but along various converging iines.

The biologic forms of one and the same morphological species, such as Puccinia graminis, may be supposed to have had a common origin, and the most probable riew is that the original form inhabited all the hosts on which its descendants now live, and some of these descendants specialised on one or other of these common host-plants. What caused them thus to specialise? It may have been either through gradually becoming adapted to certain of these host-plants in preference to others, or due to a spontaneous change arising from internal causes, as expressed in the mutation theory of De Vries.

This is Fischer's riew, and Klebahn ${ }^{1}$, after examining the evidence, sums up as follows:- "The manifold characters of the existing biological species and races appear to have come about owing to the alternating extensions and restrictions of the area of nutritive plants. These changes, and especially the restrictions of area, have been influenced by adaptation and selection, but many observations indicate that internal developmental tendencies have also played a part in determining the direation of the evolution."

The whole trend of this modern investigation is towards the recognition of more deep-seated characters in the discrimination of species. One parasite has become so thoroughly adapted to the physiological characters of a host-plant that it cannot infect another, and so the plant on which the parasite lives becomes a diagnostic feature of $\mathrm{it}$. It is so much easier, and has been so long the custom to be guided by morphological characters alone, that physiological distinctions are not readily accepted, but now that they are known, they must be recognised in some way, and the most convenient is to incorporate them in the specific characters.

- Again, the different stages of a fungus require to be known, in order to classify it properly, and the mere knowledge of the uredo or aecidial stage will not suffice for this purpose. Hence the life-history and infective power, as well as structural characters, must all be taken into account in fixing and determining species. 


\section{CHAPTER TXI.}

\section{Systematic Arrangement and Techinical Descriptions.}

The different Rusts found in Australia are here named, described, and systematically arranged. The names are necessary to distinguish one from another, for, as George Eliot happily puts it- "The mere fact of naming an object tends to give definiteness to our conception of it. We have then a sign which at once calls up in our minds the distinctive qualities which mark out for us that particular object from all others." The descriptions are necessarily technical, and give those characters which enable the species to be discriminated from others, with the help of the illustrations. When the described stage of any rust is enclosed in square brackets, this indicates that it has not been found in Australia. The systematic arrangement deals with the nine genera at present known, and arranges them according to their natural affinities. Taking a general view of the entire order, the following scheme of classification will be adopted, mainly based upon that of Engler and Prantl, in their Die natïrlichen Pflanzenfamilien:-

Order-URedineae, Tul.

Fungi parasitic on higher plants and developing in the interior of their hosts, a filiform, branching, septate mycelium. Spores arising terminally or laterally from erect, transversely divided, crowded hyphae, and usually of more than one kind. Teleutospores germinating by a short promycelium. The order may be grouped in the following four families, of which the third is not represented in Australia:-

Teleutospores stalked, single, in groups or rows, or several cells in a head. Fam I. Pucciniaceae.

Teleutospores sessile, in columnar or filiform masses. Fam. 2. Cronartiaceae.

Teleutospores sessile or stalked, in one or two-layered waxy masses. Fam. 3. Coleosporiaceae.

Teleutospores sessile, in flattened one-layered masses, or loose in the tissues of their host. Fam. 4. Melampsoraceae.

On account of their economic importance, the Graminaceous rusts are always treated first and the others are likewise grouped together under their respective families of host-plants, the order generally followed being that of Baron von Mueller's Systematic Census of Australian Plants, starting from the Grasses, and ascending to the higher forms.

\section{Fam. I. Pucciniaceae.}

Since the great majority of our Australian Rusts belong to this family, it will be treated at greater length than any of the others, and it will be interesting to trace the different forms which the teleutospore assumes in the different genera. There are a number of genera based upon very slight rlifferentiating characters, and it is not always easy to settle whether they should be retained or rejected, but I have given all those which are clearly distinct. It is a moot point whether such a genus as Diorchidium Kalch.. should be retained, where the teleutospore is two-celled, as in Puccinia, only the septum is longitudinal instead of transverse. There are several species of Puccinia in which there is a tendency to an oblique, and even a longitudinal septum, as well as transverse, but this genus is retained for those species in which the spore is distinctly divided longitudinally with a single germ-pore at the apex of each. 
From a consideration of the distribution of the Uredineae on their hostplants, Dietel ${ }^{12}$ has come to the conclusion that the genus Uredinopsis, belonging to the Melampsoraceae, and occurring on ferns, represents the oidest type of the Rusts, and that the Pucciniaceae may have developed flom the genus Melampsora. However that may be. we may assume that the primitive form of this family was one-celled, and therefore the Uromvces type forms the starting-point; also that the fransition from the one-celled to the two-celled spore as in Puccinia, was the next step in advance.

The actual evidence of this transition is seen not only in Puccinia heterospora, B. and C., where the two-celled spore has not yet become completely established, being mixed with a large number of unicellular spores, but in such forms as Uromyces vesiculosus, where there are occasional two-celled spores, Fig. 157 , U. tricorynes, Fig. $3_{34}$, and $U$. politus, Fig. 317 .

Both Uromyces and Puccinia species occur on plants of the most diverse character, and this would seem to indicate that many of the species came into existence before that specialisation had begun, which resulted in the genus Phragmidium. for instance, confining itself to the Rosaceae.

The principal genera are here arranged according to the nature of the teleutospore, and the diagrammatic representation of the spores will show at a glance the peculiarities of each :-

I. Uromyces, Link.-Teleutospore one-celled, with single germ-pore, and solitary on its stalk. Uredospores echinulate or warty all over. Fig 16.

2. Hemileia, Berk and Br.-Teleutospore one-celled as in Uromyces, but uredospore smooth on one face.

3. Uromycladium, McAlp.-Teleutospore one-celled as in Uromves. but the sporophore branching toward the apex produces either one spore with a colourless sterile spore or cyst, or two or more spores with or without a cyst. Fig. I7.

4. Puccinia, Pers.-Teleutospore two-celled. with transverse septum and with only one germ-pore in each cell. Fig. 18.

5. Gymnoconia, Lag.-Teleutospore as in Puccinia, but aecidia without pseudoperidia.

6. Uropyxis, Schroet.-Teleutospore bicellular as in Puccinia, but each cell with two or more germ-pores, and the teleutospore membrane consisting of more than two layers. Fig. I9.

7. Diorchidium, Kalch.-Teleutospore two-celled, with longitudinal septum and germ-pore at apex of each cell. Fig. 20.

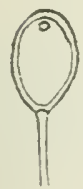

Fic. 16.

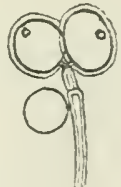

IIG 17.

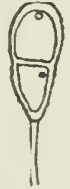

F1G, 18 .

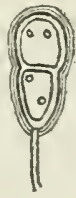

FIG. 19 .

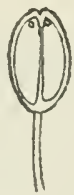

FIG 20.

8. Gymnosporangium, Hedw.-Teleutospore two-celled (rarely three to five celled), and walls which ultimately form a common gelatinous mass, with usually several germ-pares in each cell. Fig. 21.

9. Hapalophragminm, Syd.-Teleutospre three called, and consisting of two basal cells alongside of each other, with a third on top. Fig. 22.

10. Triphragmizm, Link.-Teleutospore three-celled, and consisting of basal cell supporting two others alongside of each other. Fig. 23 . 
11. Phragmopyxis. Diet.-Teleutospore three-celled in a longitudinal series, with outer laver swelling when moistened. Fig. 24.

12. Phragmidium, Link.- Teleutospore three or more celled in a longitudinal series, and outer layer not swelling when moistened. Fig. 25 .

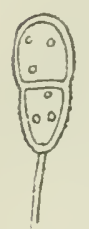

Fili. 21.

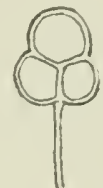

Fif;. 22.

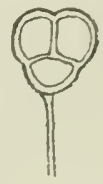

Fic. 23.

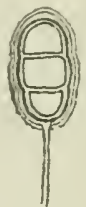

Flg, 24.

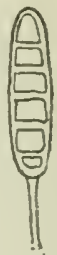

Fic, 2.5.

13. Sphacrophragmium, Magn.-Teleutospore consisting of a spherical head of four to nine cells, and arising from a single cell by longitudinal and transverse fission. Fig. 26.

14. Anthonyces, Diet.-Teleutospores forming a head of three to eight cells, borne on a single stalk, and arising from a simple cell by the formation of longitudinal septa. Several small sterile cells at base. Fig. 27.

15. Rä'€nelia, Berk.-Teleutospores forming a more or less hemispherical, many-celled head, transiersely and longitudinally septate, arising from a stalk compounded of sereral hyphae, and with several sterile cells or cysts at the base. Fig. 28 .

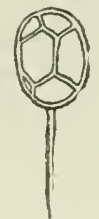

Fiv: 26 .

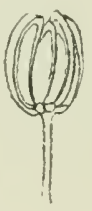

FIr: 27 .

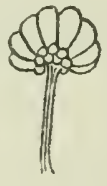

Fig. 23.

Only four of these geriera accur in Australia, and they will be dealt with in the following order:-Uromyces, Uromycladium, Puccinia, Phragmidium.

\section{UROMYCES Link.}

In this genus the teleutospores are unicellular as well as the uredospores, and this has sometimes caused the one to be mistaken for the other, but the single germ-pore in the former serves to distinguish it. Besides, the uredospores are always echinulate or warted, and while the teleutospores art usually smooth, they may also be striated or warterl, but the grenerally greater thickening of the wall, and the fact that the contents are nearly: colourless, also serve to separate them. All the different spore-forms ma! be present in the same host-plant, or they may be reduced to the teleutospore alone. In clover rust $\left(U\right.$. trifolii) and beet rust $\left(I^{*}\right.$. betac) all the sporeforms occur, but in the latter, although the rust is very common, I have seldom found the aecidia, and Plowright states that the aecidia are rery rarely found even in Britain.

l'ea rust (Cromices pisi). With its aeciltia on Euplorbia and its uredospores and teleutospores on the pea, has not been found here, nor any other heteroecious species of this genus. 
In carnation rust ( $U$. caryophyllinus) only uredo and teleutospores are known, and this grouping of spore-forms is the most common with us. Aecidia and teleutospores occur on the same host-plant in $U$. limosellae and $U$. puccinioides, the uredospores being unknown, and teleutospores alone are found in $U$. bulbinis and $U$. diploglottidis. The rusts on clorer, beet, and carnation are the best known, and since the carnation is attacked at all stages of its growth, it has suffered considerably from this disease.

General Characters.-Spermogonia mostly globose, immersed, with conical projecting neck.

Aecidia immersed, finally cup-shaped, with well-dereloped pseudoperidium; aecidiospores without distinct germ-pores.

Uredospores solitary on their stalks, with several usually distinct germ. pores.

Teleutospores unicellular, pedicellate, only one produced from each sporophore, with a single germ-pore at apex.

Sporidiola hyaline, ovoid, ellipsoid, or almost kidney-shaped.

Australian species, 27 .

\section{GPAMINEAE}

\section{Uromyces danthoniae McAlp.}

Drnthonia.

I. Accidia amphigenous, densely crowded in relatively large clusters, bright orange: pendoperidia cup-shaperl, irory white, margin regular, upright, rery finely toothed, up to $320 \mu$ in rliam.; pseudoperidial cells persistent, elongated and polygonal, with striated margin.

Aecidiospores subglobose to polygonal, orange, average $16 \mu$ diam. or $16 \times 1: \mu$.

II. Uredosori minute, erumpent, somewhat scattered, rudrly brown.

Uredospores pale yellow to orange yellow, broadly elliptical to orate, finely echinulate, with as many as six scattered germ-pores on one face, $27-32 \times 23-26 \mu$.

III. Teleutosori chocolate brown to black, elongated, running in lines, long covered by epidermis.

Teleutospores at first intermixed with uredospores, pear-shaped to orate or broadly fusiform, smooth, with thickened apex, $30-4 \mathrm{l} \times$ $20-26 \mu$, average $33 \times 22 \mu$; pedicels elongated, persistent, slightly tinted adjoining spore, up to $96 \mu$ long.

I. on leaves of Danthonia sp. II., IIT. on leaves of Danthomin semiannularis R. Br.

Victoria-Bacchus Marsh, I. Near Melbourne, Ardmona, Portland, Killara, Leongatha, Rutherglen, Nagambie, Kergunyah, dc., II., III.

Tasmania-J)omain, Hobart, Nov., 1894, II., III. (Rodway).

The aecidium found on a species of Danthonia at Bacchus Marsh is described in connexion with this species as a matter of convenience.

Puccinia graminella (Speg.) Diet. and Holw., occurring on a species of Stipa in Argentine, Chili, and California, is the only instance hitherto known where the aecidium-stage is found on a grass. Teleutospores are developed on the same mycelium alongside of the aecidia, and compressing them on either side. 
The aecidia are described as follows:- "Epiphyllous, and arranger loosely in interrupted lines; pseudoperidia persistent, composed of oblong cells, with margin irregular and lacerated. Aecidiospores elliptic or ovoid, $21-29 \times 18-21 \mu$."

I'he aecirlia on Danthonia are quite distinct. They oceur on both surfaces of the leaf, are arranged in dense clusters, the margin of the pseudoperidium is regular and very fincly toothed, and the aecidiospores are consirlerably sinaller.

There is a guod laal of confusion over the species of Danthonia in Australia, and they pobably require to be dealt with lyy a specialist. The late Baron von Mueller, in his Census, inclucled D. pallida R, Br., D. semiannularis R. Br., D. pitusr. R. Br., de., under D. penicillata F.v.M. Following the Index Leuensis, these three species will he retained, but $D$. prenicillata F.v. II, will be regarded as a synonym.

Darlucr filum Cast., is common on uredosori.

$$
\text { (Plate XVI., Figr. } 131 \text {; Plate ..) }
$$

\section{Uromyces ehrhartae MeAlp.}

Ehrharta.

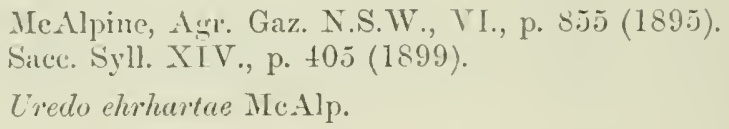

II. Uredosori on both surfaces of leaves and on sheath, minute, oval to elongated linear, sumetimes contluent, at first covered then naked, yellowish-brown to orange.

Uredospores subglobose to oval, orange, finely echinulate, 3-4 scattered gem-pores on one face, 21-25 $\times 18-20 \mu$, werage $24 \times 19 \mu$.

[1I. 'Teleutosori similar, up to $1 \mathrm{~mm}$. long, confluent in lines, chocolate brown to black.

'Teleutospores pale chocolate brown to chestnut brown, only occasional uredospores intermixed, hooded and thickened at apex $(s-9 \mu)$, and either conical or truncate, very variable in shape and size, elungated or short and stout, subglobose to elliptic, fusifurm or oblong, 19-32 × 1:3-19 $\mu$, arerage $26 \times 1.5 \mu$; pedicels persistent, tinted, elongated, up to $45 \mu$ long.

On Ehrhurlu stipoiles Labill. = Microluenu stipoides R. Br.

Victoria-Near Mclbourne, Killara, Myrniong, Kergunyah, de., June-Marel.

Uredospores common but teleutospores rather sparse, although in the ncighbourhoul of Melboune during December and January the telentosori are sometimes rather common, usually on the lower withered leaves, and intermixed with urelosori on those still partially green. Only the urelo-stage was found at first by Mr. Robinson, but latterly at Killara, in Mitreh, and Kersunyal, in November, he secured the teleutospores.

Derluee fillum Cist., is very common on uredosori. 


\section{Uromyces tenuicutis McAlp.}

Sporobolus.

II. Uredosori on both surfaces of leares, but mostly on upper, and on stems, elliptic to oblong, orange-yellow, pulvinate, generally minute, but may reach a length of $1 \mathrm{~mm}$, at first covered by epidermis, then erumpent, pulverulent.

Uredospores orange, ellipsoid to oroid, spinulose, rather large, with two distinct germ-pores on one face, equatorial or nearly so, $28-40 \times 19-24 \mu$, average $32 \times 2.2 \mu$.

III. Teleutosori on lower surface of leaf, minute, pulrinate, corered by epidermis.

Teleutospores vellowish-brown, smooth, obovate to oblong or piriform, irregularly rounded or truncate, or even pointed at apex, and slightly thickened, sometimes broader than long, 22-35 $\times$ 16-25 $\mu$, average $28 \times 20 \mu$; pedicel sometimes persistent, usually tinted, commonly 20-35 $\mu$ long, but often much shorter.

On leaves and stems of Sporobolus indicus R. Br.

Victoria-Near Melbourne, Aug.--March.

U. sporoboli E. and E., found on leaves of Sporobolus asper Kunth, in the United States, has no uredo-stage, and the teleutosori are soon naked, while the teleutospores may be subglobose and provided with long pedicels.

Darluca filum Cast., is very commonly associated with the uredospores.

(Plate XVI., Fig. 133.)

\section{LIIIACEAE:}

\section{Uromyces bulbinis Thuem.}

Bulbine.

Thuemen in Flora, p. 410 (187T).

Cooke, Handb. Austr. Fung., p. 409 (1892).

Sace. Syll. VII., p. $572(1888)$.

III. Sori amphigenous, small, densely gregarious, concentrically disposed in large circles, covered by the epidermis, firm, rather concave, brown.

Teleutospores clavate or oblong clavate, mostly rather acute at the apex, and narrowed at the base, pedicellate, epispore smooth, rather thick, especially at the apex, $30-36 \times 20-22 \mu$; pedicel deciduous, unequal, straight or slightly curved, livaline to yellowish brown, $12 \times 4 \mu$.

On living leaves of Bulbine bulbosa Haw.

Victoria-Omeo (Morrison).

New South Wales-Upper Macquarie River.

Specimen not seen.

5. Uromyces tricorynes MicAlp.

Tricoryue.

McAlpine, Agr. Gaz. N.S.W., VI., p. 756 (1895).

Sacc. Syll. XIV., p. $283(1899)$.

I. Aecidia on pale spots in small clusters, amphigenous; pseudoperidia cup-shaped, with white edges irregularly torn and reflexed.

Aecidiospores bright orange, subglobuse to somewhat polygonal, smooth, avelage $20 \times 1 i \mu$. 
[1. Uredosori on pale green patches, brick coloured to orange, amphigenous, but more common on under surface of leaves, elongated oval to elliptical, bullate, solitary or in groups, not confluent, at first papillate, then bursting through and surrounded by ruptured epidermis.

Urerlospores orange, subspherical to olliptic or ovate, finely echinulate, relatively thick-walled, with two to three gerni-pores on one face, average $20-23 \mu$ diam. or $22-25 \times 19-20 \mu$.

III. Telentosori blackish on rucldy brown spots, elongated and conthent, sometimes completely enveloping stem, at first bullate, finally with greyish epidermis amound or orer them in shreds and patches, generally $2 \mathrm{~mm}$. long, sometimes up to $3 \mathrm{~mm}$.

'Teleutospores variable in form, oval, ovate, or somewhat globular, vellowish - brown to chestnut-brown, smooth, apex thickened (up to \& $\mu$ ), round or conical, $25-32 \times 20-29 \mu$, arerage $30 \times 25 \mu$; pedicels persistent, pale yellow, especially towards spore, up to $80 \mu$ long and $9 \mu$ broad.

On leaves and stems of Tiricoryne elation R. Br.

Victoria-Near Melbourne, Oct., 1892, TI., III. (Robinson). Rutherglen, July, Oct., 1893, I., TI., IT I. MIurramurrangbong Ranges, Nor. 1902 (Robinson). Nagambie, Nov., 1904, II., III. New South Wales-Richmond, Oct. (Musson).

I. (m) both surfaces of leaves, July. II, on stems and leaves, not very common in July, but prevalent in October and November. III. on stems and lranches and both surfaces of faded leaves, very common in July, forming dark swollen patches.

Several two-elled telentospores oceurred, coloured similarly to the ordinary teleutospore and thickened at apex. The spores were constricted at septum, which might be about the middle or towards the base. They were longer than the ordinary spore, and measured about $37 \times 27 \mu$. The pedicel was occasionally rather lateral.

Durluca filum Cast., securred on the uredosori.

(PlateIVI, Fig: 13t, 13.5.)

ORCHTDACEAF.

6. Uromyces micretidis Cooke.

Ificrotis.

Cooke, Grer. XIT., p. 12 (18iti).

Cooke, Handb. Austr. Fung., p. 33:2 (1892).

Sydow, Ann. Mre. T., p. 3224 (190:3).

Sice. Syll. VIl., p. 579 (188s).

Sori ampligenous, lonsely al'anged in irregular groups, minute, punctiform, brown, pulverulent, girt by the ruptured epidermis.

IT. Uredospores irlobose, subglobose, orinte or ellipsoid, miuutely aculeate to waty, yollowish-brown, $2.2-30 \times 17-25 \mu$.

III. Telentespores intermixed with urelosperes, ovate, with hyaline apiculus, rough with walts, brown, $-.5-35 \times 17-.25 \mu$, hut may reach a leneth of $+1 \mu$, arelige $3: 2 \times 2+\mu$ : pedicel rery short, hyaline.

On living lowes of Alerotis porrifolia R. Br.

New siouth Wales-liullahilelah, II., IIT. 
Only the telentospores were described by Cooke, but in a portion of the original material kindly supplied by Massee there were numerous uredospores intermixed with the teleutospores. Sydow ${ }^{2}$ has also found the uredospores with teleutospores intermixed, on specimens of the same host-plant sent from Chatham Island, New Zealand.

If we compare the three rusts found on the Orchid genera, Microtis, Chiloglottis, and Thelymitra, it is found that aecidia oceur on Chiloglottis, but are absent, as far as known, from the other two. The teleutospores are all provided with a hyaline apiculus, but in $U$. microtidis the epispore is very rough and knobby, and the size of the spore not generally exceeding $35 \mu$ long, while in $U$. thelymitrae the epispore is generally thicker, and the spore polygonal and irregularly warted and altogether larger. The rust on Chiloylottis generally resembles that on N/Cicrotis, but the teleutospore is larger.

The following table will show the points of resemblance and difference in the teleutospores:-

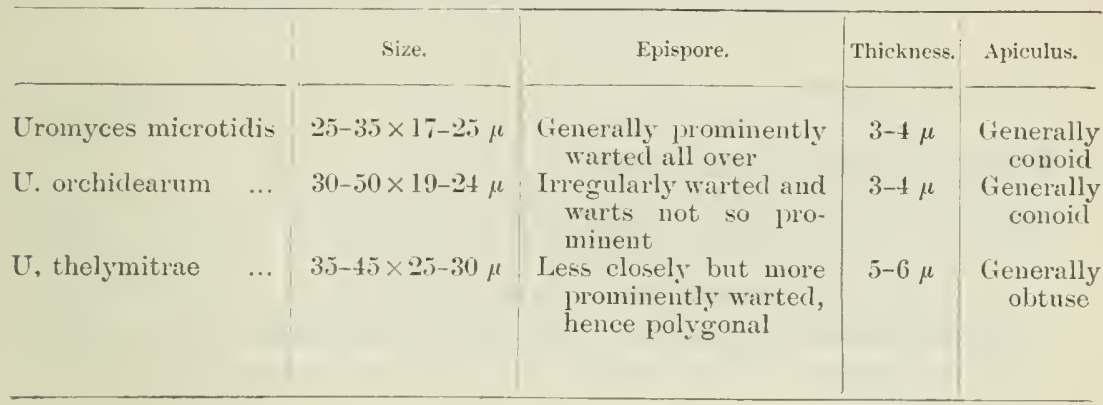

(Plate IVI., Fig. 139.)

\section{Uromyces orchidearum Cke. and Mass.}

Chiloglottis.

Cooke and Massee, Grer. XVI., p. 74 (1888).

Cooke, Handb. Austr. Fung., p. 332 (1ऽ92).

Morrison, Vict. Nat. XI., p. 90 (1894).

Sace. Syll. VII., p. 580 (1888).

I. Aecidia hypophrllous, scattered, cup-shaped; pseudoperidial cells polygonal to wedge or pear-shaped, finely notched, 32-40 $\mu$.

Aecidiospores pale vellow, subglobose to shortly elliptical, veru. culose, $16-20 \mu$ or $18-22 \times 15-20 \mu$.

II., III. Sori mostly epiphyllous, bullate, at length erumpent, goldenbrown.

II. Uredospores elliptic to oroid, honey-yellow to golden-ycllow, echinu late, with several germ-pores, $26-30 \times 16-20 \mu$.

III. Teleutuspores at first intermixed with uredospores, old gold colour variable in shape and size, elliptic to oroid or oblong, with prominent hyaline apiculus (up to 9 $\mu$ long), usually with irregularly warted epispore, which is $3-4 \mu$ thick and brightly coloured, $30-51 \times 19-24 \mu$, average $36 \times 21 \mu$; pedicel hyaline, attenuated downwards, u], to $77 \mu$ long. 
On leaves of C'hiloglottis diphylla li. Br., JJ., III.

Now Siruth Wales-IIt. Victoria (Hamilton).

Victoria-Oakleigh, July, $189+$ (Morrison ${ }^{1}$ ).

'Tasmania-Bellerive Śwamp, May, 1897 (Rodway ${ }^{1}$ ).

On C'. gunuii Linrll., T., IT., III.

Victoria-Oakleigh, Augr, 1892 (Morrison).

Tn the oricinal description of Cooke and Massee only teleutospores are recorded, hut uredospores were also obtained from the original material labelled in Cookr's handwriting.

Smmetimes there are abnomal elongated teleutospores up to $60 \mu$ long.

Sieveral bicellular spores were met with similarly coloured to the normal teleutospores, constricterl at septum, irregularly warted, with prominent hyaline apiculus, $59 \times 28 \mu$.

(Platé XVT., Figg. 138; Plate XL., Fig. 303.)

Thelymitra.

\section{Uromyces thelymitrae McAlp.}

Sori on leaf and sheath, scattered or gregarious, bullate, ellipsoid, yellowish to brownish, compact, surrounded or almost covered by rupturerl epidermis, except for a narrow slit, up to $1 \frac{1}{2} \mathrm{~mm}$. long.

II. Uredospores ellipsoid to ol,orate or pear-shaped, golden-yellow, echinulate, with as many as four equatorial germ-pores, $25-32 \times$ $18-21 \mu$.

III. Teleutospores ellipsoid to oblong, or polygonal, chestnut-brown, relatively thick-walled, irregularly knobby, with lyaline apiculus $35-45 \times 25-30 \mu$, average $36 \times 26 \mu$; pedicel hyaline, short, decirluous, up to $11 \mu$ broad adjoining spore.

On Thelymitra antenniferc Hook. f. and T'. flewosa Endl.

Victoria-Near Mclbourne, Sep. and Oct. (C. French, jun.).

An aeciclial stage has been found in Java, loy Raciborski, on Thelymitra javanicre Plume, but it has probably no comexion with our native species.

(Plate XVI., Figs. 136, 137.)

\section{SCROPHULARIACEAE.}

\section{Uromyces limosellae Ludw.}

Limosella.

Ludwig in lietel, Hedw., XXVITI., p. 18:2 (1889).

Sace. Syll. IX., p. 293 (1891).

T. Aecilia amphigenous, scattered or eregarious; pseudoperidia with whitish lateiniate margin, not rleeply inciserl.

Areidiospores rouncl to angular, hyaline, smooth, about $15 \mu$ (liatm.

III. 'Telentosori mixnd with the aecidia, often iruwded, long covered lyg epirlermis, pulvinate, dark brown. 
Teleutospores obovate, oblong or clavate, rarely round, with yellowish-brown, thick, smooth wall, strongly thickened at apex, and for the most part paler, $32-40 \times 18-22 \mu$; pedicel as long as or shorter than teleutospore.

On leaves of Limosella aquatica $\mathrm{L}$.

S. Australia-Kangaroo Island (Tepper).

It differs from $U$. scrophulaviae (DC.), to which it is otherwise allied, in the size and colour of the spores.

Dietel observed two bicellular teleutospores among the ordinary ones in a spore laser.

Specimen not seen.

\section{GOODENIACEAE.}

10. Uromyces puccinioides Berk. and F.v.M.

Selliera, Scaevola.

Berkeley and Iueller, Linn. Journ. XIII., p. 173 (1872).

Cooke, Handb. Austr. Fung., p. 332 (1892).

Sacc. Syll. VII., p. 585 (1888).

I. Aecidia aggregate, on brown orbicular spots, arranged in a circinate manner, opposite ; pseudoperidia with abbreviated margin.

Aecidiospores orange, suloglobose, $16-19 \times 13-16 \mu$.

III. Teleutosori bullate, intermixed with aecidia or surrounding them as a ring, at first covered with greyish glistening epidermis, finally naked.

Teleutospores brown, apiculate, sometimes with the apex oblique or dentate, also thickened and rounded or flattenerl, 40-44 $\times$ $18-23 \mu$, average $41 \times 22 \mu$; pedicels hyaline, persistent, up to $48 \mu$ long.

On leaves and flower stalks of Selliera radicans Cav.

Victoria-Near Melbourne, Nor.-June. Wimmera Flats, May, 1897 (Reader). Phillip Island, Jan., 1900. Portland, Jan., 1901. Point Cook, May, 1902 (C. French, jun.). Sandringham, Nor., 1905 (Robinson).

South Austialia-Glenelg (Holdfast Bay), 1854 (Berkeley ${ }^{2}$ ).

Tasmania-Bellerive Swamp, Dec., 1890, and May, 1897 (Rod-

On Sccievola sp. way $\left.^{1}\right)$.

Queensland-St. George ( Tedd) (Bailey $^{\mathrm{l}}{ }^{3}$ ).

It is recorded in Cooke's Handbook as being found on Goodenia, but there are no certain indications of this. It occurred on Goodenia herpystica Schlecht., which, however, is a synonym of Selliera radicans.

(Plate XVII., Fig. 140.)

\section{RUBIACEAE.}

11. Uromyces asperulae McAlp.

Aspervela.

McAlpine, Agr. Gaz., N.S. W., VI., p. 851 (1895).

Sacc. Syll. XIV., p. $276(1899)$.

II. Uredosori hypophyllous, minute, bullate, bursting through epidermis.

Uredospores globose, subglobose or ovate, finely echinulate, orange-yellow, single germ-pore visible on one face, 21-25 $\times$ $20-21 \mu$. 
III. Telentosori on stems towards their base, elongated oval, darkbrown, appearing almost black, confluent, erumpent.

'leleutospores at first intermixed with uredospores, yellowishbrown to chestnut-brown, smooth, oval to ovate, or elliptical to broadly clavate, apex much thickenerl (11 $\mu$ ) and rounded, sometimes taporing or Hattened, 27-37 $\times 15-19 \mu$, average $30 \times 18 \mu$; perlicels long, persistent, hyaline, up to $45 \mu$ long.

On stems and leaves of Asperula oligantha F.v.M.

Victoria-Ardmona, May to Oct., and in moist places all the year round (Robinson).

'The host-plant is given as Asperula scopuria IIork. f., in the Index feuensis, but the synonyny seems a little confused. A. oligantha F.v.M. is first given as Rabia syrticula Miq., then $R$. syrticolı is given as a syuonym of Asperula scoparia Hook. f.

(Plate XVII., Fis.. 141.)

\section{IEGUMINOSAE.}

12. Uromyces appendiculatus (Pers.) Link.

Fignu.

Link, Obs. TT., 1. 28 (1825).

Sace. Syll. VII., p. 535 (1888).

Uromyces phaseoli (Per's.) Wint.

[O. Spermogonia on minute spots, whitish.]

[I. Aecidia densely erowded in small annular groups; pseudoperidia shortly cylindrieal, whitish, with deeply cut reflexed margins.

Aecidiospores polygonal, finely warted, colourless, 1 $1-32 \times$ $14-2: 3 \mu$.

IT. Uredusori on both surfaces of leaf, round, pale cinnamon brown, pulverulent, solitary or crowded and confluent, soon naked and surrounded by ruptured epidermis.

Uredospores yellowish brown, ellipsoid to ovate, finely echinulate, $2.3-32 \times 17-22 \mu$.

II1. Teleutosori dark-burown, almost black, easily detached, otherwise like uredosori.

'Teleutospores dark lorown to chestnut brown, subulobose to ellipsoid of oblong, smooth, scarcely thickenerl at apex, with broad pals flattener pipilla, . $27-37 \times 19-05 \mu$; pedicel lyaline, persistent, elongated, up to $70 \mu$ long.

On Cowpea (Tignu cutjun!y Walp.).

New Sunth Wales,-- lichmond, May, 1905 (Musson).

The distinctions leswern the telentespores of $l$. fubue and $l$. appendionlatus is very narked. In the one the apex is thickened up to $9 \mu$, while in the other the thickening is not pereeptible. 


\section{Uromyces bicinctus M[cAlp.}

Acacie.

II., III. Sori ruddy-brown, gregarious often confluent, raised, compact, rupturing epidermis irregularly.

II. Uredospores rellowish-brown, elavate to oval or ellipsoid, rounded at apex and slightly thickened, densely warted and warts arranged in regular longitudinal lines, with distinct germ-pores, generally arranged in two bands about one-third length of spore from either end, and usually three to four in each band on one face, 30-40 $\times$ 13-18 $\mu$, occasionally reaching a length of $45 \mu$, and variable in breadth, a verage $34^{\circ} \times 15 \mu$; pedicel similarly colourerl to spore or paler.

III. Teleutospores intermixed with uredospores, pallid but thickened considerably at apex and brown $(8-11 \mu)$, smooth, ellipsoid, and rounded at both ends, occasionally prolonged into one or two processes at apex, 28-34 $\times 17-23 \mu$; pedicel persistent, hyaline, short.

On phyllodes and pods of Acacia fiasciculifera F.v.MI.

Queensland-Rockhampton, $1 \& 67$ (from host-plant in National Herbarium, Melbourne).

This species approaches somewhat to $U$. phyllorliorum (B. and Br.), McAlp., in the uredospores, but they are shorter and much narrower, and distinguished at once by the two bands of germ-pores, on account of which the specific name is given. The teleutospores are also much thickened at apex and destitute of processes as a rule, although occasionally two may appear.

(Plate XLIII., Fig. 318.)

14. Uromyces fabae (Pers.) De Bary.

Vicia.

De Bary, Ann. Sci. Nat. Ser. 4, XX. (1803).

Sacc. Syll. VII., p. 531 (1888).

[O. Spermogonia 5ellowish, in small groups on leares and stem.]

[I. Aecidia scattered, in rings or orbicular patches: pseudoperidia short, slightly prominent, flat, with torn white edges.

Aecidiospores subglobose, orange, finely echinulate, 16-26 $\mu$ diam.]

II. Uredosori amphigenous, roundish, pale brown, powdered, seattered, often confluent, soon naked.

Uredospores subglolose or ovate, ochraceous, echinulate, with three equatorial germ-pores on one face, $20-30 \times 17-20 \mu$.

[III. Telentosori rounded on the leaves, more abundint and elongated on the stems, often confluent, blackish-brown.

Teleutospores variable in form, obovate or broadly clarate, smooth, dark-brown, apex darker, thickened $(8-10 \mu)$, and rounded, truncated or conical, sometimes with colorless papilla, $24-47 \times$ $17-30 \mu$; pedicels hyaline or pale brown towards spore, persistent, up to $110 \mu$ long.]

On stems, leares, and pods of Broad Bean ( Ticia faba I.).

$\mathrm{N}$ ew South Wales.-1s94 (Cobb $\left.{ }^{9}\right)$.

Queensland._Gladfield (Gwyther) (Bailey ${ }^{19}$ ). 
This rust has not been found in Victoria, and although it is said to be very common in New South Wales, on applying to Dr. Cobb for specimens, he informed me that they had all been lestroyed by inseets. Only the uredo-stage was found in New South Wales, and the exaet speeies is still doubtful.

(Plate XLII., Fig. 307.)

\section{Uromyces fusisporus Cke. and Mass.}

Acacia.

Cooke and Massee, Grev. XVI., p. 2 (1887).

Cooke, Handb. Austr. Fung., p. 331 (1892).

Sacc. Syll. VTT., p. 555 (1888).

Sori amphigenous, solitary or in groups and then confluent, elliptic to discoid, dark-brown or black, erumpent and girt by the ruptured epidermis.

II. Uredospores golden-brown, fusiform, obtusely warted, with acuteand more or less hyaline apieulus, $3-4$ equatorial germ-pores on one face, $57-77 \times 17-25 \mu$, average $62 \times 23 \mu$.

III. Teleutospores intermixed with uredospores, ruddy brown, globose to depressed globose, epispore rather thin, scarcely $2 \mu$ thick, somewhat polygonal seen from above and then germ-pore very prominent, $25-30 \mu$ dian. or $16-21 \times 25-35 \mu$, average $18 \times 28 \mu$; perlicels deciduous, hyaline, elongated, up to $96 \mu$ long, with septum at a short distance beneath spore.

On phyllodes of Acacia salicina Lindl., and $A$. neriifolia $\mathrm{A}$. Cunn.= A. retinodes Schleeht.

Victoria_Dimboola, Dee., 1895, and May, 1897 (Reader).

New South Wales-1902 (Maiden).

On Acacia sp.

Qucensland-Islands of Torres Straits, June, 1897 (Bailey's, 19).

Portion of the original material named in Cooke's handwriting is in the National Herbarium, and our description is based upon that. In the original description by Cooke and Massee the ureclospores were unfortunately mistaken for teleutospores and rice versâ. The uredospores are easily known from being obtuscly warted and witl equatolial germ-pores, apart altogether from size and shape.

The teleutospore is solitary at the apex of the pedicel, but the septum at a short rlistance from the spore foresharlows the $C_{\text {romycladium with }}$ a colourless resicle or cyst produced laterally immediately beneath septum.

'The nature of the teleutospore and the presence of a septum in the stalk was so surgestive of $U$ romycludium that the material was specially examined to see if more than one spore was borme on a stalk, but the most careful search failed to reveal any indieations that this was the case.

(Plate NIX., Figs. 158-160.)

\section{Uromyces hardenbergiae $\lambda\left[\mathrm{c} \Lambda l_{1}\right.$.}

IIardenbergia.

Sori on under surface of leat, lnown, crowded, globose to ellipsoid, often confluent, bullate, with ruptured cpiclermic, which usually remains in large pitrhes. 
II. Uredospores golden-brown, elliptic to ovoid, echinulate, relatively thick-walled, with three distinct equatorial germ-pores on one face, $25-35 \times 20-22 \mu$, average $27 \times 20 \mu$.

III. Teleutospores intermixed with uredospores, very sparse, ruddybrown, thick-walled, smooth, ellipsoid to obovoid, slightly thickened at apex, with hyaline apiculus and showing germ-pore, $25-28 \times 18-21 \mu$, average $26 \times 19 \mu$; pedicel persistent, hyaline, elongated, up to $35 \mu$ long.

On leaves of Hardenbergia monophylla Benth.

Victoria-Kergunyah, Dec., 1903, II., III. (Robinson). Frankston, January and August, 190t, II. (Robinson).

The teleutospores were exceedingly rare, and somewhat resembled the uredospores, but slightly smaller, with ruddy smooth epispore and hyaline apiculus.

This species persists all the year round.

Darluca filum Cast., very prevalent on uredosori.

(Plate XVII., Figs. 143-145 ; Plate G., Fig. 34.)

17. Uromyces phyllodiorum (B. and Br.) MeAlp.

Acacia.

Berkeley and Broome, Linn. Trans. II., p. 67 (1883).

Cooke, Handb. Austr. Fung., p. 331 (1892).

Sacc. Syll. VII., p. 556 (1888).

Melampsora phyllodiorum Berkeley and Broome, Limn. Trans., II., p. 67 (1883).

Uromyces digitatus Winter, Rev. Myc., p. 209 (1886).

Uromyces phyllodice Cooke and Mass. Grev. XVII., p. 70 (1889).

O. Spermogonia brown at first, becoming shining black, numerous, small, blister like, seated in centre of swollen, brownish, scattered, discoid, amphigenous tubercles, varying in size from 1 to $4 \mathrm{~mm}$.

II., III. Sori surrounding spermogonia or alone, ruddy brown to darkbrown, round or elongated, crowded, often confluent, compact, raised, girt by the ruptured epidermis, which bursts irregularly.

II. Uredospores golden yellow to golden brown, oval to ellipsoid, rounded at apex or bluntly pointed and slightly thickened, densely warted, and warts arranged in regular longitudinal lines, with distinct equatorial germ pores, $3-4$ on one face, and even reaching to $6,35-5.4 \times 16-25 \mu$, a verage $38 \times 22 \mu$, with elongated and hyaline pedicel.

III. Teleutospores at first intermixed with uredospores, lemon yellow, and sometimes almost colorless towards base, fusiform to wedgeshaped, thickened at apex, and bearing finger-like erect or divaricate processes, sometimes a single process, or bifid, or several, $60-70 \times 1 t-20 \mu$, but may even reach a length of $86 \mu$; pedicels long, persistent, hyaline; paraphyses intermixed with teleutospores or with uredospores accompanied by teleutospores, elongated, variously shaped, but generally somewhat cylindrical, thickened and rounded at apex, and tapering sometimes into a slender filament at base, $70-93 \times 6-10 \mu$. 
On phylloules of Acuric notabilis F.v.A.

‥ Australia-Near Gawler, July, 1885 (Tepper) (Ludwig²).

On phyllodes of Acrecia rlalluchirenc F.v.M., and A. peneninerevis Sieber.

Tietoria -Alps, near Bright, Dee., $190 t$ (C. French, jun.)

On phrllorles of Acacia dealbata Link.

Victoria-Orbost, Dec., 1905, II. IIJ.

On phyllorles of Acacia penninerris Sieber, A. microbotrya Benth, and $A$. neriifulic $\mathrm{A}$. Cum. in National Herbarium, Melbourne.

New South Wales-Twofold Bay.

(Queensland-Brishane River.

On phyllodes of Acacia pruinosa A. Cunn.

New South Wales-Gosford, Jan., 1906 (Froggatt).

On direcin sp.

Quernsland-Brookfield, Brisbane River (Bailey ${ }^{1,19}$ ).

New South Wales- $\left(\mathrm{Cobb}^{10}\right)$.

The appearance presented by this rust varies aecorring to the presence or absence of spermogonia. In the Queensland specimens there are black discoid tubercles with spermogonia in the eentre and surrounded by the sori, while in the Alpine specimens the numerous sori are seattered over the green surface of the phyllode.

The size of the uredospores is given by Winter as $32-35 \times 20-25 \mu$, but there are occasional elongated forms which may reach a length of $5 \pm \mu$. 'They somewhat resemble those of Uromycladium notabile, but the markings on the epispore are invel closer together.

The teleutospores are very charateristic, but very variable both in shape and size. The apex may be prolongerl into a single process, or there may be quite a number, at least up to 6 . As regards size they are generally elongated, and the measurements griven are the mean of a number taken from spores encling in a single process. They germinate at once without a period of rest. The specific name of dugitatus is so appropriate that it is unfortunate it has to be set aside in obedience to the law of priority.

This species was first deseribed by Berkeley and Broone in a list of funcri from Brisbane, Queensland, as Melumpsora playllodiorum in 1 583 , and drawings accompany the deseription. Specimens of the original material have bean kindly supplied to me by Mr. F. M. Bailey; Queensland State Botmint, and uredospores and telentospores from these are shown in Pl. XXY., Figs. $218-220$. There is no doubt as to its identity.

The following is the original description of Berkeley and Brome :"Siori in ampligenous tubercles: spores arising from delicate filaments, ratler fusiform, 5.5-58 $\mu$ long, gramulated, mixed with others which are

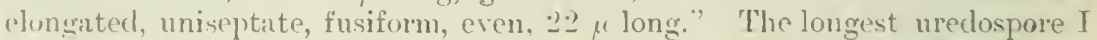
tumnd was 51,1 long, and the uniseptate spores of Drorlucu filum Cast., were alsu bery common.

Next, Winter, in 18\&6, deselibed the same fungus from s. Austrilia as Tinm?gres digitutus, the teleutospores being reorrled for the first time.

Thon Curke and Massee, in 1889 , describerl a Eromyces phyllodice furom Piristane as follows:- "Sori minute, orbieular, compract, brown, eroweded on

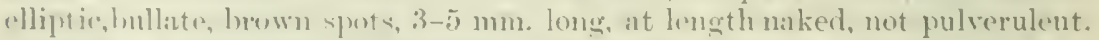
Eredoupores not secu, Toleutospores elliptic, olstuse, rarely apieulate, buwn : rpieprem mimtely wated, mather thick, hraline, thickened at the apex, $10-15 \times 16-1 \times \mu . " .1$ portion of the originil material was supplierl

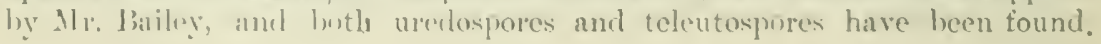


Cooke and Massee mistook the uredospores for teleutospores, but the existence of several germ-pores, together with their general appearance, indicate their true nature. Spermogonia were present in this material.

Finally Dr. Cobb, ${ }^{10}$ in 1897 , described the uredo stage of Melampsora phyllodiorum, and gives a drawing of the uredospores with an average size of $41 \times 17 \mu$. He also found the perithecia of Darluca filum Cast., among the sori, but their true nature was not recognised.

(Plate XIT., Figs. 218-228.)

1S. Uromyces trifolii (Alb. and Schw.) Winter.

Trifolium.

Winter, Die Pilze, I., p. 159 (188t).

Cooke, Handb. Austr. Fung., p. 330 (1892).

Sacc. Syll. VIT., 1). 534 (1888).

O. Spermogonia honey-coloured, disposed in small clusters.

Spermatia hyaline, globose, about $3 \mu$ diam.

I. Aecidia in circular clusters, on pallid spots; pseudoperidia cupshaped, with a white laciniate margin.

Aecidiospores subglobose, ellipsoid or irregular, very finely verrucose, pale orange, $14-2.3 \mu$ diam., or $22-25 \times 14-16 \mu$.

II. Uredosori rounded or elliptic, scattered, surrounded by the torn epidermis, ruddy brown.

Uredospores irregularly globose or shortly elliptic, echinulate, golden-brown, with two equatorial germ-pores on one face, $22-26$ $\times 18-20 \mu$.

III. Teleutosori smaller and rounded on the leaves, larger and elongated on the petioles, dark brown, almost black, bullate, long covered by the leaden epidermis.

Teleutospores generally intermixed with uredospores, ellipsoid, globose or pear-shaped, thickened at the apex with a small pale wart, smooth, dark-brown, $22-30 \times 19-22 \mu$, average $24 \times 20 \mu$; pedicels long, hyaline, deciduous.

On leaves, petioles and stems of Trifotium repens $\mathrm{L}$.

Victoria-Near Melbourne, Apr., I., II., III. Sep., I., IIJ. Bunyip,

Nov., I., II. Nyora, Apr., I., II., III. Murramurrangbong Ranges, Jan., I., II., TII.

New South Wales-(Cobbi2).

Tasmania-(Rodway $\left.{ }^{1}\right)$.

- All the stages were found together in January and April, and occurred on petiole, leaf, and stalk of inflorescence. The uredospores and teleutospores were very common, but the aecidiospores were not so common, and they were found also on the calyces. The leaf stalk was often much swollen and distorted. 'The spermogonia usually precede the aecidia. The teleutospores are considered to germinate only after a period of rest, but they were observed in April, to germinate freely while on the leaf.

The mycelium may be perennial, and Dietel ${ }^{2}$ considers this a common occurrence.

(Plate XVIT., Fig. 142; Plate G., Fig. 32.) 
19. Uromyces politus (Berk.) McAlp.

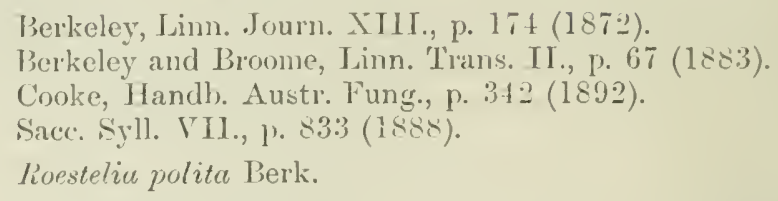

I. Accidia on dark-purplish, elongated patches, generally arrangred in lines which may be parallel, bursting through epidermis, bright orange, becoming ivory coloured with age, cylindrical to slightly compressed, straight, averaging $1 \frac{1}{2} \mathrm{~mm}$. high; pseudoperidia polished, smooth, with white, narrow, toothed margin; peridial cells oblong to angular, with striated margin, $32-35 \mu$ long.

Aecidiospores ochraceous, variable in size and shape, generally ellipsoid to ovoid or oblong, finely echinulate, $24-30 \times 19-22 \mu$.

III. 'Teleutosor'i on the same discoloured area as the aecidia and associated with or distinet from them, solitary or confluent, brownish to blackish, bullate, elongated to oval, surrounded by the raised and ruptured epidermis, compact, $1-2 \mathrm{~mm}$. long.

Teleutospores yellowish-brown, smooth, ellipsoid to oblong, rouncler or pointed and apiculate at apex, thickenerl $(6-8 \mu)$, occasionally two-celler, variable in size, $28-40 \times 20-25 \mu$, average $32 \times 2+\mu$; pedicel hyaline, persistent, elongated up to $150 \mu$.

On stems and branches of Muehlenbectia cunninghami, F.v.M.

New South Wales-Panamero Lake, Nov., 1860 (Berkeley²).

Victoria-Nurray River, Koondrook, Nov., 1905 (C. French, jr.)

This species differs from $U$. polygoni in the projecting Roestelia-like aecidia, and in the larger teleutospores with elongated pedicels. Several twocelled teleutospores oceurred, oblong, constricted at septum, upper cell with apiculate apex, thickened, and more deeply coloured than lower, which is sometimes colourless, size that of the largest ordinary teleutospores. The somewhat elongated accidia, in the absence of any other stage, led Berkeley to regard this as a species of Ropstelia, but the finding of specimens by $\mathbf{M r}$. C. French, jr., with teleutospores in addition, showed it to be one of the Uromyces.

Berkeley ${ }^{2}$ first reeorded the aecidial stage of this speeies on Muehlentectiv "unninghami in the Journal of the Linnean Society XIII., 174 (1872), and at the same time Cronartium asclepiadeum was noted on Jucksoria scoparia from the Darling Downs, Queensland.

Then just ten years later, in the transactions of the same society for 1882 , 1. 67, R. polita is recorded on the latter plant from Brisbane (Berkeley and Broome ${ }^{2}$ ), and it was rather peculiar, to say the least of it, that the same species of Roestelia, or even a Roestelia at all, should occur on plants so widely separated in a botanieal sense as Muehlenbeckia (Polygonaceac) and . Jacksonia (Iseguminusie). At the end of his deseription Berkeley remarks "The plant is identical with a specimen in the Kew Herbarium, and is srowing on the same plant, Iacksonia scoparia 12. Br."

However, on examining the speeimens on which this determination was based, it beame avident how the erom had arisen. Fortunately I have the specimen of Jeclisonie seoprevia from the National Herbarium, Melbourne, on 
which Cronartium was first determined, and Mr. Bailey has sent me a specimen from his herbarium labelled "Roestelia polita Berk.," and which was so named by Berkeler. On comparing the Brisbane specimen with the Darling Downs specimen, they are seen to be the same, and Berkeley's original determination of Cronartium is correct. When it is remembered that Roestelia polita Berk., has only been found on Muehlenbechia and not on . Jacksonia it will reconcile certain discrepancies in Berkeley's original rescriptions and drawings. In the original description of $R$. polita the spores are given as large, while in connexion with its occurrence on .Jacksonic it is stated- "the spores are globose about 0003 inch in diam. $\left(\tau-7 \frac{1}{2} \mu\right)$." If we turn to the drawings on Pl. 15, the otherwise puzzling figures become clear when they are taken to represent a Cronartium, and it will be seen from the description of this fungus on Jucksonice that the so-called aecidiospores are really the promycelial spores of that fungus.

If the identical specimen in the Kew Herbarium, to which Berkeley referrerl, is examined I have no doubt it will turn ont to be a Cronartium. At the time Berkeley wrote our knowledge of the distinctions between these forms was not so clear as now, but still the projecting pseudoperidium of the so-called Roestelia, with its characteristic peridial cells and contained spores, is quite distinct microscopically from the outwardly sinilar column of teleutospores of Cronartium which are wedged together into a solid mass.

In the original description the locality for New South Wales is given as "Bambamero" Lake, but Dr. Howitt informs me that the name is as above, and that the lake is situated 20 miles from Menindie, close to the Darling River.

(Plate XXXIX., Figs. 297, 298; Plate XLIII., Fig. 317.)

20. Uromyces polygoni (Pers.) Fekl.

Polyyonum.

Fuckel, Symb. Myc., p. $6+$ (1869).

McAlpine, Agr. Gaz., N.S. W., VII., p. 301 (1896).

Sacc. Syll. VIT., p. 533 (1888).

O. Spermogonia yellow to honey-coloured, conoid, in small groups. Spermatia hyaline, minute, $3 \times 2 \mu$.

I. Aecidia crowded in rounclish patches, bright orange, mostly hypophyllous, but often opposite; pseudoperidia rather flat, with broad whitish torn edges.

Aecidiospores subghbose, finely verrucose, pale yellow to orange yellow, $16-28 \mu$ diam.

II. Uredosori pale cimnamon to rusty brown, scattered, or arranged in a circinate manner and confluent, mostly amphigenous, pulverulent, round to oval, surrounded or partially covered by ruptured epidermis.

Uredospores ellipsoid to obovate, yellowish brown, finely echinulate, with generally two lateral germ-pores on one face, 20-29 $\times 16-21 \mu$, average $24 \times 20 \mu$.

III. 'Teleutosori scattered, blackish, pulvinate, roundish on leaves, elongated on stems, bursting through browned epidermis, confiuent in masses, surrounding and distorting stem. 
Telentospores globose, subglobose or elliptical, smooth, bright chestuut lyown, apex thickened ( $\delta \mu)$, rounded or oceasionally somewhat pointed, $22-3+2 \times 16-20 \mu$, average $2 \triangleleft \times 18 \mu$; pedicels pale ycllowish, persistent, firm, long, up to $90 \mu$.

()n leaves and stems of J'olygonnm avicularp $\mathrm{L}$.

Victoria-Near Malbourne, Rutherglen, Myrnions, Goornons, Ardmona, liunyip, Murramurrangbong Ranges, sc. Common generally throughout the year.

'Tasmania - Sandy Bay, January, 1906, IT., ITJ. (Rodway).

It is only recorded for Victoria and Tasmania, but is probably to be found wherever the host plant occurs. Accidia were first found on young plants along with the other stages in November, 1904.

The uredospores are plentiful, more particularly in the spring and summer months, but the teleutospores are formed in the autumn months.

Darluca filum Cast., commonly occurring on uredosori, was found on teleutusori in May, $190 \mathrm{f}$.

(Plate XVIII., Figs, 150, 151.)

\section{CHENOPODIACEAE.}

\section{Uromyces atriplicis MeAlp.}

Atriplea.

Sori epiphyllous, orbicular, scatterer, bullate, compact, ruddy brown, rrumpent, girt by the ruptured epidermis, about $\frac{1}{2} \mathrm{~mm}$. diam.

Il Uredosprores pale brown, ellipsoid, finely echinulate, with 3-5 scattered crem-pores on one faec, $25-29 \times 22 \mu$.

TII. Teleutospores intermixed with uredospores, dark brown, sub-globose to shortly ellipsoid, finely striated longiturlinally, slightly thickened at apex, with prominent single apical germ-pore, 2.-29 $\times$ $21-27 \mu$, average $26 \times 25 \mu$.

On leaves of Atriplex semibaccata $\mathrm{R}$. Br.

Victoria-Royal Park, near Mclbourne, April, 1899. (Brittlebank).

The sroups of spores shown in the Figures are rather smaller than the averasc, being alout $22 \times 25 \mu$. Occasionally an abnormal teleutospore necurred reaching a length of $3 T \mu$.

(Plate XV11., Figs. 146, 14i.)

22. Uromyces betae (Per's.) Kunlm.

Betir.

Kuelm, Bot. Keit., p. j) 40 (1869).

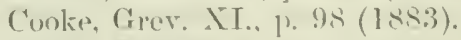

Conke, Haudl), Austr. Fuug., p. 8330 (1892).

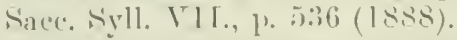

(). Surmengunia yellowish to honoy-colonerl, in small elusters, on both surfacese of leat.

Sipermatia hyaline, ellipsoid, 5-6 $\times 3 /$.

1. Arevilia disposed on orbienlar or oblong pellow spots, on both surfaces of leaf, mostly about mid-rib and on leaf stalk; pseutoperidia white, cup shaped, with seflexed fringed margin; peridial 
cells firmly united, thickened all round but thicker on one side, striated, individually somewhat lozenge-shaped, collectively elongated polygonal.

Aecidiospores angular, globose or ob!ong, orange-yellow, smooth, $18-28 \times 16-22 \mu$.

II. Uredosori cinnamon or chestnut-brown, scattered or circinate, small, surrounched by the ruptured epidermis.

Uredospores sub-globose, elliptic or oroid, yellowish-brown, echinulate, with two distinct equatorial germ-pores on one face, $25-32 \times 16-25 \mu$, average $28 \times 21 \mu$.

III. 'Teleutosori dark-brown, margined by the ruptured cuticle, scattered or orbicularly arranged.

Teleutospores orate or ellipsoid with a colourless papilla at apex, dark-brown, smooth, $26-35 \times 19-25 \mu$, average $32 \times 21 \mu$; pedicels thin, rather long, soon deciduous.

On leaves of Betu vulgaris L.-Beet and Mangel.

Victoria-This rust generally occurs wherever beet or mangels are cultivated, and has been found at Port Fairy, Maffra, II urtoa, Minyip, Ballarat, etc. It also occur's throughout the year from Jan. and Feb. to Nor. and Dec. As early as 1878 this l'ust from Ballarat was determined by Thmemen?

S. Australia-Aug., 1897 (Quinn).

Tasmania-(Rodway ${ }^{3}$ ). Devenport, Jan., 1906 (Robinson).

New South Wales-Hawkesbury Agric. College (Musson).

The teleutospores are rather scarce, but they were found at Port Fairy in August and measured $27-33 \times 22-24 \mu$.

The aecidiospores were found towards the latter end of August and up to December on young leaves of beet growing from roots left in the ground during the winter. According to Plowright they rery rarely occur in Britain in a state of nature. They were found to germinate very freely in water.

(Plate XVII., Figs. 148, 149 ; Plate XLIII., Fig. 316 ; Plate H.)

\section{SAPINDACEAE.}

23. Uromyces diploglottidis Cooke and Iass.

Diploglotis.

Cooke and IIassee, Grev. XV1I., p. 55 (1889).

Cooke, Handb. Austr. Fung., p 331 (1892).

Sace. Syll. IX., p. 294 (1891).

IIT. Sori epiphrllous, scattered, convex, minute, for a long tine covered, at length splitting, pale brown, seated on orbicular greenish spots.

Teleutospores elliptic, apex obtusely acuminate, base attenuated into a short pedicel, epispore hyaline, thick, contents granular, pallid, $50-60 \times 20-30 \mu$.

On fading leaves of Diploglottis cunninghamii Hook. f.

Queensland-Woolston Scrub, Brisbane River (Bailey ${ }^{6,}{ }^{19}$ ).

This species was very destructive to the foliage of the queensland Tamarind Tree.

Specimen kindly sent by Mr. Bailey, but spores not obtainable. 


\section{CARYOPHYILACEAE.}

Dianthus.

24. Uromyces caryophyllinus (Schrank) Sichroet.

fichroetrer, Brand. p. 10 (1869).

Ilcilpine, Agr. Gaz. N.S. WV. VTI., p. 300 (1896).

Sace. Syll. VII., p. 5) t5 (1888).

II. Uredosori ampligenous, dark brown when exposed, but long covered by epridermis, round or oblong, seattered, often confluent, iu] to 3 nim. long.

Urertospores roundish to oblong, yellowish brown to golden brown, decidedly echinulate, generally $3-4$ scattered or nearly equatorial germ-pores on one face, $21-3 t \times 17-28 \mu$, average $32 \times 2+\mu$.

TIJ. 'l'eleutosori amphigenous, blackish-brown, oblong, confluent in elongated lines, long covered by ashy epidermis, then margined by the ruptured and lagged enticle.

I'eleutospores at first intermixed with uredospores, roundish, oval or orate, eimnamon brown, generally thickened, with broad colourless papilla, averaere $28 \times 20 \mu$ or $22-32 \times 17-23 \mu$; perlicels very deciduous, hyaline, up to $45 \mu$ long.

On stems and hoth surfaces of leaves of Dionthus caryophyllus L. and D. chinensis L.-Camation and Dianthus.

Victoria-Near Melbourne, and at Ardmona. Very common in some seasons all the year round.

New South Wales-Ashfield, near Sydney. (Maiden.)

South Australia-Feb., 1902.

Queensland-Roma, 1901 ('Tryon $^{8}$ ).

There is not much difference between the naked-eye characters of the uredo and teleuto sori, only the latter are a little darker in eolour, but the spores themsolves are quite distinct, for the uredospores are corered with decided spines, while the teleutospores are relatively smooth and have a clear papilla at apex.

The teleutospore is filled with finely granular protoplasm, in the centre of which is a large valuole-like body. When the spore is examined in the chy condition, the surface appears to be eovered with numerous very fine points, which Fiseher ${ }^{5}$ regards as warts. The wall of the uredospore is beset with loosely arranged spines, which projeet at the margin when seen in optical section, while that of the telcutospore has deusely erowded fine points, which are not visible at the margin. These projecting points are so fine that the spore is generally described as smooth.

Darluen film Cist. is often parasitic on the uredosori and teleutosori.

(Plate XVIIT., Figs. 152-15.t; Plate G., Figs. 30, 31.)

\section{¿.). Uromyces scleranthi Ristr.}

Scleranthus.

limstrup, Bot. 'lidsskr., p. $10(1897)$.
Silec. Nyll. XIV., 1. 275 (1s99).

11. Urerlosiri scattered, minute, orbicular or oblong. slightly raised, pale: brown, erumpent, and surrounded by the ruptured epidrrmis. 
Uredospores golden brown, finely echinulate, ellipsoid to ovoid or oblong, 3-1 scattered germ-pores on one face, epispore $3 \mu$ thick, $25-32 \times 17-21 \mu$.

On Scleranthus diander R. Br.

Victoria_-June, 1898 (Rearler).

Only the uredo-stage was found although numerous sori were examined and while the uredospores generally agree with those of the above species they are sometimes a little longer.

It was originally found in Demmark on the stems and calyces as well as the leaves of Scleranthus peremis L.

The description is as follows:--"Sori scattered, minute, orbicular" $\mathrm{I}^{\prime}$ oblong, pale brown, long covered by epidermis. Uredospores yellowishbrown, globose, echinulate, $15-22 \mu$ diam. or oblong, $24-25 \times 18-20 \mu$.

Teleutospores rare, intermixed with uredospores, pear-shaped or obliquely ellipsoid, reddish-brown, apical papilla transversly thickened, 23-24 $\times$ $19-24 \mu$; pedicel hyaline, deciduous."

(Plate XXVIII., Fig. 248.)

\section{'ZYGOPHYLLACEAE.}

26. Uromyces vesiculosus Wint.

Zygophyllum.

Winter, Hedw. p. 22 (1885).

Cooke, Handb. Austr. Fung., p. 330 (1892).

Sace. Syll. VII., p. $5+7$ (1888).

Sori amphigenous, scattered or gregarious, often confluent, rounded or irregular, ruddy brown, covered by the cinereous resicular epidermis, which ultimately ruptures and surrounds the sorus.

II. Uredospores sub-globose, elliptic or ovate, yellow to brownish, densely warted, even prickly, epispore thin, with 3-5 equatorial germ-pores on one face, $26-35 \times 19-24 \mu$, average $28 \times 20 \mu$.

III. 'Teleutospores globose, elliptic, ovate or pear-shaped, thickened at the apex, rounded or with a broad apiculus more or less shortly conical, $21 \mu$ diam., or 23-31 $\times 17-22 \mu$, average $25 \times 20 \mu$; epispore thick, smooth, dark bay brown when mature; pedicel long, thick, persistent, may be flexuous, pale olivaceous, up to $150 \mu$.

On living leaves and stems of Zygophyllum billardieri DC.

S. Australia_Spencer's Gulf (Tepper). (Winter ${ }^{1}$ ).

On leares, stems, and fruit capsules of $Z$. ylancescens F.v.M.

Victoria-Near Dimborla, November, 1894, and Warracknabeal, March, 1904 (Reader).

S. Australia-Yorke's Peninsula, June, 1902 (Molineux).

The confluent sori may form large conspicuous elongated patches up to $10 \mathrm{~mm}$. long or more, and the greyish bladder-like epidermis remains unbroken for some tine. Several two-celled teleutospores were met with and not constricted at the septum, which was decidedly thick and rather below the middle, sometimes approaching the base. They were, in other respects similar to the ordinary teleutospores, even to the size, and measured about $27 \times 22 \mu$. 
Dirtel ohserves that the recurrence of bicellular teleutorpores is rare

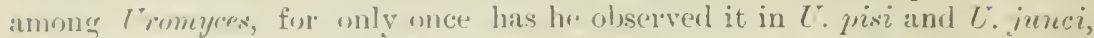
and two were found in 1 . limesellre. Dr. Cooke has also found a few in IT. trifulzi, and 1 have now to add $L$. ordhidearum, $U$. tricuryues, $L$. resiculosns and $T$. politus.

Darlun filum Carst., is generally very plentiful on uredusori.

(Plate XVIII., Fig. 15j-15i; H Hate G., Fïg. 3.3.)

\section{UROMYCLADIUM MeAlp.}

This new grenus of liusts is notewortly, not only on account of the teleutospores forming a cluster at the top of the stalk, and generally accompanied by a colorless cyst, but from the lirrge galls produced by some species which seriously disfigure and ultimately destroy many of our Wattle-trees (Acacias).

The seven species at present known show every graclation from one teleutospore accompanied by a cyst ( $L$. simplex) through two teleutospores with or without a cyst ( $U$. muritimum), (U.bisporum), and raching to three teleutospore; in a head always without il cyst (U. teppericunm). The presence of more than one telentospore at the end of a stalk is a novel feature in l'usts, and the addition of a colorless vesicle or cyst at the base reminds one of Ravenelia to which this genus is allied. The unicellular teleutospore also links it on to Uromyces, and I consirler that here we have the connecting link between Lromyces on the one hand and Ruvonelia on the other. The senus Anthomyces with only a single species is composed of a head of three or more cells uniter togrether with sterile cells at the base, and may prove a bridging species fiom Lromycladium to Ravenelia. Spermogonia, uredo anil teleuto sori oceur, but no aecidia. The two gall-producing species hitherto found are $U$. nolabile and $U$. tepperianum, both of which procluec three teleutospores at the top of the stalk, and the former has uredospores in addition. 'The only species known outside of Australia is that of $U$. lepperianum (formerly called Uronyces tepperianus, Sacc.), and it is noted for causing deformation of the shoots, but with us it is ruining whole plantations of Wattles. Near Altona Bay, Victoria, the branches of the beautiful Golden Wattle (Acuciu pycuantha) are deformed and destroyed by it when it forms numerous galls sometines as large as a potato. In the neighbourhord of Molbourne, ton, herlges of the Kingaroo thorn (A. crmata) are being gradually and completely destroyed by this fungus. Some of the shrubs liave most of their brinches infested with the chocolate colored salls, the color being due to the spores, and they may be in the torm of at succession of small ones as large as peas, or large ones the size of walnuts. The phyllorles as well as the branches in some species are deformed. On "utting across these galls they are seen to be solicl to the core, and not the proluct of insects but of the fungus, although in many cases bored and tunmelled by insects after being produced. Them our Acacias ane more closely examined for rusts no duubt the number of species will be consitlerably incratsed.

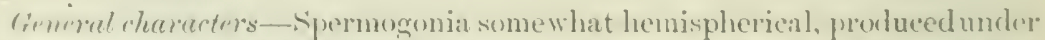
the cuticle, without paraphyses at mouth, precerling the formation of any wher spere.

Ureclospores solitary at apex of basidia, and generally much larger than tolentuspores with several listinct grem-pores.

Telentospores in clustors. composed of me spore and eyst or two or more spores with or withut a ryst, depresised slobose. 
This genus may be distinguisher from Cromyces by the arrangement of the teleutospores, by their shape, which is not elliptical, but depressed globose, and by the presence, in most cases, of a colorless resicle or cyst.

Allied with Cromyces on the one hand and Ravenelia on the other.

Australian species, $\bar{T}$.

\section{Axalytical Key to the Species.}

I. One teleutospore and vesicle in head.

A. Uredospores fusiform, with hyaline apiculus, and finely warted.

Ur. simplex:

B. Uredospores sub-elliptical, without hyaline apiculus, thickened at apex, and coarsely warted.

IT. Two teleutospores in head.

Ur. robinsoni.

A. Uredospores unknown.

III. Two teleutospores and resicle in head.

Ur. bisporum.

A. Uredospores sub-elliptical, warted all over, much thickened and dentate at apex.

Ur. maritimum.

B. Uredospores sub-clavate, evenly warted all over, and scarcely thickencd at apex.

IV. Three teleutospores in head.

Ur. alpinum.

A. Teleutospores finely warted, warts arranged in lines; uredospores known.

Ur. notabile.

B. Teleutospores with converging striae; uredospores unknown.

Ur. tepperianum.

\section{LEGUMINOSAE.}

\section{Uromycladium alpinum McAlp.}

Acacia.

O. Spermogonia minute, black, shining, punctiform, crowded, on both surfaces of phyllodes on discoloured patches, appearing before sori and ultimately surrounded or accompanied by them.

Spermatia hraline, ellipsoid, $3 \times 2 \mu$.

Sori amphigenous, rusty-brown, scattered or in groups, bullate, soon rupturing epidermis and becoming naked.

II. Uredospores rellowish-brown to golden-brown, shortly or elongated clavate, occasionally oral or oblong, warted equally all over, scarcely thickened at apex, with 3-5 equatorial germ-pores on one face, $35-51 \times 21-26 \mu$, occasionally reaching a length of $58 \mu$.

III. Teleutospores at first intermixed with uredospores, two in head with colorless resicle, depressed globose to subglobose, yellowishbrown to dark-brown, smooth, very slightly thickened at apex with distinct germ-pore, $19-22 \times 2 \tilde{5}-30 \mu$; vesicle arising from stalk immediately beneath septum, globose or slightly ellipsoid about $25 \mu$ diam. 
X. Mesospores associated with uredospores, not uneommon, ellipsoid to oblong or obovate, rounderl at apex, smooth-walled and wall of about equal thickness throughout, with colorless stalk, 15-25 $\times 10-15 \mu$. They differ from uredospores in being smorth and much smaller, and from the teleutospore in shape, in not being thickenerl at apex and without apical germ-pore.

On phyllodes of Acacia dallarhirena F.v.MI.

Victoria-Alps, near Bright, Dec., 1904 (C French, jr.).

On phyllorles of Acacia luxifolia A. Cunn.

New South Wales-New England. (From type of loost in National Herbarium, Melbourne.)

On leaves and pods of $A$. dealbata Link.

Victoria-MIrramurangbong Ranges, Jan., 1905 (Robinson).

Tasmania-Risdon, Vec., 1905, and MIt. Wellington, Jan., 1906 (liodway).

On phyllodes of $A$. implexa Benth.

Victoria-Myrniong, May, 1905 (Brittlebank).

On phyllorles and pods of Acacia linifolia Willd., in National Herbarium, Melbourne.

New South Wales--Blue Mits.

Queensland-Rockhampton, Nerhool Creek.

This species rery much resembles $U$. simplex in the appearance of the sori, but it is allied to $U$. muritimum in bearing two teleutospores and a vesicle on one sporophore. It differs from the latter, however, in the uredospores which are generally clavate and warted equally all over.

The vesicles vary in size, and are sometimes large and swollen when they are ready to burst. In old material they may have disappeared altogether. The teleutospores were much more numerous than the uredospores in December.

(Plate XXIV., Figs. 209-215.)

\section{2.. Uromycladium bisporum MeAlp.}

Acacia.

JTT. 'T'eleutosori on the branchlets forming elongated slightly swollen chocolate-brown masses, and on the under surface of the leaflets appenring as powdery patches.

Teleutroppores two in a hear, yellowish-brown, subglobose to depresserl globose, occasionally with very short, colored, stalk-like, basal projection, slightly thiekened at npex with germ-pore immediately heneath, $15-2.2 \times 2.2-30 \mu$.

On branches, leaves and porls of Acacia dealbatu Link.

Victoria-Murramurrangbong Ranges, January, 1905 (Robinson). T'asmania-Riston, Dec., 1905 (Rodway).

No vesicle oceurs below the septum, so that this species is an intermediate form between $L$. simpler with a single spore and vesicle and $U$. maritimum with two spores and a vesicle in each head. The oceasional presence of two teleutospores in $U$. simplex is a further indication of the passage from one to the other. 


\section{Uromycladium maritimum M[cAlp.}

Acacia.

O. Spermogonia at first ruddy-brown, ultimately black, dotted orer the surface of prominent discoid tubercles, formed at corresponding points on both surfaces of the phyllodes, somewhat hemispherical, but broader than rleep, and produced beneath the cuticle, averaging $120 \mu$ diam.

Spermatia hyaline, shortly ellipsoid, $3 \times 2 \mu$.

II., III. Sori dark-brown, elongated, compact, confluent, rupturing epidermis, 2-3 mm. long, partially surrounding the black discoid spermogonial tubercles.

11. Uredospores oval to elliptical or elongated elliptical, pale-brown to dark-browu, warted all over and thickened at apex, where spikes are specially prominent, forming a tuft, with very distinct equatorial pores, $3-7$ on one face, very variable in length and breadth, 45-60 $\times 24-28 \mu$; pedicel deciduous, hyaline, elongated, up to $106 \times 5 \mu$.

III. Teleutospores at first intermixed with uredospores, two on each sporophore, with a lower and lateral colorless vesicle, very rarely three spores in cluster without a vesicle, subglobose to depressed globose, dark-brown, thick walled, smooth, with finely granular contents, slightly thicker at apex, with very prominent apical germ-pore, $30-32 \mu$ diam., or $22-25 \times 24-30 \mu$; colorless resicle globose, with rery thin wall, and arising from stalk immediately beneath septum, 30-35 $\mu$ diam.

$\mathrm{X}$. Mesospores intermixed with the uredospores, or even with uredospores and teleutospores, unicellular or very rarely bicellular, pale, smooth, with wall of equal thickness and finely granular contents, without any visible germ-pores, fusiform or ellipsoid, or even occasionally clavate, solitary at the end of a stalk like the uredospores, 22-45 $\times 11-19 \mu$, occasionally up to $57 \mu$ long.

On phyllodes and stems of Acacia longifolia Willd.

Victoria-Sandringham and Beaumaris.

Tasmania-Mersey Bluff, Jan., 1906 (Robinson).

II. April to August, occurring alone, or sparingly mixed with teleutospores. III. September to latter part of spring and during summer, intermixed with a few uredospores.

In one form or another it occurs all the year round.

This rust was first found on the coast at Beaumaris in $189 \tilde{\mathrm{J}}$ on Acacic longifolia, although not investigated at the time, and it was in this species that the peculiar grouping of the teleutospores and the presence of it colourless vesicle or cyst was first observed.

The teleutospores germinate freely in water or moist air and without a period of rest. They germinate all round the sorus on the surface of the phyllodes, forming a flaky mass of spores and sporidiola, which easily peels off.

The uredospores were only found to germinate in water in the spring.

The spermogonia are associated with uredo and teleutospores occurring in the same sorus.

Only in rare instances were sori found without being accompanied by spermogonial tubercles.

(Plates XX., XXI., Figs. 166-184; XXIV., Figs. 216, 217 ; XXXII., Fig. 273 ; XLIII., Figs. 313, 311, 315.) 
30. Uromycladium notabile (Ludw.) McAip.

[ulwig, ]3ut. Centrbl. XIJTT., p. fi (1S90).

Cooke, Handb. Austr. Fung.. p. 34.3 ( 1592 ).

Sarce. Syll. XI., p. 22:2 (1895).

Trerlo notrelitis Ludw.

O. Spermogonia minute, punctiform, black, in swollen tubercles often intermixed with uredospores and teleutospores.

Spermatia hraline, ovate or ellipsoid, on elongated basidia, $4 \times$ $2-3 \mu$.

JI. Uredosori on both surfaces of phyllodes, on branches and pods, ochraceous to yellowish-bown, seated on a distorted inflated gall.

Uredospores ellipsoid to oblong, bright yellow when fresh, becoming yellowish-brown, on elongated hyaline pedicels, with 3-5) equatorial germ-pores on one face; epispore thick $(3 \mu)$, reticulate, $: 30-45 \times 18-28 \mu$.

111. Teleutosori on branches, phyllodes and legumes, forming large, swollen, distorted galls, chocolate-brown, at length very powdery.

Teleutospores intermixed with uredospores at first, in clusters of three (rarely two or four), sub-glolose to depressed globose, rellowish-brown, densely covered with warts arranged in lines, slightly thickened at apex, with germ-pore beneath, 16-23 $\times$ $21-26 \mu$.

On phyllodes of Acacia notribilis F. v. M.

South Australia-Roseworthy, Sept., 1889, IT. (Tepper).

On branches, leaves and pods of Acacia dealbata Link.

Tictoria-Murramurangbong Ranges, Jan., 1905, O., II., III. (Robinson). Bright, June, 1905, II., III. (Davey). Bairnsdale and Orbost, Dec., 190.5, III.

Tasmania-Hobart, Nay, 1905, II. (Roriway). Cataract Gorge and Dulverton, Jan., 1906, III. (Robinson).

On branches of Acricin recurrens. Willd.

Victoria-Near Melhourne, Feb., 1905, III. Mrrniong, Juls, 1905, III.

New South Wales-Exeter, near Moss Vale, May, 1905, IIT. (Baker).

On branches of Acaria elata A. Cunn.

New South Wales-Lawson on the Blue Mountains, April 1905, O., IIJ. (Baker).

On branches of 1 . binererta DC.

New South Wales - Sirdney, Sept., 1905, IIT. (Maiden.)

On branches of Aracin pruiness A. Cunn.

New South Walles-Giosford, .lan., 1906, 1T. (Froggatt.)

'The ochracesus ureclosori are generally distinct from the chocolate-brown toleutosori, but sometimes the two kinds of spores are found intermixed.

The arrangement of the teleutospores is generally the same as in $T$. tepporiamm, hut the lense corering of warty spines insteal of distinct. striac differentiate: them at once and the height of the spore is greater. The spermogonia are found in association with both uredospores and teleutospories.

The urerlospores elosely resumble in size and shipe those of Eromyces phyllodionem, hut the surface markings serve to distinguish them. In the 
latter the warts are arranged in longitudinal lines, while in the former the surface markings are net-like. See Plate XXIII., Figs. 201, 202, and Plate XXY., Fig. 226.

Some very large galls were found either survounding or terminating branches of the Black Wattle (A. decurrens). A size of $3-4$ inches in diam. was not uncommon, and one large clump resembling a big artichoke measured $5 \times 14$ inches, and weiglied 15 ounces. In some cases the branches still flourished berond the gall, but it was evidently an expiring effort of the tree to pnt forth leaves. The particular tree on which the largest galls occurred was about 30 feet high and 13 rears old, but many of the branches were decaying, and it looked altogether rather dilapidated on account of the numerous galls which were often tunnelled by insects.

The mycelium was evidently perennial, as some of these galls were several years old.

Only the uredospores of this species were found at first, and were described as Credo notabitis by Ludwig. Dietel has thrown out the suggestion in his paper on "The Genus Ravenelia," that from the nature of the uredospores in Ludwig's species they may be found to belong to Ravenetiu, and, considering the relationship of this genus with Uromycladium, the suggestion turns out to be not far from the truth.

(Plate XXIII., Figs. 196-205 ; Plate XXXVI.)

\section{Uromycladium robinsoni McAlp.}

Acacia.

O. Spermogonia on discoid tubercles, minute, punctiform, ruddy-lsrown, partially or entirely surrounded by uredosori or telentosori.

Spermatia hyaline, minute, sub-globose, about $3-4 \mu$ diam.

II., III. Sori amphigenous, numerous, crowded, up to $\frac{3}{4} \mathrm{~mm}$. diam., light r'ust color, soon erumpent, powdery, and often surrounding spermogonial tubercles.

II. Uredospores pale yellowish, oval to ellipsoid or elongated elliptical, thickened at apex (up to $6 \mu$ ), warted all over, particularly at apex, with $2-3$ equatorial germ-pores on one face, $38-45 \times$ $19-22 \mu$.

III. Teleutospores at first intermixed with uredospores, solitary at end of sporophore, with lateral vesicle beneath, golden yellow to golden brown, depressed globose to sub-globose, smooth, slightly thickened at apex, 19-26 × 25-34 $\mu$; vesicle hyaline, globose to shortly ellipsoid, often on distinct stalk with septum at base, $20-25 \mu$ diani. or $22-27 \times 16-23 \mu$.

X. Mesospores not uncommon, ellipsoid to elongated ellipsoid $\sigma \mathrm{r}^{\circ}$ elongated oblong, with thin and smooth walls, rounder at apex, without germ-pores, $18-22 \times 9-12 \mu$.

On phyllodes of Acacia melanoxylon $\mathrm{R}$. Br.

Tictoria-Murramurranghong Ranges, Nov. 1902, Dec. 1903, Jan. 1905 (Robinson). Mymiong, May, 1905 (Brittlebank). Tasmania-Hobart, Dec., 1905 (Rodway).

This species was found near Kergunyah by my assistant, Mr. G. H. Robinson, in whose honor it is named. The teleutospores give a dingy appearance to the phyllodes on both surfaces, and sometimes the sori are sor crowded as to convey the impression of a continuous mass of rust, or even 
red dust. It resembles $U$. simpler: in having a single teleutospore at the apex of the sporophore, with a lateral vesicle immediately below, but it differs chictly in the shape and size of the ureduspores. The powdery masses of teleutospores soon sprear over the leaf and germinate in situ, forming flakes which are easily detached.

The spermogonia are seaterl on tubercles along with uredo and teleutospores, but there may be jowdery patches of both kinds of spores even on the same phyllorle, without spermogronia or the associated tubercles (Plate XXXII., Fig. 27 7 ). 'This species represents one of the simplest forms of the genus, in which the sporophore bears a single teleutospore with a lateral colorless vesicle immediately beneath it.

(Plate XXII., Figs. 185-189; Plate XXXII., Fig. 27t.)

Acacia.

32. Uromycladium simplex MeAlp.

O. Spermogonia ruddy-brown, erowded, minute, punetiform, arranged in a eircinate manner on both surfaces of phyllodes and very occasionally on young branches.

Spermatia hyaline, shortly ellipsoid, $4-5 \times 3-4 \mu$.

Sori amphigenous, ruddy brown to dark brown, numerous, sometimes arranged in groups, bullate, soon rupturing epidermis and beeoming naked.

IT. Uredospores yellowish brown to golden brown, fusiform or oval, with hyaline apiculus, finely warted, with as many as six equatorial germ-pores on one face, three being very common, $4 \delta-5 \delta \times 21-25 \mu$.

III. Teleutospores at first intermixed with uredospores, solitary at end of sporophore and lateral vesicle immediately beneath, yellowish brown, depressed globose to sub-globose, smooth, slightly thickened at apex and germ-pore directly beneath, $22-25 \times 25-32 \mu$; sporophore fitting into a sort of socket on base of spore, hyaline, elongated, $80 \mu$ or longer; vesiele hyaline, globose 19-2.2 $\mu$ cliam.

On phyllodes and branches of Acacia pycnantha Benth.

Victoria-Grampians, Nov., 1900 (C. French, jun.), Dec., 1900 (Robinson). Little River, Nor., 1902 and Jan., 1905 (C. French, jun.), Feb., 1905. Werribee Gorge, Dee., 1902, and Nor, 1904. Malvern Gardens, near Melbourne, Sept., 1905.

Very occasionally the colorless vesicle is replaced hy an ordinary spore, thus showing that the sporophore bears at its apex two ipores, or a spore and its substitute.

The sori form numerous hemispherical pustules which may run together, and during the latter part of spring and early summer, while the teleutospores are being produced, the exuded spores are observed imbedded in gum, frecly germinating and readily detachable in flakes.

The uredospores somewhat resemble those of Uromyces finsisporns, but in the latter there are only $3-4$ germ-pores on one face.

'The spermogonia were first fount in September on a young tree about four years old, and they usually ocenred on distinct ruddy spots produced by Coniothyrium pycnomthas MicAlp. and other fungi.

Drerluce filum Cast. not unconmon on sori containing both uredo and teleutuspores.

(Plate XIX., Figs. 161-165; Plate XXXII., Fig. 275.) 
33. Uromycladium tepperianum (Sacc.) McAlp.

Acacia.

Saccardo, Hedw. XXVIII., p. 126 (1889).

Cooke, Handb. Austr. Fung., p. 331 (1892).

Sacc. Syll. IX., p. 291 (1891).

Uromyces tepperianus Sacc.

O. Spermogonia minute, ruddy at first, then black, brownish by transmitted light, depressed globose, $150 \mu$ diam.

Spermatia hyaline, ellipsoid, $3-3 \frac{1}{2} \times 2-2 \frac{1}{2} \mu$.

III. Teleutosori on the leaves or phyllodes forming swollen distorted gall-like masses along their whole length, and on the branches long and broadly effused, or large somewhat spherical galls coated with cinnamon to chocolate-brown powdery spores.

Teleutospores in clusters of three, sphaeroid to depressed globose, cinnamon brown, thickly channelled and striate, striae converging towards apex, slightly thickened in upper portion of wall, $14-17 \times 18-25 \mu ;$ sporophore hyaline, elongated, soon deciduous.

On branches of Acacia salicina Lindl.; A. hakeoides A. Cunn.; $A$. myrtifolia Willd.; and A. spinescens Benth.

S. Australia-Blackhills, Sandy Creek, Murray Bridge, etc., Dec., 1889 and 1892 ('Tepper). Dec., 1901 (Molineux).

On phyllodes and branches of $A$. armata R. Br.; A. implexa Benth.; A. juniperina Willd.; A. melanoxylon R. Br.; A. pycnantha Benth.; $A$. rigens A. Cunn.; A. siculiformis A. Cunn.; A. vomeriformis A. Cunn.

Victoria-Mallee near Hopetoun, Oct., 1903 (C. French, jun.). Ringwood, Aug., 1904, (C. French, jun.). Werribee Gorge, Jan., 1905, (Brittlebank). Oakleich, Jan., 1905. Little River, Jan., 1905, (C. French, jun.), and Feb., 1905. Cheltenham, May, 1905, (Robinson). Myrniong, July, 1905. MIt. Macedon, 188., and Murray River, 1874, from types of A. siculiformis and A. vomeriformis in National Herbarium, Melbourne. Common around Melbourne.

On A. diffusa Lindl.; A. rerniciflue A. Cumn.; A rerticillata Willd.

Tasmania.-Hobart, March-April, 1905 (Rodway and Lea).

On Acacia longifolia Willd.

New Sonth Wales-Rose Bay, near Sydney, July, 1905 (Froggatt).

On branches and phyllodes of A. erioclarla Benth., and A. glaucoptera Benth.

West Australia-From types of host in National Herbarium, Melbourne.

On Acaciu stricta Willd.

Tasmania-Gordon, D'Entrecasteaux Chamnel, Nor., 1905 (Rodway).

This species was first described and illustrated by Saccardo in 1889, who considered that the unicellular teleutospores were borne singly on long stalks, hence he placed it in the genus tromyces. He failed to observe, however, that each sporophore bore a cluster of three in a head. It is the inost widespread of all the known forms being found on nineteen different species of Acacia, and it shares the property with $U$. notabile of producing galls. This is particularly noticeable in the Golden Wattle (A. mycnantha), where the galls are as large as putatoes, and in some of the Wattle plantations where the trees are cultivated for their bark they hang in 
large numbers from the branclies like so many fruits, and the trees are rither dving or dearl. (Nee Frontispiece.)

Thr. dark chocolate-brown spore-masses are quite powdery, and each spore lus prominent ribs running from base to apex, so that it is easily known from heing tluted. In fact, the appearance closely resembles the markings (1)1 the exgs of some butterflies, and no doubt the purpose is the same, to strengthen the membrane which is already relatively thick, and prevent the spore collapsing when dry conditions prevail. Occusionally a spore has leen found germinating in satu, and they germinated freely in water in twenty hour's.

What is said to be the same fungus has been found on Albizzia montana Tienth., in Java, and it would be interesting to know if it occurred on any indigenous species of this genus in New South Wale:, queersland or West Australia.

On A. implexa at Myrnions there were numerous gralls, and I found one at the end of a branch in .July somewhat of a leg-of-mutton shape and weighing abuut 3 lbs. (Pl. XJi.). Witcher' brooms of various sizes also occurred on A. impleace, causerl by this rust, and one of the largest measured 15 inches in circumference (PI. ILIT.).

\section{(Plates XXII., Figs. 190-195; XXIII., Fig. 206 ; XXIIT.; XXXV.; XLI.: XLII., Fig. 305.)}

\section{PUCCIRIA Pers.}

This genus ineludes more than half of all the Australian Rusts, and is important, not only on account of its numbers, lyut from its appearing on so many of our cultivated crops. It occurs on all the cereals and many of the grasise, on celery and chicory, on fruit trees, such as peach and plum, and many garden favorites are attacked by it, such as chrrsanthemum and comflower, hollyhock, marigold and daisy; even a paravite, such as the native mistletor, is subject to it. The two-celler teleutospore is easily recognized and distinguished from the unicellular uredospore. All the spore-forms may he present on the one plant, as in I'. hederacere on the native violets (Fiolia herderarea and $V$. betonicifoliu), or reduced to the teleutospore alone, as in P. matracomm. There may also be heteroecious forms, such as $P$. caricis, with the acciclial stage on the nettle (Urticu). The teleutospore, although normally two celled, aml with a horizontal septum, is sometimes very variable in these respects. It may not only, occasionally, be one-celled, but in I'. richondiae, for instance, it may be $3-t$ celled, and it may be vertically. obliquely, or eren nuriformly divided by the septa. The most celebrated of all the species is $P$. (raminis, or wheat renst, which seems to have lost the power here of infecting the barherry, for although selminating promycelial spores have ben uswal upm specially importer barberries and rusty wheat grown around the litter: still no aecidia have been producerl.

Mesospores aro common and paraplyyses may be present in both the uredn and telento-laver.

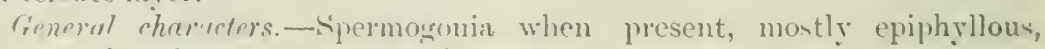
minute, sul, globose of flask-shaped, homey-coloured.

Spermatia very minute, globose or ellipsoid, hyaline.

Aecidia when present at first shobose and elosed, then cup-shaped and open, or elongated and rylindricil, with margins generally everted.

Accitiospores miginiting in scrial order and soon free, globuse, subglobose or anerular, hyaline, polluwish or urange. 
Uredosori when present, generally minute and flattened, sometimes paraphysate.

Uredospores globose, sub-globose, ellipsoid or ovate, originating singly on the terminal ends of the hyphae, with germ-pores mostly in pairs or several, rarely one, never smooth.

Teleutosori variable in size, flattened or pulvinate, sometimes paraphysate.

Teleutospores separate, varionsly shaped, pedicellate, 1-septate, with one germ-pore in each cell.

Sporidiola ovoid or reniform, generally lyaline.

Australian species, 90.

\section{GRAMINEAE.}

\section{Puccinia agropyri Ell. \& Ev.}

Agropyron, Clematis.

Ellis and Everhart, Journ. Myc. VII., p. 131 (1892).

Sydow, Mon. Ured. I., p. 823 (1901).

Sacc. Syll. XI., p. 201 (1895).

Lecidium clematidis DC. Fl. franc. II., p. 243 (1805).

O. Spermogonia amphigenous, honey-coloured, in clusters on leaves, accompanying aecidia.

Spermatia hraline, globose, minute, $3 \mu$ diam.

I. Aecidia hypophyllous, on definite spots, bright orange, in irregular cluster's; pseudoperidia cup-shaped, flattened, with reflexed lobed margin; peridial cells piriform to quadrate, striated at margin and punctate all over, $28-32 \times 16-22 \mu$.

Aecidiospores orange-rellow, ellipsoid to sub-globose, finely echinulate, $21-29 \times 16-19 \mu$, or $20-22 \mu$ diam.

II. Uredosori epiphyllous, rarely on under surface, minute, elliptic or linear, sometimes conthent, yellowish to orange.

Uredospores orange yellow, elliptical to oroid, finely echinulate, $4-5$ scattered germ-pores on one face, $25-32 \times 19-2.2 \mu$, epispore up to $2 \frac{1}{2} \mu$ thick.

III. Teleutosori hypophyllous, minute, covered by the leaden-coloured epidermis, at length occasionally erumpent, oblong or linear, sometimes forming lines on sheaths.

Teleutospores yellowish brown, cylindric clavate to elongated oblong, smooth, slightly constricted at septum, variable in size, $40-70 \times 12-2.5 \mu$, a verage $60 \times 18 \mu$; upper cell rounded or squarely truncate at apex and decidedly thickened $(6-9 \mu)$, sometimes broarler than long, darker in colvur than lower, 19-29 $\times$ $16-25 \mu$ : lower cell tapering towards pedicel or oblong, usually longer and narrower than upper, $25-41 \times 12-20 \mu$; pedicel short, generally tinted. Occasionally three-celled telentospores occur.

I. Mesospores occasional, pale brown, elongated, rounded, or slightly pointed and thickened at apex, slightly tapering towards base, 40-48 $\times 13-16 \mu$, with short coloured pedicels.

Aecidiospores on Clematis aristata R. Br.

Victoria._Murramurrangbong Ranges, Dec., 1903, and Jan., 1905 (Robinson).

Uredo and teleutospores on Agropyron scchrum Beauv.

Tictoria_Near Melbourne, Dec., 1892 (Robinson). Myrniong, March, Nor., Dec., Jan. Murramurranghong Ranges, Dec., 1903 (Riobinson). 
The teleutospores vary considerably in size and shape. They are sometimes elongated cylindric but usually cylindric clavate, the lower eell being comparatively nalow and tapering slightly towards base, while the upper cell is expaniled and considerably flattened out at apex. The length may vary from $40-70 \mu$ and the breadth from $12 \mu$ (in lower cell) to $25 \mu$ (in upper cell). It is noticeable that certain suri may consist of elongated and others of medium-sized spores.

In the Agricultural Grazelte for New South Wales, Tol. TI., p. 852, 1895 , the rust on this native grass was griven as 1 . disperse Eriks. and Hemn, but on further examination $I$ find that it approaches most closely to I. agropyri Ell. and Ev. and is named accordingly.

Specimens of $P$. agropyrina Eriks., were exanined from Eriks. Exs. 419 on Agropyron repens Beauv, and the uredospores measured 21-24 $\mu$ diam. or $24-27 \times 16-21 \mu$. 'The teleutospores, however', were considerably smaller than our own material, measuring only $33-12 \times 12-18 \mu$, arerage $39 \times 15 \mu$.

The following table will slow at a glance the different sizes of the spores on diflerent hosts of the two speeies of rust :-

7. ryropyrine Eriks, on Agropyron repens, Beaus. $\quad 16-2.5 \mu$ diam. 36-41 $\times 13-16 \mu$

Oredospore. Teleutospore. P. agropyri Ell \& Er. on A. scabrum, Beaur.

$2532 \times 19-2.2 \mu \quad 40-70 \times 1.2-25 \mu$

Although the uredospores are described as smooth by Ellis and Everhart yet in specimens from Sydow's Ured. Exs. 1362, they are seen to be decidedly echinulate and it is a question whether such a thing as a smooth uredospore exists among Puccinias. The species altogether is of the $P$. dispersa type. Dietel ${ }^{4}$ infected Clematis vitulba with the germinating teleutospores of this species and produced spermogonia and aecidia (A. clematidis DC.) so that it is considered to be a heteroecious species and called by Klebahn,' p. 292, Puccinia (clematidi) agropyri Ell. and Ev. It is suggestive that both stages have been found in the Murramurrangbong Ranges growing near to each other.

(Plate III., Fig. 2.5.)

\section{Puccinia agrostidis Pluw.}

Deyeuxia.

Plowright, Grev. XXT., p. 110 (1893) and Gard. Chron., p. $139(1 \leqslant 90)$.

McAlpine, Agr. Gaz. N.S. IT. TTT., p. $1+9$ (1ङ96).

Sylow, Mon. Ured. I., p. 717 (1903).

Sacc. Syll. XT., 1. 202 (189j).

II. [redosori elliptical to elongated, soon naked, linear and contluent.

Uredospores nange yellow, olliptical, funely echinulate, as many as 9 crem-poress sesn on one face, forming is circle inside epispore, $22-24 \times 17-1 \leqslant \mu$

111. Tolentosorj minute, black to dark-brown, long corered by the epirlemis, sometimes elongate, sometimes in smoups.

l'elentospores dark-hrown, smeoth, oblom or subelavate, apex

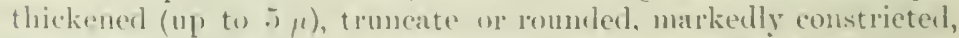
attemated below, almost sessile, very shortly stalked, $40-5 t \times$ 1.: I $\mu$, areage 4 \& $\times 18 \mu$. 
X. Mesospores fairly numerous, similarly coloured to teleutospores or lighter, oval to elongated elliptical, thickened at apex, 2t-30 $\times$ $12-14 \mu$.

On Deyenxia forsteri Kunth. = Agrostis solandri, F.v.M.

Victoria-Near Nelbourne, 1892 (Robinson). Ardmona, Oct.Dec., 1894 (Robinson). Arthur's Creek, Aug., 190.2 (Rolvinson).

New South Wales- $\left(\right.$ Cobb $\left.^{2}\right)$.

Through the kindness of Dr. Plowright, I receired some of the original material, and there is a general agreement in the spores.

Dr. Cobb has described and drawn an unnamed species of Puccinia on Deyeuxia forsteri, which undoubtedly belongs to the same speries. The teleutospores are given as $44-5 \delta \times 16-2 \cdot \mu$, but the uredospores are rather larger, being $25-30 \times 21-25 \mu$.

The life-history of this species was made out by Dr. Plowright, who found after several experimental cultures, that the teleutospores produced Aecidium aquilegiae Pers. on Aquilegia vulgaris, and that the spores of $A$. aquilegiae when applied to Agrostis alba and Pou pratensis produced the rust.

(Plate III., Fig. 27.)

36. Puccinia anthoxanthi Fckl.

Anthoxanthum.

Fuckel, Symb. Myc. II., p. 15 (1873).

MeAlpine, Agr. Gaz. N.S.TI. YTI., p. 301 (1896).

Sydow, Mon. Ured. I., p. 727 (1903).

Sacc. Syll. VII., p. 665 (1888).

II. Uredosori on both surfaces of leares, solitary or in elongated groups, elliptic or linear, confluent in lines, soon naked, pulverulent, dusky orange.

Uredospores jellowish-orange, elliptic to obovate, finely echinulate, with two to four very distinct equatorial germ-pores on one face, $25-32 \times 15-20 \mu$.

III. Teleutosori scattered, minute, dark-brown to l.lack, elliptic, naked, surrounded by r'uptured epidermis.

Teleutospores at first intermixed with uredospores, chestnutbrown, elliptic to obovate or oblong-clavate, smooth, slightly constricted, rounded and thickened $(6 \mu)$ at apex, occasionally tricellular, $28-48 \times 15-21 \mu$, average $35 \times 20$; upper cell usually darker than lower; perlicel persistent, tinted, $20-25 \times 6-7 \mu$, sometimes reaching a breadth of $10 \mu$.

X. Mesospores occasional, similarly coloured to teleutospores, obovate, thickened at apex, average $3 \tilde{5} \times 17 \mu$.

On sheath, flag and intloresceuce of Anthoxanthum odoratum L.

Victoria-Near Melbourne, Dec., 1896, II. Rutherglen, Dec., 1903, II., III. Leongatha, Feb., 1904., II.

The teleutospores were not very common. In my own garden, near Melbourne, the uredo-stage was plentiful, but no teleutospores were found, while at Rutherglen the teleuto-stage occurred on several specimens.

(Plate III., Figs. 20, 21.) 


\section{:7. Puccinia beckmanniae McAlp.}

Beckmannia.

II. Uredosori on both surfaces of leaf, but most common on under, orange, elliptic, often confluent in lines, erumpent and surrounded by ruptured epiclermis.

Ureclospores orange, elliptic, echinulate, with 3 to 4 equatorial grerm pores on one face, $25-29 \times 16-19 \mu$.

III. Teleutosori minute, black, linear, hypophyllous, long covered by epidermis, ultimately naked, about $1 \frac{1}{2} \mathrm{~mm}$. long.

Telentospores yellowish-lorown, elongated clavate, not or only slightly constricted at septum, upper cell generally darker than lower and with numerous (up to $T$ ) finger like processes, $45-60 \times 16-25 \mu$, average $56 \times 18$; pedicel very short or alssent.

X. Mesospores brown, ublong to elongated elliptical, thickened at apex, and either bare or with short stumpy processes, $32-35 \times 13-16 \mu$.

On Beckmaniria erucaeformis Host.

Victoria-Leongatha, February, March, 1904, II., IIT.

Only uredospores were met with in February, but by March the teleutospores had developed. There is a general agreenent with $P$. lolii, but the upper cell of teleutospore is generally broader.

The griss on which this rust was found was grown from seed sent by the United States Department of Agriculture for trial, and the spores must have been imported with the seed. Holway informs me that he has collected it in the State of Minnesota, and kindly forwarded me a specimen.

Darluca filum Cast., was very plentiful, both by itself and in conjunction with the rust. Probably in the former case it was parasitic on the hidden mycelium, and may have largely prevented spore formation.

(Plate II., Fig. 1.?.)

3s. Puccinia bromina Eriks.

Bromus.

Erikssun, Ann. Sci. Nat. 1... 1. 27l (1\$99).

Sirlow, Mlon. Ured. I., p. 7 I: (190:3).

Sace. Syll. IVII., p. 3ะ.2 (1905).

I'uccinia disperse, t. sp. bromi, Eriki.

II. Tredesuri $1-10 \mathrm{~mm}$. longr, 1mm. broad, ferruginous, wn leaf blade chiefly on upper surface, crowded, sometimes on sheath aud panicile.

Ureduspores bright oranere, ellipsoid, with numerous scattered serm-prores, as many as 11 on one tace, echinulate, $27-31 \times$ $15-24 \mu$.

11I. 'J'elentosori elongited elliptical to coblong, black to dark-brown, lyypophyllous, scattered or suberesarions, sometimes on sheath and panicle, covered by epidermis, divided into compartments, and anch compartment separated hy elongated, eylindric, or slightly clavate, yellowish-brown, barren filaments or paraplyses. 
Teleutospores oblong to clavate, dark chestnut-brown, constricted at septum, rounded or truncate at apex and slightly thiekened, $40-56 \times 18-24 \mu$, average ts $\times 21 \mu$; lower cell generally narrower than and almost as dark as upper; pedicel short, hyaline to pale yellowish, up to $36 \mu$ long.

I. Mesospores comparatively rare, dark chestnut-brown like teleutospores, clarate, oral or oblong, rounded or truncate and slightly thickened at apex, base sometimes attenuated, $28-36 \times 16-21 \mu$.

On Bromus mollis $\mathrm{L}$.

Victoria-Nalinga, Nov, 189s (Robinson). Kergunyah, Nov., 1902, Dec., 1903, and Jan., 1905 (Robinson). Domain, Melbourne, Dec., 1904, II., III., the latter very plentiful.

Nagambie, Nor., 1904.

New South Wales-1890 (Cobb²).

On Bromus urenarius Labill.

Victoria-Murray River.

The specimen of $B$, arenarius in the National Herbarium attacked by an Ustilago and numbered Berkeley 202, also shows this rust, which, however, was overlooked. It is interesting as probably indicating that this is a native rust, although it also occurs on the imported $B$. mollis.

Three-celled telentospores are occasionally met with, sometimes owing to the upper cell being divided rertically, but more frequently there are two transverse septa instead of one.

Specimens were examined from Eriksson's Fung. Paras. Scand., Exs. 420, and the uredospores measured $20-25 \times 1 \jmath-20 \mu$, thus being rather smaller than the above. The teleutospores were much paler in colour, and measured $36-48 \times 15-22 \mu$, the largest being about the average of the Tictorian specimens.

Fritz-MIuller ${ }^{1}$ observed aecidia on Symphytum officinale L. and Pulmonaria montana Lej., and by infection with the aecidiospores produced the rust on Bromus. He therefore named it Puccinia symphyti bromorum.

$$
\text { (Plate III., Fig. 2s ; Plate C., Figs. 11-13.) }
$$

39. Puccinia cacao McAlp.

Rottboellice.

Credo rotthoellice Dietel, Engler's Bot. Jahrb. XXXII., p. 52 (1902).

Sori on both surfaces of leaves but mostly on under, scattered or in small groups, minute, elliptical, bullate, lons covered br epidermis, about $\frac{1}{2}$ mm. long.

II. Uredospores brownish or chocolate brown, elliptic to ovoid or oblong, with distinct germ-pores, generally three equatorial on one face or may be scattered, epispore thin, dark-coloured, finely echinulate, $32-40 \times 2+-32 \mu$, average $35 \times 28 \mu$.

III. Teleutospores intermixed with uredospores, sparse, somewhat paler, oblong, smooth, rounded or flattened and unthickened at apex, slightly constricter at septum, 32-35 $\times 21-22 \mu$; lower cell tapering slight]y towards base and generally about equal in size to upper : pedicel hyaline, deciduous. 
On leares and sheaths of Rouloellia conpressa $\mathrm{L}$.

Victoria-Creswick, Jan., 1893, II. (Robinson), Werribee Gorge, Dec., 1902, IT. Killara, March, 1903, II., III. (Robinson). Kergunyal, Dec., 1903, II. (Robinson). Near Melbourne, Nov, and Jan., 1904. Various other localities.

Queensland-TT. (Bailey ${ }^{17}$ ).

The Queensland specimen is labelled Puccinia straminis DeBary.

The clocolate-brown colour of the uredospores is very characteristic. The uredo-stage of this species was first described by Dietel on a specimen from Japan; on sending him some of our material he agreed that it was the same. Sydow in his Monograph (p. 800) has described a Puccinia on $R$. arundinacea with teleutospores alone, which however do not agree with these, being thickened at the apex up to $10 \mu$ and $34-56 \times 22-27 \mu$ in size.

The uredosori frequently look quite black owing to the presence of Darluca filum Cast.

(Plate XXX., Figs. 259, 260.)

40. Puccinia cynodontis Desm.

Cynodon.

Desmazieres Exsice. IIT., No. 65.5.

McAlpine, Agr. Gaz. N.S.W. VIL., p. 150 (1896).

Sydow, Mon. Ured. I., 1) T48 (1903).

Sace. Syll. VII., p. 661 (1888).

P. alterc McAlp., Agr. Gaz. N.S. W. VII., p. 151 (1896).

II. Uredo-sor'i on both surfaces, minute, ellipsoid to lenticular, scattered or confluent, yellowish-brown to rusty-brown, soon naked, compact.

Uredospores globose to shortly eiliptical, yellowish-brown to Jrownish-yellow, delicately verrucose, $20-25 \mu$ diam., or $20-25 \times$ $17-22 \mu$.

III. Teleutosori roundish to ellipsoid or oblong, seattered or confluent, pulvinate, black.

Telentospores intermixed with uredospores, variously shaped, ellipsoid or oblong, smooth, chestnut-hrown, slightly constricted at septum, occasionally tricellular, $30-50 \times 15-21$, average $35 \times$ $2.1 \mu$; upper cell thickenerl at apex and generally elongated pointed, sometimes rounderl; lower cell rounded at base or attenuated; pedicel firm, fale yellow, persistent, elongated up to $73 \mu$.

X. Mesospores plentiful, dark-brown, ellipsoid, rounded and thickened at apex, $2 t \times 19 \mu$.

On Cynodon dactylom Pers.

Victorin-Burnley, Caulfield, Armadale, Pakenlam, Killara, Somerville, ic., Oet.-March.

On some plants the teleutwpores were of a rery regular ellipsoid shape, and rounded and thickened at apex, so that it was at first thought there were two specins on the same plant. 13ut on examining a number of specimens every gralation was found from the teleutospore, rather constant. in si\% and slape with lomuled apex, to those nexessarily longer on which the thickened apex was somewhat eonieal. 
It was likewise found by Magnus ${ }^{5}$ that two kinds of uredospores occur, the one thin-walled with numerous (up to 9) germ-pores and echinulate, while the other is thick walled, with few (1-3) germ-pores and either smooth or only with a few scatterel spines. There were transition forms between the two, and this shows how rariable a description might be according to the nature of the spores regarded as typical.

(Plate III., Fig. 24.)

41. Puccinia festucae Plow.

F'estuca.

Plowright in Gard. Chron., p. 42 (1890) and Grev. XXI., p. 109 (1893).

Sydow, Mon. Ured. I., p. 752 (1903).

Sacc. Syll. XI., p. 194 (1895).

II. Uredosori mostly on under surface of leaf, but generally present on upper as well, causing conspicuous yellow spots on upper surface, minute, oblong to elliptic, scattered or confluent, orangeyellow.

Uredospores sub-globose to ellipsoid, echinuiate, yellowish to orange-yellow, up to 5 scattered germ-spores on one face, $20-25 \times$ $16-18 \mu$.

III. Teleutosori mostly on under surface of leaf, minute, seattered or often in groups and confluent, oblong to linear, brownish-black.

Teleutospores at first intermixed with uredospores, clavate to cylindrical, brown, smooth, slightly constricted at septum, generally tapering towards base, $40-60 \times 15-20 \mu$, often $60 \times 16 \mu$; npper cell more or less truncate and thickened at apex, surmounted by a crown of 4-6 obtuse, straight or curved, sometimes bificl processes; lower cell generally elongated wedge-shaped; pedicels persistent, brown, stout, $15-25 \mu$ long.

$\mathrm{X}$. Mesospores very common, similarly coloured to teleutospores, clavate to cylindrical to somewhat oblong, thickened at apex and surmounted by processes, $31-46 \times 11-14 \mu$.

On Festuca ovina L.

Victoria-Leongatha, July, 1903, II. III.

On $F$. rigida Kunth.

Victoria-Rutherglen, Nov., 1895, II.

In 1890 Plowright experimentally proved that the aecidium on Honeysuckle (Lonicera) was genetically connected with this species, and it has since been repeatedly proved by Fischer and Klebahn.

(Plate IT., Fig. 13.)

42. Puccinia flavescentis MIcAlp.

Stipa.

IcAlpine, Proc. Linn. Soc. N.S.W., XXVIII., p. 558 (1903).

Sacc. Syll. XVII., p. 380 (1905).

II. Uredosori on upper surface of leaf, minute, linear, often confluent, soon naked, pulverulent, rusty lorown, arranged along furrows of leaf. 
Uredospores globose to shortly elliptical, finely echinulate, golden-brown, with at least 5 germ-pores irregularly distributed, $21-24 \mu$ diam. or $25-32 \times 21-24 \mu$.

III. Teleutosori minute, elliptical, numerous, black, often confluent lengthwise, soon naked.

'Teleutospores intermixed with uredospores, dark chestnut brown, oblong, constrieted at septum, with rounded and thickened apex (up to $9 \mu$ ), smooth, occasionally tricellular, $33-48 \times 18-26 \mu$, average $4 t \times 2+\mu$; upper cell generally hemispherieal, and about equal in length to lower; lower cell generally rounded at base, sometimes narrowed and elongated like upper portion of pedicel; pedicel persistent, tinted, elongated, up to $72 \mu$ long.

X. Mesospores common, similarly coloured to teleutospores, elongated ellipsoid, rounded or truncate anr thickened at apex, smooth, $34-43 \times 12-15 \mu$.

On Stipa flovescens Labill.

Victoria-Near Melbourne, Dec-April, II., III.

On stipa semibrerbata R. Br.

Victoria-Nagambie, Nov., 1904, II., TII.

The pulverulent uredosori, and the numerous minute, black teleutosori are characteristic of this species. The uredospores form a rusty powder over entire upper surface of leaf. The pedicel of the teleutospore is sometimes lateral and the septum ereet as in Diorchilium. It differs from 1'. stipae Arthur, in the uredosori being soon naked and decidedly ruddy.brown, not vellowish, while the uredospores are broader.

Tn specimens of $I^{\prime}$ stipae (Op.) Hora, taken from Syd. Ured. Exs. No. 28, on Stipa capillata I., the teleutospores are decidedly different. The upex is generally bluntly pointerl, and the size $48-5 t \times 18-21 \mu$. In specimens of $P$. stipree Arth., from Arthur and Holway's Ured. Exs. No. 27, on Stipa spartea Trin., the teleutospores are more pointed at the apex and rather thicker.

I have submitted specimens to Prof. J. C. Arthur, and he remarks that it is clearly distinct from his species, although there is very much similarity between the two, as one might expeet, from the hosts being essentially alike.

(Plate II., Fig. 17.)

\section{Puccinia graminis Pers.}

Gramineae.

Persoon, Disp. Meth., p. 39 (1797).

Cooke, Haudb. Austr. F’ung., p. 335 (1892).

Sydow, Mon. Ured. I., 1. 6922 (1903).

sice. syll. VII., 1. 622 (1888).

II. Urerlosori amphigenous, vellowish-brown, linear, 2-3 mm. or longer, either scittererl or contluent in long streaks, especially on sheaths, pulverulent, soun naked, surrounded by ruptured epidermis. 
Uredospores elongated cllipsoid to ovate oblong, brownish yellow, echinulate, generally with 3-4 equatorial germ-pores on one face, $20-36 \times 14-18 \mu$.

III. Teleutosori sparingly on leaf-blades, more commonly on sheaths stalks and inflorescence, linear, elongated, pulvinate, often confluent, up to $10 \mathrm{~mm}$. or more, dark brown to dense black, soon rupturing epidermis which is prominent.

Teleutospores clavate to oblong clavate, chestnut brown, smooth, somewhat constricted at septum, very rarely three-celled, 35-63 $\times 14-25 \mu$, average $52 \times 18 \mu$; upper cell rounded or pointed at apex, rarely truncate, considerably thickened (up to $12 \mu$ ), sometimes as broad as long, 21-29 $\mu$ long; lower cell attenuated towards base, equal to or longer than upper, 18-35 $\mu$ long; pedicel persistent, elongated, tinted, and sometimes as deeply coloured as spore, of equal thickness throughout, up to $73 \times 8 \mu$.

X. Mesospores very common, intermixed in the same sorus with uredo and teleutospores, similarly coloured, dark chestnut or paler, oblong to elongated ellipsoid, generally slender, rounded, pointed or truncated apex and thickened like teleutospore, smooth, 34-46 × 10 I.5 $\mu$; pedicel generally short or of moderate length. Occasionally an obovate form occurs, deeply coloured, rounded and thickened at apex and much broader than usual, up to $22 \mu$, with elongated pedicel.

On Wheat (Triticum vulgare Vill.), Polish Wheat ( $T$. polonicum L.), Oats (Avena sativa L.), Barley (IIordenm vulgare L.), Rye (Secale cereale L.), and rarious species of the following genera of Grasses:-Agropyron, Alopecurus, Amphibromus, Avena, Beckmanicia, Briza, Bromus, Dactylis, Deyeuxia, Echinopogon, Elymus, Festuca, Glyceria, Hordeum, Phalaris, Poa.

Common in all the States.

Occasionally I have seen a uredospore with a slight indentation on either side, just where the circle of germ-pores occurs, but never any indications of a septum. The range of variation in the size of the teleutospores is great. It may vary from $35 \times 25 \mu$ in the oblong, dark-brown, perfectly mature spore to $63 \mu$, long, and sometimes only $14 \mu$ broad in elongated clavate spores in the same sorus.

The spore itself may be colourless, while the brown colouration is in the pedicel, and this has previously bcen observed by Dr. Plowright in Australian specimens ; or the upper cell only may be pale in colour as shown in Plate I., Fig. \&, which is from abnormal material met with on one occasion.

There are no paraphyses, but there are numerous mesospores elosely resembling teleutospores, but only one-celled.

Darluce filum Cast., sometimes common on the uredosori, particularly on Wild Oat (Avence fatua) and (rlyceria stricta. It has also been found on Agropyron scabrum, and Dr. Cobb "s evidently mistook its true nature, for he say's :- "Among its red-rust spots there are certain black bodies which may constitute a fourth spore of the rust."

The following is a complete list of all the grasses and cereals on which I have found Puccinia graminis Pers. This determination of the fungus has been based on morphological characters alone, for I have not ret succeeded in infecting the Barberry. Those malked with an * are also recorded by 
other authors, and a double asterisk indicates those which have been found by Eriksson in Europe to produce aecidia on the Barberry when their spores were sown upon it:-

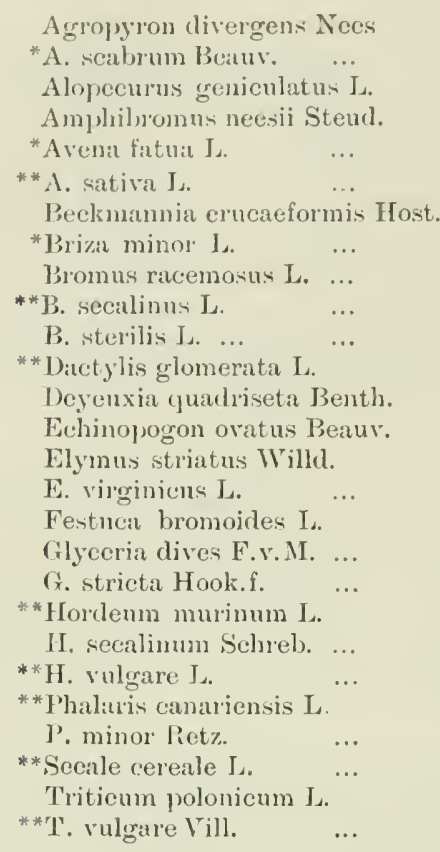

$\begin{array}{llll}\ldots & . . & \ldots & \text { II., III. } \\ \ldots & \ldots & \ldots & \text { II., III. } \\ \ldots & \ldots & \ldots & \text { II. } \\ \ldots & \ldots & \ldots & \text { II., III. } \\ \ldots & \ldots & \ldots & \text { II., III. } \\ \ldots & \ldots & \ldots & \text { II., III. } \\ & \ldots & \ldots & \text { II, III. } \\ \ldots & \ldots & \ldots & \text { II. } \\ \ldots & \ldots & \ldots & \text { II. } \\ \ldots & \ldots & \ldots & \text { II. } \\ \ldots & \ldots & \ldots & \text { II., III. } \\ \ldots & \ldots & \ldots & \text { II., III. } \\ \ldots & \ldots & \ldots & \text { II., III. } \\ \ldots & \ldots & \ldots & \text { II., III. } \\ \ldots & \ldots & \ldots & \text { II. } \\ \ldots & \ldots & \ldots & \text { II., III. } \\ \ldots & \ldots & \ldots & \text { II., III. } \\ \ldots & \ldots & \ldots & \text { II., III. } \\ \ldots & \ldots & \ldots & \text { II. } \\ \cdots & \ldots & \ldots & \text { II., III. } \\ \ldots & \ldots & \ldots & \text { II., III. } \\ \ldots & \ldots & \ldots & \text { II., III. } \\ \ldots & \ldots & \ldots & \text { II., III. } \\ \ldots & \ldots & \ldots & \text { II., III. } \\ \ldots & \ldots & \ldots & \text { II., III. } \\ \ldots & \ldots & \ldots & \text { II., III. } \\ \ldots & \ldots & \ldots & \text { II., III. }\end{array}$

While I'. yraminis has been found on the above grasses, it must not be assumed that the one will aflect the other if growing alongside of each other. It used to be considered that the same species would attack indiscriminately any of its hosts, but it has now been proved that a selection or specialisation goes on, and that the same morphological species living on different hosts is not identical in the sense of affecting all alike. By means of infection experiments with uredospores and aecidiospores obtained from definite teleutospores, liriksson arrived at this result, that $P$. graminis resolved itself into a series of specialised forms, each of which was confined to a definite and circumserihed series of host-plants.

As the result of experiments so far, six biologically distinct forms are constituted :-
1. Secalis-On Rye.
2 . Arenae-On Oat.
3. 'Tritici-On Wheat.
4. Airae-On Aira.
5. Agrostirlis-Un Agrostis.
6. P'oate-On Pual.

When time and opportunity offer, I hope to eary out experiments to determine how far the rustis of the $P$. yraminis type on the various grasses are capable of infecting each other.

(Plates I., Figs. 2, 5. 7, 8; XIV., Figs. 113-12.2 ; XI., Fig. 301 ; XIIIT., Fig. 311 ; Plate A., Figs. 3, 4.) 
44. Puccinia impatientis (Schw.) Arthur.

Elymus.

Arthur, Bot. Gaz. XXXV., p. 19 (1903).

Sydow, Mon. Ured. I., p. 751 (1903).

Aecidium impatientis Schw.

II. Uredosori epiphyllous and occasionally hypophyllous, scattered or arranged in lines and confluent, oblong, $1-1 \frac{1}{2} \mathrm{~mm}$. long, pulvinate, erumpent, powdery, reddish-brown.

Uredospores bright orange, subglobose or ellipsoid, finely echinulate, up to six scattered germ-pores on one face, $2 \tilde{5}-33 \times$ $18-23 \mu$.

III. Teleutosori hypophyllous, greyish-black, pulvinate, long covered by epidermis, densely crowded, linear, often confluent and arranged in lines between the reins, with dark-brown paraphyses in clusters.

Teleutospores brownish, oblong to oblong-clavate, smooth, slightly constricted at septum, 35-55 $516-22 \mu$, average $40 \times 16 \mu$; upper cell rounded or truncate, and thickened at apex $(3-5 \mu)$; lower cell generally paler in colour, and rounded or attenuated at base; pedicel very short, hyaline or tinted, but dark-brown at apex.

X. Mesospores not uncommon, pale brown, slightly thickened at apex, elongated, oblong, or obovoid, 29-35 $\times 12-17 \mu$.

On living leaves of Elymus condensatus Presl.

Victoria-Rutherglen, Dec., 1903.

The seed of this grass was obtained from the United States, and the rust was doubtless imported with it.

Arthur sowed germinating teleutospores from Elymus virginicus L. on Impatiens aurea Muhl., and in fifteen days aecidia were produced. This lesult was confirmed in the succeeding year.

Specimens on E. virginicus, from Iowa, in Syclow's Ured. Exs. 1380, are labelled Puccinia rubigovera (DC.) Wint., and agree with this species.

There is another Puccinia on the same host plant (P. mocera Diet. and Holw.), and according to the description it is quite distinct. The uredospores are $32-45 \times 30-35 \mu$ and the teleutospores $45-100 \mu$ long.

$P$. montanensis Ellis also differs in the teleutospores being stouter and ${ }^{\circ}$ broader, sometimes reaching a breadth of $26 \mu$.

(Plate III., Fig. 26.)

45. Puccinia lolii Niels.

Lolium.

Nielsen in Ugeskrift for Landmaend. I., p. כ 49 (1875).

Sydow, Mon. Ured. I., p. 704 (1903).

Sacc. Syll. XI., p. 203 (1895).

P. coronifera Klebahn, Zeitschr. f. Pflanzenk. II., p. 340 (1892).

II Uredosori on upper and under surfaces of leaves, forming blisterlike swellings, oval or linear, orange, soon bursting through epidermis, pulverulent, often confluent, sometimes up to $2 \mathrm{~mm}$. long. 
Uredospores orange yellow, subglolose, ovate or broadly elliptic, strongly echinulate, with 2-3 equatorial germ-pores on one face, $20-30 \times 16-2+\mu$; occisionally a few colourless capitate parapliyses intermixed.

III. Teleutosori on both surfaces of lenves, minute, black, linear or oblong, often confluent, long covered by epidermis, $\frac{1}{2}-1 \mathrm{~mm}$. long.

Telcutospores yellowish-brown to brown, clongated clavate, tapering towards base, smooth, constriction very slight or absent, sometimes unicellular, $35-60 \times 12-20 \mu$, average $53 \times 16 \mu$; upper cell brown, truncate, thickened at apex, giving off irregular, blunt, generally curved processes variable in size and shape, averaging 6 to $\bar{T}$ or more; lower cell generally paler in colour, longer than upper, and attenuated towards base; pedicel persistent, coloured, short, stout, up to $I 1 \mu$ long by $\delta \mu$ broad.

X. Mesospores exactly resembling teleutospores only one-eelled.

On stem, leaf, and inflorescence of Lolium perenne $\mathrm{L}$. Common.

Victoria-Near Melbourne, Myrniong, Port Fairy, dc., Aug.-May. South Australia-Mount Gambier, April, I903, II., III.

The teleutospores may he found as early as September, and through the summer and autumn.

In some districts this rust is very severe and kills the grass down to the roots, expecially if there are early atutumn rains and warm weather.

Darluca filum Cast., on uredosori.

\section{Puccinia lolii avenae.}

On Avena sativa L., and Avena futua $\mathrm{L}$.

Victoria-Port Fairy, Dec. 1903, and Sept.-Nov, 1904, II., III. Brighton, Jan, 1904, II., III. Myrniong, Nov., 1904, 1 . Near Melboume, Jan., ]905, II., III.

New South Wales-(Cobb:2).

Eriksson has shown that the form occurring on Lolium will not infect Avena, nor the reverse, so that there are two biologic forms, and that found on the Oat may be distinguished as 1'. lolii arenae.

This species may uccur alongside of 1 '. graminis, and the teleutosori were found togrether on the sheath of the cultivated oat. A. sativa, and the wild oat, A. future.

The teleutospores on the wild ont are sometimes very much longer than the normal. They rauge from 70 to $\& 6 \mu$ in length, and from $18-22 \mu$ in breadth at the apex, and $7-8 \tilde{\mu}$ at the base.

By infection experinents Klebahn² proved the connexion between this rust, and the aecidium on lihamens firmgula $\mathrm{L}_{\text {., }}$, but this genus does not oceur naturally in Australia.

I'. cononatu Corda, was the name originally given to the species oceurring on Lolinm prienne, frenu sutive, de, with teleutuspores surmounted by is crown of finger-like processes. It was found by culture experinents that the aceidinl stage was produced on species of hhamms, and Klebahn deterrmincel that the spores from some species of grasses produced aecidiat rxelusively on Rhemmus cotherticen, while others diel so exelusively an li. fientulue. This showed a biologrieal distinction between the two, and Klebahn proposed the name of $l$ '. coronifier for the rust producing aecidia 
on Rhamnus cathartica, while the original name was retained for the rust producing its aecidia on Rhammus frangula. Nielsen had previously used the name of $P$. lolii for Klebahn's species, and so it is retained on the score of priority.

(Plate II., Figs. 11, 14 ; Plate XXX., Fig. 261 ; Plate B., Figs. 5-8.)

46. Puccinia magnusiana Koern.

Phragmites.

Koernicke, Hedw. XT., p. 179 (1ธ76).

Sydow, Mon. Ured. I., p. 785 (190 ).

Sacc. Syll. VII., p. 631 (1880).

II. Uredosori on both surfaces of leaf, but mostly on upper, snuffy brown, erumpent, surrounded by ruptured epidermis, elliptic or linear, confluent lengthwise and forming long streaks, with clavate bright yellow paraphyses.

Uredospores elliptic or obovate, golden yellow, echinulate, with four equatorial germ-pores, $2+-35 \times 16-19 \mu$; intermixed with large numbers of clavate paraphyses, club thickened at apex, of a dark smoky-brown and stalk hyaline, commonly 80-90 $\mu$ long.

III. Teleutosori minute, black, very numerous, scattered, elliptic or linear, confluent into long black streaks on both surfaces of leaf, but mostly on upper, occasionally paraphysate as in uredosori.

Teleutospores clavate to oblong, dark chestnut-brown, generally rounded and thickened at apex (up to 12 $\mu$ ), sometimes bluntly pointed, hardly constricted at septum, 35-55 × 14-21 $\mu$, average $38 \times 18 \mu$; lower cell attenuated towards base; pedicels firm, persistent, coloured rellowish, about length of spore or longer, up to $70 \mu$.

$\mathbf{X}$. Mesospores similarly coloured to teleutospores, variable in shape, somewhat ovoid to elongated, thickened at apex, $28-38 \times 1: 3-19 \mu$.

On Phragmites communis Trin.

T'ictoria_-Orbost, Aug., 1901 (Pescott). Flinders, Jan., 1902.

Port Fairy, June-Aug., 1902 and 1905. Killara, March,

1903. Bunyip, May, 1904.

South Australia-The Grange, April, 1891 (Tepper). River Torrens, Adelaide, Apr., 1903 (Tepper).

Tasmania-( (Rodway $\left.{ }^{1}\right)$.

The clavate paraphyses are usnally described as hyaline, but Dr. Dietel compared the Australian specimens with intense dark-brown paraphyses with material from Europe, America, and the Cape of Good Hope, and he found that the latter were sometimes scarcely coloured, at other times light or dark brown.

The rust on Phragmites communis Trin., was considered as one species up to 1876 , viz., Puccinia phragmitis Schum. Then Koernicke separated it into two, riz., P. phragmitis and $P$. magnusiana. The former was characterized by the absence of paraphyses from the uredosori, the large bullate teleutosori and the very long stalked markedly constricted teleutospores, while the latter had numerous clavate paraphyses in the uredosori, minute, punctiform or linear teleutosori, and shortly stalked, hardly constricted teleutospores. The aecidia in the two cases likewise occurred on different hosts. 
Subsequent research showed that there were still other species on the same host-plant. Plowright separated a third species in 1888, mainly based upon the fact that the aecidiospores were only produced upon Rumex acetosa and not upon other plants. Next, Ludwig in 1892 distinguished another new rust on material sent from South Australia, viz., P. tepperi. Finally, Arthur in 1902 published another new species which he named $I$ '. simillima. because it was very similar to $l^{\prime}$. magnusiana.

There are thus at least five different species of Puccinia recorded upon Phragmites communis, and it is not always easy to differentiate them, at least by morphological characters. In three of them the aecidiospores were proved to occur on different host-plants by a series of cultures, and this is considered by many a sufficient specific distinction. On these grounds they would be considered biological species as in the case of Puccinias on various. cereals and grasses, but at the same time an attempt will be made here to show any points in which they differ morphologically. Only two of the five have hitherto been found in Australia, viz., $P$. magnusiana and $P$. tepperi, for although Dr. Cooke gives $P$. phragmitis in his IIandbook of Australian Fungi, it was probably intenderl for $P$. magnusiana, which has been found in Victoria and South Australia.

The life-history of this fungus was first determined by Dr. Plowright, 5 who found that the promycelial spores produced aecidia on Ranunculus repens and $R$. bulbosa, and conversely the aecidiospores produced uredospores and teleutospores on Phragmites. This was afterwards confirmed by Fischer' and Klebahn.'

The five species may be arranged according to their aecidial hosts where known, as in the following table with their special characteristics shown:-

\begin{tabular}{|c|c|c|c|c|}
\hline $\begin{array}{l}\text { Rumex sp. and } \\
\text { Rhem. }\end{array}$ & $\begin{array}{l}\text { Rumex acetosa. } \\
\text { losori without paraph }\end{array}$ & ises. & $\begin{array}{c}\text { Ranunculus repens } \\
\text { and R. bulbosa. } \\
\text { Credosori wit }\end{array}$ & $\begin{array}{l}\text { Anemone dichotoma. } \\
\text { th paraphyses. }\end{array}$ \\
\hline P. phragmitis. & P. trailii. & P. tepperi. & P. masnusiana. & P. simillima. \\
\hline $\begin{array}{l}\text { Uledospores, } \\
2.5-35 \times 1.5-23 \mu \\
\text { Teleutospores. }\end{array}$ & $2.5-3.5 \times 20-25 \mu$ & $27-30 \times 20-23 \mu$ & $24-35 \times 16-19 \mu$ & $26-44 \times 18-22 \mu$ \\
\hline $\begin{array}{l}4 \overline{3}-6 . \overline{5} \times \text { y } 6-2.5 \mu \\
\text { markedly con- } \\
\text { stricted }\end{array}$ & $\begin{array}{l}50-60 \times 20-23 \mu \\
\text { markedly con- } \\
\text { stricted }\end{array}$ & $\begin{array}{l}45-68 \times 18-26 \mu \\
\text { markedly con- } \\
\text { stricted }\end{array}$ & $\begin{array}{l}3.5-5.5 \times 14-21 \mu \\
\text { lardly con- } \\
\text { stricted }\end{array}$ & $\begin{array}{l}42-56 \times 15-2016 \\
\text { hardly } \\
\text { stricted }\end{array}$ \\
\hline $\begin{array}{l}\text { Ferlicels, } \\
\qquad 1.50-210 \mu \text { long }\end{array}$ & $7.5-100 \mu$ long & $180-250 \mu$ long & $\begin{array}{l}\text { About lengtli of } \\
\text { spore }\end{array}$ & $\begin{array}{l}\text { About length of } \\
\text { spore }\end{array}$ \\
\hline
\end{tabular}

It will be seen from the above that there are two types clearly distinguishable morphologically, paraphysate and aparaphysate, and within these limits there are only "biological species" based upon a difference of aeciclial host.

If we compare $P$. Iratii with $P$. phragmitis, the teleutospores differ in having a granular spore-membranc, and shorter and stouter pedicels. If is

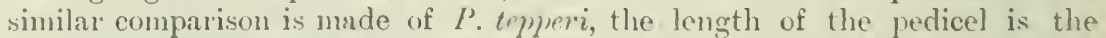
striking feature, and it is, perhaps, rather premature to separate it from I'. Juragmitis until a distinct accidial host has been proved.

According to Arthur, $P$ '. simillima is distinguished from $P$. magnusians in the slender pointed telentospores, the more elavate and less roughened uredospores and the probably diflerent accidial host, viz., Anemone dichotoma Is 
47. Puccinia maydis Bereng.

Zea

Bereng., Atti VI., Rium. sc. ital., Milano, p. 475 (1844).

Cooke, Handb. Austr. Fung., p. 337 (1892).

Sydow, Mon. Ured. I., p. 830 (1904).

Sacc. Syll. VII., p. 659 (1888).

Puccinia sorghi (in part) Schweinitz, $\mathrm{N}$ Amer. Fung., p. 295, (1831).

II. Uredosori amphigenous, elliptic or oblong, scattered or united into larger or smaller groups, here and there confluent, rather convex, soon erumpent from the longitudinal fissure of the cuticle, reddish-brown.

Uredospores ellipsoid or obovate, slightly warted, at first yellowish then reddish brown, with two to three equatorial germpores on one face, $23-38 \times 20-26 \mu$.

III. Teleutosori amphigenous, scattered or subgregarious, variable in form, mostly linear or oblong, long covered by epidermis, prominent, very black, $1-2 \mathrm{~mm}$. long.

Teleutospores obovate to oblong or subclavate, bright chestnut brown, smooth, constricted at septum, rounded or conoid and thickened at apex (up to $\& \mu$ ), sometimes truncate, roundated, base and rarely somewhat attenuated, occasionally 3 or 4 celled, $32-52 \times 16-24 \mu$, average $36 \times 20 \mu$; upper cell rarely vertically divided; epispore thick; pedicels persistent, elongated, yellowish, thickened particularly towards apex, up to $90 \mu$ long.

X. Mesospores occasional, similarly coloured to teleutospores, ovoid, rounded at both ends, thickened at apex, average $35 \times 17 \mu$.

On leaves of Zea mays L.

Victoria.-Seville, April, 189 `, II. (Hill). Tally Ho, April, 1902, IT. (Cronin). Leongatha, March, 1904, II. Near Melbourne, April, 1904, II., III.

New South Wales.-Richmond (Cobb).

Queensland.-Toowoomba, 1887 (Tryon $\left.^{1}\right)$, (Bailey $\left.{ }^{1}, 5\right)$.

Schweinitz considered that the same rust occurred on sorghum and maize to which he gave the name of $P$. sorghi, but since they are now found to be distinct Sydow in his Monograph has reserved the above name for this one.

Arthur ${ }^{4}$ inoculeted maize plants with uredospores from an aecidium on Oxalis cymosa Small, and in five days uredosori appeared in abundance. The Oxalis is supposed to have been inoculated from the telentospores of $P$. maydis, but this infection has still to be verified.

Darluca filum Cast., occur's on the uredosori.

(Plate II., Figs. 15, 16 ; Plate C., Figs. 14, 15.)

Alopecurus.

48. Puccinia perplexans Plow.

Plowright, Quart. Journ. Micro. Sc. XXT., p. $16 \pm$ (1885).

Sydow, Mon. Ured. I., p. 719 (1903).

Sacc. Syll. VII., p. 632 (1888).

II. Uredosori amphigenous and on sheath, orange, elliptic, rupturing epidermis and often confluent in lines. 
Lrerlospores orange-yellow, subglobose to clliptic, finely echinnlate, with 4-6 scattered germ-pores on one face, $25-29 \times 19-22 \mu$.

I[I. Teleutosori amphigenous and on sheath, eovered by leadencoloured epilermis, at first minute, linear, then confluent in very lonis lines and even forming patches.

Teleutuspores variable in shape, clavate to oblong, constricted at septum, brown, upper eell darker than lower, rounded or truncate at apex and slightly thickened, lower cell attenuater towards base ol rounderl, 35-52 $516-24 \mu$, average $37 \times 17 \mu$; pedicel short, hyaline, may reach a lengtli of $20 \mu$.

X. Mesospores common, similarly coloured to teleutuspores, slightly thickened at apex, elliptic to orate or pear-shalped, $25-32 \dot{0}$ $16-21 \mu$.

On Alopecurus geniculutus $\mathrm{L}$.

Victoria-Minyi]), Nov, 1903 (Eckert).

Among these plants one was badly rusted with the uredospores of I'uccinia gramizis but no trace of the teleutospores of that fungus was found, although all the specimens were growing together.

Plowright in a series of more than thirty cultures worked out the lifelistory of this fungus and showed the genetic connexion between the aecidium on Ranunculus acris and this species, which was afterwards confirmed by Dietel and Klebahn.

(Plate 1J., Fig. 23.)

\section{Puccinia poarum Niels.}

Puce.

Niclsen, Bot. Tids. II., p. 으 (18T6).

Cooke, Handb. Austr. Fung., p. 336 (1892).

Sydow, Mon. Ured. I., p. 795 (1904).

Sace. Syll. VII., p. 625 (1888).

II. Uredosori small, round or elliptical, scattered or aggregated together, orange-yellow or foxy-red.

Uredospores shortly elliptical, finely echinulate, orange-yellow, $21-2 t \times 15-18 \mu$, seated on hyaline pedicels up to $30 \mu$ long, and internixed with numerous, stiff, capitate paraphyses, reaching a length of 68 .

IIT. 'Teleutosori small or large, scattered or orbicularly disposed, (lark-b)own to black, covered by the epidermis.

'T'eleutospores elliptical or subclavate, very variable, apex truncate, rounded or conical, thickened ( $4-5 \%$ ), dark-brown, smooth, not or hardly eonstricted at septum, 35-45 $\times 15-21 \mu$, wr my reach a length of $53 \mu$ when 3-celled, average $38 \times 19 \mu$ : pedicels persistent, short, lrown.

On leares and stems of $J^{\prime}$ ou ammua $\mathrm{I}$.

Victoria-Near Mellourne, dan.-1 lec., 1ss6, de., $1 \mathrm{I} ., 11 \mathrm{I}$.

New South Wales-Sydney, 1890 (Cobb). Butanic Gardens, Syduey, May, 1s!

() l'ure cuespritesine Forst.

Vietoria-lBotanic Gardens, Mellumbe, 1)ec., 1904.

On l'un puteresis l.

Vietoria-Port Fairy, Sept., 1904. Near Melbumme, Sept., 1904. 
Uredospores have been found all the year round and teleutospores from August to December. Teleutospores are fairly plentiful in October, and they are often three-or even four-celled. The three-celled forms have either transverse septa, or the upper cell may be divided vertically or slightly oblique. The four-celled is either protuced by transrerse septa, the upper one being usually oblique, or the upper third may be divided longitudinally. In these abnormal forms the length may reach $53 \mu$ and the breadth $34 \mu$ at the apex.

The genetic connexion between the aecidium on Coltsfoot (Tussilago farfara) and this rust was first shown by Nielsen in 1876 and repeated by Plowright in 1S8:, who found that the aecidiospores produced the uredospores on Poa annua in ten to twelve days. But the Coltsfoot does not exist in Australia, and, therefore, this rust can reproduce itself without the intervention of aecidia. As might be anticipated the uredo stage carries it over the winter, and, indeed, the fungus is most plentiful in our winter and early spring months-June, July, August, and September. Poa annua as a rule dies away early in October, as soon as the warm weather comes on, except in moist shady places. Lagerheim', has found the spores on the leaves after the melting of the snow.

Darluca filum Cast., commonly occurs.

(Plate III., Fig. 22.)

50. Puccinia purpurea Cooke.

Sorghum.

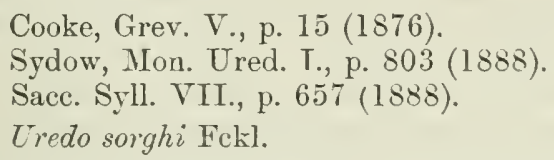

II. Uredosori amphigenous, seated on indeterminate, elongated and confluent, bright red to purple spots, scattered or in small irregular groups, corered by epidermis, and then splitting, yellowish-brown, 1-1 $\frac{1}{2} \mathrm{~mm}$. long.

Uredospores ellipsoid, obovate to piriform, yellowish-brown, loughly aculeate, with $3-t$ germ-pores on one face, 28-3t $x$ $20-25 \mu$, average $31 \times 21 \mu$; paraphyses intermixed.

[III. Teleutosori on similar spots, mostly hypophyllous, oblong, elliptic, or linear, a'ways or long corered by epidermis, reddish-brown.

Teleutospores ellipsoid, oblong or orate-oblong, rounded at apex, not or scarcely thickened, not or very slightly constricted at septum, mostly rounded at base, smooth, bright brown, with very thick epispore, $35-56 \times 22-32 \mu$; pedicel hyaline, persistent, thick, up to $100 \mu$ long; paraphyses present.]

On leaves of Johnson Grass (Sorghum halepense Pers.) and Sugar-cane (S. vulgare Pers.).

Queensland-Gladfield (Gwyther), Nerang (Shirles), (Bailey ${ }^{14},{ }^{15}$ ).

Only uredospores have been met with here.

In $P$. maydis the teleutospores are thickened at apex. Originally $P$. sorghi Schwein. included rust on Zea and Sorghum, but it is now found that the same rust does not occur on both, and Sydow, in his Monograph, has wisely determined to reserve $P$. purpurea Cooke, for Sorghum and $P$. maydis Bereng., for Ziea.

Darluca filum Cast., is very common on uredosori. 


\section{Puccinia simplex (Koern.) Eriks. and Henn.}

Eriksson and Henning, Getreider. p. 238 (1896).

McAlpine, Journ. Dep. Agr. Victorla I., pp. 430 and $529(1902)$.

Sirdow, Mon. Ured. I., p. 756 (1903).

Sacc. Syll. XVII., p. 377 (1905).

Pucinia straminis Fekl. var. simplex Koern. in Iand und Forstwirtsch. Zeit. (1865).

II. Uredosori very minute or up to $\frac{1}{2} \mathrm{~mm}$. long, sparingly seattered or sometimes numerous on both surfaces of leaves, but mostly on upper, vitron yellow.

Uredospores subglobose or ellipsoid, echinulate, yellow, relatively thick walled, with numerous scattered germ-pores, $4-7$ on one face, $21-2+\mu$ diam, or $24-30 \times 17-20 \mu$.

III. 'Teleutosor'i covered by the epidermis, amphigenous, numerous, minute, punctiform, mostly oblong and contluent, black, somewhat longer on leaf sheath than on leaf, divided into compartments by brown paraphyses, often strongly enlarged and thickened towards, the apex and spread out horizontally.

'Teleutospores oblong clavate to clavate, dark chestnut brown, smooth, usually rounded or truncate at apex, or obliquely conicinl, and slightly thickened at apex, but may sometimes reach $6 \mu$, and slightly constricted at septum, 40-54 $\times 17-24 \mu$; upper cell oblong, generally as broad as long, 15-21 $\times 17-2.2 \mu$; lower cell tapering towards pedicel, sometimes quite narrow at base, longer than upper, $21-33 \times 15-18 \mu$; pedicel short, slightly tinted.

$\mathrm{X}$. Mesospores very numerous, similarly colonred and similarly thickened at apex to teleutospores, asymmetrical, sometimes elongated, saccate or inversely triangular, very variable, $24-45 \times$ $15-24 \mu$.

\section{On Hordeum vulgare $\mathrm{L}$.}

Victoria-Port Fairy, Warnambool, Nov.-Jan.

This form was first described in 1865 by Koernicke as a rariety, but now Eriksson and Henning have raised it to the rank of a species.

A very characteristic feature of it is the great predominance of unicellular. spores. A sorus may consist entirely of these or there may be a few nomal teleutospores intermixel. 'They are produced alongside the two-celled forms, and are quite similar to them except that they are one-celled, and they evidently show the transition from the one-celled to the two-celled teleutospore. There is usually a slight thickening at the apex of both, but it rarely exceeds $t-6 \mu$. Tt was early recognised as an exeeptional form, and was named Uromyces hordei by Nielsen in 1875, and Puccinin anomala by Rostrup in 1876.

'The telentospores only germinate after a period of rest, aceording to Eriksson and llenningr'. 


\section{Puccinia subnitens Diet.}

Distichlis.

Dietel, Erythea, p. 81 (1895).

II. Uredosori liypophyllous, orange, powdery, soon naked and surrounded by ruptured epidermis, often in long lines and confluent, bullate.

Uredospores yellowish-brown, globose to slightly ellipsoid, ciensely echinulate, with 3-4 scattered germ-pores on one face, thick-walled, $21-23 \mu$ diam. or 21-28 $\times 18-20 \mu$.

IIJ. Teleutosori similar to uredosori, but dark-brown.

Teleutospores intermixed with uredospores, lark chestnutbrown, oblong to clavate, rounded at both ends or slightly tapering towards base, slightly constricted at septum and thickened at apex $(4-7 \mu)$, smooth, $28-46 \times 19-23 \mu$; pedicel persistent, yellow, up to $56 \mu$ long.

X. Mesospores not uncommon, similarly coloured to teleutospores, obovate, rounded and thickened at apex (up to $7 \mu$ ), smootl, $28-37 \times 19-22 \mu$; pedicel similar to that of teleutospore.

Darluca filum Cast., common on uredosori.

On living leaves of Distichlis maritima Rafin.

Victoria - Flinders, Jan., 1902. Near Melbourne, April and Nov., 1905̃, II., III. (Robinson).

This species is quite distinct from $P$. distichlidis E. and E., which, however, was originally found on Spartina gracilis Trin., the host-plant being mistaken for a Distichlis.

Arthur ${ }^{7}$ has obtained some remarkable results by sowing the telentospores of this species derived from Distichlis spicata Greene, on various plants. The germinating teleutospores produced aecidia on three widely-separated families of plants, viz.-Chenopodiaceae, Capparidaceae, and Cruciferae.

According to the Index Kevensis, D. spicatu is a synonym of $D$. maritima.

(Plate XXX., Fig.s. 262-264.)

53. Puccinia tepperi Ludw.

Phragmites.

Ludwig, Zeitschr. f. Pflanzenk. II., p. 132 (1892).

Sydow, Mon. Ured., I., p. 792 (1904).

Sacc. Syll. XT., p. 203 (1895).

Sori epiphyllous, large, scattered or gregarious and confluent, up to 3 cm. long, firm, thick, pulvinate, erumpent, dark-brown ; paraphyses in clusters, hyaline or pale yellow, capitate, thickened at apex, up to $75 \mu$ long.

II. Uredospores ellipsoid or pear-shaped, echinulate, pale yellowish, with as many as 9 scattered germ-pores on one face, $27-30 \times$ $20-23 \mu$.

III. Teleutospores intermixed with uredospores, subcylindrical to occasionally oblong, with rounded or acute slightly thickened apex $(4-5 \mu)$, markedly constricted at septum and upper cell often becoming detached, rounded or rarely attenuated at base, smooth, yellowish-brown, occasionally $3-4$ celled, $45-68 \times 18-26 \mu$, average $50 \times 19 \mu$; pedicel hyaline, persistent, up to $250 \mu$ long. 
X. Mesospores very lare, similarly coloured to teleutospores, elongated ellipsoid, rounded and slightly thickened at apex, tapering very slightly towards base, $58 \times 21 \mu$.

On Phragmites communis 'Trin.

S. Australia-The Grange, near Adelaide, April, 1891 (Tepper) (Ludwigr ${ }^{3}$ ).

The mesospores had all the appearance of teleutospores without the septum. 'llie rounded apex and stalk at base showed that this was not the basal cell of a normal teleutospore.

(Plate II., Fig. 19.)

\section{Puccinia triticina Eriks.}

Triticum.

Eriksson, Amn. Sci. Nat. Series VIII., p. 270 (1899).

Sydow, Mion. Ured. I. p. 716 (1903).

Sace. Syll. XVII., p. 376 (1905).

1'. dispersa f. sp. tritici Eriks. and Henn., Zeitschr. f. Pflamzenk. IV., p. 257 (1894).

II. Urerlosori 1-2 mm. long, reddish-brown, aınphigenous, but mostly on upper surface of leaf-blade, elliptic, sometimes confluent, seatterer or somewhat gregarious, oecasionally on sheath and stem.

Uredospores subglobose to shortly ellipsoid, echinulate, orangeyellow, 4-6 seattered germ-pores on one face, $20-28 \times 18-21 \mu$.

III Teleutosori oblong, black to dark-brown, bypophyllous, scattered, often arranged lengthwise in lines, sometimes on sheath and stem, covered by epidermis, divided into compartments surrounded by brown paraphyses.

Teleutospores clavate to oblong, smooth, yellowish-brown to dark-brown, slightly constricted at septum, very occasionally 3 -celled, 39-57 $\times 15-18 \mu$, average $48 \times 16 \mu$; upper cell deeply coloured, generally rounded or flattened at apex and thickened, $17-31 \times 15-18 \mu$; lower cell paler and attenuated towards pedicel, longer and narrower than upper, $22-36 \times 12-14^{\circ} \mu$; pedicel short, coloured.

X. Mesospores occasional, similarly coloured to teleutospores, ellipsoid to clavate or sub-clavate, shortly stalked, smooth, slightly thickened at apex, $25-35 \times 13-16 \mu$.

On wheat, Triticum valgare Vill. and T', polonicum L. Common.

Victoria, New Suth Wales, Queensland, South Australia, West Australia, and 'Tasmania.

'The uredospores are distinetly different from those of l'. yraminis in being subglobose insteal of elongated, and the more numerons germ-pores are seattered instead of forming an equatorial band.

Uredspores taken from young wheat plants in the winter months (JuneLugust) redily germinated in a moist chamber.

(Plate I., Figs. 3, 6, 10; Plate XL., Fig. 30:3 : Plate A., Nigs. 1, 2.) 
CYPERACEAE.

\section{Puccinia caricis (Sehum.) Rebent.}

Curex, Lritica.

Rebentisch, Fl. Neom., p. 356 (180t).

Sydow, Mon. Ured. I., p. 648 (1903).

Sacc. Syll. VII., p. 626 (1888).

Aecidium urticae DC. Fl. franc. II., p. 243 (1805).

O. Spermogonia in small or large groups, honey coloured.

Spermatia hyaline, ellipsoid, $4 \frac{1}{2} \times 2 \mu$.

I. Aecidia in rows or groups on jellowish or reddish spots, elosely crowded, reaching $1 \mathrm{~mm}$. in diam.; pseudoperidia eup-shaped, becoming wide at the mouth and campanulate, flattened $\mathrm{or}^{\circ}$ outstanding, with whitish margin which is toothed and reflexed.

Aecidiospores orange, polygonal to subglobose, finely echinulate, $16-26 \times 12-20 \mu$.

II. Uredosori elliptical or oblong, minute, hypophyllous, scattered or su bgregarious, of ten confluent in long lines, erumpent, girt by the ruptured epidermis, ferruginous.

Uredospores ellipsoid or ovoid, yellowish brown, echinulate 1-2 germ-pores on one face, $25-30 \times 19-24 \mu$.

III. Teleutosori minute, dark-brown or black, round to elliptic, seattered or gregarious, sometimes confluent, eompact.

Teleutospores elavate to elongated oblong, dark-brown, smooth, constricted at septum, apex much thickened (up to $12 \mu$ ) and rounded or bluntly pointed, lower cell generally attenuated towards base, $35-64 \times 16-22 \mu$, arerage $52 \times 22 \mu$; pedicels tinted, persistent, generally short, up to $30-40 \mu$ long.

X. Mesospores not common, elongater elliptical, coloured like telentospores, thiekened and bluntly pointed at apex, $35-14 \times$ $12-16 \mu$.

Aecidia on leaves, leaf stalks and stems of Urtica dioica L.

Victoria._Bacchus Marsh, Myrniong, Fern Tree Gully, etc.

Uredo and teleutospores on leaves of Carei breviculnis $\mathrm{R} . \mathrm{Br}$.

Victoria-Killara, Sept., 1902 (Robinson.)

On Carex pedunculate Muhl.

Tasmania-Cascades, May, 1892, II., III. (Rodway).

On Careis guniana Boott., and $C$. inversa, R. Br.

Tasmania-Longley, Dec., 189t, II. (Rodway).

On Carex alsophila F.v..IL.

Victoria--Murramurrangbong Ranges, Dee., 1903, II. (Robinson)

On Carex paniculata L.

Victoria-Gembrook Ranges, March, 1904, II., 1II. (C. French, jun.)

Dr. P. Hennings has recorded a new species, Uredo breviculmis, on Carex breviculmis var. leucochlora Bunge, from Japan, and seeing that the host plant is a native of Japan as well as of Australia, I forwarded some of this material to hin, and he replied that he scarcely thinks the two species are identical. 
Magnus first experimentally proved, in 1872, that Aecidium urticae DC., was genetically connected with Puccinia caricis occuring on Car ex hirta. J)r. Plowriglit also, in many cultures, has shown that the aecidiospores produce the uredospores on species of C'urex, and the teleutospores produce the aecidiospores on Urtica.

On the under surface of the le ves the aecidia occur in small groups, but on the leaf-stalks and stems they are in large, bright-orange patches, thickening and clistorting the parts on which they occur.

Magnus I has also shown that this rust winters on Carex hirta by means of the urelo-generation.

(Plate IV., Figs. 29, 30.)

56. Puccinia cyperi Arthur.

C'yperus.

Aithur, liot. Gaz., p. 226 (1891).

Syrlow, Mon. Ured.I., p. 6si (1903).

Sacc. Syll. XI., p. 199 (1895).

II. Uredosori hypoplyplous, on brown efiused spots, scattered irregularly or aggregated, ellipsoid to oblong, variable in size, 1-2 $\mathrm{mm}$. long, long covered by the thick epidermis, ochraceous or brownish.

Uredospores rellowish-brown, ellipsoid, echinulate, 22-25 $\times$ 19-21 $\mu$

III. Teleutosori hypophyllous, on similar spots, 1-3 mm. long, almost always covered by the epideruis, blackish brown.

T'eleutospores intermixed with uredospores, elongated oblong to elongated fusiform, brown and paler beneath, smooth, constricted or liardly constricted at septum, $35-57 \times 15-20 \mu$, average $48 \times$ $15 \mu$; upper cell rounded or of ten obtusely and obliquely acuminate at apex, and thickened (up to $13 \mu$ ); lower cell paler, oblong, but usually attenuated towards base; pedicel coloured like lower cell, persistent, $20-30 \mu$ long, but may reach a length of $40 \mu$.

X. Mesospores generally paler in colour than the teleutospores, ellipsoid to fusiform or even curved, obtusely and sometimes obliquely puinted at apex, thickened (up to $5 \mu$ ), 30-32 $\times 13-17 \mu$; pedicels similarly coloured, persistent, up to $22 \mu$ long.

On leaves of Nut grass (Cyperus rotundus L.).

Queensland-Gatton, Aug., 1903 (Shelton) (Bailey, 18, 2").

The teleutospores are very variable in shape, and sometimes the cells my be placed almost at right angles to each other. They are sometimes excessively clongated, and may reach a length of $67 \mu$.

Internixed with the teleutospores there are numerous stalked bodies similarly coloured, and representing what are usually called mesospores, although fydow describes them as palaphyses. While mesospores generally have an undombted resemblance to the teleutospores with which they are associated, theil function in this case secms to be that of paraphyses, and it may he in some other case's as well.

Derluce filum Cast., whs common on uredosori.

(Plate IV., Fig. 32.) 


\section{Puccinia longispora McAlp.}

Carex.

II. Uredo-sori hypophyllous, minute, elliptic to elongated, confluent in long lines, long covered by epidermis, rusty.brown.

Uredospores sub-globose to shortly elliptic or obovate, yellowishbrown, thick-walled, echinulate, with three equatorial germ-pores on one face, $22-30 \times 19-22 \mu$, or $23-27 \mu$ diam.

III. Teleutosori black, compact, elongated, bullate, crowded, confluent in long black lines, covered for some time, then girt by ruptured epidermis.

Teleutospores clear yellowish-brown to smoky-brown, elongated, narrow, smooth, constricted at septum, 50-80 $\times 14-19 \mu$, average $63 \times 19 \mu$; upper cell darker than lower, generally rounded and slightly expanded at apex, sometimes bluntly pointed, much thickened $(9-12 \mu)$; lower cell longer than upper, almost cylindrical or slightly attenuated towards base; pedicel yellow, short and often stout.

On Carex caespitosa L., and C. vulyaris Fr.

Victoria--Werribee Gorge, January, 1903. Gembrook Ranges, April, $190 \pm$ (C. French, jun.)

On Carex sp.

Victoria-Killara, March, 1903 (Robinson).

In immature forms of teleutospore the upper and lower cells are much alike, but ultimately the lower cell is much elongated and nearly equally broad throughout. Although 33 different Puccinias are recorded on species of Carex, the elongated narrow teleutospore with short pedicel is quite characteristic for this species. In $P$. schoeleriana Plow. and Mag., the teleutospores may be equally long, but the lower cell is more cuneiform than cylindrical, and the pedicel may reach a length of $57 \mu$. An examination of teleutospores from Carex arenaria L. in Syd. Ured. Exs., No. 282, showed these differences distinctly.

Specimens of P. cricis (Schum.) Rebent. were examined from Exsice. Sydow Ured. No. 1065 and Exsicc. Briosi and Cavara, No. 129, and the teleutospores were decidedly different.

The lower cell in $P$. longispora is much more elongated and narrower and gradually merges into the short, stout and coloured pedicel, while in $P$. caricis besides being generally considerably shorter, more wedge-shaped and somewhat inflated, the pedicel was much narrower. It is in the upper cell, however, that the difference is most striking. In P. caricis the thickened apex is one-half the length of the cell, while in $P$. longispora it is only one-third, taking the average of a number. The thickened apex, also, in $P$. caricis is much darker than in $P$. longispora. Of course, as in so many other cases where there are a number of species on the same genus of hostplant, there is a family resemblance too, between the rusts, and 1 '. caricis and $P$. longispora have many points in common along with differences in detail. 
J UNCACEAE.

Juncus.

58. Puccinia juncophila Cooke and Mass.

Cooke and IIassee, Grev. XXII., p. 37 (1893).

Syduw, Ifon. Lre.l. I., p. 6.t4 (1903).

Sace. Sy.ll. XI., p. 199 (1895).

Credo armillata Ludwig, Bot. Centrb]. XIIII. p. \& (1890).

II. Uredosori rusldy-brown, ellipsoid, erowded, confluent, often girdling stem, surrounded by the ruptured epidermis and sparingly covered by shreds of it.

Uredospores sub-ylobose, elliptic or piriform, very spinulose, relatively thick-walled $(3-4 \mu)$ yellowish-brown, $24-32 \times 16-22 \mu$.

III. Telutosori dark-brown, elliptic to oblong, surrounded by ruptured epirlermis, confluent.

'Teleutospores intermixed with uredospores, elliptical to oblong, golden-brown, with finely granular contents, slightly constricted at septum, roun led and a little thicker at apex $(\tilde{5}-6 \mu)$, lower cell rounded at base and generally resembling upper, but often somewhat narrower, $30-40 \times 20-28 \mu$, average $36 \times 25 \mu$; epispore thick, smooth; perlicel hyaline, generally deciduous, often attached obliquely, up to $5+\mu$ long.

X. Mesospores similarly coloured to teleutospores, shortly elliptical, occasionally globose, smooth, thickened at apex, $.23-28 \times 19-21 \mu$.

On Juncus effusus L., J. maritimus Lam., J. pallidus R. Br., $J$. prenciflore R. Br., and other species.

Victoria-Coromby, Oct., 18s9, II. (Tepper), the original of Uredo armillate Ludw. Dimhoola, Tov, 1891, II., III. (Reader). Oakleigh, April, 1893, II., III. (Morrison). Ardmona, Christmas Hills, Killara, Millbrook, Minvip, Mordialloc, Myrniong, near Melbourne, Phillip Islaind, Stawell, Werribee Gorge, Murramurangbong Ranges, sc.

'Tasmania-( Rodway' ').

In the original description of this species by Cooke and Massee, some mistake must have been made in the measurement of the uredospores, since they are given as $16-18 \times 12-14 \mu$.

Through the kindness of Dr. Morrion, I have also been able to examine some of the original material trom Oakleigh.

Uredo armillate was the name given at first by Ludwigin 1889 , from the uredospores only being found on Juncus pallidus, but the subsequent discovery of teleutospores intermixed with uredospores showed that it was a Puccivia. Material sent by header to hew Herbarium was originally referred to Uromyres junci by the authorities there, but the identical specimens being later forwarled to us the two-celled tolentuspores were fuund mixel with the uredospores. Cromyces junci, therefore, has not been shown to exist in Victoria.

Durlucu filum Cast., was rery common, in sume cases rendering the patches quite black. It oceurred both on urecto and teleutosori.

(Plate IV., Figs. 35, 36.) 


\section{Puccinia tenuispora McAlp.}

II. Uredosori hypophyllous, round to ellipsoid, scattered or often confluent in lines, yellowish-brown, soon naked and girt by the ruptured epidermis, compact, on irregular, confluent, purplish spots.

Uredospores yellowish to pale yellowish-brown, elliptical to obovate, echinulate, with 1-2 germ-pores on one face, $20-25 \times$ $15-22 \mu$.

III. 'Teleutosori dark-brown, ellipsoid, scattered or crowded, often confluent, pulvinate, compact, soon naked, on similar spots.

Teleutospores oblong to clavate, ochrey-vellow, tragile, smooth, apex generally rounded, rarely truncate or conical, thickened up to $11 \mu$, attenuated towards base or rounded, constricted at septum, $30-50 \times 14-20 \mu$, average, $42 \times 17 \mu$; pedicel hyaline, persistent, generally about $30 \mu$ long.

X. Mesospores abundant, clavate to obovate or oblong, smootl, thickened at apex and similarly coloured to teleutospore, $22-32 \times$ 13-16 $\mu$.

On leaves and stems of Luzula campestris $\mathrm{I}$.

Victoria-Murramurrangbong Ranges, Nov. and Dec., 1902-3, Jan., 1905 (Robinson). Wandin, Nov., 1903 (C. French, jun.)

On Luzula oldfieldii Hook. f.

Tasmania-Mt. Wellingtou, Jan., 1892, II. (Rodway).

Cooke in his Handbook of Australian Fungi gives Aecidium bellidis Thuem. which is supposed to represent the aecidial stage of Puccinia obscura Schroet., occurring on Luzula, but the aecidium found on Bellis perennis here is associated with its own teleutospores, and belongs to a distinct fungus, $P$. distincte McAlp, so that whatever may be the case in Britain, the rust on the daisy is autoecious with us.

The discovery of a rust on Luzula campestris, which does not belong to the Old World species, is a further proof against its genetic comnexion with that of the daisy. The speries differs from $P$. obscura and $P$.oblongata. The teleutospores are characteristically fragile, thin-walled, and easily collapsible, and while of the same general type as in $P$. oblongata, they are much smaller. In $P$. obscrora the colour is much deeper, and the wall is decidedly thicker and firmer. This is well shown in Plate IV., Fig. 34, in which the spores are taken from a specimen of Luzula campestris in Sydow's Ured. Exs., 1076, collected in 1896, and the material from which our descriptions are made is as recent as 1905. In $I^{\prime}$. oblongata the apex of the teleutospore is much thicker, being $10-20 \mu$, and the size is $10-80 \times 16-21 \mu$.

The teleutospores are frequently found germinating, showing that they do not require to undergo a period of rest.

Darluca filum Cast. occurs frequently on the uredosori.

(Plate IV., Figs. 33, 3t.) 


\section{LIIIACEAE.}

\section{Puccinia burchardiae Sacc.}

Saccardo, Hedw. XXXII., p. 57 (1893).

Ludwig, \%eitsch. f. Pflanzenkr. III., p. 137 (1893).

MeAlpine, Proc. Roy. Soc. Vic. VII., N.S., p. 215 (1894).

Sydow, Mon. Ured. I., p. 620 (1903).

Sace. Syll. XT., p. 197 (1895).

IT. Uredosori amphigenous, bullate, elliptical or sometimes circular, crowded, light-brown, erumpent, surxounded at base by dry cuticle of epidermis.

Uredospores elliptic to subglobose, yellowish-brown, epispore echinulate, $28-31 \times 2.2-25 \mu$.

III. Teleutosori amphigenous, numerous, small or large, erumpent, surrounded at base by cuticle of epidermis, circular cr elliptical, black.

Teleutospores clavate, constricted at septum, thickened at apex (up to 14 or $15 \mu$ ) and rounder, sometimes truncate or acute, $40-60 \times 14-23 \mu$, average $48 \times 20 \mu$, but sometimes attaining a length of $70 \mu$; lower cell tapering towards pedicel, yellowishbrown; upper cell elliptical or rarely spherical, chesteut-brown, $21-23 \mu$ broad; epispore smooth; pedicel hyaline, $30-60 \times 5-6 \mu$.

X. Mesospores fairly common, similarly coloured to teleutospores or paler, clavate to ovate, rounded or pointed at apex and thickened, $37-43 \times 12-15 \mu$.

On stems and leaves of Eurchardia umbellata R. Br.

Victoria-Dandenong Creek, Oct., 1891. (C. French, jun.). Near Melbourne, Sept.-Feb. Myrniong, Sept., 1898, and Dec., 1903. Murrumurangbong Ranges, Dec., 1903 (Robinson).

S. Australia-'Teatree Gully, Oct., 1890 ('T'epper).

The first record of this species appeared in Hedwigia of March and April, 1893, where Saccardo described it as differing from the type IP. metancurthecii Pat.

$$
\text { (Plate V., Figs. 3£, 39.) }
$$

\section{Puccinia wurmbeae Cooke and Mass.}

Wrumbea.

$$
\begin{aligned}
& \text { Cooke and Massee, Grev. XVT., p. } 74 \text { (1887). } \\
& \text { Cooke, Handl. Austr. Fung., p. } 337 \text { (1892). } \\
& \text { Sydow, Non. Ured. T., p. 640 (1903). } \\
& \text { Sace. Syll. VTI., p. } 664 \text { (1885). }
\end{aligned}
$$

Sori elongated, bullate, dark-brown.

11. Uredospores elliptic, granulate, brown, 25-28 $\times 15-18 \mu$.

IIr. Teleutospores clavate, slightly constricted at septum, smooth, upper cell convex or truncate, at apex darker, lower cell triangular, attenuated downwarels into the short, hyaline pedicels, $48-60 \times 21-28 \mu$, arouge $50 \times 24 \mu$ (according to Cooke and Massee, $60-70 \times 20-25 \mu)$; pedicels persistent, gener:1lly short, but attaining a length of $522 \mu$ and $a$ breadth of $7-8 \mu$, beins broalcest at the junction with the spore. 
X. Mesospores numerous, similarly coloured to teleutospores, elongated, elliptical to oblong, thickened at apex and acute, rounded or truncate, $40-49 \times 17-21 \mu$.

On leaves of Wrumbea dioica F. v. II.

South Australia-Beltana, 1887 (Richards).

No uredospores were found on the specimen in National Herbarium.

(Plate V., Fig. 3T.)

\section{HAEIIODORACEAE.}

62. Puccinia haemodori P. Henn.

Haemodorum.

Hennings, Hedw. XL., p. (96) (1901).

Sydow, Mon. Ured. I., p. 609 (1903).

Sace. Syll. XVII., p. 366 (1905).

III. Teleutosori amphigenous, round or often oblong, scatterer or aggregated and then confluent, pulvinate, compact, erumpent, black, surrounded by the ruptured epidermis, 1-2 mm. long.

Teleutospores oblong to oblong clarate, obtusely rounded or apiculate at apex and strongly thickened $(8-13 \mu)$, slightly constricted at septum, attenuated or rounded at base, smooth, chestnut-brown, 40-57 $714-20 \mu$, average $46 \times 19 \mu$; pedicel persistent, slightly brownish towards apex, 40-55 $\times 5-7 \mu$.

$\mathrm{X}$. Mesospores vers common, subfusoid or oroid to subclavate, apex gibbous to apiculate, somewhat obtuse or two-horned, thickened at apex (up to $9 \mu$ ), brown, $25-40 \times 12-18 \mu$; pedicel hyaline to brownish. Occasionally a more deeply coloured spore occurs, with somewhat truncated apex, 30-16 × $5-7 \mu$.

On leaves of Haemodorum sp.

West Australia-Near Perth (1900).

Hennings described uredospores in his original diagnosis, but Sydow did not find them afterwards in the original material. He remarks that the teleutospores readily separate into their two constituent cells, and since the supposed uredospores agree with the upper cell of the teleutospore, they are probably the same.

No uredospores were found by me in the specimen kindly sent by Hennings.

The teleutospores are somewhat rariable in shape, and occasionally the upper cell may be ellipsoid and deep chestnut, while the lower is cylindrical, much paler in colour, and two-thirds the entire length.

(Plate V., Fig. 40.)

\section{AMARILLIDACEAE.}

63. Puccinia hypoxidis IIcAlp.

Hyporis.

MeAlpine, Agr. Gaz. N.S.WV. VI., p. 853 (1895).

Srdow, MIon. Ured. I., p. 607 (1903).

Sace. Syll. XIV., p. $3 \pm 1$ (1899).

II. Uredosori on both surfaces and margins of leares, minute, rustcoloured, rounded or oral, bullate, gregarious or scattered, bursting through and surrounded by epidermis. 
Uredospores shortly elliptical, yellowish, fincly echinulate, 20-23 $\times 16-18 \mu$, average $21 \times 16 \mu$.

IIT. 'Teleutosori amphigenous, black, blister-like, largely confluent and distorting leaf, long covered by epiclermis.

Teleutospores with a few uredospores intermixed, elongated clavate, chestnut-brown, slightly or not at all constricted at septum, commonly truncate and much thickened at apex, 36-5 $4 \times 15-22 \mu$, average $42 \times 18 \mu$; upper cell squarish or oblong or club-shaped, apex very much thickened (up to $15 \mu$ ), sometimes strongly beaked, generally shorter than lower cell, dark chestnut-brown; lower cell tapering towards base, lighter in colour than upper, of a yellowish or golden brown; pedicel pale yellow, persistent, generally about $18-20 \mu$ long.

X. Mesospores chestnut to pallid, rounded or beaked at apex and thickened, somewhat fusiform to elongated elliptical, 25-36 $\times$ $11-18 \mu$.

On leaves of IIypoxis glabella $\mathrm{R}$. Br.

Victoria-Ardmona, July, 1893 (Robinson). Burnley, Rutherglen, \&c., July-Oct.

It differs from $P$. burchardiae Sacc. in the much smaller uredospores, and decidedly in the teleutospores, which in the latter are generally rounded at the apex or beaked, and distinctly constricted at the septum.

(Plate V., Fig. +1.)

\section{LABIATAE.}

\section{Puccinia menthae Pers.}

Wentha.

Persoon, Syn., p. 227 (1801).

Sydow, Hon. Ured. I., p. 282 (1902).

Sacc. Syll. YII., p. 617 (1888).

[O. Spermogonia either arranged in small groups or scattered, honeycoloured.]

[1. Aecidia hypophyllous, or frequently on stems which are much swollen, more rarely on purplish-red spots on leaves, seldom scattered; pseudoperidia immersed, flat, opening irregularly and margin scarcely or irregularly torn.

Aecidiospores subglobose, ellipsoid or polygonal, coarsely granular, pale yellowish, $24-40 \times 17-25 \mu$.

II. Uredosori hypophyllous, small, seated on pale spots, roundish or elliptical, scattered or aggregated, soon pulverulent and contluent, sirt by the ruptured epidermis, cinnamon-brown.

Uredospores subglobose, ellipsoid or obovate, echinulate, palebrown, generally three equatorial pores, 20-30 × 16-19 $\mu$.

11T. 'Telentosori similar, but blackish-brown in colour.

Teleutospores at first intermixed with uredospores, ellipsoid to ovate, rounded at both ends, apical papilla pale or hyaline, broadly expanded, hardly constricted at septum, finely warted, golden to cliestnut-brown, $24-32 \times 19-2 \cdot 2 \mu$, but commonly $24-25 \times$ $19-20 \mu$; pedicel hyaline, slender, generally surpassing length of spore, up to $40 \mu$. 
X. Nesospores, occasional, similarly coloured, nearly globose, ver'y slightly roughened, $20 \mu$ diam.

On leaves of Mentha laxiflora Benth.

Victoria-near Melton (Reader).

On leaves of Mentha pulegium L.

Victoria-Myrniong, Aug., 190t, II., III. (Brittlebank).

The teleutospores are prominently warted.

(Plate XXIX., Fig. 250.)

\section{ACANTHACEAE.}

\section{Puccinia mussoni McAlp.}

Ruellia.

Sori amphigenous, minute, usually rounded, bullate, scattered or sometimes in groups.

II. Uredospores yellow with thick, chestnut wall, globose to shortly ellipsoid, strongly echinulate, with two germ-pores on one face, $30-35 \mu$ diam., or $28-34 \times 18-23 \mu$.

III. Teleutospores intermixed with uredospores, dark chestnut-brown, oblong, with thickened wall and roughened surface, sometimes slightly constricted, rounded at both ends, not thickened at apex, $36-46 \times 28-36 \mu$; upper cell resembling lower, but usually a little larger; pedicel generally lateral and even sometimes on a level with the septum, flexuous, hyaline, up to $60 \mu$ long and $7 \mu$ broad.

On living leaves of Ruellia australis Cav.

New South Wales-Richmond Piver, June, 1896 (Musson).

The teleutospores were not very plentiful in the specimens examined, but the sori containing them could be detected by their darker brown colour. The lateral pedicel to the teleutospore naturally suggests $P$. lateripes $B$. and Rav., but a closer inspection reveals important difterences in the two kinds of spores.

I have compared the Australian species with specimens on the leares of R. strepens L. from N. America in Sydow's Ured. Exs., No. 1374, and Kellerman's Ohio Fungi, No. 130, and it is evident that we are dealing with similarity of type due to the aftinity of the host-plants, with considerable divergence in the character of the spores. Unfortunately, $P$. lateripes $\mathrm{B}$. and Rav. and $P$. ruelliae (B. and $\mathrm{Br}$.) Lagh. are confounded, for although Sydow labels his specimen as the former, in his Monograph he names it the latter. In this specimen the finely echinulate uredospores are ellipsoid to ovate, and measure $24-28 \times 19-21 \mu$, while here they are larger. The teleutospores likewise only measure $29-3 t \times 18-22 \mu$, and are very strongly warted.

This species differs from P. longiana Syd., in the larger uredospores and the teleutospores not being thickened at apex, and from $P$. lateripes and $P$. ruellice in the larger size of uredo- and teleuto-spores. 


\section{CONVOLVULACEAE.}

\section{Puccinia dichondrae Hont.}

Dichondra.

Montagne in Gray's Fl. Chil. VIII., p. 46 (1845).

Cooke, Handb. Austr. Fung., p. 3.38 (1892).

Sydow, Mon. Ured. I., p. 321 (1902), and p. 881 (1904).

Sacc. Syll. VII., p. 717 (1888).

P. dichondrae Berk. Linn. Journ. XII., p. 173 (1S72).

P. berkeleyana De Toni, Sace. Syll. V11., p. 717 (1S88).

P. munita Ludwig, Zeitseh. f. Pflanzenk. II., p. 133 (1892).

III. 'Teleutosori hypophyllous, punetiform, very minute, erumpent to superficial, somewhat pulverulent, densely gregarious and often covering entire surface, deep cinnamon, nestling among hairs, $70-100 \mu$ diam.

Teleutospores clavate to oblong, golden brown, constricted at septum, with comparatively thin epispore, thickened at apex and produced into a hyaline apiculus (oceasionally two), with granular contents, and each cell 1-guttulate, occasionally 3 to 4 celled, $30-40 \times 12-18 \mu$, average $32 \times 14 \mu$; pedicel hraline, sometimes tinted, persistent, generally slender, up to $\$ 6 \mu$ long, oceasionally $6 \mu$ broad.

X. Mesospores sub-ellipsoid to oblong, similarly eoloured to teleutospore, thickened at apex and usually with hyaline apieulus, 21-30 $\times$ $15-22 \mu$.

On Dichondra repens Forst.

Victoria-Near Melbourne, 1886 (Peader). Cheltenham, Nor. 1887 (French). Goulburn River Flats, Oct., 1896 (Robinson). Christmas Hills, May, 1900 (Robinson). Point Cook May, 1902 (French, jun.). Murramurrangbong Ranges, Nov. 1902 (Robinson). Mt. Blackwood, Dec., 1902. Port Fairy, Aug., 1905. Mentone, throughout the year, 1905, etc.

New South Wales-1901. (Camfield). Richmond, April, 1905 (Musson). Reeorded by Mairlen?

South Australia-Mount Lofty, near Adelaide, Oct., 1891 (Tepper). 'Tismania-North East (Mueller).

I have examined the original material from the National Herbarium, Melbourne, and find that there must have been some mistake over the measurements of the spores, which were given as .005 inch $(130 \mu)$ by Berkeley, which is evidently a misprint. Next, Dr. Cooke in his IIandhook of Australian frungi makes a eorrection by giving the size of the spores as 12-13 $\mu$ longr, which evidently errs on the other side. Then De Toni changed the name to $P$. berkeleymana, seeing that the size of the spores as given did not at all agree with those of $l$. dichondrae, Mont.

Another unfortunate error has arisen in connexion with this speeies through the wrong naming of the host-plant. Mr. Tepper sent a rust to Prot. Ludwig from S. Australia, said to be on the living leaves of $I y d r o c o t y l e$ hirta R. Br., who determined it as a new speeies, P'. mnnita. Buton Prof. Lurlwig kindly sending me some of the original material it was found that the leaves belonged to Dichondra repens and that the rust was P'. dichondrae, a conclusion with which Prof. Ludwig agreed after examining the speeimens sent to him. 
The teleutospores are frequently $3-4$ celled, and there is great variety in the arrangement of the septa. The spore may be divided vertically as in Diorchidium, or it may have a vertical or oblique septum in its upper or lower cell. The septa may even be arranged muriformly. There may be a lateral hyaline apiculus in the lower as well as in the upper cell, and the pedicel may stand out at right angles to the lower cell.

There is thus every gradation from the unicellular spore and the bicellular, in which the upper cell is more or less atrophied, up to the multicellular, which is vertically, obliquely or muriformly divided.

Aecidia have been found on this plant and are regarded as belonging to this species, but although numerous specimens have been examined from various localities no trace of aecidiospores has been found here.

It is worthy of note that some of our native species of Viola closely resemble the Dichondra, and the one may easily be mistaken for the other when no flowers are present.

(Plate V., Fig. 42 ; Plate XL., Fig. 299.)

\section{APOCYNACEAE.}

67. Puccinia alyxiae Cooke and Mass.

Alyxia.

Cooke and Massee, Grev. XVI., p. 2 (1887).

Cooke, Handb. Austr. Fung., p. 338 (1892).

Sydow, Mon. Ured. I., p. 336 (1902).

Sacc. Syll. VII., p. 714 (1888).

III. Teleutosori generally hypophyllous, occasionally epiphyllous, discoid, compact, dark-brown, girt by the ruptured epidermis, $1-2 \mathrm{~mm}$. diam.

Teleutospores almost pear-shaped or oblong, yellowish to brownish, constricted in the middle, thickened at apex and generally apiculate, sometimes rounded or truncate, occasionally 3 -celled, $40-52 \times 20-25 \mu$, arerage $45 \times 20 \mu$; epispore thick, smooth, coloured; perlicels persistent, hyaline, broadish, elongated, up to $130 \mu$, occasionally at right angles to the spore.

X. Mesospores not uncommon, similarly coloured, elongated oblong, thickened and sometimes apiculate at apex, $38-50 \times 19-21 \mu$.

On leares of Alyxia buxifolia R. Br.

Victoria_Brighton and Broadford, Sept., I\&ST (Miss Campbell ' ${ }^{\text {). }}$

Beaumaris, March, 1895 . Cheltenham, May, 1902 (C. French, jun.) Sandringham, April, 1905. (Robinson).

South Australia-Gawler, Sept., 1893. (Tepper).

Tasmania-Near George’s Bay, Nor., 1892. (Rodway ').

The sori are generally isolated, much inflated and surrounded by a conspicuous, brown, elevated ridge. When on both surfaces they are opposite to each other.

In the Cheltenham material, the spores had germinated on the leares lying on the ground on 19th May, while the spores on the Gawler material found in September had not.

This spore probably undergoes a period of rest during the summer before germination. Cooke and Massee have given the length of the spores as $50-70 \mu$, but this is evidently a misprint.

(Plate VI., Fig. 46.) 
68. Puccinia carissae Cooke and Mass.

C'arissa.

Cooke and Massee, Grev. XXII., 1). 37 (1893).

Sydow, Mon. Urerl. T., p. 336 (1902).

Sacc. Syll. XI., p. 195) (1895).

III. 'Teleutosori hypophyllous, gregarious, on orbicular spots, forming rings which are at length confluent, rather compact, dark-brown.

Teleutospores elliptic, constricted at septum, rounded at ends or occasionally flattened, smooth, brown, $30-34 \times 17-25 \mu$, average $32 \times 22 \mu$; nccasionally 3 -celled, then reaching to a length of $49 \mu$; pedicel hyaline, deciduous or persistent, sometimes originating laterally, rather long.

X. Mesospores occasional, just resembling a teleutospore, but without the septum, elliptic, with hyaline pedicel, $29-31 \times 22-35 \mu$.

On living leaves of Carissa ovata $\mathrm{R}$. Br.

Queensland-Gladficld, (Gwyther) (Bailey $\left.{ }^{13}\right)$. Dalby, (Bancroft) (Bailey ${ }^{16}$ ).

$\mathrm{Mr}$. Bailey has kindly sent me some excellent material from his herbarium and the teleutospores have been carefully measured. In the original description the size is given as $20-22 \times 16 \mu$, but probably $30-32 \mu$ was intended for the length.

Sometimes both upper and lower cell have an oblique division.

It differs from $P$. alyxicue Cooke and Mass., in which the spores are much larger and thickened at the apex.

(Plate VI., Fig. 45.)

\section{GOODENIACEAE.}

Brunonia.

69. Puccinia brunoniae McAlp.

McAlpine, Agr. Gaz. N.S. W. VI., p. 851 (1895).

Sydow, Mon. Ured. I., p. 193 (1902).

Sacc. Syll. XIV., p. 320 (1899).

O. Spermogonia dark honey-coloured, disposed in clusters on rellowish spots, or intermixed with aecidia on the same surface of the leaf, usually the upper.

I. Aecidia scattered or more often circularly arranged on reddish, slightly swollen indeterminate spots, mostly on upper surface of leaves and on petioles; pseudoperidia with white margin, torn. slightly recurved and soon falling away, average $\frac{1}{3} \mathrm{~mm}$. dian.: isolated peridial cells, generally short and stout, less commonly elongated oblong, punctate, with striated margin, generally $24-31 \times 14-17 \mu$, ol when elongated $38-45 \times 21-24 \mu$.

Aecidiospores subglubose or angular, or even oval, deep orange, smooth, $17-21 \mu$ diam. or $18-21 \times 15-16 \mu$, occasionally as long as $21 \mu$. 
III. Teleutosori amphigenous, but mostly on upper surface, very rarely mixed with aecidia, forming clusters of black, bullate pustules on indefinite, pale, ruddy, thin spots, oral or elongated, usually confluent, arranged circularly, or in lines, at first girt by ruptured epidermis, which finally falls away.

Teleutospores clavate, golden-brown to chestnut, thickened at apex, constricted at septum, sometimes 3 or 4 celled, $45-60 \times$ $18-21 \mu$, average $50 \times 20 \mu$; upper cell generally pointed, but often rounded and occasionally truncate, deeper in colour than lower; lower cell tapering towards base and generally longer than upper; pedicels persistent, pale-yellowish to hyaline, $40-50 \times$ $9-10 \mu$.

X. Mesospores occasional, similarly coloured to teleutospores, rather oblong, thickened at apex, rounded or truncate, slightly narrowed at base, $28-38 \times 17-21 \mu$.

On leares and petioles of Brunonia australis Sm.

Victoria-Drysdale, Oct., 1895, III. Murramurrangbong Ranges. Nov., 1902, Dec., 1903, O., I., III., and Jan., 1905, III, (Robinson). Alps, near Bright, Dec., 1904, III. (C. French, jun.). Rutherglen, Dec., 1904, III.

Three-celled teleutospores occasionally seen, varying in length from $60-73 \mu$ and in breadth from $21-24 \mu$, the lower cell generally about as long as the other two.

Four-celled teleutospores are rery rare, elongated clavate, $63 \times 24 \mu$, the two upper cells about $33 \times 24 \mu$, and the two lower $30 \times 14 \mu$. In the same group there were three 3 -celled teleutospores with an average size of $59 \times 23 \mu$.

At first no aecidia were known, but these were found along with the teleutospores by G. H. Robinson.

The discovery of aecidia rendered it necessary to carefully compare the two fungi found upon the Goodeniaceous plants, Brunonia and Goodenia, and a large number of specimens and slides were accordingly examined and compared.

While the rusts are of the same general type, they differ in several important respects. The aecidiospores in $P$. saccardoi are considerably sinaller, and the peridial cells are generally much more elongated, and more than twice as long as broad.

In the original description by Dr. Ludwig the size of the aecidiospores is given as 13-15 $\mu$ diam., and the peridial cells as $18-25 \times 15-18 \mu$, but if the latter are measured when isolated ther are found to be much longer. Again in $P$. saccurdoi the teleutospores are generally intermixed with or surround the aecidia, but this very rarely occurs in $P$. brunoniae. In the former the teleutospores are generally rounded at apex, but in the latter. generally pointed and altogether narrower.

In the Murramurrangbong Ranges where the aecidia and teleutospores of $P$. brunoniae were found very plentifully in November, though Goodeniaceous plants which, in other districts are affected by $I$ '. saccardoi, were exceedingly common and were often growing alongside the Lrunonia, no rusts were found on them, even although the country was subjected to in most exhaustive search. The rusts, therefore, on the two different genera are considered to be specifically distinct. 
70. Puccinia dampierae Syd.

Sydow, Mlon. Ured. I., p. 193 (1902).

Since. Syll. XVII., p. 315 (1905).

I. Aecidia on stems and both surfaces of leaf, gregarious, bright or ange; pseudoperidia with white reflexed and torn margins, $\frac{1}{85}-\frac{1}{2} \mathrm{~mm}$. in diam. ; peridial cells lozenge-shaped to oblong, with thick striated margins, $30-40 \mu$ long.

Aecidiospores orange, subglobose, ellipsoid to oblong, finely echinulate, $15-17 \mu$ diam. or 17-19 $\times 13-14 \mu$.

IIT. 'Teleutosori on stems, scattered or aggregated, round or oblong, about $1 \mathrm{~mm}$. diam., compact, dark-brown, girt by the ruptured epidermis.

Teleutospores clavate, rounded or acute at apex and strongly thickened $(8-11 \mu)$, constricted at septum, attenuated downwards, rarely round, smooth, brown, 48-66 $\times 16-26 \mu$; pedicel yellowish, persistent, up to $80 \mu$ long.

X. Mesospores intermixed with teleutospores, clavate, 40-55 x 14-22 $\mu$.

On stem and leaves of Dampiera stricta R. Br.

Victoria-Mlonbulk, Dec., 1905, I. (C. French, jr.).

On wings of the stems of Dampiera alata Lindl.

Wẹst Australia, ITI. (L. Preiss).

Though $\mathrm{I}$ have not seen the West Australian specimens I prefer to regard the aecidia found in Victoria as a stage of the same fungus. If they should prove to be unrelated they would be eissily separable at any time.

\section{Puccinia gilgiana P. Henn.}

Leschenaultia.

Hennings, Hedw. XL., p. (95) (1901).

Sydow, Mlon. Ured. I., p. $19+(1902)$.

Sace. Syll. XVII., p. 314 (1905).

Accidium perkinsice P. Henn. Hedw., XL., p. (96) (1901).

I. Aecidia on thickened and slightly deformed parts, gregarious or scattered; pseudoperidia hernispherical to cup-shaped, semiimmersed, yellowish to ruddy; peridial cells round or oblongpolygonal, sublyaline, reticulate, $18-24 \times 16-20 \mu$.

Aecirliospores subglobose or ellipsoid, angular, finely echinulate, yellowish, $15-20 \mu$ diam.

IT. Uredosori on stems, gregarious in streaks, oblong, surrounded or almost covered by the ruptured brown epiclermis, somewhat pulverulent.

Uredospores subglobose, oroid or ellipsoid, yellowish to brown, echinulate, $14-21 \times 12-18 \mu$.

III. 'Telentosori similar, but black.

'l'eleutospores clivate or oblong, constricted at septum, smooth, obtusely rounded or truneate at apex and slightly thickened (up to $5 \mu$ ), obliquely papillate and oceasionally crested, romeled at base or attenuated, brown, 30-45 $316-22 \mu$, arerage $42 \times 20 \mu$; pedicel brownish, thick, persistent, 30-50 $\mu$ long. 
X. Mesospores very common, oblong or oblong-clavate, thickened at apex, rounded or acute, chestnut-brown, smooth, stalked, 23-32 $\times 15-20 \mu$.

On petioles, calyx and stems of Leschenaultia linurioides DC.

West Australia-Near Perth, 1900 (Pritzel). stems.

Aecidia on petioles, flower-stalks, and calyx; uredo and teleutosori on

Specimens kindly supplied by Hennings.

(Plate VI.,Fig. 47.)

\section{Puccinia saccardoi Ludw.}

Goodenia, Telleia.

Ludwig, Hedw. XXVIII., p. 362 (1889).

Cooke, Handb. Austr. Fung., p. 337 (1892).

Sydow, Mion. Ured. I., p. 193 (1902).

Sacc. Syll. IX., p. 309 (1891).

P. nigricaulis McAlp., Agr. Gaz. N.S.W. VII., p. 151 (1896).

Aecidium goodeniacearum (in part) Berkeley, Linn. Journ. XIII., p. 173 (1872).

I. Aecidia on Jellowish or brownish spots, scattered or in groups arranged in circular patches (up to $6 \mathrm{~mm}$. diam.), amphigenous causing distortion of stem; pseudoperidia cup-shaped, with white torn, everted edges, $215-325 \mu$, diam.; isolated peridial cells punctate, with striated margin, generally elongated oblong, or somewhat oval or lozenge-shaped, more than twice as long as broad, $35-42 \times 16-21 \mu$.

Aecidiospores subglobose, polygonal to oval, orange, very finely verrucose, $14-16 \mu$, diam., or $15-17 \times 13-14 \mu$.

III. Teleutosori on both surfaces of leaves and on stems, black, compact, roundish or elongated, confluent in long swollen patches, generally intermixed with or surrounding aecidia, bursting through epidermis.

Teleutospores clavate to oblong, dark-brown, constricted at septum, smooth, variable in size, rarely 3 -celled, $40-66 \times 17-25 \mu$, occasionally up to $70 \mu$ long, average, $54 \times 20 \mu$; upper cell subglobose or somewhat quadrate, thickened at apex (up to $9 \mu$ ), generally rounded or truncate, occasionally pointed, 21-30 $\times$ $17-25 \mu$, sometimes reaching $32 . \mu$ in length; lower cell generally paler in colour than upper, elongated and tapering towards base, sometimes subglobose, longer and narrower than upper, 17-35 $\times$ 16-2L $\mu$, occasionally $38 \mu$ long; pedicel usually persistent, hyaline, occasionally pale-yellow, $3 \tilde{5}-60 \times 7-12 \mu$.

X. Mesospores common, similarly coloured to teleutospores or paler, variously shaped, ellipsoich to oval, or oblong to clavate, smooth, with pointed and thickened apex (up to $9 \mu$ ), and generally slightly tapering towards base, $25-49 \times 12-21 \mu$, or averaging $36 \times 17 \mu$. 
On stems, leaves and calyx of Goodenia geniculata P. Br., Gr. glauea F. v. M., $G$. pinnatifirla sichlecht., $G$. albiflora Sohlecht., $G$. hederacea Sm., and G. ovecte Sin.

Victoria-Port Phillip, 1886, I. Dimborla, Sept., 1892 , I., JII. (Reader). Minyip, near Colac, Grampians, Warracknabeal, Nhill, Killara, MIt. St. Bernard, Borung, Gembrook, neal Melbourne.

S. Australia-Tanunda Serub, Oet., 1887 (Tepper). MIt. Brown Creek, near Quorn, Sept., 1892 (Molineux).

Tasmania-Cascades, Jan., May, Nov., 1892 and 1893, I. (Rodway $^{2}$ ). Devonport, Jan., 1906, I., III. (Robinson).

On Velleia macrocalyx. De Triese.

New South Wales-Guntawang, Sept., 1886 (Hamilton).

On Velleic paradoxa R. Br.

Victoria-Pine Plains, I. (Reader).

New South Wales-Guntawang, Sept., 1886, I. III. (Hamilton).

I have received from Prof. Saccardo some of the original material on $G$. geniculata from S. Australia, and on comparing it with $P$. nigricaulis MeAlp., have no doubt but that they are the same. The Victorian specimens, however, occur very plentifully on the stems as well as on the leaves, and under farorable conditions the fungus obtains such profuse development as to cause blackening and distortion of the stems.

Aecidium goodeniacearum Berk. belongs partly to $I^{\prime}$. saccardoi and to Lromyces puccinioides. In specimens of Goodenia pinnatifida, received from F. M. Reader, Dimboola, the fungus is named A. goodeniacearum Berk. in Massee's handwriting, while the teleutospores of $l$ '. saccardoi are also met with intermixed with the aecidia.

In Velleia paradoxn, from New South Wales, while the teleutospores are of the general type, there are quite a number in which the apex is truncate and prolonged laterally into a thickened, more or less beak-like projection. But Ludwig observed in the original type on Goodenin geviculata a similar variety, so that the spores on the genera Goodenia and Telleir cannot be differentiated. He writes-" Mlixed among the normal teleutospores there are three and one-celled spores, the latter sometimes of abnomal size, as I have observed under similar conditions in $P$. heterospom. Frequently very peculiar forms appeared, in which the upper cell bore 1-3 horn-like projections as long as the cell itself, or finger-like cells, as long as the upper, proceeded from the lower cell."

(Plate TI., Figs. 48, 49.)

\section{CAMPANULACEAE.}

73. Puccinia aucta Berk. and F. r. M.

Lobetia, Pratia.

Berkeley and F. von Mueller, Limu. Journ. AIII., p. 173 (1572).

Cooke, Grov. XT., p. 9s (1883).

Cooke, Taudb. Austr. Fung., p. 338 (1892).

Sydow, Mon. Ureel. I., l) $196\left(190^{\circ}\right)$.

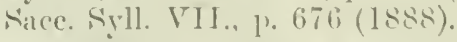

Apcidium mierostomum Berk. Journ. Linn. Soc. XIII, p. 173 $(187:)$.

A. loleliar Thuem. Grev. IV., 1. T5 (15ij). 
O. Spermogonia slightly raised, with projecting paraphyses, honey coloured, in groups.

Spermatia numerous, hyaline, ellipsoid, 5-6 $5.3 \mu$.

I. Aecidia amphigenous, rouncled or orate, scattered or densely gregarious and occupying the entire surface of the leares or petioles, at first covered by the epidermis, then free and rupturing like a broken blister, vesicular, ochraceous; pseudoperidial cells, oral to oblong, covered with spines, loosely connected, 30-10 $\times$ $18-2.5 \mu$.

Aecicliospores irregularly globose, sub-angular or ellipsoid, finely echinulate, with distinct wall, ochraceous, $18-22 \mu$ or $22-28 \times$ $18-20 \mu$.

III. Teleutosori on under surface, numerous, bullate, then girt by the ruptured epidermis so that they resemble little Pezizce.

Teleutospores cylindric to sub-clavate, elongated, yellow, thickened apex $(9-10 \mu)$, rounded or truncate, deeply constricted at septum $56-70 \times 15-26 \mu$, average $60 \times 24$, occasionally biand tri-septate when they may reach a length of $80 \mu$; upper cell generally broader than lower ; lower cell generally evlindrical, and may taper slightly towards pedicel; pedicel hyaline, short, stout, 7-13 $\mu$ broad.

Aecidiospores on Lobelia anceps I., L. pratioides Benth., L. purpurascens R. Br., Pratia erecte Gaudich., P. pedunculata Benth., P. platycaly $x$ Benth.

Victoria-Colac (F. v. Mueller), (von Thuemen). Murtoa, Oct., 1892, (Reader). Ringwood, Oct., 1892 (Robinson). Minyip,

Oct., 1901 (Eckert). Werribee Plains, June, 1902 (C. French, jun.).

New South Wales-Guntawang, Sept., 1886 (Hamilton). Kurrajong Heights, Apr., 1894 (MLsson).

Tasmania-Bellerive Swamp, Dec., 1891 (Rodway).

Teleutospores on leaves of Lobelia anceps $\mathrm{L}$.

South Australia-Port Lincoln, Nor., 1852 (C. Wilhelmi), $\left(\right.$ Berkeley $\left.^{2}\right)$.

The aecidium was first determined by Thuemen on a specimen of Pratia platyculyx sent by the late Baron von Mueller from Colac, and named A. lobeliae. Then Berkeley received a specimen from the same source on $P$. pedunculata which he named $A$. microstomum.

I have examined portions of the original material of both these specimens, and as a rule it is difficult to detect a peredial wall even in tine sections, so much so that they were as first taken for caeomata. But there is occasionally a loosely fitting layer of surrounding cells, so that we may regard them as aecidia. The aecidial stage is given in connexion with the teleuto stage since, although not found actually together, they occur separately on the same species, Lobelia anceps.

The teleutospore is occasionally tri-septate, and is then slightly curved, and the lower septum oblique.

The description of the teleuto stage is drawn up from original specimens in the National Herbarium, named in Berkeley's handwriting.

(Plate VI., Fig. 51 ; Plate XXXIX., Fig. 289.) 


\section{Puccinia angustifoliae McAlp.}

I. Aecidia in dense clusters on the leaves, more sparingly on stems, about $\frac{1}{3}$ to nearly $\frac{1}{2} \mathrm{~mm}$. dian.; pseudoperidia with finely laciniate everted margins.

Accidiospores orange-yellow, globose to elliptical or subquadrate, $16 \times 11-13 \mu$ or $13-14 \mu$ diam.

III. Teleutosori on leaf and stem, black, long covered by epidermis, confluent, forming elongated patches, partially rupturing and throwing off epidermis, distinct from or along with aecidia.

T'eleutospores clavate to oblong, smoky-brown, slightly constricted at septum, smooth, generally rounded and thickened at apex (up to $9 \mu$ ), slightly tapering towards base or often rounded, $40-53 \times 16-21 \mu$, average $50 \times 20 \mu$; pedicel hyaline, deciduous, generally short, up to $38 \mu$ long and $9 \mu$ broad.

X. Mesospores common, similarly colored to teleutospores: or paler, generally somewhat oval, thickened at apex, 25-30 × 16-17 $\mu$.

On Scorzonera angusífolia I.

Victoria-Dimboola, Nov,, 1892, I., III. (Reader).

This species differs from $P$. podospermi DC., $P$. scorzonercie (Schum.) Jacky and $P$. tragopogi (Pers.) Corda, in the absence of uredospores and the smooth teleutospores.

$$
\text { (Plate TII., Fig. 53.) }
$$

\section{Puccinia brachycomes MeAlp.}

Brachycome.

I. Aecidia erowded on swollen and distorted portions of leaves, also on stems and branches, about $\frac{1}{3} \mathrm{~mm}$. diam.; pseudoperidia round, out-standing, with white, slightly everted, laciniate margin; pseudoperidial cells firmly united, oblong to sub-quadrate, punctulate all over, with broad striated margin.

Aecidiospores yellowish, sub-globose to ellipsoid, finely echinulate, $13-16 \mu$ diam. or 13-16 × 10-13 $\mu$.

II. Teleutosori elliptical, pustulate, black to blackich-brown, long covered by epiclermis, crowded, confluent, and ultimately forming elongated patches several mm. in length.

Telcutospores clavate, dark chestnut-brown, smooth, very slightly constricted at septum, 48-6+ $\times 18-25 \mu$, average $50 \times 20 \mu ;$ upper cell truncate or conoirl, oceasionally rounded at apex, thickened (up to ? $\mu$ ) ; low(r cell generally attenuated towards base, sometimes rounderl and generally longer than upper ; pedicels persistent, tinted or hyaline, up to $35 \mu$ long.

X. Nesuspores not uncommon, similarly coloured to telentospores, ellipsoid, either rounded or pointed, and thickened at apex, $28-30 \times 14-19 \mu$.

On Brechycume, rilinis Less., T., 1II., and B. pachyptera Turez., I. Victoria-Dimboola, May-only, 1896 and 1898 (Reader).

On limeluycome sinpiformis DC. and B. dirersifolia, Fischer and Mev. Victoria-Buflalo Ranges, Dec., 1904, I., III. (C. French, jun.).

Dorluce filum Cisst., is a very common parasite on the aecidia.

(Plate V'III., Fig. 66.) 
76. Puccinia calendulae MrcAlp.

Calendula.

McAlpine, Proc. Linn. Soc. N.S. W. XXVIII., p. 558 (1903).

Sydow, Mon. Ured. I., p. 852 (1904).

Sacc. Syll. XVII., p. 280 (1905).

Aecidium calenclulae McAlp. Agr. Gaz. N.S.IV. VIT., p. $152(1896)$.

I. Aecidia amphigenous or on stems, orange-yellow, in clusters up to $6 \mathrm{~mm}$. diam, sometimes circinate, or may be scattered irregularly ; pseudoperidia with white, torn and reflexed margin; peridial cells quadiate or polygonal, striated at margin, $21-24 \mu$ long.

Aecidiospores very irregular, sub-globose to polygonal, very finely echinulate, pale orange, $14-17 \times 11-12 \mu$ or 12-16 $\mu$ diam.

III. Teleutosori intermixed with aecidia, black, erumpent, soon naked, girt by the ruptured epidermis, circular to elliptical, minute, compact, often confluent.

Teleutospores yellowish-brown, clavate to oblong clavate, constricted at septum, rounded or acute at apex and thickened (up to $12 \mu$ ), attenuated towards base, smooth, 36-52 $\times 19-23 \mu$, average $48 \times 20 \mu$; upper cell darker in colour and broadler than lower, 21-31 $\mu$ long; lower cell shightly or not at all tapering towards pedicel and averaging same length as upper; pedicel persistent, hyaline, but coloured towards apex, $28-37 \times 7-8 \mu$, but may attain a breadth of $10 \mu$ at junction with spore.

$X$. Mesospores not uncommon, similarly coloured to teleutospores, ovate to elliptical or pear-shaped, thickened at apex, 30-42 $\times$ $21-23 \mu$.

On leaves and all green parts, including fruits of Calendula officinalis $\mathrm{L}$. Victoria-Near Melbourne, growing in gardens, 189-2 dc. Killara, July-Oct., 1902. Geelong, Nov., 1901, I., 1II. (Pescott). Frankston, August, 1904 , I.

Aecidial stage all the year round, but less common in mid-summer, persisting only in shady gardens. Teleutostage from March to November.

The aecidial stage was the only one found at first, and was described in the Agricultural Gazettz of New South Wales for 1896 at p. 152. Then in March, 1902, the teleutostage was found by Mr. G. H. Robinson, and was very plentiful. Both stages very common in University Gardens, Melbourne, in autumn and winter of 1905 . Mesospores germinating at apex like teleutospores, and producing sporidiola.

It causes swelling, discoloration and distortion of the flower-stems and leaves, and the bright orange colour of the aecidia on the leaves at once attracts attention from its harmonising with the flower-head.

(Plates VIII., Fig. 65; XLIII., Fig. 312; Plate E., Figs. 22, 23.)

77. Puccinia calocephali McAlp.

Calocephalus.

I. Aecidia very sparse on upper surface of hairy leaves, about $\frac{1}{3} \mathrm{~mm}$. diam.; pseudoperidia saucer-shaped, laciniate at margin; periclial cells, oblong to lozenge-shaped, striated, $25-32 \mu$ long. 
Acridiosjores sub-globose to angular, orange-yellow, smooth, showing up to 4 germ-pores on one face, $16-19 \times 12-13 \mu$ or $1+-16 \mu$ diam.

III. Telentosori black to blackish-brown, long covered by learlen epidermis, pulvinate, compact, round to elongated, sometimes confluent, $1-1 \frac{1}{2} \mathrm{~mm}$. long.

Treleutospores clavate, dark brown, particularly in uppor erell, slightly constricted at septum, smooth, $10-57 \times 17-24 \mu$, average $45 \times 22 \mu$; mper cell rounded, scoop-shaped, sometimes truncate and thickened at apex (up to $11 \mu$ ): lower cell yellowish hrown, atteruated towards base; pedicels persistent, tinted to hraline, uj to $35 \mu$ long and sometimes $10 \mu$ broad.

X. Mesmines common, elongated, elliptical to oblong, generally paler than teleutospore, thickencod at apex, and generally scoop-shanerl, $25-35 \times 13-16 \mu$. Less.

On leares and stem of Calocephalus drummontii Benth., and C. lacters

Victoria-Dimboola, Sept., 1891, III. (Reader). Phillip Island, Nor, 1901, I. (C. French, jun.)

The teleutosori anrl teleutospores grenerally resemble those of $I$ '. fusmanica liet., but they are not intermixed with aecidia. They both belong, however, to the same general type.

(Plate VIT., Fig. 5.s.)

\section{Puccinia calotidis McAlp.}

Calotis.

T. Aecidia amphigenous, in irregular clusters, orange; pseudoperidia cup-shaped, with whitish, reflexed, laciniate margins.

Aecidiospores subglobose to polygonal, finely echinulate, $13-1+\mu$ diam., or $13-15 \times 12 \mu$.

IIT. Teleutosori minute, black, ermmpent, gregarious, compact. 'Teleutospores dark chestmut-brown, oblong to elongated oblong or clavate, smooth, constricted at septum, romded or bluntly pointed and thickened at apex (up to $9 \mu$ ), $37-50 \times 15-29 \mu$, average

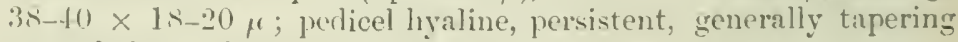
towards base, about $30 \mu$ long, or shorter than spore.

X. Mesuspores not uncommon, similarly coloured to teleutospores, and stalked, olowoid to ellipsoid, rounded or bluntly pointed and thickened at apex $(6-8 \mu), 28-37 \times 15-1=\mu$.

On Colutis cunnifolin R. Br. and C'alutis sp.

New South Wales-Guntawang, Sept., 1s,6 (Hamilton). Condoblin, Aug., $1 \leq 297$ (Maiden).

The taleutespores generally resemble those of $P$. rittadiniae, but thes are longer on the arerage. 
Chrysanthemum.

79. Puccinia chrysanthemi Roze.

Roze, Bull. Soc. Myc. France, p. 92 (1900).

Sydow, Mon. Ured. I., p. 46 (1902), p. 854 (1904).

Sace. Syll. XVI., p. 296 (1902).

P. chrysanthemi chinensis P. Henn. Hedw. XI., p. (26) (1901).

II. Uredosori on both surfaces of leaf, but mostly hypophyllous, sparingly on stem, generally round, soon naked, powdery, scattered or crowded, often confluent, sometimes arranged circularly, snuff brown, arerage $1-1 \frac{1}{2} \mathrm{~mm}$. cliam., causing dirty-brown, indefinite spots on upper surface of leaf, which gradually extend and ultimately decay.

Uredospores ellipsoid to obovoid, yellowish-brown to goldenbrown, echinulate, with 3 equatorial germ-pores on one face, $28-35 \times 22-25 \mu(32 \mu$ long very common, occasionally reaching a length of $t 5 \mu$; pedicels hyaline, rarely persistent, stout, long, up to $60 \mu$.

[III. Teleutosori on both surfaces of leaf, but chiefly on under surface, prominent, roundish, pulvinate, solitary or confluent in groups, often concentrically arranged, dark-brown to black, soon naked, compact.

Teleutospores at first sparingly intermixed with uredospores, ellipsoid to pear-shaped or clavate, rounded or occasionally truncate at apex, and thickened (up to $9 \mu$ ), mostly rounded at base or sometimes slightly attenuated, chestnut-brown, with strong, finely punctulate epispore, $35-60 \times 19-28 \mu$; pedicel hyaline, stout, persistent, $40-80 \times 7-9 \mu$.]

[X. Mesospores rare, ellipsoid to clavate, similarly coloured to teleutospores, rounded and thickened at apex, finely punctulate, $28-46 \times$ $22-25 \mu$.

On cultivated Chrysanthemums (Chrysanthemum indicum L.).

New South Wales-Sydney Botanic Gardens, April, 1904 (Maiden). Sychey, May, 1904.

This species has been assigned to $P$. hieracii by Massee, but Jacky $1,2,3$ has shown, by means of infection experiments, that it confines itself to the one genus, and does not infect other Compositae. He has also experimented with the Japanese chrysanthemum rust, $P$. chrysanthemi-chinensis $P$. Henn., and proved it to be the same species as the other.

Through the kindness of Professor Ideta, of the A cricultural College, Osaka, Japan, I have receired abundant material of the Japanese rust, both in its uredo and teleuto stages, and am thereby enabled to compare it with the rust occurring in Australia, as far as the uredo stage is concerned. The uredospores are quite similar, having three equatorial germ-pores on one face, and measuring $28-37 \times 22-25 \%$. Jacky ${ }^{3}$ succecded in infecting C. indicum L., with material from $C$. sinense Sabine, and thus showed the identity of the two rusts, although apparently in Europe and Australia it is gradually losing the capacity to form teleutospores. Indeed, Niss Gibson ' goes so far as to say that there is no nccessity for resting-spores, for the young shoots are above ground long before the old ones die away, and these young shoots are taken as cuttings, so that there is no time when there are no leaves upon which the rust can live. 
Tire sam? author also resurds tho fiut that there are certain varieties of chrysanthemum which do not take the rust, although growing among plants badly rusted, but . Jacky" tested a number of different varieties and found them equally predisposed to the rust.

Our chrysinthemum grower's som times express a fear that the rust seen on hollyhock, sunfiower, and other plants may pass to the chrysanthemum when it has suddenly bacome temporarily weak through drought or other causes; but it ought to reassure them to know that the specific rust, known iss Presenie rhrysenthemi, is alone capable of producing infection on that particular lust.

In the Europan miterial Jacky detected what he considers to be twocelled uredospores, but Sydow regards them as two unicellular spores stuck together. It $m$ uy ba mentioned here to show the wonderful variety, that in the Japanesc material I found two uredospores borne on the same stalk, the one slightly beneath the other.

The teleutosjore is sometimas described as smooth, but by careful focussing it may be seen to be finely punctulated all over in the young stage, although in the maturo and deeply-coloured spore this is difficult to see, only being visible on the thickened apex.

The mesospores were obtained from the Japanese material, and are rather jarc.

This rust was probably introduced into Europe from Japan, and it may have reached Australia either from Europe or Japan. It is strange that the rust has not yet found its way into Victoria, considering the number of chrysantliemums imported from England, France, America, and Japan.

It was first observed in England in 1895 , although it probably existed there before that time; in America in 1896; in France and Italy in 1897 ; and about 18.98 it spread to Germony, then to Denmark and Switzerland, and at length it has found its way to Australia. In 1904 it was also recorded for New Zcaland by Kirk.

It is found that muny of the Australian-raised varieties are less liable to rust than others when grown in England or America.

(Plate XXIX., Figs. 251-2うう; Plate E., Fig. 21.).

\section{Puccinia cichorii (DC.) Bell.}

Cichorium.

Bell., in Kickx. Fl. Fland. H. p. 65 (1867).

Sydow, Mlon. Ured. 1., p. 49 (1902).

Sace. Syll. VII., p. 606 (1888); XYII., p. 311 (1905).

II. Credosori amphigenous or on stem, minute, pulverulent. scattered or: conlluent, grit or partially corered by ruptured epidermis, (inn:แmon.

Uredospores globose, subglobose or ellipsoid, echinulate, yellowish-bown, with one or two germ-pores on one face, sometimes ilree to four, $22-29 \times 19-23 \mu$, or $22-25 \mu$ diam.

JiT. 'l'etentosori similar, clark-brown.

Telentospores intermixed sparingly with uredospores, ellipsoid or ovatedlipsoisl. brown to golilen-bown, smooth, not or hardly comstricted at septum, apex rounded not thickened, base for the most part rounded or very slightly attenuated, epispore thin, germ jore in ach all prominent, with fimely gramular contents. $27-38 \times 19-25 \mu$, oceasionally wehing 50 i long. but averaging 3.) \times 20 \mu$ : pedicel hyaline, short. 
On leaves and stems of Cichorium intybus L.

Victoria-1885 (Mueller ${ }^{3}$ ) II. Near Melbourne, Aug., 1896. Phillip Island, Jan., 1900 ; March, 1904.

The uredospores were common chiefly on the leaves, but the teleutospores were rather scarce, and occurred mostly on the midribs. Fischer ${ }^{5}$ describes the teleutospores as being finely warted, while Sydow considers them to be smooth. When the uredo and teleutospores are examined together, as they often occur in nature, the forner are seen to be covered with decided prickles, which project from the margin, while the latter have fine points on the surface, which are only to be seen at the margin by careful focussing.

Although no mesospores were met with there were sereral cases where the upper cell of the teleutospores was colourless, shrivelled, and much reduced in size, while the lower cell was enlarged. The two cells are generally equal in length, but in one of the cases referred to the lower cell was $25 \mu$ long, and the upper colourless one only $6 \mu$.

Darluca filum Cast., was plentiful on the uredosori and the sori containing uredo and teleutospores intermixed.

(Plate VIII., Fig. 61 ; Plate D., Fig. 18.)

\section{Puccinia cinerariae $\mathrm{MIcAl}$ p.}

Cineraria.

I. Aecidia on both surfaces of the leaf, running along veins and gregarious, causing depressions on upper surfice and swelling of the reins on under surface, $\frac{1}{3} \mathrm{~mm}$. diam.; pseudoperidia very slightly projecting, with margins white, everted, fimbriate; peridial cells roughly quadrangular, often rounded at one end, longer than broad, with radiating marginal lines, $22-26 \times 19-21 \mu$.

Aecidiospores bright orange, subglobose to polygonal, rery finely verrucose, $15-19 \mu$ diam. or $15-17 \times 13 \mu$.

III. Teleutosori intermixed with aecidia, black, comparatively rare.

Teleutospores clavate, chestnut-brown, generally rounded and much thickened at apex or bluntly pointed, occasionally truncate, constricted at septum, 36-5t $\times 17-2 t \mu$, average $40 \times 23 \mu$; upper cell usually darker in colour, hemispherical, apex thickened to a depth of $9 \mu, 17-24 \mu$ long; lower cell gradually tapering towards base, somewhat triangular, $18-30 \mu$ long; pedicel persistent, tinted, up to $15 \mu$ long.

X. Mesospores chestmut-brown, obovate to elongated elliptical, much thickened at apex, with long pedicel, $27-36 \times 13-23 \mu$.

On leares of cultivated Cineraria.

Tietoria-In nursery near Melbourne, April, 1899 (Cronin).

The following note accompanied the specimen:-The plants were grown under glass, and were generally very healthy. There are not many leaves so affected owing to the care that is taken to cut out the spots as soon as noticed. The disease spreads rapidly if neslected, and completely spoils a plant by denuding it of its foliage.

Cacoma cinerariae Rostr., was found on leares and stems in Jutland. 
8.2. Puccinia cyani (Schleich.) Pass.

C'entaureu.

Passerini in Rabh. Fung. Eur., No. 1767.

Sydow, Mon. Ured. I., p. 38 (1902).

Sace. Syll. VII., 1. 634 (1888); XVII., p. 206 (1905).

II. Crerlosori mostly hypophyllons, scattered or crowded, minute, orbicular or elliptic, pulverulent, reddish brown.

Credospores yellowish brown, globose, subglobose to ellipsoid finely cchinulate, with two germ-pores on one face, 25-27 $\times$ $19-24 \mu$.

III. Teleutosori ampligenous, and on stem, scattered, pulverulent, dark-brown, orbicular to elliptic, soon naked, $111 \mathrm{~m}$.

Teleutospores intermixed with uredospores, ehestnut-brown, ellipsoid, rounded at both ends, unthickened at apex, not constricted at septum, delicately warted, germ-pores conspicuous, $30-40 \times 22-30 \mu$, average $32 \times 24 \mu$; epispore about $3 \mu$ thick; pedicel hyaline, short, deciduous.

On leaves and stems of C'enturere cyrmus L.

Victoria-Near Melbourne, Jan. and Feb., $190 t$ (C. French, jr.).

This is evidently of the Puccinia hierrecii type.

The teleutospores are very regular and well defined, and there is no tendency to abnormality.

(Plate VIIT., Fig. 64.)

\section{Puccinia distincta MeAlp.}

Bellis.

Medlpine, Agr. Gaz. N.S. WY. VI., p. 853 (1895).

Sydow, Mon. Ured. I., p. 29 (1902), and p. 850 (190t).

Sace. Syll. XIT., p. 311 (1899).

I. Aecidia seated on discoloured spots, amphigenons, arranged in a circinate manner, or irregularly disposed, and often distributed over entire surface; pseudoperidia cup-shaped, with reflexed torn margins, alout $\frac{1}{4}-\frac{1}{2} \mathrm{~mm}$. diam. ; peridial cells elongated elliptical to oblong, punctulate all over, $25-29 \times 13-19 \mu$.

Aecidiospores subglobose to oval or ellipsoid, orange-rellow, very finely echinulate, $1+-19 \mu$ diam, or $1+-20 \times 13-16 \mu$.

III. Teleutosori intermixel with and often surrounding accidia, brownish black, oval, $12-1 \mathrm{~mm}$. long, generally contluent, bursting through and surrounded by the leaden-coloured epidermis.

Teleutospores cliestnut-brown, clavate or oblong clavate, at tenuated at base, smooth, constricted at septum, $3 t-50 \times$ 1.5-:-1 $\mu$, average $42 \times 17 \mu$ : upper cell gencrally darker in colour than lower, rounded and thickened at apex (up to $9 \mu$ ): pedicel persistent, pale yellow or coloured similarly to lower eell, "1p to $50 \mu$ long.

X. Mesospores numerous, elongated clavate to sumewhat ovate, chentnut brown, usually thickencel at apex, $34-37 \times 13-16 \mu$.

On leaves, scapes, involuce and petals of bellis permis $\mathrm{L}$.

Victoria-Nor Molbourne, Oet., 1.992, July-Oct., 1904, I., 11 I. (liobinson). Kiorumburra, May, 190:3, i. 
Tasmania-Near Huon Road, Nor., 1890, I. (Rodway).

Sonth Australia-Norwood, April, 1903, I., III. (Tepper). Port Pirie, Oct., 1903, i., III. (Dickens).

Aecidiospores abundant from April to September, and even to January. The aecidia may even occur on the petals, and they have been described before the Microscopical Society of Victoria as early as 1880 .

Teleutospores in Ostober or November, although they occur sparingly as early as April. The spots are generally pale-yellowish to pale greenish in colour. This aecidium from Victoria was determined by Cooke as A. bellidis 'Thuem., which belongs to P'. obscura schroet., but now that the telentospores belonging to it have been found on the same host-plant the Precinia is seen to be a distinct species.

(Plate VIlI., Fig. 67 ; Plate E., Fig. 26.)

\section{Puccinia erechtitis $\mathrm{MIcAl}$.}

Eirechtites.

MeAlpine, Proc. Roy. Soc. Tic. VIT., N.S., p. 216 (189t).

Sydow, Mon. Ured. I., p. Ts (1902).

Sacc. Syll. XTY., p. 309 (1899).

O. Spermogonia on brownish patches on upper surface of leaf, in groups, brown to honey-colour, yellowish by transmitted light.

Spermatia hyaline, oval, :3 $\mu$ long.

I. Aecichia on stem and leaves, causing distortion and swelling, paleyellow at first, becoming orange-yellow, arranged close together in lines or irregularly; pseudoperidia cup-shaped, with white, torn, revolute edges; peridial cells firmly united, warted all over, lozenge-shaped, and nearly iso-diametric, or elongated and oblong, with striated margins.

Aecidiospores variable in shape, imegularly globose or elliptic orange-yellow, smooth, $16-19 \times 12-17 \mu$.

III. Teleutosori long corered by epidermis, crowded together, pulvinate, black.

Teleutospores clarate to oblong, yellowish-brown, constricted at septum, smooth, $41-57 \times 17-25 \mu$, average $47 \times 19 \mu$; upper cell dark-brown, rounded or pointed, occasionally truncate and thickened at apex; lower cell usually yellowish-brown and tapering towards base, elongated wedge-shaped; pedicel persistent, paleyellow or hyaline, up to $40 \mu$ long and $9 \mu$ broad.

X. Mesospores common, coloured like teleutospores, elongated oblong or oval, thickened at apex, $32-43 \times 13-17 \mu$.

On leaves and stems of Erechtites quadridentata DC., and E. arguta DC. Victoria-Ardmona, Dimboola, Myrniong, and Marrsville, Alp̣s near Bright, and Mt. St. Bernard, de.

On E. puadridentata, E. arguta and E. prenanthoides DC. Tasmania-Huon Road, Dec., 1891, March, $1 \unlhd 93$, I. (Rodway).

On Evechtites sp.

New South Wales-Guntawang, I. (Hamilton).

I. Very common all the year round, except during midelle of summer.

III. From January to June, but not so common.

The New South Wales specimen was named Aecidium sonecionis Desm. by Cooke.

(Plates VII., Fig. 59; XXVII., Fig. 240.) 
85. Puccinia gnaphalii (Specg.) P. Henn.

G'naphalium.

Hennings, Hedw. XLI., p. (66) (1902).

Morrison, Vietorian Nat. XI., p. 120 (1894).

Sydow, Mon. Ured. I., p. 88 (1902).

Sitec. Syll. XV ., p. 295 (1902).

Uredo gnaphalii Speg. Fung. Arg. IV., p. 28 (1882).

Puccinire gnaphaliicola P. Henn. Hedw. XXXVIII., p. (68) (1899).

II. Uredo-sori eommon on stem and leaves, on the latter amphigenous, but mostly on under surface, bursting through and surrounded by epidermis, also piercing woolly tomentum, scattered, sometimes asgregated, compact, einnamon, cireular or oval, lenticular on stem, $\frac{1}{2}-\frac{1}{3} \mathrm{~mm}$. diam.

Uredospores glubose, sub-globose ur ellipsoid, brown, finely echinulate, $21-24 \mu$ diam. or $21-26 \times 17-21 \mu$.

III. Teleutosori similar, but chestnut-brown to black.

Teleutospores at first intermixed with uredospores, oblong $\mathrm{Or}^{\circ}$ oblong-elavate, dark chestnut-brown, slightly eonstricted at septum, rounded or obtusely pointed or even beaked at apex, and thickened (up to $S \mu$ ), usually slightly attenuated towards base, smooth, $35-53 \times 15-24 \mu$, average $4.8 \times 20 \mu$; pedicel hyaline, persistent, up to $66 \times 8 \mu$.

X. Mesospores similarly coloured, few, oral or elongaterl, elliptical, thickened at apex and sometimes beaked, $24-38 \times 15-18 \mu$. Thumb.

On stems and leaves of Gnaphalium purpureum L., and G. japonicum

Victoria-Oakleigh, Jan., 1904 (Morrison). Drysclale, Jan., 1896, and Oet., 1903. Whittlesea Ranges, Nor., 1898 (C. French, jun.) Killara, Oct., 1902. Near Melbourne, Feb. and Nov., 190 t. Murramurrangbong Ranges, Nov., 1904 (Aitken).

The teleutospores are rather variable in length and breadth, sometimes being short and stout and sometimes rather elongated and slender. The perlicels average $40-50 \mu$ in length, and may vary in breadth trom $4 \mu$ up to $10 \mu$ at junction with spore. Sydow gives size of teleutospores as $32-56 \times$ $18-24 \mu$, and Dietel as $30-35 \times 19-2.1 \mu$.

I am indebted to Dr. Mlorrison for some of the original material from which he determined this fungus as $I^{\prime}$. investita Schwein. He found spermogones immersed among spores in the sori, and the spermatia were fusiform. Plenty of Dorluca filum Cast., was found, and nu doubt these were nistaken for spermogonia.

(Plate VII., Fig. j̃.)

\section{Puccinia helianthi Schwein.}

IIelianthus.

Schwoinitz, syr. Carol., p. 73 (18:21).

Cooke, Handb. Anstr. Fune., p. 33:3 (189:).

Sydow, Mon. Ured. T., p. 9: (1902).

Siace. Siyll. VII., p. 603 (1sss).

[O. Spermogonia honey-colored, in small clusters.]

[I. Aecidia cloweded or orlsicular', or armanged in broadly expanded, oblong spots; pseudoperidial cylindrieal, plane, with white laciniate matrins. 
Aecidiospores orange-reck, ellipsoid to polygonal, finely echinulate, $21-28 \times 18-21 \mu$.]

II. Uredosori roundish, chestnut-brown, scattered or confluent, pulverulent, often on yellow or pale green spots on upper surface of leaf but generally forming brown inass on under surface.

Uredospores sub-globose, elliptic or obovate, golden-yellow, echinulate, epispore sub-hyaline, showing one germ-pore on one face, $21-24 \mu$ diam. or $24-29 \times 15-22 \mu$.

III. Teleutosori roundish, dark-brown or black, prominent, scattered at first but ultimately in clusters, confluent, dotting both surfaces of leaf, but most prominent on under.

Teleutospores at first intermixed with uredospores, chestnutbrown, oblong-elliptical or pear-shaped, smooth, but occasionally a little rough at apex, slightly constricted at septum, thickened at apex $(6-9 \mu)$, generally rounded at base, $36-50 \times 21-27 \mu$, average $44 \times 26 \mu$; upper cell similar in colour or just a shade darker than lower, and rather larger, 22-29 × 21-27 $\mu$; lower cell either the counterfeit of upper or slightly tapering towards base, $17-23 \times 20-22 \mu$; pedicel hyaline, persistent, generally much longer than spore, up to 90 and $110 \mu$ long.

On leaves, branches, involucral bracts and corolla-leaves of Helianthus annuus L., and $H$. tuberosus $\mathrm{L}$.

Victoria-Very common, December-April.

New South Wales-Mudgee and Guntawang, Feb., 1887 (National

Herb.) (Hamilton). Sydney Botanic Gardens, Feb., 1901.

Queensland-Ipswich, 1888, Bailey5 ; Brisbane, 1889.

This rust was first observed in South Carolina and Pennsylvania, then it appeared in Russia where the sunflower is largely cultivated, and soon it spread over Europe, extending to Australia. The teleutospores are very regular and definite in shape.

Aecidia have not been found in Australia, although the rust is plentiful.

Sydow in his Monograph comes to the conclusion that this species possesses no aecidial stage, since he has examined specimens from numerous localities without result, but Carleton ${ }^{3}$ has collected the thee stages in America and remarks:- "The aecidium occurs rarely in comparison with the occurence of other stages, but it is to be found on a number of hosts and occasionally in considerable abundance. This rarity of its occurrence, together with the occurrence of spermogonia so often with the uredo, may be accounted for by the fact that the uredo is often produced by direct teleutosporic infection."

According to Woronin ${ }^{1}$ the teleutospores germinate equally well whether they have been kept dry in a room or taken from leaves which had lain under the snow throughout the winter. Carleton ${ }^{2}$ says that they also germinate at once without a resting period.

(Plate VII., Fig. 56.)

87. Puccinia hypochoeridis Oud.

IIypochoeris.

Oudemans in Nederl. Kruidk. Arch. II., Ser. 1, p. 175 (1873).

Sydow, Mon. Ured. I., p. 100 (1902).

Sacc. Syll. TII., P 634 (1888); XVII., p. 302 (1905).

Puccinia microseris McAlp., Agr. Gaz. N.S.W. VI., p. 757 (1895). 
II. Urerlosori amphigenous or frecuently on stem, renerally seated on minute spots, scattered, pulverulent, cinnamon-brown.

Uredospores globose, sub-globose or ellipsoicl, echinulate, palebrown, with one prominent germ-pore on one fiace, $21-25 \mu$ diam. or $20-28 \times 18-2+\mu$.

TIT. Teleutosori amphigenous, often on stem, scattererl or crowderl, punctiform, blackish to dark-biown, pulverulent, generally romnclish on leaf and up to $1 \mathrm{~mm}$. diam., lut often smaller, elongaterl on stem and up to $2 \mathrm{~mm}$. long.

Teleutosporss at first intermixed with uredospores, oblong, ellipsoid or olwrate, apex gencrally rounded, and not thickened, rominded at base or slightly attenuated, hardly constricted at septum, dark-brown, very delicately punctate, occasionally tricellular, $30-49 \times 17-2+\mu$, arerage $32 \times 20 \mu$; pedicel hraline, senerally deciduous, sometimes persistent and nlay reach a length of $77 \mu$.

On $H_{y j p h}$ horis radicate L., very common.

Victoria-Dimboola, Nov., 1889 (Rearler). Arrlmona, 1894 (Pobinson). Mrrniong, March, 1900 (Brittlebank). Year Melbourne, Apr., 1901. Dookie, Oct., 1903. Altona Bay, Oct., 1903 (C. French, jun.). Murranurrangbong Ranges, Dec., 1903 (Robinson).

New South Wales-ITagoa (Maideu).

On H. glabra L.

Victoria-Dimboola, Nov., 18s9, and .July, 1892- (Reader).

Queensland-Brisbane, 1886 (Bailey ").

The punctation on the teleutospores is su fine that it may easily be orerlooked, but when the spores are mounted in water it is clearly seen.

A specimen from Syd. Ured. Exs. 673 on $H$. glabra asreed very closely, the uredospores being on an average $2.5 \times 21 \mu$, and the teleutospores :3 4 × $18 \mu$.

This species closely resembles in morphological characters $P$. hieracii (Schum.) Mart., but Jacky has shown by means of cultures that the latter can only grow on Hierccium species, and cimnot be transferred to othel genera of Composites. Occasionally there may be a three-eelled teleutospore reaching a length of $56 \mu$.

P. microseris clescribed as a new species in the Agricultural Gazette of New South Wales was based upon a wrong determination of the host-plant ljy the collector since it was afterwards found to be Hypochoeris radicata $\mathrm{I}$.

Derlucu filnm Cast., is sometimes common on the mixed uredo and teleutosori.

$$
\text { (Plate VIII., Figs. 62, 63.) }
$$

\section{ss. Puccinia kalchbrenneri De Toni.}

Ilelichry:um.

De Toni in Sace. Sirll. VII., p. 64.5 (188s).

Cockle, Haudb. Austr. Fung., l. 3:37 ( $1 \leqslant 902)$.

Sydow, MIon. Urerl. I., p. 93 (190:).

II. [redusori on both surfaces, but mostly on under, seater on indeterminate spots which are often confluent and rariously coloured, scattered or urearious, minute, at first corererl, convex, firm, ultimately free and discoid, ocharacens. 
Uredospores globose, subglobose or ellipsoid, warted, yellow to pale brown, $20-30 \times 19-26 \mu$.

III. Teleutosori hypophyllous, seated on the same spots, minute, brown.

Teleutospores oblong or subclavate to lanceolate, apex thickener, attenuated or rarely truncate, constricted at septum, smooth, dark-brown, $40-57 \times 15-22 \mu$, rarels up to $27 \mu$ broad; pedicel hyaline, short, deciduous.

On living leares of Helichrysum sp.

Tictoria.

There is no specimen of this species from Australia in the Kew Herbarium, and I have not found it on any species of Helichrysum, though this genus is exceedingly common near Melbourne.

89. Puccinia lagenophorae Cooke.

Lagenophora.

Cooke, Grev. XIII., p. 6 (1884).

Cooke, Handb. Austr. Fung., p. 335 (1892).

Sydow, MIon. Ured., I., p. 111 (1902), and p. 863 (1904).

Sacc. Syll. VII., p. 612 (1888).

P. hypochoeridis McAlp., Proc. Roy. Soc. Vic. VII., N.S., p. 217 (1894).

P. macalpini Sydow, MIon. Ured., T., p. 100 (1902).

I. Aecidia amphigenous, spots none; pseudoperidia scattered or in groups, semi-immersed, margin lacerated, white, 200-2t0 $\mu$ diam.; peridial cells finely warted, lozenge shaped or elongated, 24-31 $\mu$ long.

Aecidiospores subglobose or elliptical, orange-yellow, very finely echinulate, $12-14 \mu$ diam. or 17-19 $\times 14 \mu$.

[II. Uredosori scattered, small, pulvernlent, brown or mixed with teleutosori.

Uredospores globose, brown, epispore rough, $20 \mu$ diam.]

III. Teleutosori amphigenous, scattered, or surrounding aecidia, rather compact, dark-brown to black, raising and rupturing epiciermis.

Teleutospores clavate, constricted at septum, dark-brown onls in upper cell, epispore thickened, smooth, $45-66 \times 16-22 \mu$, average $49 \times 17 \mu$; upper cell subglobose or oblong or somewhat conical, rounded, flattened, or bluntly pointed at apex, which is considerably thickened, generally equal in length to lower cell; lower cell pale in colour, attenuated into pedicel and narrower than upper cell; pedicel persistent, generally slightly tinted, attaining a size of $4.2 \times 7 \mu$.

I. Mesospores relatively numerous, pale coloured, elongated elliptical, thickened at apex, with persistent hyaline pedicel, $38-42 \times$ $16-17 \mu$.

On stems and leaves of Lugenopleora billardieri Cass.

Victoria-Omeo, 1884 (Stirling). Ardmona, Oct., 1894 (Robinson). Near Melbourne, Sept., 1900, I. (C. French, jun.) Murramurrangbong Ranges, Nor., 1902, Dec., 1903, Jan., 1905 I., III. (Robinson). 
On L. huegelii Benth., and L. billrerdien Cass.

Tasmania-Mt. Dromedary, near Hobart, Dec., 1894, I. (Rodway'). Mt. Direstion, Oct., 1895, I., III. (Rodway'). Devonport, Jan., 1906 (liobinson).

Although material was very plentiful, careful search failer to reveal the presence of uredospores, and I have given tirem on the authority of Cooke. Massee informs me that $P$. lagenophorre Cooke, is not represented in the Kew Herbarium, and he, therefore, cannot refer to the type specimens. I have examined scores of plants with this rust upon thern from different localities and at different seasons, and I have never found urerlospores.

The leaves on which P. hypochoeridis McAlp., was found proved to be not IIyporhoeris radicata but Largenophora billardieri, and the fungus agreed with the above.

(Plate VII., Figs. 54, 5j; Plate F., Fig. 27.)

\section{Puccinia podolepidis Mis Alp.}

Podoleqis.

O. Spermogonia on small, honey-coloured spots, forming minute, darkcoloured points, hemispherical, pale yellow by transmitted light, with round mouth, without projecting paraphyses, about $120 \mu$ diam.

spermatia minute, hyaline, oval, $3 \times 2 \mu$.

I. Aecidia bright orange, on both surfaces of the leaf, numerous, generally arranged in circular groups, which, however, often coalesce into large patches; pseudoperidia cup-shaped, embedded in tissue, with white reflexed, laciniate margins; peridial cells oblong to lozenge shaped, with striated margins, $28-3.2 \times 16-18 \mu$.

Aecidiospores deep orange, ellipsoid to subglobose, smooth, $24-32 \times 16-22 \mu$, or $22-24 \mu$ dian.

III. Teleutosori black, surrounding the aecidia.

Teleutospores chestnut-brown, oblong to clavate, constricted at septum, smooth, rounded or truncate or oceasionally pointed and thickened at apex $(9-12 \mu)$, rouncled or attenuated towards base, upper cell darker than lower, 38-5 4 × $2-32 \mu$; pedicel per. sistent, hyaline, relatively short.

X. Mesospores common, similarly coloured to teleutospores or often paler, ellipsoirl, obovate to wedge-shaped or subclavate, rounded and thickened at apex, pedicellate, $32-4 t \times 16-22 \mu$.

On leaves of Podolepis longiperlatr A. Cmnn.

Victoria-Buffalo Mts., Nov, 1903, I. (C. French, jun.). Alps, near Bright, Dec, 1904, I., III. (C. French, jun.).

Several teleutospores had two germ pores in upper cell, one on either sirle, but only one in lower cell.

The telcutosori were rather sparse.

(Plate XXIX., Figs. 256, 2.7\%.)

9). Puccinia prenanthis (Pers.) Iindr.

Lactuon.

Lindrotl, Myk. Mittheil, p. 6 (1901).

Cooke, Handb. Austr. Fung, p. 334 (1s92).

Syclow, Mon. Ured. T., p. 106 (1902).

sace. Syll. IVIT., p. 306 (1905). 
I. Aecidia hypophyllous, a few rarely epiphyllous, or on petioles, seated on orbicular or elongated yellow or purple spots, up to $1 \mathrm{~cm}$. in diam., in round or irregular groups, at first hemispherical, then flat, yellow or whitish, sometimes yellowish purple.

Aecidiospores globose, subglobose or ellipsoid, delicately warted, pale orange, $13-24 \mu$ diam.

II. Uredosori hypophyllous, on pale indeterminate irregular spots, scattered, minute, punctiform, pulverulent, pale brown.

Uredospores globose or subglobose, echinulate, yellowish-brown, 16-24. diam.

III. Teleutosori similar, girt by the ruptured epidermis, dark-brown.

Teleutospores ellipsoid, rounded but not thickened at apex, mostly rounded at base, not constricted at septum, delicately warted, brown, 26-36 × 16-24 $\mu$; perlicels hyaline, very short.

On living leaves of Lactuca.

Victoria, New South Wales, S. Australia.

No specimen seen. It is given on the authority of Cooke, but Mueller ${ }^{3}$ only records the aecidial stage for Victoria. The aecidial wall is very imperfectly formed in this species, and there is a close approach to caeoma forms.

92. Puccinia tasmanica Diet.

Senecio.

Dietel, Aun. Myc. I., p. 535 (1903).

Sydow, Mon. Ǔred. I., p. 867 (1904).

Sacc. Syll. XVII., p. 277 (1905).

I. Aecidia on blister-like swellings on stem and branches, on upper and under surface of leaves, on flower-head stalks and involucre, causing discoloration and distortion, and usually surrounded by paler green tissue, about $\frac{1}{3} \mathrm{~mm}$. in diam., disposed in large circular or oval clusters or irregularly; pseudoperidia cup shaped, with white, irregularly laciniated everted edges, tubercular before opening; periclial cells firmly united, overlapping each other, with striated margins and usually broader at one end, irrlividually slippershaped, $25-3 j \times 13-17 \mu$.

Aecidiospores spherical or angular, orange colored, very delicately warted, $13-16 \mu$ diam., or 14-17 $\times 11-15 \mu$.

III. Teleutosori for a long time covered by epidermis, then erumpent and epidermis usually thrown off or remaining in shreds and patches, intermixed or running parallel with aecidia, black, pulvinate, oval, up to $1 \mathrm{~mm}$. long, often confluent in elongated lines.

Teleutospores oblong to clavate, chestnut-brown, slightly constricted at septum, smooth, 36-63 x 15-25 $\mu$, average $54 \times 20 \mu$, occasionally tricellular when $48-73 \mu$ long; upper cell deep chestnut-browl, rounded or somewhat oval, conoid, or truncate and thickened at apex (up to $13 \mu$ ) ; lower cell usually paler in colour, rounded at base or tapering, often elongated relatively to upper; pedicels persistent, pale yellow to hyaline, sometimes longer than spore.

I. Mesospores very common, elongated oval, oblong, or somewhat elliptical, apex roundect or pointed and usually thickened, goldenyellow to chestnut-brown, 29-44 $\times 13-17 \mu$. 
On leaves and stems of Senerio vulgaris $\mathrm{I}$.

Victoria (Ralph), (Rubinson), (French, junr.), \&e., I. III.

New south Wales (Hamilton), I.

'T'asmania-1891, 1893, 1595, 1R97, I. TII. (Rodway ').

On Senecio pectiurtus DC.

New South Wale;-Mount Kosciusko, Jan., 1s93, I. (Maiden).

On Semerin brachyglossus F.v.M.

Victoria-Aucrust, 1900, J. (Rearder).

On Senecio velleirides, A. Cunn.

Victoria-Sealer's' Cure, 185t. I. Port Phillip, 1886, I.

It differs from $P$. senecionis Lib., in the aeciclia being amphigenous and not hypophyllous; also in the teleutospores being considerably larger, thickened at apex, and not provirled with a hyaline papilla, while the pedicel is rlecidedly persistent and elongated. Crroundsel, or S. vulgaris, being an imported plant, and so cosmopolitan in its character, it was considered strange that a new species of rust should be found upon it, and althours I had named it in MS. I'. anstratiensis, yet I delayed publishing it under that name, hoping to find the teleutospores on a natire Senecio.

Teleutospores are very common in some localities during the winter and spring months, and the Groundsel growing on the coast at Port Fairy was so overrun with both aecidia and teleutosori that the plants were stunted in growth.

S. pectinatus DC, occurs in the three States from which Pucrinia tasmanira has been recorded, but only the aecidial stage has been met with in New South Wales.

(Plate TII., Fig. 52.)

\subsection{Puccinia vittadiniae MeAlp.}

Tittadinia.

I. Aecidia on both surfaces of leaf, but mostly on upper, scattered or in groups and confluent, minute; pseudoperidia white becoming yellowish, immersed, with lobed margin : peridial cells with striated margin in section, striae projecting and appearing as points in surface view, oblong, $25-322 \times 13-16 \mu$.

Aecidiospores yellowish, ellipsoid, very finely verrucose, 14-17 $\times$ $11-13 \mu$.

IIT. Teleutosori minute, black, sparsely developed, intermixed with arciclia.

Teleutospores dark cliestuut-brown, oblong to elongated oblong or clavate, smooth, constricterl at septum, generally rounded at base and apex, sometimes bluntly pointed or truncate, and thickened at apex $(6-9 \mu), 31-16 \times 1,-25 \mu$, average $34 \times 21 \mu$ : upper cell diuker than lower and similar or sometimes considerably broader ; pedicel liyaline, persistent, $30-40 \mu$ long, and up to $9 \mu$ broad ardjoining spore.

X. Mesmpores very common, similarly coloured to teleutospores and stalkert, oroid to eloninted ellipsoid, rounded or beaked at apex and thictened (up to $9 \mu$ ), $25-3+3+1+-17 \mu$. 
On leaves including leaf stalks of Vittadinic ustralis A. Rich.

Victoria_Dimboola, June, 1900 (lieader).

In Agr. Gaz. N.S. WT. VI., p. 757 (1895), I described a new species under the name of Aecidium vittudiniue upon a plant forwarded to me as rittadiniu australis, but which was afterwards found to be an Erechtites, so that the present description replaces the previous one.

(Plates XXXIX., Fig. 292 ; XLIII., Figs. 30s, 309.)

\section{RUBIACEAE.}

\section{Puccinia coprosmae Cooke.}

Coprosmu.

Cooke, Grer. XIX., p. 2 (1890).

Sirdow, Mon. Ured. I., p. 209 (1902).

sacc. Syll. IX., p. 300 (1891).

P. coprosmatis Morrison, Vict. Nat. XT., p. 90 (1s9t).

III. Teleutosori hypophyllous, sometimes epiphyllous, rusty-brown, prominent, compact, round or elliptic, usually in groups, sometimes forming mammilated tubercles, rarely solitary, densely crowded and confluent, sometimes surrounded by the ruptured epidermis or naked and deforming the leaves.

Teleutospores elongated oblong to clavate, pale yellowish to brownish, the two cells about equal and more or less ovate, apex bluntly pointed or rounded, thickener, (from 6-8 $\mu$ ), rounded or slightly tapering at base, smooth, constricter at septum, $35-51 \times 16-22 \mu$, average $43 \times 18 \mu$; perlicel hyaline, persistent, elongated, up to $110 \mu$ long and \& $\mu$ broad.

I. Mesospores common, similarly coloured to teleutospores, ovoid to ellipsoid, or somewhat fusoid, usually pointed and thickencel at apex, $32-41 \times 19-22 \mu$.

On leaves of Coprosma billardieri. Hook.

Victoria-Kew and Dandenong, Oct. and Feb., 1893.

Tasmania-( Rodway'1).

On Coprosmu hivella Labill.

Tictoria-Murramurrangbong Ranges, Dec. 1903, Jan. 1905 (Robinson).

I am indebted to Dr. Morrison for some of the original material on which he founded his new species 1 '. coprosmatis, but it is iclentical with the above species first determined by Dr. Cooke on Coprosma lucida from New Zealand.

Darluca fllum Cast., was very plentiful on the telentosori on Coprosmu billardieri, and was described by Morrison as a spermogone witlı spermatia.

$$
\text { (Plate X., Fig. Ts.) }
$$

95. Puccinia oliganthae MeAlp.

Asperula.

II. Uredosori hypophyllous, cinnamon-brown, round to ellipsoid, soon naked, girt by the ruptured epidermis, confluent into elongated patches. 
Uredospores globose to shortly elliptical or obovate, goldenbrown, finely echinulate, one to two germ-pores on one face, $25-29 \times 2.2-25 \mu$, or $25-27 \mu$ diam.

III. 'Teleutosori on stems, dark-brown to black, elongated, bullate, soon naked, compact, $2 \mathrm{~mm}$. long or more.

'Teleutospores narrowly clavate to oblong, brown, constricted at septum, thickened at apex $(9-10 \mu)$, and rounded or bluntly pointed, or may lo truncate, lower cell generally attenuated towards base aud paler in colour, 32-54 $\times 16-21 \mu$, average $48-16 \mu$; pedicel yellowish, persistent, up to $45 \mu$ long.

I. Mesospores oecasional, similarly coloured to teleutospores, somewhat fusiform, with pointed and thickened apex, 28-32 × 12-13 1 .

On stem and leaves of Asperula oligantha F. $\mathrm{r}$. M.

Victoria-In shady gullies of Murramurrangbong Ranges, Nor., 1902 (Robinson).

'The cxamination of specimens of $P$. punctata Link, on species of Asprarula from Exsice. Syrlow Ured. 465, 466 , showed that the two were distinct. In $P$. oligantha the uredospores are broader, and while the teleutospores average only about $16-18 \mu$ broad, in $I^{\prime}$. menctata they are about 20-22 $\mu$. In the latter tor the apex is much thicker, reaching up to $16 \mu$. The species closely resembles I'. asperulas odoratae Wurth, but aecidia are present on the latter, and the teleutospores are only thickened at the apex to the extent of $7 \mu$.

(Plate X., Fig. 77.)

96. Puccinia operculariae (Morr.) Sỵd.

Opercularia.

Morrison, Vietorian Nat. XI., p. 119 (1894).

Sydow, Mon. Ured. I., p. 2:4 (1902).

Since. Syll. XIV., p. 321 (1899); XTII., p. 317 (1905).

Aecidium cystoseiroides Berkeley, Fl. Tasm., p. 270 (1ミ60).

T. Pustulate, deforming the leaves ; pseudoperidia immersed.

Aecidiospores orange, subangular.

T1I. 'Telentosori hypophyllous, on orbicular brownish to yellowish spots, solitary or a few together, round or elliptic, compact, reddishhrown, girt or partially eovered by the ruptured epidermis, up to $2 \mathrm{~mm}$. long.

'T'eleutospores golden-bı own, oblong to oblong clavate, constricted at septum, smootll, 35-5t $\times 14-20 \mu$; upper cell rounded or pointer and thickened at apex (up to $11 \mu$ ), about equal in length to lower; lower cell usually tapering towards base or sometimes roumled; pedicel hỵaline, persistent, s0 $\mu$ or more long and $6-i \mu$ broad.

On living leaves of Opercularia aspera Gaertu.

Victoria-Genoa River (F. I. Mueller).

On larbes and petioles of Opercularia varia Hook. f.

Victoria-Oakleigh, Nos, 1893 (Morrison).

'Tismania-Near Hobart Rivulet, Nov, 1§60, I. (Gumu), 1902 (Rorlway"). 
Morrison states that this fungus deforms the leaf and produces a concavity on the opposite side. He made this a variety of 1 . coprosmae Cooke, and certainly there is a very close resemblance, but the sori in the latter are generally in groups, and the apex of the spore is not quite so thick.

No specimens of the aecidial stage were seen, but being on the same host-plant as the teleutospores, it is included in this species.

Darluca filum Cast., is common on the teleutosori, although it is usually only found on uredosori.

(Plate XXIX., Fig. 258.)

\section{LORANTHACEAE.}

\section{Puccinia loranthicola McAlp.}

Loranthus.

I. Aecidia imbedded in raised brownish to dark brownish, often confluent cushions on one or both surfaces of leaf, orange; pseudoperidia tubular, with white, reflexed, much torn margins; peridial cells oblong, with striated margins, $43-50 \times 27-31 \mu$.

Aecidiospores ellipsoid to oblong or sub-angular, bright orange yellow, decidedly echinulate, $37-56 \times 22-31 \mu$.

II., III. Uredosori amphigenous, brownish, bullate, in scattered groups, often arranged in circles and confluent, surrounding central darker teleutosori, epidermis splitting lengthwise and persistent.

II. Uredospores orange yellow, ellipsoid to oval, obovate or oblong; coarsely echinulate, with $3-5$ equatorial germ-pores on one face, $40-65 \times 22-32 \mu$, occasionally $80 \times 22 \mu$; epispore $3-4 \frac{1}{2} \mu$ thick.

III. Teleutospores intermixed with uredospores, subhvaline, crlindrical to clavate cylindrical, smooth, slightly constricted at septum, rouncled and slightly or not at all thickened at apex, tapering slightly towards base, $65-94 \times 15-24 \mu$, oceasionally 3 -celled, when about $86 \mu$ long; pedicel hyaline, persistent, elongated up to $200 \mu$ long, and swollen towards apex up to $14 \mu$.

$\mathbf{X}$. Mesospores subhyaline and with elongated pedicel like that of teleutospore, smooth, fusoid, hardly thickened at apex, $71-77 \times$ $25-28 \mu$.

On living leaves of Loranthus celastroides Sieb., growing on Stringybark (Eucalyptus sp.).

$$
\text { Vistoria-Murramurrangbong Ranges, Jan., } 1905 \text { (Robinson). }
$$

All the stages were found on the same tree, but the aecidia on separate leaves. All the spore-forms are particularly large, a fact which probably has some relation to the peculiar nutrition of the fungus, and the height at which it occurs, some specimens being obtained fully 50 feet from the surface of the ground.

The aecidia are very conspicuous on raised cushions, with corresponding depressions on the opposite side, where aecidia may also occur.

The uredosori are of a ruddy brown, in isolated groups, generally arranged circularly and with teleutosori in the centre. Prccinia loranthi Speg., has only teleutospores, and it is doubtful if they are to be regarded as such. P. mucrocarya Rac. on leaves of Loranthus in Java has only aecidia and teleutospores.

(Plate XXXI., Figs. 268-271.) 
CMPELLIFERAE.

98. Puccinia thuemeni (Thuemen) McAlp.

Apizem.

$$
\text { P. custuynei 'Thuemen, hev. Myc. II., p. } 86 \text { (1880). }
$$

O. Śpermogonia on both surfaces of leaf, pale yellow, round, in groups on minute raised yellow spots, about $150 \mu$ diam.

Spermatia hyaline, cllipsoid, $3 \cdot \overline{5}-4 \times 2-2 \cdot 5 \mu$.

II. Uredosori amphigenous, bullate, round or ellipsoid, scattered or crowded, and becoming eonfluent, surrounded or partially covered by the ruptured epidermis, pulverulent, cinnamor-brown, $1 \mathrm{~mm}$. or more long.

Uredospores olovate to ellipsoid, golden-brown, echinulate, with thickened hood-like apex $(\bar{\imath}-\$ \mu)$, and three or four, more or less equatorial germ-pores on one face, $25-38 \times 19-22 \mu$, average $30-3$. $\times 21 \mu$; the hyaline pedicel may reach a length of $56 \mu$.

III. Teleutosori similar to medosori, dark-brwm, also on both surfaces of leaf, but more common on under.

Teleutospores similarly coloured to and intermixed with uredospores, shortly oblong to ovate-oblong, slightly or not at all constricted at septum, fincly warted, rounded at apex, and not perceptibly thickened, $29-40 \times 16-22 \mu$, average $32 \times 20 \mu$; lower cell rounded at base or slightly attenuated; pedicel hyaline, short, deciduous.

On stems and leaves of A pium prostratum Labill.

Victoria-Beaumaris, Dec.-July, II., III. (IIT. in Aprii). Portland, Jan., 1901, II., II1. Sandringham, Jan. and Feb., 1904, II., III. (III., very sparse). Mentoue, Jan.-Sept., 1905, II. III.

Tasmania-Hobart, Sept., 1905 (Rodway). Mersey River, January, 1906 (Robinson).

It may be found in sheltered spots all the year round.

On Apium grareolens L.

Victoria-Near Melbourne, Apri]-Nept., II. III.

'lasmania-Hobart, Sept., 190.) (liorlway).

Very common in the early spring months.

spermogonia were only found on the native celery ( 1 pinm prostratum) issociated with uredospores and teleutospores.

The germ-pores of the medospores may be in a transverse band, or one may be placed above the other. When fully dereloped the uredospores are similarly coloured to the teleutospores, otherwise they are yellowish. On A pium yraveolens both uredospores and teleutospores agree almost exactly in average size, though of the latter there are usually very few more than $33 \mu$ in length. There are occasionally elongated telentospores which reach it length of $40 \%$. The finely warted ppispore is a constant fenture of the teleutuspores on both hosts.

The illustrations of spores in Pl. IX., Figs. 68-7:- show that the rust on the native celery (Apium mostrutum), and on cultivated celery (.1. yrareolens) is the sime in Australia. Figs. $7: 3,7 t$ show the smooth telentospores of 1'. apii Corda on Apinm yrareolens from sydow's Lred. Exsice. 5is, which is quite distinet from the finely wated $I$ '. themeni, and lig. i. shows the very rough und knobloy telentospores of $l^{\prime}$. Gnellata (Per's.) Seliroet. 
on Aethusa cynapium from Sydow's Ured. Exsice., 1261, which is readily distinguishable from either of the above. There is thus a clear distinction between these three recognised species, but the synonymy is rather confusing. The reason for the name I have adopted may first be given. $P$. castagnei Thuem., on cultivated celery agrees with our species, but $P$. castagnei Schroet., in Cohn's Beitrïge, ITI., 62 (1879), was first applied to a Puccinia on Thalictrum angustifolium, and Thuemen's name being thus preoceupied, I have substituted $P$. thuemeni.

As regards the synnnyms, Cooke, in his Australian Handbook, -gives $P$. apii Corda at first, and then in an addendum substitutes $P$. castagne $i$ Thuem. for it.

Then Saccardo, in his Sylloge, gives $P$. bullata with $P$. apii as a synonym, and $P$. castagne is regarded as distinct. Further, Sydow in his Monograph includes $P$. apii Corda, and $P$. castagne $i$ Thuem., under $P$. apii Desm., and $P$. butlata is given separately, although he remarks that the latter is probably a collective species. The telentospores of $P$. bullata are described as smooth, and therefore do not agree with the quoted specimen from Sydow. Finally, it may be noted that Tranzschel ${ }^{3}$ las shown that the host-plant of $P$. castagnei Schroet., is not Thalictrun angustifolium, but an Umbellifer, and probably Silaus pratensis, so that this species is a synonym of $P$. bullnta.

Darluca filum Cast., occurs on the uredosori and teleutosori.

(Plate IX., Figs. 68-75; Plate C., Figs. 16, 17.)

99. Puccinia xanthosiae MicAlp.

Xanthosia.

II. Uredosori amphigenous, and on leaf-stalks, dark-brown, pulvinate, gregarious, elliptical, often confluent, rupturing epidermis, about $\frac{3}{4} \mathrm{~mm}$. long, often causing entire leaf to become brownish.

Uredospores golden-brown, thick-walled, echinulate, globose to elliptical, 30-32 $\mu$ diam., or $30-37 \times 24-23 \mu$, a verage $34 \times 26 \mu$; pedicel colourless, $4-6 \mu$ broad.

III. Teleutosori rare, on leares of previous rear, minute, biack.

Teleutospores oblong to oblong clavate, dark-brown, smooth, constricted at septum, 40-60 × $20-25 \mu$, average $42 \times 20 \mu$; upper cell generally darker than lower, rounded and slightly thickened at apex, occasionally truncate; lower cell rounded at base or attenuated towards stalk ; pedicel persistent, tinted, about $20 \mu$ long.

X. Mesospores occasional, similarly coloured to teleutospores, obovate, thickened at apex, $32 \times 20 \mu$.

On Tanthosia pusilla Bunge.

Victoria-Frankston, Oct., 1899, II. : Oct., 1903, III. Sandringham, Sept., March, II, III. ; Feb., II. 
100. Puccinia epilobii-tetragoni (DC.) Wint.

Winter, Pilze, p. $21+(1884)$.

Sydow, Mron. Urerl. T., p. 424, (1902).

Sacc. Syll. VII., p. 608 ( 1888 ).

I. Aecidia distributed over the entire surface of the leaf, scattered or crowded, lyppophyllous: pseudoperidia cup-shaped, with white, laciniate, revolute margins.

Aecidiospores orange yellow, polygonal, finely warted, 16-20 $\mu$ diam., 18-21 $\mu$ being common.

II. Uredosori chestnut-brown, scattered, or often orbicularly arranged, sometimes confluent, pulverulent, hypophyllous, soon naked.

Uredospores ellipsoid or ovoid, clear brown, echinulate, with two gerra-pores on one face, 21-27 $\times 16-21 \mu$, occasionally reaching a length of $31 \mu$.

III. Teleutosori dark-brown, round, often arranged on ring-like spots, hypophyllous, soon naked, pulverulent.

Telentospores intermixed with uredospores, elliptic or oblong, yellowish-brown, slightly constricted at septum, smooth, 27-36 $\times 15-21 \mu$, average $30 \times 18 \mu$; upper cell with a cap-like thickening at apex $(5-6 \mu)$; lower cell usually rounded at bases or sometimes slightly tapering ; pedicel hyaline, slender, deciduous, short.

X. Mesospores exceedingly rare, similarly coloured to teleutospores and thickened at apex $(5 \mu)$, subclavate to obovoid, smooth, $21-27 \times$ 1:3-15 $\mu$, with hyaline pedicel.

On leaves of Epilobium glabellum Forst.

Victoria_Dimhoola, Dec., 1892, I., II., III. (Reader). Ardmona, Arthur's Creek, Kergunyah, Nyora, Palienham, ic., Aug. Dec., I., II., III.

On E. billardierianum Ser.

Tasmania-Great Take, Feb., $189+$ (Rodway $^{1}$ ).

On Epilobium sp.

Tasmania-Summit of Mt. Wellington, Jan. 189., I. (Rodway).

Syclow, in his Monograph, distinguishes between P. epilobii DC., with teleutospores alone, $P$ epilulii-fleischeri Fisch., with aecidia in addition to teleutospores, and the present species with the three stages.

(Plate X., Figss. 79, 80, sı.)

ROSACEAE.

101. Puccinia gei Medip.

Geum.

Medlpine, Agr. Gaz. N.S.WT. VI., p. 756 (1s95).

Sydow, Mon. Ured. I., p. 4it (1903).

Sitce. Syll. XIV., p. $: 297(1899)$.

III. Teleutosori hypophyllous, contluent, coflee-brown, on greenishyellow spots, which also oceur on upper surface of leaf. 
Tejeutospore brownish-yellow, smooth, fusiform to clavate, constricted at septam, epispore chestnut-brown, 30-40 × 13-18 , average $35 \times 1+\mu$; upper cell elongated and tapering $\mathrm{Ol}^{\circ}$ rounded, thickened at apex, 18-22 $\mu$ long; lower cell elongated and tapering towarks base, or bulging, 16-22 $\mu$ long; pedicel pellucid, sometimes $54 \mu$ long.

X. Mesospores occasional, coloured like teleutospores, elongated ellipsoid to oblong; rounded and thickened at apex, occasionally somewhat pear-shaped, and the basal portion prolonged like a stalk, as sometimes happens in the bicellular spore, $28-35 \times$ $12-18 \mu$.

On living leaves of Germ renifolium F. v. MI.

Tasmania-The Calf, Adamson's Peak, March, 1895 (Rodway').

The specimen was gathered on an out-of-the-way mountain, at an altitude of nearly $4,000 \mathrm{ft}$.

(Plate X., Fig. 82.)

\section{Puccinia pruni Pers.}

Prunus.

Persoon, Syn. Fung., p. 226 (1808).

Cooke, Grev. XI., p. 97 (1883).

Sydow, Mon. Ured. I., p. 484 (1903).

Sacc. Syll. VII., p. 648 (1888).

II. Uredosori hypophyllous, occasionally epiphyllous, minute, light brown to cimmamon brown, orbicular, scattered, but often grouped in patches and confluent, soon naked, pulverulent, usually seated on discoloured spots, which also show on upper surface.

Uredospores variable in shape, oblong to ovoid oblong, ellipsoid to somewhat piriform, closely echinulate, yellowish, with two or occasionally three sub-equatorial germ-pores on one face, apex yellowish brown, thickened (average, 5-6 $\mu$, or papillate up to $9 \mu$ ) with spines less prominent, bluntly conical or rounded, 25-38 $\times$ $12-18 \mu$, occasionally reaching a length of $40 \mu$ or more, average $30 \times 15 \mu$; paraphyses intermixed, numerous, capitate, pale yellow, long-stalked, sometimes attaining a length of $70 \mu$.

III. Teleutosori hypophyllous, scattered $\mathrm{Ol}^{\circ}$ confluent, isolated or in groups, very pulverulent, seal-brown, paraphysate, known from the uredosori when fully developed by their dark, almost black appearance.

Teleutospores at first intermixed with uredospores, dark-brown, oblong to ellipsoid or obovoid, densely warted, often composed of two globose or depressed globose cells, readily separating from each other, very rarely 3 -celled, $25-45 \times 17-25 \mu$, average $36 \times 25 \mu$; upper cell usually darker in colour, and broader than lower, globose or depressed globose, often slightly thickened at apex, and thickly studded with short stout spikes, average 16-22 $\mu$ diam.; lower cell generally oblong to obovoid, and equal to or longer than upper, $14-24 \times 14-19 \mu$; pedicel short, hyaline, deciduous.

On leaves, fruits and stems of Peach (Prunus persica Stokes).

On leaves and fruits of Almond and Apricot (Prunus amygdalus Stokes, and $P$. armeniaca L.). 
On leaves of Plum (Prunus domestica I.) and Necturine. Tictoria, Now South Wales (Cobb'), Queensland (Bailey ${ }^{5}$ ) (Tryon ${ }^{1}$ ), South Australia, West Australia, and Tasmania (Rodwayl).

Common. November to June, the teleutospores beings very common in March on Prumus domestica.

This rust is usually most prevalent towards the autumn, but in some seasons it appear's in the early summer. It not only destroys the foliage, but may even attack the fruit, and in some seasons it actually ruptures the bark, especially in rapidly growing nursery stock. When the rust oceurs on the fruit, uredospores may be produced both at the surface and in the pulp.

There are said to be two kinds of urerlospores by Dumce and Maire', but $\Gamma^{33}$ have shown that this is simply due to an error of interpretation, and that they are always thickened at the apex when seen in their natural pusition, and not obliquely. Teleutospores are comparatively rare on the Apricot and Peach, less so on the Almond, and very common on the Plum. Tn April, 1904, both stages of the rust were found on leaves of all the hostplants. According to Prillieux ${ }^{-1}$, teleutospores often appear alone, without having being preceded by uredospores, but this has never been known to occur in Australia. The arrangement of the teleutospores in the sorus is worthy of note. With a magnifying glass the spores can be seen to be arranged in minute clusters, and each cluster under the microscope is seen to consist of a number of spores, the stalks of which have become agglutinated together, and to the free end of each a spore is attached. (McAlpine ${ }^{3 t}$ ).

On the leaves of the Peich the sori are situated on yellow spots, which are very prominent on the upper surface. There they often run together, and have the appearance of yellow ochre. In the Apricot the spot is hardly noticeable at first, but when held up to the light the indeterminate yellow spots are seen clearly. The leaf soon turns yellow, and then the spots are of a pale green. In the Plum the spots are very pale on the lower surface, but on the upper surface the yellowish-green is very promineut.

Tranzschel 2 has proved experimentally that the aecidial stage of the rust on Almond occurs on Anemone coronaria L., and it has hitherto been known as Aecidium punctatum Pers.

Darluca filum Cast., is found on the uredosori.

(Plate X., Figs. 83-86 ; Plate D., Figs. 19, 20.)

\section{TEGUMINOSAE.}

\section{Puccinia zorniae (Diet.) MeAlp.}

Zornia.

$$
\text { Ĺredo zorniue Dietel, Hedwigia XXXY III., p. 257 (1ミ99). }
$$

II. Urerlosori on both surfaces of leaf, but most numerous on under, yellowish when young, then ruddy-brown, round to clliptic, bullate, at first covered, then erumpent and surrounded by runtured epidermis, gresarions and sometimes contluent.

Uredospores old-rold colonr, ellipsoid to occisionally obwoid, finely echinulate, with two germ-pores on one face, $25-32 \times 19-2 \cdot 2 \mu$.

III. Telentosori as above, but dirk-brown.

'Telentospores intermixed with uredospores and similarly coloured, oblong, smonth, deeply constricted at septum, two cells about efual in size or lower sometimes a little longer, $3:-4 t \times$ $20-2.1 \mu$, wrerage $36 \times 21 \mu$ : upper cell rounded and thickened at apex (up to $6 \mu$ ), lower coll rounded at base : pedicel hyaline, prersistent, about length of spore. 
On living leaves of Zornic diphylla Pers.

New South Wales-Richmond River, May, 1904 (Musson).

U'edo zorniae Berk., is mentioned by Cooke in Grev. XX., p. 110, as on Zornia in Mauritius, but no diagnosis is given. This is the first record of the teleuto stage, since Dietel in his Uredineae brasilienses only mentions the uredo stage on the same plant from Rio Janiero, and thus describes it :- "Sori hypophyllous, scattered, surrounded by the ruptured ochraceous epidermis, minute, brown. Uredospores globose, obovate or ellipsoid, 21-28 × 18-23 $\mu$; epispore brown, echinulate, with three germ-pores."

Darluce filum Cast., occasionally on sori.

(Plate X., Fig. 87.)

FICOIDLAE.

104. Puccinia tetragoniae McAlp.

Tetragonics

Mcdlpine, Agr. Gaz. N.S.IV. VI., p. 8.5t (189.5).

Sydow, Mon. Ured. I., p. 563 (1903), p. 895 (1904).

Sace. Syll. XTV., p. 295 (1899).

O. Spermogonia orange, numerous, aggregated, amphigenous, 150-170 in diam.

Spermatia hyaline, globose to oval, $2 \frac{1}{2}-3 \frac{1}{2} \mu$ diam.

I. Aecidia hypophyllous, crowded, often arranged in lines, greenish to yellowish-brown knob-like swellings before bursting; pseudoperidia white, cylindrical, with torn edges, average $630 \mu$ diam.

Aecidiospores orange-yellow, minutely warted, variously shaped, globose to ovate or mussel-shaped, $27-39 \times 22-25 \mu$.

II. Uredosori amphigenous, soon naked, bullate, orange-red, generally orbicular, 1-1 $\frac{1}{2} \mathrm{~mm}$. diam.

Uredospores orange-yellow, ellipsoid to ovoid, strongly echinulate, $27-37 \times 22-25 \mu$, a verage $31 \times 24 \mu$.

III. Teleutosori amphigenous, black, compact, bullate, orbicular, irregular or elongated, scattered, covered by epidermis for some time, then erumpent.

Teleutospores golden brown to chestnut-brown, elliptical to oblong, usually rounded at both ends, slightly constricted at septum, smooth, $40-60 \times 25-36 \mu$, arerage $50 \times 30 \mu$; pedicel hyaline, stout, persistent, up to $80 \mu$ long.

X. Mesospores similarly coloured to teleutospores, ellipsoid or elongated, thickened at apex, 35-54 × $25-29 \mu$.

On leaves and stems of Tetrayonia implexicoma Hook. f.

Victoria.-On the coast at Sandringham, Beaumaris, Flinder's, Portland, ic., all the year round.

Tasmania-Hobart, about rocks, Auco, 1897, I., II., III. (Poodway' $\left.^{\prime}\right)$.

All the stages are usually very plentiful in the month of August.

The spermogonia precede or accompany the aecidia on upper and under surface of the leaves, are flask-shaped and the neck projects slightly between the watery vesicles which stud the surface of the leaf. They often form 
large, orange, blister-like clusters quite conspicuous against the green of the leaf, and the rust-derouring Diplosis was frequently met with there and probably scatters the spermatia.

The aecidia are usually swarming with the Diplosis, dipping into them as an insect inserts its proboscis into a flower, and sometimes it is entirely inside the cups. The larvae are invariably coated with the aecidiospores. Occur Augrust to October and subsequently.

Uredospores just beginning to appear in October, and the Diplosis was also found on the sori.

Teleutospores are scanty in October, and they occur on the same leaves as uredospores.

The uredo and tcleutosori are often associated together in the same cluster, and the three spore-forms may all occur on one leaf.

(Plate XI., Figs. S8, 89.)

\section{POLYGONACEAE.}

Pumex.

\section{Puccinia ludwigii Tepp.}

Tepper, Bot. Centralb., XLIII., p. 6 (1890).

Cooke, Handb. Austr. Fung., p. 336 (1892).

Sydow, Mon. Ured. I., p. 581 (1903).

Sacc. Syll. XI., p. 196 (1895).

II., III. Sori minute, circular, irregularly scattered or aggregated into small grouns, soon naked and girt by the ruptured epidernis, on both surfaces of leaf, up to $\frac{1}{2} \mathrm{~mm}$. diam.

II. Uredospores sub-globose to ovate, very finely echinulate, pale yellowish-brown, $22-28 \times 16-20 \mu$, or $19-22 \mu$ diam.

III. T'eleutospores at first intermixed with uredospores, oblong to ellipsoid, rounded at both ends, very coarsely warted, slightly constricted at septum, not thickened at apex but generally with livaline apiculus, sometimes three or four celled, dark brown, 30-40 $\times 20-25 \mu$, average $32 \times 21 \mu$; pedicel short, hyaline, deciauous.

X. Mesospores similarly coloured to teleutospores, warted and with hyaline apiculus, oval, with short hyaline pedicel, $28-31 \times 18-23 \mu$.

On leaves of Rumex brounii Campd.

Victoria-Coromby, Oct., 1889 (Tepper). Shepparton, on river llats, Nov., 1895 (Robinson). Flinders, Jan. Murramurrangbung lianges, Dec. Killara, March. Myrniong, Aug.

Queensland - Emnogera (Bancroft). Brisbane, Sept., 1886 $\left(\right.$ Bailey $\left.{ }^{4}\right)$.

Tasmania-Devonport, January, 1906 (Robinson).

On Rumex flexuosus Sol.

Victoria-Warracknabeal, Oct., I903 (Reader)

I have had plenty of material of this species, both from Victoria and Queensland, as well as some of the original material from Ludwigr, and examination shows that it is the same fungus in each ease.

Mr. Bailey kindly supplied specimens from Quecnsland, and there is one in the National Herbarium, Melbourne, sent from Queensland to Dr. Coske in 1886 , and it is named in his own handwriting P. rumicis Lasch., $=P$. acetosae (Schum.) Koern. It has the same characters as tho others, and on comparing it with $P$. acetosue from Syd. Ured. Exs., 1163, I find that it 
differs in the more finely echinulate uredospores, but more particularly in the teleutospores, which are coarsely knobbed and altogether characteristic.

The introduced Rumex crispus and $R$. acetosella are exceedingly common weeds in Victoria, and may be seen growing alongside rusty $R$. brononii, but no rust has ever been detected on them.

$R$. brownii is a native species, and its parasite is evidently a native also.

The teleutospores are varied in shape, and three and four celled forms are met with. In the three-celled forms they may either be after the Phragmidium or Triphragmium type, and in the four-celled forms the upper third cell is vertically divided. Just as in $P$. dichondrae there is every gradation from the one to the four-celled spore.

Darluca filum Cast., is common on the uredo and teleutosori.

(Plates XI., Figs. 90, 91, 92 ; XL., Fig. 300.)

106. Puccinia muehlenbeckiae (Cooke) Syd.

Wuehlenbeckia.

Sydow, Mon. Ured. I., p. 566 (1903).

Sacc. Syll. IX., p. 299 (1891).

Puccinia rumicis-scutati (DC.) Wint. var. muehlenbecliae Cooke, Grer. XIX., p. 47 (1890), and Handb. Austr. Fung., p. 336 (159:).

II. Uredosori hypophyllous, scattered or in irregular groups, sometimes circularly arranged, round or elliptic, girt by the torn epidermis, cinnamon-brown.

Uredospores yellowish-brown, ellipsoid or ovoid, echinulate, $24-32 \times 16-21 \mu$, average $28 \times 19 \mu$.

III. Teleutosori similarly arranged to uredosori, but dark-brown.

Teleutospores at first intermixed with uredospores, clavate to oblong, dark-brown, constricted at septum, thickened at apex (up to $7 \mu$ ), and rounded o1 obtuse, sometimes $3-4$ celled, $32-45 \times$ 14-19 $\mu$, occasionally reaching a length of $55 \mu$, average $40 \times$ Is $\mu$; lower cell generally somewhat triangular ; pedicel hyaline, generally persistent, up to $40 \mu$ long.

X. Mesospores occasional, similarly coloured to teleutospores, ellipsoid to elongated oblong, smooth, rounded or conoid and thickened at apex (up to $5 \mu$ ), 31-34 × 12-18 $\mu$.

On leaves of Iruehlenbeclia adpre'ssa Meissn.

Victoria-Brighton, May, 1894 (Morrison). Near Melbourne, Jan.-July. Cape S'chanck, March, 1903 (C. French, jun.). Frankston, Feb., 1904 (Robinson). Sandringham, Sept., 1905 , II., III.

On Muehlenbectia gracillima Meissn.

Queensland--Gladfield (Gwyther) (Bailey ${ }^{15}$ ).

N.S. Wales-Kurrajong Heights (Musson).

Some of the mesospores show their connexion with teleutospores rery clearly. In one instance two germ-pores were formed in the usual positions, while in another there was a slight notch on one side as if the beginning of a septum. They are evidently one-celled teleutospores, and have all their characters with the exception of the septum. 
There were spots on the upper surface of the leaves with purplish-red margins, but these were due to gall-mites. The spores are of the greneral type of $P$. rumicis-scutati, but both kinds are somewhat smaller. I had a large amount of material to operate upon, and found the sori to be hypophyllous, although Cooke inadrertently describes them as epiphyllous. In a specimen of 1 . mumicis-scutati, from Syd. Ured. Fxs. 25, the telentospores are of a deep chestnut-brown, and attain a length of $57 \mu$. Sydow himself had not seen any specimens of the rust on I/nehlenbectia, but even from the brief description of Cooke he was right in making a species of it.

Darluca filum Cast., sometimes common on uredosori.

(Plate XI., Fig. 93.)

\section{CHENOPODTACEAE.}

\section{Puccinia dielsiana P. Henn.}

Threlheldia.

Hemnings, Hedw. XL., p. (95) (1901).

Sydow, Mon. Ured. I., p. 566 (1902).

Sacc. Syll. XTIT., p. 361 (1905).

III. Teleutosori on stems, large, compact, bullate, erumpent, up to $\frac{3}{4} \mathrm{~cm}$. long.

Teleutospores ellipsoid or ohlong ellipsoid, grenerally rounded at both ends or obtuse and slightly thickened at apex $(3-5 \mu)$, smooth, very slightly constricted at septum, with granular contents, chestnut or dark-biown, $35-18 \times 18-28$, arerage $38 \times 22 \mu$; pedicel sub-hyaline, persistent, $80-120 \times \tilde{\mathrm{j}}-6 \mu$.

X. Mesospores occasional, ellipsoid to ovoid, coloured and thickened at apex like teleutospores, $34 \times 23 \mu$.

On stems of Chenopodiaceae-Threlkeldic drupata Diels.

W. Australia-Near Perth, 1900.

The teleutospore has occasionally a rertical septum, and in elougated slender specimens the breadth is reduced to $15 \mu$.

(Plate XI., Fig. 94.)

108. Puccinia kochiae Mass.

Kochia, Enchylaena.

Massee, Grev. XXIT., p. 17 (1893).

Sydow, Mon. Ured. T., p. 565 (1903).

Sace. Syll. XT., p. 190 (1895).

II., I1I. Sori amphigenous, discoid, plane, very compact, blackishbrown to black, often aggregated together, girt by the ruptured epidermis, up to $1 \mathrm{~mm}$. diam.

II. Uredospores elliptical, golden-brown, decidedly cchinulate, with numerous prominent germ-pores, as many as twelve on one face, $29-3 t \times 15-25 \mu, 3: 2 \times 23 \mu$ being very common.

III. 'Teleutospores densely packed, intermixed with uredospores, elliptic-oblong, rounded at both ends, or the apex with al slight indication of at papilla which is often oblique, perfectly smooth, chestnut-brown, hardly constricted at septum, epispore about $3 \mu$ thick, $35-45 \times 22-29 \mu$, average $37 \times 25 \mu ;$ pedicel tinted yellowish, persistent, $30-40 \times 6 \mu$, but may reach a length of $96 \mu$.

X. Mesospores few, similarly coloured to telentospores, oval to thattened at apex, $23-35 \times 2.2-25 \mu$. 
On leaves and stems of Kochia sedifolia F. v. M.; Kochia villosa, Lindl.; and Enchylaena tomentosa R. Br.

Victoria-Dimboola, Nor. and Dec. (Reader).

I have some of the material from Dimboola, portion of which was sent to Massee, and the golden-brown uredospores are seen along with the telentospores. No uredospores were mentioned in the original description, a striking feature of which is the numerous germ-pores. The teleutospores have occasionally their septum lengthwise.

(Plate XI., Figs. 95, 96.)

\section{CARYOPIIYLLACEAE.}

\section{Puccinia arenariae (Schum.) S'chroet.}

Stellaria.

Schroeter, Pilz. Schles., p. 345 (1872).

Sydow, Mon. Ured., I., p. 553 (1903).

Sacc. Syll. VIT., p. 683 (1888).

III. Teleutosori compact, pulvinate, rounclish, scattered, often circinate, pale-brown to dark-brown.

Teleutospores fusoid or clavate, apex pointed or rounded, often thickened $(6-8, \mu)$, base rounded or attenuated, slightly constricted at septun, smooth, pale jellowish brown, $30-50 \times 14-20 \mu$, arerage $35 \times 16 \mu$, very rarely tricellular, $48 \times 16 \mu$; pediccls hyaline, persistent, equal to or longer than the spores, $60-100 \mu$.

X. Mesospores occasional, similarly coloured to teleutospores, obovoid or somewhat wedge-shaped, rounded or obtusely pointed or truncate at apex and thickened up to $6 \mu$, generally resembling the upper cell of the teleutospore, with elongated pedicel, $22-29$ $\times 16-17 \mu$.

On leares and stems of Stellaria media Cyrill.

Victoria-Gellibrand, Feb., 1896 (Hill). Gembrook Ranges, April, 1904 (C. French, jun.).

The germ-tubes of the sporidiola of this species have been known to enter the stomata of Dianthus barbatus L., and it seems to be the only known case in the genus Puccinic of such germ-tubes entering stomata.

$$
\text { (Plate XII., Fig. 97.) }
$$

\section{MALVACEAE.}

110. Puccinia heterospora Berk. and Curt.

Abutilon, Hibiscus.

Berkeley and Curtis, Journ. Limn. soc. X., p. 356 (1868).

Cooke, Handb. Austr. Fung., p. 338 (1892).

Sydow, Mon. Ured. I., p. 472 (1903).

Siace. Syll. VII., p. 695 (1888).

III. Teleutosori minute, hypophyllous, soon naked, crowded in orbicular, glomerules, dark-brown, on determinate purplish or yellow spots.

Teleutospores very variable in size and shape, smooth, thickwalled and more deeply thickened at apex, dark chestnut-brown, elliptic or oblong, not or scarcely constricted at septum, occasionally dị̣ided vertically, 20-38 $\times 17-28 \mu$; pedicel hyaline, slender, elongated, three to four times as long as spore. 
I. Mesospores much more common than teleutospores, subglobose or elliptical, apex more thickened, pale-brown, $17-22 \mu$ diam., or $2 \overline{5}-32 \times 17-22 \mu$.

On leaves of Abutilon crispum Sweet, and Hiliscus sp. (Briley ${ }^{16}$ ).

Queensland-Gulf of Carpentaria and St. George, Oct., 1885 (F. v. Mueller in National Herbarium).

On Abutilon avicennae Gaertn.

New South Wales-North-west part, Oct., 1887 (Bauerlen).

There are only relatively few bicellular spores present, and at first they were overlooked, the fungus being named Cromyces pulcherrimus B. and C., and $U$. theraitesii $B$. and Br.

The so-called mesospores are probably of the nature of one-celled teleutospores, and this species may be regarded as a transition stage from the unicellular Uromyces to the bicellular Puccinia.

(Plate XII., Fig. 101.)

Althaea, Lavatera, Malva, Plagianthus.

111. Puccinia malvacearum Nont.

Montagne in Gay's Hist. Chili VIII., p. 43 (1852).

Cooke, Handb. Austr. Fung., p. 338 (1892).

Sydow, Mon. Ured. I., p. 476 (1903).

Sacc. Syll. VII., p. 686 (1885).

III. Teleutosori generally hypophyllous, brown to reddish-brown or orange, but grayish when spores are germinating, compact, round, pulvinate, elongate on the stems, scattered or crowded, seldom confluent, at first corered by epidermis, soon naked.

Teleutospores fusiform, attenuated at both ends, apex sometimes rounded, slightly constricted at septum or not at all, apical thickening slight, smooth, yellowish-brown, rarely tricellular, $35-75 \times 12-26 \mu$, average $50 \times 17 \mu$; pedicels firm, long, persistent, occasionally septate, sometimes measuring $170 \mu$ long.

X. Mesospores occasional, same colour as teleutospores, somewhat fusiform, slightly thickened at apex, $40-4 j \times 17-19 \mu$.

On all green parts of Mrulva rotundifolia $\mathrm{L}_{\text {. }}$, .M. syliestris I., Althaea rosea Cav., Lavatera plebera sims, and Plagianthus spicatus Benth. Exceedingly common.

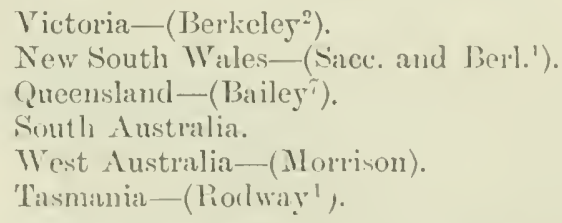

The sori first appearing were earefully eximined for any trace of aceompanying spermogonia, lut none were found. spores iccusionally 3-celled, and reaching a length of $7 \bar{\tau} \mu$.

This fungus, which was originally described by Montagne, has now ovelspread the earth and oecurs on both wild and cultivated species of Malvaceous plants. Dr. Plowright" states that he has a specimen in his horbarium from Melbourne, gatherel as early as $1 \$ 6 j$ on .Malru sylerstris. 
Puccinia malvacearum is one of the commonest of rusts, and the different stages in the growth of the spore are well seen in this species. A group may be observed springing from a common hypha, and at first they are without septa, but soon a transverse septum is formed, and, although specially looked for, I have never seen a partial septum as recorded by Fischer ${ }^{5}$.

Germination occurs as soon as the spore is ripe, but some may hibernate. Occasionally the pedicel has a septum. Mr. French, Government Entomologist, has observed this rust on Hollyhocks in a nursery near Melbourne as early as $185 \%$.

(Plate XII., Figs. 99, 100 ; Plate XV., Figs. 123-130 ; Plate F., Fig. 28.)

\section{Puccinia plagianthi McAlp.}

Plagianthus.

McAlpine, Proc. Roy. Soc. Vic. VII, N.S., p. 218 (1894).

Sydow, Mon. Ured. I., p. 480 (1902).

Sacc. Syll. XIV., p. 295 (1899).

III. Teleutosori hypophyllous, sparingly epiphyllous, scattered, pulverulent, soon naked, up to $1-1 \frac{1}{2} \mathrm{~mm}$.

Teleutospores golden-brown, oblong to clavate, rounded at apex, slightly attenuated towards base or rounded, slightly constricted at septum, very rarely three celled, epispore with reticulated markings, $38-50 \times 17-23 \mu$, average $41 \times 20 \mu$; pedicel hyaline, short, deciduous, but may attain a length of $60 \mu$.

On leaves and flowers of Plagianthus sidoides Hook. Tery common.

Tasmania-Mount Wellington, southern slope, Aug.-April (Rodway $\left.^{1}\right)$.

The spore is described as smooth by Syclow, but it is seen to be corered with a fine irregular network.

(Plate XII., Fig. 98.)

\section{GERANIACEAE.}

\section{Puccinia geranii-pilosi MIcAlp.}

Geranium.

II. Uredosori hypophyllous, chocolate-brown, scattered or sub-gregarious, orbicular, soon naked and surrounded by ruptured epidermis, compact, up to $1 \mathrm{~mm}$. diam., often on purplish-red spots or portions of leaf becoming coloured.

Uredospores yellowish-brown, elliptical to oborate, echinulate, epispore slightly thickened at base, $25-30 \times 19-22 \mu$.

III. Teleutosori elongated, dark-brown to black, sometimes confluent, erumpent, compact, $1-1 \frac{1}{2} \leadsto$ long, commonly on petiole.

Teleutospores at first intermixed with uredospores, oblong to oblong-clavate, chestuut-brown, smooth, slightly constricted at septum, sometimes short and stout and about as broad as long, $32-48 \times 22-32 \mu$, a verauge $36 \times 25 \mu$; upper cell rounded at apex, not or slightly thickened; lower cell rounded at base or occasionally slightly tapering; germ-pore generally indicated at apex by a paler groore; pedicel hyaline, deciduous, elongated, up to $80 \mu$ long. 
X. Mesospores occasional, similarly coloured, subglobose, thickened at apex, $25-26 \mu$ diam.

On living leaves of Gertuinm pilosim Sol.

Victoria-Killara, Nov., 1902, II., March, 1903, II., [II. (Robinson).

New South Wales-Richmond (Musson).

Occisionally a teleutospore occurs in which the septum is vertical as in Diorchidium.

In the reeorded species of Puccinia on Geranium there are only teleutospores with the exception of $P$. callarguensis Neger, on leaves of Geranium broteriun Colla, in Chili.

It differ's from this species however in the teleutospores being smooth and not minutely verrucose, and in the elongated pedicel.

The lost-plant is varionsly named. It is found in all the Australian States, and was called $G$. pilosim by Solander.

In the Index Fevensis it is given as a synonym of $G$. dissectum, but the late Baron von Mueller used the name of $G$. pilosum, considering it "more exact than that of $G_{r}$. crorolininnum and $G$. dissectum."

F. II. Bailey, in his Cueensland Flora, divides G. dissectum into two principal races, one of which is pilosum.

The species of Puccivic found upon it is new, and while it is not customary to determine a host-plant from the species of rust found upon it, still in this instance it lends probability to the view that we are here dealing with an indigenous form of Geranium, differing from $G$. dissectum. For this reason I have not followed the Index liencensis in naming the host.

(Plate XII., Figs. 103, 101.)

\section{Puccinia morrisoni Mcdip.}

I'elargonium.

I. Aecidia amphigenous, delicate, minute, orange, cireinate, either alone or accompanied by telentospores; pseudoperidia with expanded and lobed marerin; perirlial cells subyuadrate to oblong with striated margin, and punctate all over, firmly united, $28-32 \times 16-22 \mu$.

Aecidiospores pale orange, finely echinulate, elliptic to subquadrate, $19-22 \times 16 \mu$ or $18-19 \mu$ diam.

II. Uredosori mostly on under surface of leaf, round, small, brownish, rulverulent, solitary or arranger in confluent sroups.

L'redospores subglobose to ellipsoid, yellowish brown, cchinnlate, $2.2-2+\mu$ diam., or $2.2-27 \times 19-22 \mu$.

III. Telentosori intermixed, solitary or arranged in small contluent. groups, generally round, black, compact, surrounded by ruptured epirlermis.

'Telentospores chestnut brown, clavate, constricted at septum, smoutl, often oblingely pointed or roumled and thickened

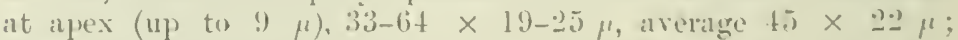
lower cell usually paler in colour and attenuited tuwards base: perlicels tinted, gencrally slout, persistent, up to 3 s. $_{\mu}$ long by $6-9 \mu$ brond.

X. Mesospores coloural like telentospores, oblonir to oval, bluntly pointed and thickened at apex, 33-38 $\times 16-20 \mu$. 
On stems, leaf-stulks and leaves of Pelargonium australe Jacq.

Victoria-1892. II., III. (Morrison). Phillip Island, Jan., 1900, II., III. Nurramurrangbong Ranges, Dec., 1903., I., II., III. (Robinson).

Tasmania-Devonport, Jan., 1906 (Robinson). Ranges.

The only locality where aecidia were found was the Murramurangbong

It differs from $P$. geranii Corda, to which this species was referred by Cooke in Grevillea, XXI., p. 39, in the uredospores being nearly twice as large, and in the much longer and broader telentospores.

There are two species of Prccinin already recorded upon the genus Pelargonizm from S. Africa, viz., I' pelargonii (Thuem.) Syd., and $P$. granilaris Kialch. and Cooke.

In $P$. pelargonii the aecidia are hypophyllons, and not amphigenous, and the teleutospores are rather shorter and narrower. In $l^{\prime}$. gramularis there are no aecidia.

(Plate XII., Fig. 102; Plate F., Fig. 29.)

\section{RUTACEAE.}

\section{Puccinia boroniae P. Henn.}

Boronia.

Hennings, Hedw. XLII., p. (73) (1903).

Sydow, Mon. Ured. I., p. 831 (1904).

Sacc. Syll. XTIL., p. 351 (1905).

III. Teleutosori on branches, erumpent, pulvinate, tuberculate, dark cinnamon, compact, confluent lengthwise up to $2 \mathrm{~cm}$. long, surrounded at base by the ruptured epidernis.

Teleutospores ellipsoid to ovate, oblong, brown, smooth, rounded or bluntly pointed at apex and slightly thickened (up to $5 \mu$ ), generally rounded at base, $28-40 \times 16-21 \mu$, arerage $35 \times 20 \mu$, occasionally 3-celled and elongated, $52 \times 25 \mu$; pedicel hyaline to yellowish, persistent, up to $120 \mu$ long.

I. ILesospores common, similarly colonred to teleutospores, ellipsoid to obovoid, rounded or bluntly pointed at apex and slightly thickened, $30-34 \times 17-18 \mu$.

On Boronia spinescens Benth.

West Australia-Aron, Oct., 1903 (Diels).

A very interesting Leptopuccinia which projects from the cortex of the branches in thick, often confluent pustules, and partially surrounds them.

A specimen was kindly forwarded by Hennings, and the mesospores were observed which are not given in the original description. The size of the teleutospores, as given by Hennings, is $20-32 \times 15-18 \mu$, by Sydow: 22-35 $\times 16-19 \mu$, and I have made the average $35 \times 20 \mu$, my measurements being corroborated by those in the photographs, which are also about $35 \times 20 \mu$.

$$
\text { (Plate XIII., Fig. 107.) }
$$

\section{Puccinia correae MicAlp.}

Correa.

McAlpine, Proc. Roy. Soc. Vict. VII., N.S., p. 215 (1894).

Sydow, Mon. Ured. I., p. 462 (1903).

Sace. Syll. XIV., p. 297 (1899).

III. Teleutosori hypophyllous, cushion-shaped, circular or interruptedly circular, dirty brown, scattered, soon naked. 
Teleutospores yellowish-grey, long-stalked, elongated fusoid, constricted at septum, $4+60 \times 17-20 \mu$, average $50 \times 18 \mu ;$ upper cell elongated, tapering and rounded at apex; lower cell tapering towards base; perlicel light grey, several times as long as teleutospore.

X. Mesospores similarly coloured and stalked, ovoid, with truncated apex, $2 \overline{5}-28 \times 16-19 \mu$.

On leaves of Correa laurenciana Hook.

Tasmania-Mount Wellington, Dec. Coast near Trial Harbour, Jan., 1894 (liodwaly').

The sori stand out very distinctly from the cinnamon-brown under surface of the leaves, causing corresponding circular depressions on upper surface, of a yellowish-green colour. Although the plant is very common, the rust was very rare.

(Plate XIIX., Fig. 106.)

\section{Puccinia eriostemonis McAlp.}

Eriostemon.

III. 'Telentosor:i hyphophyllous, dark-orange, ellipsoid, somewhat circularly arranged, erumpent, surrounded by ruptured epidermis, up to $2 \mathrm{~mm}$. long.

'Teleutospores clavate to ellipsoid, with finely granular orange contents, compact, smooth, generally rounded at apex, sometimes pointed, slightly thickenerl, usually tapering towards base, constricted at septum, 30-15 $\times 15-18 \mu$, average $32 \times 16 \mu$; pedicel persistent, hyaline, elongated, up to $125 \mu \operatorname{long}$ by $3-5 \frac{1}{2} \mu$ broad.

X. Mesospores occasional, similarly coloured to teleutospores, ellipsoid, thickened and bluntly pointed at apex, 30-32 $\times 13-16 \mu$.

On leares of Eriostemon myoporoides DC.

Victoria-NIt. Bernarel, Nov., 1903 (C. French, jr.). Alps, near Bright, Dec., 1901 (C. French, jr.)

Occasionally a spore eccurs in which the septum is longitudinal.

This species differ's from $T^{\prime}$. correne Mc.llp., in the sori being orange instead of brown, the spores are smaller, with finely granular orange contents, and the epispore rather thicker.

(Plate XIII., Fig. 105.)

TIEIIANDRACEAE.

118. Puccinia pritzeliana P. Henn.

Tremandra.

Hemings, ILedw. XI., p. (9.) (1901).

sydow, Mon. Ured. I., p. $460(1902)$.

Sace. siyll. XVIT., p. 350 (1905).

III. Telentusori hypoplyyllous, on mund brown spots, frequently with purplish margin, scattered or in orbicular gromps, pulvinate,

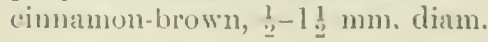


Teleutospores oblong or oblong clarate, obtusely rounded at apex, which may or may not be thickened, sometimes two-papillate, or occasionally somewhat crested, slightly constricted at septum, generally rounded at base, yellowish, smooth, 40-60 $\times 15-25 \mu$, average $48 \times 20 \mu$; pedicels hyaline, persistent, up to $150 \mu$ long.

$\mathrm{X}$. Mesospores rare, similarly coloured to teleutospores, somewhat oblong and bluntly apiculate at apex, $43 \times 28 \mu$.

On living leaves of Tremandra stelligera $\mathrm{R}$. Br.

West Australia-Near Perth, Oct., 1900 (Pritzel).

Quite distinct from $P$. tremandrae Berk. from Ceylon.

(Plate XIII., Fig. 108.)

\section{VIOLACEAE.}

\section{Puccinia hederaceae McAlp.}

riola.

O. Spermogonia arranged in small or large groups, crowded, honeycoloured.

Spermatia hyaline, globose, minute, $2 \frac{1}{2}-3 \mu$ diam.

I. Aecidia on all green parts of the plant and flowers, on both surfaces of leaf but mostly hypophyllous, disposed in circular or irregular groups; pseudoperidia flat, about $\frac{1}{2} \mathrm{~mm}$. diam. with white, torn, revolute edges.

Aecidiospores subglobose to shortly elliptical, finely warted, orange-yellow, about $16 \mu$ diam., or 16-19 $\times 12-14 \mu$.

II. Uredosori minute, brown, roundish, erumpent, scattered, soon naked, on both surfaces of leat.

Uredospores subglobose or shortly elliptical, golden-brown, strongly echinulate, $2-3$ germ-pores on one face, $25-29 \times 18-22 \mu$, average $25 \times 21 \mu$ and $22-25 \mu$ diam.

III. Teleutosori minute, black, roundish, erumpent, usually surrounded by ruptured epidermis, pulverulent.

Teleutospores at first intermixed with uredospores, elliptic or oblong, rounded at both ends or slightly attenuated towards base, hardly constricted at septum, distinctly warted all over but prominently on upper cell, chestnut-brown, usually with hyaline apiculus, occasionally unicellular, $29-49 \times 17-22 \mu$, arerage 35 $\times 19 \mu$; pedicel hyaline, deciduous, short.

On living leaves of Tiolc hederacea Labill.

Victoria-Near Melbourne, Oct., Nov., and Dec., 1885, 1886 (Reader). Wandin, Dec., 1895. Murramurrangbong Ranges, Nov., 1902, Dec., 1903, Jan., 1905 (Robinson). Mit. Blackwood, Dec., 1902. Alps, near Bright, Dec., $190+$ (C. French, jun.)

Tasmania-Casca de Rivulet, Dec., 1892 (Rodway '). MIt. Dromedary, Dec., 1894 (Rodwayl). Deronport, Jan., 1906 (Robinson).

On $r$. betonicifolia Sm.

Tasmania-Ben Neris, April, 1896 (Rodway).

New south Wales-Monga (Bauerlen), recorderl as Aecidium violae Schum. by Baker'. Richmond (Musson).

Victoria-Murramurrangbong Ranges, Nor., 1902 (Robinson).

438. 
A few one-celled teleutospores were olserved among the ordinary teleutospores, which they resemhled in every respect except si\%e and shape, eren having the germ-pore quite distinct bencath the apex, ellipsoirl, with small hyaline apiculus, $25-26 \times 20 \mu$.

Aevidium violap S'chum. is given by Dr. Cooke in his Tandbrook as oecurring on Vietorian native vislets, but it is the aecilium belonging to P. Lerleraceae $\mathrm{McAl}$.

'This speeies was at first letermined as I'. aeyra Grove by Winter ${ }^{2}$, lut on comparing the two species they are seen to be decidedly different.

It is closely allierl to $I$. violue (Schum.) DC., lout differs in the telentospores being larger, and warted all over. specimens of $P$. violae were examinel from Syd. Ured. Exs., No. 286, on Fiola arenaria, and from Kellerman's Ohio Fungi, No. 96, on Fiola blandu. The average size of the teleutospores was found to be $22-32 \times 16-19 \mu$, and were generally smouth, although oceasionally il little warterl.

P. aegru Grove, is recorded by Cooke for Australia; but all the specimens I have met with, including part of the same collection of material forwarded to Dr. Cooke, have echinulate aecidiospores, and warted teleutospores, and are therefore not this species.

(Plate XIII., Figs. 109-112 ; Plate E., Figs. 24, 25.)

\section{CRUCIFERAE.}

\section{Puccinia cruciferae MeAlp.}

I. Aecidia amphigenous and on stems, in irregular clusters or circinate, large, cup-shaped, $\frac{1}{3}-\frac{1}{2} \mathrm{~mm}$. diam.; pseudoperidia with whitish edges, crenulate, slightly revolute: pseudoperidial cells ovoid or oblong, punctulate all over, with striated margin, average $25 \mu$ long. diam.

Aecidiospores orange, subglobose, finely echinulate, $14-16 \mu$

III. Teleutosori on upper surface of basal leaves, associated with aeciclia, a few together, round, bullate, compact, corered at first by raised arey epidermis, which splits irregularly, up to $1 \mathrm{~mm}$. diam.

Teleutospores black in mass, dark chestnut-brown individually. oblong to clavate, smootl, slightly constrieted at septum, blunty pointerl, romded or trunciate at apex and thickened up to $9 \mu$, tapering slightly or rounded at base, $37-62 \times 18-25 \mu$; pelicels usually slightly tinted towards apex, persistent, up to $50 \mu$ long and $10 \mu$ broakl.

X. Mesospores common, similarly coloured to, or paler than, teleutospores, variously shaped, ellipsoid, oblong or ovate, pointed, rounded, or trimcate at apex, and thickenel up to $i \mu$, $25-3+\times 11-20 \mu$, with pecicels equally long and similar to those of teleutospores.

On Cruciferous plint.

Now South Wales-Guntawang (Hamilton).

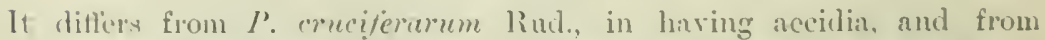
I. buburren Cooke, in which the telentospores are broally lanceolate aud eonsiderably narrower. 
This is a portion of the original material which was named Aecidium burbareae in Cooke's Handbook of Australian Funji but, on closely examining it, teleutosoli were found. The host-plant is not Barbarea vulgaris $\mathrm{R}$. Br., which is the only species of that genus in Australia.

(Plate NXX., Fig. 266.)

\section{IILLENTACEAE.}

\section{Puccinia hibbertiae McAlp.}

Ilibbertia.

III. Teleutosori ruddy-brown to black, compact, soon naked, up to $1 \mathrm{~mm}$. diam., on under surface of leaves.

Teleutospores pale yellowish-brown, oblong to somewhat clavate, smooth, constricted at septum, 35-41 $\times 18-21 \mu$; upper cell rounded at apex to somewhat conical, usually thickened (up to $6 \mu$ ) ; lower cell generally rounded at base, sometimes slightly attenuated; pedicel hyaline, persistent, elongated, slender, $120-150 \mu$ long.

X. Mesospores occasional, similarly coloured to teleutospores, generally fusiform and thickened at apex, sometimes elongated oblong, $33-3 \tilde{5} \times 12-16 \mu$.

On Ilibbertia sericea Benth.

Victoria-Cheltenham, July, $190 t$ (Robinson). Oakleigh, Sept., 1904 .

The small size of the leaf together with the scanty sori render this species easily overlooked. The teleutospores are often noticed germinating in situ.

(Plate XIX., Fig. 265.)

\section{PHRAGMIDIUM Link.}

This genus occurs exclusirely on the Rose family, and of the $t 6$ species recorded by Dietel ${ }^{13}$, only four are found in Australia. They are all autoecious, and in some instances spermogonia accompany aecidia. The aecidia are of the caeoma type, but paraphyses take the place of a peridium. The species, (P. baruardi) on the native raspberry (Pubus parrifolius) does considerable damage, and the imported species-P. subcorticium-is spreading extensively on the sweetbrier.

General Charaters. - Spemogonia thattened or slightly raised, generally arranged in concentric circles.

Aecidia after caeoma type, surrounded by a dense crown of inwardlycur'red paraphyses.

Caeomospores with numerous distinct germ-pores distributed orer the entire surface.

Uredosori likewise surrounded by paraphyses.

Uredospores solitary on basidia, with numerous germ-pores.

Teleutospores separate, pedicellate, consisting of from three to ten, superimposed cells, the uppermost of which has one to three germ-pores, the others about three to four each, placed laterally.

sporidiola spherical.

Australian species, $t$. 


\title{
ROSACEAE.
}

\section{2.. Phragmidium barnardi Plow. and Wint.}

\author{
Winter, Rev. Myc., VIII., p. $208(1886)$. \\ Cooke, Handb. Austr. Fung., p. 3.39 (1892). \\ Silce. Syll. V II., p. $746(1588)$.
}

O. Spermogonia on numerous, minute, discoloured patches on upper surface of leaf, appearing as ruby coloured, minute, blister-like puckered swellings, with round central pore, and arranged in small concentric circles.

Spermatia goklen-yellow in mass, hyaline individually, minute, narrowly ellipsoid, embedded in mueilagre, $4-6 \times 2 \frac{1}{2}-3 \mu$.

II. Uredosori scittered on under surface of leaf, corresponding to spots on upper surface, very irregular in outline, ochraceous, also sparingly on upper surface of leaf, usually on reins, ellipsoid to elongated ellipsoid, surrounded by ruptured epidermis, and pale in colour.

Uredospores globose or ellipsoid, epispore thick, warty, dark yellow, $17-19 \mu$ diam. or 21-26 × 17-19 $\mu$; paraphyses surrounding them, at first colourless, finally gellowish-brown, variously and peculianly shaped, generally curved and pointed at apex, 30-40 $\times$ $9-12 \mu$.

III. Teleutosori seattered or gregarious, minute, dark brown, not rarely confluent, pulverulent.

Telentospores at first intermixed with uredospores, golden-brown, cylindrical, equal, rounded at apex, sometimes with a short, hyaline, conoid apiculus, 6-9 septate (o very common), constricted at septa, smooth, usually two germ-pores on one face in each cell, or three altogether, $60-115 \times 23-28 \mu$ : pedicels liyaline, cylindrical, or a little inflated, sometimes uniseptate towards base, very long, up to $207 \times 10-19 \mu$.

(1) living leaves of Native Ratspberry (Rubus parrifolius I.).

Victoria-il]ps noar Bright, Arthur's Creek, Flinders, Killara, Murramurrangbong Ranges, Myrniong, near Melbourne, Phillip Island, Sermour, dic.

South Australia-Mount Lofty ('Tepper ${ }^{2}$ ).

Tasmania-Huonville, Jan., 1592 (Rodway ${ }^{1}$ ). Mount Wellington, Jan., 1892 (Rodway).

As early as 1886 this species was determined by Plowight and Winter from specinens sent ly that reteran microscopist, Ml. F. Barnard, kew, Victoria.

The teleutuspores oceur on the sime leares as the uredospores, and they germinate on thr living plant immoliately un ripening. The grem-pores in each cell may be seren rery elear and distinct. 'There are two in each seen on one face, situited laterally and inmediately below each of the septa, and by means of carcul formssing it ean be sern that there is one behind, thus miking there in eith cell. In the apical cell there are also two just ahore the softum, and a third mav also be seen as in the other cells.

bietel 1 ramarks thit thare is only one germ pore in each cell of this species, but, as inclienterl abowe, there can usually be seen with sueh distinctuess that they :Ire c"prable of being photographed, as shown in the Figures. 
Teleutospores were found germinating on the living plant. The promycelium was stout and consisted of four cells with a basal cell, the contents being greyish like the sporidiola. The sporidiola are subglobose and $7-S \mu$ diam.

This fungus does considerable damage to the native raspberry, causing the leaves to fall prematurely.

(Plate XXVI., Figs. 234, 235 ; Plate I., Fig. 38.)

\section{Phragmidium longissimum Thuem.}

Rubus.

Thuemen, Flora, p. 379 (1875).

Cooke, Handb. Austr. Fung., p. 340 (1892).

Sacc. Syll. VII., p. 750 (1888).

Hamaspora longissima Koern. Hedw. XVI., p. 23 (1877).

II. Uredosori hypophyllous, scattered or gregarious, or even confluent, clear orange, surrounded by a dense layer of paraphyses.

Uredospores globose or obovate or shortly elliptical, pale yellow, with thick epispore, $16 \mu$ diam.

III. Teleutospores on both surfaces of leaf, agglutinated in long filaments up to $6 \mathrm{~mm}$. long, rather gelatinous when moist, but when dry twisted up and silky-fibrillose, 4 to 6 celled, commonly 4 -celled, vellowish to cream-coloured, containing granular protoplasm, cylindric acuminate, with apex sharply pointed and hyaline, 110-190 × 12-15 $\mu$; pedicel liyaline, tapering gradually towards base to a fine point, hollow, just slightly narrower than spore, 10-12 $\mu$ broad, and reaching a length of $500 \mu$.

Ou leaves of Rubus moluccanus $\mathrm{L}$.

Queensland-Eudlo Creek (Bailey ${ }^{9}$ ).

This species was first observed on Rubus in S. Africa, and destroys the foliage of one of the blackberries indigenous to Queensland. Bailey kindly sent me specimens in which the teleutospores are germinating in situe.

Scattered over the leaves are groups of silky-looking twisted filaments, and on being teased out are seen under the microscope to consist of innumerable spores with their long pedicels inextricably blended.

The germinating spores are seen to have one ger'm pore in each cell, and the order of germination is basipetal. The promycelial branches are stout, elongated, and transversely septate, and they may either all arise on one side of the spore, or partly only on one side. The promycelial spores are subglobose, finely warted and $9-10 \mu$ diam.

The teleutospores were very commonly $140 \mu$ long, and one 6-celled individual attained a lengtl of $190 \mu$. As might be expected in such a long and variously septate spore there is consiclerable difference in the lengths recorded. It was originally given as $200-240 \mu$, then Massee reduced it to $70-130 \mu$, and in the Queensland specimens I have found it to be 110-190 $\mu$. The stalks are excessively long, and they may reach a length of $500 \mu$ or more.

The teleutospores arree with those of Phragmidium in being three or more transversely septate, but they are agglutinated together into a gelatinous cylindrical filamentous mass, and each cell only possesses one germ pore. 
Massee ${ }^{3}$ from an examination of fresh material comes to the conclusion that it is not a Phragmidium nor a IIamaspora, although he does not undertake the responsibility of forming a new genus.

Dietel ${ }^{8}, 11$, on the other hand, consider's that there are no substantial grounds for scparating this species from l'hragmidium, although he recognises a resemblance to Cymnosporangium in the arrangement and structure of the teleutospores.

(Plate XXXI., Fig. 272.)

\section{Phragmidium potentillae (Pers.) Karst.}

Accena.

Karsten, Fung. Fenn., No 94 (1S68).

Winter, Rev. Myc. VIIT., p. 208 (1886).

Cooke, Handb. Austr. Funæ., p. 339 (1892).

Sacc. Syll. VII., p. 743 (1888).

[J. Cateomata arranged in circular groups, often confluent, orange yellow to reddish.

Caeomospores erowded in a short series, glabose, ovate or ellipsoid, echinulate, $17-2 t \times 14-19 \mu$.

IT. Ureslosori hypophyllous, orange-red, roundish, seattered or gregarious, often confluent, surrounded by a crown of club-shaperl paraphyses.

Uredospores spherical, elliptical or ovate, yellowish, echinulate, $17-24 \times 14-20 \mu$, average $15 \times 15 \mu$.

[III. Telentosori orbicular, black, pulvinate, minute.

Teleutospores oblong, 2-6 septate (usually 3-5), slightly constricted, obtuse, or obtusely apieulate above, slightly attenuater below, smooth, yellowish-brown, $50-70 \times 20-2.2 \mu$; pedicels colourless, firm, 100-150 $\mu$ lons.]

On living leaves of Acaena sanguisorba Vahl.

Victoria-Near Melbourne, 1886 (Reader). (Winter. ${ }^{2}$ )

On Acaena orina A. C'unn.

$$
\text { S. Australia-Sept., } 1898 \text { (Quinur). }
$$

The specinen from Victoria was originally determined by Wrinter, and portion of the same material, kindly supplied by lieader, shows only uredospores.

Darluca filum Cast. is plentiful on some of the sori.

125. Phragmidium subcorticium (Schrank) Winter.

Riose.

Winter, Die Pilze T., p. 2.2s (1884).

Cooke, Handb. Austr. liung., l. 339 (1892).

sace. Syll. VII., p. Tt6 (1885).

I. Caneomata forming lange dence swellings on stems, leaf-atalks, and fruits, and lesser swellings on lower snifice of leares, effused, generally conthent, luright orange, with club-shaperl parapliyses.

Caemunores ellipsoid to woid, echiaulate, epispore hyaline, and (o) 
II. Uredosori hypophyllous, on yellow spots, yellowish red, minute, orbicular, scattered or crowded, with tubular paraphyses slightly swollen towards apex, and not particularly club-shaped.

Uredospores ellipsoid, oroid or piriform, finely echinulate, reddish orange, 4-6 germ-pores on one face, 22-29 $\times 16-20 \mu$.

III. Teleutosori hypophyllous, minute, scattered or crowded, black, readily detachable.

Teleutospores oblong, dark-brown, warted, obtuse at the apex with a colourless apiculus, $7-8$ celled, with $2-3$ germ-pores on one face in each cell, $75-102 \times 32-36 \mu$; pedicel hyaline, except pale-brown towards apex, expanded in the lower half, 100-150 $\mu$ long and broadened up to $22 \mu$.

On Rosa rubiginosa I., R. canina L., and R. laxa Retz.

Victoria-Pascoe Vale, Oct., 1898 (Cronin). Ferntree Gully, April, 1899 (Hill). Brighton, Nor., 1901, Aug., 1903, June, Oct. and Dec., 1904, March, 1905, II.

S. Australia-Third Creek Garden, Mt. Lofty Range, Nov, 1899

(Tepper). Nor., 1900 (Agricultural Bureau), II., III.

Tasmania-Launceston, Oct., 1902 (Littler). Hobart, Apr., 1903, II., III. (Rodway).

This species is now very common around Melbourne, particularly on the sweetbrier (R. rubiginosa). It has also become a pest in the nurseries, causing considerable damage to the dog-rose stocks ( $R$. canina). Seedlings are attacked very sererely in a favorable season and killed outright. This rust occurs in some of its stages, practically all the year round, but is less common in midsummer. The uredospores resemble the caeomospores in their size and shape, but may be distinguished by their long stalks (up to $56 \mu$ ) and their germ-pores.

The mycelium of the caeoma may winter in the stems, so that by means of cuttings the disease was probably introduced into Australia. "It may also have been introduced with the seeds of the sweetbrier, for that was among the first European plants to be imported into Tasmania and New South IVales, and used as hedges.

(Plate XXVI., Figs. 229-233 ; Plate I., Fig., 37.)

\section{CRONARTIUIM Fries.}

Only one species of this genus is known here, and it occur's rather commonly on certain leguminous plants. So far teleutospores only have been found. This genus produces uredo and teleutospores on one host plant, and the aecidial stage on another, but the latter has not yet been found in Australia. In Europe there is a bladder-rust on the bark of I'inus sylvestris, and this has been proved to be the aecidial stage of Cronartium asclepiauleum (Willd.) Fr. As in so many other similar cases, this stage was considered to be an independent form, and named Peridermium cornui Rostr. and Kleb.

General characters.--Spermogonia truncate to conoid.

Aecidia with bladder-like, irregularly opening pseudoperidia (Peridermium).

Aecidiospores without germ-pores, separated by distinct intermediate cells, epispore always more or less regularly warty reticulated.

Uredo-layer included in hemispherical pseudoperidum, which opens at apex by a narrow pore. 
Uredospores echinulate, without germ-pores.

'T'elcutospores unicellular, united into a cylindrical, vertical, horny column, germinating in situ, surrounded at base by the uredospores.

Sporidiola subglobose, hyaline.

Australian species, 1.

\section{LEGUMINOSAE.}

\section{Cronartium jacksoniae P. Henn.}

Jacksonia, dec.

P. Hennings, Hedw. XL., p. 127 (1901).

O. Spermogonia honey-coloured, crowded or in lines, circular, flattened, on branches and lower surface of leaves.

Spermatia hyaline, ovoid to ellipsoid, 5-6 $\times 2 \frac{1}{2}-3 \mu$.

III. Teleutosori forming ruddy-brown, straight or curved, simple columns, crowded, 2-2 $\frac{1}{2} \mathrm{~mm}$. high, with blunt apex, on young and swollen branches.

Teleutospores ruddy-brown in mass, more or less colourless indidividually, elongated, generally somewhat tapering towards each end, with largo vacuole, cylindrical to fusiform, contents granular, $40-50 \times 8-10 \mu$; teleutospores germinate at once and produce promycelia with promycelial spores, which are hyaline, globose, and a verage about $6-7 \mu$ diam.

On Jacksonia scoparia R. Br.

Queensland-Darling Downs (Law), (Bailey2). Near Brisbane $\left(\right.$ Baile $\left.^{1}\right)$.

On Platylobium formosum Sn.

Victoria-Murramurrangbong Ranges, Nov. and Dec., 1902-3 (Robinson).

On Gompholobium latifolium Sm.

Victoria-MIurlamurrangbong Ranges, Dec., 1903 (Robinson).

On Bossiaen cinerea R. Br.

Victoria-Near Melbourne, Nov., $190+$ (Robinson).

Tasmania-Bellerive, Dec., 1905 (Rodway).

On Actus rillosa Sm.

Victoria - Near Melbourne, Sept., O. Nov., 1904, III. (Robinson).

It deforms the shoots of the plant on which it grows, causing malformation of branches and multiplication of shoots (witches' brooms), and is so common in some parts that the ereat majority of the shrubs are attacked.

The spermogonia were only found on dotus and before the appearance of the teleutospores, but the multiplication and deformation of the shoots had alleady been produced. On Bossiacu cinerea on one oceasion Aecidium eburnem McAlp. was found on the same plant near Melbourne.

The horn-like aggregation of teleutospores varies in length from $1-2 \mathrm{~mm}$.

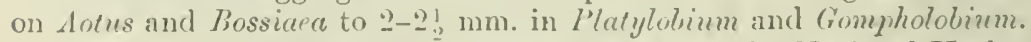

The original specimen on . Furksonia scoperia in the National Herbarium, Melbourne, is given as a variety of $C$. astepiadenm (Willd.) Fr., in Berkeley's handwriting, and is recorded in the Jourual of the Jimnean Society, p. Iit (18s3), with the remark that the only specimens are in a young state. The same species was subsequently found by G. H. Robinson very plentifully in Victoria on valdous sprecies of Tceguminous plants, and the germinating teleutospores were elenrly seen. 
Considering its occurrence on indigenous Leguminous plants, together with the narrower teleutospores and colourless promycelial spores, as compared with $C$. asclepiaderm, I considered it a new species and had named it C. leguminum. But I find that Hennings in a footnote in Hedwigia XL., p. $12 \bar{i}$, states that the form occurring on Jacksonia is specifically distinct from $C$. asclepiadeum, and had better be named $C$. jacksoniae, the name now adopted.

\section{(Plates IXIVII., XXYVIII.)}

\section{MELAMPSORA Cistagne.}

In this genus there are both heteroecious and autoecious species, but only the latter occur in Australia. The two species known are on native plants, but they also occur in Britain on the same genera. They only possess uredo and teleutospores, but the three spore-forms may occur on the same host -(M. amygdalinae Kleb.), or only aecidia and teleutospores (M. saxifragarum (I)C.) Schroet.).

The teleutospores form flat irregular crusts, and are united to each other like the cells of a honeycomb.

Rostrup first pointed out in 1883 the comnection between this genus and Caeoma species, and now the relation between a number has been proved by cultures.

General description.--Spermogonia forming a minute, hemispherical, flattened stratum, often subcuticular, otherwise subepidermal.

Aecidia after the caeoma type, destitute of a pseudoperidium, usually without paraphyses, pustular.

Uredospores usually without distinct germ-pores, included in more or less developed peridia.

Teleutospores unicellular, rarely transversely divided, coalescing in a plane, firm, black or dark-brown stratum. Sporidiola globose, yellow, then orange.

Australian species, 2.

\section{HYPERICACEAE.}

\section{Melampsora hypericorum (DC.) Schroet.}

IIypericum.

Schroeter, Brand und Rost., p. 26 (1872).

Sacc. Syll. TII., p. 591 (1888).

II. Uredosori mostly liypophyllous, scattered or subgregarious, at first bright orange, becoming pale, pulverulent, small, up to $\frac{1}{2} \mathrm{~mm}$. diam, erumpent and surrounded by the ruptured epidermis.

Uredospores subglobose to ellipsoid, finely verrucose, orange yellow, with two germ-pores on one face, 14-21 $\times 11-17 \mu$, average $17 \times 14 \mu$; paraphyses intermixed, numerous, hyaline, capitate, over-topping the spores, 50-68 $\mu$ long, with head 18-24 $\mu$.

III. Teleutosori minute, dark-brown, flat, irregular, solitary or gregarious.

Teleutospores yellowish-brown, intercellular, subcylindrical or prismatic, $25-37+6-9 \mu$.

On leaves and occasionally on stems of IIypericum japonicum Thunb.

Victoria-Hurramurrangbong Ranges, Nov, and Dec., 1902-3, and

Mit. Blackwood, Jan., 1903 (Robinson). Buffalo Mits. and

Alps, near Bright, Nov, and Dee., 1903-4 (C. French, jr.).

Near Mlelbourne, Nov., Jan. 
The paraplıyses are noted as absent by Dr. Plowright in his Monograply of the Uredineae, but in these specimens they are particularly abunclant, and form a striking feature of the uredosori. Fischer ${ }^{3}$ also found the paraphyses wanting, and he came to the conclusion with otliers, that the caeoma form harl been mistaken for the uredo, since the spores were in chains. But Klebahn ${ }^{3}$ has proved the existence of both the caeoma form without paraphyses and the urerlo form with paraphyses, so that the three stages may nccur on species of $I$ ypericum. Aecidium disseminatum Berk. is found here on the same host-plant and in the same locality as this species.

\section{LINACEAE.}

\section{2s. Melampsora lini (Pers.) Tul.}

Linum.

Tulasne, Anm. Sci. Nat., p. 93 (1ऽ54).

Cooke, Grev. XI., p. 98 (1883).

Cooke, Handb. Austr. Fung., p. 332 (1892).

Sace. Syll. VII., p. 588 (1 885 ).

II. Uredosori scattered, rounded, orange, soon pulverulent, up to $1 \frac{1}{2}$ mm. diam.

Uredospores round or ovate, bright orange-yellow, echinulate, pedicellate, $15-25 \times 1: 3-18 \mu$, exceptionally reaching a length of $25 \mu$; paraphyses curved, markedly capitate, $17-20 \mu$ thick.

III. 'Teleutsori flattenerl, often confluent, redrlish brown, then black, shining.

Teleutospores densely crowrled beneath epidermis, eylindrically prismatic, intercellular, polygonal in section, 45-60 × 17-20 $\%$, very occasionally two-eellet.

On leaves and stems of Limum muginale A. Cunn. Widely distributed. Vietoria-Near Melbourne, Oct., 1885 (Reader). Ardmona, Kergunyah, Killara, near Melbourne, Rutherglen, ic., Oct., Mareh.

New South Wales-Hume River, l\&S6 (Jepheott). Guntawang, Muclgee (Hamilton) ; Merilla, Oct., 1890 (Cobb ${ }^{2}$ ).

South Australia-Murray River, 1890 ('Tepper), (Ludwig ${ }^{2}$ ).

Tasmania-Near Waterworks, Hobart, Jan., 1892 (Rodwayl).

On Limem usitatissimum L. wherever Hax is cultivated.

Victuria-Near Melbourne, 1902. Donalk, Nov., 1903, II., III.

Port Fairy, Jan., 1904, II., TII., ie.

South Australia-Near Adelaide, 1889 (C'rawford).

New South Wales-Brungle, 18!1 $1\left(\mathrm{Cohb}^{4}\right)$.

In the .Tonrmal of Hycoloyy for 1889 , Galloway records this rust as being sent to him from Sumth Australia by the late Frazer S. Crawford, who wrote that it harl destrosed a erop of flax near Adclaicle, and was likely to spread and prove a tromblesome pest. Bolley informs me by letter that in Dakota it is a very abmudant rust on all the wild varieties of Limum, and is always more or lesis destructive in the thax crop. He further states that it was expecially destructive in 1904, in mayy cases practically destroying crops which he had bred from seals supposed to be immune to the wilt disease or llax-sick soil disense.

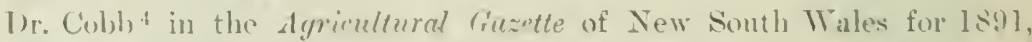
notes it as causing serious injury to cultivated flax, and in some parts of Victoria, farticularly at l'ort Fary, I have fouml it injuring the crop.

(l'late N. II., Nig. 236; Plate I., Fig. 36.) 
CAEOMA Link.

There are sereral imperfect forms which only occur in one stage and cannot with certainty be assigned to their proper genera. For such it is convenient to have a form-genus, which simply serves as a resting-place until their true affinities are determined. At first they were considered to be independent fungi and had generic names assigned to them. These formgenera are Caeoma, Aecidium, and Credo, and of the former there are only two known for Australia, one of which was called an Aecidium by Cooke and the other a Uredo by Berkeley. This is not surprising when one considers that the caeoma is not distinct from the aecidium, as in those cases where the one merges into the other. Thus in Puccinia prenanthis (Pers.) Lindr., the aecidial wall is very imperfectly formed, so that the aecidia approach caeoma-forms. Barclay ${ }^{2}$ also found a variety of this species in Simla, in which there was not a vestige of a peridium, and he considers this, along with others, an interesting example of an intermediate and mostly ranishing stage between Aecrdinm and Cacoma. In the aecidial stage of Puccinia aucta (Aecidium lobelice Thuem., A. microstomum Berk.), the peridial wall was sometimes absent, so that I described it at first as a Cueoma.

Caeomata are generally considered to be stages in the life-history of the Melampsoraceae, but since true caeoma-forms occur in connexion with Puccinia, and species such as Melampsora tremulae Tul, have so-called caeoma-forms as Caeoma laricis (Westc.) Hart. with an investment of barren cells, the evidence for this connexion is weakened and the necessity for retaining this as a form-genus much reduced. In Saccardo's Sylloge Fungorum the isolated forms are treated as a sub-genus of Lredo with subcatenulate spores. They have no special significance here, but elsewhere they form witches'-brooms.

General Characters.-They are simply aecidia without peridia, the spores are produced in chains, with or without paraphrses, and accompanied by spermogonia.

Caeoma-forms, 2.

\section{APOCYNACEAE.}

\section{Caeoma apocyni McAlp.}

Tabernaemontana.

I. Sori on both surfaces of leaf, minute, crowded, brownish, bullate.

Spores yellowish, very variable in shape, ellipsoid, ovoid, pearshaped, oblong or angular, with finely granular contents, 25-34 $\times 20-26 \mu$ : epispore hyaline, coarsely verrucose, $5 \mu$ thick.

On Taberncemontana orientalis $\mathrm{R}$. Br.

Queensland-Brisbane, (Bailey ').

Mr. Bailey kindly sent me a specimen of this from his herbarium, which had been named by Dr. Cooke Aecidium apocyni Schwein., as given in his Handbook of Australian Fungi, p. $3 \pm 1$ (1902). It has no pseudoperidium, however, and is therefore a Caeoma, and since the spores do not apparently agree even with those of Cacoma (Aecidium) apocynatum Schwein., it is constituted a new species. 


\section{Caeoma clematidis Thuem.}

Thuemen, Mre. Univ. No. 539.

Berkeley, Hook. Journ. VI., p. 205 (185t).

Cooke, Hanrtb. Austr. Fung., p. 314 (1892).

Sace. Sylt. VII., p. 867 (1888).

Urerlo clematidis Berk.

T. Sori hypoplyllous, generally on pale-green portions of leaf, solitary or arranged in circular groups, more or less rounded, pulvinate, ruddy. brown at first and bright orange when burst.

Spores in rows, bright oringe, variable in shape, ellipsoid, ovate, ublong or polygonal, epispore hyaline, scolloped, 22-32 $\times$ $16-20 \mu$.

On living leaves of Clematis aristata R. Br., and C. microphylla DC.

Victoria-Near Colac, Sept., 1897 (Hill). Phillip Island, Jan.,

1900. Murramurrangbong Ranges, Dec., 1903 (Robinson).

Near Melbourne, Feb. and July, 1904. Frankston, Jan., 1904,

Aug., 1904 (Robinson).

Queensland-Bailey ${ }^{15}$.

This species was first described from S. Africa as a Uredo, but it has the spores in chains and is a true Cacoma. Specimens were examined from 'Thuemen's Myc. Univ. 539 and found to be the same.

\section{AECIDIUIM Per's.}

Several of the aecidia given in Dr. Cooke's Mandbook of Australian Fungi are now referred to their proper Puccinias. A. urticae is accepted as a stage in the life-history of Puccinia caricis, and described in connexion with that form. A. goodeniacearm, A. senecionis and $A$. violae are placed under their proper I'uccinia or Lromyces, and the aecidium on the dais (A. bellidis) is now found to belong to $P$. distincta McAlp., and to have no connexion, as in Britain, with P. obscura on Luzula. The most noteworthy aceidium is that found on a grass ( 1 . danthonice), and constitutes the second known example. They often cause deformation of the branches known as witches' brooms, and various swellings, and in some instances compound galls are formed up to $5 \mathrm{~cm}$. across (A. enylerianmm). One species causes thickening and distortion of the leaves in Feronica, and nettle stems are often abnormally swollen fiom the same cause.

General Characters. - Pseudoperidia cup-shaped or mrn-shaped, rarely cylindrical, with margin often crenate or laciniate and revolute.

Spores, globose or angular, commonly orange yellow, growing in chains.

Accidium-forms, 15 .

\section{SCROPHUIARTACEAE.}

\section{Aecidium disciforme $\lambda(\mathrm{c} A]_{\mathrm{P}}$.}

Yeronica.

O. Spermogonia on under surfico of upper and younger leaves, honeycoloured, flit, numerous, minute.

Spermatia hyaline, elliptical, 5-6 $\mu$ long. 
I. Aecidia on both surfaces of leaves, but mostly on under, bullate, brownish, resembling dotted dises, often confluent, at first entirely enclosed, ultimately opening irregularly by small pore, $1-1 \frac{1}{2} \mathrm{~mm}$.; peridial cells hyaline, loosely adherent, subglobose, elliptic or lozenge-shaped when united, with striated margin, 25-30 $\mu$.

Aecidiospores orange-yellow, subglobose to elliptic, $16-20 \mu$ diam., or 19-22 $\times 14-16 \mu$.

On Teronica gracilis $\mathrm{R}$. Br.

Tasmania-Sandy Bay, Hobart, Aug., 1896 (Rodway).

On Veronica calycina $\mathrm{R}$. Br.

New South Wales-Kogarah, Oct., 1900 (Maiden).

This species causes thickening and distortion of the leaves. It is quite distinct from A. veronicce Berk., of which there is a portion of the original material in the National Herbarim, Melbourne. The latter forms a regular cup with fimbriate margins, while the former only opens by a minute pore. The spores are also quite different.

\section{Aecidium veronicae Berk.}

Teronica.

Berkeley in Herb., Grev. XT., p. 97 (1883).

Sacc. Syll. VII., p. 814 (1888).

I. Aecidia numerous, crowded, semi-immersed, on under-surface of leaf and a few scattered on upper surface, $\frac{1}{2} \mathrm{~mm}$. diam.; pseudoperidia cup-shaped, becoming discoloured and dark-brown with age, with fimbriate margins; peridial cells, oblong to angular, with very broad striated margin, average $32 \times 2 \pi \mu$.

Áecidiospores dark yellow, variously shaped, ellipsoid, oblong or angular, with finely-granular contents, 24-30 × 16-20 $\mu$; epispore hyaline, finely verrucose, about $2 \mu$ broad.

\section{On Veronica sp.}

Victoria-(F. v. Mueller).

Tasmania-(Rodway).

There is an old sperimen in the National Herbarium which had been submitted to Berkeley by the late Baron von Mueller. There are plenty of spores still in the cups, but probably the thoroughly mature ones have fallen away.

$$
\text { (Plate XXXIX., Fig. 287.) }
$$

\section{PLANTAGINACEAE.}

\section{Aecidium plantaginis-variae McAlp.}

Plantago.

O. Spermogonia on both surfaces of leaf, but mostly on upper, honeycoloured, numerous, 160-180 $\mu$ diam.

Spermatia hyaline, elliptical, $4-\overline{5} \mu$ long.

I. Aecidia on both surfaces, sub-gregarious or gregarious; pseudoperidia: cup-shaped, outstandling, with recurved and lobed margins; peridial cells oblong to lozenge-shaped, or polygonal, with broad striated margin, 35-40 $\mu$ long.

Aecidiospores bright orange-yellow, elliptic to oblong, finely echinulate, $22-25 \times 16-23 \mu$, sometimes reaching a lengtl of $28 \mu$. 
On leaves of Plontego veric R. Br:

Victoria-II rramurrangbong Ranges, Nov, 1902 (Robinson). Mt. Jilackwood, March, 1905 (Cyril Brittlebank).

New Sonth Wales - Guntawang, near Mudgee (Hamilton).

Tasmania-Kinucklofty, Oct., 1895 (Rodway ').

This species is given as 1. ylantraginis Ces., in Cooke's Mandloosti of Australian frumi, lut there are no spots on the leaves, and the spores are echinulate not tuberculate, as well as considerably larger.

The Victorian specimens were rare, and the fungus was much overrun by Darlace filum Ciast.

(Plate XXXTX., Fig. 288.)

GENTIANACEAE.

\section{Aecidium nymphoidis DC.}

Limnanthemum.

De Candolle, Fi. fr. 1I., p. 597 (1805).

Cooke, Hinnib. Austr. Fung., p. 341 (1 892$)$.

Sace. Syll. TIT., p. 809 (1888).

I. Aecidia on upper surface of leaf, gregarious, disposed without order on rounded spots, or in concentric zones; pseudoperidia scutelliform, maryin searcely prominent, entire, or irregularly laciniate.

Aecidiospreres orange-ycllow, angular, delicately warted, 12-20 $\mu$ diam.

On Limnanthemum indicum Thw.

Queensland-Near Brisbane, 1884 (Baileyt).

This aecidium was first found on the leaves of Limnanthemum nymphoides Hoff. and Link and its connexion with Paccinia scirpi DC., was first suggested by Chodat'. Then Bubak-1, by means of cultures, proved the connexion, but until the teleuto stage is found in Australia only the aecidium stage will be given.

specimen not seen.

\section{COMPOST'MAE.}

\section{Aecidium cymbonoti Thuem.}

Cymbionotes.

Thuemen in Muell. Supp. Phyt. Austr. XI., p. 96 (1,80). sace. Srll. I'H., p. $83: 3$ (1888).

O. Spermogonia minute, honey-eolomred, in groups, surrounded bs aceidia, 130-160 $\mu$ diam.

Spermatia minute, hyaline, ellipsoisl, $3 \mu$ long.

T. Aecirlia on upper surface of leares, markedly circinate, about $\frac{1}{3} \mathrm{~mm}$. diam.; psendnperidial yellowish, with fimbriate nargin : peridial cells consiclerably overlapping each other, elongated oblong to sliprerslapperl, with striated maruin and reticulate all over, $28-38 x$ $16-17 \mu$.

Aecillospores orange-yellow, ellipsoid to sub-globose, fincly echinulate, $1: 3-18 \times 13-15 \mu$. 
On Cymbonotus lansonianus Gaudich.

Victoria-Dookie, Jan., 1892 (Pye). Dimboola, Mas, 1896.

(Reader). Preston, April, 1900 (C. French, jun.). Myrniong (C. C. Brittlebank).

Some of the specimens were orerrun with Darluca filum Cast.

There is no clue to the description of this species, but I have drawn out the above from abundant material.

(Plate XIXIX., Fig. 290.)

136. Aecidium monocystis Berk.

Abrotanella.

Berkeley, Flor. N.Z. IT., p. 196 (1855).

McAlp., Proc. Roy. Soc. Yic. VII., N.S., p. 218 (1894).

Sacc. Syll. IX., p. 319 (1891).

I. Aecidia solitary, relatively large $\left(\frac{3}{4} \mathrm{~mm}\right.$. diam. $)$ persistent on the upper surface of the leaves towarls their tips, surrounded with a tough border; pseudoperidia white, with margin toothed; peridal cells somewhat wedge-shaped to angular oblong, appearing hexagonal when united, corered with projecting points, $50 \times 22 \mu$.

Aecidiospores pale orange-yellow, ellipsoid, finely verrucose, $25-30 \times 19-22 \mu$.

On leaves of Abrotanella forsterioides Hook. $\mathrm{f}$.

Tasmania-Summit of Mt. Wellington, Feb. 1891 (Rodway).

This is a very characteristic species, occurring solitary at the tips of the leaves. It was first recorded on Phyllachne (Helophyllum) colensoi Berggr. from New Zealand, but L. Rodway, Government Botanist of Tasmania, has grave doubts as to the correct determination of the host-plant. $H e$ is of opinion that this rust is attributed to New Zealand by mistake, and that it was really found in Tasmania. He informs me that this Accidium is abundant on every tuft of $A$. jorsterioides, which grows in profusion near Hobart, and is not likely to have been overlooked by the earls botanists. The coloured drawing of the plant in the New Zealand Flora certainly closely resembles Abrotanella, and I have forwarded a specimen of the plant to the Director of the Royal Gardens, Kew, for comparison with the original. It is not likely that the same Aecidium occur's on a Composite and a sitylidiaceous plant.

(Plate IXXIX., Fig. 291.)

137. Aecidium oleariae Mcdlp.

Oleuria.

I. Aecidia crowded on stems and leaves, generally running in lines lengthwise, about $1 \mathrm{~mm}$.; pseudoperidia round to elongated, with lacerated margins; peridial cells hexagonal, striated, 35-42 $\mu$ long.

Aecidiospores orange, elliptic to oblong, with granular contents, $2-2-26 \times 1+-17 \mu$

On stems and leaves of Olearia avillaris F.v.M.

Tictoria-Port Fairy, Jume, 1899 (Robinson).

The aecidia occur most commonly on the stem, and are deeply imbedded in the tissues of this coast shrub. 


\section{RUBIACEAE.}

138. Aecidium plectroniae Cooke.

C'antlinom.

Conke, Grev. X., p. 124 (1882).

liailey, Queensland Agr. Jomn. IV., p. 281 (1899).

Sace. Syll. VII., p. 795 (1858).

0. Spermorgonia on upper surface of same spots which bear the aecidia, sometimes accompanied by one or a few accidia.

I. Accidia hypophyllous, rotund, in small clusters on orbicular discoloured spots; pseudoperidia somewhat prominent, whitish, margins sub-entire; perirlial cells ovate to somewhat quadrate, punctate all over, and with striate margin.

Aecidiospores yellow, finely echinulate, sub-globose to ellipsoid

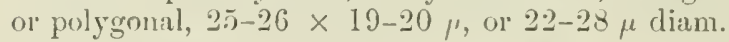

On leaves of C'unthium coprosmoides F. v. MI.

Queensland-Endeavour River (Roth) (Bailey, 21. 22).

The host-plant is sometimes placed under the genus Plectronia.

This species was first found on Crenthium (P'lectronia) guenzii Sond., from Natal, and the spores were undescribed, but I have been able to redescribe it from specimens kindly sent from Queensland by Bailey.

\section{I.EGUMINOSAE.}

\section{Aecidium eburneum NIcAlp.}

Bossiaea.

MeAlpine, Proc. Roy. Soc. Vic. VII., N.S., p. 218 (1395).

P. Hennings, Hedw. XL., p. 35:2 (1901).

Sace. Syll. XIV., p. 375 (1899).

A. bossiaene P. Hennings, Hedw. XL., p. 352 (1901).

I. Aecidia mostiy hypophyllous or on stems and legumes, scattered or in dense clusters, bright orange, average $\frac{1}{3} \mathrm{~mm}$. diam.; pseudoperidia cup-shaped, becoming ivory-coloured then brownish, with reflected finely toothed margin ; peridial cells polsgonal, reticulated, $24-31 \mu$ long.

Accidiospores ellipsoid, bright orange, very finely cchinulate, $18-28 \times 12-17 \mu$. legumes.

On Bossinen cincreit R. Br., stems, leaves, flower-stalks, calyx, and

Victoria-Near Melbourne, Sept.-Nor. (Barnarl, Robinson, fre.).

'Tasmania-Bellerive swamp (Rodway '), and Dec., 1905.

On leaves of Bossiaen limopluylla R. Bri.

West Australia-King George's Sound, July, 1901 (Pritzel).

() fruit of Bossinen rhombifuliu sieber and li. mierophylla sm.

Now south Wales-lichmond, Nov., Is96, and Falconbridge, Oct., 190.4 (Maiden).

On fruit of liossiner helerophylla Veut.

Now Sunth Wales, sep., 1 sig (Mairlen).

T have rovised the deseription of $A$. ehurnem from fresh specimens, and have no doubt but it is the sane as Henning' speeies, a specimen of which 
he kindly sent me. The spores in both cases are very finely echinulate, and in the Test Australian specimens they are $18-23 \times 15-18 \mu$, while in the other they are $18-28 \times 12-17 \mu$.

On the stems of $B$. cinerea there are oval to lenticular swellings, sometimes half an inch long, separate or close together, with dark purplish border, and often becoming depressed in the centre. On the leaf-stalks the swelling may completely surround them, and on the leaf there are brown raised orbicularspots, with aecidia on both surfaces, but sparingly on upper. On the flower-stalks the swellings are similar to those on the leaf-stalks, and on the legumes large circular or irregular patches are formed on margins and both valves.

(Plate XXVII., Fig. 239.)

140. Aecidium platylobii McAlp.

Platylobium.

O. Spermogonia honey-coloured, minute, scattered, either associated with or on opposite side to aecidia.

Spermatia very numerous, hyaline, cylindrical, $3 \times 1 \mu$.

I. Aecidia on pallid spots or on swellings on pods, amphigenous, in small groups or in dense clusters, deep orange; pseudoperidia cylindrical, white, with small portion inserted in matrix, margin finely toothed, up to $1 \mathrm{~mm}$. long.

Aeciciiospores orange, elliptic to sub-angular, finely warted, $21-25 \times 14-18 \mu$.

On leaves and legumes of Platylobium formosum Sm.

Victoria-Murramurrangbong Ranges, Nov., 1902, Dec. 1903, and Jan. 1905 (Robinson).

It is closely related to Aecidium soleniiforme Berk., but until further stages are found it will be retained as a distinct species.

While the bright orange aecidia are very conspicuous and very plentiful on both surfaces of the legumes, they are very rare upon leaves, having hitherto only been found on the first or second pair of leaves of young seedlings.

The mycelium bearing the aecidia penetrated the fruit cover and entered the seed, so that the young plant is probably infected from the start.

(Plate XIVII., Figs. 237, 238.)

141. Aecidium soleniiforme Berk.

Goodia.

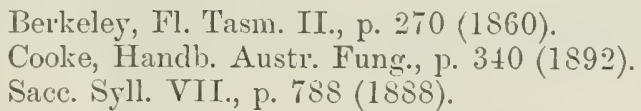

I. Aecidia on brown orbicular spots, sometimes densely crowded, particularly when on fruit; pseudopericlia cylindrical, elongated up to $\frac{1}{2} \mathrm{~mm}$. , white, radiately laciniate at margin.

Aecidiospores rather angular, orange, 25-26 $\mu$ diam.

On leaves and fruits of Goodia lotifolia Salisb.

Victoria-Nov., 1895 (French). Gellibrand River, Dec., 1895 (Hill).

Tasmania-1860 (Archer). (Berkeley')

The aecidia, as the specific name denotes, are rather tubular at first.

(Plate XXXIX., Fig. 293.) 


\section{AMARANTACEAE.}

\subsection{Aecidium deeringiae Cooke and Mass.}

Cooke and Massee, Ann. Rej. Dept. Agrr. Queensland, p. 40 (1893).

O. Spermogonia on discoloured spots on the upper surface.

I. Aecidia crowded on orbicular pallid spots $(2-3) \mathrm{mm}$.) on the under surface, which are somewliat thickened, semi-immersed, margin white, crenulate.

Aecidiuspores sub-globose, very finely echinulate, $12 \mu$ diam.

On living leaves of Deeringia relosioides $\mathrm{R}$. Br.

Queensland-Gladfield (Gwyther), (Bailey. ${ }^{12}$ )

The colour of the spores could not be determined in the dried specimens.

Only the name of this fungus was given in the Annual Report, and Dr. Cooke has kindly furnished me with the description in MS.

Uromyces deeringiae Syd. occurs on Deeringia indica in Java and the Philippine Islands, but the aecidiospores are $22-28 \mu$ diam., so that they are quite distinct from the present form unless there has been a mistake in the transcription of the size of the spores. The host in both cases is the same according to the Index lieversis.

(Plate XXXIX., Fig. 294.)

\section{HYPERICACEAE.}

\section{Aecidium disseminatum Berk.}

Iypericum.

Berkeley in Hook. Handb. Fl. N.Z., p. 756 ( $1 \& 67)$.

Sace. Syll. IX., p. 322 (1891).

I. Aeciclia on under sulface of leaves, causing cotresponding elevations on upper surface, sub-gregarious or crowded, sometimes confluent, fully $\frac{1}{3} \mathrm{~mm}$. diam.; pscudoperidia raised, with white margin, reflexed, fimluriate; peridial cells sub-quadrate, averige $30 \times 22 \mu$.

Aecidiospores orange-rellow, sub-ellipsoid to sub-angulitr, fincly verrucose, $16-17 \times 11-13 \mu$.

On IIypericum japonicum Thunb.

Victoria-Jluramurrangbong Ranges, Nov. 1902, and Dec., 190:3 (Robinson).

The original description by Berkeley is very brief: "Spots none or effused. Peridia scittered, short; margin lobed; spores white." Since it wis hardly possible from this description to be sertain of the species, a specimen was sent to the Royal Gardens, Kew, for comparison with the type specinen there, and it was found to be irlentical.

This recidium oecurs on the same host-plant as Ifelamprora hypericorum (I)C.) Schroet. and is uccasionally found on the same leaf with the uredosuri. 


\section{RANUNCULACEAE.}

\section{Aecidium calthae Grev.}

Caltha.

Greville, Fl. Ed., p. 146 (1824).

McAlpine, Proc. Linu. Soc. N.S. W., XXIV., p. 301 (1899).

Sacc. Srll. VTI., p. 602 (1888).

O. Spermogonia arranged in small groups, honey-coloured.

I. Aecidia distributed on upper surface of leaf and often confluent, about $\frac{1}{3} \mathrm{~mm}$. diam.; pseudoperidia white, margin laciniate; peridial cells pentagonal or hexagonal, margin finely streaked, 2s-32 $\mu$.

Aecidiospores bright orange, angular to sub-globose or oval, finely echimulate, average $22-23 \times 17-20 \mu$.

On living leaves of Caltha introloba F. v. M.

New South Wales-Mt. Koscinsko, Jan., 1399 (Maiden).

I have provisionally named this as above, althongh Greville describes the aecidium as hypophyllous and on the petioles, while here it was epiphyllous, and only on the blade of the leaf. Howerer, the spores and pseudoperidial cells quite agree with British specimens. The host-plant is indigenous to Australia, and was found in a rocky creek, on eastem side of ILueller's Peak, Mt. Kosciusko, at a height of about 6,500 feet. This was the only nicro-fungus found there by Mr. Maiden. The Puccinia-stage of this fungus occurs in Europe and America, and has hitherto only been found on the marsh marigold (Caltha palustris L.); until that stage has been discovered here, it cannot be definitely stated that the two fungi are the same.

(Plate XXXIX., Fig. 295.)

\section{Aecidium ranunculacearum DC.}

Ranunculus

De Candolle, Fl. fr. VT., p. 97 (1805).

Cooke, Handb. Austr. Fung., p. 340 (1892).

Sacc. Syll. VII., p. $776(1886)$.

I. Aecidia hypophyllous or surrounding lobes of leaf and on stalk, densely crowded, very bright orange, often causing a swelling; pseudo-peridia cup-shaped to cylindrical, whitish, with margin brittle and lacerated, $1 \mathrm{~mm}$. high ; peridial cells somewhat quadrate and tapering to a point where they dovetail into each other, with striated margin, $27-28 \times 18-22 \mu$.

Aecidiospores orange-yellow, polygonal to oblong or ellipsoid, very finely echinulate, $17-30 \times 14-20 \mu$, average $22 \times 17 \mu$.

On Ranunculus parviflorus L., R. rivularis Banks and Sol., R. lappaceus Sm. and R. gunnianus Hook.

Victoria-Mount Eınu Creek, 1s54. Omeo, Nov., 1882 (Stirling). Ardmona, 1896 (Robinson). Near Dimboola, Nov., 1897 (Reader). Murramurrangbong Ranges, Nov., 1902 (Robinson). Buffalo Ranges, Dec., 1904 (C. French, jun.).

On Ranunculus sp.

New South Wales-Guntawang and Mudgee (Hanilton). Richmond (Musson).

Tasmania-St. Patrick's River, Nov., $184 t$ (Gunn), (Berkele $\left.{ }^{\prime}\right)$.

This aecidium occurs on several species of Ronumculus, and varies somewhat in general characters, although the aecidiospores all agree in being very finely echinulate. As the result of cultures, this has been found to be 
a composite species, the aecidiospores infecting various grasses on which they produce uredo and telcutospores. Until similar experiments are carried out here, the different aecidia, occurring on species of lianunculus must be grouperl together.

Darluca filum Cast. was found associated with the aecidia.

(Plate XXXTX., Fig. 296.)

\section{UREDO Pers.}

This stage probably belongs to teleutospore-forms which have not been observed, and which may only rarely be produced. But it is also quite possible that some may possess a perennial mycelium, and dispense with the necessity of forming teleustopores. Several in Dr. Couke's IIandhook of Australian Fungi have been referred to their proper genera. IT. notabilis Ludw., belongs to Uromycladium notabile, and $U$. armillata Ludw., to Pucrinia juncophila. $U$. clematidis Berk., has already been shown to be a C'cooma, and $U$. cichoracearum DC., as determined by Cooke, belongs to $U$. bidentis $P$. Henn.

General characters. - Sori without pseudoperidium, covered or erumpent, for the most part orange-yellow, rather pulverulent, and spores produced singly on the terminal ends of hyphae, never smooth. Germination by germ. tube, which enters the host-plant through stomata.

Uredo-forms, 13.

\section{GRAIINEAE.}

\section{Uredo kuehnii Krueg.}

Saccharum.

Krueger, Bericht. Zuck. Java IX., p. 117 (1891).

Cobb, Agr. Gaz. N.S. W. IV., p. 799 (1893).

Sacc. Syll. XI., p. 182 (1895).

Uromyces knchnii Krueg.

II. Sori mostly hypophyllous, linear, at length bursting through epidermis and forming elongated brownish or blackisl narrow streaks, single or confluent, with clavate, brown paraphyses.

Uredospores globose to ellipsoid or piriform, brown or orange, rather thin-walled, echinulate, $47-53 \times 28-35 \mu$; pedicels hyaline, clavate, somewhat shorter than spore.

Common on leaves of Saccharum officinarum L.

New South Wales-Clarence River (Cobbi $)$.

Queensland-Brisbane and Mackay, $1898\left(\operatorname{Tryon}^{5}\right)$.

Dr. Cobb found the spores to possess four equatorial germ-pores, and I have given his measurements, although Krueger makes them out to be $28-57 \times 18-34 \mu$.

Specimen not seen.

\section{CYPERACEAE.}

\section{Uredo scirpi-nodosi Mcגlp.}

Scirpus.

II. Sori bullate, elongated, splitting lengthwise, running in lines on stem, $1 \mathrm{l}-2 \mathrm{~mm}$. long.

Uredospores lorown, subglobose, ellipsoil to oblong, variable in size, $25-32 \mu$ diam., or $27-36 \times 19-25 \mu$; epispore echinulate, often $3 \mu$ thick. 
On Scirpus nodosus Rottb.

Victoria-Mordialloc, Dec., 1885 (Reader) (Winter ${ }^{2}$ ).

This specimen is given as Puccinia rimosa (Link) Wint., by Winter, but. on carefully examining some of the original material, there are coarsely echinulate uredospores and nothing else. It is evidently not that species described by Winter in Hedwigia, p. 28 (1880), and since it does not agree with the uredo stage of Prccinia scirpi DC. of which I have examined specimens from Sydow's Ured. Exs. 685 on Scirpus lacustris L., I have named it as above.

(Plate XXVIII., Fig. 2t1.)

\section{LILIACEAE.}

148. Uredo anguillariae Cooke.

IIrormbea.

Cooke, Grev. XIV., p. 11. (1885).

Cooke, Handb. Austr. Fung., p. 343 (1892).

Sacc. Syll. VII., p. 840 (1S88).

II. Sori on both surfaces, gregarious, elliptic, bullate, long covered by the epidermis.

Uredospores globose or globosely oval, smooth, brown, epispore thin, $20-22 \times 20 \mu$, on short deciduous hyaline pedicels.

On leaves of ITurmbea (Anguillaria) dioica F. v. M.

New South Wales-Guntawang (Hamilton).

It is curious to note that Cooke and Massee have also described a Puccinia with uredo and teleutospores on this plant, the uredospores being $25-28 \times 15-18 \mu$.

Specimen not seen.

149. Uredo geitonoplesii McAlp.

Geitonoplesium.

II. Sori on under surface of leaves on vinous patches, in small groups minute, elliptical, ultimately rupturing epidermis.

Uredospores yellowish to yellowish brown, elliptical to ovoid, very finely echinulate, $19-27 \times 17-19 \mu$.

On Geitonoplesium cymosum A. Cunn.

Victoria_Orbost, July, 1901 (Pescott).

150. Uredo schelhammerae McAlp.

Schelhammera.

IT. Uredosori epiphyllous, yellowish-brown, round to ellipsoid, compact, scattered or in groups, occasionally confluent, soon naked and surrounded by ruptured epidermis, $\frac{1}{2} \mathrm{~mm}$. diam. or up to $1 \mathrm{~mm}$. long.

Uredospores golden yellow, ellipsoid to obovate, very finely echinulate, usually with two germ-pores on one face, $22-26 \times$ $15-20 \mu$, average $24 \times 18 \mu$.

On Schelhammera undulata R. Br.

New South Wales-Kurrajong Heights, 1892 and 1903 (Musson). 


\section{RIANINACEAE.}

151. Uredo spyridii Cooke and Mass.

Spyridium, Pomaderris.

Cuoke and Massce, Grev. XV., 1). 99 (1Ssi).

Cooke, Handb. Austr. Fung., 1). 313 (1592)

Sace. Syll. VJT., p. 861 (1588).

II. Sori hypophyllous, punctiform, generally scattered, sometimes confluent, ochraceous to snuffy brown, soon bursting through epidermis, pulverulent.

Uredospores yellowish to orange-yellow, ellipsoid to obovate, distinctly echinulate, with coarsely granular contents, $22-31 \times$ $17-22 \mu$; paraphyses enveloping sori, long, curver, tufted, hyaline to pallid, generally slightly swollen at apex.

On leaves of Spyridium parvifolium F.V.MI.

Victoria-Oakleigh, June, 1886 (Watts). Sept., 1887 (Mrs. Martin). Murramurrangbong Langes, Dec., 1903, and Jan., 1905 (Robinson).

On Pomaderris apetala Labill.

Victoria-Murramurrangbong Ranges, Jan., 1905 (Robinson).

Tasmania-Devomport, Jan., 1906 (Robinson).

On both genera of host plants the sori are surrounded by paraphyses.

The rust is very plentiful on the leaves, and, although a large quantity of material has been examined at different seasons of the year, only the uredostage has been found.

(Plate XXVIII., Fig. 245.)

\section{STYLIDIACEAE.}

\section{Puccinia stylidii McAlp.}

Stylidium.

II. Sori on both surfaces of leaf, solitary or sub-gregarious, elliptic, bullate, and splitting raised epidermis, sometimes eonfluent laterally, reaching $1 \mathrm{~mm}$. or more in length.

Uredospores orange-yellow, elliptic to subglobose, echinulate, with solitary germ-pore on one face, $2.2-24 \times 16-18 \mu$, or $22-24 \mu$ diam.

III. Teleutosori, p. 링.

On leaves of Stylidium graminifolium Sm.

Tasmania-New Waterworks, Hobart, Nov. 1892, II. (Rodway).

Darluca filum, Cast., literally corered some of the sori.

(Plate XYVIII., Fig. 24:.)

\section{COMPOSITAE.}

\section{5:3. Uredo bidentis P. Henn.}

Bidens.

$$
\begin{aligned}
& \text { Hennings, Hedw. XXXV., p. } 251 \text { (1\$96). } \\
& \text { Silec. Syll. XIV., p. } 395 \text { (1899). }
\end{aligned}
$$

11. Sori scattered or lensely greararious, amphigenous, most numerous on under surface, minute, pulvinate, then thattened or somewhat patelliform, ochraceous, surrounded by the epidemis.

Uredospores oroid, ellipsoid or subglobose, yellow or pale brown, epispore pale chestnut-brown, $2-3 \mu$ thick, finely echinulate or almost smooth, $25-35 \times 2.2-2 T \mu$, in exceptional cices $41 \mu$ long: parapliyses numerous, hyaline, clavate, 50-60 $\mu$ long. 
On leatlets ard leaf stalks of Bidens pilosa L.

Queensland-Brisbane, 1886 (Bailey ${ }^{5}$ ).

Part of the original specimen named br Dr. Cooke Uredo cichoracearum DC., was kindly forwarded to me by Mr. Bailey, and on comparing it with the above species in Exsicc. Srd. Ured., 16t7, it was found to be the same. Even the paraphyses, which are not recorded by Hennings, occurred in both.

Puccinia bidentis Diet. and Holw. was deseribed in the Botanical Gazette, IXIT., 32 (1897), on a species of Bidens in Mexico, and probably is the complete stage of this uredo. The original species was founded on Bidens pilosa from Brazil.

(Plate XXTIII., Figs, 243-214.)

154. Uredo crepidis-japonicae Lindr.

C'repis.

Jindroth, Acta Soc. Fauna et Flora fennica, XXII., p. 11 (1902).

Sacc. Syll. XVII., p. 438 (1905).

II. Sori amphigenous, but often hrpophyllous, cinnamon brown, round, minute, at first surrounded by epidermis.

Uredospores sub-globose or broadly ellipsoid, yellowish, finely echinulate, with three scattered germ-pores and epispore $1 \mu$ thick, 14-18 $\mu$ diam.

On leaves of Crepis japonica Benth.

Queensland.

Specimen not seen.

155. Puccinia oleariae McAlp.

Olearia.

McAlpine, Agr. Gaz. N.S.IV. VI., p. 756 (1895).

Sacc. Syll. XIV., p. 278 (1899).

Uromyces asteris McAlp.

II. Uredosori hypophyllous, pulvinate, scattered, bright orange.

Uredospores oval or irregularly pear-shaped to spathulate, stalked, bright orange, apiculate at apex and somewhat thickened, with three equatorial pores on one face, 39-51 × 19-2.t $\mu$; epispore longitudinally striate, average thickness $1 \frac{1}{2} \mu$; pedicels relatively short, hyaline, and continuous with spore.

III. Teleutosori similar but brownish.

Telentospores intermixed with uredospores, bright orange, oblong to oblong-clavate, smooth, fragile, constricted at septum, rounded at apex, generally tapering slightly towards base, $62-90$ $\times 18-28 \mu$; pedicel hyaline, persistent, shoit, up to $56 \mu$ long.

X. Mesospores occasional, similarly coloured, elongated ellipsoid, rounded at both ends, $60-68 \times 18-22 \mu$.

On leaves of Olearia argophylla F. v. M. (Aster argophyllus Labill.).

Tasmania-Near Hobart, November, II. (Rodway'). Cataract Gorge, Jan., 1906, II., III. (Robinson).

This species was originally described as tromyces asteris, but on extended critical examination of the type material I placed it in the genus Uredo on account of the number of the equatorial germ-pores. Since then additional material has been found, showing it to be a Precinia.

(Plate XXVIII., Fig. 249.) 


\section{PIRO'TEACEAE.}

156. Uredo angiosperma 'Thuem.

Ilakea.

Thuemen, Symb. Myc. Austr. IV., No. 95 (1880).

Cooke, Handb. Austr. Fung., p. 343 (1892).

Sacc. Syll. TII., p. 840 (1888).

II. Sori on both surfaces, large, commonly disposed about a circle, corered by the splitting, torn, and elevated epirlermis, powdery, brown.

Uredospores oval or cllipsoid, rounded at the apex, somewhat narrowed at the base, $45 \times 30 \mu$; epispore smooth, pale brownish, כ-7 $\mu$ thick.

On living leaves of Halien sp.

West Australia-Oct., 1877 (F. r. Mueller) (Thumen ${ }^{2}$ ).

Specimen not seen.

\section{CRASSULACEAE.}

157. Uredo tillaeae McAlp.

Tillaea.

McAlpine, Agr. Gaz. N.S.WV. VI., p. 757 (1895).

Sacc. Syll. XIV., p. 390 (1899).

II. Sori hypophyllous, minute, round to oval, sometimes confluent.

Uredospores variable in size and shape, usually globose or somewhat oval, smooth, orange-yellow, about $19 \mu$ diam. or $20 \times 16 \mu$.

On leaves of Tillaea sieberiana Schult.

Victoria-Studley Park, near Melbourne (Barnard).

\section{LEGUMINOSAE.}

\section{Uredo bossiaeae McAlp.}

Bossiaea.

II. Ureclosori on both surfaces of leares but mostly on under, chocolate brown, erumpent, surrounded by ruptured epidermis, compact, scattered or aggregated, sub-globose, $1-1 \frac{1}{2} \mathrm{~mm}$. diam.

Uredospores elliptic, finely echinulate, golden-brown, epispore about $3 \mu$ thick, $24-31 \times 17-21 \mu$.

On leares of Bossicae prostrata R. Br.

Tasmania-Hobart, April, 1893 (Rodway).

An Aecidium has been found on species of Bossiaea in West Australia, Victoria, New South Wales, and Tasmania, but there is nu eridence to connect it with this form. It is also noteworthy that a Cronartium is found on species of Bossiaea.

$$
\text { (Plate XXYIII., Fig. 2ł6.) }
$$

Cassia.

159. Uredo pallidula Cke. and Mass.

Cooke and Massee, Grev. XXII, p. 37 (1§93).

Sacc. Syll. Xl., p. 2222 (1895).

II. Sori pallid, convex, gregarious, splitting irregularly and then girt by the ruptured epidermis, on both surfaces.

Uredospores pulverulent, tawny in the mass, pale-yellow by transmitted light, elliptical to ovoid, finely echinulate, 16-19 $\dot{x}$ $12-13 \mu$. 
On leaves, twigs, and legumes of Cassia sp.

Queensland-Gladfield (Gwyther) (Bailey ${ }^{13}$ ).

In the original description, the spores are given as smooth, and $12-14 \times$ 8-10 $\mu$, but on examining material kindly supplied by Mr. Bailey, of Brisbane, they were found to be as above.

(Plate XXVIII., Fig. 217.)

\section{CHENOPODIACEAE.}

160. Uredo rhagodiae Cke and Mass.

Rhagodia.

Cooke and Massee, Grev. XV., p. 99 (1887).

Cooke, Handb. Austr. Fung., p. $3+3$ (1892).

Sacc. Syll. VII., p. 859 (1888).

II. Sori hypophyllous, scattered, globose, ruddy-brown, a long time covered, at length torn and girt by the remains of the epiclermis, up to $1 \mathrm{~mm}$. diam.

Uredospores yellowish, ellipsoid, echinulate, with four or more scattered germ-pores on one face, $2+40 \times 17-22 \cdot \mu$.

On leaves of Rhagodia billardieri R. Br.

Victoria-Botanic Gardens, Melbourne, June, 1886 (Watts).

Sandringham, April, 1905 (Robinson).

Cooke and Massee gave measurements of spores as $20 \times 15 \mu$ from Watts' specimen from Botanical Gardens, Melbourne. I have been able to examine part of that same material returned by Cooke and Massee to the National Herbarium and find the spores to measure 24-30 $247-22 \mu$. The rust is fairly abundant along the eastern shores of Port Phillip, and in fresh material examined the spores have the same measurements, roughly about $27 \times 20 \mu$.

Darluca filum Cast. is often found on the sori.

(Plate XXX., Fig. 267.)

\section{EXCLUDED OR DOUBTFUL SPECIES.}

When one considers that specimens of the various Rusts have hitherto been mostly sent to Britain or Germany for determination, it can readily be understood that sometimes the material was in an imperfect condition or not in the best possible state for proper examination. Hence in some cases the species were wrongly determined, and there are several recorded in Cooke's Handbook of Australian Fungi, which on further investigation must be removed from the list of Australian species. Sornetimes, although rarely, it happened that the host-plant of the parasite was wrongly given, and then a new species has been created which afterwards turned out to be a known one. On these and other grounds the following are excluded :-

1. Uromyces amygdali Pass. - Cooke determined this on Peach and Aimond leaves from Victoria, New South Wales, and Queensland, but when complete specimens were examined it was found to be merely the uredostage of Puccinia mruni Pers.

2. Uromyces junci (Desm.) Wint.-This species has not been found in Australia, as it was wrongly determined at Kew Herbarium for Puccinia juncopltila Cooke and Mass.

3. Puccinia acetosae (Schum.) Koern.-This rust was determined by Cooke on a native species of Rumex, but on the examination of a specimen in the National Herbarium, Melbourne, named in his own handwriting, it 
was found to agree with $P$. ludurgii Tepper. I'. recetosae and its synonym,

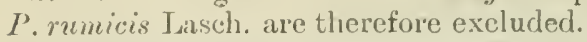

4. Puccinia aegra Grove- - $P$. depauperans (Vize) Syd.-The rust on the native violets (Yiola hederacea and $V$. betonicifolia) is comparatively common, and has been collected at various localities in Victoria, New South IVales, and 'Tasmania. It was at first determined by Winter as this species, and Cooke has also recorded it, but the examination of 'numerous specimens, inclucling part of the same material forwarded to Dr. Cooke, showed the teleutospores to be warted, not smooth, and aecidiospores likewise finely warted, and therefore not this species.

5. Puccinia apii Desm.- The rust found on Celery, both native and imported, in Australia, is found to be quite distinct from this species.

6. Puccinia caulincola Corda is given by Cooke on Mypochoeris glabra, but the species on this lost-plant is undoubtedly I'. hypocheneridis Oud.

7. Puccinia geranii Corda was the name given by Cooko to the rust occurring on Pelroryonizm australe, but it is now found to be a different species, P. morrisoni McAlp.

8. Puccinia investita Schw. was determined by Dr. Morrison on species of Graphalium, but on investigating the original material I found it to be $P$. gnaphalii (Speg.) P. Henc.

9. Puccinia microseris McAlp.-Since the host-plant of this species was really II ypochoeris radicata it is now excluded.

10. Puccinia phragmitis (Schum.) Koern.-This species has not yet been found in Australia, only P. magnusiance Koern and $T^{\prime}$. tepperi Ludw.

11. Puccinia rimosa (Link.) Wint.- This species is given by Wintel ? as occurring on Isolepis nodosa $\mathrm{R}$. Br. = Scivpus nodosns Rottb. in Victorii, but an examination of the original material only shows uredospores which do not agree with those of this species, and Sydow 1 has arriverl at the same conclusion. The local specimen I have named Uredo scirpi-nodosi.

12. Puccinia violae (Schum.) DC.-This species is also given by Cooke as occurring on violets in Victoria, but the history of the specimens shows how necessary it is to guard against recording species as Australian which may have been imported in the dry condition. The original material, with the name in Cooke's handwriting, is accompanied by the following note from the collector, Mr. Reader:- "On leaves of what appears to be riola sp. found in an old book." I was so convinced, however, that P. violae did not occur on our native violets, and had not been found growing on cultirated species, that I communicated with the collector, who informed me that the leaves on which this species was found hal been brought from Europe and forwarded with other specimens for determination to Dr. Cooke. Unfortunately, on the strerigth of this determination, Mr. Tryon, in Queensland, and others, have also credited Australia with this species. Mr. Rearler, who is a chemist, also sent myself some jaborandi leaves (Pilocarpus pennatifolins, Lem.) with a rust upon them, and it was found to be Puccinia pilocarpi Cooke, but of course it had been imported.

13. Cronartium asclepiadeum (Willd.) Fries. - This willely listributed species is recorded on a leguminus plant from (queensland, and the name is given in Berkeley's handwriting on the specimen in the National Herharium. Dietel, howerer, regards it as a new species, and has named it $C$. jachsonine.

14. Melampsora nesodaphnes B. and Br.-This species was found on the fruit of lieilsshmiediu (. Fesoduphne) olmsitolia Benth., sent hy Bailey to Berkeley from Queensland, and I also found it on the finit of Cinnumomm oliveri Bail, sent by Baker from New Soutl, Wiles. There is a mass of poweley spores on the surface of the fruit which is swollen and distorted. 
These spores are exceedingly numerous, and very variable in size and shape. They are hyaline individually, although ochraceous in the mass and finely sranular. They vary from elliptic to ovoid or pear-shaped, and are occasionally slightly curved. There is a clear central axis to the spore, and it is generally broken in the centre, $\mathrm{or}^{\mathrm{r}}$ may be several times transversely divided. Their average size is $24-32 \times 9-10 \mu$. They are usually borne on short hyaline filaments, and occasionally a long filament is adherent to a detached spore.

There is nothing in the appearance or nature of this fungus to indicate that it is a Uredine; it rather suggests some form of Hyphomycete.

15. Aecidium apocyni Schwein.-The specimen referred by Cooke to this species is Caeoma apocyni.

16. Aecidium barbareae DC.-The Cruciferous host-plant is not a Barbarea, and a portion of the original specimen shows teleutosori as well as aecidia. I have named the rust Puccinia crucifercae.

17. Aecidium bellidis Thuem., was determined by Cooke on Bellis perennis from Victoria. This is considered to represent the aecidial stage of Puccinia obscura Schroet. which oceurs on Luzula, but since teleutospores have been found from year to year on Victorian specimens along with the aecidia, it is evidently quite a distinct species. I have, therefore, named it Puccinia distincta.

Mr. Cheeseman, one of our leading nurserymen, informs me that the seeds of Bellis perennis are imported from England and Germany, mostly from the latter country. He also states that some have had to give up growing the plants on account of the rust (Puccinic distincte), since it attacks the youngest seedlings sometimes, and at other times the plants remain healthy till late in spring and then become badly attacked. One would naturally conclude that the rust had been imported with the seed, but it is strange that no teleutospores have been found accompanying the aecidia in the countries named. Although I have provisionally recorded it as a native rust, the probabilities are that it will be found to exist in the countries from which the seed has been derived.

18. Aecidium compositarum liart.-All the species occurring on Compositae have been distributed among their respective host-plants.

19. Aecidium plantaginis Ces.-The species on the native Plantago varia is distinct from this, the spores being echinulate instead of tuberculate, and considerably larger. It has been named $A$. plantaginis variae.

20. Aecidium senecionis Desm.-This has also been determined in the absence of complete specimens, but since the teleutospores have been found assuciated with the aecidia, it has been determined as a new species by Dietel, and named $P$. tasmanica. It is a striking fact that on three such common imported plants as the garden daisy, Bellis perennis, groundsel, Senecio vulgaris, and narigold, Calendula officinalis, there should have been new species of Purciniu rliscovered. As regards the groundsel, aecidia have been found on native species of Senerio, probably belonging to the same rust.

21. Aecidium violae schum., is also recorded, but this belongs to $P$. violae, and is therefore exclucled.

22. Uredo cichoracearum DC. originally determined by Dr. Cooke on Bidens piluse is now found to be $U$. liventis P. Henn.

23. Uredo leguminum Desm.-This species originally occurred on Phaseolus, and is recordel by Cooke as being found on pods of Acacia in Queensland, but since there is every reason to believe that the rust on a bean is distinct from that on a wattle it is excluded from the list. Probably it is a stage of a Lromycladium. 


\section{ADDENDA.}

\section{AMARAN'TACEAE.}

\section{Uromyces polycnemi IcAlp.}

Polycnemum.

I. Aecidia bright orange, wenerally covering lower surface of leaves, erowded, eylindricat, surrounderl at base by ruptured epidermis, up to 1 ! mm. loner ; psendoperidia colourless, with toothed margin; periclial cells oblong to somewhat lozenge-shaped, with moderately thick striated margins, $37-40 \mu$ long.

Aecidiospores orange, ellipsoid to oblong or sub-globose, very finely echinulite, $22-23 \times 17-20 \mu$ or $20-22 \mu$ diam.

II. Uredo-sori on both surfaces of leaf, bullate, at first covered by lealen-coloured epidermis, then splitting, scattered or gregarious, sometimes confluent, up to $2 \mathrm{~mm}$. in dian.

Uredospores ellipsoid to oval, orange coloured, finely echinulate, with three equatorial germ-pores on one face, $28-32 \times 18-22 \mu$.

III. 'Telento-sori similar to uredo-sori, but generally larger and darker in colour.

Teleutospores dark golden-brown in mass, tawny brown individually, ellipsoid to elongated ollipsoid, rounded at both ends, oceasionally slightly thickened at apex and germ-pore prominent, sinooth, 34-46 × 17-25 $\mu$; perlicel liyaline, persistent, comparatively short.

On Polycnemum pentandrum F.v.M.

Victoria-Port Fairy. Dec., 1905.

The accilia were very conspicnous, often covering the under surface of every leaf, and as the host plants grew in dense masses, in the saline marshes near the coast, it was dilticult to find one without the rust.

A Tuberculina was frequent!y parasitic on the aecidia.

$$
\text { (Plate XLIII., Fig. 319.) }
$$

\section{S'TYLIDIACEAE.}

\section{Puccinia stylidii MLAlp.}

Stylidium.

IT. Uredosori, p. 204.

1II. Teleutosori on both surfaces of leaf, dark-brown to black, round to elliptic, sometimes contluent in long lines, pulvinate, splitting and surrounded by epidermis, up to $1 \frac{1}{2} \mathrm{~mm}$. or longer.

'Teleutospores at first intermixed with uredospores, bright chestnut-brown, clavate to oblong, smooth, slightly constricted at septum, rounded or bluntly pointed and thickened at apex $(9-11 \mu)$, rounded or attenuated at base, not infrequently three-celled, very variable in shipe and size, $40-62 \times 17-28 \mu$; pedicel lyaline, persistent, up to $4 \bar{j} \mu$ long.

X. Mesospores common, similarly coloured to teleutospores, thickened at apex, oval to ovoid or clongated ellipsoid, 30-40 $315-23 \mu$.

On leaves of Stylidium graminifolium Sm.

T'asmania-Devomport, Jan., 1906 (Robinson).

Only the uredospores were at first sent by Rolway in Nov., 1892, and the discovery of the final stage shows that riedo stylidii is a Prucciniu, the description of which is now completed. 
Abstriction.-The formation of a spore by pinching off the end of a spore-forming hypha, without the Froduction of a septum.

Aecidiospore.-A spore formed in an aecidium, serially and successively abstricted.

Aecidium.-A spore-body consisting of a cup-shaped envelope or peridium with a hymenium at the bottom of the cup, from which aecidiospores are successively detached; also the generic name originally applied to the aecidiospores.

Amphigenous. - Growing on both surfaces of a leaf.

Amphispore.-A modified uredospore with thickened wall, and only germinating after a resting period.

Appressorium.-The vesicle fornied by the tip of a germ-tube over the stoma of a leaf before entering it.

Autoecious.-Applied to a parasitic fungus of which all the spore-forms are capable of being produced on the same host.

Basidium.-The mother-cell or ligpha from which spores are given off.

Basipetal.-Growing in the direction of the base from above downwards.

Bullate.-Raised like a blister.

Caeoma.-A spore-layer in which the spores are formed in cliains but without an envelope of peridjal cells; an aecidium without a peridium.

Caeomospore.-A spore formed in a caeoma.

Capitate.-Ending in a head, as when the free end of an upright hypha enlarges in a spherical manner.

Chemotaxis.-A form of sensitiveness which certain organisms possess towards certain chemical substances.

Circinate.-Arranged in a circular manner or nearly so.

Clavate.-Club-shaped, enlarging towards the apex.

Deciduous.-Falling away, applied to the pedicel of a spore when it does not remain attached to it.

Echinulate.-Covered with short spines.

Elliptical.-Shaped like an ellipse or oval.

Endochrome.-The peculiar colouring matter in the cells, and usually applied to the coloured cell-contents of spores.

Endospore.-The innermost coat of a spore.

Epiphyllous.-Growing on the upper surface of a leaf.

Efiteospore.-A name suggested for a uredospore which functions as an aecidiospore, and the sorus contains or is surrounded by prominent paraphyses.

Erumpent.-Bursting through the surface of the host-plant.

Fimbriate.-Fringed, when the margin is bordered by slender processes.

Form-genus.-A genus in which the species are only represented by single stages of what is believed to be an incomplete life-history, as Uredo, Aecidium.

Gall.-A morbid enlargement or hypertrophy of the cells of a plant, due to para. sitic agency.

Gametophyte.-The stage in the life-cycle of the plant which bears the sexual organs.

Germ-pore.-An opening on the surface of a spore through which the germ-tube passes.

Germ-tube.-A tubular process developed from the spore in germination, and may either become a mycelium or promycelium.

Gibbous.-.-Swollen at the base.

Globose.-Spherical.

Haustorium.-A short lateral branch of a hypha, penetrating a cell of the host-plant and acting as a sucker as well as an organ of attachment.

Heteroecious.-Applied to a parasitic fungus of which certain spore-forms occur on one host and others on plants widely remote.

Host.-A plant which nourishes a parasite.

Hyaline.-Colourless or translucent. 
Hymenium. $-\Lambda$ spore-bearing layer of hyphae.

Hypertrophy.-An abnormal enlargement or excessive growth of particular parts, which may be causerl by excess of nourishment or induced by parasites.

Hypha.-A tubular thread-like cellular structure, collectively constituting the vegetative boily or mycelium of the fungus.

Hypophyllous.-Growing on the under surface of a ieaf.

Indigenous. - Native to a country, and not introduced.

Intercellular.-Between the cells of the host-plant.

Intracellular. -Within the cells of the host-plant.

Laciniate. - Cut up into narrow lobes.

Lumen.-The cavity bounded by the walls of an organ.

Mesospore.-A single-celled spcre-forn related to the teleutospore, and probably representing a transition from the unicellular Cromyces.

Micron or Micromillimetre.-Indicated by the sign $\mu$, is the standard unit for microscopical measurements, and equals $\mathrm{I}-\mathrm{ropoth}$ of a millimetre, or 1-25,000th of an inch.

Mutation.-That kind of variation produced by internal influences, in which the equilibrium of the organism is disturbed and a new position of equilibrium found strikingly different from the original one, sometimes called spontaneous variation.

Mycelium.-The vegetative portion of a fungus composed of one or more hyphae. Nucleus.-An organized proteid constituent of the cell, necessary for its continued growth and life.

Obligate parasite.-One in which a parasitic mode of life is indispensable for complete development.

Orbicular.-Applied to a flat body with a circular outline.

Papillate.-Covered with protuberances or terminating in a papilla.

Paraphyses.-Barren filaments associated with the spores, either slender or variously swollen, hyaline or colonred.

Parasite.-An organism living on or in another living orgarisin, and at its expense.

Pedicel.-Spore-bearing stalk.

Persistent.-Lasting, not soon falling away, applied to the pedicel of a spore.

Firiform.-Pear-shaped.

Plasmodium.-A mass of naked protoplasm, containing many nuclei and exhibiting movement.

Plurivorous.-Applied to a parasite which can exist on a variety of host-plants.

Predisposition. - The tendency to lisease exhibiterl by an organism when the conditions are favorable to the development of the paraste.

Primordia.-The beginnings of any structure, such as the aecidium.

Promycelial spore.- The spore prorluced by a promycelium, also known as a sporidiolum.

Promycelium. -The short germ-tube of a teleutosiore, which produces a few spores unlike the teleutospores, and then perishes.

Protomycelium.-A term used by Friksson to denote the exrly plasmodia-like stage of the mycelium in certain Rusts.

Protoplasm.-The living substance in plants, consisting of albuminoid matter.

Psendo-parenchyma.-False tissue or compace mycelium, so called because it is formed by the union of previously separate elements or hyphae into a dense mass, while true tissue is derived from a single cell, which divides and forms a coherent, more or less firm, mass of cells.

Psendo-peridium.-The outer anelope of the aecidium, consisting of sterile cells.

Pulverulent.-Powdery

Pulvinate.-Cushion-shaped.

Reticulate.-Covered with lines or ridges crossing each other on an to form a net. work.

Saccate-Bag-shaped.

Saprophyte.-A fungus which preys upon dead organic matter only, in contrast to a parasite.

Seplate.-Partitioned off into distinct divisions.

Sorus.-A cluster of spores conntituting a spore-bed, as uredosorus, teleutosorus. 
Spermatium.-A minute detachable cell produced in a spermogonium, and formerly considered to have a male sexual function.

Spermogonium.-The receptacle in which spermatia are produced and detached. It is sometimes called a pycnidium, although that term is generally reserved for a spore-receptacle in another division of Fungi.

Spore.-A detachable cell, capable of reproducing the fungus.

Sporidiolum.-Spore produced by the germ-tube of a teleutospore. Also called sporidium, but since this term is already used as equivalent to an ascospore, Saccardo has proposed the present name.

Sporophyte. -The stage in the life-cycle of a plant which bears the spores.

Sterigma.-A delicate stalk from which a spore is detached and arising from a basidium.

Stcma.-A breathing pore or aperture in the epidermis forming a means of communication between the inside of the plant and the outer air.

Stroma.-A cushion or receptacle hearing reproductive bodies.

Symbiosis. - The living together of dissimilar organisms, both contributing to their mutual welfare. It differs from parasitism in which the benefit is all on the side of the parasitic organism.

Teleutospore.-Generally regarded as the final spore in the life cycle of the Rusts, which germinates and produces a promycelium and promycelial spores.

Truncate.-Cut off abruptly.

Uredo.-The generic name originally applied to the uredospores.

Lredospore.-A spore detached from the apex of a pedicel and producing a mycelium.

Verrucose.-Covered with small warts.

Witches' broom.-A diseased state of the shoots of a plant, when they are developed in tangled masses or tufts, due to parasitic agencies and especially fungi.

\section{LITERATURE.}

A.

1. Arthur, J. C.-The Aecidium as a Device to Restore Vigour to the Fungus. Proc. Soc. Prom. Agric. Sci., Yol. 23, p. 65. 1902.

2. Problems in the Study of Plant Rusts. Bull. Torr. Club, Vol. 3o, p. I, 1903.

3. - Taxonomic Importance of the Spermogonium. Ibid. Vol. 31, p. II3. 1904.

4. The Aecidium of Maize Rust. Bot. Gaz., Vol. 38, p. 64. 1904.

5. - Amphispores of the Grass and Sedge Rusts. Bull. Torr. Club, Yol. 32, p. 35.1905 .

6 A New Uredineous Fungus from Mexico-Baeodromous holwayi Arth. Ann. Myc., Vol. 3, p. IS. 1905.

7. Cultures of Uredineae in I904. Journ. Myc. Vol. 11, p. 54. 1905.

S. - Terminology of the Spore-Structures in the Uredinales. Bot. Gaz., Vol. 39, P. 219. 1905.

I. ArthlR, J. C., and Holway, E. W. D.-Desciptions of American Uredineae. Bull. Lab. Nat. Hist., Univ. Iowa, Yol. 5, p. 329. 1902.

I. Atkisson, J.-An account of Agriculture and Grazing in New South Wales. London. 1826.

\section{B.}

I. BaILEr, F. MI.-Synopsis of the Queensland Flora, pp, 774-776. Brisbane, $188_{3}$.

2. Contributions to the Queensland Flora. Proc. Roy. Soc., Queensland, Vol. I, Part I., p. I8. I 884 .

3. Ibid, Part II., p. 92. ${ }_{1} 884$.

4. - Synopsis of the Queensland Flora, First Supplement, pp. S $_{4}, S_{5}$. Brisbane. 1886 .

5. — Ibid, Second Supplement, pp. 125-127. Brisbane. ISS8.

6. Ibid, Third Supplement, p. 123. Brisbane. 1 Sgo.

7. - Additional Fungus Blights ubserved to have injured Plants during the

year. Ann. Rep. Dep. Agric. of Queensland, p. 45. Brisbane. r8go-91.

3. Contributions to the Queensland Flora. Botany Bull. 2, p. 34. Brisbane. 1891 .

9. - Ann. Rep. Dep. Agric. of Queensland p. 5I. Brisbane. I89i-2. 
I0. Bailey, F. M.-A Review of the Fungus Blights which have been observed to in. jure living vegetation in Queensland. Rep. Aust. Assoc. Adv. Sci., Hobart, Vol. 4, pp. 392, 395, 396, 397, 398, and 400. 1892.

11. Contributions to the Queensland Flora. Botany Bull. 5, p. 36. 1892.

12. - Ann. Rep. Dep. Agric. of Queensland, p. 40. Brisbane. I892-3.

13. Contributions to the Queensland Flora. Botany Bull. S, Pp. Iro-riz. Brisbane. 1893 .

14. - Ann. Rep. Dep. Agric. of Queensland, p. 31. Brisbane. 1893-4.

15. Contributions to the Queensland Flora. Botany Bull. 9, pp. I6, I7. Brisbane. 1894.

16. Ann Rep. Dep. Agric. of Queensland, p. 35. Brisbane. 1894-5.

I7. Queensland Blight Fungi. Proc. Conf. Austr. Fruit-growers, New Zealand, p. 208. WVellington. 1806 .

18. - Ann. Rep. Dep. Agric. of Queensland, p. 39. Brisbane. I897-8.

19. - Botany Contributions. Queensland Agric. Journ., Vol. 2, p. $3^{8}$. Brisbane. 1898 .

20. - Contributions to the Flora of Queensland. Ibid. Vol. 3, p. 205. Brisbane. 1898 .

21. Ann. Rep. Dep. Agric. of Queensland, p. 33. Brisbane, 1898-9.

22. Contributions to the Flora of Queensland. Agric. Journ., Vol. 4, p. 284. Brisbane. $\quad$ 8 899.

I. BAKer, R. T.-Contributions to a Knowledge of the Flora of Australia. Proc. Linn. Soc., New South Wales, Vol. 24, p. 447.1899.

1. BANI, W.-Beiträge zur Biologie der Uredineen (Phragmidium subcorticium (Schrank) Winter). Hedw., Vol. 42, p. 118. 1903.

I. Barciay, A.-Aecidium urticae Schum. var. himalayense. Sci. Mem. Med. Off. Army of India, p. 29. Calculta. 1887.

2. - On the Life History of a Remarkable Uredine on Tasminum grandi. florum, L. (Uromyces cunninghamianus, n. sp.). Trans. Linn. Soc., London, Vol. 3, p. 141. 189r.

3. - On Two Autoecious Caeomata in Simla. Scientific Memoirs by Med. Officers of Army of India, Part VI. I 891 .

4. - Rust and Mildew in India. Journ. Bot., Vol. 30, p. 349. I892.

r. BARY, A. DE.-Neue Untersuchungen ueber die Uredineen, insbesondere die Entwickelung der Puccinia graminis und den Zusammenhang derselben mit Aecidium berberidis. Monatsber. K. Acad. d. Wiss, p. 25. I $_{5} 5$.

2. Comparative Morphology and Biology of the Fungi, Mycetozoa and Bac. teria. English Edition, Oxford. 1387.

I. Beacrerie, M. J.-Essais d'immunisation des regetaux contre les maladies cryptogamiques. Compt. rend. Vol. 133, p. Io7. Igor.

1. Berkeley, M. J.-Flora of Tasmania-Fungi. Hooker's Botany of the Antarctic Voyage, Part III., Vol. 2, p. $270 . \quad$ i86o.

2. Austraiian Fungi. Journ. Linn. Soc., London, Vol. 13, pp. I73, I74, 1872 .

I. Berkelex, M. J., and Broone, C. E.-List of Fungi from Brisbane, Queens. land. Trans. Linn. Soc., London, Voi. I, p. 407. I8 8 .

2. - Ibid, Part II., Vol. 2, P. 67. 1882.

3. Ibid, Part III., Vol. 2, p. 221.1886.

I. Blackman, V. H.- On the conditions of Teleutospore germination and Spori. dia formation in the Uredineae. New Phytologist. Vol. 2, p. 10. 1903.

2. - On the Fertilisation, Alternation of Generations, and general Cytology of the Uredineae. Ibicl. Vol. 3, p. 23. ino4.

3. - On the Fertilisation, Altermation of Generations, and general Cytology of the Uredineae. Ann. Bot., Vol. 18, 1). 323. 1904.

I. Bolley, H. L.-The Heteroecismal Pucciniene. An. Micro. Journ., Vol. ro, p. 169. I 889 .

2. Wheat Rust. 13ull. 26. Agr. Exp. Station, Indiana. ISSg.

3. - Wheat Kust: Is the infection local or general in origin? Agric. Science, Vol. 5. 189 .

4. - Einige Bemerkungen ueber die symbiotische Mykoplasmatheorie bei dem Getreiderost. Centralb. f. Bakt., Vol. 4. p. S 55. iŞS.

5. - New work upon wheat rust. Science N.S. Vol. 22, p. 50. 1905.

1. Bubak, F.-Puccinia scirpi DC. Oesterr. Bot. Zeitschr, Vol. 4 S, p. 1 4. $189 S$.

2. Uredo symphyti DC., und die zugehörige Teleutosporen und Aecidienform. Ber. d. Deutsch Bot. Gesellsch., Vol. 21, p. 355. 1903.

I. Butlfr, E. J.-The Indian Wheat Rust Problem. Bull. No. 1, Dept. Agric., India. Calcutti. 1903. 
C.

1. Campbeli, F. M.-Victorian Fungi. Vict. Nat. Vol. 4, p. 96. i887.

1. Carleton, M. A.-Cereal Rusts of the United States. U.S. Department of Agriculture, Division of Vegetable I'hysiology and I'athology, Bull. No. I6. Washington. I $\$ 99$.

2. Culture Methods with Uredineae. Journ. Applied Microscopy and Lab. Methods. Vol. 6, p. 2109. Rochester, N.Y. 1903.

3. - Investigations of Rusts. U.S. Department of Agriculture, Bureau of Plant Industry. Bull. 63. Washington. I904.

1. Chodat, R.-Identité du Puccinia scirpi DC. avec Aecidium nymphoidis DC. Verh. Schweiz. Nat. Ges., p. 43. I888-9.

I Christuan, A H.-Sexual Reproduction in the Rusts. Bot. Caz., Tol, 39, p. 267. 1905.

1. Coвв, N. A.-Peach Rust in our Orchards. Agric. Gizz., N.S. Wales. Vol. I,

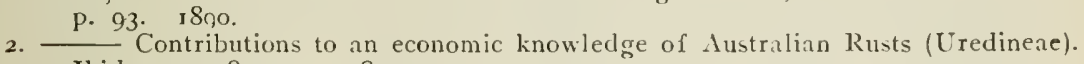
Ibid., PP. $185-214 . \quad 1890$.

3. Maize Rust. Ibid. Vol. 2, p. $215 . \quad 1891$.

4. Notes on Diseases of Plants. Ibid, Pl. 157, 286.1891.

5. - Report on Rust in Wheat. Proc. Conf N.S. Wales. ISor.

6. Contributions to an eccnomic knowledge of Australian Rusts (Lredineae). Agric. Gaz., N.S.W., Vol. 3, PP. 44-68. 1802.

7. - Fungus Disenses of the Sugar-cane. Ibid. Vol. 4, p. 799. 1893.

Host and Habitat Index of the Australian Fungi. Dep. Agric., N.S. Wales. I 893 .

9. - Notes on Diseases of Plants. Agric. Gaz., N.S. Wales Vol. 5, p. 384 . I 994 .

10. 1897.

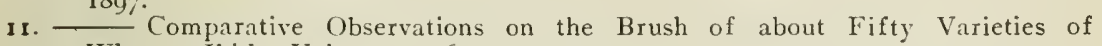
Wheat. Ibid. Vol. I3, p. 647. 1902.

12. - Letters on the Diseases of Plants. Ibid. Vol. 15, Pp. 8-14. Igo4.

I. CoBb, N. A., and Oliff, A. S.-Insect Larve (Cecidomyia sp.) eating Rust on Wheat and Flax. Agric. Gaz., N.S.IV. Vol. 2, P. 67. 189r.

I. Connold, E. T.-British Vegetable Galls. London. roor.

г. Cooke, M. C.-Australian Fungi. Grevillea, Vol. 11, pp. 97, 98.1883.

2. - Ibid, Vol. 12, p. 20. I $\$ 8_{3}$.

3. - Fungi australiani (reprinted from Grevillea, Vols. 9, 10, 11, 12). 1883.

4. - Australian Fungi. Grevillea, Vol. 14, PP. 11, 12.1885.

5. - Ibid. Tol. 15, p. 99. I88 5 .

6. Ibid. Vol. 16, p. 2. 188\%.

7. - - Ibid. Vol. 16, p. 74. I 888.

8. - Ibid. Vol. 17, pp. 55, 7o. 188\%.

9. - Ibid. Vol. 19, p. 46. 1890.

10. Handbook of Australian Fungi, pp. 330-344. London. ${ }_{1} S 92$.

I. CORDA, A.-Icones Fungorum. $6 \mathrm{Fasc}$. ${ }_{1} \&_{3} S-56$.

D.

1. Dangeard, P. A., and Sappin Tronffy, P.-Recherches histologiques sur les Urédinées. Compt. rend. Vol. 116, P 211.1893. 2. L Une pseudofécondation chez les Trédinćes. Ibid. Vol. Ir6, p. 267.

1. Dietel, P.-Beiträge zur Morphologie und Biologie der Úredineen. Bot. Centralb. Vol. 32, p. 54, \&c. 188 -

2. - Verzeichniss der in der Umgebung von Leipzig beobachten Uredineen.

Ber. Natf. Ges. Leipzig. I888-89.

3. Ueber das Vorkommen von zweierlei Teleutosporen bei der Gattung Gymnosporangium. Hedwigia, Yol. 28, p. 99. I 880.

4. Ueber den Generationswechsel von Puccinia agropyri E.11. and Ev. Oesterr. Bot. Zeitschr. Vol. 42, p. 261 , 1892.

5. Die Gattung Ravenelia. Hedw., Vol. 33, pp. 22 and 367. 1894.

6. - Ueber Rostpilze mit wiederholter Aecidienbildung. Flora. Vol. 8r, p. 394. 1895.

7. 3 Waren die Rostpilze in früheren Zeiten plurivor? Bot. Centralb. Vol. 79 , p. 81 and 113 . 1899 . 
8. Dieter, P.-Uredinales in Ficrer and Praxtl, Die natürlichen Pflanzenfamilien. ryoo.

9. - Ueber die biologische Bedeutung der 1'iraphysen in den Uredolagern von Rostpilzen. Hedw., Vol. 4I, p. (58). 1902.

10. Ueber die auf Leguminosen lebenden Rostpilze und die Verwandtschafts verhältnisse der Gattungen der Pucciniaceen. Ann. Myc. Vol. r,

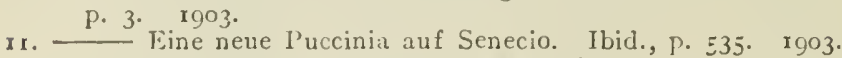

12. - Betrachtungen ueber die Vertheilung der Uredineen auf ihrer Nährpflanzen. Centraib. f. Bakt., Vol. 12, p. 218.1904. 13. - Ueber die Arten der Gattung Phragmidium. Hedwigia, Vol. 44, p. I22

r. Dumee, l'., and MAIRE, R.-Remarqques sur les Creslospores de Puccinia pruni Pers. Bull. Soc. Myc., France. Vol. x $\%$, p. 308. I901.

E.

1. Ehrlich, and Huebener,-Ueber die Vererbung der Immunität bei 'Tetanus. Zeitschr. f. Hygiene. Vol. is. I894.

I. Eriksson, J.-Ueber die Spezialisierung des Parasitismus bei deu Getreiderostpilzen. Ber. Deutsch. Bot. Ges. Vol. 12, p. 292. I894.

2. Ueber die Förderung der Pilzsporenkeimung durch Kälte. Centralb. $f$. Bakt. Vol. I, p. 557. 1895 .

3. - Ueber die verschiedene Rostempfänglichkeit verscliedener Getreidesorten. Zeitschr. f. Pflanzenk. Vol. 5, pp. So and r 56.1895 .

4. - Ist die verschiedene Widerstands fähigkeit der Weizensorten konstant oder nicht? Ibid., p. 19\$. 1895.

5. Welche Rostarten zerstören die australischen Weizenernten? Ibid. Vol. 6, p. r 4 r. $\mathrm{r} 896$.

6. Welche Grasarten künnen die Berberitze mit Rost anstecken? Ibid., p. 193. 1896 .

7. - Neue Untersuchungen ueber die Spezialisierung, Verbreitung und Herkunft des Schwarzrostes (Puccinia graminis Pers.). Jahrb. f. Wiss. 13ot. Vol. 29, P. 499. г 896 .

8. Der heutige Stand der Getreiderostfrage. Ber. Deutsch. Bot. Ges. Vol. 1 5, p. 183 . 1897 .

9. - Vie latente et plasmatique de certaines Urédinées. Compt. rend. Vol. r24, p. 475 . 1897 .

10. - Ueber die Dauer der lieimkraft in der Wintersporen gewisser Rostpilze. Centralb. f. Bakt. Vol. 4, p. 376. rSos.

I r. - Sur l'Origine et la Propagation de la Rouille des Céréales par la Semence. Ann. Sci. Nat. Bot., Ser. S. Vol. 14, p. ro7. I901.

12. - Ueber die Spezialisierung des Getreideschwarzrostes in Schweden und in anderen L.ändern. Centralb. f. Bact. Vol. 9, p. 590. 1902.

13. The Researches of Professor H. Marshall Ward on the Brown Rust of the Bromes and the Mycoplasm Hypothesis. Arkiv för Botanik udg. of $\mathrm{K}$. Sv. Vet. Akad. Vol. I, p. r39. 1903.

14. - Ueber das vegetative Leben der Getreiderostpilze. K. Sv. Vet. Akad. Vol. 27 , No. 6, I. rno.4.

15. - Ibid. Vol. 38, No.1 3, II.-TII. rno4.

16. - On the Vegetative Life of some Uredinene. Ann. Bot. Vol. 19, p. $55^{\circ}$ 1905.

17. - Zur Frage der Fntstehung und Verbreitung der Rostkrankheiten der Pflanzen. Arkiv. f. Botanik. K. Sv. Vet. Akad. Yol. 5, No. 3. rgo5.

18. - Teber das vegetative Leben der Getreiderostpilze. "K. Sv. Vet. Akad. Vol. 39, No. 5, IV. 1905.

I. Eriksson, J., and Hexisc, F.-Die Hauntresultate einer neuen I"ntersuchung neber die Getreideroste. Zeitschr. f. Pflanzenk. Vol. 4, l'p. 66 and 140. is $\mathrm{S}_{94}$.

2. Die Getreideroste, ihre Geschichte und Natur, sowie Massregeln gegen dieselben. Stocliholm. IS96.

F.

r. Fariow, W. Cr.-Notes on some Species in the Thircl and lileventh Centuries of Eillis' North American l'ungi. Proc. Am. Acal. Arts and Sci. Vol. IS. Boston. is $S_{3}$.

2. C The (onception of Species 115 allected he recent Turestigations on Fungi. American Naturalist. Vol. 32, 1, 675. x 8 ys. 
I. FARRER, W.- The making and improvement of Wheats for Australian condi. tions, together with Eriksson's (ieneral review of the principal results of a Swedish research into the rust of cereals. Agric. Gaz., N.S. Wales, Vol. \%, p. 239.1898 .

2. - Some notes on the Wheat "Bobs"; its Ieculiarities, Economic Value, and Origin. Agric. Gaz., N.S. Wales, Vol. 15, p. 739 and p. 849. 1904.

1. Fischer, E.-Ueber Gymnosporangium sabinae (Dicks.) Wint. and G. confusum Plowright. Zeitschr. f. Pflanzenk. Vol. 1, p. 260. 1Sg1.

2. - Experiences d'infection avec les Puccinia helvetica Schroet. et P. magnusiana Koern. Arch. Sci. Phys. and Nat. Vol. 28, p. 376. I892.

3. Die Zugehoerigkeit von Aecidium penicillatum. Hedw. Vol. 34, p. 1. 1895 .

4. Die biologischen Arten der parasitischen Pilze und die Entstehung neuer Formen im Pflanzenreich. Verh. Schweiz. Nat. Ges. Vol. S6. Locarno. p. 49, 1904 .

5. - Die Uredineen der Schweiz. Beitr. zur Krypt. Flor der Schweiz. Vol. 2, part 2, 1904.

I. Freman, E. M.-Experiments on the Brown Rust of Bromes (Puccinia dispersa). Ann. Bot., Vol. 16, p. $48_{7} .1902$.

G.

I. Gallowiy, B. T.-Rust of Flax. Journ. Myc., Vol. 5, p. 215. i 889.

I. Gibson, C. M.-Notes on Infection Experiments with various Uredineae. New Phytologist. Vol. 3, p. 1 84.1904.

H.

1. Halsted, B. D.-Mycological Notes-Observation in Wind infection of a Rust. Bull. Torr. Bot. Club. Vol. 25, p. 159. I $\$ 98$.

I. Henning, E.-Ueber verschiedenartige Prädisposition des Gotreides für Rost. Land. Akad. Handl. Tids. I 894 .

I. Hennisgs, P.-Fungi Warburgiani. Hedw., Vol. 32, p. $216 . \quad$ i $\$ 93$.

2. - Anpassungsverhältnisse bei Uredineen bezüglich der physikalischen Beschaffenheit des Substrats. Hedwigia, Vol. 40, p. 125. I901.

3. - Fungi Australiae occidentalis I. Ibid., pp. 95 and 352. rgor.

4. - Fungi australienses. Ibid., Vol. 42 (p. 73). 1903.

5. - Einige Beobachtungen ueber das Gesunden pilzkranker Pflanzen bei veränderten Kulturverhältnissen Zeitschr. f. Pflanzenk. Vol. 13, p. 41. rgo3.

1. Hitchcock, A. S., and Carleton, M. A.-Preliminary Report on Rusts of Grain, Kans. Agr. Expt. Sta. Bull. No. ${ }_{3} 8$. I 893.

2. - Rusts of Grain, II. Ibid. Bull. No. 46.1894.

1. Ноoker, J. D., and Jacksox, B. D.-Index Kewensis. Oxford. 1895, \&c.

].

1. JACKy, E.-Die Compositen-bewohnenden Puccinien vom Typus der Puccinia hieracii und deren Spezialisierung. Zeitschr. f. Pflanzenk. Vol. 9, pp. I93, $26_{3}$, and 330. 1899 .

2. - Der Chrysanthemum-Rost. Ibid. Vol. 10, p. 132. 1900.

3. - Der Chrysanthemum-Rost. Centralbl. f. Bakt., Vol. 10, p. 369. 1903.

K.

1. Kienitz-Gerloff, F.-Die Gonidien von Gymnosporangiun clavariaeforme. Bot. Zeit. Vol. 46, p. $389 . \quad 1888$.

I. Klebahn, H.-Die Wirtwechselnden Rostpilze. Berlin. I904. (This masterly work includes references to Klebahn's numerous contributions to the literature of the Rusts.)

2. - Kulturversuche mit heteroecischen Uredineen. Zeitschr. f. Pflanzenkr. Vol. 2, p. 337. 1892.

3. - Kulturversuche mit Rostpilzen xii. Bericht (1903-rg04). Zeitschr. f. Pflan. zenkr. Vol. 15, p. 106. 1905.

I. Kuehn, J.-Der Rost der Runkelrübenblatter, Uromyces betae. Bot. Zeit., p. 540. 1869. 
L.

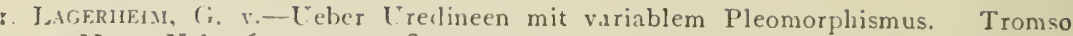
IIus. Vol. 16, p. 105. I894.

r. LACRENT, E.-De l'action interne du sulfate de cuivre dans la resistance de la pomme de terre au Phytophthora infestans. Compt. rend, Vol, 135, p. 1040. 1902.

I. LiNDrotu, J. I.-Cecidomyia-larver, som äta rostsporer. Iledd. Soc. Fauna. Fl. Fenn. Vol. 26, p. 25. 1900.

I. Lunwis, F- Ueber einen neuen Coodeniaceenrost aus Südaustralien. Hed»r. Vol. 28, p. $362 . \quad$ i 889 .

2. Ueber einige neue Pilze aus Australien. Bot. Centralb. Vol. 43, p. 5. 1800.

3. U' Ueber neuc australische Rostkrankheiten. Zeitschr. f. Pflanzenkrankheiten, Vol. 2, p. 130 . 1802

4. Ueber einige Rost-und Brandpilze Australiens. Ibid., Vol. 3, p. 137.

5. ${ }^{1893}$ I.ehrbuch der niederen Kryptogamen, p. 455. Stuttgart. I892.

II.

I. Magnus, P.-Ueberwinterung der Puccinia caricis. Verh. Bot. Ver. Prov. Brand. Vol. is, p. 27. 1885 .

2. - Ueber das Auftreten der Stylosporen bei den Uredineen. Ber. der Deutsch. Bot. Gesellsch., Vol. 9, p. 85. I 89 r.

3. Zur Kentniss des Verbreitung einiger Pilze. Ber. Deutsch. Bot. Ges., Vol. 10, p. 195. 1802 .

4. Die systematische Unterscheidung nächst verwandter parasitischer Pilze auf Grund ihres verschiedenen biologischen Verhaltens. Hedwigia, Vol. 33, P. 362: I894.

5. - Fungi Pars. II. in J. Bornmueller, Iter Persico-turcicum. IS92-9.3. Verhandl. Zool.-bot. Giesellsch. Wien, Vol. 49, p. 05. ISo9.

6. Ueber eine Function der Paraphysen von Uredolngern. Ber. Deutsch. Bot. Fies., Vol. 20, p. 334. 1002.

7. - Kurze Bemerkung zur Biologie des Chrysanthemum-rostes. Centralb. f. Bakt. Vol. Io, p. 575. r 903.

r. Maide, I. H.-Report on Botanic Gardens and Domains, p. ro. N.S. Wales. 1002.

I. MarchaI, E.-De la spécialisation du parasitisme :hez. l' Erysiphe graminis. rompt. Renrl., Vol. 135, p. 2 ro. 1902.

2. De l' immunisation de la Laitue (Lettuce) contre le Meunier. Ibid p. 1067. 1902.

I. Massee, G.-On the Presence of Sexual Organs in Aecidium. Ann. Bot., Vol. 2, p. 47. 188S.

2. Notes on Exotic Fungi in the Royal Herbarium, Kew. Grev., Vol. 21, p. 4. 1892 .

3. - Australian Fungi. Firev., Vol. 22, p. 17. ${ }_{\mathbf{1}} \mathrm{S}_{03}$.

4. Mycological Flora of the Royal Gardens, kew. Kew Bull, p. iji. 1897.

5. Chrysanthemum Rust. Gardeners' Chronicle, Sth Oct., ISgS.

6. - The Cereal Rust Problem. Does Eriksson's MIycoplasma exist in Nature? Natural Science, Vol. 15, p. 33\%. 1800\%.

7. - To protect Cucumbers and Tomatoes from fungus. Journ. Roy. Ifort. Soc., Vol. 28 , p. 142.1903.

S. - $\triangle$ Text-book of Plant Diseases, 2nd. I\%d. I.ondon. 1003..

9. On the Origin of l'arasitism in Fungi l'hil. 'Trans. Royal Soc., Ser. M, Vol. 197, p. $7 . \quad 1904$.

1. Marus, O-Die Peridlienzellen der V'redincen in ihrer Abhängigkeit ron Standortsverhältnissen. Centralb. f. Bakt., Vol, ro. p. 644. r903.

I. MCAtpine, D.-The Tife-history of the Rust of Wheat. Mull. 14, Dep. Agric., Victoria, pp. 22-32, pls. 2. 1 S 91 .

2. - Rust of Wheat. Ibid. pp. 33, 34. ISnt.

3. - Beet-leaf Rust or Blighted Hangel leaves (L'romyces betae). Ibid. pl. $45,46 . \quad \mathbf{S}$ S? 1 .

4. - Report on Peach and P'lum I.eaf-Rust (Puccini fruni). Ibid, Pp. ${ }_{3} \mathrm{~S}$, 14.4, pls. 3. 1 Sog.

5. - Report on Rust in Wheat as Victorian Delegate. l'roc. Conf., N.S. IV iales. I $S_{i) 1 .}$ 
6. McAlpixe, D.-Ueber die Verwendung geschrumpfter Koerner von rostigem Weizen als Saatgut. Zeitschr. f. Pflanzenkrankh., Vol. 2, p. I93. I\$92.

7. - Report on Rust in Wheat as Victorian Delegate. Proc. Conf. S. Australia. $1 \delta_{92}$.

8. _- The Undescribed Uredospores of Puccinia burchardiac. Vict. Nat., Vol. 10, p. $192 . \quad 1894$.

9. - Report on Rust in Wheat Experiments at School of Horticul. ture, Burnley. Illustrated with maps and drawings, pp. 66. Dep. Agric., Victoria, 1894 .

10. - Report on Rust in Wheat as Victorian Delegate. Proc. Conf., Queensland. $\quad \mathrm{r} 894$.

r1. - Australian Fungi. Proc. Roy. Soc., Victoria. Vol. 7, p. 214. I 895.

r 2. - Systematic Arrangement of Australian Fungi, together with Host Index and List of Works on the subject. Dep. Agric., Victoria. IS95.

13. Notes on Uromyces amygdali-a Synonym of Puccinica pruni Pers. Proc. Linn. Soc., N.S. Wales. 2nd series, Vol. 10, p. 440. rS95.

14. - Puccinia on Groundsel with Trimorphic Teleutospores. Ibid., p. $46 \mathrm{r}$. I 895 .

15. - Australian Fungi. Agric. Gaz., N.S. Wales, Vol. 7, p. $75^{2}$. 1895 .

16. - Ibid, P. 850 . I 895 .

17. - Ibid. Vol. 7 , p. 147. 1896 .

IS. - Ibid, p. $209 .{ }_{1} \$_{96}$

19. Two Additions to the Fungi of New South Wales. Proc. Linn. Soc., N.S. Wales. Vol. 21, p. 722 . 1896.

20. - New South Wales Fungi. Ibid. Vol. 22, p. 36.1897.

21. - Rust in Wheat Experiments, $18_{94-139-}$. Dep. Agric., Victoria, $1 \mathrm{~S}_{97}$.

22. The Fungi on the Wheat Plant in Australia. Agric. Gaz., N.S. Wales, Vol. 9, p. 1009. ${ }_{1} 89 \mathrm{~s}$.

23. - Rust in Wheat during the dry season of ${ }_{1} \mathrm{Sg}_{97}$. Ibid. p. 1421. 1898 .

24. - On a micro-fungus from Mount Kosciusko, and on the first record of Uncimula in Australia. Proc. Linn. Soc., N.S. Wales. Vol. 24, p. 30r. r899.

25. — Two Mallee Fungi. Vict. Nat., Vol. 16, p. 141. I899.

26. — Rose Rust. Journ. Dept. Agric., Vic., p. 81. Igo2.

27. - Fungus Diseases of Stone-fruit Trees in Australia, and their Treatment.

Dept. of Agric., Victoria. 1902

2S. ——Cereal Rusts. Journ. Dept. Agric., Vic., p. $4^{25} 1902$.

29. - Peach and P'lum Rust. Ibid. P. 6r-. 1902.

30. - - Justralian I.ungi, new or unrecorded, Decades T.-TI. Proc. Linn. Soc., N.S. Wales. Vol. 23, p. $55^{8}$. 1903.

3r. - Rerraf-A Rust-resisting Wheat. Journ. Dept. Agric., Vic., Vol. 2, p. 531.1904.

32. Diseases of Cereals, Rust and Take-all in Wheat. Ibid. p. 7oo. 1904.

33. - Some Misconceptions concerning the Uredospores of Puccinia pruni Pers. Ann. Myc., Vol. 2, p. 344. I 1904.

34. - Note on the Arrangement of Teleutospores in Puccinia pruni Pers. Ibid. p. 348 . 1904.

35. - Bobs-A Rust-resisting Wheat. Journ. Dept. Agric. Vic., p. 166. 1905.

36. - A new genus of Uredineae-Lromycladium. Ann. IIyc. Vol. 3, p. 303. 1905 .

1. Millesi, M., and Traverso, G. B.-Saggio di una monografia del genere Triphragmium. Ann. Myc., Vol. 2, p. r43. rgo4.

r. Moliseux, A.-Some Remarks about Red Rust. Journ. Agric., S. Australia. Vol. 8, p. 95. 1904 .

I. Morrisox, A.-New Victorian Micro-fungi. Victorian Nat., Vol. II, pp. 9o, 91. I $\delta_{94}$.

2. Notices of Victorian Fungi. Ibid. pp. 119, 120. $1 \mathrm{~S}_{94}$.

r. Mfueller, F. v.-Fragmenta Phytographiae Australiae-Supplement, Vol, ir, p. 96. is8o. (Fungi enumerated by Dr. Cooke.)

2. - Census of the genera of plants hitherto known as indigenous to Australia. Proc. Roy. Soc. N.S. Wales, Vol. 15, 1). 254, 255 IS81.

3. - Notes on Victorian Fungi. Victorian Nat., Vol. 2, p. So. ISS 5 .

4. - Lecture on Rust in Cereals. Sandhurst, Victoria. r 865.

I. Mteller, Fritz.-Beiträge zur Kentniss ler Grasroste. Bot. Centralb. Beilhefte IO, P. ISI. IgOI.

3. Muterler, J-Die Rostpilze der Rost-und Rubusarten und die auf ilınen vor. kommenden Parasiten. Landw. Jilırb., Vol. 15, p. 7ig. I $\$ \$ 5$. 
N.

1. Neger, F. W.-Beitrïrre zur Biologie der Erysipheen. Flora po, p. 221. rgoz.

1. Nelmixi, R.-Ueber die Entwickelungsgeschichte der Aecidien und Spermogonien der Üredineen. Hedwigia, Vol. 33, 1. 346. I\$94.

P.

1. P'FEFFER, W.-Ceber chemotaktische Bewegungen von Bakterien, Flagellaten und Volvocineen. Untersuch. Bot. Inst., Túbingen. Vol. 2, p. 582. 1888.

1. Plowright, C. B.-The connexion of Wheat Mildew (Puccinia graminis Pers.) with, the Barberry Aecidium (Aecidium berberidis Gmel.) Gard. Chron. Ser. 2, Vol. 18, p, 231. r 882.

2. Podisoma juniperi and Roestelia lacerata. Ibid, p. 553.

3. Reproduction of Heteroccious Uredines. Linn. Soc., London. Botany, Vol. 21, p. $368 . \quad$ I $8 S_{4}$.

4. On the Life-history of certain British Heteroecismal Uredines. Quart. Journ. Micro. Sci., Vol. 25 , p. 156 . 1885 .

5. - A Monograph of the British Uredineae and Ustilagineae. London. 1889 .

6. - Barberry and Wheat Mildew. Gard. Chron., Vol. 23, p. 45. 1898.

1. Prafn, D.-Rust in Wheat in the Australian Colonies. Agric. Ledger No. 16, Calcutta. I 1897 .

1. Prillieux, E.-Maladies des Plantes Agricoles. Pt. I, D. 242. Paris, 1895.

R.

1. Ralph, T. S.-On the Aecidium affecting the Senecio vulgaris or Groundsel. Victorian Nat., Vol. 7, pp. 18, 19. r89o.

I. Rathay, E.-Untersucluungen ueber die Spermogonien der Rostpilze. Denkschrift. d. K. Akad. d. Wiss. Wien, Vol. 46, p. 51 . is $\$ 83$.

1. Richards, H. M.-On some points in the development of Aecidia. Proc. Amer. Acad. Sci., Vol. 31, p. 255. 1895.

1. Rodwar, L.-Tasmanian Fungi. Proc. Roy. Soc., Tasmania, pp. r42, 143. $\mathrm{I} \mathrm{S}_{97}$.

1. Roze, Mr. E.-Le Puccinia chrysanthemi. Bull. Soc. II yc. France, Vol. 16, p. 88.1900.

S.

1. Saccardo, P. A.-Sylloge Fungorum. Vols. 7, 9, rr, 14, r6, r7 r8SS-r905.

2. - Mycetes aliqquot australiensis. Hedw., Vol. $2 S$, p. r26. rSS9.

3. - Ibid. Bull. Soc. Myc. France, Vol. 5, p. IrS. ISS?.

4. - Ibid. Hedw., Vol. 29, p. 155. r 890.

5. - Ibid. Hedw., Vol 31, p. 5\%. I893.

I. Saccardo, P. A., and Berlese, A. N.-Fungi australiensis. Rer. Myc., Yol 7, p. 93. $\quad 18 S_{5}$

I. Salmon, E. S.-Mycological Notes. Journ. Bot., Vol. 42, p. r $S_{4}$. rgot.

2. Cultural Experiments with "Biologic Forms" of the Erysiphaceae. Pliil. Trans., B., Vol. 197, P. 107. r904.

3. - Cultural Experiments with the Barley Mildew, Erysiphe graminis DC. Ann. Myc., Vol. 2, p. SS. rgo4.

r. Sippin-Trouffy, P.-Ia Pseudo-Fecondation chez les Uredinećs el les phénomènes qui s'y rattaclient. Compt. rend., Vol. 1r6, p. 1304. is93.

2. - Recherches listologiques sur la famille des Urédiné́s. Le Botaniste, Vol. 5, Pp. 59-244. I \& $96-97$.

r. Sheтt, F. T.-The effect of Rust on the Straw and Grain of Wheat. Nor: II'est Farmer, Wimipeg. Manitoba, 20th Oct., r904.

I. SMrri, W. G.-Diseases of Field and Garden Crops. London. ISS4.

1. Smith, R. E.-The Water relation of Puccinia asfarigi. Mot. Caz.. Vol. ${ }_{3}$ S, p. in. 1904 .

1. Soracer, P.-Das. Verlalten des fietreiderostes in trockenen und nassen Jahren. 7.eitschr. f. Pflanzenkr., Vol. 4, p. 121. rS04.

2. Die Prädisposition der Pflanzen für parasitïre Krankheiten. Deutsch. Landwirts. Ges., Berlin. 1903.

1. Sinow, P. and H.-Monographia Uredinearum. Vol. I. 1002-04.

2. - Nene und kritische Uredineen. Ann. Mỵc., Vol. 1, p. 324.1003. 
T.

1. Tassi, F.-La Ruggine dei Crisantemi (Puccinia chrysanthemi Roze). Bull. Lab. Bot., Univ. di Siena. November, rgo3.

I. Tate, R.-A list of the Charas, Mosses, Lirerworts, Lichens, Fungi, and Algals of Extra-tropical South Australia. Proc. Roy. Soc. S. Australia, Vol. 4, p. I2. ISSI.

1. Tepper, J. G. O.-Red Rust : Its nature, approximate cause and probable cure. Proc. Roy. Soc., S. Australia, Vol. 3, p. 13. IS-g.

2. Notes on Australian Fungi. Ibid., Vol. 12, p. I5o. r889.

3. - Contributions to the Fungal Flora of Australia. Proc. Roy. Soc. S. Australia, Vol. 13, p. 55. r89o.

1. Tenison-Woods, J. E., and Bailer, F. M.-On some of the Fungi of New South Wales and Queensland. Proc. Linn. Soc., X.S. Wales, Vol. 5, p. S3. 1880 .

I. Thompsox, E. H.-A Hand-book to the Insect Pests of Farm and Orchard (including Fungi). Dep. Agric. of Tasmania. Bull. I, pp. 29-34. ISg2.

I. Thuesen, F. v.-Symbolae ad floram mycologicam Australiae. I. Grevillea, Vol. 4. p. 75. is 75 .

2. Ibid. II. Flora No. 28. is 88

3. - Ist der Berberitzenrost notwendig zur Erzeugung des Grasrostes? Oesterr. Landw. Wochenbl. r $188_{3}$.

I. Tranzschel, W.-Ceber einige auf Grund ron irrtümlicher Bestimmung der Nährpflanzen aufgestelle Puccinia Arten. Ann. Myc., Vol. 2, p. I5S. 1904.

2. —_ Ueber die Möglichkeit, die Biologie wirtswechselnder Rostpilze auf Grund morplologischer Merkmale vorauszusehen. Arbeit. der Kais. St. Petersburg. Naturf. Gesell. Vol. 35, p. I. 1904.

1. 'TRrox, H.-Report or Insect and Fungus Pests, pp. 97, rg6. isSg.

2. Ann. Rep. Dep. Agric. of Queensland-Vegetable Pathology, PP. 39, 40. I $894-5$.

3. Ibid. p. 39. I $\$ 95-6$.

4. - Ibid. p. 37 . IS96-7.

5. - Ibid. pp. 43,44 . ${ }{ }_{97}-8$.

6. - Ibid. p. 35. I $898-9$.

7. Ibid. p. 30. 1899-1900.

S. - Ibid. p. 26 . rgoo-r.

I. Tubeuf, K. F. V., and Sirth, Wr. G.-Diseases of Plants induced by Cryptogamic Parasites. London. 1897 .

IV.

1. WARD, H. Marshall.-Illustrations of the Structure and Life-history of Puc. cinia graminis. Inn. Bot., Vol. 2, p. 21\%. ISSS.

2. The Bromes and their Brown Rust. Brit. Assoc. Rep., Glasgow, p. 今36. 1901 .

3. - The Bromes and their Rust-fungus (Puccinia dispersa). Ann Bot., Vol.

4. ${ }^{15}$, P. 560 . IGor. Camb. Phil. Soc., Vol. 11, p. 326. 1902.

5. - On pure Cultures of a Uredine, Pnccinia dispersa. Proc. Roy. Soc., Vol. 69, p. 45r. 1002 .

6. On the Relations between Host and Parasite in the Bromes and their l3rown Rust, Pnccinia dispersa. Ann. Bot., Vol. 16, p. 233. 1902.

7. - Experiments on the effect of mineral starvation on the Parasitism of the Uredine-fungus, Puccinia dispersa, on species of Bromus. Proc. Roy. Soc., Vol. 71, p. 138 . 1902.

S. - Further Observations on the Brown Rust of the Bromes, Puccinia disfersa, and its adaptive Parasitism. Ann. Myc., Vol. I, P. 132. 1903.

9. - On the Histology of Uredo dispersa Eriks., and the Mycoplasm Hypothesis. Phil. Trans. B., Vol. 196, P. 29. rgo3. $\therefore$ o. Recent Researches on the Parasitism of Fungi. Ann. Bot., Vol. r9, p. r.

r. Webrer, HI. J.-Peridial Cell Characters in the Classification of the Uredineae. Amer. Nat., Vol. 24, p. 177. I890.

1. Wryter, G.-Exotische Pilze II. Hediwigia, Vol. 24, p. 22. ISS5.

2. Fungi australienses. Rev. Myc., Vol S, p. 208. 1886.

I. Worosix, II.-Untersuchungen ueber die Entwickelung des Rostpilzes (Puc. cinia helianthi), welcher die Kranliheit der Sonnenblume rerursacht. Bot. Zeit., p. 6-7. I $\$ ;-2$. 
PLATE A.

(All Figures nat. size.)

Fig.

PUCCINIA TRITICINA ON WHEAT.

I. Uredosori on upper surface of leaf.

2. Teleutosori on under surface.

\section{PUCCINIA GRAMINIS ON WHFAT.}

3. Uredosori on upper and under suriace, also on sbeath.

4. Teleutosori os stem. 


$$
\text { Wy }
$$




PLATE B.

(All Figures nat. size.)

Fig.

PUCCINIA LOLII AVENAE ON OATS.

5. Uredosori on under surface of leaf.

6. Teleutosori on under surfacc

PUCCINIA LOI.II ON RYE.GRASS.

7. Uredosori on under surface of leaf.

8. Teleutosori on upper surface.

PUCCINIA SIMPLEX CN BARLEY.

9. Teleutosori on sheath and blade.

I. Uredosori on under surface of leaf. 
PLATE B.

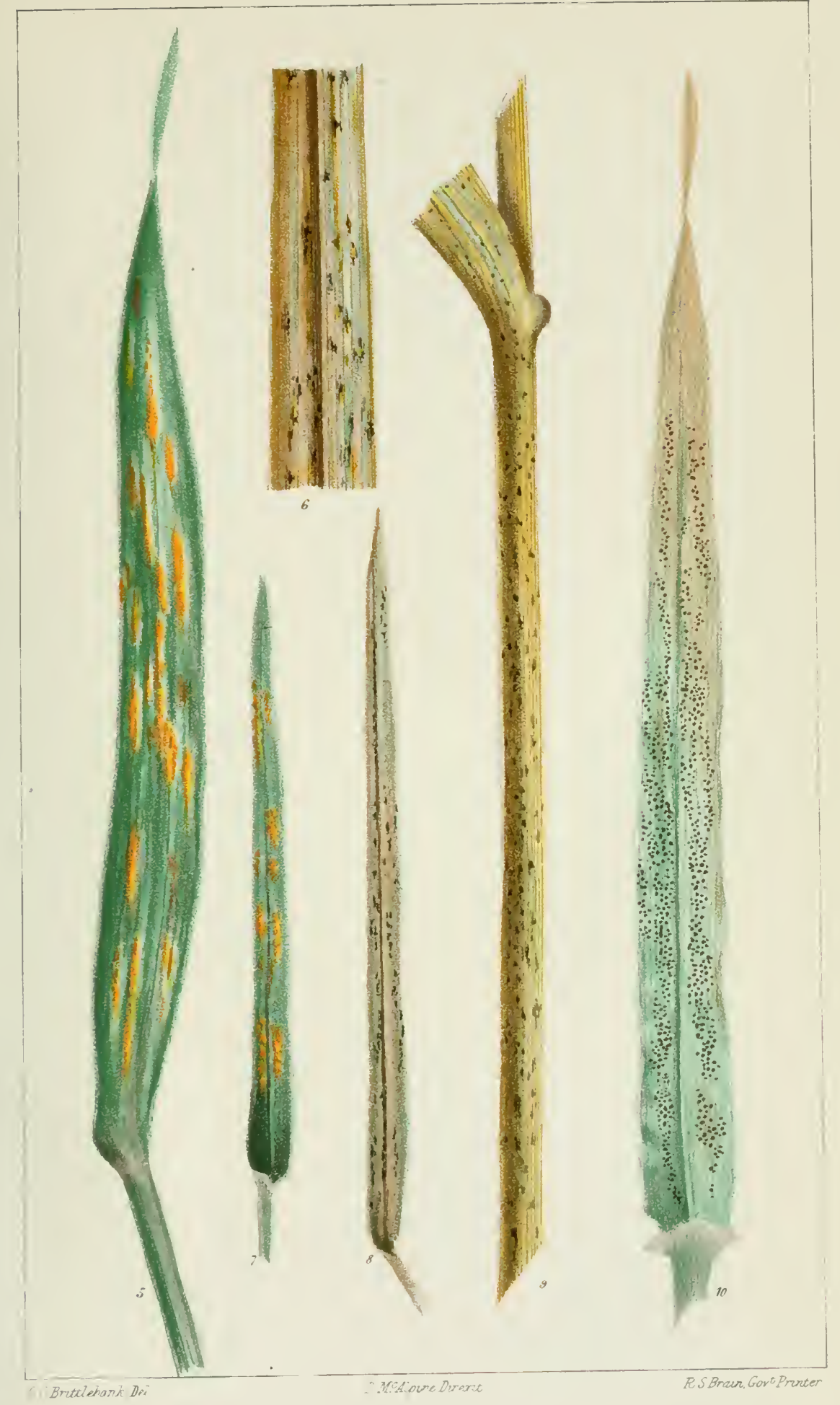

OAT, RYE-GRASS, AND BARLEY RUSTS. 



\section{PLATE C.}

(All Figures nat. size.)

PUCCINIA BROMINA ON SOFT BROME (Bromus mollis).

Fig.

II. Uredosori on under surface of leaf.

12. Teleutosori on under surface.

13. Teleutosori on stem.

PUCCINIA MANDIS ON MAIZE (Zes mays).

14. Uredosori on under surface of leaf.

15. Teleutosori on young stem.

PUCCINIA THUEMENI OX CELERY (Apium graveolens).

16. Uredosori on upper surface of leaf.

17. Uredosori on under surface. 
PLATE $C$.

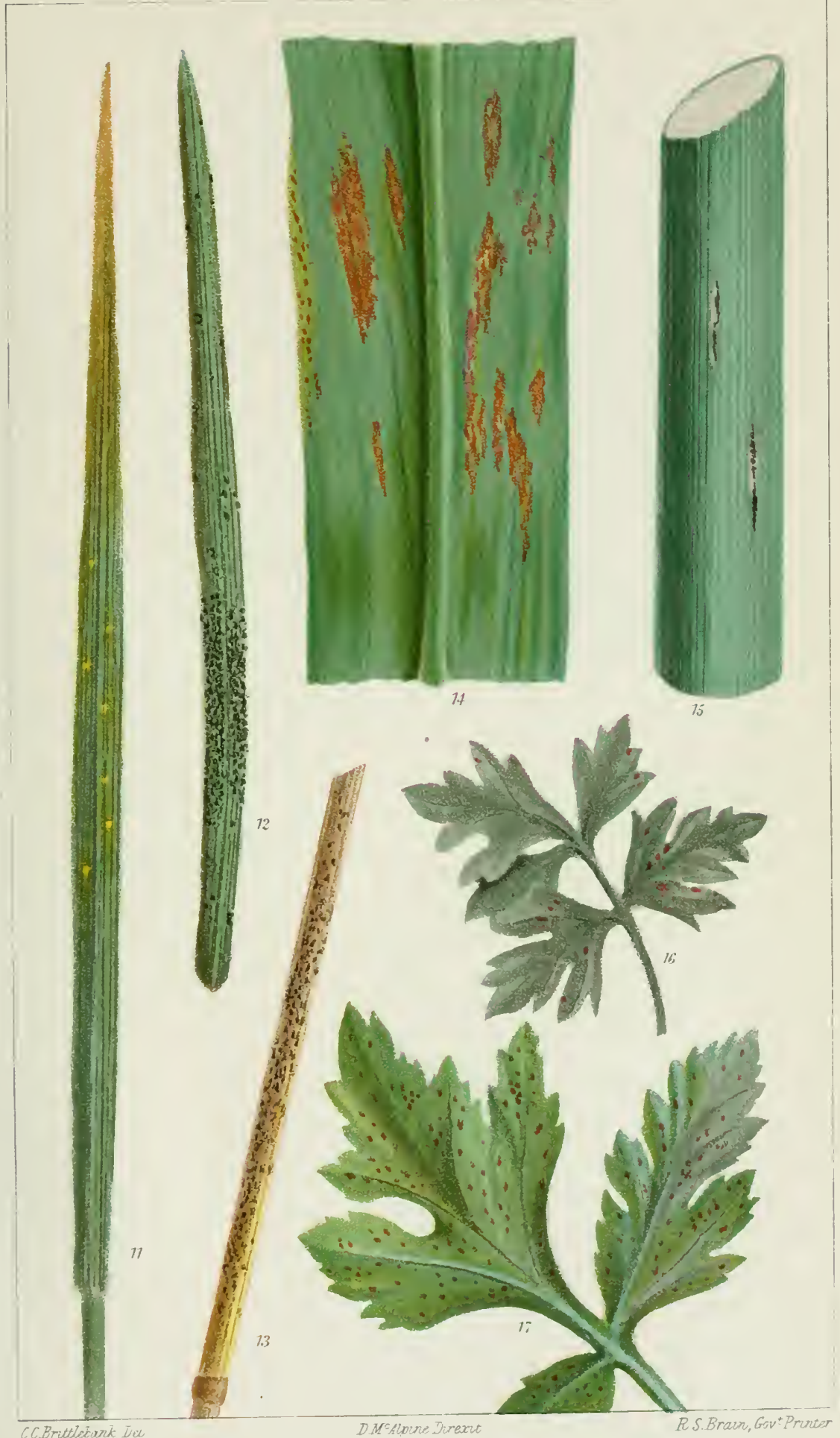

BROME-GRASS, MAIZE, AND CELERY RUSTS. 




\section{PLATE D.}

\section{(All Figures nat. size.)}

PUCCINIA CICHORII ON CHICORY (Cichorium intybus).

Fig.

18. Chiefly uredosori on lower surface of chicory leaf.

PUCCINIA PRUNI ON PEACH AND APRICOT (Prunus persica and P. armeniaca).

19. Uredo and teleutosori on lower surface of peach leaf.

20. Uredo and teleutosori on lower surface of apricot leaf. 


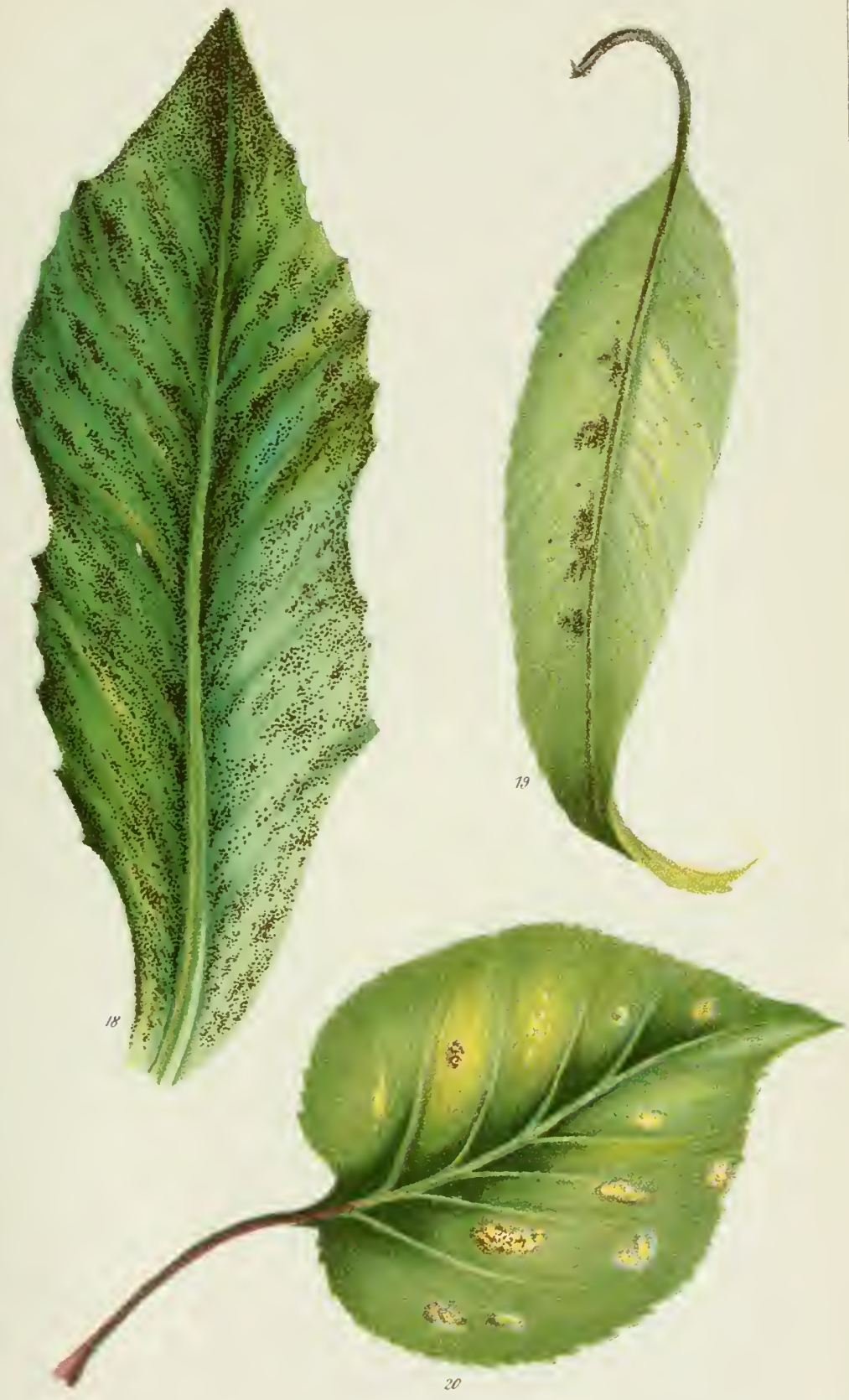




PLATE E.

(All Figures nat. size.)

\section{PUCCINIA CHRYSANTHEMI ON CHRYSANTHEMUM.}

Fig.

21. Uredosori on under surface of leaf.

PUCCINIA CALENDULAE ON MARIGOLD (Calendula officinalis).

22. Aecidia and teleutosori on under surface of leaf.

23. Uredo and teleutosori on stem.

PUCCINIA IIEDIERACEAE ON NATIVE VIOLETS.

24. Lredo and teleutosori on under surface of leaf of Viola hederacca.

25. Aecidia on under surface of leaf of $V$. betonicifolia.

PUCCINIA DISTINCTA ON DAISY (Bellis perennis).

26. Aecidia and teleutosori on ipper surface of leaf, showing the dark teleutocori surrounding the other. 
PLATE E.

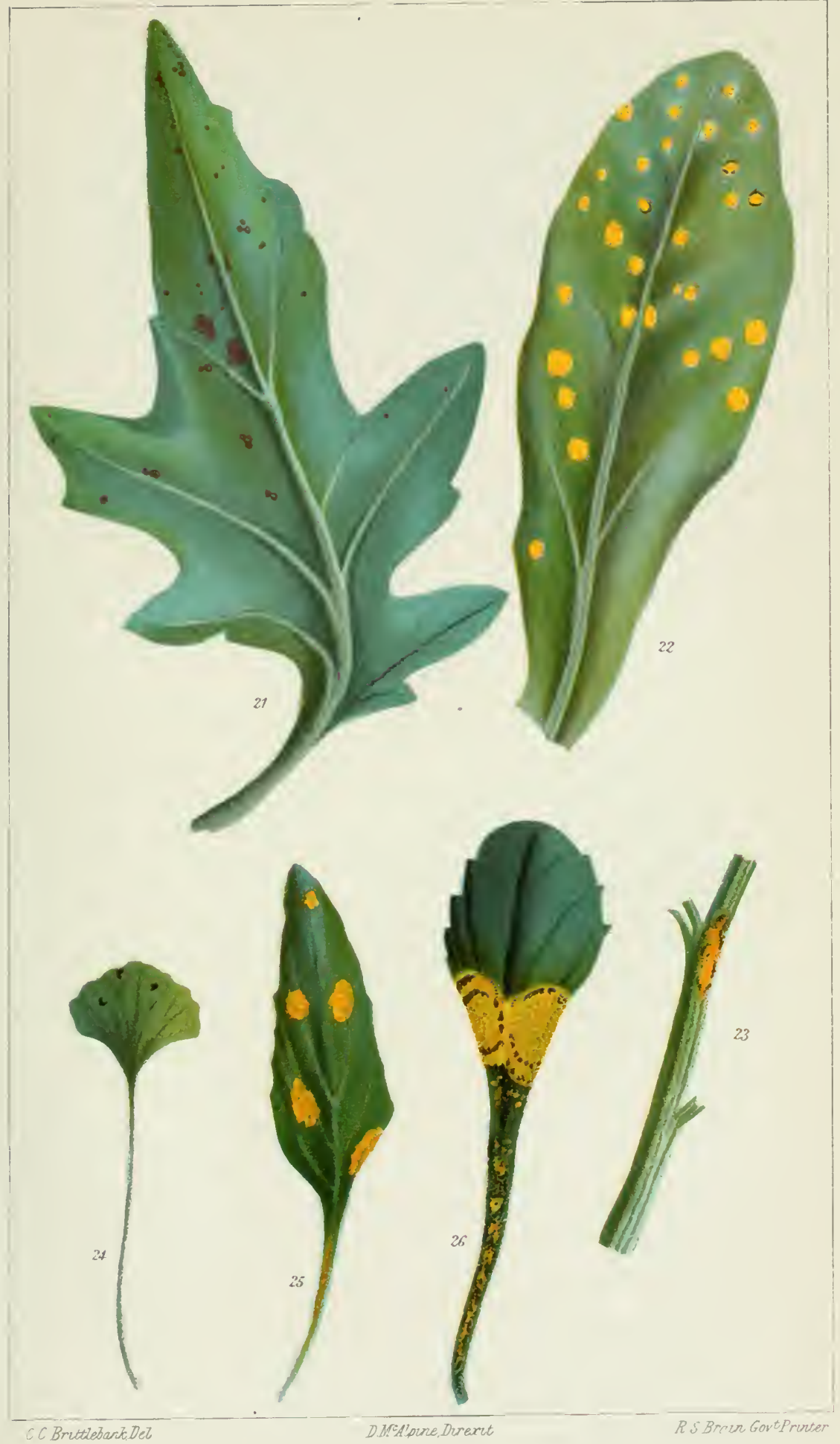

CHRYSANTHEMUM, MARIGOLD, VIOLET, AND DAISY RUSTS. 




\section{PLATE F. \\ (All Figures nat. size.)}

PUCCINIA LAGENOPHORAE ON LAGENOPHORA BILLARDIERI.

Fig.

27. Aecidia and teleutosori on both surfaces of leaves.

PUCCINIA MALVACEARUM ON LAVATERA PLEBEIA.

2S. Teleutosori on under surface of leaf and on leaf-stalk.

PUCCINIA MORRISONI ON PELARGONIUM AUSTRALE.

29. Accidia, uredo, and teleutosori on under surface of leaf, and teleutosori on stem. 
PLATE F

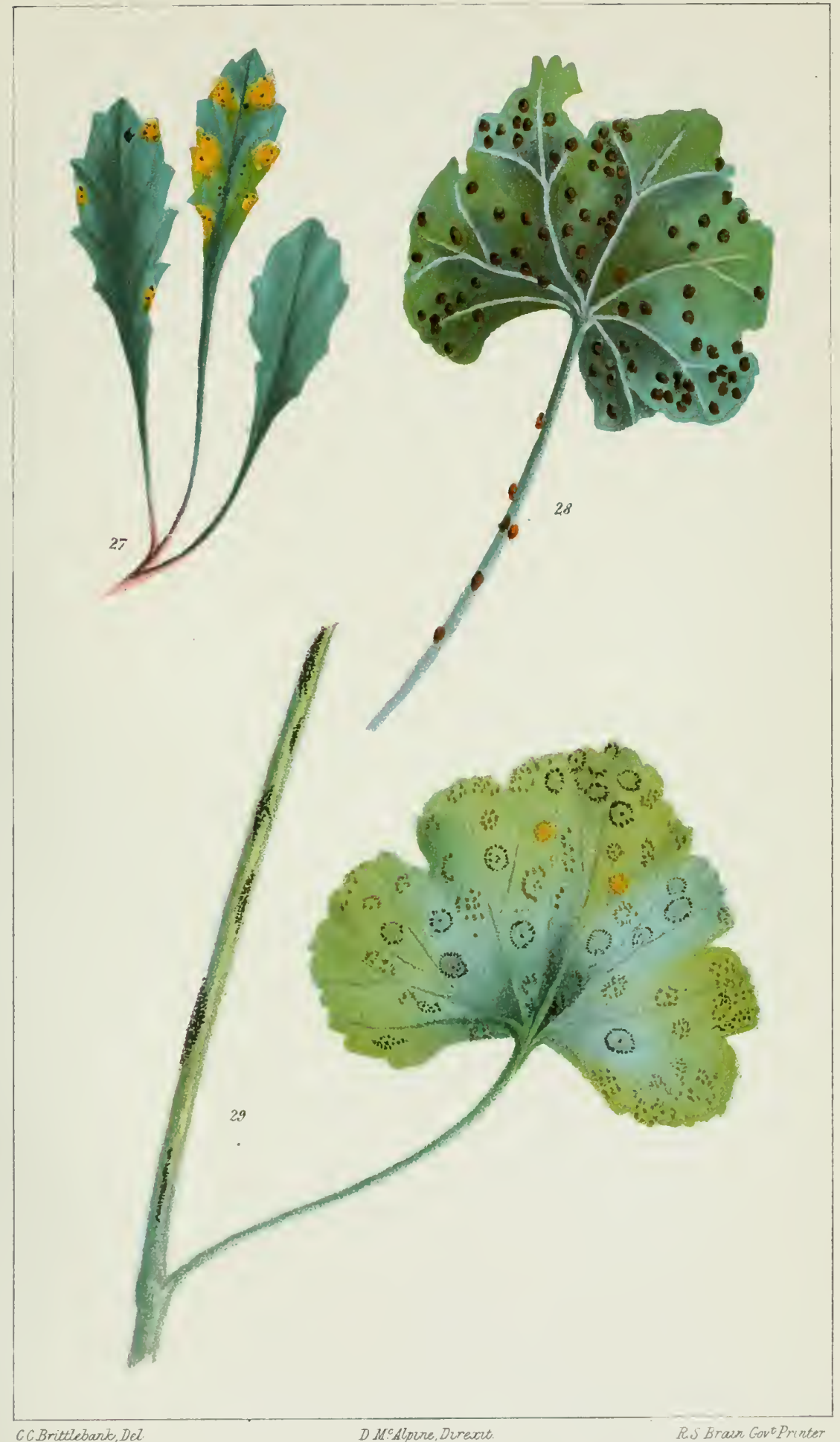

LAGENOPHORA, MALLOW, AND PELARGONIUM RUSTS. 




\section{PLATE G.}

(All Figures nat. size.)

UKOMYCES CARYOPHYLLINUS ON CARNATION (Dianthus caryophyllus).

Fig.

3o. Uredosori on upper surface of leaf.

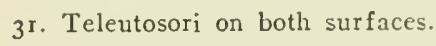

UROMYCES TRIFOLII OX WHITE CLOVER (Trifolium repens). 32. Aecidia, uredo, and teleutosori on leaf.

UROMYCES VESICLLOSLS ON ZYGOPHYLLUM GIALCESCENS.

33. Uredo and teleutoscri on both surfaces of leaves and on stems.

UROMYCES IHARDENIBERGIAE ON IIARDENBERGIA MONC:HYLLA.

34. Uredosori on under surface of leaf. 
PLATE G

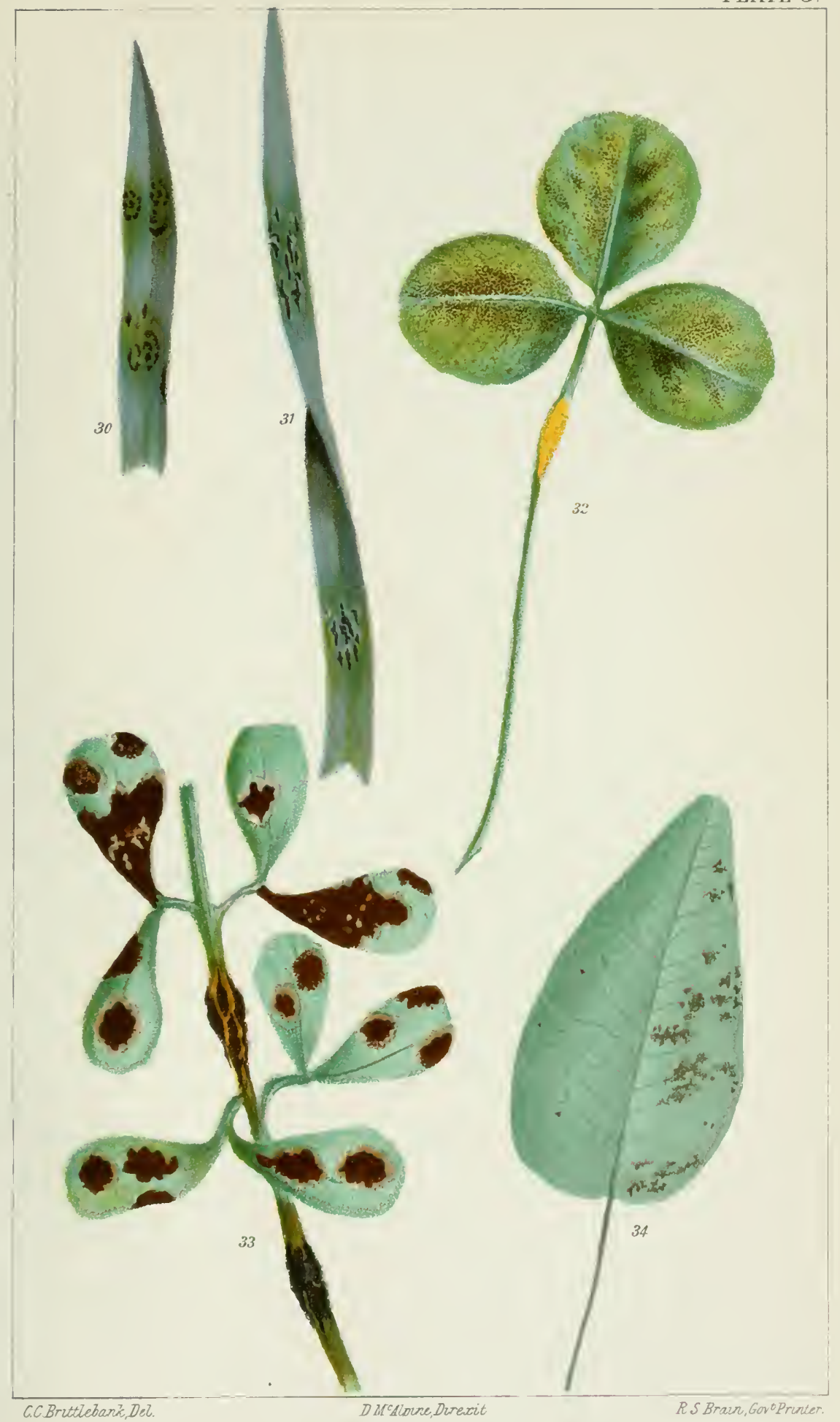

CARNATION, CLOVER, AND OTHER RUSTS. 


PLATE H.

(Natural Size.)

Fig.

UROMICES BETAE ON MANGEL (Beta vulgaris).

35. Uredo and teleutosori on under surface of leaf.

This leaf was obtained from Mangels, the roots of which had been planted in August for seed, and in January the plants were fully six feet high, with abundance of foliage covered on both sides with rust. 


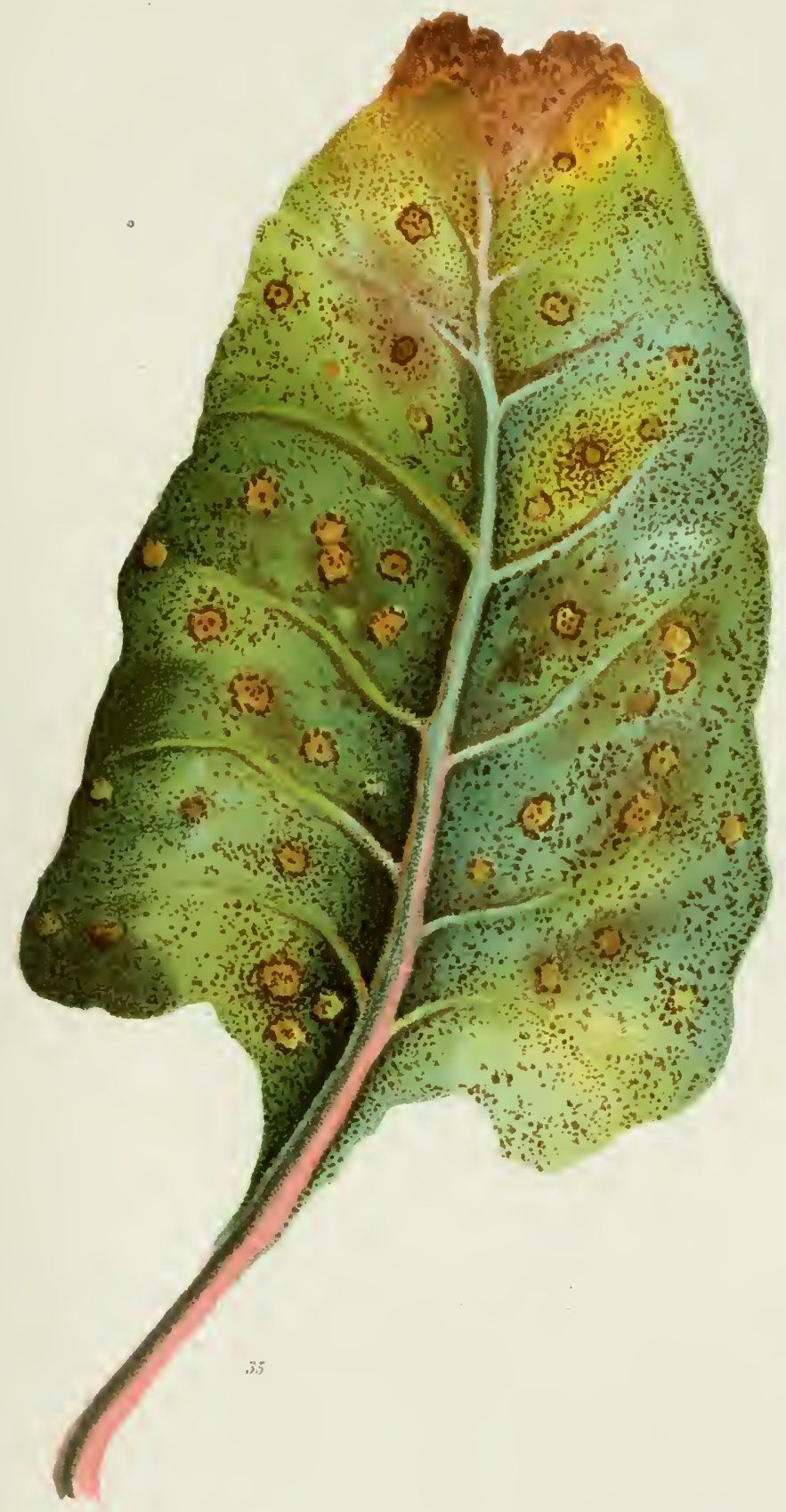






\section{PLATE I.}

(All Figures nat. size.)

Fig.

MELAMPSORA LINI ON NATIVE FLAX (Linum marginale).

36. Uredo and teleutosori on stem.

PHRAGMIDIUM SUBCORTICIUM ON SIVEET-BRIER (Rosa rubiginosa).

37. Aecidia (Caeomata) showing large swollen patches on stems and small patches on lower surface of leaves.

PHRAGMIDIUM BARNARDI ON NATIVE RASPBERRY (Rubus parvifolius).

38. Ochraceous uredosori on lower surface of leaves and floter-stalls, powdery teleutosori accompanying uredosori. 
PLATE I.

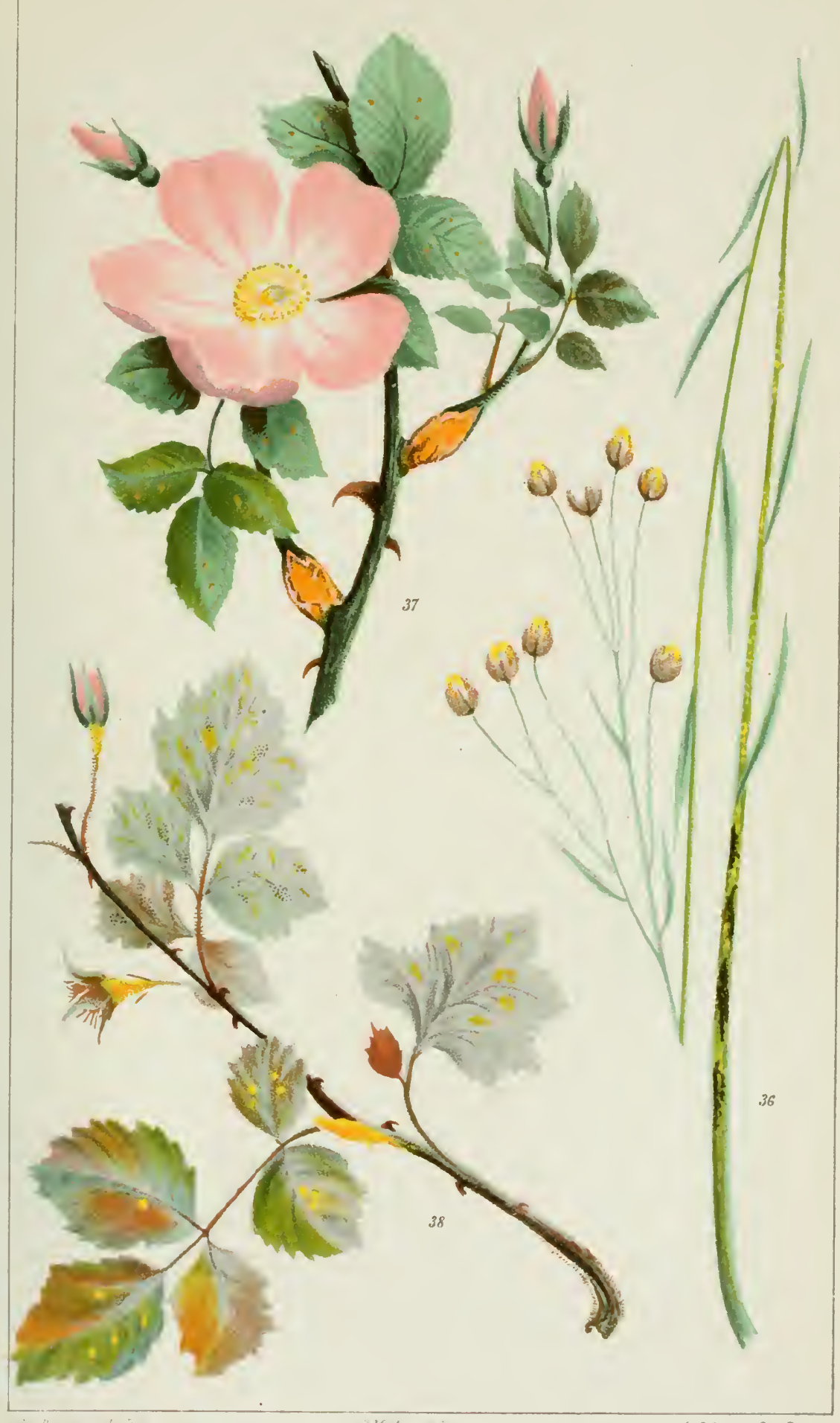

\& Sfrain Gour Proper 



\section{PLATE J.}

Fig.

AECIDIUM ON DANTHONIA.

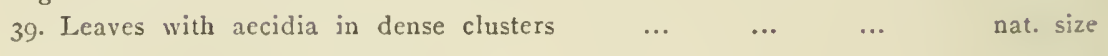

4. Cl Cluster of aecidia on leaf $\ldots \begin{array}{llllllll} & \ldots & \ldots & \ldots & \ldots & \ldots & \ldots & \times 15\end{array}$

41. Section of aecidium showing peridial wall and spores in chains $\ldots \quad \times 5^{\circ}$

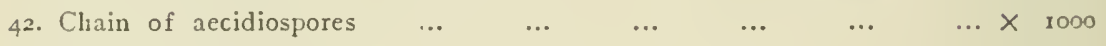

43. Single spore detached and morc or less rounded $\quad \ldots \quad \ldots \quad \ldots \quad \ldots \times 1000$

44. Pseudoperidial cells seen from the surface $\ldots \quad \ldots \quad \ldots \quad \ldots \quad \ldots \quad \ldots \quad \times 550$ 


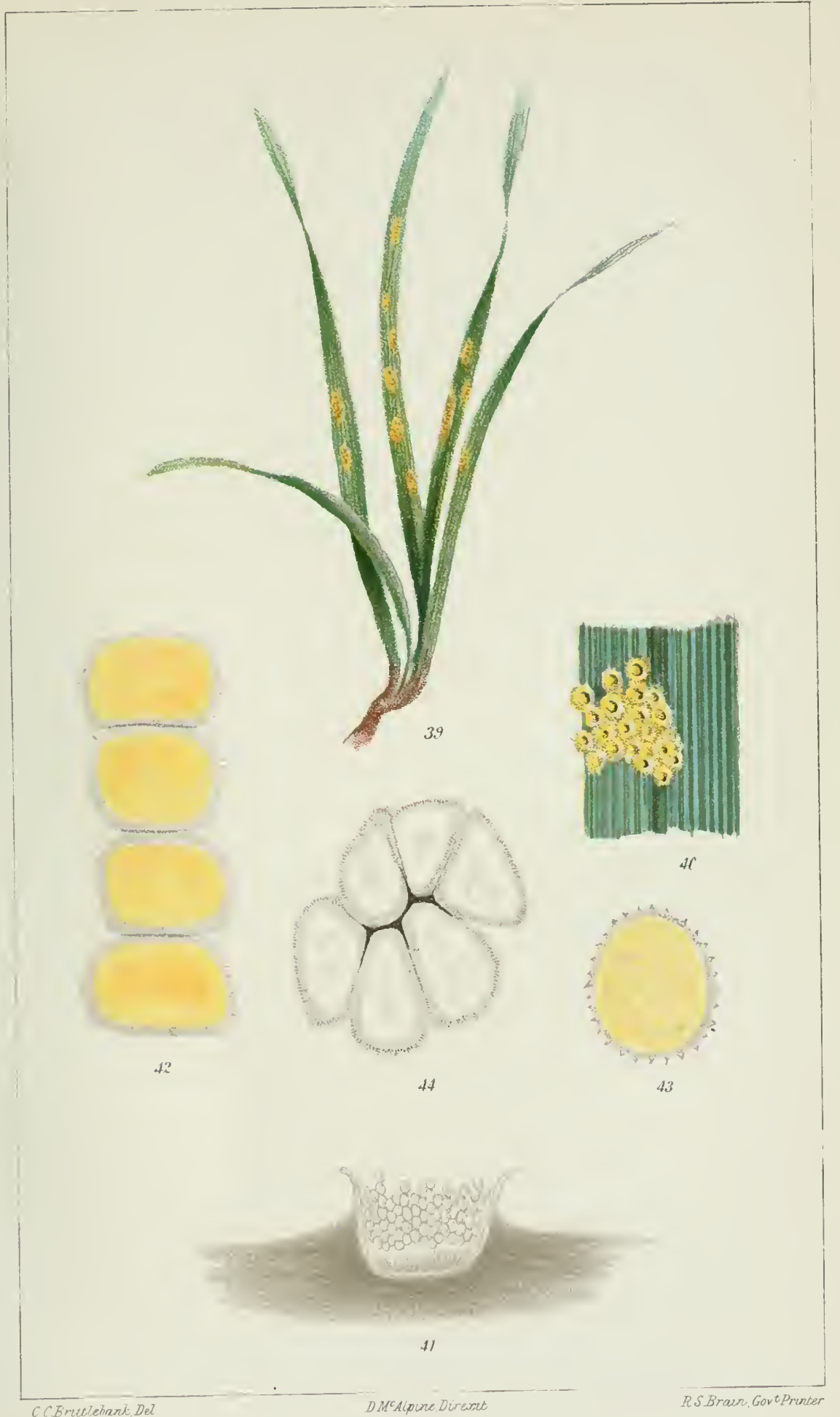

WALLABY-GRASS RUST. 




\section{PLATE I.}

\section{(All Figure's $\times 250$ muless otherwise stated.)}

\section{PUCCINIA.}

Fig.

I. Portion of sheath of barley (Hordcum vulgare) showing numerous crowded black dots, the teleutosori of Puccinia simplex, the spring or orange rust of $\begin{array}{lllllllll}\text { barlcy } & \ldots & \ldots & \ldots & \ldots & \ldots & \ldots & \ldots & \text { nat. size }\end{array}$

2. Portion of sheath of wheat (Triticum vulgare), the broad dark lines representing the uredosori of $P$. graminis, summer rust of wheat $\ldots \quad \ldots$ nat. size

3. Portion of flag of wheat, the small dark dots representing the uredo and teleu. tosori of $P$. triticina, the spring or orange rust of wheat $\ldots$ nat. size

4. Uredospores of $P$. simplex from barley, the numerous germ pores appearing as paler dots scattered promiscuously over the face of the spore.

5. Uredospores of $P$. graminis from whent, with their three equatorial germ pores.

6. Uredospores of $P$. triticina from wheat with germ porcs promiscuously scattered over the face.

7. Teleutospores of $P$. graminis from wheat, the thickened apex being very pronounced.

8. Teleutospores of $P$. graminis from whent, upper cells checked in their development by some unknown cause as shown by their pale colour, not due to germination having already occurred.

9. Teleutospores of $P$. simplex from barley, only one being two-celled.

10. Section of teleutosoms of $P$. triticina on wheat, with paraphyses at left.

Notr.-The whole of the photomicrographs in this and the succeeding plates were taken with the horizontal laboratory camera made by Messrs. Watson and Sons, of I.ondon, using their IIoloscopic lens of $12 \mathrm{~mm}$. $65 \mathrm{~N}$..A. 10 obtain the magnification of 250 diams., and the $6 \mathrm{~mm}$. $.95 \mathrm{~N} . \mathrm{A}$. for 500 diams. 


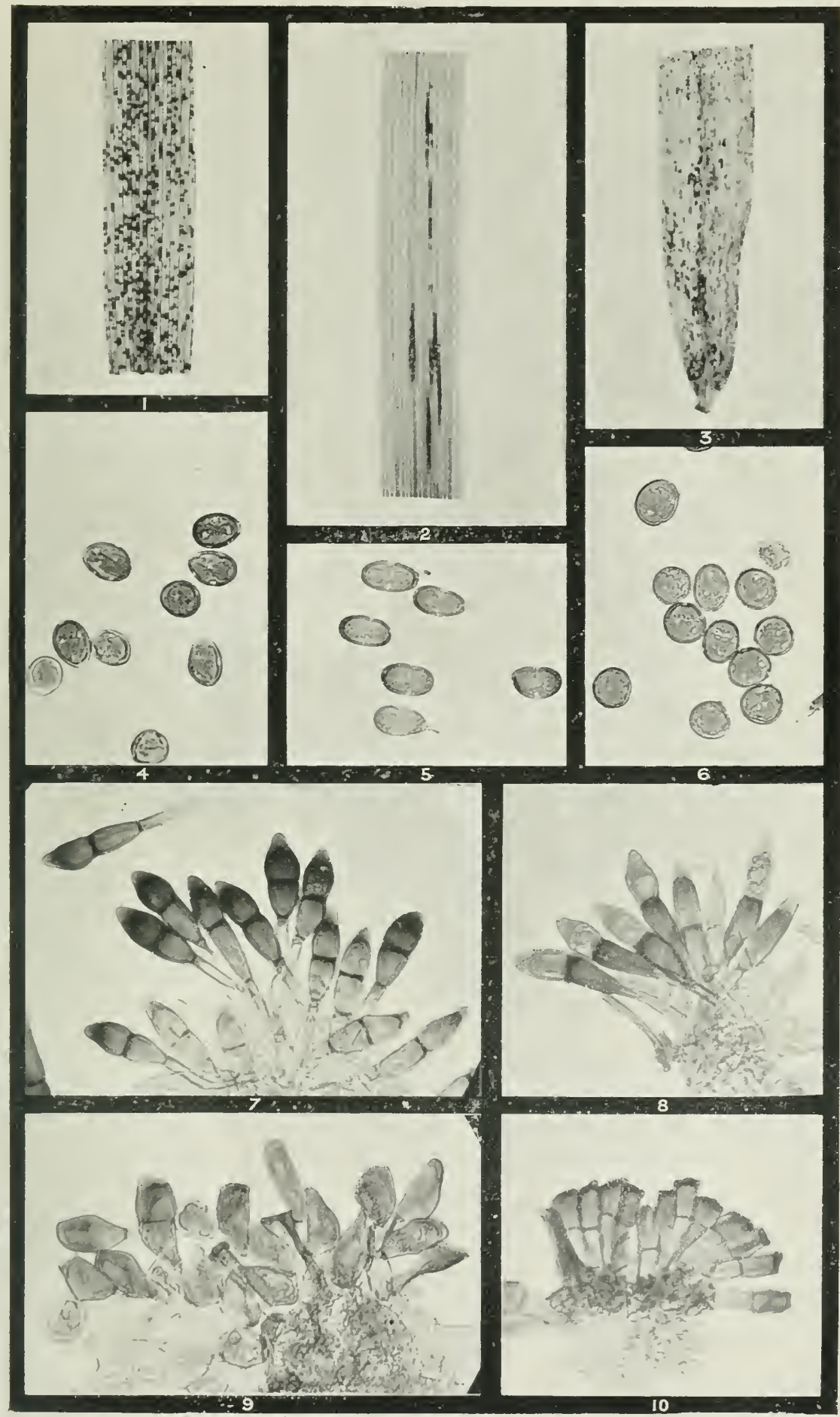

c. H. Rulinson, Phot

Yut, size and $\times$ 25็

PUCCINIA.

GRAMINEAE. 




\section{PLATE II.}

\section{(All Figures $\times 250$. \\ PUCCINIA.}

Fig.

1. Section of telentosorus of Puccinia lolii avenae on oat (Avena sativa) with several unicellular as well as bicellular teleutospores.

12. Group of teleutospores of P. beckmanniae on Beckmannia erucacformis.

13. Section of teleutosorus of $P$. festucae on Festuca pratensis.

14. Section of teleutosorus of $P$. lolii on Lolium perenne.

15, 16. Groups of teleutospores of $P$. maydis on Zea mays, including one fourcelled spore.

17. Teleutospores of $P$. flavescentis on Stipa flavescens.

18. Section of teleutosorus of $P$. magnusiana on Phragmites communis.

rn. Five teleutospores of $P$. tepperi on Phragmites communis, showing the extremely long pedicels. 


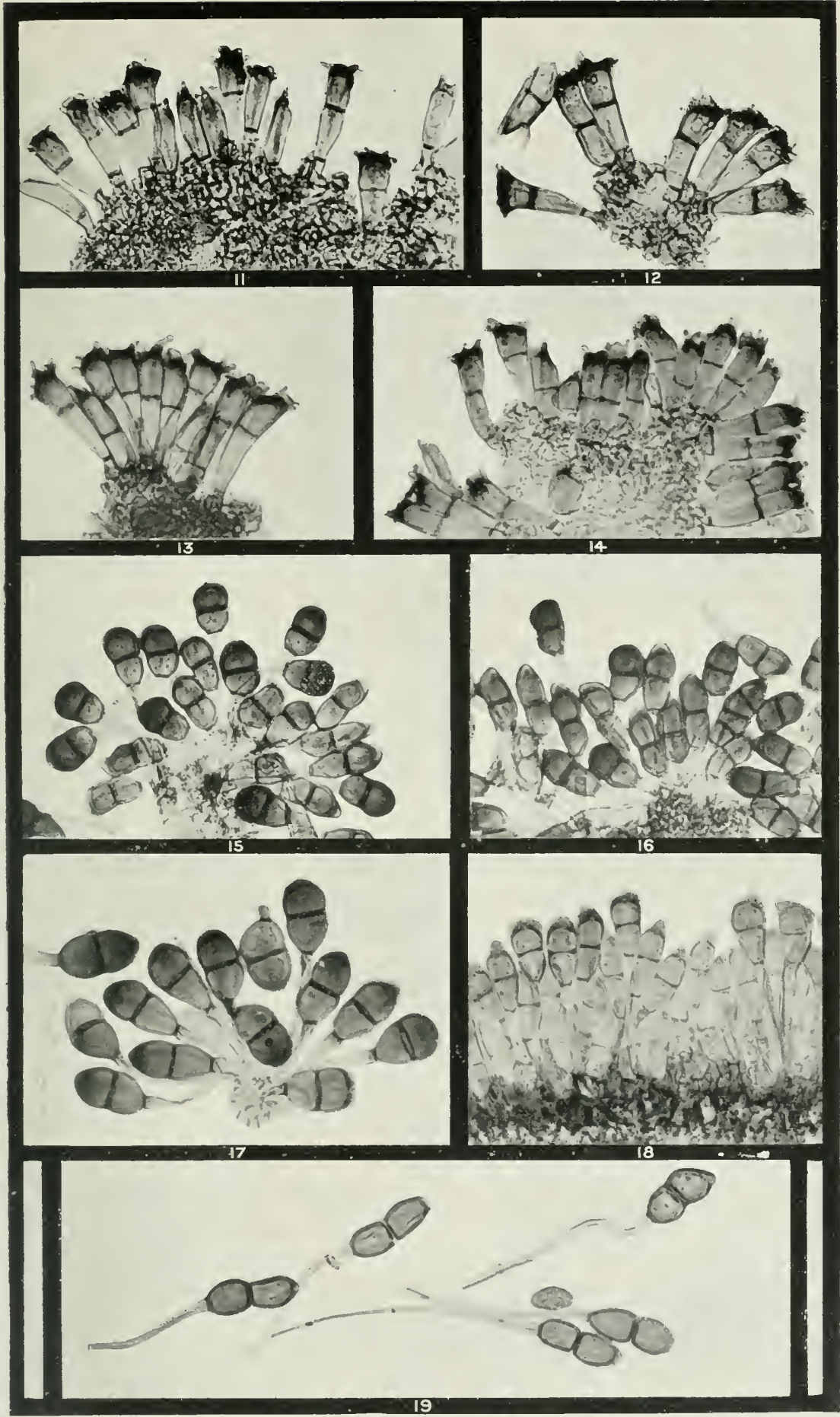

G. H. Robinson, Phot,

PUCCINIA.

GRAMINEAE. 




\section{PLATE III.}

\section{(All Figures $\times$ 250.) \\ PUCCINIA.}

Fig.

20. Section of teleutosorus of Puccinia anthoxanthi on Anthoxanthum odoratum, une spore with a septate pedicel laterally inserted.

21. Group of teleutospores of the same, one with a much inflated pedicel.

22. Teleutospores of $P$. poarum on Poa annua.

23. Teleutospores of $P$. perplexans on Alopecurus geniculalus.

24. Teleutospores of $P$. cynociontis on $C$ ynodon dactylon.

25. Section of teleutosorus of P. agropyri on Agropyron scabrum.

26. Group of teleutospores of $P$. impatientis on Elymus condensatus.

27. Group of teleutospores of $P$. agrostidis on Deyeuxia forsteri.

28. Section of teleutosorus of P. bromina on Bromus mollis. 


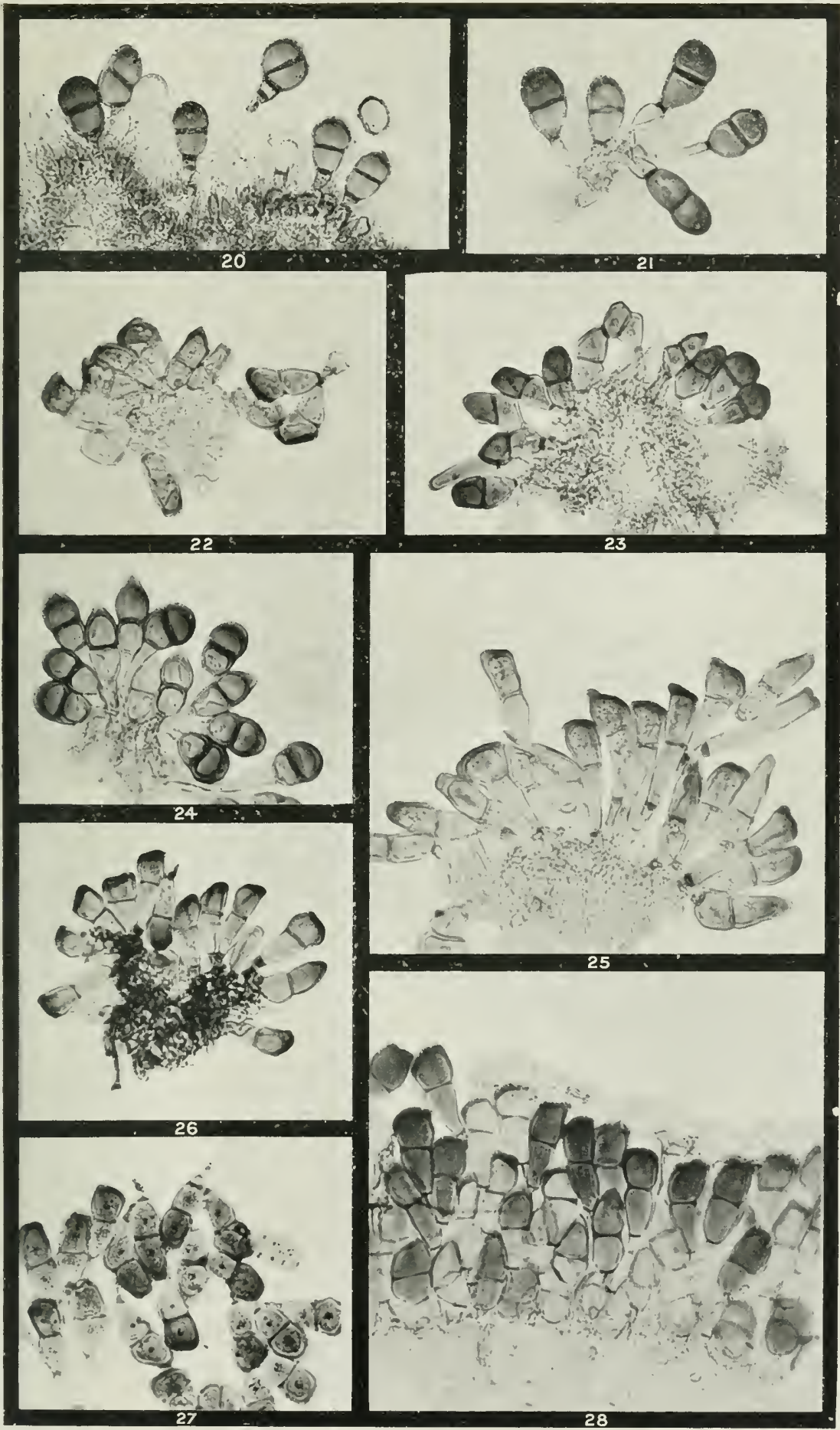

G. H. Robinson, Phot.

PUCCINIA.

GRAMINEAE. 

438. 


\section{PLATE IV.}

\section{(All Figures $\times 250$.)}

PUCCINIA.

Figs.

29. Froup of telentospores of Puccinia curicis on Carex breviculmis, Killara, Victoria.

30. Froup of teleutospores of Puccinia caricis on Carex stricta. Berlin, Germany (Sydow, Uredineen, 460).

31. Teleutospores of $\mu$. longispora on Carex caespitosa.

32. Teleutospores of $P$. cyperi on Cyperus rotundus.

33. Group of teleutospores of $P$. tenuispera on Lusuliz campestris, Murramurrangbong Ranges, Victoria.

34. Teleutospores of P. obscura on Luzula campestris, Berlin, Germany (Sịdow, Ure. rineen, $(0 ; 6)$. The spores of this species are differently shaped, much thicker in the wall and much darker than those of $P$. ienuispora.

35. Uredospores of $P$. juncophila from sorus containing both uredo and teleutospores on Tuncus maritimus.

36. Teleutospores of the same. 


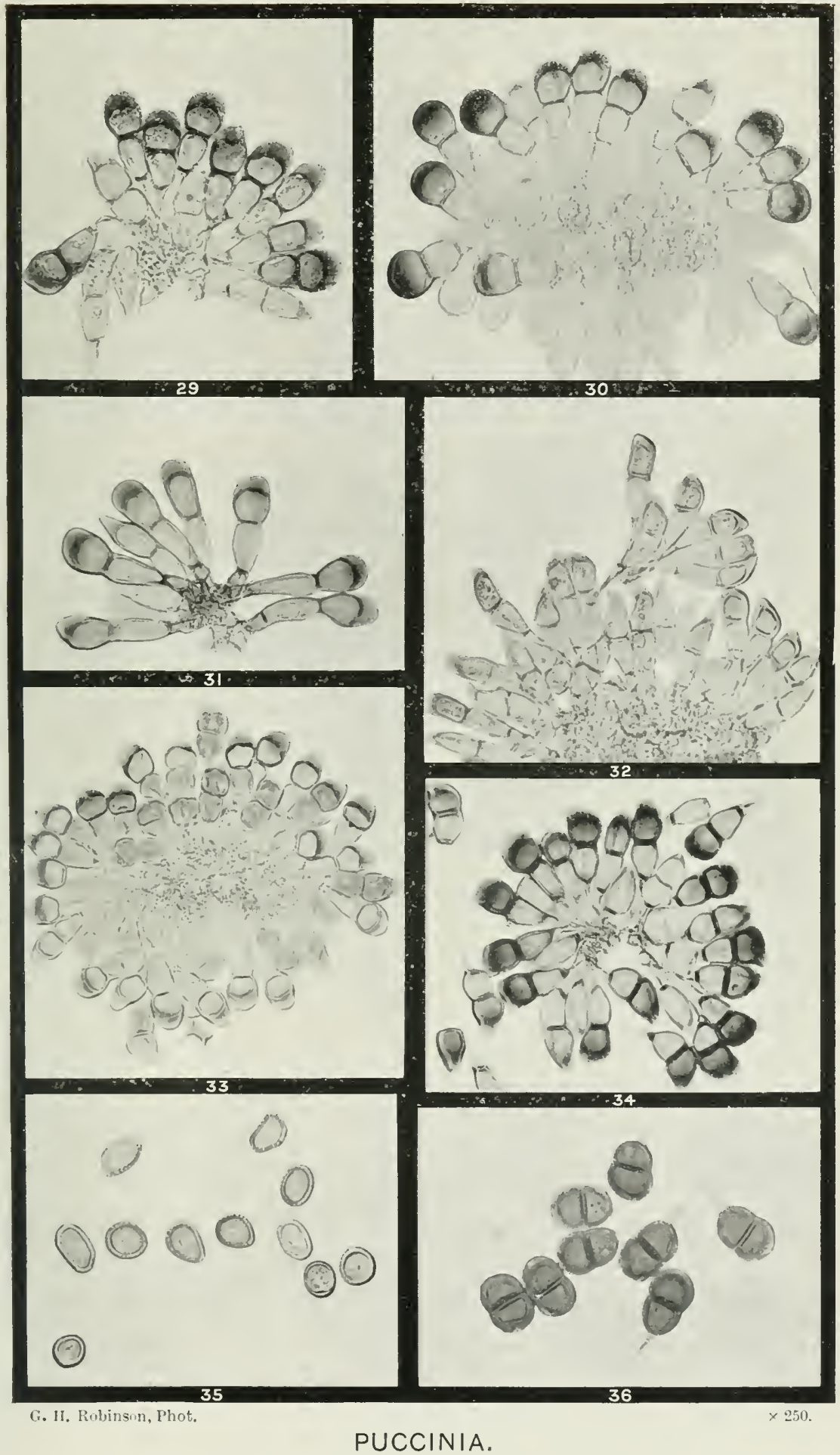

CYPERACEAE AND JUNCACEAE. 



\section{PLATE V.}

\section{(All Figures $\times$ 250.)}

Fig.

\section{PUCCINIA.}

37. Teleutospores and mesospores of Puccinia wurmbeae on Wurmbea dioica

.38. Uredospores of P. burchardiae on Burchardia umbellata.

39. Teleutospores, one three-celled, of the same.

40. Teleutospores and mesospores of P. haemodori on Haemodorum sp.

41. Teleutospores and mesospores of P. hypoxidis on Hypoxis glabella.

42. Teleutospores, two three-celled, of $P$. dichondrae on Dichondra repens.

43. Teleutospore and uredospore of P. mussoni on Ruellia australis, Richmond River, New South Wales.

44. Teleutospores of P. ruelliae on Ruellia strepens, Columbus, Ohio, U.S.A. (W. A. Kellernan, Ohio Fungi, 13o). 
I'LATE T.

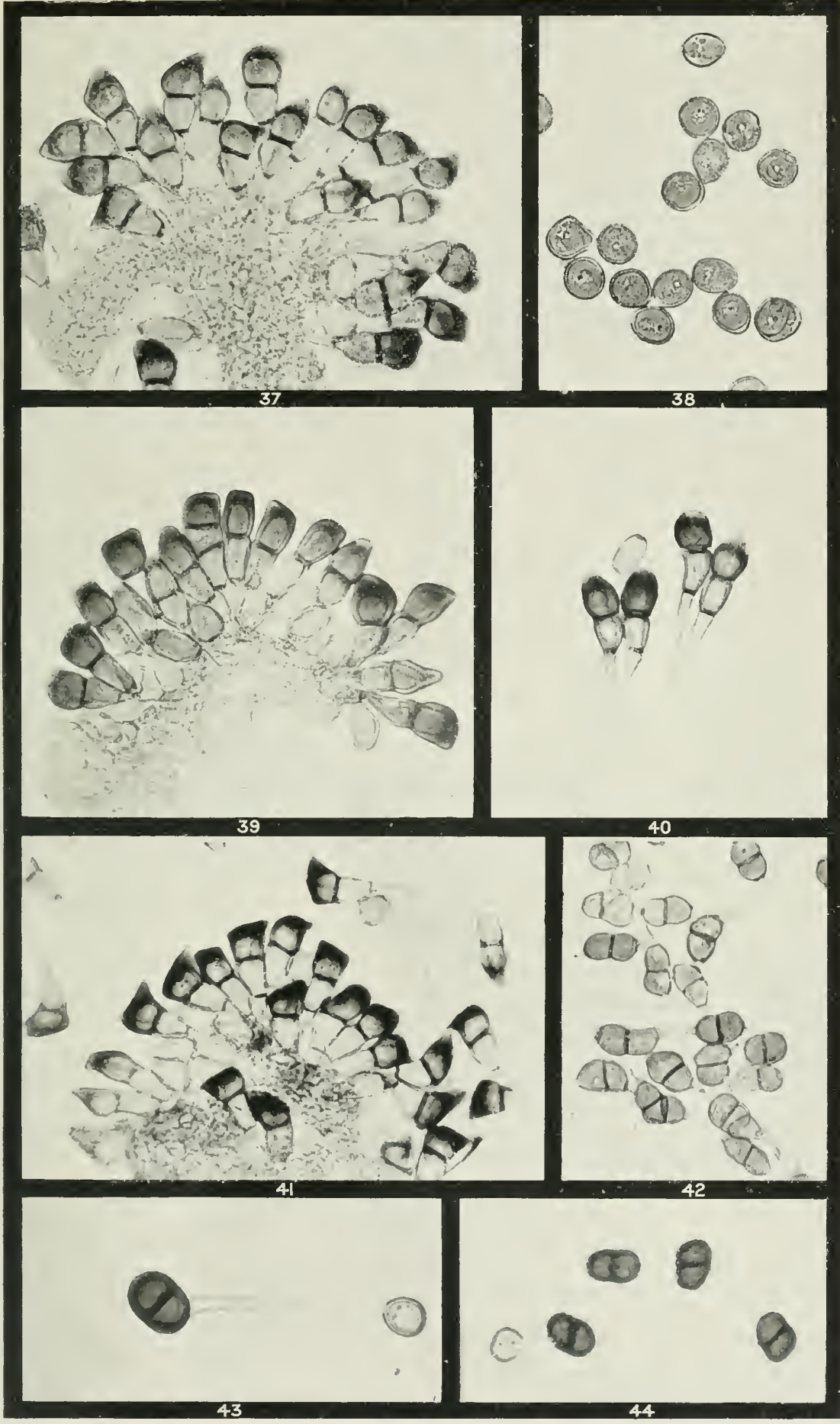

G. 11. Liobinson, Phot.

PUCCINIA.

LILIACEAE, HAEMOdORACEAE, AMARYLLIDEAE, AND ACANTHACEAE. 


PLATE VI.

\section{(All Figures $\times 25^{\circ}$.)}

\section{PUCCINIA.}

Fig.

45. Group of teleutospores of Puccinia carissae on Carissa ovata.

46. Section of teleutosorus of P. alyxiae on Alyxia buxifolia, with teleutospores and mesospores.

47. Teleutospores of $P$. gilgiana on Leschenaultia linarioiaies.

48, 4\%. Teleutospores and inesospores of P. saccardoi ua Goodenia geniculala.

50. Telcutospores and mesospores of $P$. brunoniae on Brunonia australis, with onc three-celled and one four.celled teleutospore.

51. Telentospores of P. aucta on Lobelia anceps. From a drawing by C. C. Brittlebank from the original material from Berkeley in the National Herbarium, Melbourne). 
I'LATE VI.

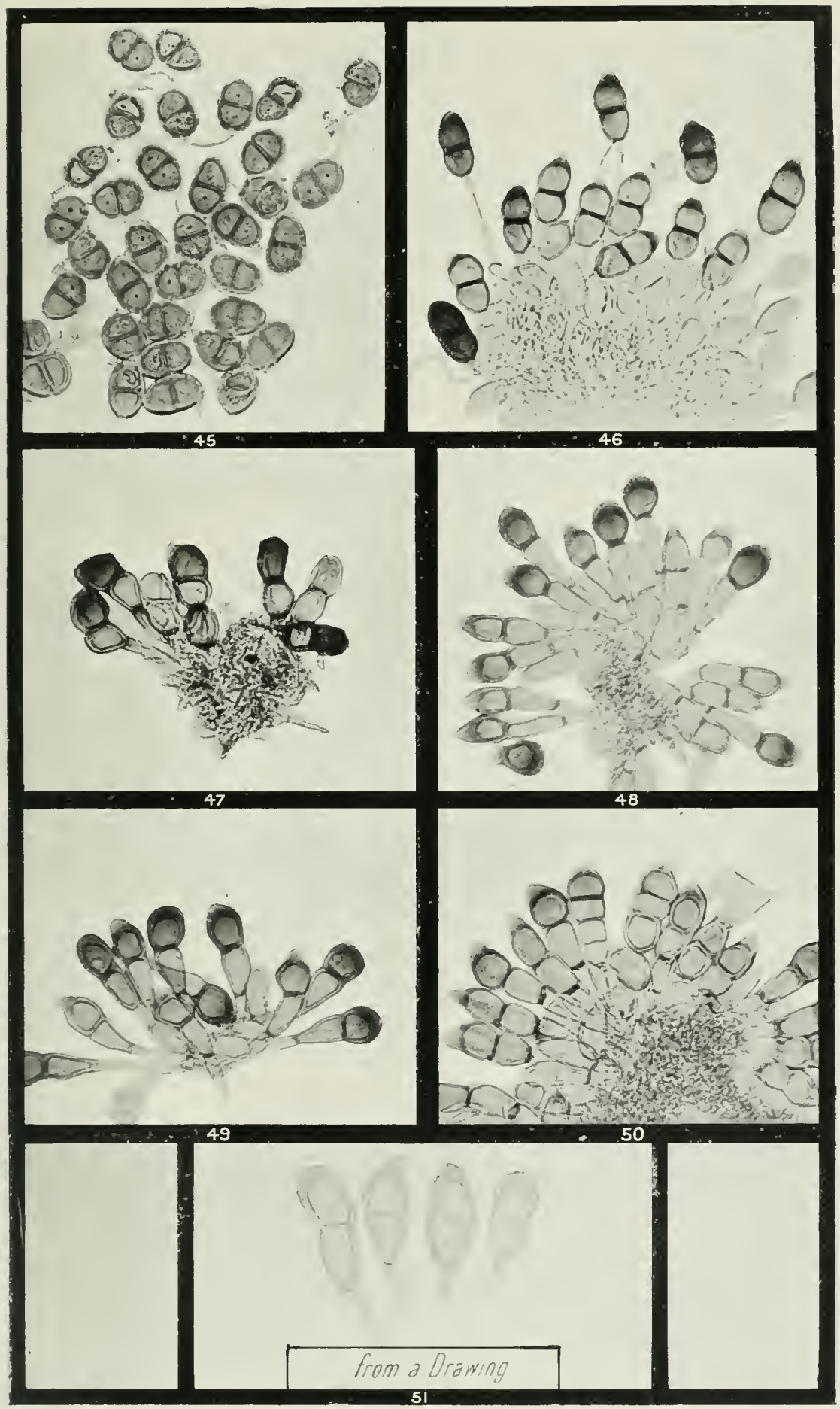

(i. II Robinson, Phot

PUCCINIA.

APOCYNACEAE, GOODENIACEAE, and CAMPANUlACEAE. 



\section{PLATE VII.}

(All Figures $\times$ 250.)

\section{PUCCINIA.}

Fig.

52. Teleutospores and mesospores of Puccinia tasmanica on Senecio vulgaris, one teleutospore being three-celled.

53. Teleutospores anả mesospores of $P$. angustifoliae on Scorzonera angustifolia.

54, 55. Sections of teleutosori of P. lagenophorae on Lagenophora billardicri, showing mesospores and teleutospores.

56. Teleutospores and mesospores of $P$. helianthi on Helianthus annuus.

57. Teleutospores of $P$. gnaphalii on Gnaphalium japonicum.

58. Teleutospores and mesospores of $P$. calocephali on Calocephalus drummondii.

59. Teleutospores and mesospores of $P$. erechtitis on Erechtites quadridentata. 


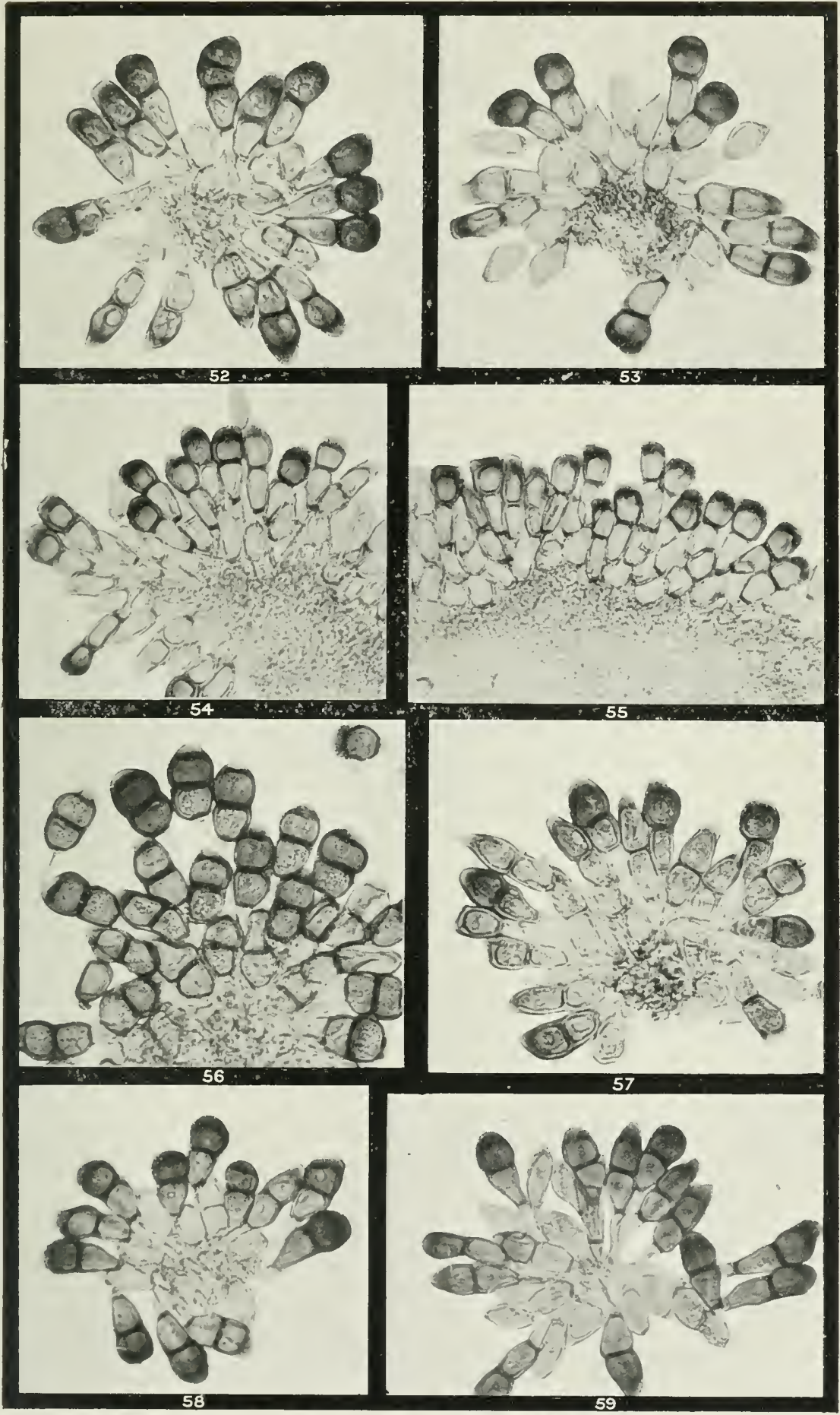

G. H. Kohinson, Phot. 



\section{PIATE VIII.}

\section{(All Figures $\times 250$.)}

\section{PUCCINIA.}

Fig.

6o. Section of teleutosorus of Puccinia cinerariae on Cineraria sp. cult. with teleutospores and mesospores.

6r. Three uredospores and several teleutospores of $P$. cichorii on Cichorium intybus.

62. Uredospores and teleutospores of $P$. hypochocridis on Hypochoeris radicala.

63. Teleutospores of the same.

64. Two uredospores and numerous teleutospores of $P$. cyani on Centaurea cyanus.

65. One mesospore and several teleutospores of $P$. calendulae on Calendula officinalis.

66. Mesospores and teleutospores of P. brachycomes on Brachycome ciliaris.

67. Teleutospores and mesospores of $P$. distincta on Bellis perennis. 
I'LATE III

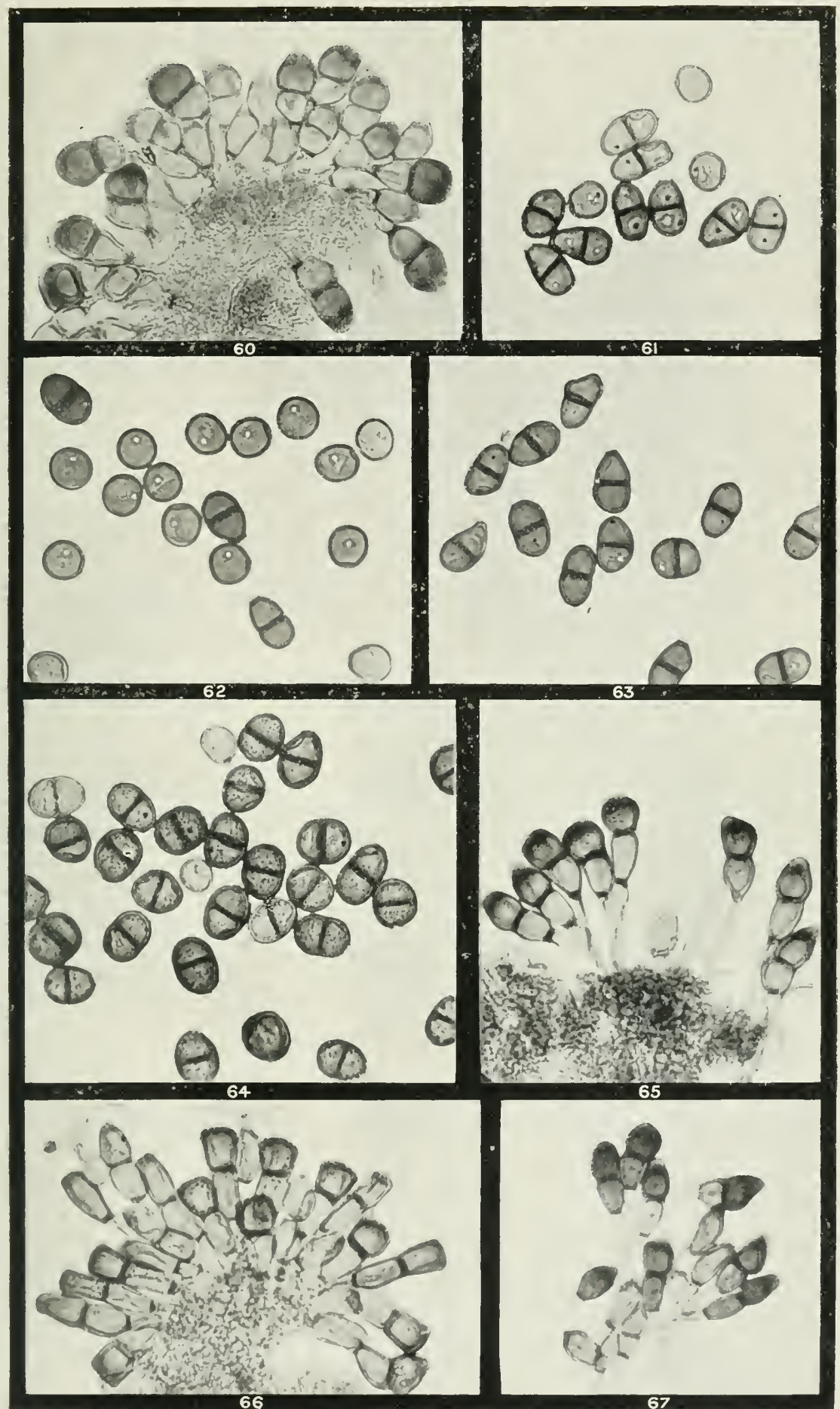

(i. H. Rohinson, Phot.

PUCCINIA.

COMPOSITAE. 




\section{PLATE IX.}

(All Figures $\times 250$ unless otherwise stated.)

\section{PUCCINIA.}

lig.

68. Three uredospores and four teleutospores of Puccinia thuemeni on Apiun prostratum, showing thickened apex of uredospore and slight warting of teleutospore. Beaumaris, Victoria.

69. Uredospores and teleutospores from same, but in greater variety.

7o. One uredospore and two teleutospores from the same, but more highly magnified, and showing more clearly the roughened epispore of both uredo and teleutospores ...

7x. Teleutospores of $P$. thuemeni on Apium graveolens, from Brighton, Victoria.

72. Uredospore and teleutospore from the same as $7 \mathbf{x}$, showing roughened epispore

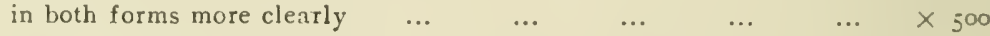

73. Uredospores and teleutospores of $P$. apii on Apium graveolens, Berlin, Germany. (Sydow, Uredineen, 558.)

74. Teleutospores as in Fig. 73, showing distinctly smooth epispore $\ldots \times 500$

75. Teleutospores of $P$. "rullata on Acthusa c1'nafium, with coarsely warted epispore. (Sydow, Uredineen, 1261.) $\quad \ldots \quad \ldots \quad \ldots \quad \ldots \quad \ldots \times \quad \ldots \times 500$

76. Teleutospores of P. xanthosiae on Xanthosia pusilla. 
Plate IX.

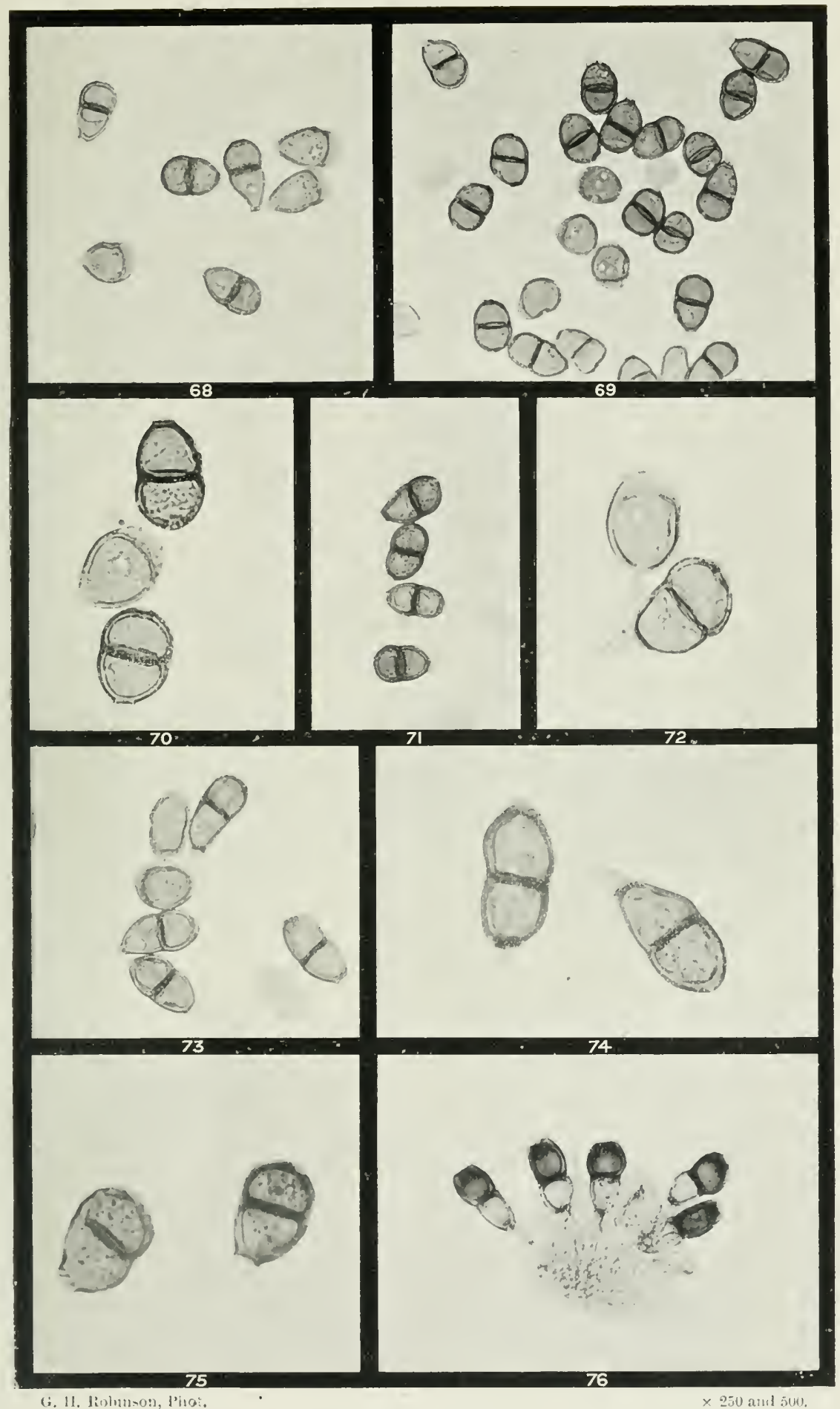

PUCCINIA.

UMBELLIFERAE. 




\section{PLATE X.}

\section{(All Figures $\times$ 250.)}

\section{PUCCINIA.}

Figr.

77. Teleutospore of l'uccinia oliganthae on Aspirula oligantita.

78. Teleutospores, some having germinated, of P. coprosmae, on Coprosma hirtella.

79. Uredospores and teleutospores of $\%$. epilobii-tetragoni on Epilobium glabellum, Murramurrangbong Ranges, Victoria.

So. Uredospores and telentosprores of $P$. cpilobii-lelragoni on Epilobium montanum. (Sydow, Uredineen, i369.)

Sı. Teleutospores of $P$. cpilobii DC: on Epilobium roseum, the teleutospores having much thimer walls, and being more variable in shape than those of $P$. epilobii-tetragoni and also finely verrucose. (Sydow, Uredineen, 14IS.)

S2. Telentospores of $P$. gei on Geum reurifolium.

83. Uredospores of $P$. pruni on Prunus persica.

$९_{4}$. Paraphysis and uredospores of $P$. pruni on Prunus persica.

S5. Telentospores of $P$. pruni on Prumus persica, rather smaller than average.

86. Teleutospores of P. prunion Prunus demestica.

8-. Uredospores and teleutospores of $P$. zerniare on Zernia difhylla. 


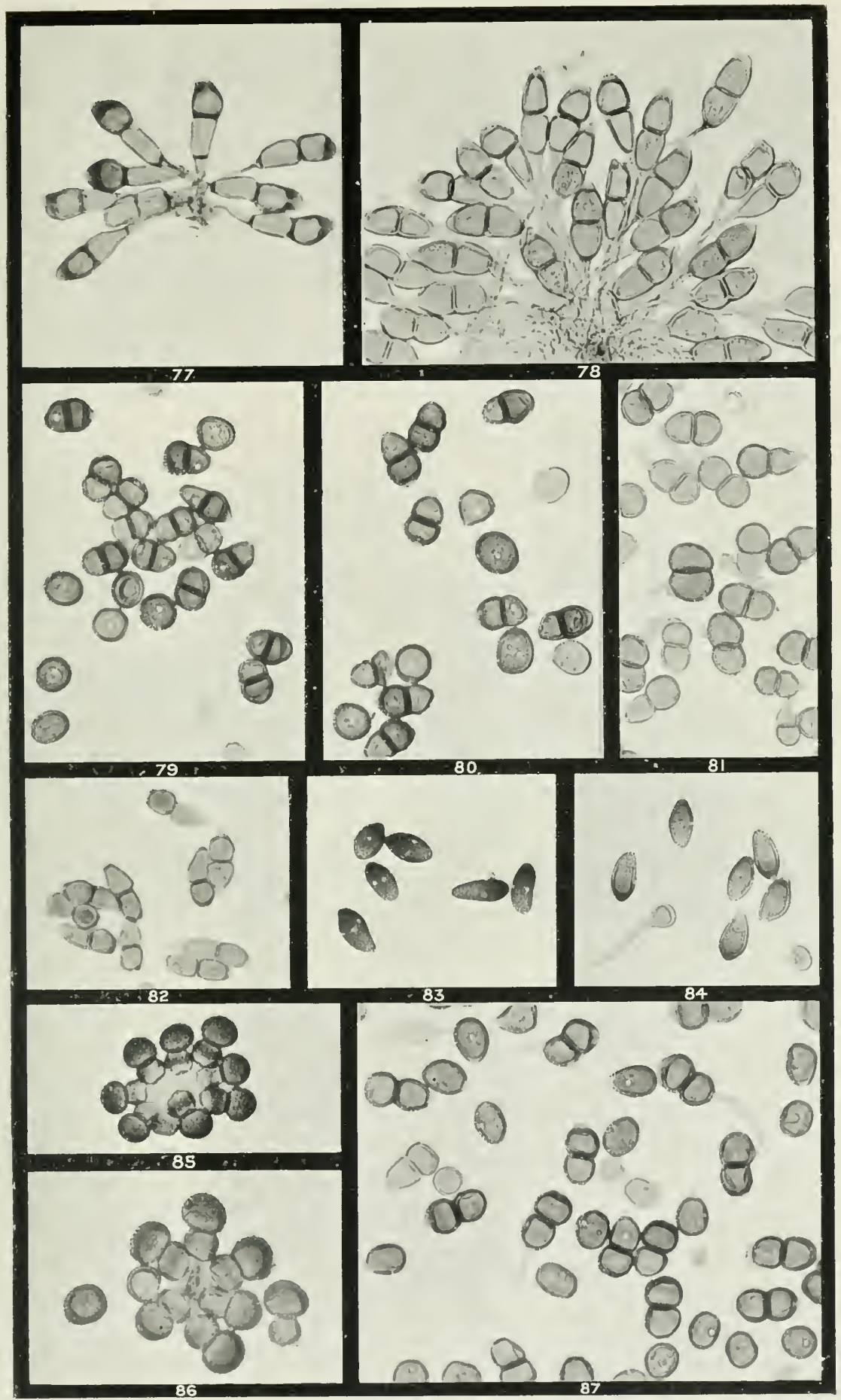

G. II. liobinson, Phot.

PUCCINIA.

RUBIACEAE, onAGRACEAE, ROSACEAE, and LEguminOSAE. 




\title{
PLATE XI
}

\author{
(All Figures $\times 250$.)
}

\section{PUCCINIA.}

Fig.

88, 89. Teleutospores of Puccinia tetragoniae on Tetragonia implexicoma, one with nearly vertical septum in upper cell.

9o. 'Teleutospores, strongly warted, of $P$. ludvigii on Rumex flexuosus.

91. Teleutospores strongly warted, of P. ludwigii on Rumex brownii, one spore being Triphragmium-]ike.

92. Uredospore and teleutospores of $P$. acetosae on Rumex arifolius, all the latter with smooth walls. (Sydow, Uredineen, 954.)

93. Teleutospores of $P$. muchlinbeckiae on Muchlenbeckia adpressa.

94. Teleutospores and mesospore of $P$. diclsiana on Threlkeldia sp.

95. Uredospores of $P$. kochiae on Kochia sedifolia, showing the characteristic numerous germ pores.

96. Teleutospores of $P$. kochiae on Kochia sedifolia. 
PLATE XI.

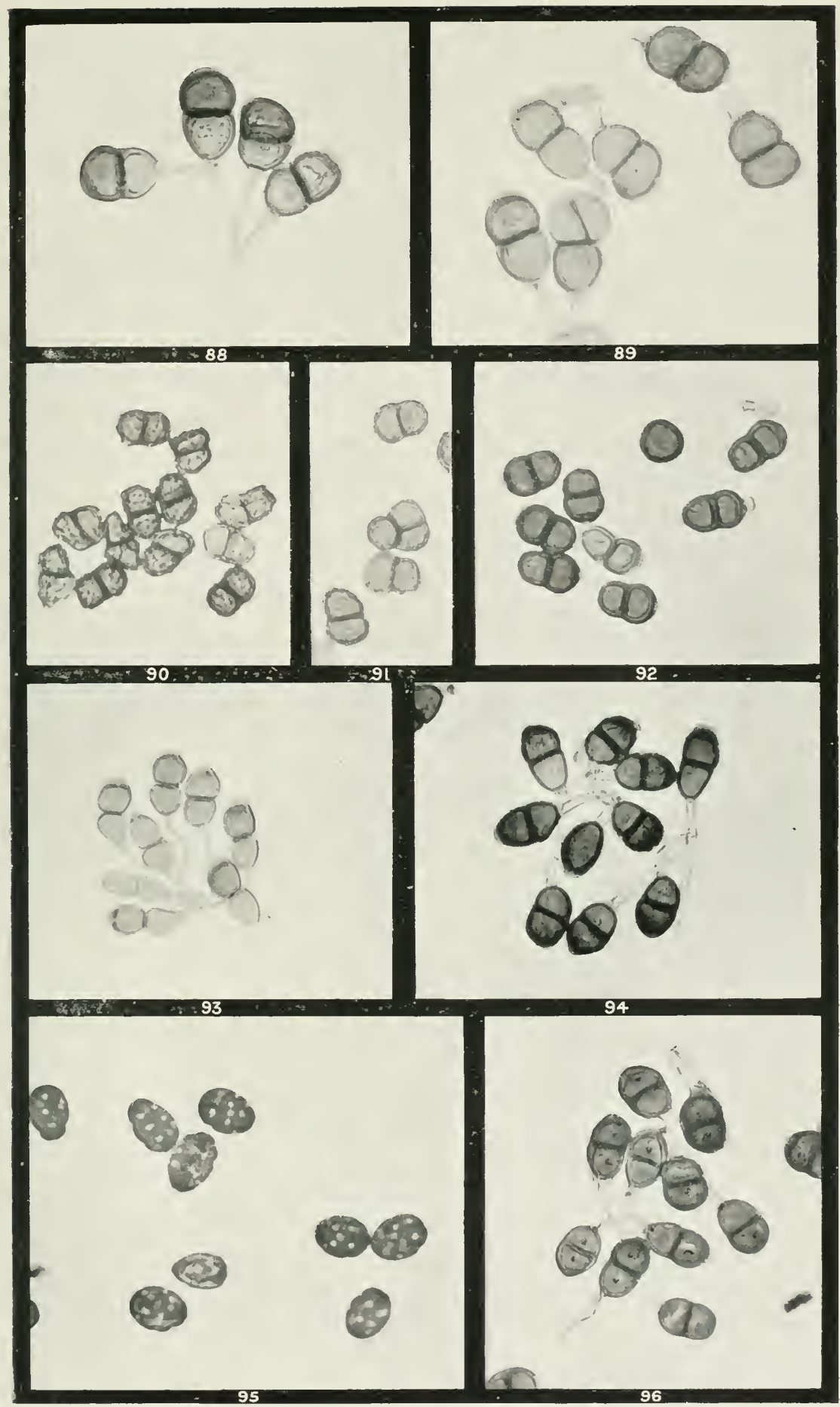

G. II. Pubitson, Phot.

PUCCIN!A.

FICOIDEAE, POLYGONACEAE, ANO CHENOPODIACEAE. 




\section{PLATE Xī́ \\ (All Figures $\times 250$.) \\ PUCCINIA.}

Fig.

97. Teleutospores of Puccinia arenariae on Stellaria media.

98. Teleutospores of $P$. plagianthi on Plagianthus sidoides, the epispore being slightly channelled.

99. Teleutospores (stained) of P. maliacearum on Malza rotundifolia.

100. Teleutospores and mesospore of $P$. malvaccarum on Lavatcra plebcia.

Ior. Teleutospores, mostly one-celled, of 2 . heterospora on Abutilon cristum.

102. Teleutospores and mesospores of $P$. morrisoni on Pelargonium australe.

103. Uredospores of P. gcranii-pilosi on Geranium pilosum.

104. Teleutospores of the same, the single germ pore being noticeable as a paler channel through the apex of the cell wall. 
J'LATE III.

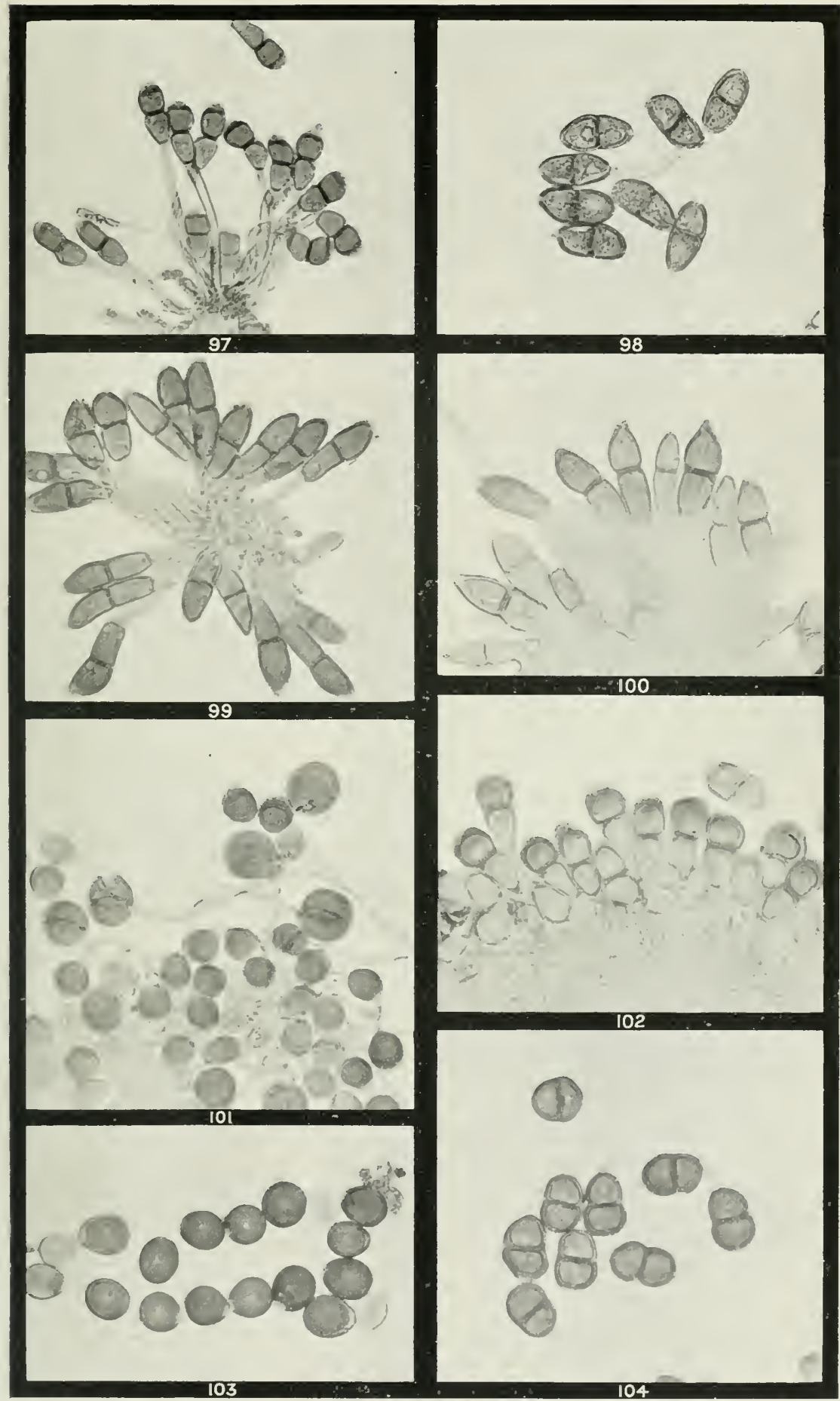

(i. I1. Kobinson, l'hot.

PUCCINIA.

CARYOPHYLLACEAE, MALVACEAE, AND GERANIACEAE. 



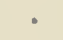




\section{PIATE ẌIII.}

(All Figures $\times 250$ unless otherwise staled.)

\section{PUCCINIA.}

Fig.

105. Teleutospores of Puccinia eriostemonis on Eriostemon myoporoides. .

106. Teleutospores of $P$. correae on Correa lawrenciana.

107. Teleutospores and mesospores of $P$. boroniae on Boronia spinescens.

108. Teleutospores and mesospores of $P$. pritzeliana on Tremandra stelligera, some teleutospores having germinated.

Ion. Teleutospores of $P$. hederaceae on Viola hederacea.

110. Teleutospores of the same, more highly magnified, to show more clearly the

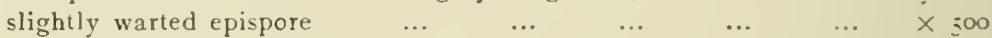

I11. Teleutospore of $P$. aegra on V'iola tricolor with smooth epispore. (IV. B. Grove in Rabh. Fungi Europaei, 3ir3) $\quad \ldots \quad \ldots \quad \ldots \quad \ldots \quad \ldots \quad \ldots \quad \ldots$

112. Teleutospores of $P$. violae on Viola arenaria, with smooth epispore. (Sydow, Uredineen, 286) 
Plate NIII.

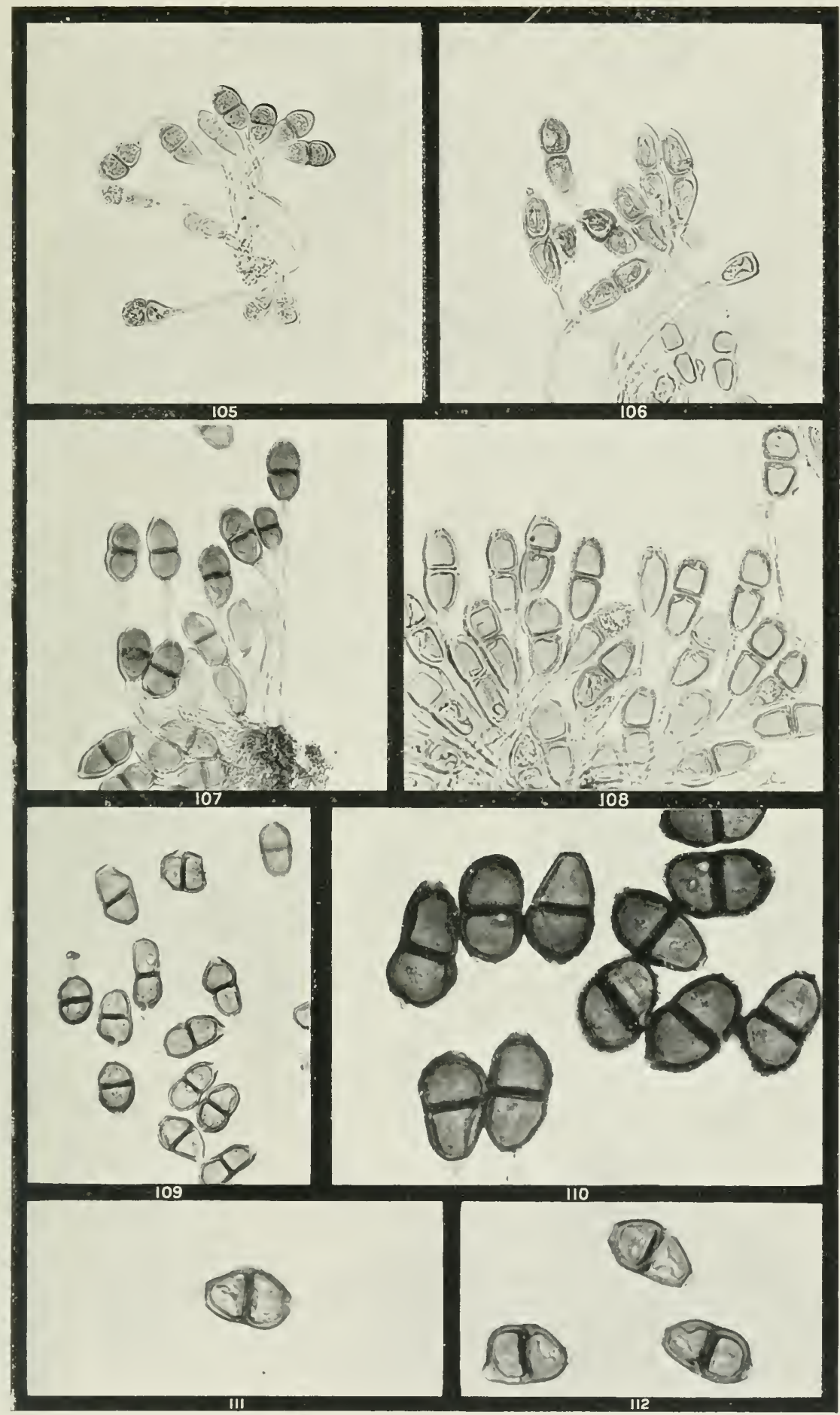

G. H. liobinson, Phot.

PUCCINIA.

RUTACEAE, TREMANDREAE, AND VIOLACEAE 

, 


\section{PLATE XIY.}

(All ligures $\times 250$.)

\section{PUCCINIA RRAMINIS OX VARIOUS GRASSIS.}

Fig.

I13. Teleutospores and mesospores on wild oat, Avena falua.

I4. Teleutospores on barley, Hlordeum vingare.

115, ri6. Teleutospores, mesospores, and uredospore, one of the first three-celled, on native barley, Echinopogon ovalus.

r. Teleutospores on cocksfoot, Dactylis glomerata.

ir8. Teleutospores and uredospores on silver grass, Festuca bromoides.

Ir). Teleutospores and uredospores on an imported barley grass, Hordeum secalinum.

120. Teleutospores on small canary-seed grass, Phalaris minor.

121. Teleutospores on native wheat grass, Agropyron scabrum.

122. Teleutospores on Amphibromus neesii. 


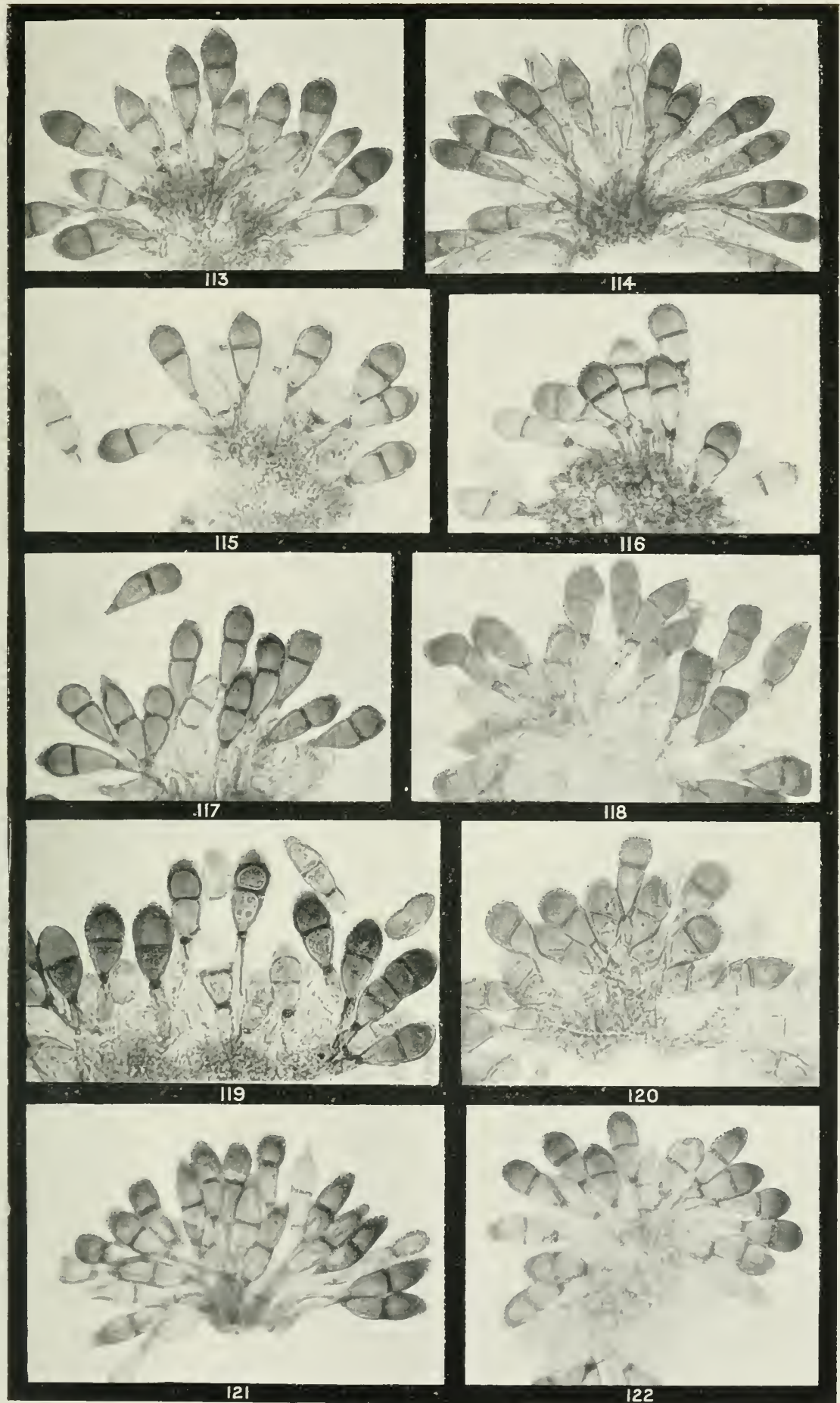

(4) H Robinson, Phot.

PUCCINIA GRAMINIS ON VARIOUS GRASSES. 



$$
\text { , }
$$




\title{
PLATE XV.
}

\author{
(All Figures $\times 250$ unless otherwise stated.)
}

\section{GERMINATION OF TELETTOSPORES OF PUCCINIA MALVACEARUM.}

Fig.

123. Germinating teleutospore, from eac! cell of which a pronycelium has been pushed forth, cell contents collected towards apex of tube, and segmentation commenced.

124. Germinating teleutospore at a later stage, the promycelium having become divided into four segments, and comparatively stout tubes emitted from each segment.

125. Two germinating teleutospores, in the one on the left only the two median segments of the promycelium as yet bear sporidiola.

126. Germinating teleutospore with stout elongated and contorted filaments arising from the promycelial cells, those from the two median cells ultimately giving rise to abnormaily small sporidiola.

12\%. Crerminating teleutospore in which the upper two promycelial cells have produced sporidiola, while in the third from the apex the formation of the sporidiolum is just commencing.

128. Germinating teleutospore, the promycelium bearing three sporidiola on stout elongated sterigmata. The sporidiolum second from the base is already germinating and putting forth a germ tube extending across to the promycelium. The segment second from the apex has not so far produced a sporidiolum, though a stout elongated filament has been emitted.

129. Promycelial spores

130. Germinating promycelial spore

NOTE. - All the above were grown in droplets of water on slides in a noist cliamber, and prepared for photographing by being first dried, then fixed with a saturated solution of mercuric bichloride, washed, rinsed in dilute acetic acid, washed again, and after drying stained with alcoholic 13 ismarck brown, again washed and mounted in glycerine and water. 
PLATE IV.

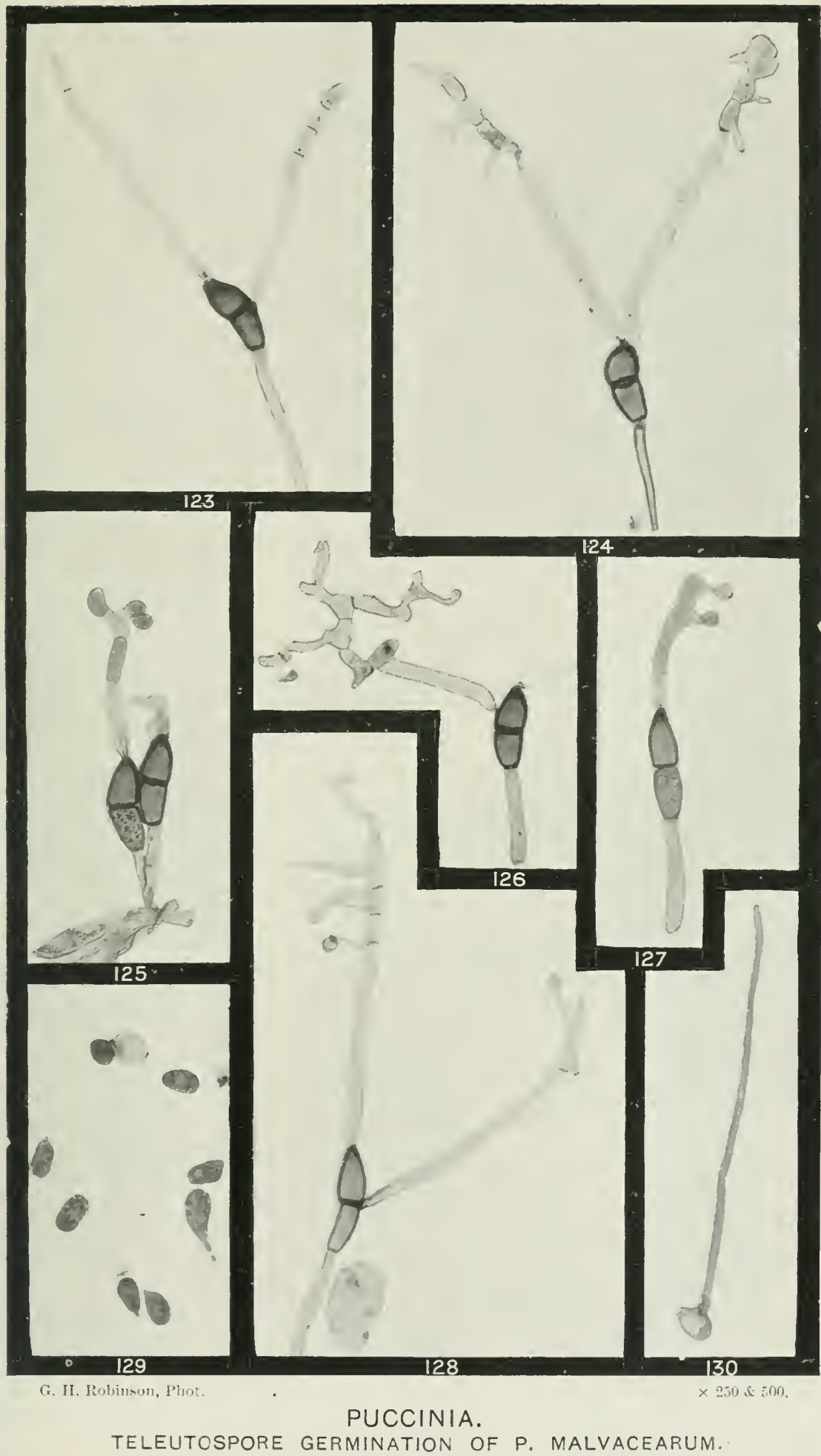





\section{PLATE IVI.}

\section{$($ dil figures $\times 250$.)}

\section{UROMYES.}

lïg.

13r. Group of teleutospores of Lromyces danthoniae on Danthonia semannularis.

132. Teleutospores of $U$. ehrhartae on .Microlaena (Ehrharta) stipoides.

133. Teleutospores of $U$. tenuicutis on Sporobolus indicus.

134. Two one-celled and one two-celled telentospore of $L$. tricorynes on Tricoryne elatior.

135. Teleutospores of $U$. tricorynes on Tricoryne elatior.

136. Uredospores of $U$. thelymitrae on Thelymitra antennifera.

13,- Telentospores of the same.

${ }_{13}$ S. Teleutospores of $\mathcal{L}$. orchidearum on Chiloglottis diphylla, from original type material in National Herbarium.

1.3(). Teleutospores of $l$. microtidis on Micr tis purrifolia from type material from Massee. 


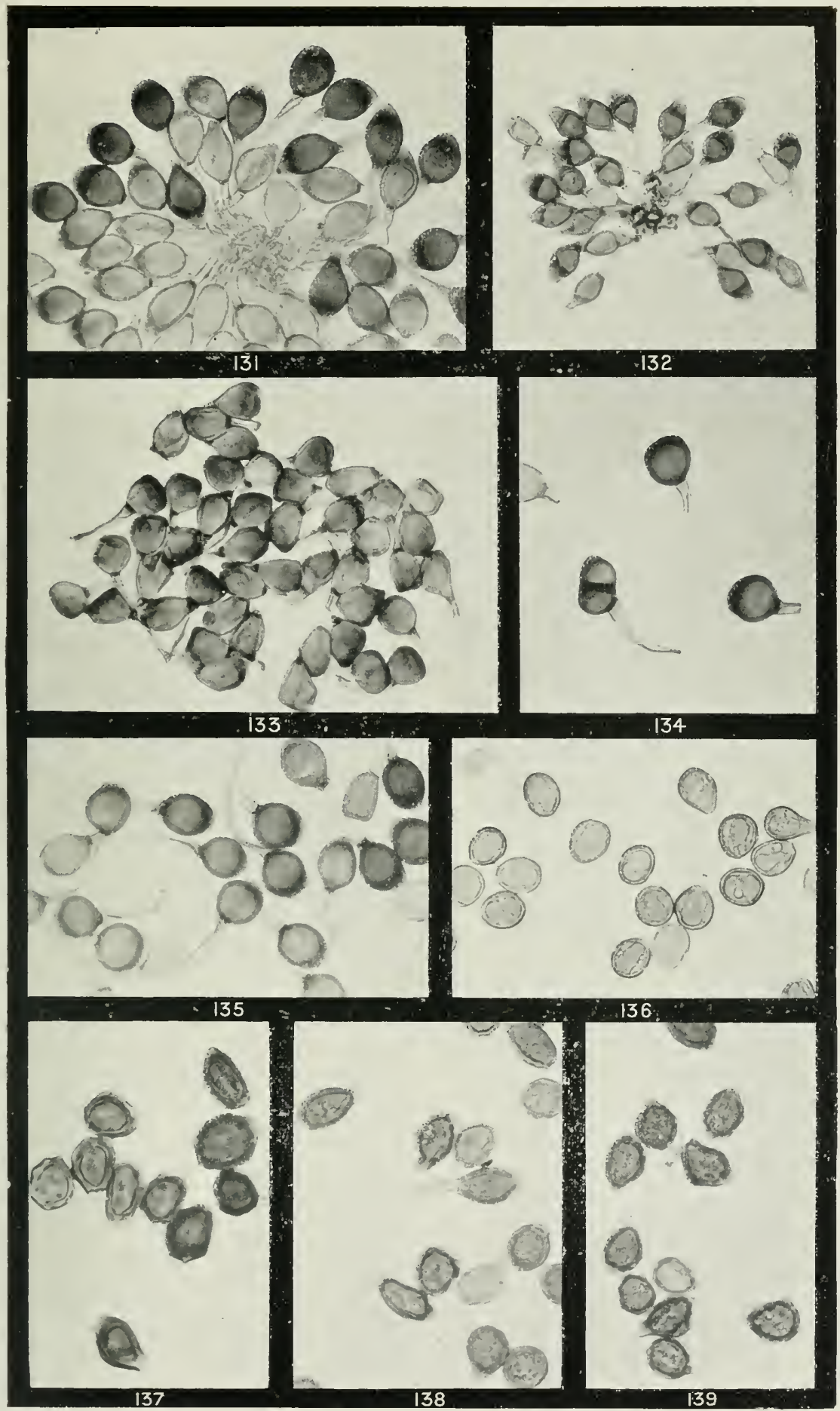

G. H. Rol,inson, Phot.

UROMYCES

GRAMINEÁE, LILIACEAE AND ORCHIDACEAE. 



\section{PLATE XVII.}

(All Figures $\times 250$.)

Fig.

\section{UROMYCES.}

140. Group of teleutospores of Liromyces puccinioides on Selliera radicans.

14. Telentospores of $U$. asperulae on Asperula oligantha.

142. Uredospores and teleutospores of $U$. trifolii on Trifolium repens.

14.3. Uredospores of $U$. hardenbergiae on Hardenbergia monophylla.

144. Teleutospore of the same.

145. Two uredospores of same at top and one teleutospore below.

146. Section of teleutosorus of $U$. atriplicis on Atriplex semibaccata The teleutospores are faintly striate with one prominent germ pore at apex.

147. Two teleutospores of same at left and four uredospores at right.

148. Uredospores of U. betae on Beta vulgaris.

149. Teleutospores of same with prominent hyaline apiculus. 
Plate XVII

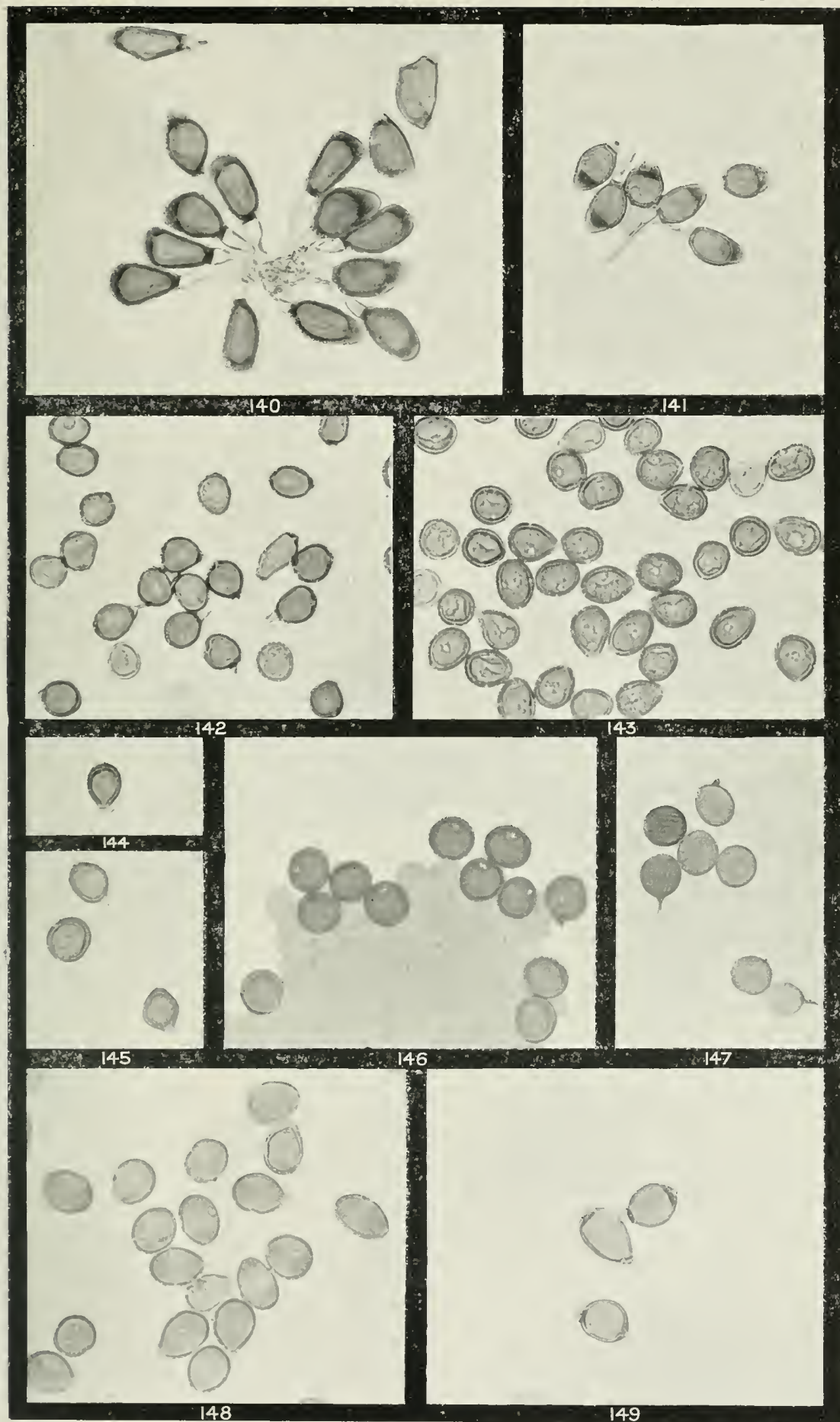

G. II. Robinson, Plot.

UROMYCES.

$\times 50$.

goDdeniaceae, RUBIACEAE, LEguminOsae, AND CHENOPODIACEAE. 




\section{PLATE XVIII.}

\section{(All Figures $\times 250$ unless otherwise statcd.)}

\section{UROMYCES}

Fig.

150. Uredospores of Uromyces polygoni on Polygonum aviculare.

151. Teleutospores of same.

152. Uredospores of $U$. caryophyllinus on Dianthus caryophyllus, with prominent scattered germ pores.

153. Teleutospores and one uredospore of same.

154. Section through leaf of Dianthus carycphyllus, showing uredosorus of $U$. caryophyllinus with two pycnidia of Darluca filum growing upon it, and two young pycnidia on opposite surface of leaf $\quad \ldots \quad \ldots \quad \ldots \quad \times 5^{0}$

155. Uredospores of $U$. vesiculosus on $Z$ yophyllum glancescens.

156. Teleutospores of same.

157. Two-celled teleutospore of same. 


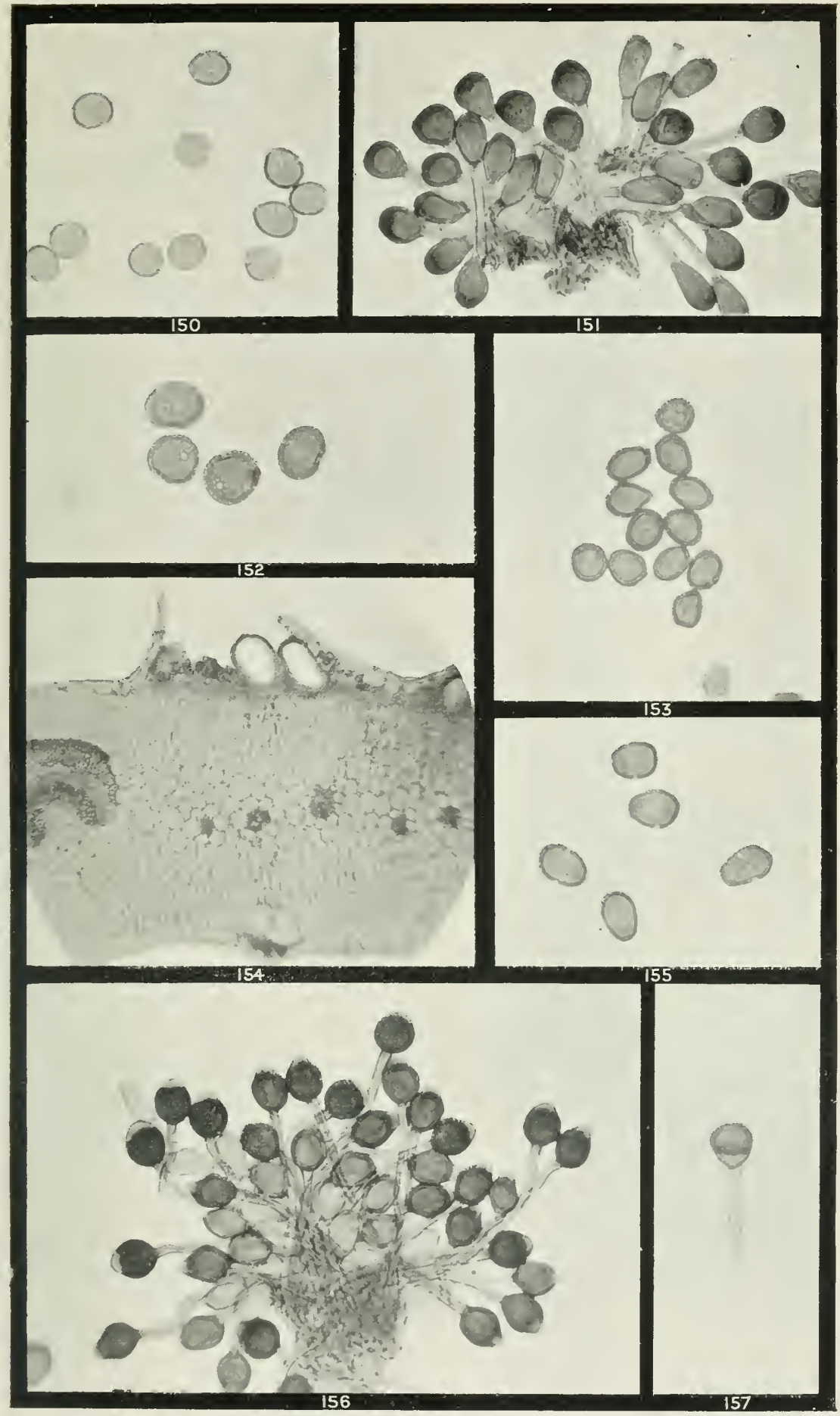

G. H. Robinson, ['hot.

$\times 50 \leqslant 230$.

UROMYCES.

POLYGONACEAE, CARYOPHYLLACEAE, AND ZYGOPHYLLACEAE. 




\section{PLATE XIX.}

\section{(All Figures $\times 250$ unless otherwise stated.)}

\section{UROMYCES.}

Fig.

158. Teleutospores, seen from above, of Uromyces fusisporus on Acacia neriifolia. 159. Side view of same.

16o. Uredospores of same, with pronounced apiculus and equatorial band of germ pores.

\section{UROMYCLADIUM.}

16r. Teleutospores of Uromycladium simplex on Acacia pycnantha, part of the pedicel being still attached with the remains of the vesicle. (Stained).

162. Young teleutospores of the same showing the vesicles still attached. (Stained).

163. Portion of thake of gummy material on leaf of Acacia pycnantha, in which numerous teleutospores of $U$. simplex are embedded, nearly all germinating and producing sporidiola.

164. Germinating sporidiolum of same. (Stained) $\quad \ldots \quad \ldots \quad \ldots \quad \ldots \quad \times 500$

165. Uredospores of same, being very similar to those of Uromyces fusisporus, fig. 160 , though somewhat shorter and broader and possessing more germ pores. 
PHAt IIX.

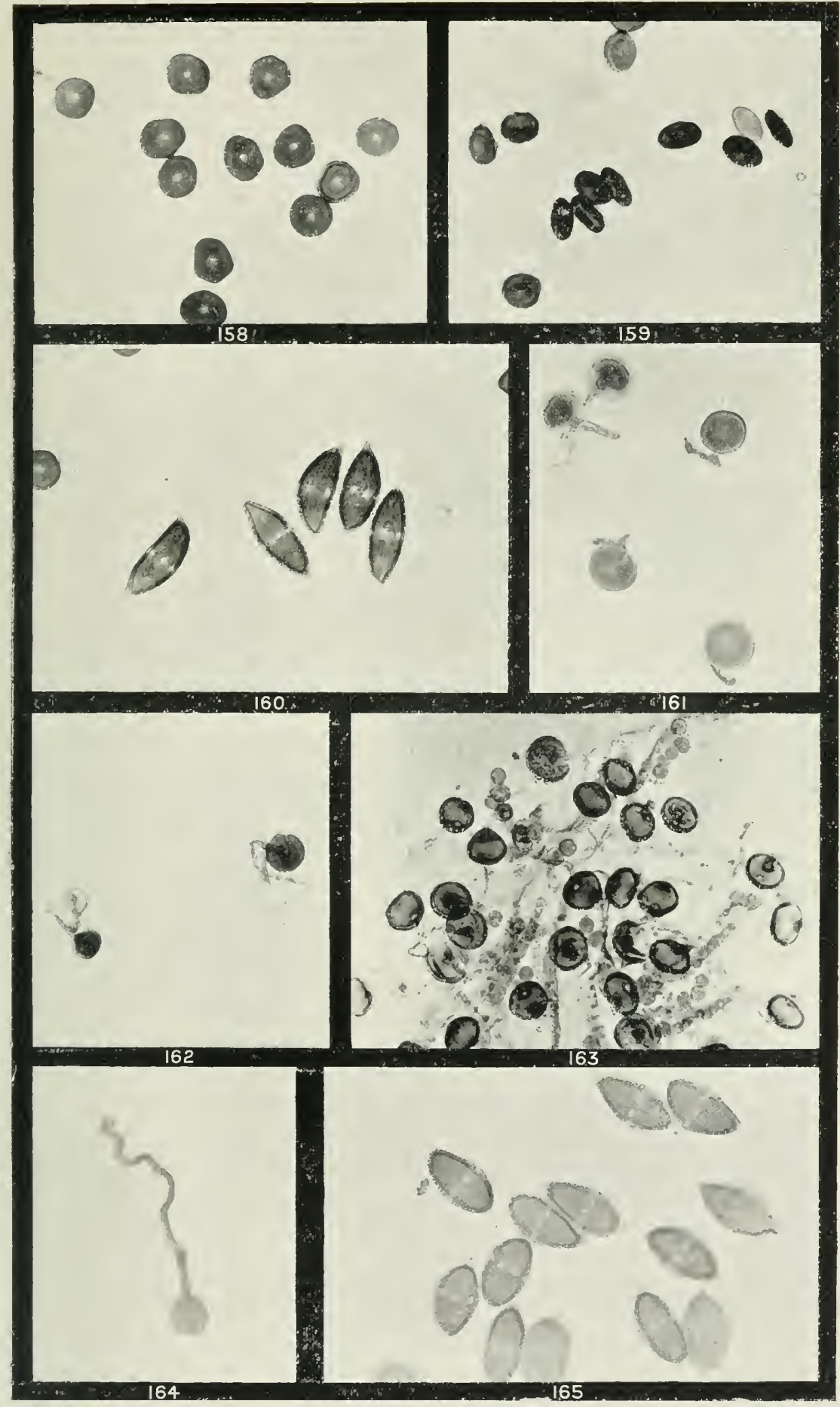

G. H. Robinson, Phot.

UROMYCES AND UROMYCLADIUM. LEGUMINOSAE-ACACIA. 



\section{PLATE XX.}

\section{(All Figures $\times 250$.)}

\section{UROMYCIADITII MARITIMUM.}

Fig.

165. Section of teleutosorus of $U$. maritimum on Acacia longifolia, the mature teleutospores having the remains of the vesicles attached to the pedicels.

16-. Group of mature teleutospores of the same.

108. Formation of teleutospore head; a young cluster, showing the two young spores at the apex, and the lateral vesicle below the septum. (Stained.)

r69, r7o. Sinilar heads, more advanced. (Stained.)

17x. Mature telentospore head, two telentospores above and one resicle below.

172. Abnormal development of head of teleutospores, the lateral vesicle beingr replaced by a true spore, and a septam placed in the stalk beneath it. In the normal hearl of two spores ancl a vesicle there is no septum below the vesicle.

r73. Teleutospores germinating while still attached to each other: two sporirliola on one promycelium, others so far undeveloped.

I74. Ureilospores with prominent equatorial germ pores and serraterl epispore. thickened and dentate at apex.

:-5. One-celled spores (mesospores ?), occasionally found intermixed with uredospores.

1;6. Inmature two-celled colourless spore, of same character, from ureilosorus. (Stained). 
PLATE XI

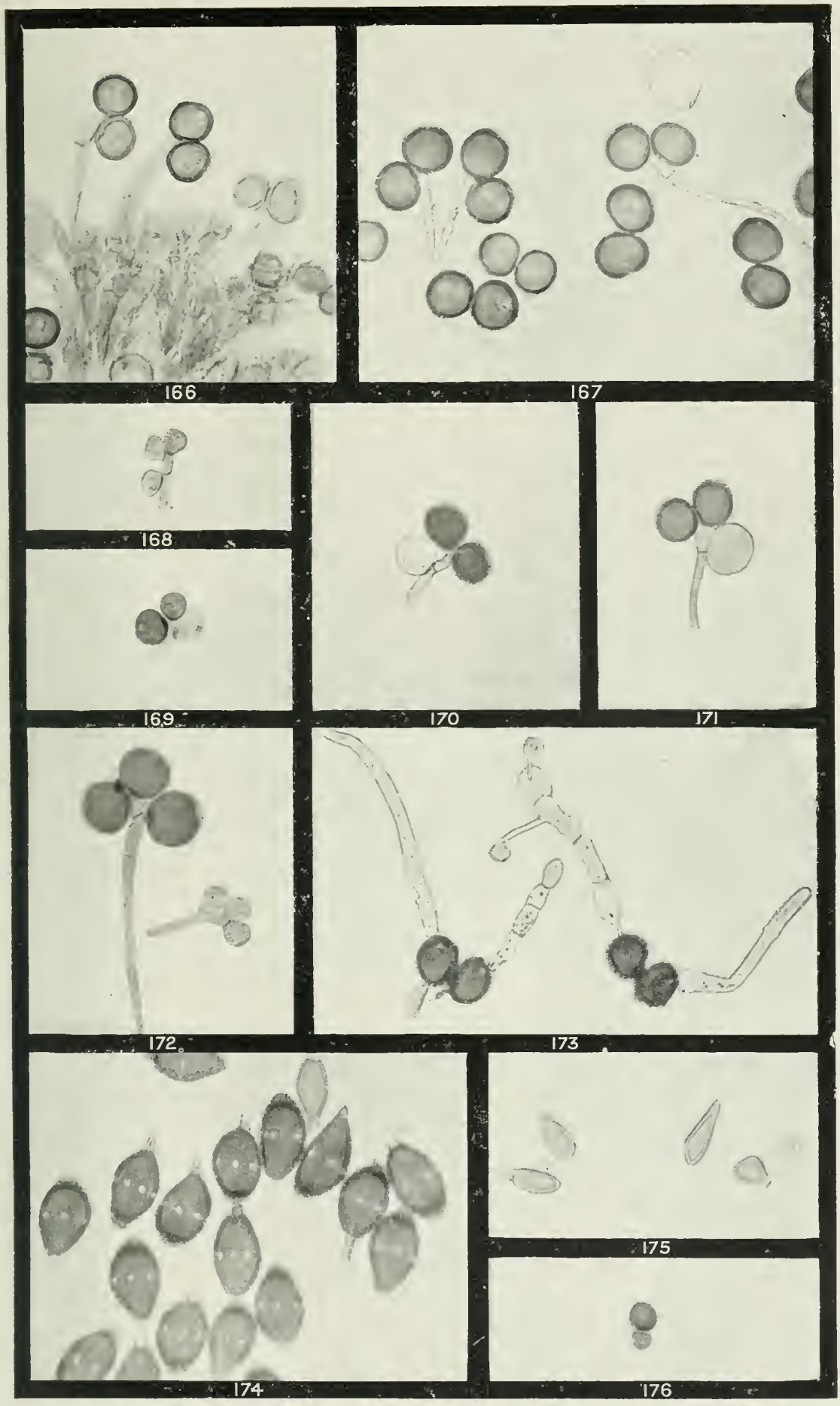

(i. 11. Rohinson, thot.

UROMYCLADIUM MARITIMUM. LEGUMINOSAE-ACACIA LONGIFOLIA. 

K 2 


\title{
PLATE XXI.
}

\author{
(All Figures $\times 500$.
}

Fig.

\section{UROMICLADIUM MARITIMUM.}

177. Two young teleutospore heads, arising from common stalk, the one on the right being younger than that on the left, and both intermediate between $\mathrm{T}^{2}$ and $\mathrm{T}^{3}$ in next figure. (Stained.)

17S. Main stem, bearing teleutospore heads in various stages of development; $T$, filament with two septa, the upper two segments destined to become teleutospores, the lowermost a vesicle; T1, similar filament, somewhat more advanced, the vesicle beginning to push out from the lowermost segment; $T$, similar filanent still more advanced, the uppermost cell distending, in the next growth is taking place at the side, and in the lowest the vesicle has attained considerable development; $\mathrm{T}^{3}$, nearly mature head, with two dark teleutospores; $\mathrm{U}$, basidium of a detached uredospore. (Stained.)

17g. Abnormal teleutospore hear of three teleutospores, a septum beneath the lowermost.

180. Normal teleutospore head, with two teleutospores above septum and a resicle below, there being no septum below the vesicle.

I $\{$ I. Teleutospore head in which the vesicle is apparently at the apex, but this is probably due to displacement in mounting.

$1 \$_{2}, 183$. Normal teleutospore heads.

1 $\$_{4}$. Uredospores with prominent germ pores, serrated epispore thickened and dent ate at apex. 
PLATF: XXI,

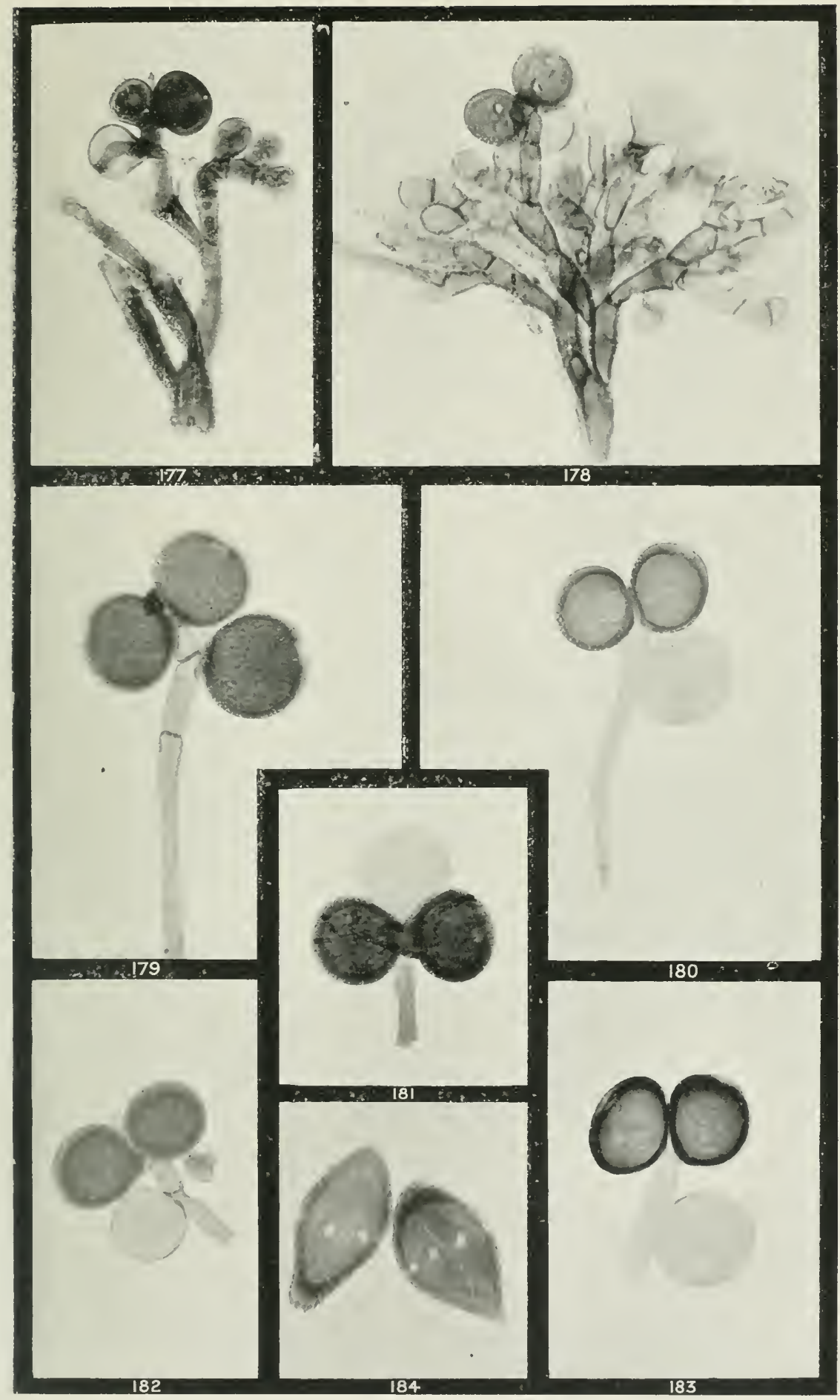

(i. H. Iivbin-un, l'hot.

UROMYCLADIUM MARITIMUM. LEGUMINOSAE-ACACIA LONGIFOLIA. 



\section{PIATE XXII. '}

(All Figures $\times 250$ unless otherwise siated.)

\section{UROMYCI.ADILM.}

Fig.

$1 \&_{5}, 186$. Tredospores of $\%$. robinsoni on Acacia melanoxylon. The solitary large smooth-willed spore (?) in Fig. 186 is difficult of interpretation.

187. Young and mature teleutospores of same, with and without attacherl resicles. (Stained.)

188. Mature teleutospores of same, with resicles.

18. Mature telentospore of same germinating, the sporidiola just abont to be formert. (Stained.)

100, 191 , 102. Successive stagres in the development of a teleutospore head of $L^{\prime}$. tepperianum on Acacia salicina, the striaterl epispure being clearly shown in

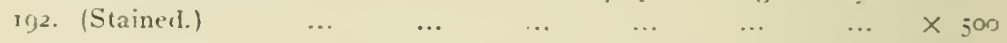

203. Single teleutospore of same, seen from above, and showing striated mark $\begin{array}{lllllllll}\text { ings } \ldots & \ldots & \ldots & \ldots & \ldots & \ldots & \ldots & \ldots & \times \\ & & \end{array}$

194. Nature telentospore liead of same. (The markings are inclistinct on account of poor condition of material) $\quad \ldots \quad \ldots \quad \ldots \quad \ldots \quad \ldots \quad \ldots$ jor,

105. Detacherl teleutospores of sime. 


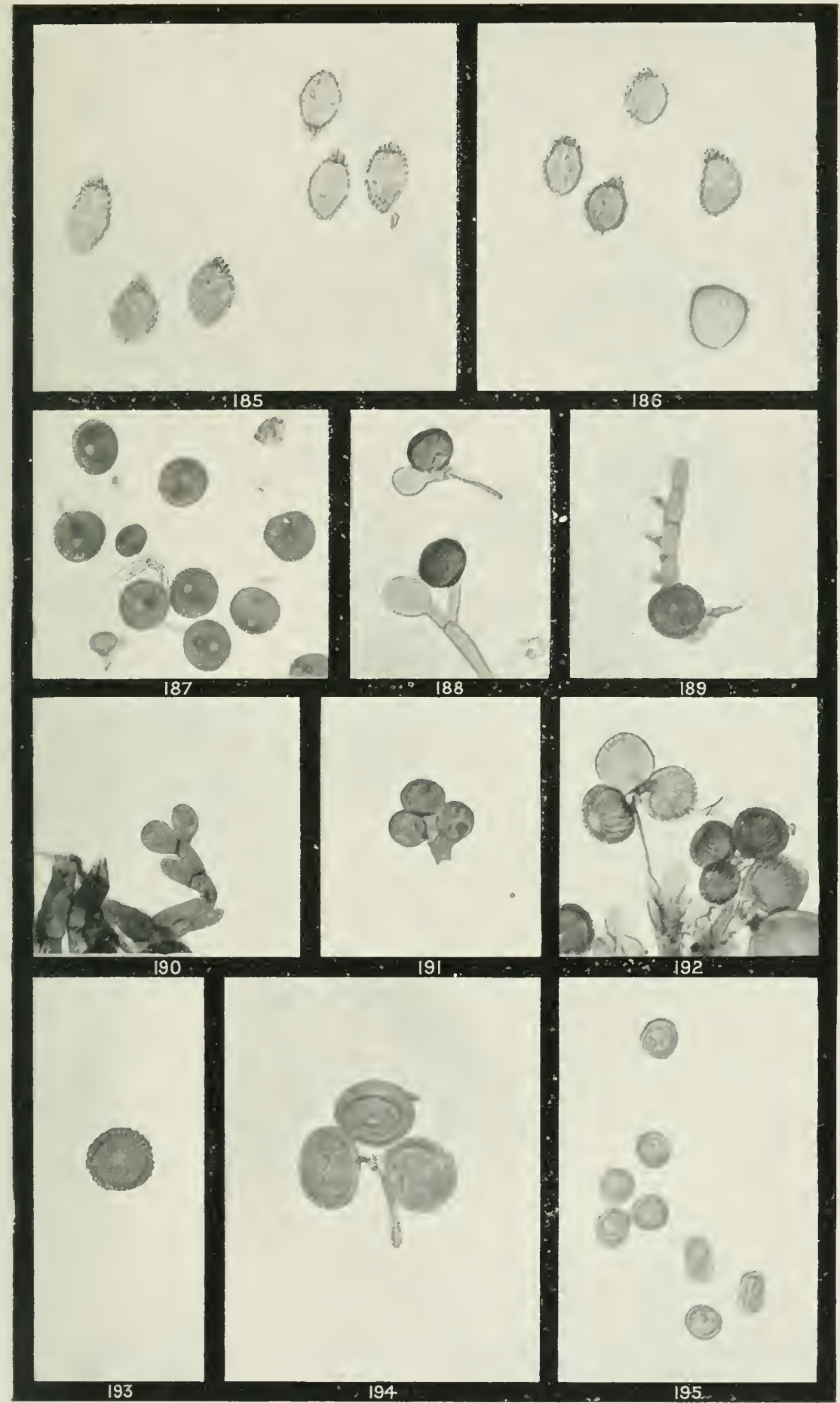

c. H liobin-un, l'tut.

$\times 250 \& \varepsilon$ \&

UROMYCLADIUM.

LEGUMINOSAE-ACACIA. 




\section{PLATE XXIII.}

\section{(All Figures $\times 250$ unless otherwisc statcd.)}

Fig.

\section{I'ROMYCIADIUM.}

Jif. Uredospores of $L$. notabile on Acacia nctabilis. Original type material of Uredo notabilis Ludw. (Somewhat swollen by lengthened treatment with caustic potash.)

197. Uredospores of the same, showing the net-iike surface markings. $\ldots \quad \times 500$

Ig $\delta$. Compound stem, with basidia and uredospores of the same.

199. Compound structure from uredosorus of same, being probably comnencement

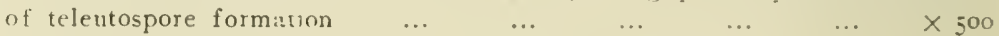

2(r). Urerlosjores of $U$. notabile on Acacia dealbata.

201,202 . Lredospores of the same, showing the net-like surface markings... $\times 500$ 203. Portion of spermogonium of the same, with basidia bearing spermatia in $\begin{array}{llllllll}\text { chains. (Stained) } & \ldots & \ldots & \ldots & \ldots & \ldots & \times 500\end{array}$

204. Cluster of three immature spores of the same, attached to their stalk. (Stained.)

205. Mass of mature teleutospores of the same, separated from each other, from Acacia decurrens.

206. Mass of scarcely mature telentospores, separateil from each other, of $L$. teppcrianum, on Acacia melanoxylon, from Cheltenham, showing striated markings on the surface. These are considerably sma!ler than the average. 


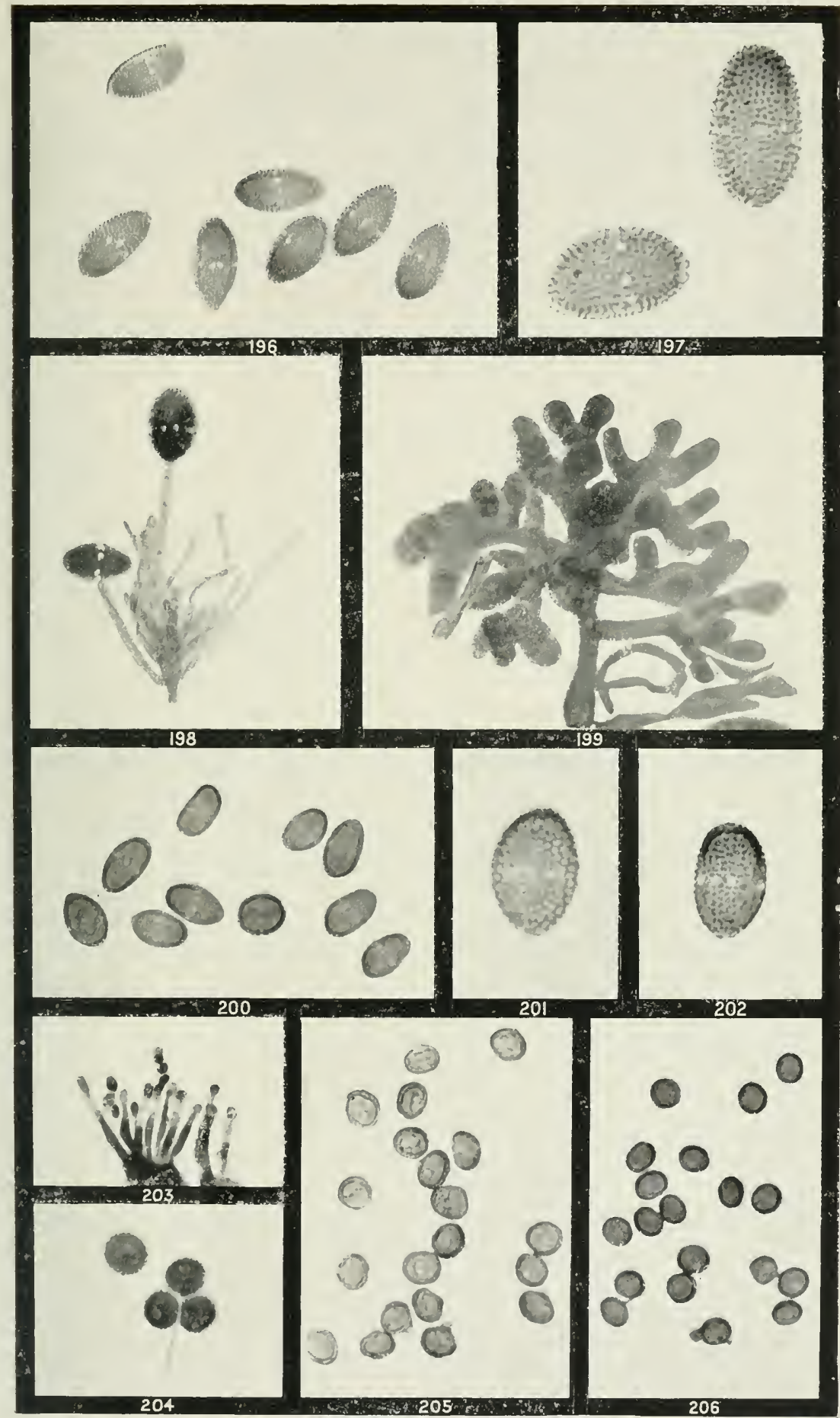

(i. H Rubinson, I'hot. 




\section{PLATE XYIV.}

(All Figures $\times 250$ unless otherwise statcd.)

Fig.

UROMYCLADITII.

207. Telentospores of 1 . Bisporum, on Acacia dealbata, one cluster of two showing the common staik.

208. Telentospores of the same.

20y. Uredospores of $U$. alfinum, on Acacia dealbata.

$210,21 \pi$. Teleutospores of the same.

212. Five uredospores of $U$. alpinum on Acacia dallachiana, mised with teleutospores and one mesospore (M).

213. 214. Successive stages in the development of teleutospore clusters of the same. (Stained.)

215. Croup of telentospores of the sime.

216. Section of leaf of Acacia longifolia attacked by $U$. maritimum, the uredosori being at the margin of the inflater tubercle, and the spernogonia in the $\begin{array}{llllllllll}\text { centre } & \ldots & \ldots & \ldots & \ldots & \ldots & \ldots & \ldots & \times 30\end{array}$

217. Ureslospore of $U$. maritimum attacked by some Hyphomycete, which has gained access to the interior of the spore and grown within it preparatory to forming the long septate threads which have piercel the wall near the gern pores. 
PLATE XNIV.

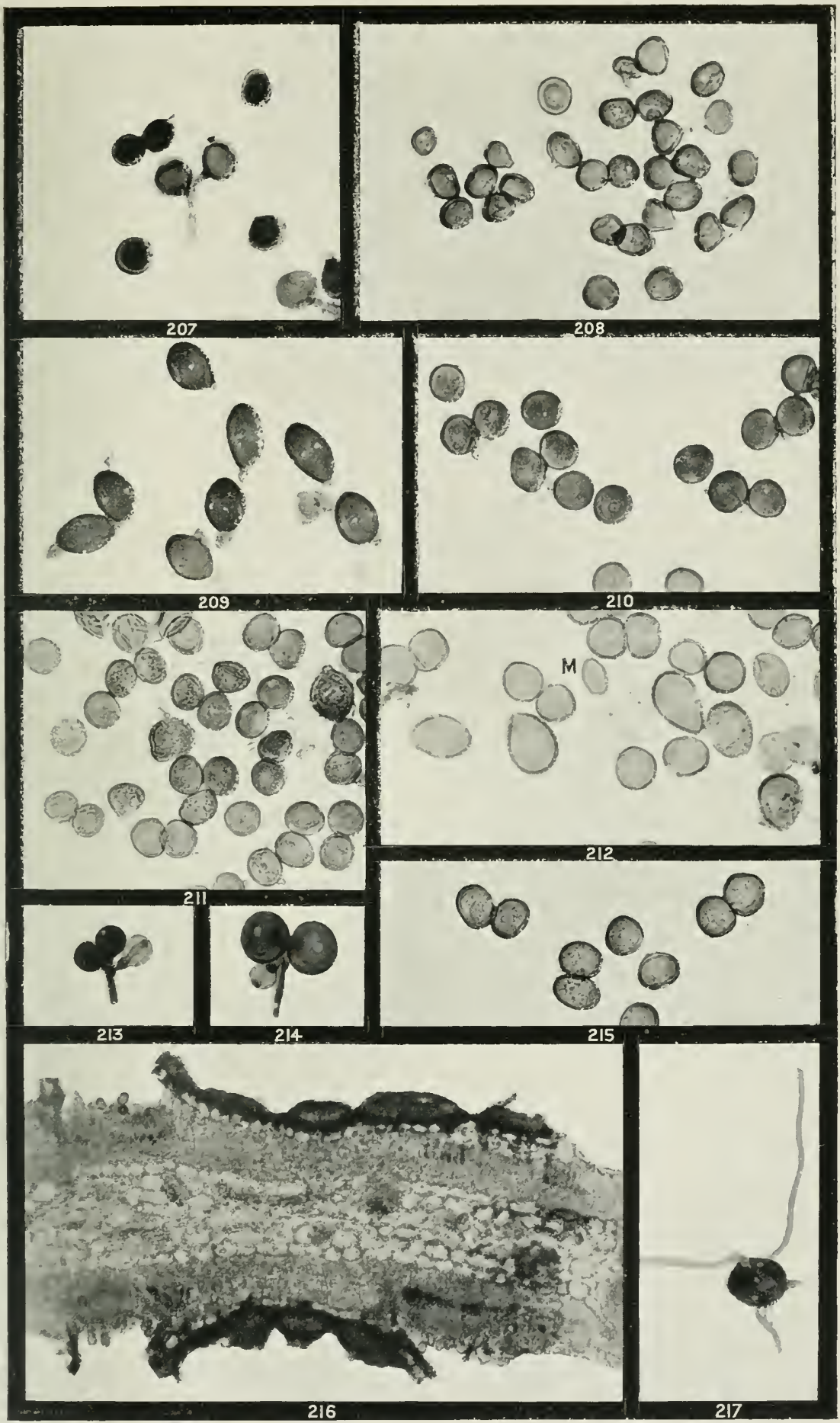

G. H. Robinnon, Phot

$\times 20 \lll 250$

UROMYCLADIUM.

LEGUMINOSAE-ACACIA. 




\section{PLATE XXV.}

(All Figures $\times 250$ unless otherwise statcd.:

\section{UROMYCES PHYLIODIORUM.}

Fig.

21. Two uredospores of $U$. phyllodionum (B. and Br.) McAlp., on Acacia sp. from Queensland. (Type material of Melampsora phyllodiorum B. and Br., from Herbarium of F. M. Bailey, Government Botanist, Queensland.)

zig. One of the very sparse digitate teleutospores present in the same material.

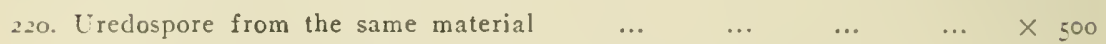

(All the above from old and much faded material.)

2.1 2. 22. Uredospores of $U$. phyllodiorum, on Acacia sp. from Queensland. (Type material of Uromyces phyllodiae Ccoke ind Mass., these uredospores being (lescribed as teleutospores. From Herbarium of F. M. Bailey.)

223,224 . Two of the few digitate teleutospores present in the same material.

(Material of above old and much faded.)

25. Uredospores of $U$. phyllodiorum on Acacia dallachiana, from Bright, Vicioria.

226. Two of the same, more highly magnified, to show surface markings $\ldots \times 500$

227,228 . Teleutospores from the same material, some beginning to germinate. (Stained.)

Vi)TE. - T he markings of the uredospores are arrangred in distinct lines, and are not net-like as in Uromycladumn notabile. 
Pint IIV.

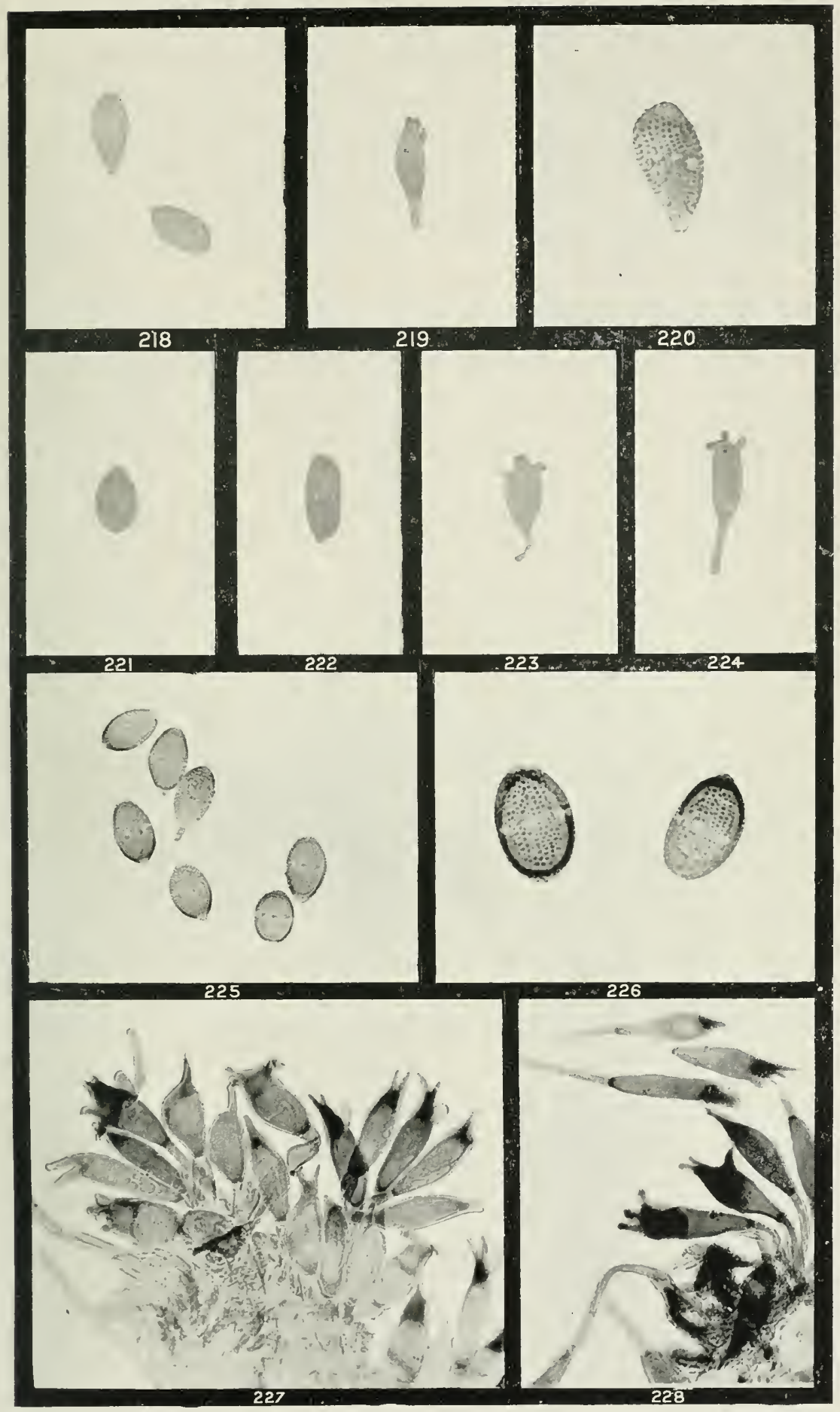

G. H. Robinson, Phot. 




\section{PLATE XXVI.}

(All Figures $\times 250$ unless othervise stated.)

PIIR.IGMIDIUM, MEIAMPSORA.

Fig.

229. Aecidiospores of Phr. subcerticium on Rosa rubignosa.

230. U'redospores of same.

231, 232. Teleutospores of sime.

233. Twig of Rosa rubiginosa, the uppermost shoot of which is swollen and distorted by the aecidia of Phr. subcorticium. $\quad \ldots \quad \ldots \quad \ldots$ nat. size

234, 235. Teleutospores and uredospore of $P$. barnardi on Rubus parvifolius, two germ pores being often seen on one face of each cell.

236. Teleutospores, closely attached to each other, of Melampsora lini on Linum usitatissimum. 
PJ.ITF NXI

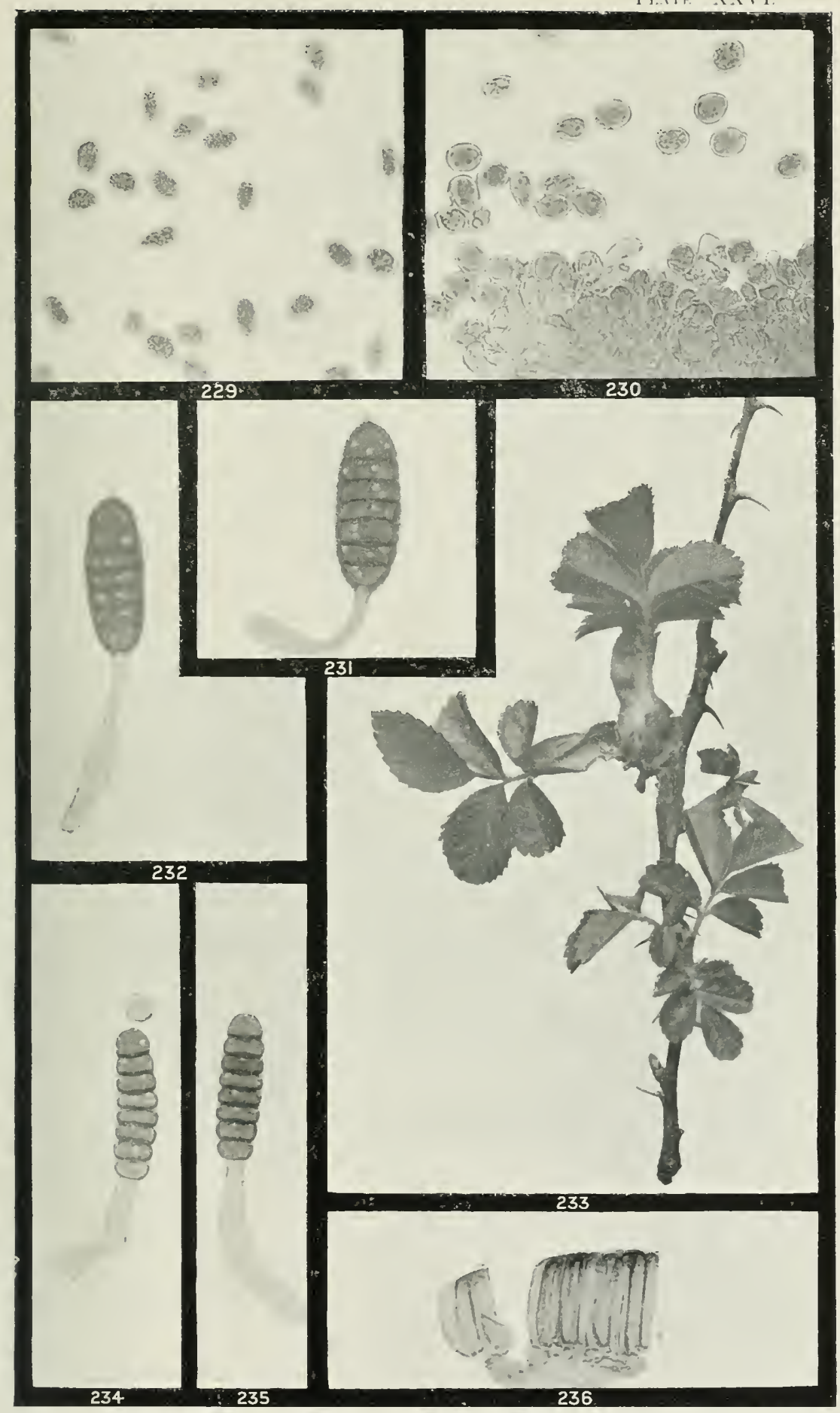

(; 11. Robinson, Phot.

PHRAGMIDIUM AND MELAMPSORA. ROSACEAE AND LINACEAE. 




\section{PLATE XXVII.}

\section{AECIDIU.M.}

Fig.

237. Young seedling of Platylobium formosum, with Aecidium platylobii on leaves and leaf stalks

$\begin{array}{lllllll}\ldots & \ldots & \ldots & \ldots & \ldots & \text { nat. size }\end{array}$

238. Fruiting branch of the same, with aecidial cups on the pods

... nat. size

239). Section through cups of Aeciaium eburneum on pod of Bossiaea hetero. $\begin{array}{lllllllllll}\text { phylla } & \ldots & \ldots & \ldots & \ldots & \ldots & \ldots & \ldots & \times & \ldots\end{array}$

240. Section of aecidial cup of Puccinia erechtitis on Erechtites quadridentata $\times 50$ 


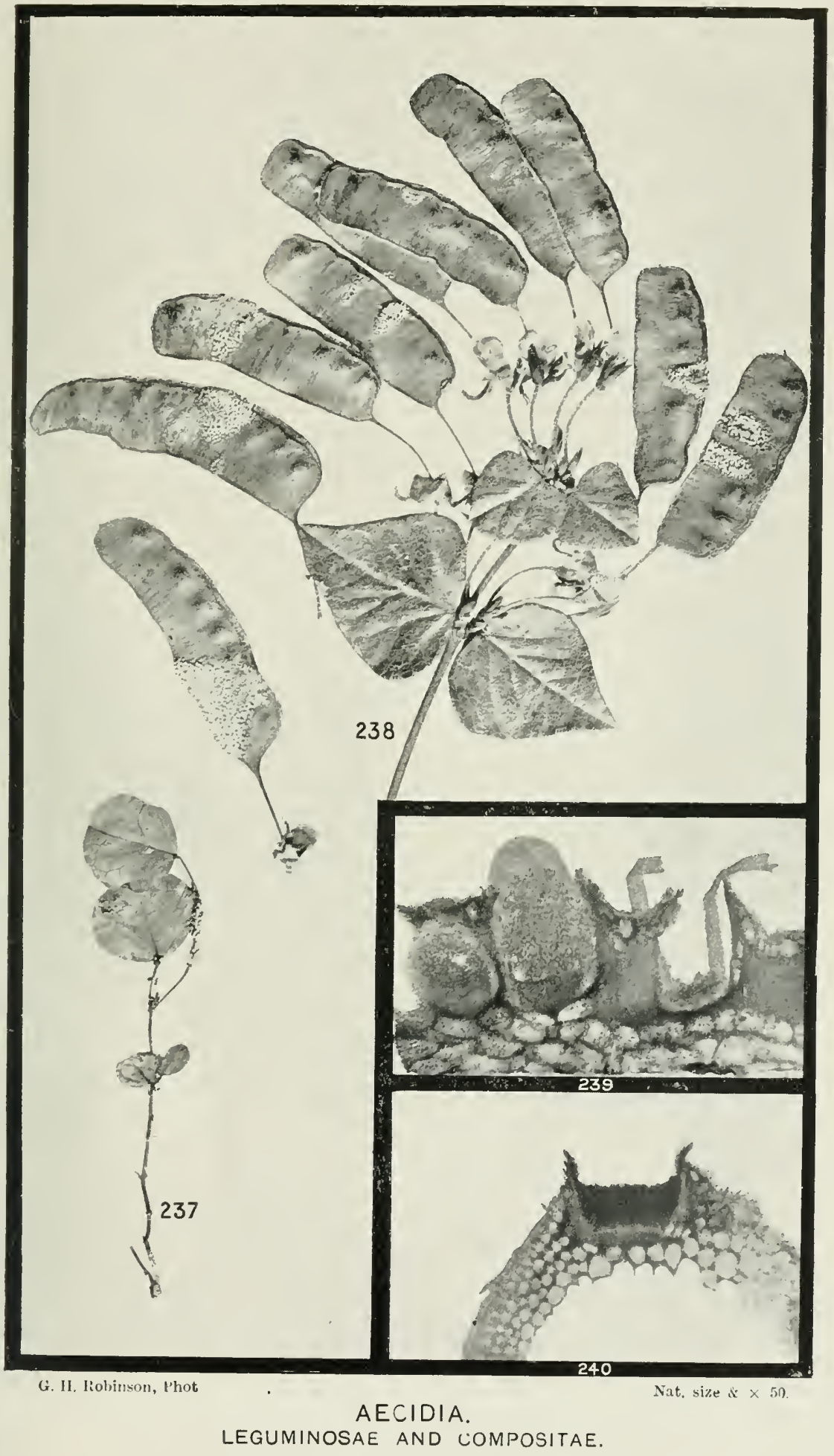






\title{
PLATE XXVIII.
}

\author{
(All Figure's, $\times 250)$.
}

\section{UREDO}

Fig.

241. Spore of Uredo scirpz-nodosi or Scrrtus nodosus.

242. Uredospores of Puccinia stylidii on Stylidium graminifolium

243. U. bidentis on Bidens pilosa from Queensland.

244. U. bidentis on Bidens pilcsa from Brazil. (Sydow, Uredineen, 1647.)

245. U. spyridii on Spyridium parvifolium.

246. U. bossiaeae on Bossiaca prostrata.

247. U. pallidula on Cassia sp.

${ }_{24} \mathrm{~S}$. Uredospores of Uromyces scleranthi on Sclcranthus dianair.

249. Uredospures of Puccinia oleariae on Olearia argopizylla, epispore finely striate. 
PLATE XITIII

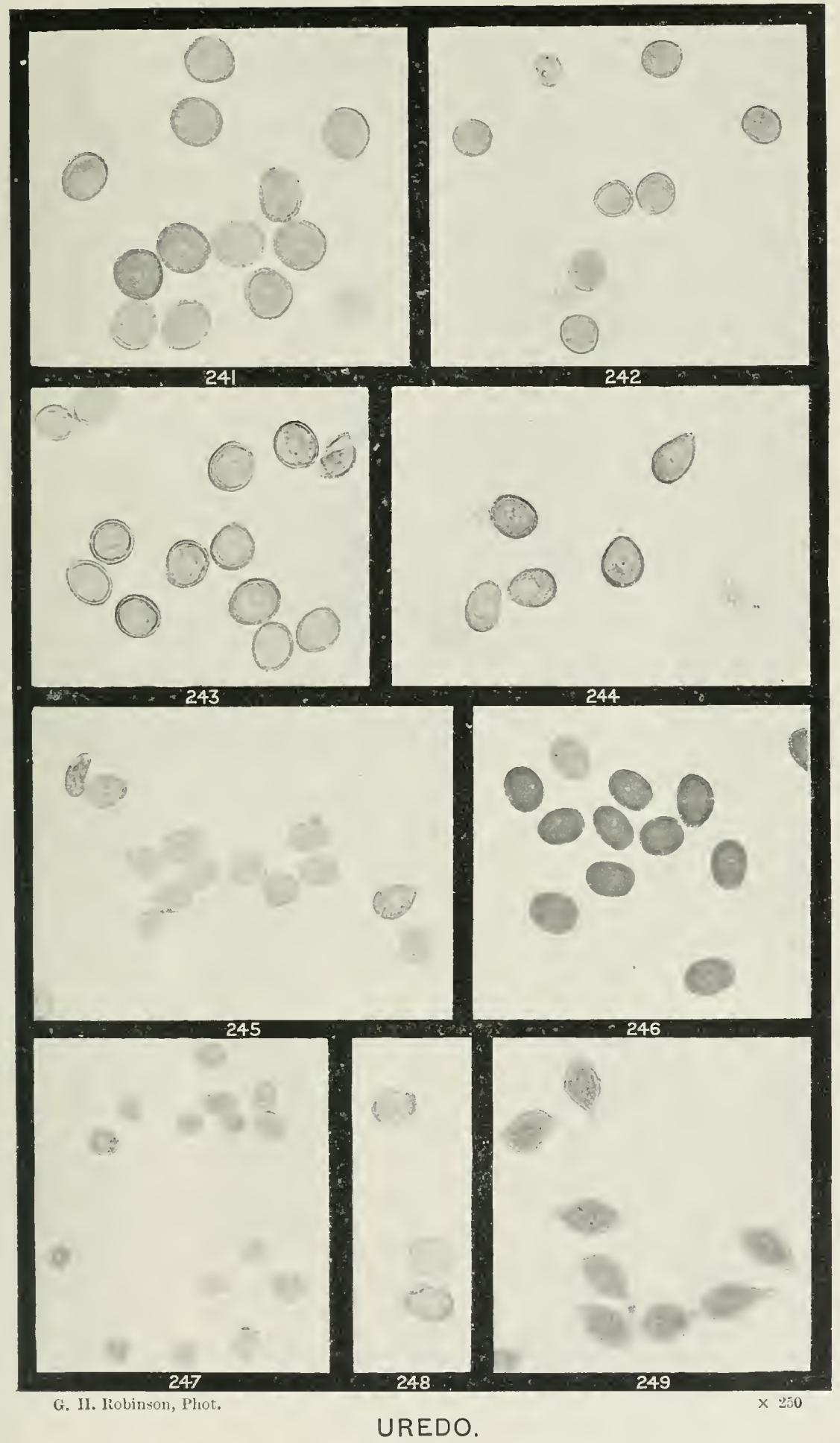





\section{PLATE XXIX.}

\section{(All Figures $\times 250$.}

\section{ADDENDA TU PUCCINIA.}

Fig.

250. Uredospores and teleutospores of Puccinia menthae on Mcntha pulegium.

251. Uredospores of P. chrysanthemi on Chrysanthemum indicum, from New South Wales.

252. Isolated teleutospore found associated with the same.

253. Uredospores and teleutospores of P. chrysanthemi on Chrysanthcmum cult., Japan. (Herbarium A. Jdeta.)

254. Abnormal teleutospore associated with uredospores and teleutospores of same.

255. Mesospore from same.

256. Group of teleutospores and mesospores of P. podolefidis on Podolepis longipedata.

257. Teleutospore from same, with hyaline gern pore at each side of apex of upper cell.

${ }_{25}$ S. Teleutospores of $P$. operculariae on Ofercularia :aria. 
Plate XXIX.

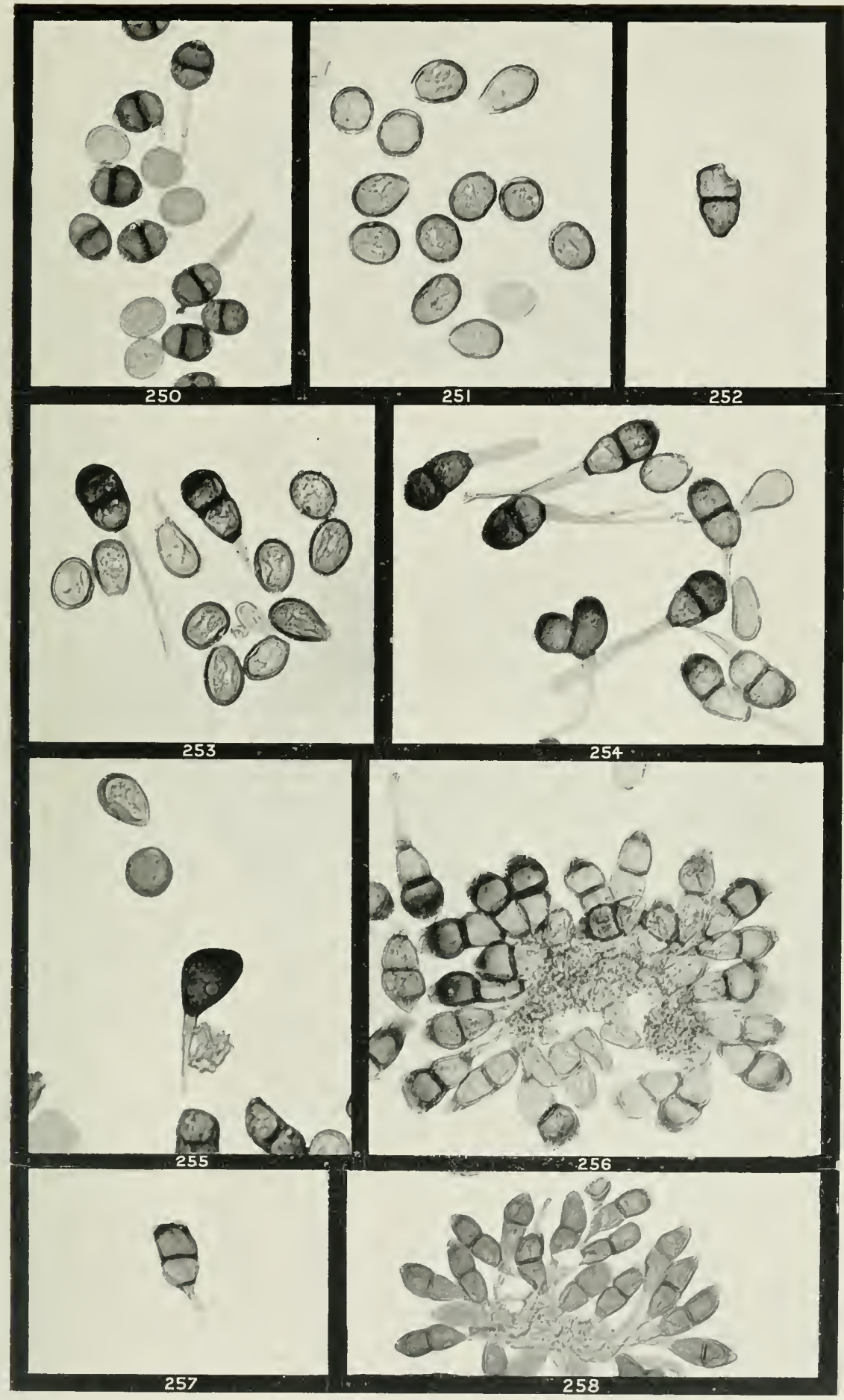

(i. II. Pohinson, Phot.

PUCCINIA.

LABIATAE, COMPOSITAE AND RUBIACEAE. 


PLATE XXX.

(All Figure's $\times 25^{\circ}$.)

\section{ADDENDA TO PUCCINIA AND UREDO.}

likg.

259. Uredospores of Puccinia cacao on Rollboellia compressa 26ro. Uredospores and one teleutospore of same.

26r. Uredospores of $P$. Lolii avenae on Avena sativa, germinating in water after 24 hours. (Stained.)

262. 'Tredospores of $P$. subnitens on Distichlis maritima.

263,264 . Teleutospores from same.

265. Teleutospores of $F$. hibbertiae on Itibbertia sericea.

266. Teleutospores of $P$. cruciferaz on an undetermined Crucifer. From type material referres to Aecidium barbareas DC., at Kew.

26-. L'redo rhagodiae on L'hagodia billardieri. 
Plate XXX.

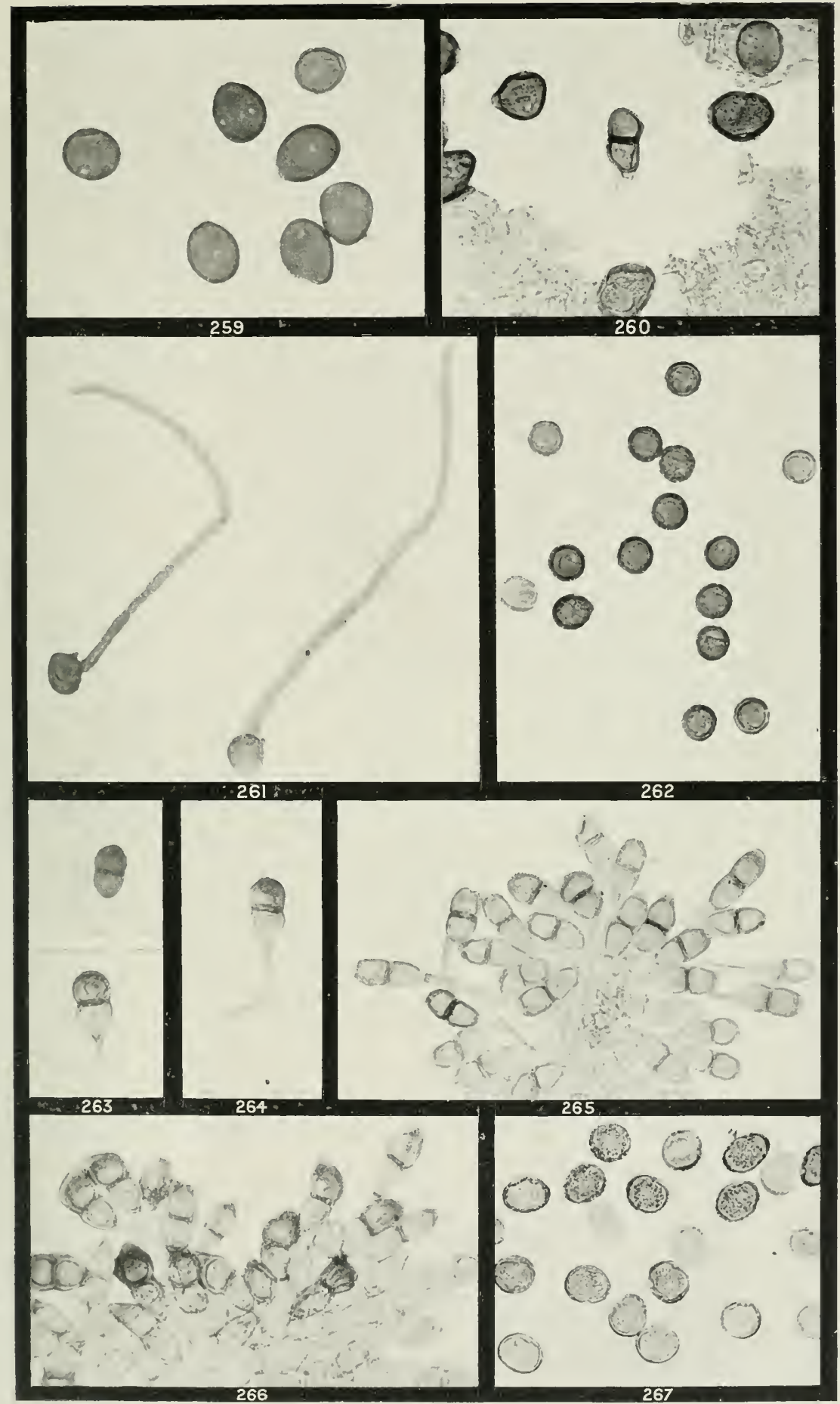

G. II. Robinson, Phot.

PUCCINIA AND UREDO. 




\section{PLATE XIXI.}

(All Figures $\times 250$ unless otherwise stated.)

\section{ADDENDA TO PCCCINIA AND PHRAGMIDICM.}

Fig.

265. Leaf of Loranthus celastroides, showing uredosori and teleutosori of Puccinia $\begin{array}{lllllllll}\text { loranthicola } & \ldots & \ldots & \ldots & \ldots & \ldots & \ldots & \ldots & \text { nat. size }\end{array}$

20g. Teleutospores from same.

2;0. Uredospores from síme.

271. Leaf of Loranthus celastroides, with aecidia of same $\quad \ldots \quad \ldots \quad \ldots$ n.t. size 2;2. Teleutospores of Phragmidium longissimum.

a. Four and five celled spores, before germination.

$b$. Spores commencing to germinate, with one germ tube divided by a septum.

c. Spore cell, giving rise to four-celled promycelium, with loose sporidiola around it.

The material was fourteen years old, and although there were plenty of sporidiola, none were found attached to the pronycelia.

Notr.-Figs. $272, a, b, c$, from drawings. 
Plate NXXI.

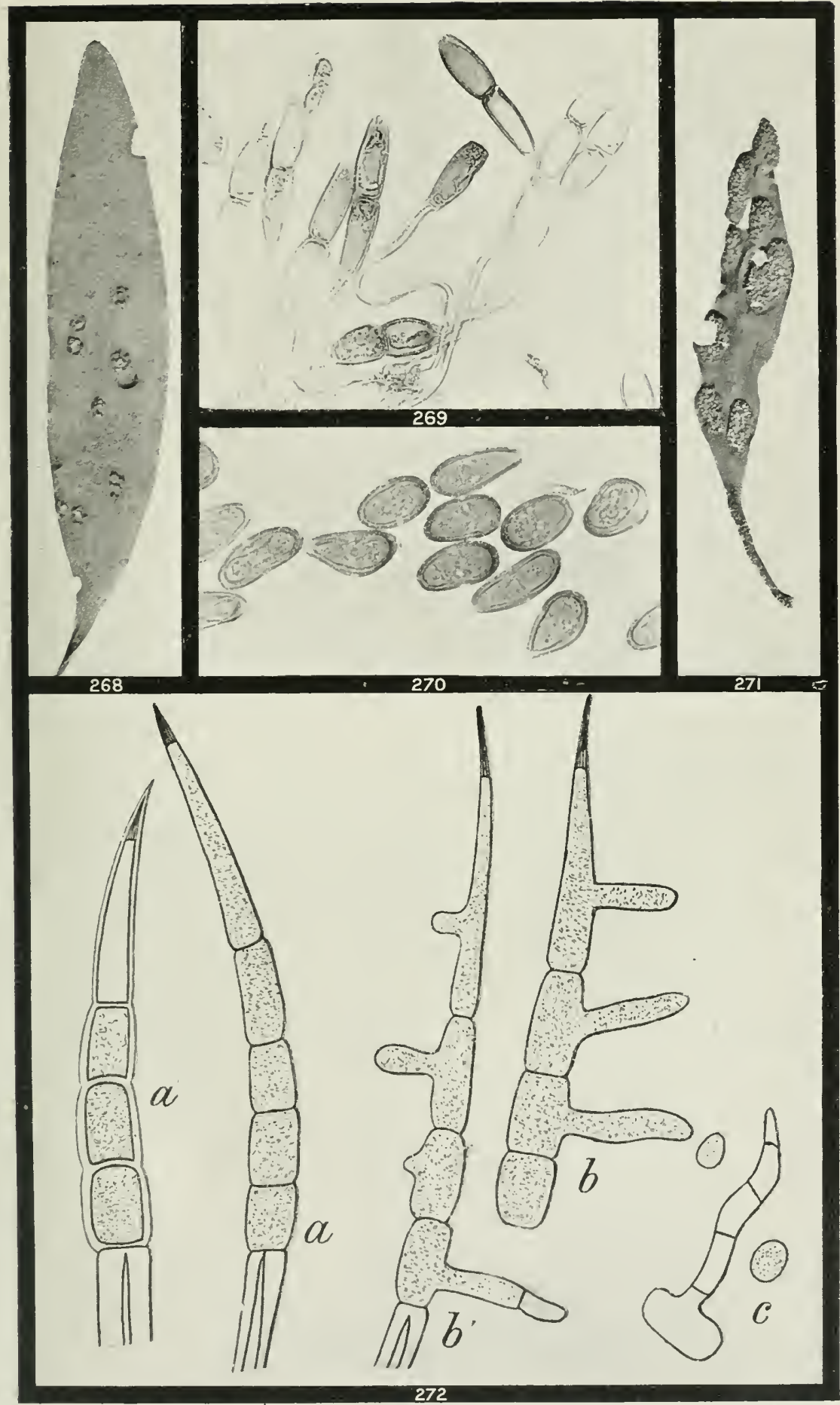

G. H. Robinson, Phot,

PUCCINIA AND PHRAGMIDIUM.

LORANTHACEAE AND ROSACEAE. 



\section{I'LATE XIXII.}

\section{UROMYCLADIUM}

Fig.

273. Leaves of Acacia longifolia, with the tuberculate spermogonial sori of C'romy$\begin{array}{llllllll}\text { cladium maritimum } & \ldots & \ldots & \ldots & \ldots & \ldots & \text { nat. size }\end{array}$

274. Leaves of Acacia melanoxylon, the upper with tuberculate spermogonial sori, and the lower with minute pulverulent sori, loth of $U$. robinsoni... nat. size 275. Leaf of Acacia pycnantha, with the minute powdery sori of $U$. simplex. nat. size 
Piate IXXIT.

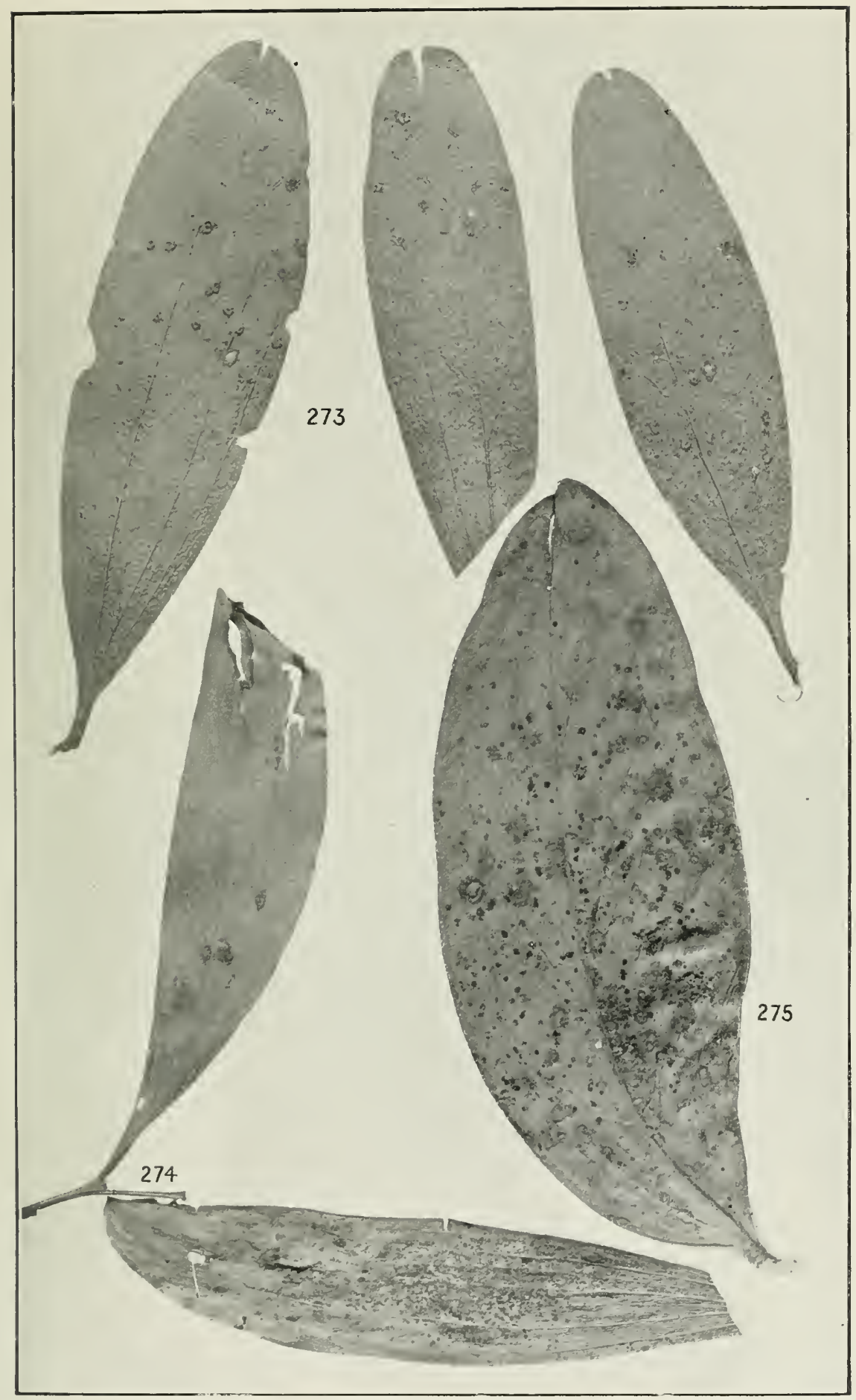

li. H. Kobinson, Phot.

UROMYCLADIUM.

U. MARITIMUM, U. ROBINSONI, AND U. SIMPLEX ON ACACIA. 


PLATE XXX̃II.

LROMICIADITM BISPORLM.

Fig.

$2-6$. Sori of $L^{\prime}$. bisporum on stems and leaf stalks of Acacia dealbata ... nat. size.

2ii. Sori on fruits

nat. size 


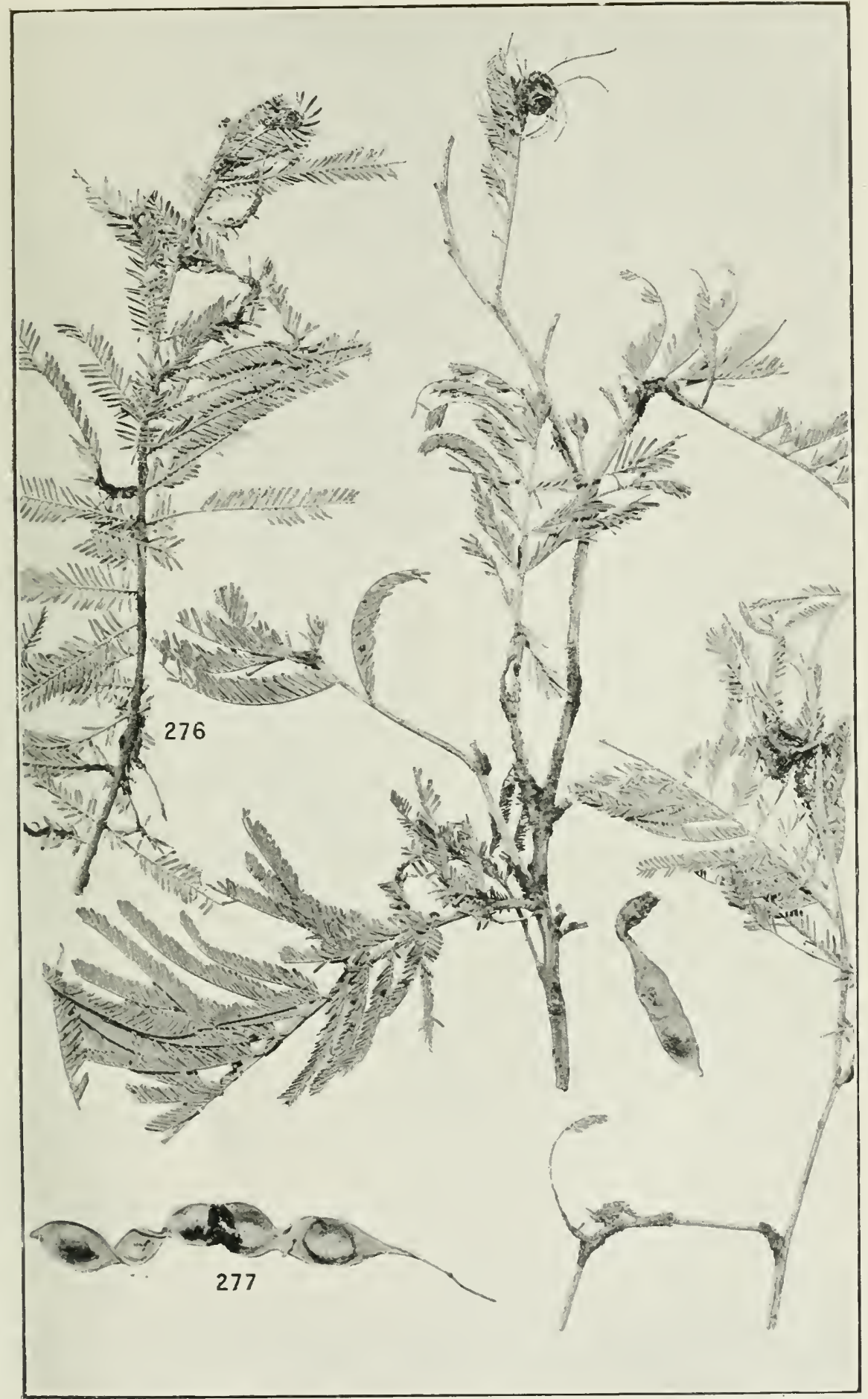

G. H. Robinson, Phot.

UROMYCLADIUM.

LEGUMINOSAE - ACACIA DEALBATA. 



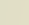




\section{PIATE XXXIV.}

Fig.

\section{UROMYCLADIUM TEPPERIANUM.}

278. Branch of Acacia armata showing the powdery galls caused by the growth of $U$. tepperianum 


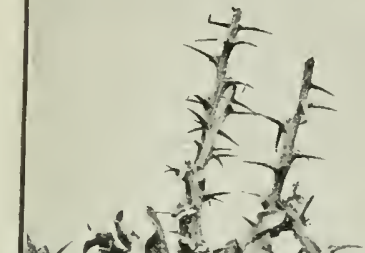

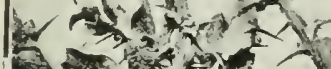

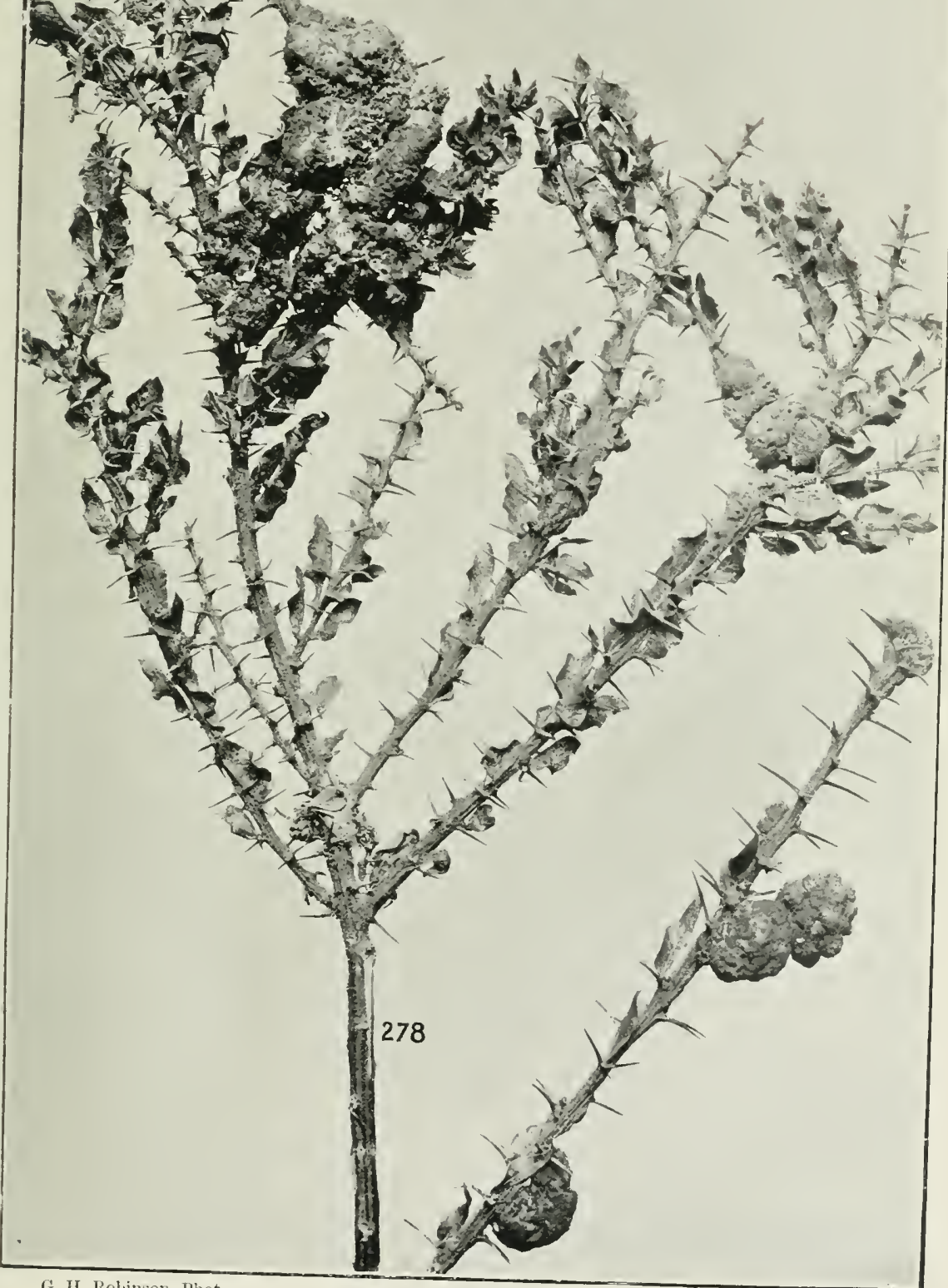

G. II. Robinson, Phot.

UROMYCLADIUM.

Nat. size.

LEGUMINOSAE-ACACIA ARMATA. 



\section{PLATE IXIV.}

\section{UROMYCLADIUM TEPPERIANLM.}

Fig.

279. Galls attached to branches of Acacia pycnantia, caused by $U$. tcf. $\begin{array}{lllllllll}\text { perianum } & \ldots & \ldots & \ldots & \ldots & \ldots & \ldots & \ldots & \text { nat. size }\end{array}$ 28̂o. Galls detached 


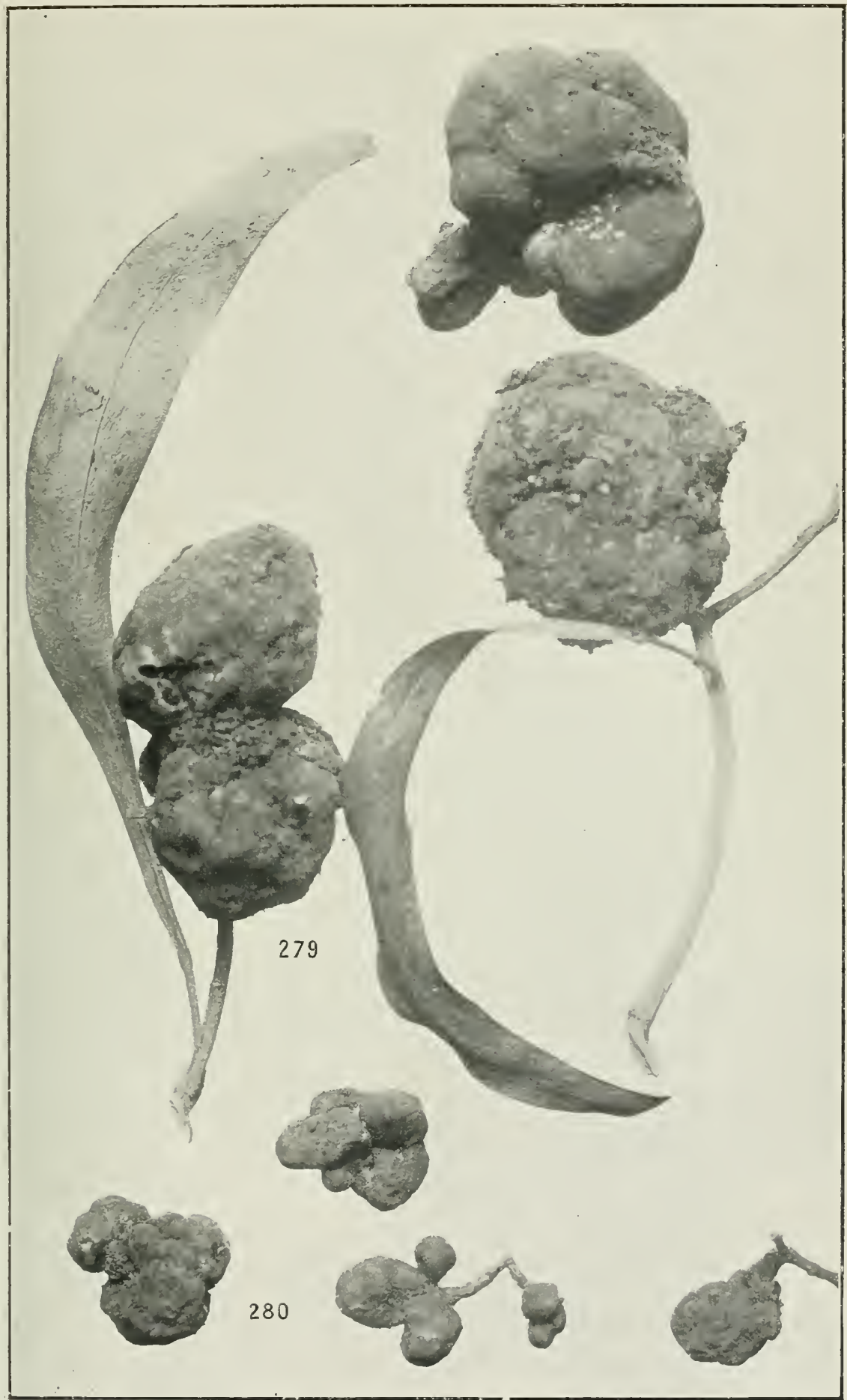

G. H. Rot inson, Phot.

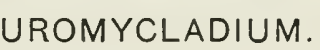

Nat. size.

\section{U. TEPPERIANUM ON ACACIA PYCNANTHA.}



Fig.

PLATE XXXVI.

\section{UROMYCLADIUM NOTABILE.}

281. Numerous young galls on Acacia dealbata, bearing the uredospores of $U$. $\begin{array}{lllllllll}\text { nntabile } & \ldots & \ldots & \ldots & \ldots & \ldots & \ldots & \ldots & \text { nat. }\end{array}$

(Being on the young growth of the current season, the galls are necessarily comparatively small, though many of several years' growth bearing teleuto. spores have been found as large as potatoes, and weighing nearly I lb. each.) 


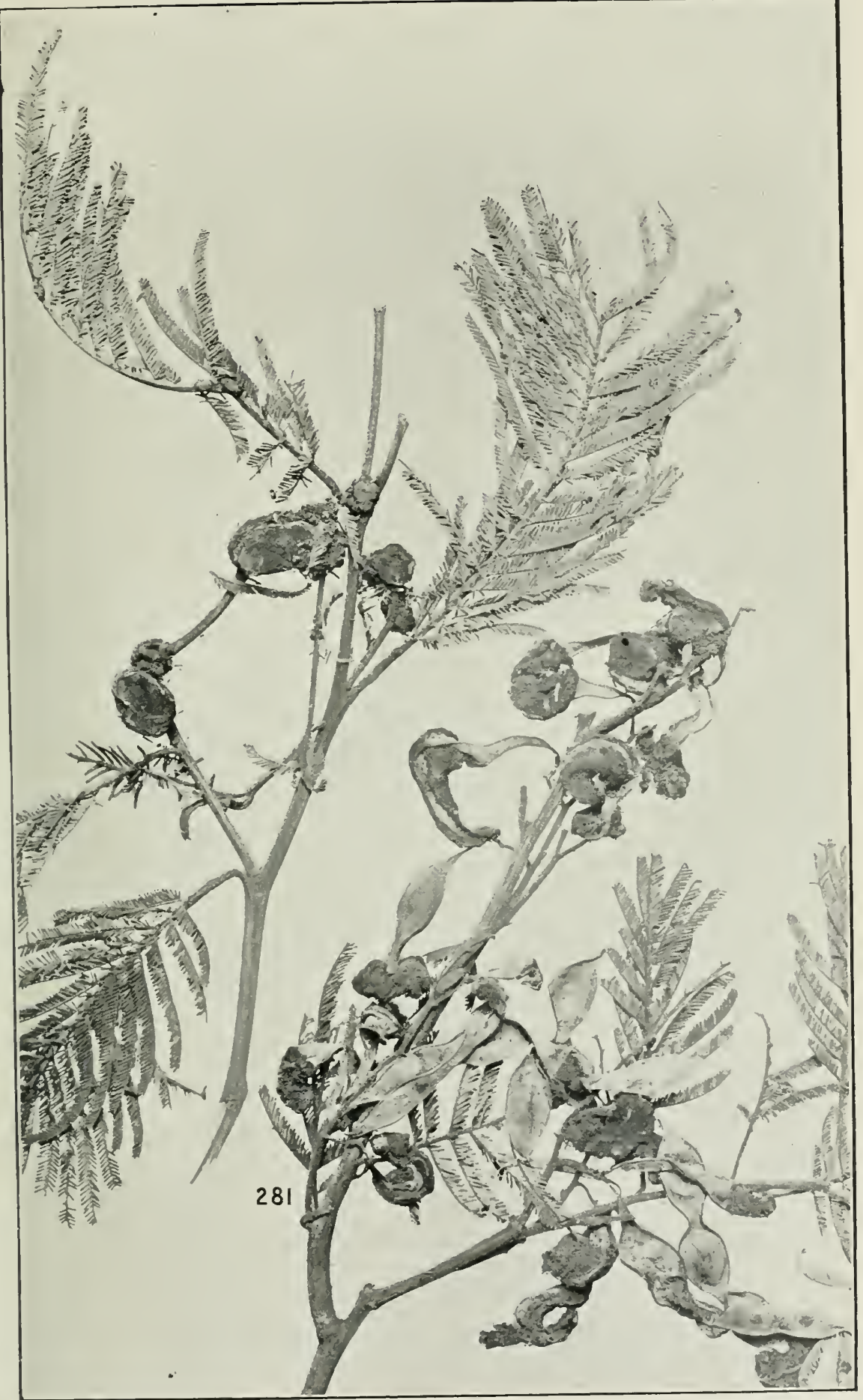

(i. H. Robiuson, Phot.

UROMYCLADIUM.

U. NOTABILE ON ACACIA DEALBATA. 



\section{PLATE IXIVII.}

Fig. CRONARTIUM JACKSONIAE.

282. C. jacksoniae deforming shoot of Platylobium formosum $\ldots$... nat. size 283. Witches' brooms due to C. jacksoniae on branches of Aotus villosa ... nat. size 284. Normal healthy shoot of Aotus villosa ... nat. size 


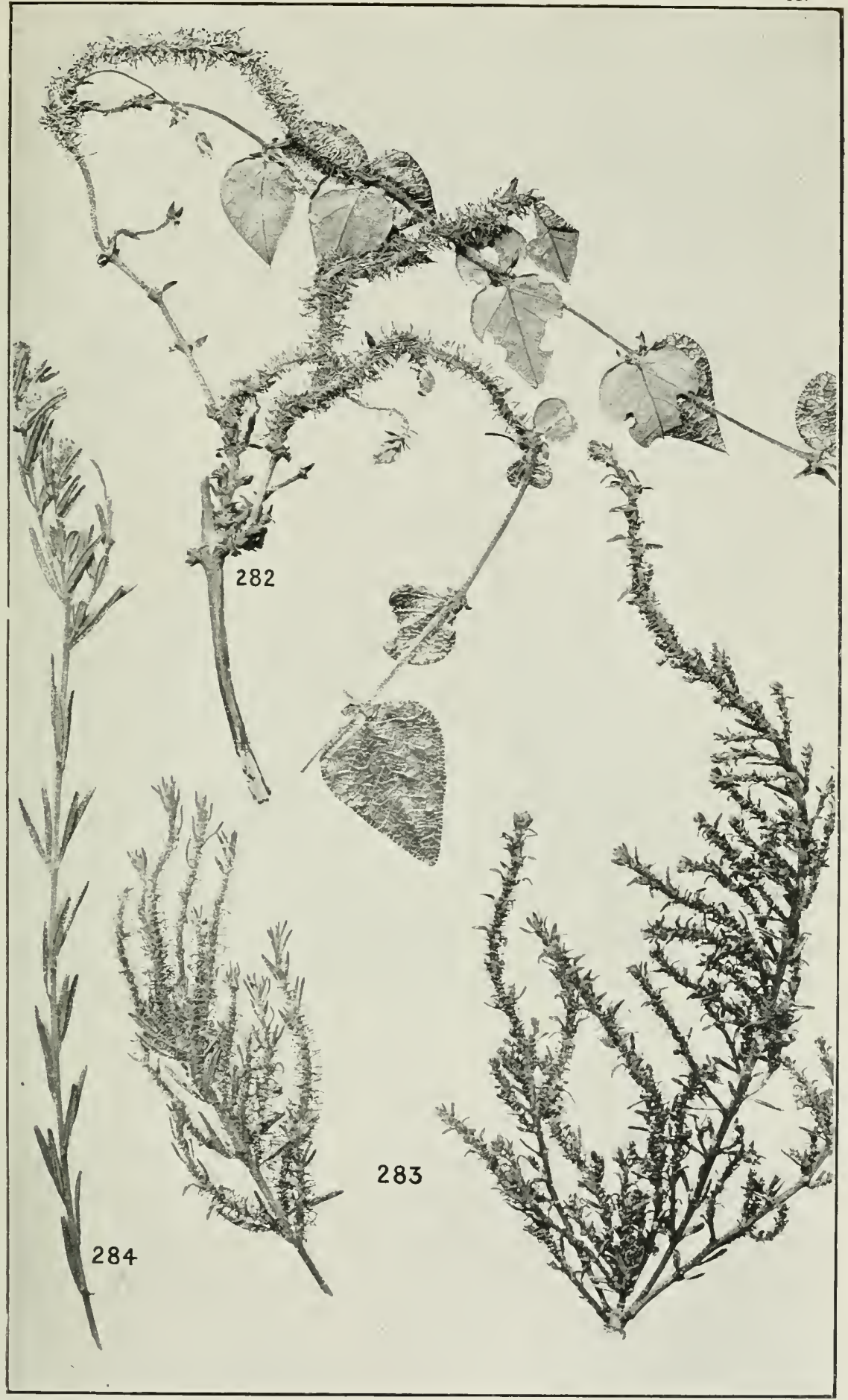

G. H. Robinson, Phot.

C. JACKSONIAE ON PLATYLOBIUM AND AOTUS.

Nat. size, 




\section{PLATE XXXVIII.}

\section{CRONARTIUM JACKSONIAE.}

Fig.

${ }_{2} \varepsilon_{5}$. Witches' broom, due to C. jacksoniae on Gompholobium latifolium ... nat. size 286. Normal healthy shoot of Gompholobium latifolium ... nat. size 


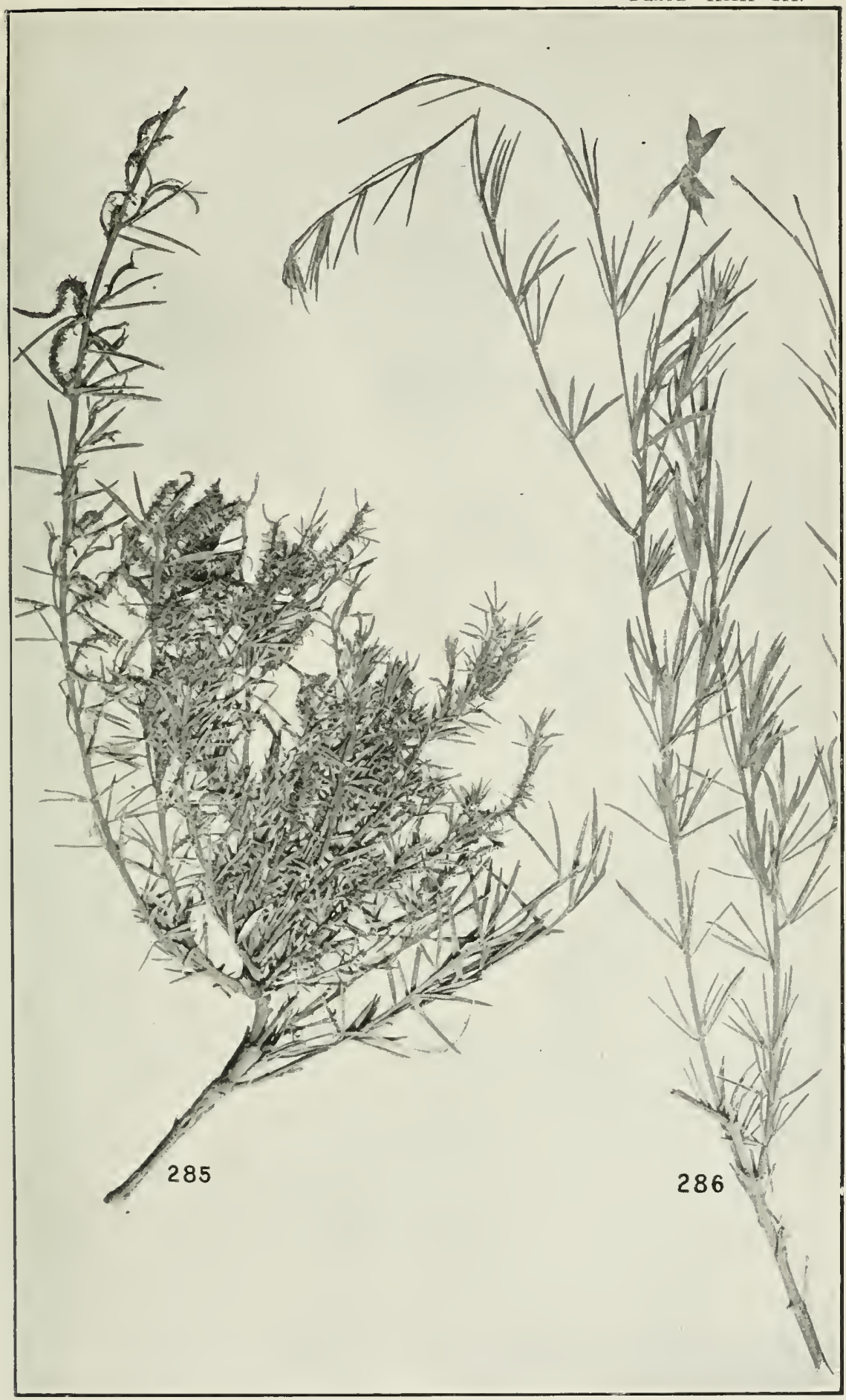

G. H. Robinson, Phot.

Nat. size.

CRONARTIUM.

C. JACKSONIAE ON GOMPHOLOBIUM LATIFOLIUM. 




\section{PLATE XXXIX.}

(All aecidia $\times 50$, and aecidiospores $\times 300$.)

\section{AECIDIUM.}

Fig.

287 . A. veronicae on Veronica sp.

288. A. plantaginis-variae on Planiago varia.

289. A. lobeliae Thuem., on Lobelia tratioides, described in connexion with Puccinia aucta. The free margin ruptures irregularly, and it is sometimes difficult to detect a peridial wall, so that it partakes of the nature of a Caeoma.

29o. A. cymbonoti on Cymbonotus lazsonianus.

29r. A. monocystis on Abrotanella forsterioides.

292. A. vittadiniae on Vittadinia australis.

293. A. soleniiforme en Goodia lotifolia.

294. A. deeringiae on Deeringia celosioides.

295. A. calthae on Caltha introloba.

2c.6. A. ranunculacearum on Ranunculus rivularis.

297. Aecidium of Uromyces politus on leaves of Muehlenbeckia cunninghami-a. nat. size, $b$. aecidial tubes $\times 5$.

29S. Aecidiospores of same $(X 300)$ and pseudoperidial cells $\left(\begin{array}{l}X \\ 150\end{array}\right)$. 
Plate: IXXIX

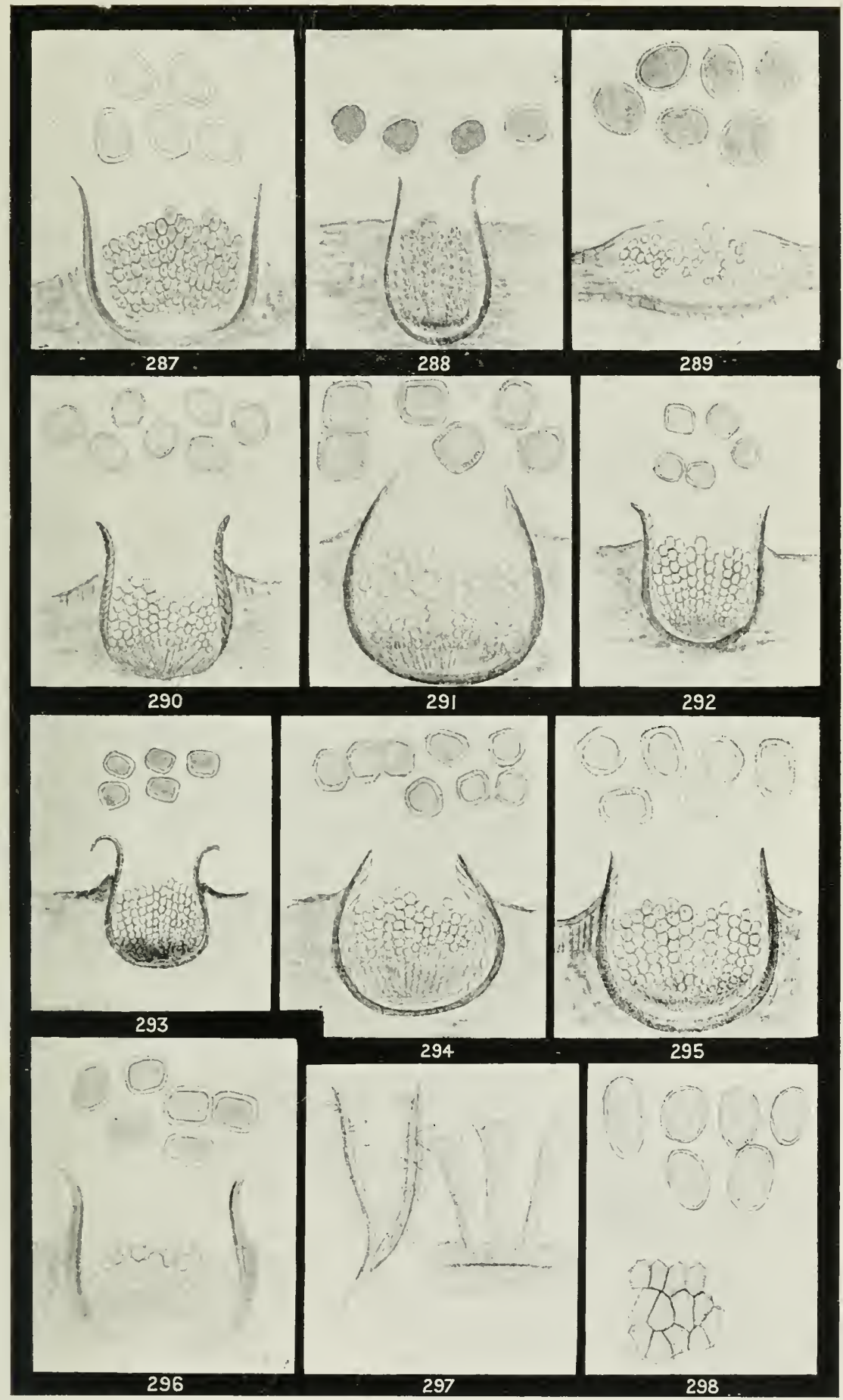

C. C. Brittlebint, Del,

$\times 5,50,150 \leqslant 300$. AECIDIUM. 




\author{
PLATE XL. \\ (All Figures $\times 500$.)
}

NORMAL AND ABNORMAL SPORES OF PUCCINIA AND UROMICES.

Fig.

\title{
PUCCINIA DICHONDRAE.
}

20g. The teleutospores exhibit a great variety of shape and size, and range from one to four celled forms. In the two-celled forms the septum may either be transverse or longitudinal, and in the three-celled forms the septa may either be transverse or oblique, and the upper or lower cell may be livided longitudinally. The four-celled forms may, in addition, become somewhat spherical, and be divided longitudinally and obliquely, so as to resemble a Sphaerophragmium. The variation even in the same sorus is sometimes greater than it is between some different species.

\section{PUCCINIA LUDWIGII.}

300. Teleutospores may be divided generally as in the above, although the fourcelled forms are not quite so frequent.

\section{PUCCINIA GRAMINIS.}

30I. Teleutospores are also one to four celled, but the septa are generally transverse, while the upper cell may occasionally be longitudinally divided.

\section{PUCCINIA TRITICINA.}

302. The teleutospores do not show such a wide variation as in $P$. graminis, but they may be from one to three celled, and the upper cell may be longitudinally livided.

\section{UROMYCES ORCHIDEARUM.}

303. This species shows very well the transition from the unicellular (Uromyces) to the bicellular (Puccinia) teleutospores. Some of the two-celled spores are equally divided by the transverse septum and constricted, so that they depart entirely from the liromyces type. 
Plate Xl.
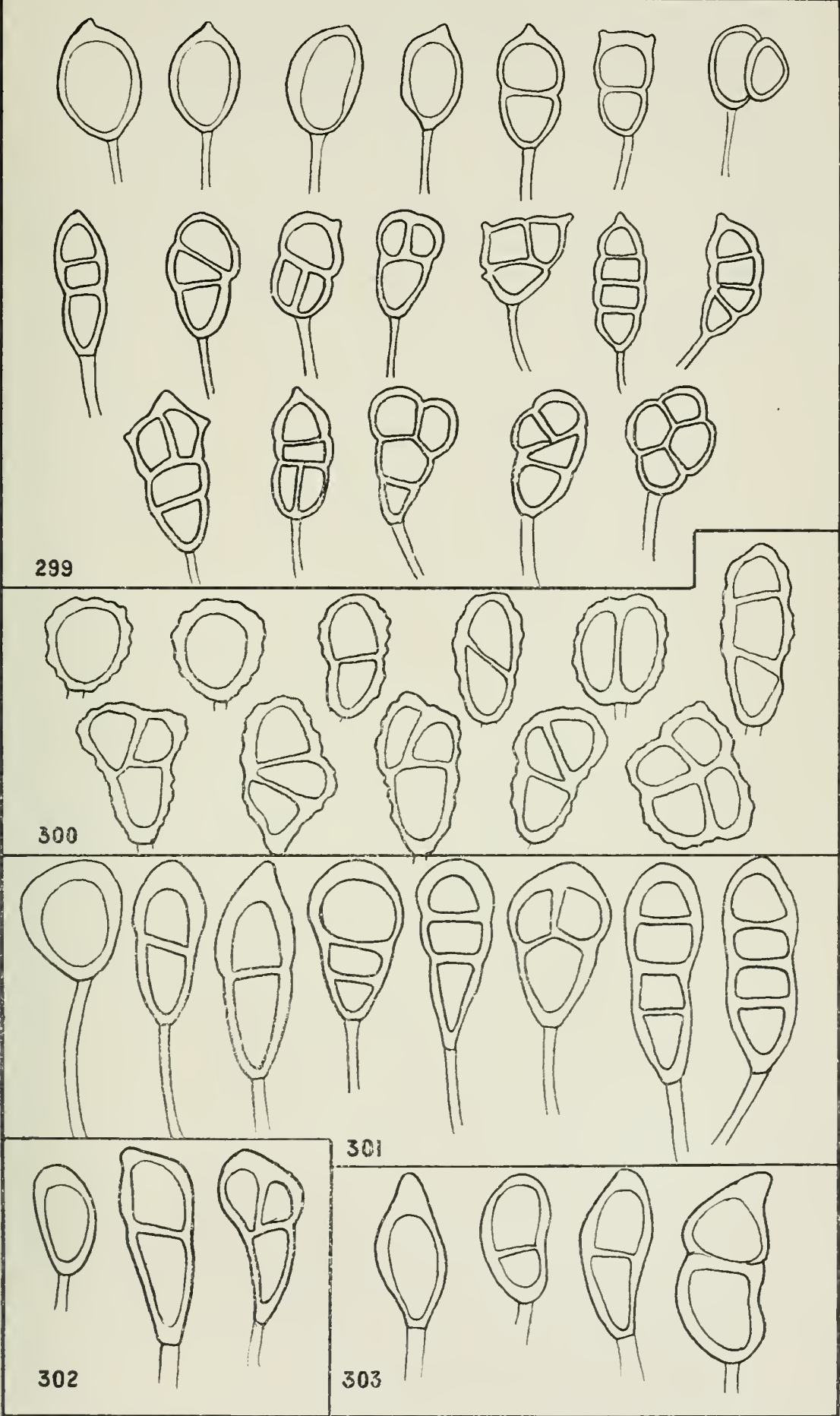

i. C. Brittlebank. Del.

FUCCINIA AND UROMYCES.

NORMAL AND ABNORMAL TELEUTOSPORES. 


PLATE XLI.

Fig.

UROMICIADIUM TEPIERIANUM.

304. Large gall on Acacia imflexa, weight 3 lbs.

.. $\quad \ldots \quad \ldots \times \frac{1}{2}$ 


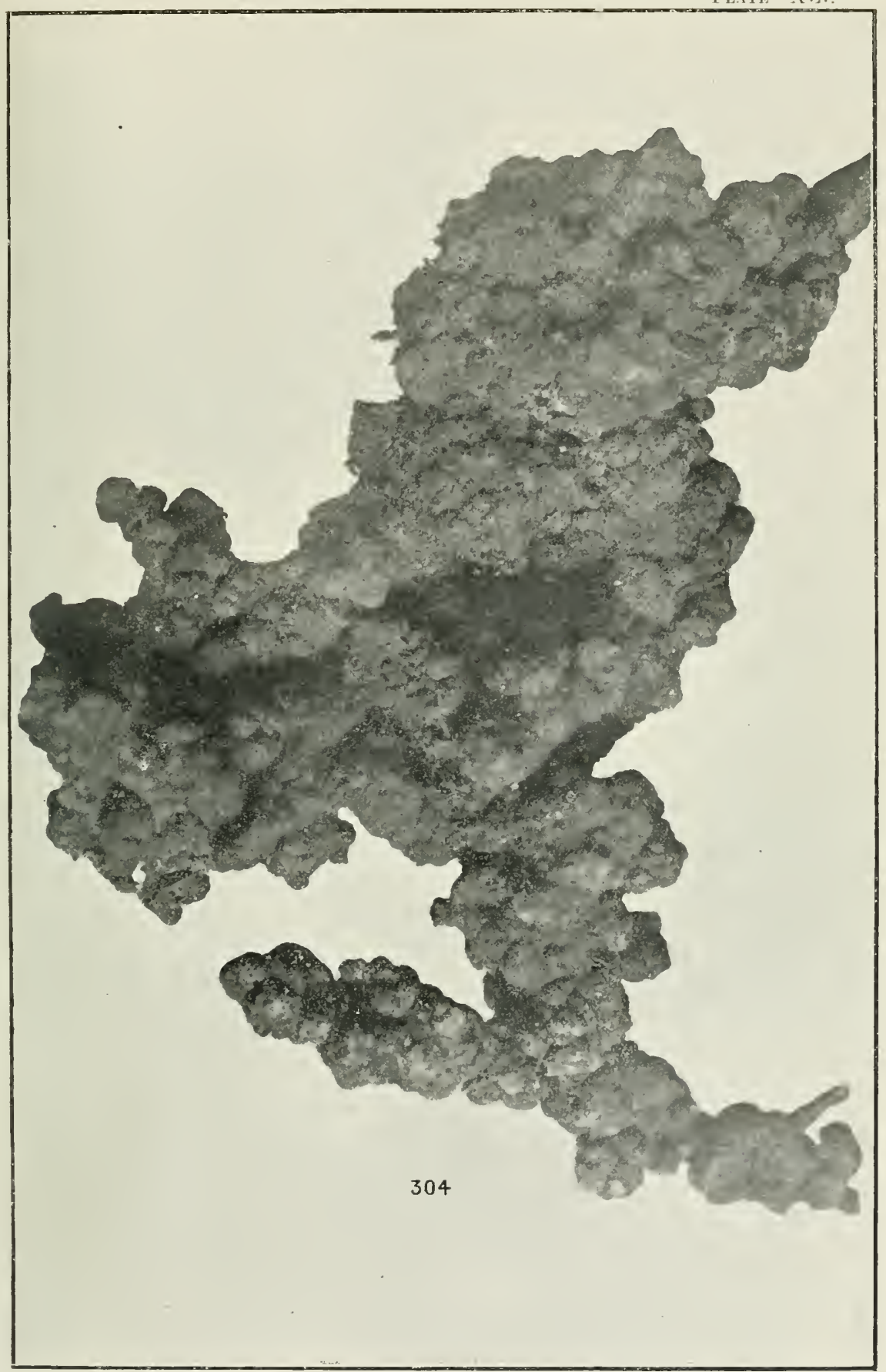

(i) H, Roljinson, Phot.

UROMYCLADIUM.

LEGUMINOSAE-ACACIA IMPLEXA. 



\section{PLATE XLII.}

Fig.

\section{UROMYCLADIUM.}

305. Witches' broom on Acacia implexa, due to Uromycladium tepperianum ... $\times \frac{1}{4}$

\section{UROMYCES.}

306. Teleutospores of Uromyces appendiculatus on Vigna catjang or Cow-pea, from

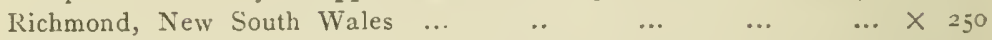

307. Teleutospores of C'romy'ces fabae on Lathyrus z'enosus. (Sydow, Uredineen, I353) $\ldots$ 

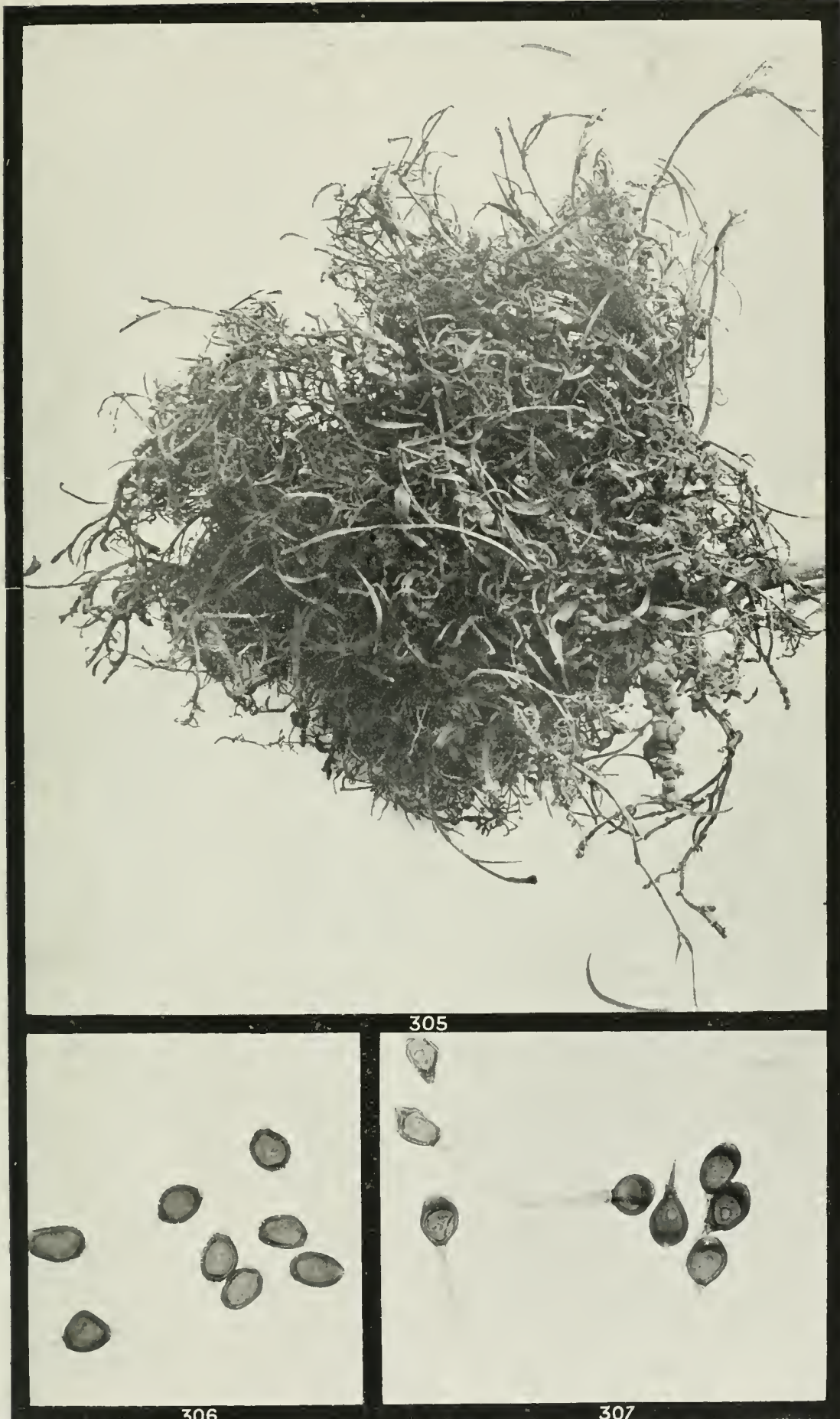

G. H. Kobinson, Phot.

UROMYCLADIUM, UROMYCES. LEGUMINOSAE. 




\title{
PLATE XLIII.
}

\author{
(All Figures $\times 250$.
}

Fig.

\section{PUCCINIA}

308. Teleutospores of $P$. viltadiniae, mostly of a short broad type, on Villadinia australis.

309. Teleutospores and mesospores of the same.

3ro. Teleutospores and mesospores of $P$. calotidis on Calotis sp.

3x. Uredospore of $P$. graminis on Avena falua, germinating in water, showing branching growth at the end of twenty-four hours. (Stained with Congo red.)

312. Mesospore of $P$. calendulae on Calendula officinalis, germinating in water after three days, two sporidiola produced, both of which have already germinated. (Stained with Bismarck brown.)

\section{UROMYCLADIUM.}

3'3. Teleutospore of $U$. maritimum on Acacia longifolia, germinating after twentyfour hours in water, and producing four sporidiola from the lengthy promycelium. (Stained with Congo red.) (In some cases the promycelium may be quite three times the length of that shown when germination takes place in water.)

314. Sporidiola of the same germinating in water three lours after formation. (Stained with Congo red.)

315. Uredospores of the same germinating after three days in water. The germ tubes are very broad, with almost colourless contents, and extremely thin wall. At first they are generally much contorted, and sometimes bifurcate at the apex. (Stained with Congo red.)

\section{UROMYCES.}

316. Aecidiospore of $U$. belae on Bela vulgaris, germinating in water after twentyfour hours, the contents being collected towards the end of the tube where branching is commencing. (Stained with Congo red.)

317. Teleutospores of $U$. politus, one being two-celled, on Muchlenbeckia cun. ninghami.

318. Uredosjores with two bands of germ pores, and teleutospores of $U$. bicinctus on Acacia fasciculifera.

319. Uredosjores and teleutospores of $U$. polycnemi on Polyenemum pentandrum. 
Prate XLIIT.

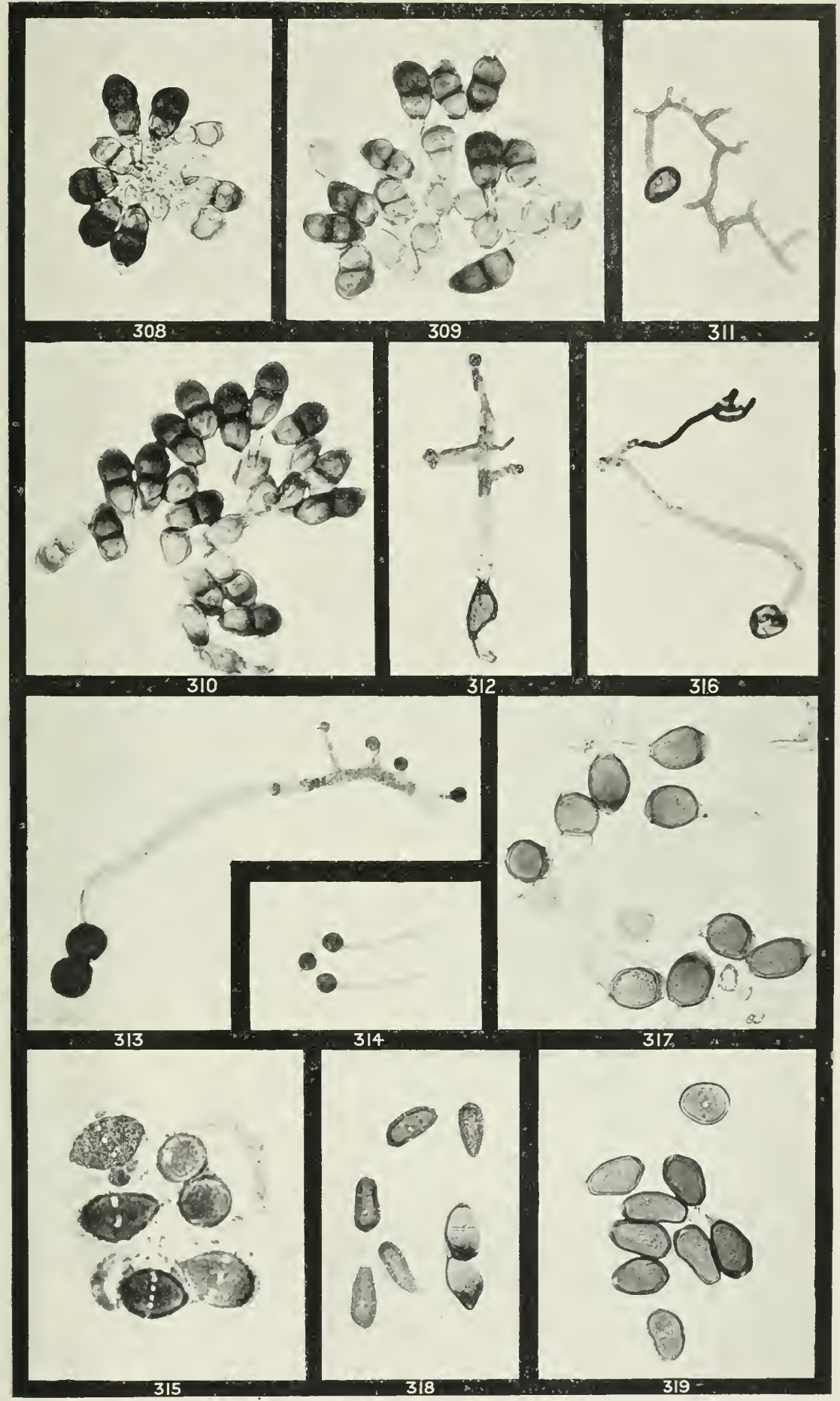

G. H. Robinson, Phot.

PUCCINIA, UROMYCLADIUM, AND UROMYCES. 

PLATE XLIV.

\section{RUST-RESISTING AND RUST-LIABLE WHEATS.}

Fig.

320. Rerraf, a variety of wheat generally found to be rust-resisting, and the straw is shown to be perfectly clean.

321. Queen's Jubilee, a rust-liable variety, grown alongside of the other, and badly attacked by Puccinia graminis. 


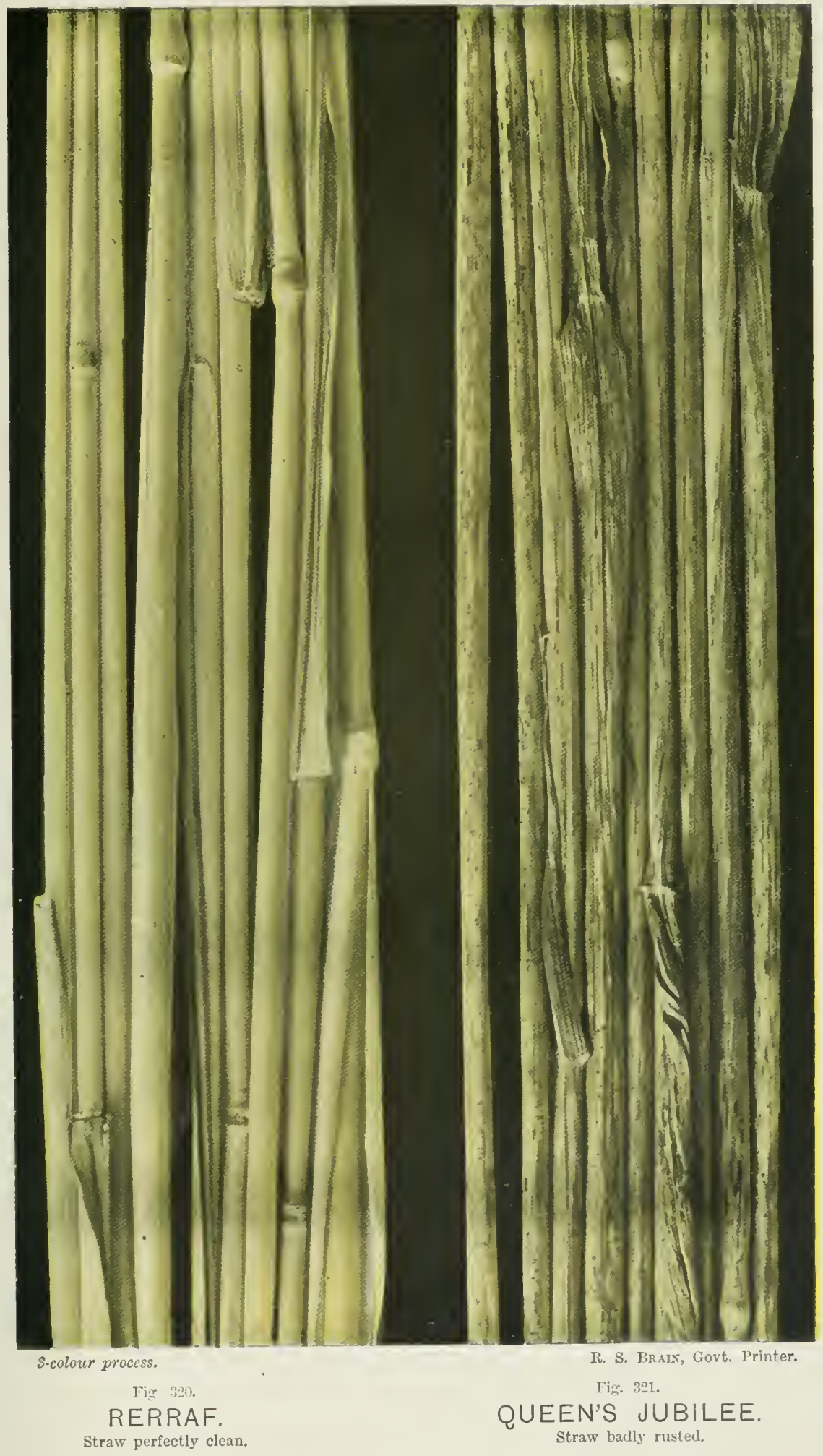





\section{HOST INDEX.}

Abrotanella forsterioides Hook. f. Aecidium monocystis, Berk.

Abutilon avicennae Gaertn.

Puccinia heterospora, Berk, and Curt.

Abutilon crispum Sweet.

Puccinia heterospora, Berk, and Curt.

Acacia L.

Uromyces fusisporus, Cke. and Mass.

Uromyces phyllodiorum (B. and $\mathrm{Br}$.) MeAlp.

Acacia armata R.Br.

Eromycladium tepperianum (Sacc.) McAlp.

Acacia buxifolia A. Cunn.

Uromycladium alpinum, McAlp.

Acacia binervata DC.

Uromycladium notabile (Lndw.) McAlp.

Acacia dallachiana F.v.M.

Uromyces phyllodiormm (Berk. and Br.) McAlp.

Uromycladium alpinum, McAlp.

Acacia dealbata Link.

Uromyces phyllodiornm (B. and Br.) McAlp.

Uromycladium alpinum, McAlp.

U. hisporum, McAllp.

U. notabile (Ludw.) McAlp.

Acacia decurrens Willd.

Uromycladium notabile (Ludw.) McAlp.

Acacia diffusa Lindl.

Uromycladium tepperianum (Sacc.) McAlp.

Acacia elata A. Cunn.

Uromycladium notabile (Ludw.) McAlp.

Acacia erioclada Benth.

Uromycladium tepperianum (Sacc.) MTc Al l

Acacia fasciculifera F. v. 11 .

Uromyces hicinctus, McAlp.

Acacia glaucoptera Benth.

Uromycladium tepperianum (Sacc.) McAlp.

Acacia hakeoides A. Cunn.

Uromycladium tepperianum (Sacc.) IcAlp.
Acacia implexa Bentl.

Uromycladium tepperianum (Sacc.) IcAlp.

U. alpinum, McAlp.

Acacia juniperina Will.

[romycladium tepperianum (Sacc.) IcAlp.

Acacia linifolia Willd.

Uromycladium alpinum, IcAlp.

Acacia longifolia Willd.

Uromycladium maritimun, McAlp.

U. tepperianum (Sacc.) McAlp.

Acacia melanoxylon R. Br.

Uromycladium robinsoni, AlcAlp.

Uromycladium tepperianum (Sacc.) McAlp.

Acacia microbotrya Benth.

Uromyces phyllodiorum (B. and $\mathrm{Br}$.) McAlp.

Acacia myrtifolia Willcl.

Uromycladinm tepperianum (Sacc.) McAlp.

Acacia neriifolia A. Cunn.

Uromyces fusisporus, Cke. and Mass.

U. phyllodiorum (B. and Br.) McAlp.

Acacia notabilis F.v.NI.

Uromyces phyllediorum (B. and Br.) McAlp.

Uromycladimm notabile (Ludw.) Mcdlp.

Acacia penninervis Sieber.

Uromyces phyllodiorum (B. and Br.) McAlp.

Acacia pruinosa A. Cunn.

Uromyces phyllodiorum (B. and Br.) McAlp.

Uromycladium notabile (Ludw.) NeAlp.

Acacia pycnantha Benth.

Uromycladium simplex, McAlp.

U. tepperianmm (Sacc.) $\mathrm{McAl}_{\mathrm{p}}$.

Acacia retinodes Schlect $=$ Acacia neriifolia, A. Cumn.

Acacia rigens $\mathrm{A}$. Cumn.

Uromycladium tepperianum (Sace.) McAlp.

\section{Acacia salicina Lindl.}

Uromyces fusisporus, Cke. and Mass.

Uromycladium tepperianmm (Sacc.) IIeAlp. 
Acacia siculiformis A. Cunn.

Uromyclaclium tepperianum (Sacc.) Meslp.

Acacia spinescens Benth.

Uromycladium tepperianum (Nacc.) IIcAlp.

Acacia stricta Willd.

Uronycladiun tepperiannm (Sace) IcAlp.

Acacia verniciflua A. Cum.

Uromyclaclinu tepperianum (Sacc.) MeAIp.

Acacia verticillata Wille.

Uronycladium tepperianum (Sacc.) McAlp.

Acacia vomeriformis A. Cunn.

Uromycladium tepperianum (Sacc.) MeAlp.

Acaena ovina A. Cunn.

Phragmidium potentillae (Pers.) Karst

Acaena sanguisorbae Vahl.

Phragmidium potentillae (Pers.) Karst.

Agropyron divergens Nees.

Puccinia graminis, Pers.

Agropyron scabrum Beauv.

Puccinia agropyri, Ell. and Ev.

$P$. graminis, Pers.

Agrostis solandri F.v.M.= Deyenxia forsteri, Kunth.

\section{Alopecurus geniculatus $\mathrm{L}$.}

Puccinia graminis, Pers.

P. perplexans, Plow.

Althaea rosea Car.

I'uccinia malvacearum, Mont.

Alyxia buxifolia R. Br.

I'uccinia alyxiae, Cke, and Mass.

Amphibromus neesii Stcud.

Puccinia graminis, Pers.

Anthoxanthum odoratum L.

Puccinia anthoxanthi, Fekl.

Aotus villosa Sm.

Cronartium jacksoniae, P. Hem.

Apium graveolens L.

Puccinia thuemeni, NlcAlp.

Apium prostratmm Labill.

Puccinia thuemeni, Medlp.
Asperula oligantha F.ı.M. (.A. scopuria, Hook. f.)

Uromyces asperulae, McAlp.

Puccinia oliganthae, McAlp.

Atriplex semibaccata $\mathrm{R}$. Br.

Uromyces atriplicis, McAlp.

Avena fatua $\mathrm{I}$.

P'nccinia graminis, P'ers.

Y. lolii avenae.

Avena sativa $\mathrm{L}$.

Puccinia graminis, Pers.

P. lolii avente.

Beckmannia erucaeformis Host.

Puccinia beckmanniae, McAlp.

P. graminis, Pers.

\section{Bellis perennis L.}

Puccinia distincta, McAlp.

Beta vulgaris $\mathrm{L}$.

Uromyces hetae (Pers.) Kuehn.

Bidens pilosa L.

Uredo bidentis, P. Henn.

Boronia spinescens Benth.

Puccinia boroniae, P. Henn.

Bossiaea cinerea R. Br.

Aecidium eburneum, McAlp.

Cronartium jacksoniae, P. Henn.

Bossiaea heterophylla Vent. A ecilium eburnem, McAlp.

Bossiaea linophylla R. Br. Aecislum eburneum, McAlp.

Bossiaea microphylla Sm. Aeciclium eburneum, McAlp.

Bossiaea prostrata R. Br. Uredo bossiaeae, McAlp.

Bossiaea rhombifolia Sieber. Aecillium elurneum, McAlp.

Brachycome ciliaris Less. Puccinia brachycomes, MIcAlp.

Brachycome diversifolia Ficch. and Mey.

Puccinia brachycomes, McAlp.

Brachycome pachyptera Turcz. Puccinia brachycomes, McAlp.

Brachycome scapiformis DC. Puccinia brachycomes, MeAlp.

Briza minor $\mathrm{J}$.

Puccinia graminis, l'er's

Bromus arenarius labill.

I'uecinia bromina, liriks. 
Bromus mollis L.

Pnccinia bromina, Eriks.

Bromus racemosus L.

Puecinia graminis, Pers.

Bromus secalinus L.

Puccinia graminis, Pers.

Bromus sterilis $\mathrm{L}$.

Puccinia graminis, Pers.

Brunonia australis Sm.

Pnccinia brunoniae, McAlp.

Bulbine bulbosa Haw.

Uromyces bulbinis, Thuem.

Burchardia umbellata R. Br.

Puccinia burchardiae, Sacc.

Calendula officinalis L.

Puccinia calendulae, McAlp.

Calocephalus drummondii Benth.

Puccinia calocephali, McAlp.

Calocephalus lacteus Less.

Pnccinia calocephali, McAlp.

Calotis R.Br.

Puccinia calotidis, McAlp

Calotis cuneifolia $\mathrm{R}$. Br.

Puccinia calotidis, McAlp.

Caltha introloba F.v.MI.

Aecidium calthae, Grev.

Candollea serrulata Labill.=Sty-

lidium graminifolium, Sw.

Canthium (Plectronia) coprosmoides F.v. II.

Aecidium plectroniae, Cooke.

Carex L.

Puccinia longispora, McAlp.

Carex alsophila F.v.M.

Puccinia caricis (Schum.) Reb.

Carex breviculmis, R. Br.

Puccinia caricis (Schum.) Reb.

Carex caespitosa L.

Puccinia longispora, McAlp.

Carex gunniana Boott.

Puccinia caricis (Schum.) Reb.

Carex inversa R.Br.

Puccinia caricis (Schum.) Reb.

Carex paniculata L.

Pnccinia caricis (Schum.) Reb.

Carex pedunculata Mnlıl.

Puccinia caricis (Schum.) Relo.
Carex vulgaris Fr.

l'uccinia longispora, McAlp.

Carissa ovata R.Br.

Puccinia carissae, Cke, and Mass.

Cassia Tourn.

Uredo pallidula, Cke. and Mass.

Centaurea cyanus L.

Puccinia cyani (Schleich.) Pass.

Chiloglottis diphylla R.Br.

Uromyces orchidearum, Cke. and Miass.

Chiloglottis gunnii Lindl.

Uromyces orchidearum, Cke. and Mass.

Chrysanthemum indicum $\mathrm{L}$.

Puccinia chrysanthemi, Roze.

Cichorium intybus $\mathrm{L}$.

Puccinia cichorii (DC.) Bell.

Cineraria L.

Puccinia cinerariae, MeAlp.

Clematis aristata R.Br.

Caeoma clematiclis, Thuem.

Puccinia agropyri, Ell. and Ev. I. (Aecidium clematidis DC.).

Clematis microphylla DC.

Caeoma clematidis, Thuem.

Coprosma billardieri Hook.

Puecinia coprosmae, Cke.

Coprosma hirtella Labill.

Puccinia coprosmae, Cke.

Correa lawrenciana Hook.

Puccinia correae, McAlp.

Crepis japonica Benth.

Ureclo crepidis-japonicae, Lindr.

Cruciferae.

Puccinia cruciferae, McAlp.

Cryptandra hookeri F.r.M. = Spyridium parvifolium, F.v.M.

Cymbonotus lawsonianus faudich. Aecidium cymbonoti, Thuem.

Cynodon dactylon Pers. l'uecinia cynorlontis, Desm.

Cyperus rotundus L. Puccinia cyperi, Arth.

Dactylis glomerata L. Puccinia graminis, Pers.

Dampiera alata Lindl. Puccinia dampierae, Syd. 
Dampiera stricta $\mathrm{R}$. Br.

Puccinia rampierae, Syd.

Danthonia I)C.

Uromyces danthoniae, IICAlp. I.

Danthonia semiannularis $\mathrm{R} . \mathrm{Br}$.

Uromyces danthoniae, McAlp. II., III.

Deeringia celosioides R.Br.

Accidium deeringiae, Cke, and Mass.

Deyeuxia forsteri Kunth. (Agrostis solandri F. v. M.)

Puccina agrostidis, Plow.

Deyeuxia quadriseta Benth.

Puccinia graminis, Pers.

Dianthus caryophyllus L.

Uromyces caryophyllinus (Schrank) Schroet.

Dianthus chinensis $\mathrm{L}$.

Uromyces caryophyllinus (Schrank) Schroet.

Dichondra repens Forst.

Puccinia dichondrae, Mont.

Diploglottis cunninghamii Hook. f. Uromyces diploglottidis, Cke. and Mass.

Distichlis maritima Rafin. Puccinia subnitens, Diet.

\section{Echinopogon ovatus Beauv.}

Puccinia graminis, Pers.

Ehrharta stipoides Labill. = Microlaena stipoides, R.Br.

Elymus condensatus Presl.

Puccinia impatientis (Schw.) Arth.

Elymus striatus Willd.

Yuccinia graminis, Pers.

Elymus virginicus L.

Puccinia graminis, Pers.

Enchylaena tomentosa R.Br.

Prtccinia kochiae, Mass.

\section{Epilobium Dill.}

Puecinia epilobii-tetragoni (DC.) Wint.

Epilobium billardierianum Ser.

I'uccinia epilobii-tetragoni (DC.) Wint.

Epilobium glabellum Forst. P'necinia epilobii-tetragoni (1)C.) Wint.

Erechtites liatin.

I'uccinii erechtitis, McAlp.
Erechtites arguta DC.

Puccinia erechtitis, McAlp.

Erechtites prenanthoides DC.

I'uccinia erechtitis, McdIp.

Erechtites quadridentata DC.

Puccinia erechtitis, McAlp.

Eriostemon myoporoides UC.

Puccinia eriostenonis, IIcAlp.

Festuca bromoides $\mathrm{L}$.

Puccinia graminis, Pers.

Festuca ovina L.

Puccinia festucae, Plow.

Festuca rigida Kunth.

Puccinia festucae, Plow.

Geitonoplesium cymosum A. Cunn. Uredo geitonoplesii, McAlp.

Geranium pilosum Sol.

Puccinia geranii-pilosi, McAlp.

Geum renifolium F. v. II. Pnccinia gei, McAlp.

Glyceria dives F. $r . M$.

Puccinia graminis, Pers.

Glyceria stricta Hook. f. Puccinia graminis, Pers.

Gnaphalium japonicum Thunb. Puccinia gnaphalii (Speg.) P. Henn.

Gnaphalium purpureum L. Precinia gnaphalii (Speg.) P. Henn.

Gompholobium latifolium Sm. Cronartium jacksoniae, P. Hemn.

Goodenia albiflora Schlecht. Puccinia saccardoi, Ludw.

Goodenia geniculata R. Br. luccinia saccardoi, Luciw.

Goodenia glauca F. r. 11 . Puccinia saceardoi, Ludw.

Goodenia hederacea Sin. Puecinia saceartoi, Luctw.

Goodenia ovata Su. Puccinia saceardoi, Ludw.

Goodenia pinnatifida Sill leclıt. I'nccinia saceardoi, Ludw.

Goodia lotifolia Nilish. Aecidium soleniiforme, Berk.

Haemodorum sim.

Puccinia haemotori, l'. Henn. 
Hakea Schrarl.

Uredo angiosperma, Thuem.

Hardenbergia monophylla Benth. (K'mnedya monophylla Vent.)

Uromyces hardenbergiae, $\mathrm{IcAl}_{1}$.

Helianthus annuus L. Puccina helianthi, Schw.

Helianthus tuberosus L. Puccinia helianthi, Schw.

Helichrysum Vaill. Puccisia kalchbrenneri, De Toni.

Hibbertia sericea Benth.

l'uccinia hibbertiae, McAlp.

Hibiscus L.

Puccinia heterospora, B. and C.

Hordeum murinum $\mathrm{L}$.

Puccinia graminis, Pers.

Hordeum secalinum Schreh.

Pnecinia graminis, Pers.

Hordeum vulgare $\mathrm{L}$.

Pnecinia graminis, Pers.

P. simplex (Koem.) Eriks. and Henn.

Hypericum japonicum Thunb.

Ielampsora hypericorum (DC.) sichroet.

Aecidium dissenninatum, Berk.

Hypochoeris glabra L.

Puccinia hypochoeridis, Oud.

Hypochoeris radicata $L$.

Puccinia hypochoeridis, Oud.

Hypoxis glabella R. Br.

Puccinia hypoxidis, McAlp.

Jacksonia scoparia P. Br. Cronartium jacksoniae, P. Henn.

Juncus effusus $\mathrm{L}$.

Pnccinia juncophila, Cke and Mass.

Juncus maritimus Lam.

Puccinia juncophila, Cke and Iass.

Juncus pallidus Pv. Br.

Puccinia juncophila, Cke and Mass.

Juncus pauciflora R. Br.

Puccinia juncoplila, Cke and Mass.

Kennedya monophylla, Vent. = Hardenbergia monophylla, Benth.

Kochia sedifolia F. v. M.

Puccinia kochiae, Mass.

Kochia villosa Lindl.

Pnceinia kochiae, Mass.

Lactuca $\mathrm{L}$.

Puccinia prenanthis (Pers.) Lindr.
Lagenophora billardieri Cass. Puccinia lagenophorae, Cke.

Lagenophora huegelii Benth. Puccinia lagenophorae, Cke.

Lavatera plebeia Sims. Pnccinia malvacearum, Mont.

Leschenaultia linarioides DC. Puccinia gilgiana, P. Henn.

Limnanthemum indicum Thw. Aecidium nymphoidis, DC.

Limosella aquatica $\mathrm{L}$. Uromyces limosellae, Ludw.

Linum marginale $\mathrm{A}$. Cunn. Melampsora lini (Pers.) Tui.

Linum usitatissimum L. Melampsora lini (Pers.) Tul.

Lobelia anceps $\mathrm{L}$.

Puccinia aucta, Berk. and F. v. M.

Lobelia pratioides Benth.

Puccinia ancta, Berk. and F. v, M.

Lobelia purpurascens R. Br. Puccinia ancta, Berk. and F. v. M.

Lolium perenne $L$. Puecinia lolii, Niels.

Loranthus celastroides Sieher. Puccinia loranthicola, McAlp.

Iuzula campestris DC. Puccinia tenuispora, McAlp.

Luzula oldfieldii Hook. $t$. Puccinia tenuispora, MeAlp.

Malva rotundifolia L. Pnccinia malvacearım, Mont.

Malva sylvestris L. Puccinia malvacearum, Mont.

Mentha laxiflora Benth. Puccinia menthae, Pers.

Mentha pulegium L.

Puccinia menthat, Pers.

Microtis porrifolia R.Br.

Uromyces microtilis, Cke.

Microlaena stipoides R. Br'. (Ehrhartr stipoirles Labill.)

Uromyces ehrhartae, McAlp.

Muehlenbeckia adpressa Meissn. Puccinia muehlenbeckiae (Cke.) Syıl.

Muehlenbeckia cunninghami F.v. M. Uromyces politus (B. and Br.) McAly. 
Muehlenbeckia gracillima Neissu.

Puccinia muehlenbeckiae (Cke.) Syd.

Olearia argophylla F. r. M. (Aster). l'uccinia oleariac, McAlp.

Olearia axillaris F.v.M. Aecilium oleariac, McAlp.

Opercularia aspera Gacrtm. Puccinia operculariae (Morr.) Syd.

Opercularia varia Hook f. Puccinia operculariae (Morr.) Syd.

Pelargonium australe Jacq. Puccinia morrisoni, McAlp.

Phalaris canariensis $\mathrm{L}$.

Puccinia graminis, Pers.

Phalaris minor Retz.

Puccinia graminis, Pers.

Phragmites communis Trin.

Puccinia magnusiana, Koeru. P. tepperi, Ludw.

\section{Plagianthus sidoides Hook.} Puccinia plagianthi, McAlp.

Plagianthus spicatus Benth.

Puccinia malvacearum, Mont.

Plantago varia P. Br. Accidinm plantaginis-variae, McAlp.

Platylobium formosum Sm. Aecidium platylobii, McAlp. Cronartium jacksoniae, P. Henn.

Plectronia coprosmoides $=$ Canthium coprosmoides, F. Y. II.

Poa annua $\mathrm{L}$.

Puccinia poarum, Niels.

Poa caespitosa Forst.

Puceinia proarum, Niels.

Poa pratensis $\mathrm{I}$.

Puccinia poarum, Nicls.

Podolepis longipedata A. Cunu. Puecinia podolepiclis, McAlp.

\section{Polygonum aviculare $\mathrm{I}$.} Uromyces polygoni, Fcki.

Pomaderris apetala Lillill. Uredo spyridii, Cke. and Mass.

Pratia erecta Gaudich.

Puccinia atucta, Rerk, and F. I. M.
Pratia pedunculata Benth. P'uccinia aucta, Berk, and F. r. M.

Pratia platycalyx Benth. Puccinia aucta, Berk, and F. v. M.

Prunus amygdalus Stokes. Puccinia pruni, Fers.

Prunus armeniaca L. Puccinia pruni, Pers.

Prunus domestica L. Puccinia pruni, Pers.

Prunus persica Stokes. Puccinia pruni, Pers.

Ranunculus $\mathrm{L}$.

Aecidium ranunculacearum, DC.

Ranunculus gunnianus Hook. Aecidium ranunculacearum, DC.

Ranunculus lappaceus Sm. Accidium ranunculacearum, DC.

Ranunculus parvifiorus L. Aecidium ranunculacearum, DC.

Ranunculus rivularis Banks and Sol. Aecidium ranunculacearum, DC.

Rhagodia billardieri R.Br. Uredo rhagodiae, Cke. and Mass.

Rosa canina $\mathrm{L}$.

Phragmidium subcorticium (Scl)rank) Wint.

Rosa laxa Retz.

Phragmidium subcorticium (Schrauk) Wint.

\section{Rosa rubiginosa $\mathrm{I}$.}

Phragmidium subcorticium (Schrank) Wint.

Rottboellia compressa L.

Puceinir cacao, MeAlp.

Rubus moluccanus L.

Phragmidium longissimum, Thuem.

Rubus parvifolius L.

Phragnidium barnardi, Plow: and Wint.

Ruellia australis Car.

l'uceinia mussoni, MeAlp.

Rumex brownii Campl.

l'uecinia Indwigii, Tepp. 
Rumex flexuosus Sol.

Pnccinia ludwigii, Tepp.

Saccharum officinarum L. Uredo kuehnii, Krueg.

\section{Scaevola L.}

Uromyces puccinioides, Berk. and F. v. M.

Schelhammera undulata R. Br.

Uredo schelhammerae, McAlp.

Scirpus nodosus Rot $t$ b.

Uredo scirpi-nodosi, McAlp.

Scleranthus diander $\mathrm{R}$. Br. Uromyces scleranthi, Rostr.

Scorzonera angustifolia L.

Puccinia angustifoliae, McAlp.

Secale cereale L.

Puccinia graminis, Pers.

Selliera radicans Car.

Uromyces puccinioides, Berk. and F. v. M.

Senecio brachyglossus F. v. M.

Puccinia tasmanica, Diet.

Senecio pectinatus DC.

Puccinia tasmanica, Diet.

Senecio velleioides A. Cunn.

Puccinia tasmanica, Diet.

Senecio vulgaris L.

Puccinia tasmanica, Diet.

Sorghum halepense Pers.

Puccinia purpurea, Cke.

Sorghum vulgare Pers.

Puccinia purpurea, Cke.

Sporobolus indicus R. Br.

Uromyces tenuicutis, McAlp.

Spyridium parvifolium F. v. M. (Cryptandra hookeri F. v. M.)

Uredo spyridi, Cke and Mass.

Stellaria media Cyrill.

Puccinia arenariae (Schum.) Schroet.

Stipa flavescens Labill.

Puccinia flavescentis, McAlp.

Stipa semibarbata R. Br.

Puecinia flavescentis, McAlp.

Stylidium graminifolium Sn. (Cun. (dollece serrulata Labill.)

Pnecinia stylidii, McAlp.
Tabernaemontana orientalis R. Br. Caeoma apocyni, McAlp.

Tetragonia implexicoma Hook. f. Puccinia tetragoniae, McAlp.

Thelymitra antennifera Hook. f. Uromyces thelymitrae, McAlp.

Thelymitra flexuosa Endl. Uronyces thelymitrae, McAlp.

Threlkeldia drupata Diels. I'uccinia dielsiana, P. Henn.

Tillaea sieberiana Schult. Uredo tillaeae, McAlp.

Tremandra stelligera $\mathrm{R}$. $\mathrm{Br}$. Puccinia pritzeliana, P. Hemn.

Tricoryne elatior $\mathrm{P}$. Br. Uromyces tricorynes, McAlp.

Trifolium repens $\mathrm{L}$. Uromyces trifolii (Alb. and Schw.) Winter.

Triticum polonicum L.

Puccinia graminis, Pers. P. triticina, Eriks.

Triticum vulgare Vill. Pnccinia graminis, Pers. P. triticina, Eriks

Urtica dioica $\mathrm{L}$.

Puccinia caricis (Schum.) Reb. I. (Aecidium urticae Schnm.)

Velleia macrocalyx De Triese.

Puccinia saccardoi, Ludw.

Velleia paradoxa $\mathrm{R}$. Br. Puccinia saccardoi, Ludw.

Veronica L.

Aecidium veronicae, Berk.

Veronica calycina R. Br. Aecidium disc, forme, McAlp.

Veronica gracilis $\mathrm{R}$. $\mathrm{Br}$. A ecidium disciforme, McAlp.

Vicia faba L.

Uromyces falıe (Pers.) De Bary.

Vigna catjang Walp. Uromyces appendiculatus (Pers.) Link.

Viola betonicifolia Sm.

P'uccinia hederaceae, McAlp. 
Viola hederacea Litbill.

Puccinia hetieraceac, MicAlp.

Vittadinia australis Rich.

Puccinia vittuliniae, McAlp.

Wurmbea dioica F. v...l.

Pruccinia wurmbeae, Cke. and Mass.

Uredo anguillariae, Cooke.

Xanthosia pusilla Bunge.

Puccinia xanthosiae, McAlp.
Zea mays $\mathrm{I}$.

l'uccinia maydis, Bereny.

Zornia diphylla l'er.

Puccinia zorniae (Diet.) McAlp.

Zygophyllum billardieri I)C.

Uromyces vesiculosus, Wint.

Zygophyllum glaucescens F. V.M.

Uromy"ces vesiculosus, W'int. 


\section{FUNGUS INDEX.}

Synouyms in italies:. "Species excluded from Antralia; †ouhtful species.

Aecidium Pers.

*apocyni, Schwein. (See Caeoma apocyni, MIcAlp., p. 193)

*larbareae, DC. (See Puccinia cruciferae, McAlp., p. 1S4)

*bellidis, Thuem. (see Pnccinia distincta, MicAlp., p. 156)

bossicueae, P. Henn. = Aecidinm elurneum, McAlp.

calendulae, McAlp. = P'uccinia calendulae, McAlp.

ealthae, Grev.-Caltha introloba

Eli. \& Ev. I.

$\cdots$
$\cdots$
$\cdots$

clematidis, DC. = Puccinia agropyri, Ell. \& Ev. I. _.. ..

* compositarum, Mart. (See Puecinia tasmanica, Diet., p. 163)

cymbonoti, Thuem. - Cymbonotus lawsonianus ... . . . . . .

cystose iroides, Berk. = Puccinia opereulariae (Morr.) Sycl. I. $\quad \ldots$

$\begin{array}{lll}\text { deeringiae, Cke. and Mass. - Deeringia celosioides } & \ldots \\ \text { disciforme, McAlp. - Veronioa calycina, } V \text {. gracilis } & \ldots\end{array}$

$\begin{array}{llll}\text { disseminatum, Berk.-Hypericum japonicum } \ldots & \ldots & \ldots & \ldots \\ \text { eburneum, McAlp.-Bossiaea cinerea, B. heterophylla, B. linophylla, } & \ddot{B}\end{array}$

PAGE.

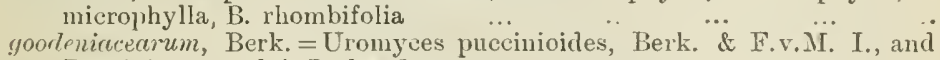

Puccinia saccardoi, Ludw. I.

impatientis, Schw. = Puccinia inpatientis (Schw.) Arth. ...

lobelicu, Thuem. = Puccinia aucta, Berk. \& F.v.M. I.

microstomum. Berk, = Puccinia aucta, F.v.M. I.

monocystis, Berk.-Abrotanella forsterioides ...

nymphoidis, DC.-Limnanthemum indieum $\ldots$

oleariae, McAlp.-Olearia axillaris

perkinwiat, P. Henn.= P. gilgiana, P. Henn. I.

* plantaginis, Ces. (See A. plantaginis-variae, McAlp., p. 19.5)

plantaginis-rariae, MeAlp.-Plantago varia ... ...

platylobii, McAlp. - Platylobium formosum ... ...

plectroniae, Cke.-Canthium (Plectronia) coprosmoides
ranunculacearum, DC.-Ranunculus sp., R. gunnianus, R. lappacens, R.

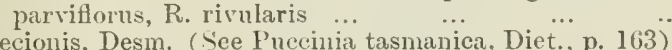

** senecionis, Desm. (See Puccinia tasmanica, Diet., p. 163)
soleniiforme, Berk. - Goodia lotifolia ...

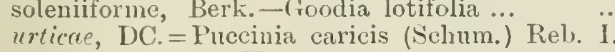

relonicae, Berk.-Teronica sp.

*violae, Schum. (See Puccinia hederaceae, Mc $\mathrm{Alp} ., 1 \% .1 \mathrm{~s} 3$ )

vittceliniae, McAlp. = Puccinia vittadiniae, McAlp.

Caeoma Link

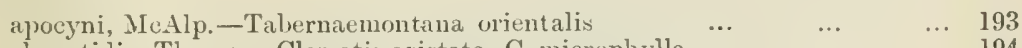

Cronartium Fr. ..

*asclepiadeum (Willd.) Fries (See C. jacksoniae, P. Henn., p. 190)
jacksoniae, P. Henn.-Jacksonia scoparia, Aotus villosa, Bossiaea cinerea, Gompholobium latifolium, Platylobium formosum $\ldots$. ... $\quad .$.

Hamaspora Koern.

longissimu, Koern.=Phragmidium longissimum, Thuem.

\section{Melampsora Cast}

hypericorum (1)C.) Schroet.-Hypericum japonicum

lini (Pers.) T'u]. - Linum marginale, L. usitatissimum.

tnesolaphnes, Berk. and Br. Probahly a Hyphomycete ...

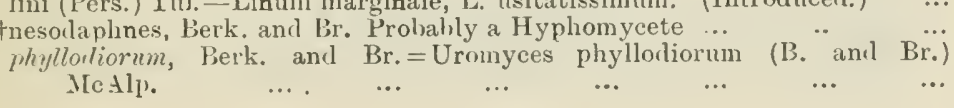


Phragmidium Link

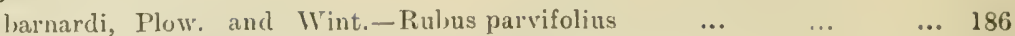

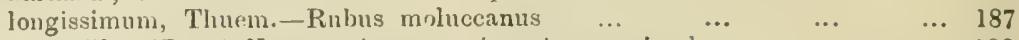
potentillae (Pers.) Karst. - Acaena ovina, A. sanguisorba $\quad \ldots . \quad \ldots \quad 188$ subcorticium (Schrank) Wint.-Rosa canina, R laxa, R. Inbiginosa.

$\begin{array}{lllllllll}\text { (Introduced). } & \ldots & \ldots & \ldots & \ldots & \ldots & \ldots & \ldots & 158\end{array}$

Puccinia l'ers.

$\begin{array}{lllll}\ldots & \ldots & \ldots & \ldots & 112\end{array}$

*acetosae (Schum.) Kocrn. (See P. ludwigii, Tepp. p. 17t) N $\ldots \quad$... 29\%

*aegra, Grove. (See P. hederaceae, McAlp., p. 1S3) $\ldots . \quad \ldots . \quad \ldots .208$

agropyri, Ell and Es.-Aeropyron scabrum II., III.; Clematis aristata I. 113

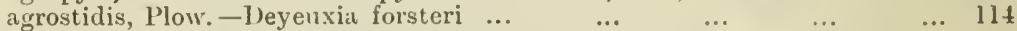

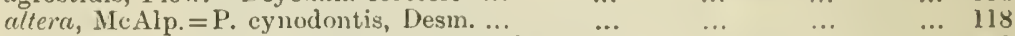

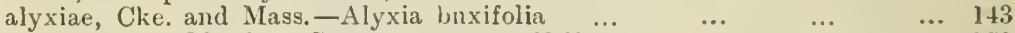

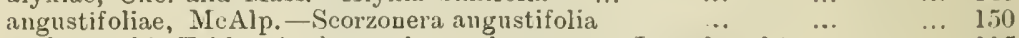

anthoxanthi, Fckl. - Anthoxanthum odoratum. (Introincer.) ... $\quad . . .115$

*apii, Desm. (See Puccinia thuemeni, McAlp., p. 168) ... ... ... 2us

alenariя (Schum.) Sehroet. - Stellinria media. (Introduced.) ...

aucta, Berk. and F.v.M.-Lobelia anceps, L. pratioides, L. purpurascens,

Pratia crecta, P. pedunculata, P. platycalyx $\quad \ldots . \quad \ldots \quad \ldots l 18$

beckmamniae, IIcAlp.-Beckmannia erucaeformis. (Introduce t.) $\quad \ldots .116$

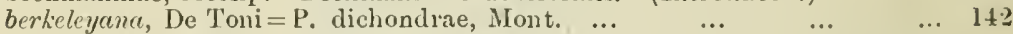

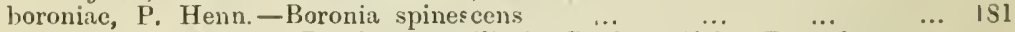

brachycomes, McAlp. - Brachycome ciliaris, B. diversifolia, B pachyptera,

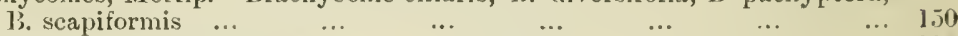

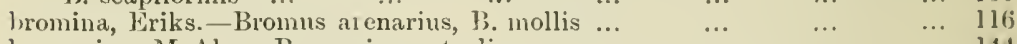

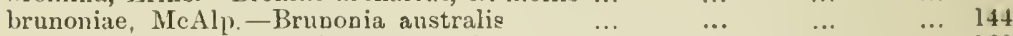

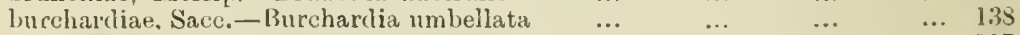

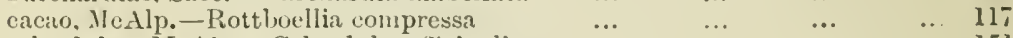

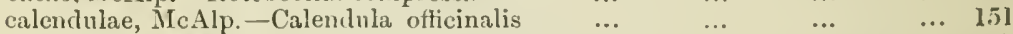

calocephali, McAlp.-Calocephalus drmmondii, C. lactens $\quad$... $\quad \ldots \quad 151$

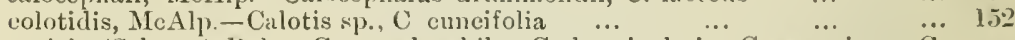

caricis (Schum.) Rel,-Carex alsophila, C. breviculmis, C. gunniana, C. inversa, C. panieulata, C. pedunculata, II., III. ; Urtica dioica I. I.. 133

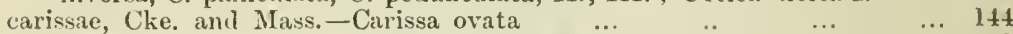

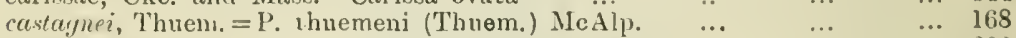
* caulincola, Cla. (See P. hypochoeridis, Oud., p. 159.)... $\quad \ldots . . .208$ chrysanthemi, Roze-Chrysanthemum indicum. (Introlucerl.) ... $\quad$... 153 cichorii (DC.) Bell._Cichorium intylus. (Introduced.)... $\quad \ldots . \quad \ldots \quad 154$

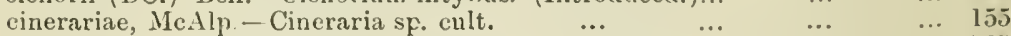

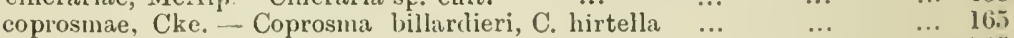

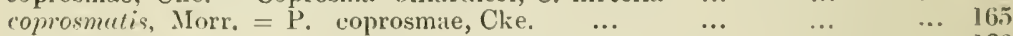

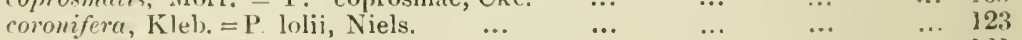

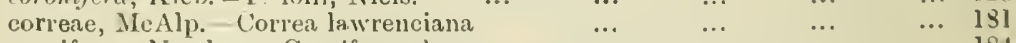

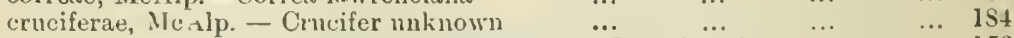

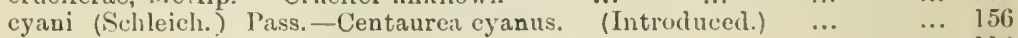

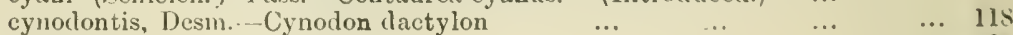

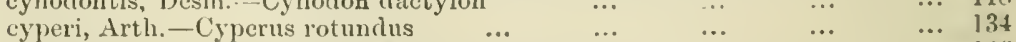

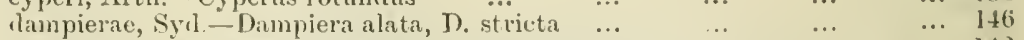

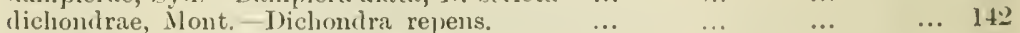

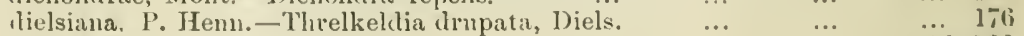
*lispersa Eriks. (Nee P. Jnmina, lriks, and P. triticina, Eriks.)...

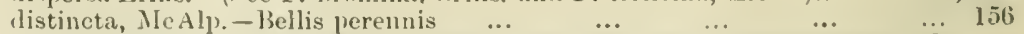
epilobii-tetragoni (DC.) Wint -- Epilobium sp., E. billardieranum, $\mathbb{E}$

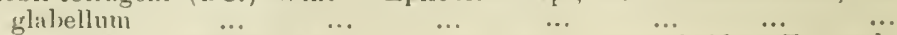
erechtitis, Medlp. Wrechtites sp., E. argnta, \#. prenanthoides, F. '[ual$\begin{array}{llllllll}\text { ridentata } & \ldots & \ldots & \ldots & \ldots & \ldots & \ldots & \ldots \\ 15\end{array}$ eriostemonis, McAln...Eriostemon myoporoiles festucae, Plow.-Festuca nvina, F. rigita. (Introdnceil.) $\quad \ldots . \quad \ldots .119$ flavescentis, McAlp. - Stipra tlavescens, S. semilırbatia $\quad \ldots . \quad \ldots$ II!

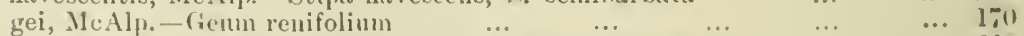

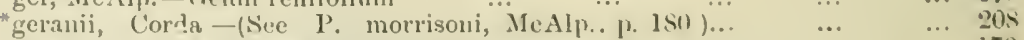

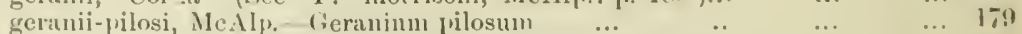

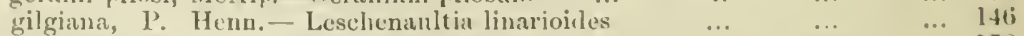
gnaphalii, (speg.) P. Henn-Cnaphalium japonicum, G. purpuremu ... 15s

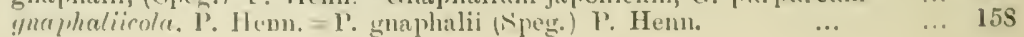


graminis, Pers.-Agropyron dirergens, A. scabrum, Alopecurus geniculatus, Amphibromus neesii, Avena fatua, A. sativa, Berkmannia erucaeformis, Briza minor, Bromus racemosus, B. secalinus, B. sterilis, Dactylis glomerata, Deyeuxia quadriseta, Echinopogon ovatus, Elymus striatus, E. virginicus, Festuca bromoides, Glyceria dives, G. stricta, Hordeum murinum, H. secalinum, H. vulgare, Phalaris canariensis, P. minor, Secale cereale, Triticum polonicum, T. vulgare. (Introdnced.) ...

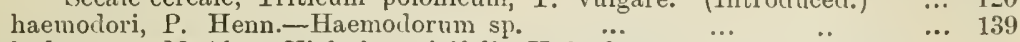

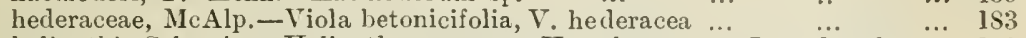
helianthi, Schwein.-Helianthus annuus, $\dot{H}$. tuberosus. (Introduced.) … 155 heterospora, Berk. and Curt. - Abutilon avicennae, A. crispum, Hibis-

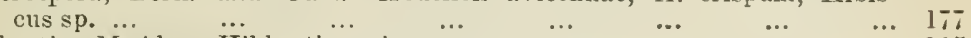

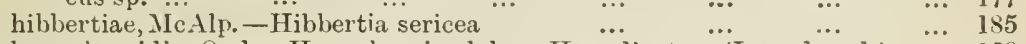
hypochoeridis, Oud. - Hypochoeris glabra, H. radicata. (Introduced.) $\quad \ldots .159$ hypochoeridis, MICAlp. - P. macalpini, Syd.)=P. lagenophorae, Cke. $\quad \ldots .161$

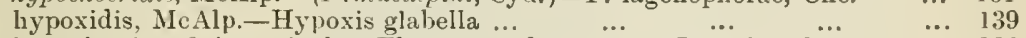
impatientis, (Schw.) Arth._Elymus condensatus. (Introduced.) $\quad . . .123$

*investita, Schw.-(See P.gnaphalii (Speg.) P. Henn. … ... $\quad \ldots .15 \mathrm{~S}$ juncophila, Cke. and Mass.-Juncus effusus, J. maritimus, J. pallidus $\ldots . .136$ kalchbrenneri, De Toni-Helichrysum sp. kochiae, Mass. - Enchylaena tomentosa, Kochia sedifolia, K. villosa $\quad \ldots . \quad 176$

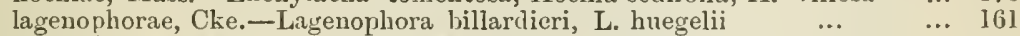
lolii, Niels.-Avena fatua, A. sativa, Lolimm perenne. (Introduced.) … 123

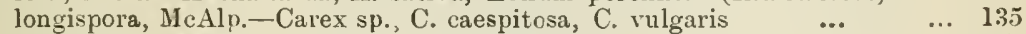

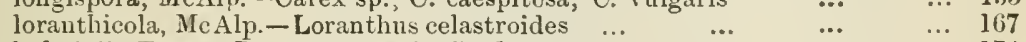

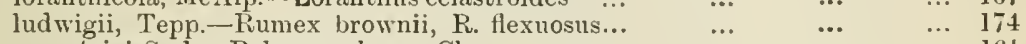

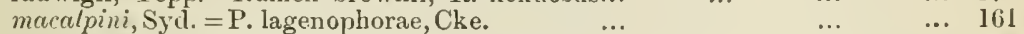

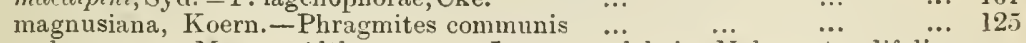

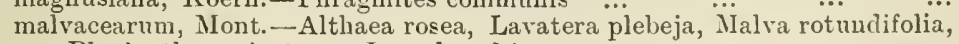

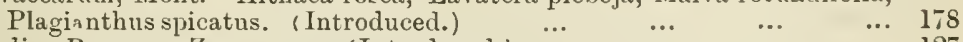

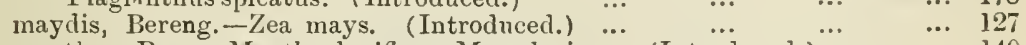
menthae, Pers.-Mentha laxiflora, M. pulegium. (Introduceci.)... $\quad \ldots \quad \ldots \quad 140$

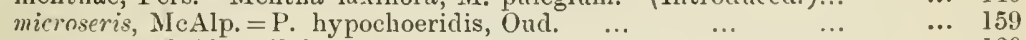

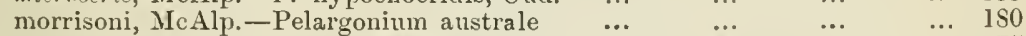
muehlenbeckiae (Cke.) Syd.-Muehlenbeckia adpressa, … gracillima $\quad \ldots . \quad 175$

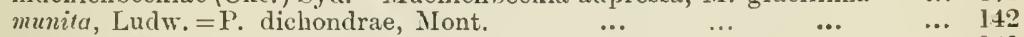

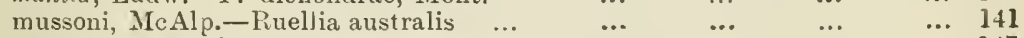

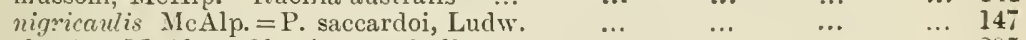

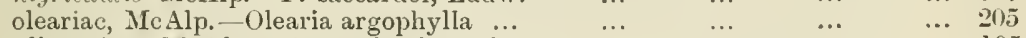

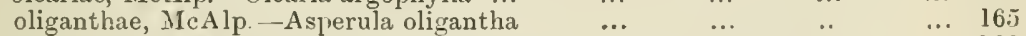
operculariae (Morr.) Syd._Opercularia aspera, O. varia $^{\ldots} \quad \ldots . \quad \ldots .166$

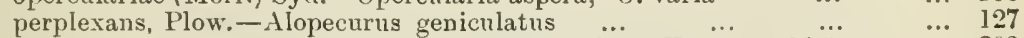
* phragmitis (Schum.) Koern. - (See P. magnusiana, Koern, p. 125) $\quad \ldots .208$

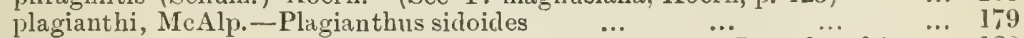
poarum, Niels. - Poa annua, P. caespitosa, P. pratensis. (Introduced.) ... 128

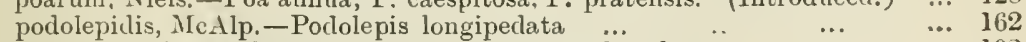

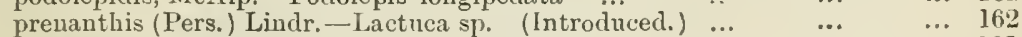

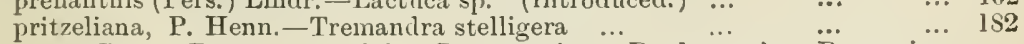
pruni, Pers.-Prunus anygdalus, $\mathrm{P}$. armeniaca, P. domestica, $\dddot{\mathrm{P}}$. persica.

$\begin{array}{lllllllll}\text { (Introduced.) } & \ldots & \ldots & \ldots & \ldots & \ldots & \ldots & \ldots & 171\end{array}$ purpurea, Cke.-Sorghum halepense, ${ }^{\text {.. }}$ s. vulgare. (Introduced.) * rimosa, Link.-(See Uredo scirpi-nodosi, McAlp., p. 203) ... $\quad \ldots .208$

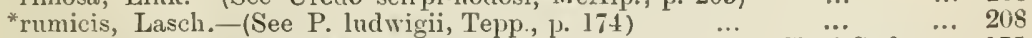
rumzcis-scutati var. muehlenberkicie, Cke.=P. muehlenbeckiae (Cke.) Syd. ... 175 saccardoi, ludw. - Goorlenia albiflora, G. geniculata, G. glanca, G. hederacea, G. ovata, G. pinnatifida, Velleia macrocalyx, V. paradoxa ... 147 simplex (lioern.) Eriks. anil Henn.-Hordeum vulgare. (Introduced ) ... 130 sorthi Schw. =P. maydis, Bereng., and P. purpurea, Cke. (Introduced.) 127, 129

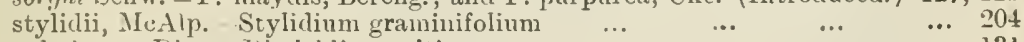

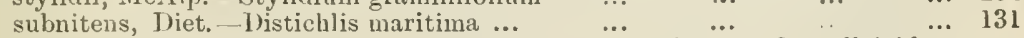
tasmanica, Diet. - Senecio brachyglossus, S. pectinatus, S. velleioiles, S. vulgaris

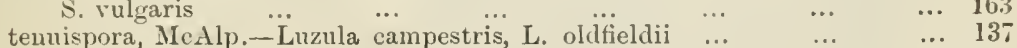

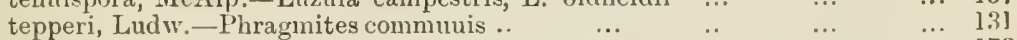

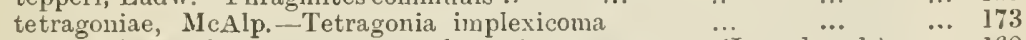
thuemeni, McAlp. - A pium graveolens. A. prostratum. (Introduced.) $\ldots .16 \mathrm{~S}$ triticiua, Eriks. - Triticum vulgare. (Introduced.) 
Puccinia Pers. - continuerl.

*violae, (Schum.) DC.-(S'ce I. hederuceae, McAlp), j. 18:3)

rittadiniae, McAlp. - Vittadinia australis ... J ...

... $\quad$... था

wurmbeae, Cke. and Mass. - Wurmbea dioica ... xanthosiae, McAlp. - Xanthosia pusilla

zorniae (Diet.) MeAlp. -\%ornia diphylla

-...

-.. $\quad \cdots$

$\begin{array}{lll}\ldots & \ldots & 16 j t \\ \cdots & \ldots & 135\end{array}$

Uredo Pers.

$\begin{array}{lllll}\ldots & \ldots & \ldots & \ldots & \ldots \\ \text { angiosperma, Thuem. }- \text { Hakea sp. } & \ldots & \ldots & \ldots\end{array}$

armillata, Lndw. = Puccini 2 juncophila, Cke. anil Mass.

bidentis, 1 '. Henn. - Bidens pilosa $\quad \ldots \quad$...

bossiaeac, iIcAlp. - Bossiaea prostrata

* cichoracearum, DC.-(See Uredo bidentis, P. Henn., p. 204 )

clematiclis, Berk. - Cieoma clematidis, Thuem.

crepiclis-japonicae, Lindr.-Crepis japonica

ehiharfae, IIcAlp. = Uromyces ehrhartae, $\mathrm{McAl}$.

geitonoplesii, McAlp — Geitonoplesium cymosmu

maphalii Speg. = Precinia gnaplalii (Speg.) P'. Henu. ...

kuehnii, Krueg, -Siccharum officinarum. (Introducel.)

*leguminum, Desm. - Acacia sp.

notcbilis, Lndw. = Uromycladium notabile (Lurw.) McAlp.

pallidula, Cke. and Mass - Cassia sp. ... ... ...

rhagodiae, Cke, and Mass. -Rhagorlia billardieri

rotthoellice, Diet. = Purcinia cacao, AlcAlp.

schellammerae, McAlp. - Schelhammera undnlata

scirpi-nodosi, McAlp.-Scirpus norlosus

sorghi, Fckl. = l'u.cinia purpurea, Cooke.
spyridii, Cke. and Mass. - Ponaderris apetala, Spyri,lini. parvifolium

... 169

$\begin{array}{lll}\cdots & \cdots & 17 \cdot 2 \\ \cdots & \cdots & 170\end{array}$

$\begin{array}{lll}\cdots & \ldots & 202 \\ \ldots & \ldots & 006\end{array}$

$\begin{array}{lll}\cdots & \cdots & -\ldots \\ \cdots & \ldots & 203\end{array}$

$\begin{array}{lll}\ldots & \ldots & 1365\end{array}$

$\begin{array}{lll}\ldots & \ldots & 204\end{array}$

... $\quad \ldots 206$

$\begin{array}{lll}\ldots & \ldots & 209\end{array}$

$\begin{array}{llll}\ldots & \ldots & 194\end{array}$

$\begin{array}{llll}\cdots & \cdots & 1 & 1 \\ \cdots & \cdots & 20.5\end{array}$

$\begin{array}{lll}\ldots & \ldots & \$ 6\end{array}$

$\begin{array}{lll}\ldots & \ldots & 203\end{array}$

.. $\quad \ldots \quad 1.55$

$\begin{array}{llll}\ldots & \ldots & 202\end{array}$

$\begin{array}{lll}\ldots & \ldots & 209\end{array}$

… $\quad \cdots \quad 105$

$\begin{array}{lll}\ldots & \ldots & 206\end{array}$

206
$\cdots \quad 207$

... 117

‥ 203

‥ $20: 2$

... 129

‥ 204

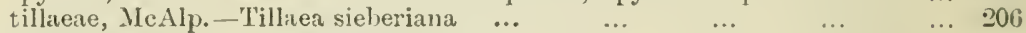

Uromyces Link

*anygdali, Puss. (See Puccinin pruni, Pers., 11. 171)

appendisulatus, (Pers.) Link - Tigna catjang. (Intruducerl.)

asperulae, MeAlp - Aspernla oligantha

asteri, McAlp. = Ureclo dubia, McAlp....

atriplicis, McAlp.-Atriplex semibaccatum …

betae (Pers.) Kuehn.-Beta inlgaris. (Introduced.)

bicinctus, MuAlp. - Acacia fascicnliferia

bulbinis, Thuem.-Bulline bulbosa

caryophyllinus (Schrank) Sichroet. - Dianthus caryophylius, D chinensis.

(Introshuced.)

danthoniae, MeAip. - Danthonia sp., D. semiannularis

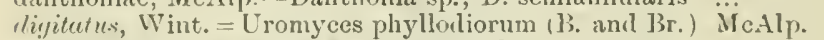

diploglottilis, Cke. and Mass. - Diploglottis cunninghamii

ehrhartae, IICAlp - Iicrolaena (Ehrharta) stipoilles ...

fabae (Pers.) De Bary. - Vicia faha. (Introduced.)

fusisp irus, Cke. aud Mass. - Acacia neriifolia, $A$ salicina

hardenbergiae, Mc $\mathrm{H}_{0}$ - Hardenbergia (Kemerlya) monophylla

*junci (Desm.) Tul. - (Sec Puccinia juncophila, Ćke, and Mass. p. 136.)

knehnii, Krueg = Uredo kuehnii, Krueg.

limosellae, Ludw.-Limosella aquatica...

microtidis, Cke - Microtis porrifolia

orehidearum, Cke. and Mass - Chiloglottis diphylla, C. gunnii

phaseoli (Pers.) Wint = Uromyees appendienlatus (l'ers.) Link. phyllodice, Cke. and Mass. = Üromyces phyllodiorm (B. and Br.) McAlp. phyllotiorum (B. and Br.) Nc.Alp.-Acacia sp., A. dallachiana, A. micro-

botrya, A. nerifolia, A notabilis, A. pouninervis, A. pruinosa 
PAGE.

Uromycladium $\mathrm{McAl}$.

alpinum, McAlp.-Acasia buxifolia, A. dallachiana, A. dealbata, A. implexa,

A. linifolia
bisporum, XeAlp.-Acaeia dealbata
maritimum, MeAlp. - Acacia longifolia

$\begin{array}{lll}\cdots & \cdots \\ \cdots & \cdots\end{array}$

notabile (Ludw.) McAlp. - Acacia line

$\ldots \quad \ldots 105$

104 elata, A. notabilis, A. pruinosa

robinsoni, McAlp.-Acacia melanoxylon

dealliata, $A$, decurrens, $A$.

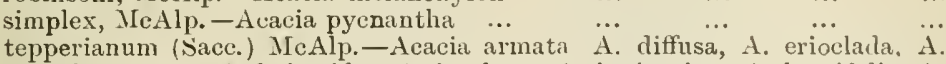

$\cdots$

... $\quad \ldots \quad 100$ glaucoptera, A. hakeoides, A. implexa, A. juniperina, A. longifolia, A. melanoxylon, A. myrtifolia, A. pyenantha, A. rigens, A. salicina. A. siculiformis, A. spinescens, A. stricta, A. verniciflua, A. verticillata, A. vomeriformis ... 



\section{GENERAL INDEX.}

$\begin{array}{llrr} & & & \\ \text { Acacia, gall fungi } & \ldots & \ldots & 5\end{array}$

$\begin{array}{llll}\text { Kangaroo } & \ldots & \ldots & 6\end{array}$

Acacia cormatce

dealbata

decurrens

implexa

pycnanthe

salicina

Aecidiospores, binucleate ...

coloured membrane in Gymno. sporangium ...

$\begin{array}{llll}\text { colouring matter } & \ldots & \ldots & 16\end{array}$

development $\quad . . . \quad 17$

distinction from ureclospores 36

germination in Puccinia $\begin{array}{llll}\text { tasmanira } & \ldots & \ldots & 16\end{array}$

$\begin{array}{lllll}\text { infection } & \ldots & \ldots & 16\end{array}$

$\begin{array}{llll}\text { origin } & \ldots & \ldots & \ldots 17,36\end{array}$

partaking of character of

teleutospores $\quad \ldots \quad$...

repeated formation... ...

retention of germinating $\begin{array}{lllll}\text { power } & \ldots & . . & \ldots & 16\end{array}$

Aecidium, colour $\quad$... $\quad$.. 16

$\begin{array}{llll}\text { development } & \ldots & \ldots & 17\end{array}$

invigorating power $\quad$... $\quad 17$

in heteroecious species $\quad . . \quad 58$

on grass $\ldots . \quad \ldots \quad \ldots 18,57$

on seeds $\ldots \quad \ldots . \quad \ldots \quad 70$

$\begin{array}{llll}\text { origin } & \ldots & \ldots & \ldots 17,75\end{array}$

$\begin{array}{lll}\text { paraphyses } & \ldots & 22,36\end{array}$

$\begin{array}{lllll}\text { peridium } & \ldots & \ldots & \ldots & 17\end{array}$

primary and secondary $\quad . . \quad 18$

pseudoperidial cells $\quad$... $\quad 17$

repeated formation $\quad \ldots \quad$ is

$\begin{array}{llll}\text { sterile cells } & \ldots & \ldots & 16\end{array}$

$\begin{array}{lll}\text { sexuality } & \ldots & 14,17,75\end{array}$

Aecidium abietinum $\quad$... $\quad . . \quad 56$

$\begin{array}{lllll}\text { bellidis } & \ldots & \ldots & \ldots & 209\end{array}$

berberidis, spore germination $\quad 16$

$\begin{array}{llll}\text { importatum } & \ldots & \ldots & 61\end{array}$ platylolii, mycelium in seed 70

Algae

Alopecurus pratensis with Puc$\begin{array}{llll}\text { cinia graminis } & \ldots & \ldots & 68\end{array}$

$\begin{array}{lllll}\text { Amphispore } & \ldots & \ldots & \ldots & 25\end{array}$

$\begin{array}{llll}\text { germination } & \ldots & \ldots & 25\end{array}$

Ancegallis aremesis, importation 43

Anchusu $\quad \ldots . \quad \ldots \quad \ldots .53,80$

Anthomyces $\quad \ldots \quad \quad \ldots . \quad \ldots \quad 84$

Apium, grareolen (Prccinia) $\quad$.. 42 prostratum (Pucciniu) $\quad$... 42

Appressorium

Asclepiateae, Cronartiun $\quad$... 53

Ascomycetes ... $\quad$... $\quad . . \quad 40$

Asparagus rust (Puccinia axparagi), (listributed by wind 7

water relation 9

Atmospheric influences on spore $\begin{array}{llll}\text { germination } & \ldots & \ldots & 10\end{array}$

Auriculariaceae $\quad$... $\quad . . .-32$

Australian rusts, number $\quad \ldots \quad 50$ $\begin{array}{llll}\text { distribution } & \ldots & \ldots & 51\end{array}$
Autoecious species

most numerous

repetition of aecidia $\quad \ldots \quad 18$

Avena elation with Puccinia $\begin{array}{llll}\text { graminis } & \ldots & \ldots & 6 S\end{array}$

$\begin{array}{lllll}\text { Bueodromus } & \ldots & \ldots & \ldots & 33\end{array}$

Barberry, connexion with wheat $\begin{array}{llll}\text { rust } \quad \ldots & \ldots & \ldots 55,58\end{array}$ in Australia $\quad \ldots \quad \ldots \quad 66$ infection experiments, local $\quad 66^{3}$ in Kew gardens $\quad \ldots \quad \quad \ldots \quad 68$

Barberry rust (Accidium ber$\begin{array}{lllll}\text { beridis) } & \ldots & \ldots & \ldots & 16\end{array}$

absent in Australia $\quad \ldots .6 \quad 66$

connexion with wheat rust ... 55

increasing vigor of wheat rust $5 \mathrm{~S}$

local attempts at inoculation $\quad 66$

$\begin{array}{lllll}\text { Barclayella } & \ldots & \ldots & \ldots & 33\end{array}$

$\begin{array}{llll}\text { Basickia in aecidia } & \ldots & \ldots & 16\end{array}$

$\begin{array}{llll}\text { Basidiomycetes } & \text {... } & \ldots & 40\end{array}$

Bean rust (Uromyces fabae) $\quad$... 20

Beckmanniaerucaeformis, importation of rust on seed $\quad . . \quad 43$

Beet rust (Uromyces betue) $\quad$... 84

$\begin{array}{llll}\text { Binucleate spores } & \ldots & \ldots & 14\end{array}$

Biologic forms, and classification $\quad 79$ evolution of $\quad \ldots \quad \ldots . \quad 54$

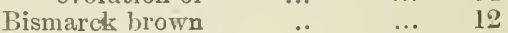

Black wattle gall fungus (Uromycladium notabile) $\quad$... 6

$\begin{array}{llll}\text { Brachypuccinia } & \ldots & \ldots & 11\end{array}$

Bremia lactuca, effect of copper $\begin{array}{lllll}\text { salts } & \ldots & \ldots & \ldots & 63\end{array}$

$\begin{array}{llll}\text { Briclging species } & \ldots & \ldots & 53\end{array}$

Brome rust (Puccinia bromina) ... 3

infection by uredospores ... 3

starvation of host ... $\quad \ldots \quad 60$

uninfluenced by structural peculiarities of leaf $\quad \ldots \quad 61$

Brown Rust (Puccinia dispersa) ... $\quad 79$

Burning stubble, effect on wheat

$\begin{array}{ccccc}\text { rust } \quad \ldots & \ldots & \ldots & 72\end{array}$

$\begin{array}{lllll}\text { Caeoma } & \ldots & \ldots & \ldots 17,36\end{array}$

Caeomospores ... $\quad \ldots \quad$... 36

Carnation lust (Uromyces caryophyllinus) $\quad$... $\quad .$.

Caustic potash for softening tissues 12

Cecilomyia, eating rust spores ... 7

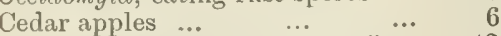

Celery rust (Pücinia thuemeni) ... $\quad 42$

Cereal rusts not liable to affect other cereals indiscrimin$\begin{array}{lllll}\text { ately } & . . & \ldots & \ldots & 53\end{array}$

Chemotaxis, parasitism due to positive and negative $\quad \ldots 52,62$

Chickweed rust (Puccinia aren$\begin{array}{lllll}\text { aricie }) & \ldots & \ldots & \ldots & 42\end{array}$

Chicory rust (Pucinia cichorii) .. 42

Chrysanthemnm rust (Puccinice chrysanthemi) $\quad$... $\quad \ldots \quad 21$ germination of uredospores 21 $\begin{array}{llll}\text { importation } & \ldots & \ldots & 43\end{array}$ 
PAGR.

Chrysomyxa, absence of fir trees germination of teleutospore origin of speeies in Alps ...

uredospores in ehains $\quad . . \quad 19$ ysomyxu, abietis $\quad \ldots . \quad \ldots .56$

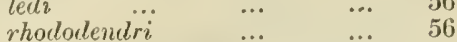

Chrysopsora, teleutospore of exeeptional form

Classification and biologie forms of Uredines

79

Clover rust (Uromyces irifolii) ... 18, 84

Cluster cups ... $\quad$... $\quad \ldots \quad 16$

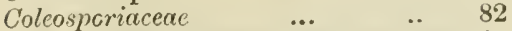

Coleosporium, function of parapliyses 30 teleutospore in $\quad$.. $\quad \ldots . \quad 32$ uredospores in chains $\quad \ldots . \quad 19$

Colecsporium senecionis, and fir trees 58

Collemu, fertilisation in $\quad$... 37

Compositae, native rusts on $\quad . . \quad 45$

Compound telentospores $\quad$... 24

Copper salts, influence on fungi ... $\quad 62$

Cronartiaceae ... $\quad . . . \quad 82$

Cronartium, asclepiadeum on varied hosts ...

jackisoniae producing witches' brooms ... ... ...

Crossbrceding wheats for rustresistance $\quad . . . \quad \ldots$

Crown or coronate rusts $\quad .$.

Cucumber cliseases and eopper salts

Cycle of development, in heteroecious species $\quad \ldots \quad$... 58

in rusts ... $\quad \ldots \quad \ldots 2,10$

$C y p e r a c e r e$, number of native rusts $\begin{array}{lllll}\text { on } \quad \ldots & \ldots & \ldots & 45\end{array}$

$\begin{array}{llll}\text { Dactylis glomerata } & \ldots & \ldots & \ldots\end{array}$

Disy rust (Puccinia listincta) $\quad$... $\quad 10$ introduced on sced... $\quad$... 209

Danthonia aecidium $\quad \ldots . \quad \ldots 18,57$

Uarluce filum, a common parasite 22 mistaken for spermogonia $22,158,165$

Development of fungi $\ldots \quad$... 40

Dew necessiry for infection $\quad$... 10

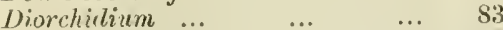
doulstul genus $\quad \ldots \quad \ldots$.

Distribution of Austrilian species 50

Distribution of spores... $\quad$... 7

1) oubtful species $\quad \ldots \quad \quad \ldots \quad 207$

Drainage, effect on rust $\quad$... 71

Dry atmosphere and spore ger$\begin{array}{llll}\text { mination } & \ldots & \ldots & 10\end{array}$

Farly maturing wheat eseiping rust it

lichinulate medospores... $\quad$... 19

liffect of rust on straw and grain

Llymus condensatus, importation of l'ust on seed ... ...

Endcchrome 17

Endophyllum, teleutospores $\quad \ldots$.

Endospore, in aecirliospores $\quad \ldots \quad 16$ in teleutospores $\quad \ldots \quad$... $\quad 23$

binzymes in leaf cells ... $\quad$... $\quad 54$

lisispore of teleutospore $\quad$... $\quad 23$

lipiteospores ... $\quad$... $\quad \ldots . .20$

Eirysiphaccae, specialisation of parasitism ... ...

Erysiphe graminis, biologic formis

Eucalyptus ylobulus, supposed rust
Euphorliu, aecidinm of Pea rust 55 $\begin{array}{lllll}\text { dentata } & . . & \ldots & \ldots & 70\end{array}$ rust (Uromyces euphorbiae) ... $\quad$ 70

Eupuccinice $\quad$.. $\quad$... $\quad$... 11

Excluded species $\quad$... $\quad \ldots \quad 207$

Fallowing, effect on rust $\quad$... $\quad 72$

Fertilisation, in aecidium $\quad . .17,75$ in Uredineut $\quad \ldots \quad \ldots 14,75$

Fir trees and rust $\quad . .5 \quad 5 S$

Flax rust (Melamp:ora lini) _.. 43, 60 first record in Australia ... 44

Formalin treatment of seed wheat 73

Frangula alnus $\quad$... $\quad$... 53

Fungi, origin and development ... 40

Fusion of nuclei $\quad . . . \quad \ldots 14,75$

Gall formation... $\quad \ldots \quad \ldots \quad$ j

Gall fungi, on wattles (Aeacias) ... 6

Genera, Austrulian, and number of $\begin{array}{llll}\text { species ... } & . . & \ldots & 50\end{array}$

General parasites $\quad \ldots . \quad \ldots \quad 53$

Germinating power, duration, in aecidiospores $\ldots . \quad \ldots \quad 16$

in teleutospores $\quad \ldots \quad$... $\quad$ S

in uredospores $\quad \ldots \quad \ldots, \quad \ldots, 21$

Germinating spores, methods for aecidiospores and uredosnores ... $\quad . .6 \quad \ldots . \quad 7$

telentospores $\quad \ldots \quad \ldots 6 \quad 66$

Germination, of aecidiospores of $\begin{array}{lll}\text { Puccinie tasmanice } & \text {... } & 16\end{array}$

of amphispores $\quad$.. $\quad \ldots . \quad 25$

of teleutospores, factors influencing $\quad . . \quad$.. s of Puccinia grammis $\quad 8,24,66$ of $P$. maleacearum $\quad$.. 24, 27 of Phragmidium rubi abnornal ... ... ... 35

of mredospores, of Puccinia bromina $\quad \ldots \quad \quad \ldots \quad 3,8$ of $P^{\prime}$. chrysanthemi $\quad \ldots \quad 21$ of $P$. dispersa $\quad \ldots \quad$... 3 of $P$. yraminis ... $\quad$... 21 of $P$ rubigorcra... $\quad$... of $I^{\prime}$ triticina $\quad \ldots \quad$... 21

Germ-pores, demonstrating $\quad \ldots \quad$ 12

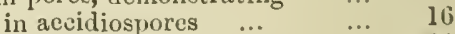

in teleutospores ... $\quad . . . \quad 24$ of I'uccinia porlolepillis ... 35

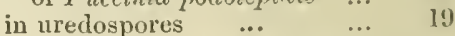
solitary in I'uccinia monopore ... ...

Glycerine, and water ... $\quad \ldots . .1 \%$ $\begin{array}{lllll}\text { jelly } & \ldots & \ldots & \ldots & 12\end{array}$

Golden rust (P’urcinia glumarum) 73

Folden wattle galls $\ldots .60 . . .6$

Gradations of specific variation ... $\quad 79$

Gramineae, native rusts on ... 4.

Cirass accidium $\quad \ldots \quad \ldots 1$... 57

Grasses, and heteroecious rusts ... 57 and wheat rust $\ldots . \quad \ldots .69$

Groundsel rust (Puceinia tar-
manica)

Gymnoconin, characters... $\quad \ldots \quad s 3$

Gymnosporanyium, recidiospores colored nembrane 6

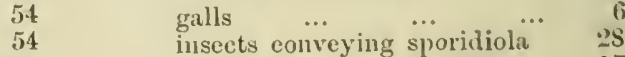
49) sculpturing of periulial cells ... 17 
Gymnosporangium clavariaeforme, direct infection by teleutospores ...
confusum, separating $\quad \ldots$... teleutospores, thickness of cell wall $\quad \ldots . \quad \ldots$

Hapalophragmium $\quad \ldots . \quad \ldots$

Hard 1 issues, softening... ...

Harresting methods and rust ...

Haustoria $\ldots$...

Hawthorn $\quad \ldots . \quad \ldots, \quad \ldots$

Helianthus anmus, aecidia

Hemiluasidii

$\begin{array}{lllll}\text { Hemileia } & \ldots & \ldots & \ldots & \text {.. } \\ \text { Hemipice } & \ldots & \ldots & \text { S3 }\end{array}$

Hemipuccinia... $\quad \ldots \quad$... 11

Heteroecious species $\quad \ldots . \quad \ldots . \quad 53$

indigenous $\quad \ldots \quad \ldots \quad$... 45

regular development $\quad$... $\quad 57$

$\begin{array}{lllll}\text { Heteroecism ... } & \ldots & \ldots & 55\end{array}$

beneficial ... $\quad \ldots \quad$... 58

causing increased vigor $\quad \ldots .5$...

discnvery ... $\quad$... $\quad$... 55

$\begin{array}{lllll}\text { origin } & \ldots & \ldots & \ldots & 55\end{array}$

when possible $\quad \ldots \quad$... 55

Heracium, Puccinia ... $\quad$... 80

Hollyhock rust (Puccinia malvace$\begin{array}{lll}\text { arum) } & \ldots & \ldots\end{array}$ wide distribution $\ldots .$.

Holobasidlii $\quad . . \quad$...

Honeydew of spermogonia $\quad$...

Host and parasite, relation
Host-plants, imported, and new rusts $\ldots$... .. indigenous, and rusts $\quad .$. starved $\ldots$... $\quad$...

Hot-water treatment of seed $\quad \ldots \quad 73$

Hypertrophy of nettle $\quad$... $\quad 6$

$\begin{array}{llll}\text { Hyphae } & \ldots & \ldots & \ldots\end{array}$

Immunity acquired $\quad \ldots \quad \quad \ldots \quad 60$

and predisposition.. $\quad$... 60

attempts to secure ... ... 62,75

due to physiological peculiar $i$. ties

factors infiuencing ...

Importation of rusts ...

on cuttings . ...

on seed ...

...

on straw ...

$\begin{array}{ccc}\text { on straw } \ldots & \ldots & \ldots \\ \text { Incubation period } & \ldots & . .\end{array}$

Indigenous species, table of $\quad .$. and hosts ... $\quad . . \quad \ldots$ heteroecious $\quad \ldots . \quad \ldots$

Infection, aided by injury and age of parts attacked ... by aecidiospores ... ... by internal germ of disease... by sporidiola germ tubes enteringstomata by teleutospores ... by uredospores ... ... germ tubes piercing epidermal cells

dew necessary for ... ... experiments, with barberry in Australia with foreign host plants factors influencing
Injuries, influence on infection ... Inoculation, protective... ... Insects attracted, by colour of $\begin{array}{llll}\text { spores } \ldots & \ldots & \ldots & 3 S\end{array}$ $\begin{array}{llll}\text { by honeydew } & \ldots & \ldots & \\ \text { by } & \ldots & \ldots & 13\end{array}$ by scent of spermogonia ... 13 $\begin{array}{lll}\text { conveying sporidiola } & \ldots & 28\end{array}$ eating spores $\quad \ldots \quad \quad \ldots .7$

Intermerliate hosts of wheat rust 70

Internal developmental tendencies $\quad 53$

Introduced species $\quad$... $\quad$... 42 how introduced $\quad \ldots \quad$... on native hosts $\quad . . \quad \ldots 42,49$

Investigation of spores... $\quad \ldots, \quad 11$

Irrigation and wheat rust $\quad . .671$

Kangaroo thorn, gall fungus ... 6 Knot-wetd rust (Uromyces polygoni) 43

Lactic acid showing upgerm pores 12

Ledum pulustre $\quad$... $\quad$... $\quad 56$

Leguminosae, native rusts on $\quad . . \quad 45$

Leptopuccinia ... $\quad$... $\quad \ldots, \quad 11$ one species with warted epipspore ... ...

Lettuce, attempt to confer immunity from disease $\quad$... 63

Liability to disease $\quad . .6 \quad \ldots .60$ influenced or not by structural characters

Lichen-furgi ...

... $\quad$... 37 fe-cycles of rusts $\quad \ldots \quad \ldots .2,10$ $\begin{array}{llll}\text { heteroecious } & \ldots & \ldots & 58\end{array}$

Life-history of rusts $\quad \ldots \quad$... $\quad 1$

Liliaceae, native rusts on $\quad$... 45

Linum marminale $\quad$.. $\quad$.. 43 $\begin{array}{llll}\text { usitatissimum } & \ldots & \ldots & 43\end{array}$ rust-resisting variety $\quad \ldots \quad 60$

Lolium nerenne, crown rust $\ldots . \quad 53$ with introduced rust $\quad \ldots \quad 42$

Mahouia in kiew gardens, rust free $\quad 68$

Maize rust (Puccinia mayclis) $\quad$... $\quad 42$

Mallow rust (Pitcinia malracear'tm 43

Manures and wheat rust $\quad \ldots \quad 72$

Marigold rust (Puccinia culendulae) 10, 42

Measuring spores by photography 12

Melampsora, germinaticn of teleutospore ... ... ...

Melampsora excalypti, merely a

$\begin{array}{ccc}\text { name } \ldots & \ldots & \ldots \\ \text { hypericonim } & \ldots & \ldots\end{array}$

lini

introdnced parapliyses

Melampsoraceae

Mesospores, in Puccinia $\quad \ldots 25,26$

$$
\text { in Uromyclaclium } \quad \ldots \quad \ldots . \quad \ldots 5
$$

$\begin{array}{llll}\text { Micropuctinic... } & \ldots & \ldots & 11\end{array}$

Iint, native, rust (Puccinia menthae) $\quad \ldots . \quad \ldots$

Mounting spores $\quad$... $\quad \ldots, \quad 12$

Mycelium, development of $\quad$... 3 in seed of annuals ... $\quad \ldots .5,70$ iuvestigation $\quad$... $\quad \ldots . \quad 3$ localized, causing hypertrophy $\quad 6$ perennial causing galls $\quad \ldots \quad 5$ no evidence in wheat grain 70 of Puccinia arrhenctheri... $5 \mathrm{~s}$ of Uromyces euphorbice ... 70 
PAGR.

Mycoplasm theory $\quad \ldots \quad \ldots 4,74$ learing on rust in wheat ... 70

Native celery ... $\quad \ldots \quad \ldots \quad \ldots \quad 42$ flax $\quad \ldots \quad \quad \ldots \quad \ldots 42,44$ $\begin{array}{llll}\text { mint } \quad \ldots & \ldots & . . & 42\end{array}$ rusts, and native hosts $\quad \ldots \quad 4.5$ on importerl hosts $\quad . . \quad 49$

Nettle rust (Aerielinm urtirae) ...

Nuclear eyele... $\quad$... $\quad$... 14

Nuclei, fusion of $\quad \ldots . \quad \ldots 14,7$...

Oat, wild, and wheat rust $\quad$... 69

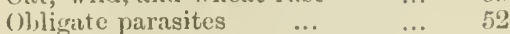

Orhropsorce $\quad \ldots \quad$... $\quad \ldots . \quad 32$

Oilnur of spermogonia ... $\quad$... $\quad$ 13

Omission of spote-forms $\quad . . \quad$ 10

Origin of heteroecism ... $\quad \ldots \quad 55$ of parasitisn $\quad$... $\quad$... 52 of spore-forms $\quad \ldots \quad \quad \ldots \quad 31$

Paraphyses, function ... $\quad$... $\quad 29$ in aceidia $\quad \ldots . \quad \ldots 29,20$ in spermogonia $\quad \ldots \quad \ldots 13,29$ in telentosori $\quad \ldots \quad 22,24,75$ in nredosori $\quad . . \quad \quad . . \quad 22$

Australian species with ... 20

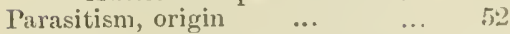
specialisation $\quad \ldots \quad \quad \ldots \quad 52$

Pea rust (Uromyces risi) $\quad \ldots \quad 55$

Peach or prume rust (Pucinia musi) $\ldots . \quad \ldots \quad$... 19, 44

Perlicel of teleutospore ... $\quad$... 23

Peltandra viryinica $\quad$... $\quad$... 61

Pereninal mycelium $\quad . ., \quad \ldots .5$

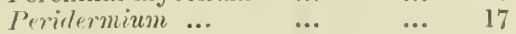

Peridial eells ... $\quad \ldots \quad$... 17

Peridium, = Pseudoperidium $\quad 16$ $\begin{array}{llll}\text { often wanting } \quad \ldots & \ldots & 17\end{array}$ $\begin{array}{llll}\text { varied forms } & \ldots & \ldots & 17\end{array}$

Phalaris, I'uccinia $\quad \ldots \quad$... 5.

Photography in measuring spores 12

Phraymilim bumardi, germ pores 2t

$\begin{array}{llll}\text { paraphyses } & \ldots & \ldots & 22\end{array}$

$\begin{array}{llll}\text { longissimum } & \ldots & \ldots & 44\end{array}$

potentillue... $\quad$... $\quad \ldots \quad 44$

rubi, telentospore germination 35

$\begin{array}{llll}\text { subcoricium } & \ldots & \ldots & 5,: 36\end{array}$

paraphyses, in aecirli a...$\quad 22$

in medosori ... $\quad . . \quad 2 \%$

peremnial mycelimm $\quad . .5 \quad 5$

I'hragmitcs communis, I'recinia ... 29, 42

Phregmopyxis $\quad$... $\quad \ldots \quad \$ 4$

$\begin{array}{llll}\text { Phycomycetes ... } & \ldots & \ldots & 40\end{array}$

Phytopthora infestans, and coples.

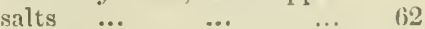

$\begin{array}{lllll}\text { Picee excelsa } & \ldots & \ldots & \ldots & \text {... } \\ & \ldots & \ldots & 50\end{array}$ moriula .. $\quad \ldots \quad \quad \ldots \quad 33$

Ploughing, influence on wheat rust 71

l'lum or prune rust (P'uccinia muni) $\ldots . \quad \ldots . \quad \ldots$

Pou ummua ...

$\begin{array}{lllll}\text { pretensis } & \ldots & \ldots & \ldots & \cdots \\ & & \ldots & \ldots & -2.0\end{array}$

Jorlisoma $\quad$... $\quad$... $\quad$...

l'olygonum arirulare ... $\quad$... $4: 3$

I'otash, canstic, for softening tissues ... $\quad \ldots \quad \ldots . \quad \ldots \quad 12$

l'redisposition... $\quad \ldots \quad \quad \ldots \quad 00$

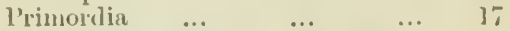

Promyeclial spores isee Sporidiola) $\begin{array}{llll}\text { Promyeclium } & \ldots & \ldots & 1\end{array}$

alonormal ... $\quad \ldots \quad \quad \ldots \quad 35$

cells of, separating $\quad$... 35

$\begin{array}{llll}\text { elongated ... } & \ldots & \ldots & 27\end{array}$

in various genera ... $\quad \ldots \quad 33$

$\begin{array}{lllll}\text { septa } & \ldots & \ldots & \ldots & 27\end{array}$

Irotective inoculation ... $\quad \ldots \quad 62$

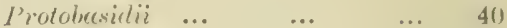

l'rotomycelium $\quad$... $\quad$... $\quad 4$

l'seudoparenchyma

Psendoporiclial cells (see l'ericlial cells)

P'seudoperidium (see Peridium)

l'ucciniu, introduced species ... 42 variation in telentospores $\quad . . \quad 39$

Pneciniu ayrolnyri, heteroecious ... 45 $\begin{array}{llll}\text { agropyrina } & \ldots & \ldots & 53\end{array}$ $\begin{array}{llll}\text { agrostidis ... } & \text {.. } & \ldots & 45\end{array}$ $\begin{array}{llll}\text { anthoxanthi } & \ldots & \ldots & \\ \end{array}$ arenaricu, introduced $\quad \ldots . \quad 43$

sporidiola germ-tules entering by stomata $\quad$... $\quad 10$

arhenatheri, perennial myce-

limm ... $\quad . . . \quad \ldots .5$

a.sparayi, influence of wind ... 7

water relation $\quad . . \quad \quad \ldots \quad 9$

berlonumicie. imported $\quad$... 42

bromina contrasted with $I^{\prime}$. $\begin{array}{llll}\text { triticina... } & \ldots & \ldots & \text { so }\end{array}$

paraphyses in telentosori ... 24, 75 urerlospore, duration of germinating power ... S 8 germination and infection 3,8

calendelue. marigold rust $\quad \ldots \quad 10$

Australian species $\quad$... $\quad \$ 9$

short cycle $\quad$... $\quad$... 10

caricis, heteroccious $\quad$... 45

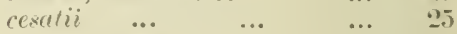

chryscunthemi, germination of ureclospores ... $\quad$... 2$]$

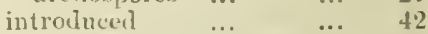

two-èlled uredospores $\quad . . \quad 19$

cichorii, introduced $\quad$... 4 +2

$\begin{array}{llll}\text { cineranat... } & \ldots & \ldots & 49\end{array}$

$\begin{array}{lllll}\text { corometa } & \ldots & \ldots & \ldots & 53\end{array}$

cyani, introluced ... $\quad \ldots .42$

diumthi, sporidiola germ-tubes entcring stomata $\quad$... 10

lichondrce, variation in telentospores ... $\quad$... 39

divyer*a, liologic forms ...

subdivision $\quad \ldots . \quad \ldots .53$

distincte, daisy rust, Ans. tralian species $\quad$... 49

introduced on seed $\quad$... 209

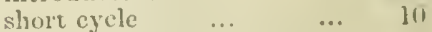

festuce, introinced $\quad \ldots . \quad 42$

glmmarm, mycoplasm theory 4 yremine lle, with aecidium on

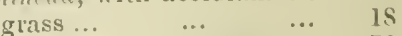
graminis, biologic forms $\quad \ldots \quad$ i? muried over froll year to

$\begin{array}{llll}\text { year } & \ldots & \ldots & 69\end{array}$

in Australia $\quad \ldots 21,69$

colleetive species $\quad \ldots$ i?

cycle of derelopment ... is

forms on special hosts ... 53

heteroecism increasing

vigor

$5 S$ 
PAGE.

Puccinia graminis, importation on straw

injurious rust in Australia no aecidia in Australia ... on grasses, wheat, \&c. ... repeated formation of uredospores

reproduced by uredospores in Australia ... specialisation of forms ... teleutospores, from A ustralia not germinating in England, and ince vers $d$... germinating power ... germination, exposure to cold not necessary ...

in Australia... ... 24, 6 7

in water $\quad . . . \quad \ldots . \quad 36$

time for $\quad \ldots \quad$...

variation $\quad$... $\quad \ldots \quad 39$

uredospores, germinating

power $\quad . . . \quad$...

on old straw ...

germination ... ...

persist through winter ... graminis and barberry rust,

connexion first discovered

in Australia ...

...58, 66

in Kew Gardens ...

of

helianthi, germination of teleutospore ... ..

heterospora, one-celled teleutospores most common ...

transition form ... ...

hiercicii, spermogonia with uredo...

...

subdivision of $\quad \ldots \quad \ldots$

impatientis, introduced ...

liliacearum, spermogonia with teleuto

... 13,37

lolii, introduced ... $\quad . . \quad 4 \%$

paraphyses in uredosori ...

magnusianx, heteroecious ...

paraphyses, in teleutosori and uredosori

malvacearum, causing "shothole"

germination of teleutospores 24, 27

importation and widespread distribution

suppression of spermogonia mayclis, introduced... ... menthue, introduced ... obtegens, spermogonia with uredo... $\quad . . \quad$... perplexans, on native host ... paraphyses in uredosori ...

plagianthi, epispore $\quad$...

poarum, introduced $\quad . . \quad 42$

paraphyses in uredosori ... 22, 29

uredo withstanding cold ... 22

podolepidis, two germ pores in upper cell of teleutospores

prainiana, abnormal telentospore germination $\quad$... 36

prenanthis, introducel _... 42

peridium often wanting....

2

5

Puccinia pruni, causing "shot-hole" first record in Australia ... producing uredospores within fruits ... $\quad$... 19 supposed spermogonia $\quad \ldots \quad 22$ purpurea, introduced $\quad \ldots .42$ rubigovera, germinating power of uredospores ... s paraphyses in teleutosori .. $\quad 24$ subdivision $\quad \ldots . \quad \ldots \quad 79$ senecionis, repetition of aecidia 18 simplex, aecidia unknown ... 5. $\begin{array}{llll}\text { introduced } & \ldots & \ldots & 42\end{array}$ $\begin{array}{llll}\text { mesospores } & \ldots & \ldots & \text {.. } 6\end{array}$ suaveolens, scent of spermogonia $\quad . . . \quad \ldots$ tasmanica, germination of aecidiospores ... $\quad \ldots . \quad 16$ groundsel rust $\ldots . \quad \ldots 42,49$ thuemeni, introduced rust attacking native host .. 42, 49 triticina, aecidia unknown 58 comparatively harmless ... 64, 66 contrasted with $P$. bromina 80 germination of uredospores 21 paraphyses in telentosori ... 22, 75 preference for certain parts $\quad 60$ vexans, amphispores $\quad . . \quad 25$

$\begin{array}{llll}\text { Pucciniucecie } & \ldots & \ldots & \end{array}$

Pucciniopsis $\quad . . \quad$... $\quad \ldots \quad$ II

Queen's Jubilee wheat, rust spores on grain ... $\quad \ldots \quad$... 69

Ranuculacece, Cronartinem $\quad \ldots .5$

Ranunculus ficaria, infection ex$\begin{array}{llll}\text { periments } & \ldots & \ldots & 56\end{array}$

$\begin{array}{lllll}\text { Ravenelia } & \ldots & \ldots & \ldots & \$ 4\end{array}$ compared with Uromycladium 104

Repetition, of aecidia ... $\quad$... $\quad$ is of spore forms $\quad \ldots \quad$... $\quad$ II and spermogonia... $\quad \ldots \quad 14$ $\begin{array}{llll}\text { of uredospores } \quad \ldots & \text {.. } & 19\end{array}$

Rerraf, a rust-resisting wheat ...6 64, 74 $\begin{array}{lllll}\text { Rhamnus } & \ldots & \ldots & \ldots & 57\end{array}$ $\begin{array}{llll}\text { cathartica } & \ldots & \ldots & 53\end{array}$

Rhododendron, Chrysomyxa $\quad \ldots \quad 56$

$\begin{array}{lllll}\text { Rioestelia } & \ldots & \ldots & \ldots & 17\end{array}$

Rose rust (Phragmidium subcorticium) $\ldots . \quad \ldots \quad \ldots . \quad 5$

Rotation of crops and rust $\quad \ldots \quad$ 7I

Rubiacene, native rusts... $\quad$... 45

Rust Conference $\quad \ldots . \quad \ldots \quad 71$

Rnst of wheat... ... ... $\quad 70$ early theories $\quad . .6 \quad \ldots .68$ effect of, drainage ... $\quad$... 71 early maturing wheats ... 74 $\begin{array}{llll}\text { fallowing } \quad \ldots & \ldots & 72\end{array}$ $\begin{array}{llll}\text { irrigation } & \ldots & \ldots & 71\end{array}$ $\begin{array}{llll}\text { manures } & \ldots & \ldots & 72\end{array}$ muggy weather $\quad \ldots 67,72$ ploughing $\quad . . \quad \ldots .71$ rotation of crops $\quad \ldots . \quad 71$ $\begin{array}{llll}\text { seed bed } \quad \ldots & \ldots & \text { il }\end{array}$ $\begin{array}{lll}\text { seed treatment } & \ldots & 71 \\ & \ldots & 73\end{array}$ . stubble burning $\quad \ldots . \quad 7: 2$ effect on straw and grain $\ldots .64$ first appearance in season $\quad \ldots . \quad 21$ first record in Australia $\ldots . .74$ 
PAS.

Rust of wheat, how carricd over

$$
\text { from year to year } \quad . .21,68
$$

how spread $\quad \ldots \quad \ldots 6$

infection from within, myeoplasm theory $\quad \ldots \quad \quad \ldots \quad 4,70$

influence on yield ... ... (ji)

losses from $\quad$... $\quad \ldots .64$

myeelium not in seed $\quad \ldots \quad$ in

mycoplasm theory $\quad . .44,70$

not sprearl from other cereals $5:$ :)

prevention and mitigation ... il

question, present position in

Australia $\quad \ldots \quad \ldots 6 \quad$...

spores, in soil $\quad \ldots . \quad \ldots \quad$...

$\begin{array}{llll}\text { on seed } & \ldots & \ldots & 6 !\end{array}$

to destroy $\quad \ldots \quad$...

wintering $\quad \ldots . \quad \ldots . \quad \$, 20$

spraying impracticable $\quad \ldots \quad 73$

Rust-lialle soils $\quad \ldots \quad$...

Rust-proof wheat unknown ... $\quad$ (i2

Rust-resistance and structural characters ...

Rust-resisting wheats ... _.. 62, 74

Rusts, Australian, and their hosts 45 cycle of development $\quad . .2,2,10$

in heteroecions species ... 58

incligenous and introduced ... 42

influence of parasitic habit ... 40

relation to other fungi $\ldots \quad 40$

sexuality $\quad \ldots \quad 14,17,7, j$

Rusty siraw and grain analyzed 65

$\begin{array}{lllll}\text { Rye, rust } \quad \ldots & \ldots & \ldots & 53\end{array}$

Saccollustia orisyora $\quad . . \quad \quad$... $\quad 32$

Saproplyytes becoming parasitic 52

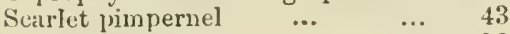

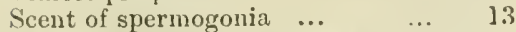

Serophulariaceae, Cronartium $\quad . . \quad 53$

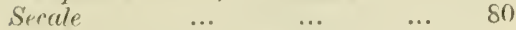

Seed, perennial inycelium not in wheat $\quad . . \quad$...

Seed-bed and rust $\quad \ldots \quad$... 71

Seed-treatinent for rust $\quad$... 7 ?

$\begin{array}{llll}\text { Seeds with aecidia } & . . & \ldots & 70\end{array}$

Selection and crossbreeding wheat it

Self-sown wheat aud rust $21,69,72$

Senerio vulgaris $\quad \ldots \quad \ldots . \quad 16$

$\begin{array}{lllll}\text { Septa... } & \ldots & \ldots & \ldots & 3\end{array}$

formation in promyeelia $\quad \ldots \quad 27$

Sexuality and nuclti $\ldots \quad \ldots 14,75$ of aecidia $\quad \ldots \quad \ldots 15,17$

Shot-hole caused, by Purrinia malirerearmem ... by $I$ '. muni

$$
\text { ... } \quad \text {... }
$$

Silver wattle gall fungus ( $L$ romyrlculium notabile)...

Softening tissues for microscopical examination ...

Soil moisture, influence on rust ...

Soils, rust-liable and rust-free ... treitment with copper salts to prevent clisease

… 62

Sorus, urealo ...

… 1!

Speciul corpuscles $\quad \ldots \quad \quad \ldots \quad 4$

Sipecialisation of parasitism $\quad \ldots \quad$ \$2 in Erysiphacene ...
Specific variation, gradations

Spermatia, embedded in sugary secretion 13

formation ... $\quad \ldots . \quad \ldots 13,: 8$

germination $\quad \ldots \quad \ldots 13,37$

not male cells $\quad \ldots \quad \quad \ldots \quad 13$

uninueleate $\quad \ldots \quad \quad \ldots \quad: 4$

Spernogonia, associated with certain spore forms ... $\quad \ldots, 13,37$

attractive to inseets $\quad . .13,3$, 5

I) arluce filum mistaken for ... 2.2

funetionless $\quad \ldots \quad 13,37,39$

iniportanee $\quad$... $\quad$.. 14

$\begin{array}{llll}\text { oecurrence } & \ldots & \ldots & 13\end{array}$

$\begin{array}{lllll}\text { origin } & \ldots & \ldots & \ldots & 38\end{array}$

$\begin{array}{llll}\text { paraphyses } & \ldots & \ldots & 13\end{array}$

repetition of spore forms $\quad \ldots \quad 14$

suppressed $\quad \ldots \quad \ldots 14,37$

$\begin{array}{lllll}\text { Spore-bed } \quad \ldots & \ldots & \ldots & 19\end{array}$

Spore-forms $\quad \ldots \quad$... $\quad \ldots \quad$ 7

$\begin{array}{llll}\text { investigation } & . . & . . & 11\end{array}$

origin of principal ... $\quad \ldots \quad 31$

repetition... $\quad \ldots \quad 11,18,19$

suppression $\quad$... $\quad \ldots \quad 10$

Spores, listribution $\quad$... $\quad$... $\quad 7$ germination, of aecicliospores 7,16 of amphispores ... $\quad . . . \quad 25$ of spermatia $\quad \ldots \quad \ldots 13,37$ of sporidiola $\quad . . \quad \quad \ldots \quad 27$ of teleutospores ... S S $24,27,66$ $\begin{array}{llll}\text { aluormal } & \ldots & \ldots & 3.5\end{array}$ of uredospores $\ldots \quad 7,19,21,27$ $\begin{array}{lllll}\text { nuclei } \quad \ldots & \ldots & \ldots & 14\end{array}$

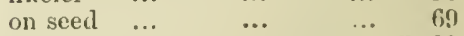
parasites ... $\quad \ldots \quad \ldots \quad 7,22$ wintering, of teleutospores ... \& of ureilospores ... $\quad . . \quad$ S, 20

Sporidiola, air necessary for formation $\quad \ldots \quad$... 27

conveyed by insects $\quad \ldots . \quad 25$

$\begin{array}{llll}\text { distribution } & \ldots & \ldots & 25\end{array}$

earliest sprore forn... $\quad \ldots \quad 32$

$\begin{array}{llll}\text { formation ... } & \ldots & \ldots & .27\end{array}$

$\begin{array}{llll}\text { germination } & \ldots & \ldots & 27\end{array}$

incupable of infecting grasses

bearing them $\quad . .6 \quad \ldots .59$

infection ... $\quad \ldots \quad \ldots, 9,28$

$\begin{array}{lllll}\text { origin } \quad \ldots & \ldots & \ldots & 3:-2\end{array}$

uninucleate $\quad \ldots . \quad \ldots \quad 14$

Spraying for rust of wheat im- 73

$\begin{array}{llll}\text { Sitaining spores } & \ldots & \ldots & 12\end{array}$

Starvation of lost and infective

Stellaria media $\quad$... $\quad$.. $\quad 43$

$\begin{array}{lllll}\text { Siterigma } \quad \ldots & \ldots & \ldots & 31\end{array}$

Sitructural characters of host aml
susceptiluility, to lisease ... 61

to wheat rust $\quad \ldots$... $\quad$ 6]

Stublele burning and rust $\quad . . . \quad 72$

Sugar, influence on germ tubes of fungi $\ldots . \quad \ldots \quad \ldots 2,6: 2$

Sulphate of eopper, in seed treatment for rust $\ldots . \quad \ldots \quad 73$

treatment of soil with $\quad \ldots .606$

Suppression of spore forms $\quad$.. $\quad 11$

Surface markings of spores $\quad$.. $\quad 12$ 
PAGE.

Susceptibility of host, due to physiological peculiarities

influence of structural characters

Teleutospores ... $\quad \ldots .613$ direct infection by germ tube 35 function ... $\quad \ldots . \quad \ldots \quad 23$ germination, factors influenc$\begin{array}{lllll}\text { ing } \quad . . & \ldots & \ldots & 35\end{array}$ in Phragmidium ruli $\quad$... $\quad 35$ in Puccinia graminis $\quad 8,24,66$ in $P$. malcacearum $\quad \ldots 24,27$ germ-pores $\quad \ldots . \quad \ldots .24$ $\begin{array}{llll}\text { occurrence } & \ldots & \ldots & 23\end{array}$ origin and development $\quad \ldots \quad 33$ $\begin{array}{llll}\text { peculiarity } & \ldots & \ldots & 34\end{array}$ simple or compound $\quad \ldots \quad$... 24 two kinds... $\quad$.. $\quad \ldots . \quad 25$ uninucleate $\quad \ldots \quad$... 14 variability, of form $\quad$... $\quad 39$ of germination $\quad . . \quad \ldots 33,35$

Telentsori paraphysate... $\quad \ldots 24,75$

Tomato, copper salts and disease 63

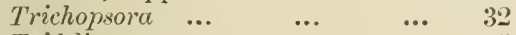

Trifolinm repens. $\quad$... $\quad \ldots . \quad 5$

Triphragmizm ulmariae $\quad$... 36 primary and secondary ureto. $\begin{array}{lll}\text { spores ... } & \ldots & \ldots 20,36\end{array}$ spermogonia with uredo $\ldots 13,37$ Uninucleate spores $\quad . . \quad$... 14 Uredineae in relation to other $\begin{array}{lllll}\text { fungi } \ldots & \ldots & \ldots & 40\end{array}$

$\begin{array}{lllll}\text { Uredinopsis } & \ldots & \ldots & \ldots & \end{array}$

Uredo dispersa, histology $\quad$... $\quad 3$ kuehni, paraphyses $\quad$... $\quad 22$ spyridii, paraphyses $\quad \ldots 22,29$

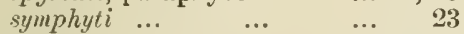

Uredosori, paraphyses ... $\quad \ldots 22,29$ parasites ... $\quad \ldots \quad \quad \ldots, 7,22$

Uredospores, bimuleate $\quad$... 14 derived from teleutospores ... $\quad 34$ distribution $\quad \ldots \quad \quad \ldots \quad 7$

$\begin{array}{llll}\text { formation ... } & \ldots & \ldots & 19\end{array}$

$\begin{array}{lllll}\text { function } & . . & \ldots & \ldots & \end{array}$

germinating power $\quad$.. 20

$\begin{array}{llll}\text { durution of } & \ldots & \ldots & 8\end{array}$

germination, in Puccinia chry$\begin{array}{llll}\text { sauthemi } \quad \ldots & \text {... } & 21\end{array}$

in $P$. rubigoverc ... $\quad$... $\quad$ S

germ tubes, piercing cells ... 10

infection by germ tubes $\quad . . . \quad 3$

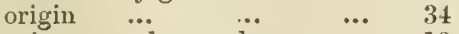

primary and secondary $\quad \ldots . \quad 19$

produced within fruit in $P u c$ $\begin{array}{llll}\text { cinic pruni } \quad . . & \text {... } & 19\end{array}$

repeated formation $\quad \ldots . \quad 19$

two celled, in Puccinia chrysanthemi

wintering ...

$\begin{array}{lll}\ldots & \ldots & 19 \\ \ldots & \ldots 20,21\end{array}$

Uromyces

... $\quad \ldots 24,83$

distiuction between uredospores and teleutospores .. $S 4$

betae $\quad \ldots \quad \quad \ldots \quad \ldots 42,84$

bulbinis $\ldots . \quad \ldots \quad$... $\quad$ S5

caryophyllinus $\quad \ldots . \quad \ldots 43,85$
Uromyces dactylidis, paraphyses

PAEE.

danthoniae, with aecidium on

$\begin{array}{llll}\text { grass } \quad \ldots & \ldots & \ldots 18,57\end{array}$

diploglottidis $\quad \ldots . \quad \ldots 10,85$ euphortiae, perennialmycelium 5,70 jalcee in Ecuador ... $\quad . . \quad 20$

limosellae ... $\quad . . \quad$... $\quad$ S5 orchidearum, two-celled teleu-

$$
\text { tospores } \quad \text {... } \quad \ldots \quad 39
$$

phyllodiorum, paraphyses ...24, 29

pisi $\quad . . \quad \quad \ldots . \quad \ldots \quad 84$

politus, $\dddot{t w o}$ celled teleuto-

spores ... $\quad . . \quad \quad \ldots \quad 83$

polygoni ... $\quad \ldots . \quad \ldots 43,55$

proëminens transition forms

from telentospore to uredo-

spore .. $\quad \ldots . \quad \ldots \quad 35$

\begin{tabular}{llll} 
puccinioides & $\ldots$ & $\ldots$ & \\
\hline
\end{tabular}

scutellatus, origin of uredospore ... $\quad$.. $\quad \ldots \quad 34$

uredo with teleuto spore ... $\quad 36$

$\begin{array}{llll}\text { solidaginis } & \ldots & \ldots & 36\end{array}$

tricorynes, two-celled teleutospores ... $\quad . .6 \quad \ldots 39,83$

trifolii-complete cycle $\quad \ldots \quad \$ 4$ introduced $\quad . . . \quad \ldots .43$ perennial mycelium $\quad \ldots . r 5$

tuberculatus $\quad$... $\quad \ldots .35$

vesiculosus, two-celled teleu-

tospores $\quad \ldots . \quad \ldots 39,83$

Uromycladium... $\quad \ldots . \quad 24, \mathrm{S3}, 104$

forming galls often $\quad \ldots \quad 6$

mesospores $\quad \ldots \quad \ldots 25,26$

spermogonia $\quad \ldots \quad \ldots . \quad \ldots \quad 14$

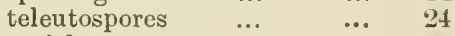

$\begin{array}{lllll}\text { vesicles } & . . & \ldots & \ldots & 24\end{array}$

Uromycladium maritimum, occur-

rence of spermogonia $\quad \ldots 13,37$

motabile ...

perennial mycelium and $\begin{array}{llll}\text { galls } . . . & \ldots & \ldots & 6\end{array}$

rolinsoni, spermogonia $\quad \ldots \quad 13$

tepperianum, spermogonia ... 13,37 perennial mycelium and

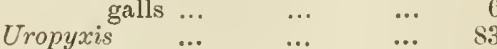

$\begin{array}{lllll}\text { Ustilagines } & \ldots & \ldots & \ldots & 40\end{array}$

Vegetative organs, mycelium ... 3

Verrucose uredospores... $\quad$... $\quad 19$

Vesicle in Uromycludium $\quad$... $\quad 2 t$

Violet rust, native (Puccinia $\begin{array}{llll}\text { hederaceac) } & \ldots & \text {... } & 208\end{array}$

Water relation, for Puccinic on asparagus $\quad$.. $\quad \ldots \quad 9$

to infection, direct and in$\begin{array}{llll}\text { direct ... } & . . & \ldots & 9\end{array}$

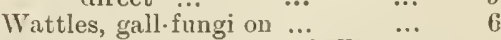

Wheat rust. See Rust of Wheat.

Wheat, rust-resisting ... ‥ 62, 74 self-sown and rust... $21,69,7: 2$

Wild outs and wheat rust $\quad . .6 \quad 69$

'Vind distribution of spores $\quad$... 7

Wintering of rust spores $\quad \ldots . \quad s, 20$

Witches' brooms $\quad . . \quad \ldots . \quad$.. 5

By Authority: Rozt. S. Brain, Government Printer, Melbourne. 




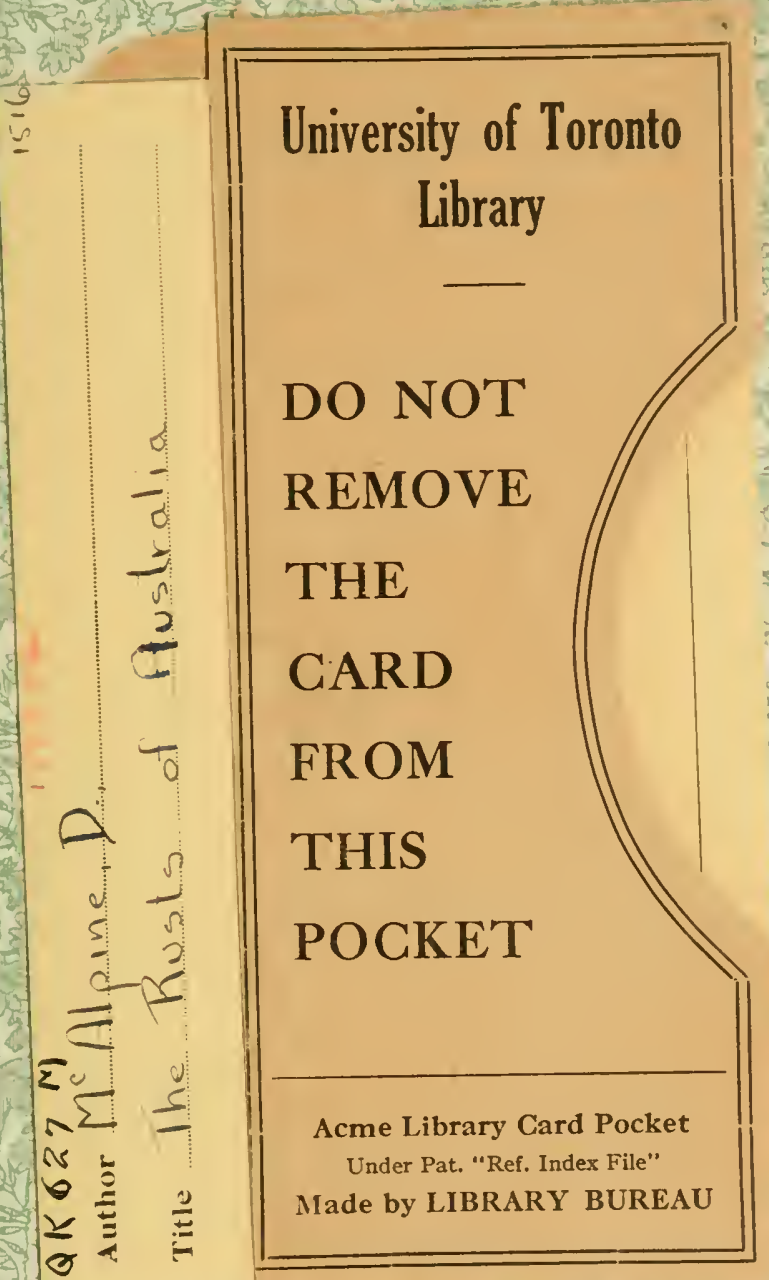




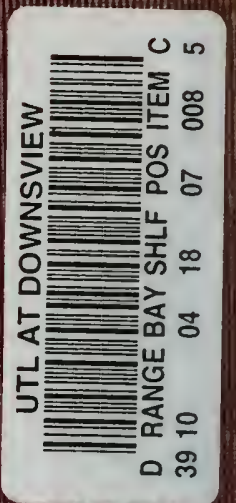

